S T A T E OF I L L I NOIS

Dwight H. Green, Governor

DEPARTMENT OF REGISTRATION AND EDUCATION

Frank G. Thompson, Director

NATURAL HISTORY SURVEY DIVISION

Theodore H. Frison, Chief

\title{
The Plant Bugs, or Miridae,
} of Illinois

\author{
HARRY H. KNIGHT
}

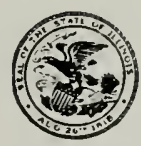

Printed by Authority of the State of Illinows

URBANA, ILLINOIS

September 1941 


\section{S T A T E OF I L L I N O I S \\ Dwight H. Green, Governor}

\section{DEPARTMENT OF REGISTRATION AND EDUCATION}

Frank G. Thompson, Director

\section{BOARD OF NATURAL RESOURCES AND CONSERVATION}

Frank G. ThOMPSON, Chairman

William Trelease, D.Sc., LL.D., Biology

Ezra J. Kraus, Ph.D., D.Sc., Forestry

L. R. Howson, B.S.C.E., C.E., Engineering
William A. Noyes, Ph.D., LL.D., Chem.D., D.Sc., Chemistry

Edson S. Bastin, Ph.D., Geology

Arthur Cutts Willard, D.Eng., LL.D.,

President of the University of Illinois

\section{NATURAL HISTORY SURVEY DIVISION Urbana, Illinois}

\section{SCIENTIFIC AND TECHNICAL STAFF \\ Theodore H. Frison, Ph.D., Chief}

\section{Section of Economic Entomology}

W. P. Flint, B.S., Chief Entomologist

C. C. Compton, Ph.D., Associate Entomologist

M. D. Farrar, Ph.D., Research Entomologist

J. H. Bigger, B.S., Associate Entomologist

S. C. ChandLER, B.S., Southern Field Entomologist

L. H. Shropshire, M.S., Northern Field Entomologist

B. G. Berger, M.A., Assistant Entomologist

H.!B. PetTy, B.A., Assistant, Entomology Extension

M. M. Petrakis, B.A., Entomological Assistant

C. J. Weinman, Ph.D., Research Fellow in Entomology

George F. Ludvik, B.A., Research Fellow in Entomology

T. F. WIn Burn, M.S., Associate Entomologist (U.S.B.E.P.2. and Commodity Credit Corporation, cooperating)

Section of Insect Survey

H. H. Ross, Ph.D., Systematic Entomologist

CARL O. MoHr, Ph.D., Associate Entomologist, Artist

B. D. Burks, Ph.D., Assistant Entomologist

G. T. RiegeL, M.S., Entomological Assistant

Kathryn M. Sommerman, M.S., Artist, Entomological Assistant

\section{Section of Forestry}

James E. Davis, M.F., Extension Forester

LeE E. YEAGER, Ph.D., Forester

\section{Section of Aquatic Biology}

David H. Thompson, Ph.D., Zoologist

George W. Bennett, Ph.D., Limnologist

D. F. Hansen, Ph.D., Assistant Zoologist

Bruno Limbach, B.S, Zoological Assistant

R. G. Rennels, M.F., Assistant Aquatic Biologist

Section of Game Research and Management Ralph E. Yeatter, Ph.D., Game Specialist

\section{Section of Wildlife Experimental Areas}

Arthur S. Hawkins, M.S., Game Technician (On leave)

F. C. Bellrose, Jr., B.S., Assistant Game Technician

J. B. Low, Ph.D., Assistant Game Technician

W. H. Elder, Ph.D., Assistant Game Technician

Cooperative Wildlife Restoration Program

(State Department of Conservation and U. S. Fish and Wildlife Service)

Harry G. Anderson, M.A., Funior Biologist

L. G. BRown, B.S., Funior Biologist

R. E. HesselschWerdt, B.A., Funior Biologist

C. S. Spooner, M.F., funior Biologist

Section of Applied Botany and Plant Pathology

L. R. TeHon, Ph.D., Botanist

D. B. CReAGER, Ph.D., Research Pathologist

J. C. Carter, Ph.D., Assistant Botanist

G. H. Boewe, M.S., Field Botanist

Section of Publications

James S. Ayars, B.S., Editor

Consultant: Herpetology, Howard K. Gloyd, Ph.D., Director of the Museum, Chicago Academy of Sciences

This paper is a contribution from the Section of Insect Survey. 
$\mathrm{T}$ HE Miridae, or plant bugs, containing well over a third of the species of the order Hemiptera, have long attracted attention because of their abundance, their diversity of shape and the great variety of plant hosts they attack. Except for a few predacious species, they suck the juices from plant leaves and, with the leafhoppers, aphids and scale insects, rank as one of the most important groups of plant sucking insects in Illinois.

Early in 1930, a project to investigate the Miridae of Illinois and to prepare a comprehensive report on the state fauna was organized. Dr. Harry H. Knight, Iowa State College, Ames, Iowa, was enlisted as leader of the project to direct the initial intensive collecting for the group, identify the material and write the final report, and he was employed by the Survey as Assistant Entomologist during the summers of 1930. 1932, 1933 and 1937 to acomplish these objectives.

Intensive collecting was begun in 1930 . Prior to this date much material had been assembled by earlier Illinois collectors, particularly C. A. Hart and C. W. Stromberg, whose specimens in the Natural History Survey collection formed not only a good general collection of the group but also included several species not taken in our recent search. Much interesting material collected in Illinois by W. J. Gerhard was lent us by the Field Museum of Natural History, Chicago.

Field work for this group followed very closely the pattern developed during an earlier study of Illinois aphids (Hottes \& Frison 1931). Collecting was done in every part of the state, from south to north, east to west, and repeated at different seasons in an attempt to capture species which might be restricted to certain periods of the year or to limited local habitats. Using known mirid host plants as a guide, we attempted to collect from every species of probable host in every locality visited.
This procedure was followed in 1930 and 1932. In 1931, drought conditions reduced the mirid population to a low ebb, making collecting for this group impractical. In 1934, 1935 and 1936, intensive collecting for leafhoppers turned up many more Miridae, including a large number of new records for Illinois. A total of about 20,000 specimens was accumulated, including the 5,000 specimens already in the collection before our drive for this group began. All members of the Insect Survey Section staff have at various times aided with the field work and preparation of material for identification and preservation.

Much of the work of final identification of material and completion of the manuscript was done by Dr. Knight at Ames, Iowa, while not attached to the Survey, and I wish to express our gratitude to him for spending so much of his own time in bringing this project to a successful conclusion.

Several members of our staff in the Insect Survey Section also have contributed greatly to the final manuscript. The many full illustrations of Miridae are with few exceptions the work of Dr. C. O. Mohr, Associate Entomologist and Artist. Dr. Mohr and Miss Kathryn M. Sommerman, Entomological Assistant, also added many illustrations used to illustrate key characters and male genitalia. Summarizing the Illinois collection data and adding it to the manuscript, modification of the keys to emphasize as much as possible characters which could be illustrated, and adapting the manuscript to current Survey practices represent the painstaking and effectual work of Dr. H. H. Ross, Systematic Entomologist, and Dr. B. D. Burks, Assistant Entomologist. The section on economic status and control is in part the work of Prof. W. P. Flint, Chief Entomologist. Finally the manuscript was read and styling determined by the Editor, Mr. James S. Ayars.

T. H. Frison, Chief

Illinois Natural History Survey 

INTRODUCTION . . . . . . . . . . . . . . . . . . .

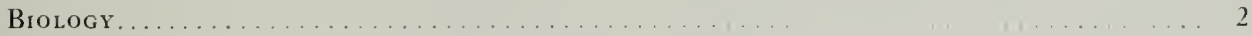

Life Cycle.-Hibernation.-Feeding Habits.

Distribution and Habitat Preference. . . . . . . . . . . 5

Mirids in Restricted Areas.-Forest Mirids.-Grass and Marsh Mirids.-Widely Distributed Species.-Collecting Notes.

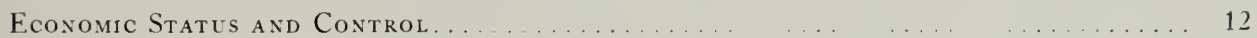

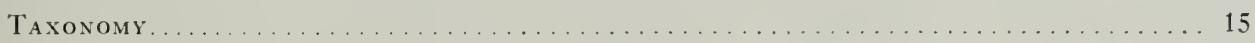

Systematic Characters.-Phylogeny.-Present Holders of Material: Symbols.-Mleasurements and Records.- Tarsal Claw Key Characters.

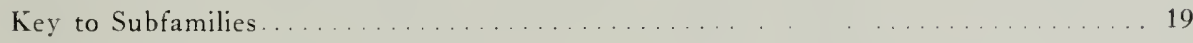

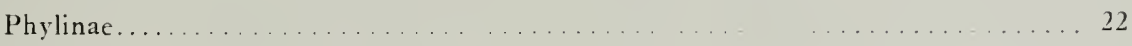

Dicyphinae. ............................ 52

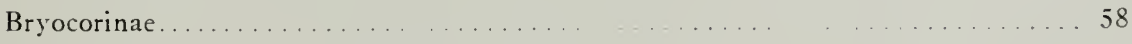

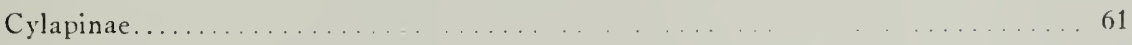

Clivineminae........................ 63

Deraeocorinae................................. 64

Orthotylinae. ....................... 74

Mirinae.................................. 124

Capsinae............................... 131

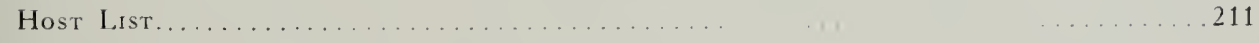

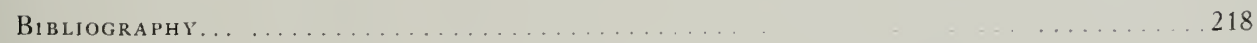

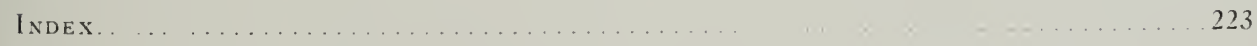




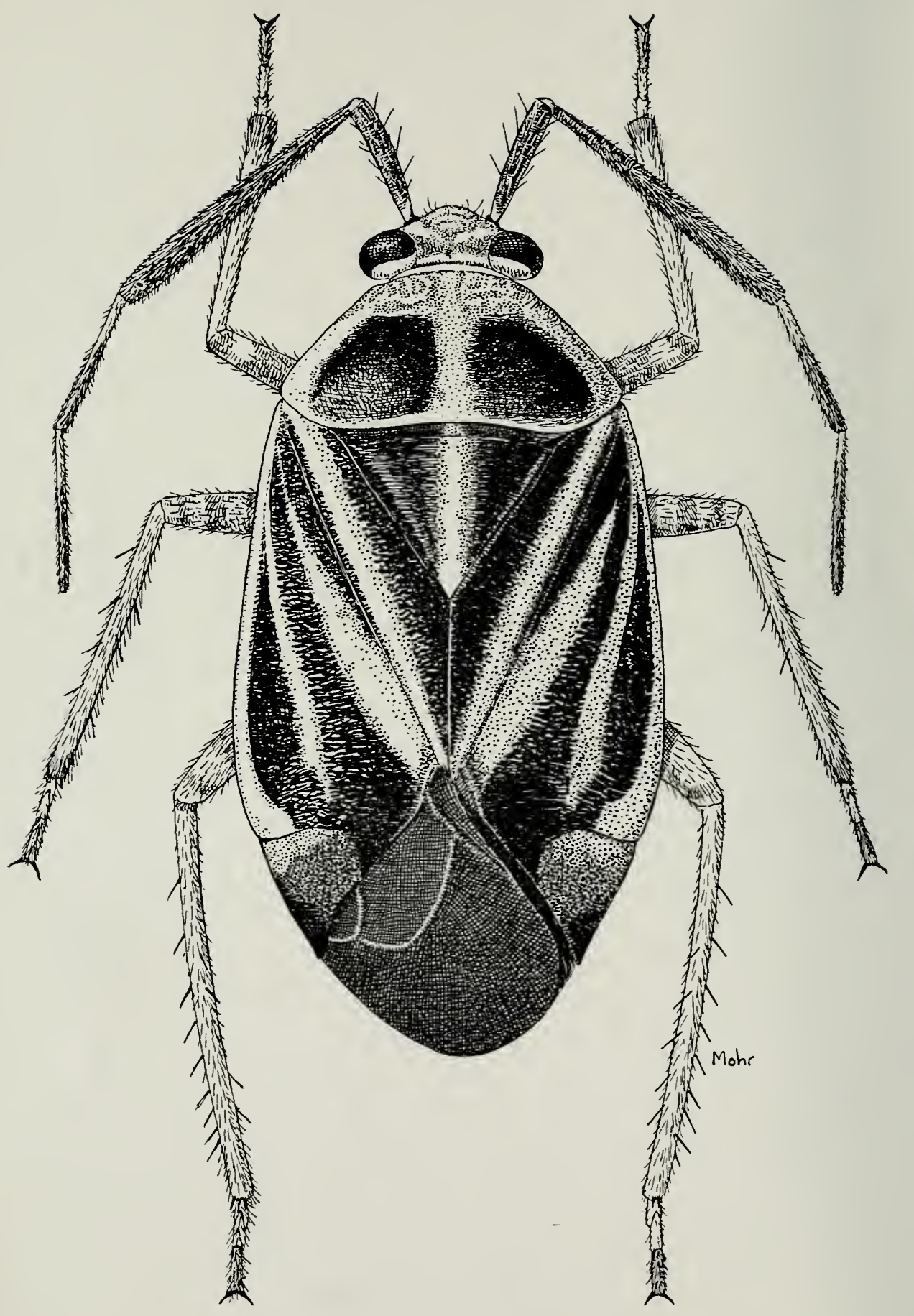

Horcias illini.

Typical in general outline of many plant bugs found in Illinois, but among the more striking in coloration and markings. 


\title{
The Plant Bugs, or Miridae, of Illinois
}

\author{
HARRY H. KNIGHT*
}

\section{Introduction}

$\mathrm{T}$ HE list of Miridae of Illinois now stands at 330 species. It is apparent, however, that species known from neighboring states will eventually be found in Illinois. Furthermore, in the study of Illinois species, it was found that many records of these species were a great distance from any other previously known records. Hence, it was thought advisable to include in the keys other species and varieties known from the entire general region in which Illinois is situated. One hundred ten extralimital species were, therefore, included, bringing the total number treated in this report to 440 species. It seems highly probable that from two-thirds to three-fourths of these extralimital species will eventually be found in this state, which would bring the list of Illinois Miridae to about 400 species.

In the list of insects for New York (Leonard 1928), + I recorded 296 species of Miridae, but since publication of this list additional records have raised the total to 316. A list of Miridae for the District of Columbia and vicinity (Knight \& McAtee 1929) records 200 species of Miridae within a 25-mile radius of Washington, D. C. The state of Illinois, which includes within its borders the cypress swamps about Cairo and the northern tamarack bogs bordering Wisconsin, represents an ecological range scarcely exceeded by any other state east of the Mississippi River. This range undoubtedly accounts for the large list of Miridae.

In number of species, the Miridae far exceed other families of Hemiptera. In the Palearctic region, where the total number of Hemiptera is best known, the "Oshanin Katalog" (Oshanin 1910) enumerates 1,078

*Iowa State College, Ames, Iowa; Assistant Entomologist, Illinois Natural History Survey, during summers of 1930, 1932,1933, 1937.

†Miridae, Isometopidae (Knight 1923b), pp. 110.35 species for the family Miridae and but 2,486 species for all other families of Hemiptera combined. In North America, north of Mexico, approximately 1,500 species of Miridae are known; of other families of Hemiptera, about 2,500 species.

Because of the fragile nature of the pubescence and appendages of the mirids, special attention had to be given to their collection. The collecting party, consisting of two or three members, equipped with nets, bottles, pinning and mounting accessories, and desk lamps, was usually in the field for periods of 10 days to 2 weeks. Each day, collecting was discontinued at about 4 P.M., and headquarters were set up for work in a hotel room where the day's catch was pinned to prevent unmounted insects from being battered in transit.

The collecting party used sweeping nets, each having a ring 15 inches in diameter and a bag of bolter's silk. These were found ideal for mirids, since they excluded so little light from the bottom part of the net that the mirids did not swarm too rapidly to the top. Test-tube cyanide bottles about 6 inches long were used, with the cyanide in the bottom; the diameter of the tube was as large as could be stoppered by the operator's thumb. In each tube were a few loose strands of cellucotton. The bugs were "picked" off the sides of the nets into the bottle, which could be conveniently stoppered by the thumb until emptied.

With this group, care must be taken to have only a small number of individuals in each bottle at one time; otherwise considerable pubescense is rubbed off. After the specimens are dead, they may be transferred to pill boxes or other temporary containers. If mirids are left in the cyanide bottle too long, some of the yellow and orange colors change to deeper tones, sometimes to red. 
As mirids are much easier to handle before they have dried out than after, each day's catch was pinned up the following night to insure the best possible specimens. All mirids were mounted on card points with a crimp and in such a way that the crimp was glued to the side of the mesothorax and not to the legs only. The mounted specimens were then pinned in Schmidt boxes for traveling and taken back to the laboratory at Urbana, where they were labeled and later identified.

\section{Biology}

The eggs of most mirids hatch early in the season when the host plants are making tender new growth. It is worthy of note that in the case of species known to produce

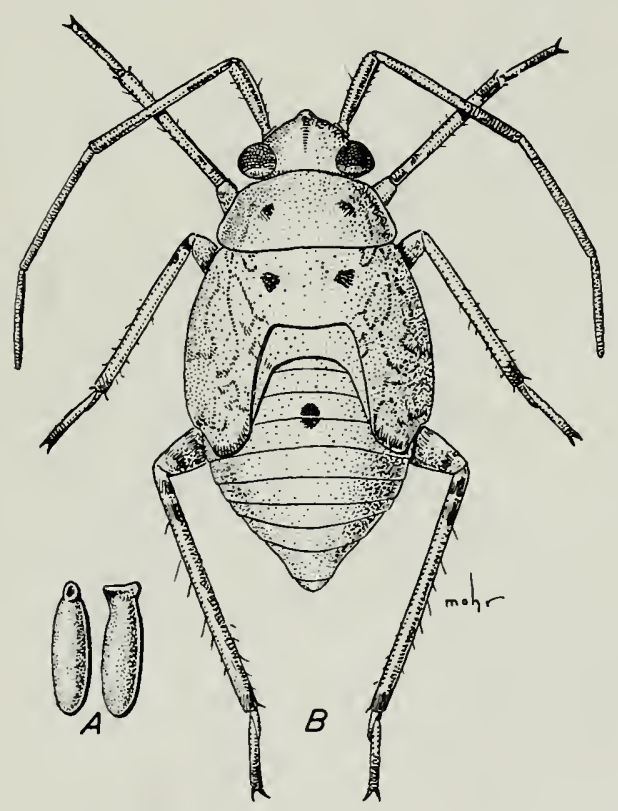

Fig. 1.-Lygus oblineatus; $A$, egg, front and lateral view; $B$, fifth instar nymph.

a second generation the host plant is one which produces succulent growth during the summer season. Thus, the tiny young nymphs find the maximum amount of sap for food which is essential for plant feeders. Mirid eggs, fig. $1 A$, are elongate, slightly curved or bean shaped, with a cap and micropyle on the end pointing to the outside of the plant substance where embedded.

\section{Life Cycle}

Mirid nymphs pass through five instars or stages of development and at the fifth molt attain sexual maturity and, except in special cases where the adults are wingless, a set of wings. The time required for nymphal development varies with different species, but many of them are known to require 20 to 30 days. Beginning with the third nymphal instar the development of wing pads may be observed. During the fourth instar the wing pads are clearly evident, while in the fifth instar, fig. $1 B$, the wing pads usually extend back to the middle of the abdomen. Many mirid species have been observed to possess during nymphal development the curious habit or ability of protruding a posterior portion of the rectum; when a nymph is dislodged and falls from a branch or leaf to the foliage below, the rectum is protruded, and, being provided with sticky material, acts as an adhesion disk upon striking foliage of the limbs below. The nymph then scrambles for a foothold, pulls the adhesion disk free, retracts the rectum and runs for cover among the leaves. Thus the eversible rectal disk saves many falling nymphs from losing contact with the host plant.

The adult females may mate within 2 or 3 days after emergence but do not start laying eggs until a week or 10 days later. The males are generally the first to mature, but they do not live so long as the females.

I have described (1915) in detail the oviposition work of four mirid species but here recount only selected parts. Observations on Heterocordylus malinus Reuter were made on crabapple and cultivated apple in western New York. Females that matured June 12 were observed to oviposit on June 21. On the morning of June 23, four different females were observed while ovipositing.

When a female is ready to oviposit she moves up and down the branch, patting the surface with antennae and touching the bark here and there with the tip of the proboscis. In this manner one spent 6 minutes searching for a place to oviposit. Another individual required 15 minutes before she found a suitable place. The female-begins to drill the hole by means of the proboscis, and this operation may require from 5 to 18 minutes before the hole is ready for the insertion of 
the ovipositor. After drilling the hole with the beak, the female arches the abdomen, stands as high as possible, then unsheaths the ovipositor and thrusts it forward to locate the place prepared. She turns her head under with the tip of the proboscis in the hole to help guide the ovipositor. One female was observed to make seven attempts before inserting the ovipositor. Most individuals make two or three attempts before succeeding. After each failure, the female inspects the hole and works upon it for a time with her beak. Once insertion of the ovipositor is started, the female works the abdomen up and down with a rapid, jerky motion until the ovipositor is inserted to its base. An alternate contraction and expansion of the abdomen then occurs while the egg is being worked down into position. This operation requires about 2 or 3 minutes. The female then withdraws the ovipositor and rests for 3 to 5 minutes before inserting the second egg. After this interval, she again locates the hole by means of antennae and beak and then repeats the operation of inserting the ovipositor. In some cases only one egg is laid in a place, but two eggs appear to be the normal number for this species.

The number of eggs laid varies with the individual from day to day. One female was observed to oviposit in six different places between 10:00 A.M. and 12:00 o'clock noon. This same female was observed to oviposit daily from June 23 to 27 , but died on June 28.

The apple redbug, Lygidea mendax Reuter, breeds on hawthorn and apple; it matures a week to 10 days later than Heterocordylus malinus. In 1914, at Batavia, New York, the majority of females matured about June 20. Several females were watched closely but no eggs were obtained until July 8. When ready to lay, the female moves about over the twigs, searching for lenticels on wood of the previous year's growth. She drills the lenticel by means of the proboscis. One female required $10 \mathrm{~min}-$ utes for this operation. She failed in three attempts to insert the ovipositor but on the fourth she succeeded. She took $21 / 2$ minutes to lay the egg. After an interval of 4 minutes, she returned to the hole and upon the second trial inserted the ovipositor and laid an egg. She then sealed the wound by means of the proboscis. The lenticels are normally light colored but, after being injured by the process of oviposition, they appear reddish brown. The eggs are placed in the cambium at such an angle that the lower ends rest on solid wood and their tips are $1.5 \mathrm{~mm}$. apart. Females of this species were observed ovipositing on trees in an orchard as late as July 18.

The pear plant bug, Neolygus communis Knight, oviposits in the cambium of pear twigs. The actions of the female are very similar to those of the species described

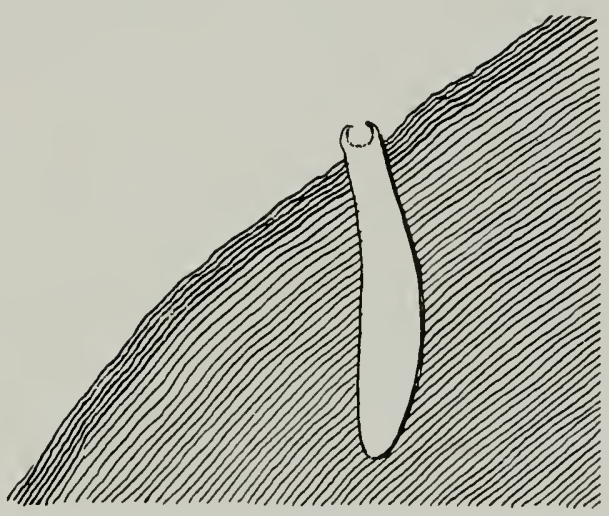

Fig. 2.-Egg of Paracalocoris colon, shown in cross section of ncw growth of apple bark. Adapted from Knight (1915).

above. Examination of one oviposition point revealed that six eggs had been laid in a space $1.0 \mathrm{~mm}$. long. The eggs were closely packed in a double row lying flat just within the cambium layer. Eggs measured were $1.05 \mathrm{~mm}$. in length by $0.26 \mathrm{~mm}$. wide.

An apple mirid, Paracalocoris pallidulus McAtee, was found to lay eggs only where dead wood was available. Females that were caged on limbs free from scars and dead stubs did not oviposit. Four females were observed to lay when placed on branches having dead stubs. Five eggs were placed around the margin of one stub, a new hole being made for each egg. The egg of this mirid differs from those of several species at least in having a white cap with two keels that curve up and nearly meet over the top of the egg, fig. 2. The egg cap projects from the cavity as shown in the figure but is not conspicuous because of the uneven character of the rough bark and surrounding wood. Eggs laid in July remain until the following spring before hatching.

A majority of mirid species produce only one generation per year, but a few have been 
tound to produce two or more generations in one season.

Lygus oblineatus (Say) may produce two or three generations in one season; Halticus bracteatus (Say) breeds continuously during the warm season and is credited with five generations in South Carolina. Adelphocoris lineolatus (Goeze) rears two generations in a season on alfalfa and sweet clover. Neoborus amoenus (Reuter) rears two generations in one summer on white ash. The cotton flea hopper, Psallus seriatus (Reuter), breeds continuously as long as the succulent host plants remain green.

\section{Hibernation}

A majority of mirid species pass the winter in the egg stage. Usually the eggs are embedded in some part of the host plant. In the hop mirid, Paracalocoris hawleyi Knight, the female bugs embed their eggs in the poles used for support of the host vines. The writer observed several females of Neolygus johnsoni Knight laying eggs in the soft, punky stubs formed by the breaking off of old dead limbs on the host tree, hornbeam (Carpinus caroliniana). Many species, such as Lopidea davisi Knight, Labopidea allii Knight and Adelphocoris lineolatus, lay eggs in stems or leaves of herbaceous plants and pass the winter in the dry stems. The apple redbug, Lygidea mendax, Heterocordylus malinus and Neolygus communis place eggs in the living cambium on branches of the host tree where they pass the winter.

Mirid eggs, fig. 2, have a relatively impervious chorion which permits them to remain viable for several months, although embedded in material which is almost completely desiccated.

Relatively few species hibernate as adults. Stenodema vicinum (Provancher) and $S$. trispinosum Reuter are known to do so and no doubt other members of the genus do likewise. Adults of Lygus oblineatus, L. vanduzeei Knight, L. plagiatus Uhler, $L$. pabulinus (Linnaeus), L. campestris (Linnaeus) and L. rubicundus (Fallen) have all been taken in hibernation, and it seems a characteristic of the genus to overwinter in the adult stage. Species of the subgenus Camptobrochis of Deraeocoris hibernate as adults, so far as known, with $D$. nebulosus (Uhler), D. poecilus McAtee, D. histrio (Reuter), D. nubilus Knight frequently taken in winter. Here again hibernation ap- pears to be a group characteristic. Dicyphus vestitus Uhler and $D$. discrepans Knight also have been taken in hibernation.

\section{Feeding Habits}

Probably a majority of the species of Miridae are plant feeders, but a large number are now known to be chiefly predacious. The predacious habit is only partially developed in certain species and thus insect blood serves merely to supplement the sap obtained from particular food plants. In the genus Deraeocoris the different species appear to be chiefly predacious; $D$. aphidiphagus Knight feeds on the elm aphid, Eriosoma americanum Riley, and its honeydew; D. nitenatus Knight feeds on the woolly apple aphid, Eriosoma lanigerum (Hausmann); D. pinicola Knight feeds on Chermes pinicorticis (Fitch). It seems highly probable that most members of the subfamily Cylapinae are predacious or mycetophagous; namely, species of Fulvius and Peritropis and Cylapus tenuicornis Say; known species of these genera are normally found about dead trees, hiding in crevices of the bark on logs and stumps. In the large genus Phytocoris, several species are known to be predacious, particularly the darkcolored, bark-inhabiting ones. Fulton (1918, pp. 93-6) demonstrated that Pilophorus perplexus Douglas \& Scott feeds freely on apple aphids, three nymphs having reduced a colony of 50 aphids to 6 within 2 days.

Among the plant feeders, probably the greater number of species are limited to a single host, or to a genus of plants, while a very few, such as Lygus oblineatus and Halticus bracteatus have a wide range of food plants. Even among species which always breed on a single host plant, a general dispersal of individuals usually takes place. Following the time of emergence and mating, individuals of Tropidosteptes cardinalis Uhler, Lopide a staphyleae Knight and others have been observed to migrate from their host plant to shrubbery in the general vicinity; thence they doubtless become dispersed over wider territory and to new plants, although, in the normal course of their life, they eventually return to suitable growth of the preferred host plant for the purpose of oviposition.

Since a majority of species of Miridae are definitely limited to a single species of plants or at least a genus of plants, we may expect 
the distribution of the bugs to be limited to areas where the host species grow. No doubt in times of migration and when buffeted by strong winds, many individual bugs may be carried far from their normal host and hence perish without successful reproduction. It appears that several species of Miridae are so restricted by ecological factors that their distribution is more limited than the host upon which they live. This is certainly true of the apple redbug, Lygidea mendax, which normally breeds on species of Crataegus; but the Crataegus grows far south and west of the areas where $L$. mendax can be found.

While making a close study of Lygidea mendax the author noted that the bugs were never found on isolated trees exposed on high ground where the sun was hot and the atmosphere very dry. The bugs seemed to thrive only in valley areas where the humidity rarely dropped to desiccating levels. The nymph of $L$. mendax is very delicate, the body wall evidently only thinly chitinized; so it can live only where the humidity is high enough to prevent desiccation. The writer believes that the southward distribution of this species is limited chiefly by the high temperatures and desiccating atmosphere frequently encountered west of the Mississippi and south of the Ohio rivers. It seems likely that other Miridae of the Boreal region may have their southern distribution limited for the same reasons.

In contrast to the above, we may take another species, Heterocorlylus malinus, of which the favorite wild host is Crataegus. This insect is more widely distributed than Lygidea mendax, for it is frequently found on Crataegus in Texas and Mississippi, apparently able to live wherever the host plants thrive. If we examine nymphs of $H$. malinus we find the body wall is more heavily chitinized than in $L$. mendax. The nymphs are not subject to fatal desiccation when the leaves of the host plant wilt under the heat of a hot, dry day. Some years ago the writer reared in breeding cages many nymphs of both species, and at that time first observed the more delicate nature of $L$. mendax. When both species are kept in cages on host plant foliage, and the host leaves are allowed to dry out, L. mendax will die immediately whereas $H$. malinus will live for several hours.

\section{Distribution and Habitat Preference*}

In Illinois the distribution patterns of the Miridae are linked primarily with those of their plant host species. Other factors also play a very important part in determining mirid distribution patterns, but the influence of these is not always obvious from a study of such a limited area as one state. The greater part of the uncultivated areas of Illinois is covered with either oak-hickory forests or prairie and the various types of community which lead up to them. There are certain restricted areas, however, in which we find mirid hosts found nowhere else in Illinois. These are the result of the rather axial geographic position of Illinois. This state is a long, narrow area, the northern end just bordering some of the coniferous communities which are common in Wisconsin and its southern end extending slightly into conditions typical of the southern states. In respect to east and west, Illinois is the mingling ground of the eastern deciduous forests and the western grasslands, with here and there an invasion of typical western

*This section is the work of Herbert H. Ross, Systematic Entomologist. Iliinois Natural History Survey. plants in some of the sand areas. Small areas of peculiar interest are marked on the accompanying maps.

\section{Mirids in Restricted Areas}

The tamarack bogs, fig. $3 E$, are remnants of the glacial bogs. In Illinois they are restricted to the small area in the vicinity of Volo and Antioch in the extreme northeastern portion of the state. They have been encroached upon by agriculture to a considerable extent, but a few remain which have preserved their flora and fauna practically intact. These bogs, fig. $f$, are the only place in this state where occurs native tamarack, Larix laricina, which is the exclusive host of the following plant bugs in this state: Deraeocoris laricicola Knight, Pilophorus uhleri Knight, Plagiognathus laricicola Knight. These species do not feed on other species of larch used for ornamental planting in various localities, so that our records for the larch mirids are confined to the northern bogs, fig. 5 .

Along the shore of Lake Michigan, north of Waukegan, is a narrow sand area, fig. 
$3 F$, which combines a great variety of grass, sedge, herb and shrub species, many of them found nowhere else in the state. This area offers excellent collecting for some of the rarer species of the Miridae. It combines grass, sedge and herb communities, fig. 6, and open woods with luxuriant herbaceous undergrowth, fig. 7. One of our most interesting captures was Plagiognathus syrticolae Knight on the sand-loving willow, Salix syrticola, restricted in Illinois to this area.

White Pines Forest State Park, fig. 3B, in Ogle County, contains an area of white pine forest which is the only large stand of this tree in Illinois, fig. 8. Scattered specimens of the white pine occur in Starved Rock State Park, fig. 3C. Restricted to white pine are four mirid species taken in this state: Deraeocoris pinicola Knight, which we have taken only at White Pines

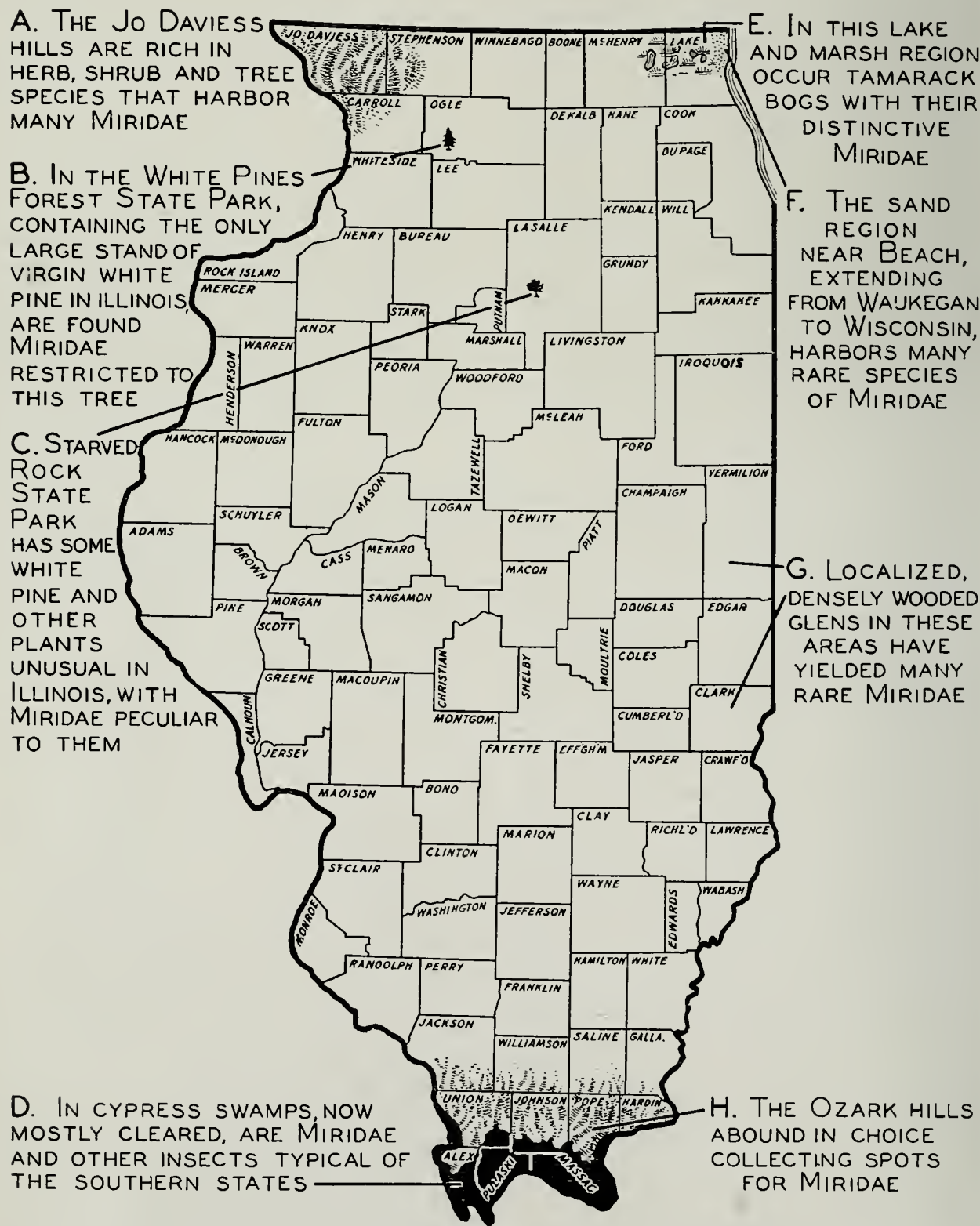

Fig. 3.-Map of Illinois showing mirid habitats of unusual interest. 


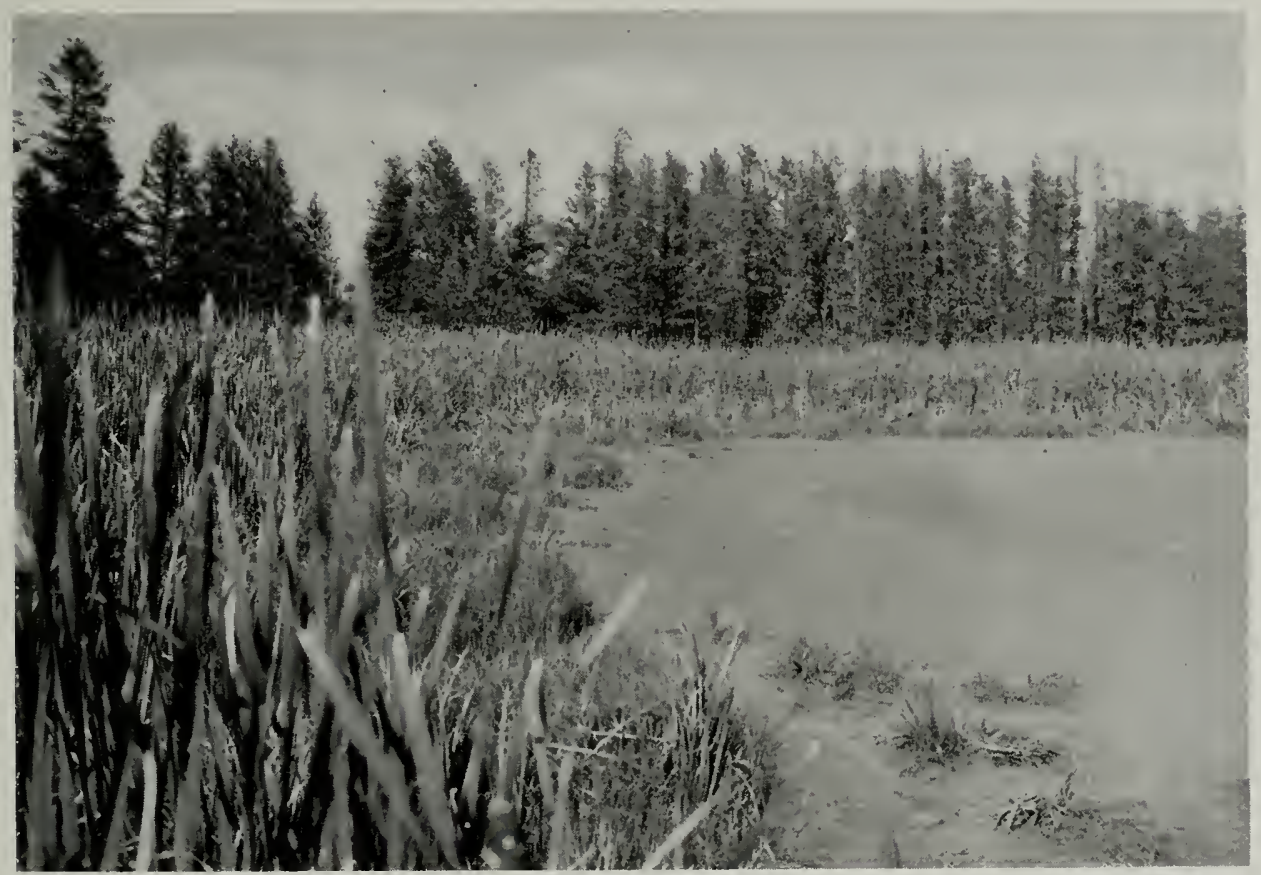

Fig. 4.-(Above.) Tamarack bog at Volo, 111. Tamarack is the sole host of three Miridae found in Illinois.

Fig. 5.-(Right.) Map showing the distribution in Illinois of Pilophorus uhleri. This species is confined to tamarack, in Illinois found only in the northeastern corner of the state.

Forest State Park; Deraeocoris nubilus Knight and Phytocoris diversus Knight, which have been taken at both White Pines Forest State Park and Starved Rock State Park; and Pilophorus strobicola Knight, which is found not only on these natural stands but also on ornamental white pines throughout the state.

In the extreme southern tip of the state are several fine examples of cypress swamps, fig. $3 D$. Originally cypress swamps covered an extensive area in Alexander, Pulaski and Massac counties, but most of this has been cut over, drained and put into cultivation. There remain, however, one or two cypress areas which have retained their natural biota, such as at Horseshoe Lake, fig. 9. Cypress in Illinois has yielded the following records of Miridae: Pilophorus taxodii Knight, Parthenicus taxodii Knight, Orthotylus taxodii Knight, Ceratocapsus taxodii Knight, Phytocoris taxodii Knight. All these species are restricted to cypress and have

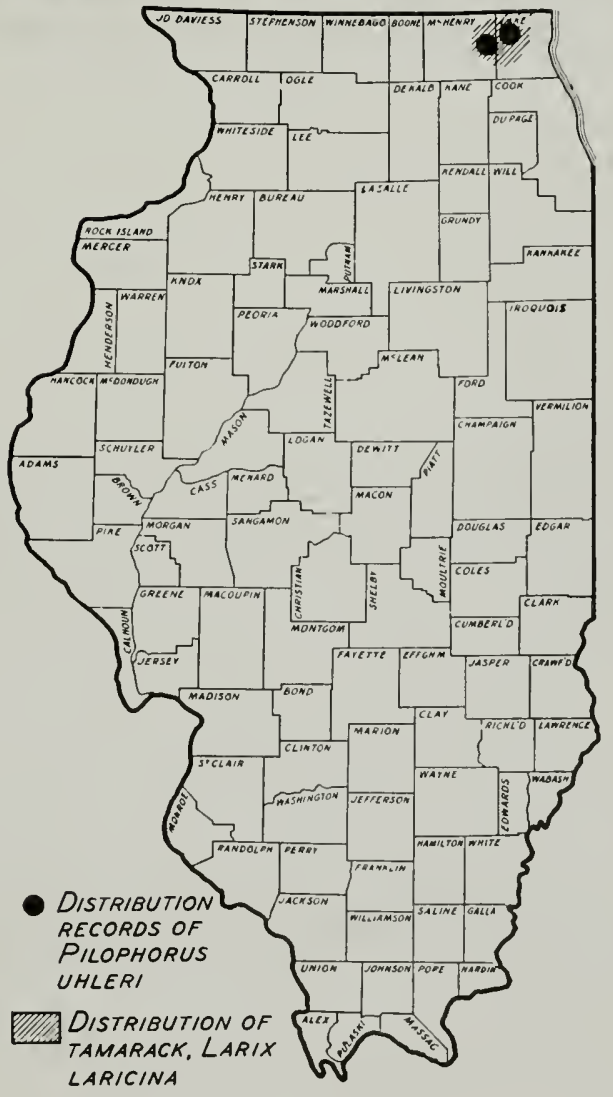




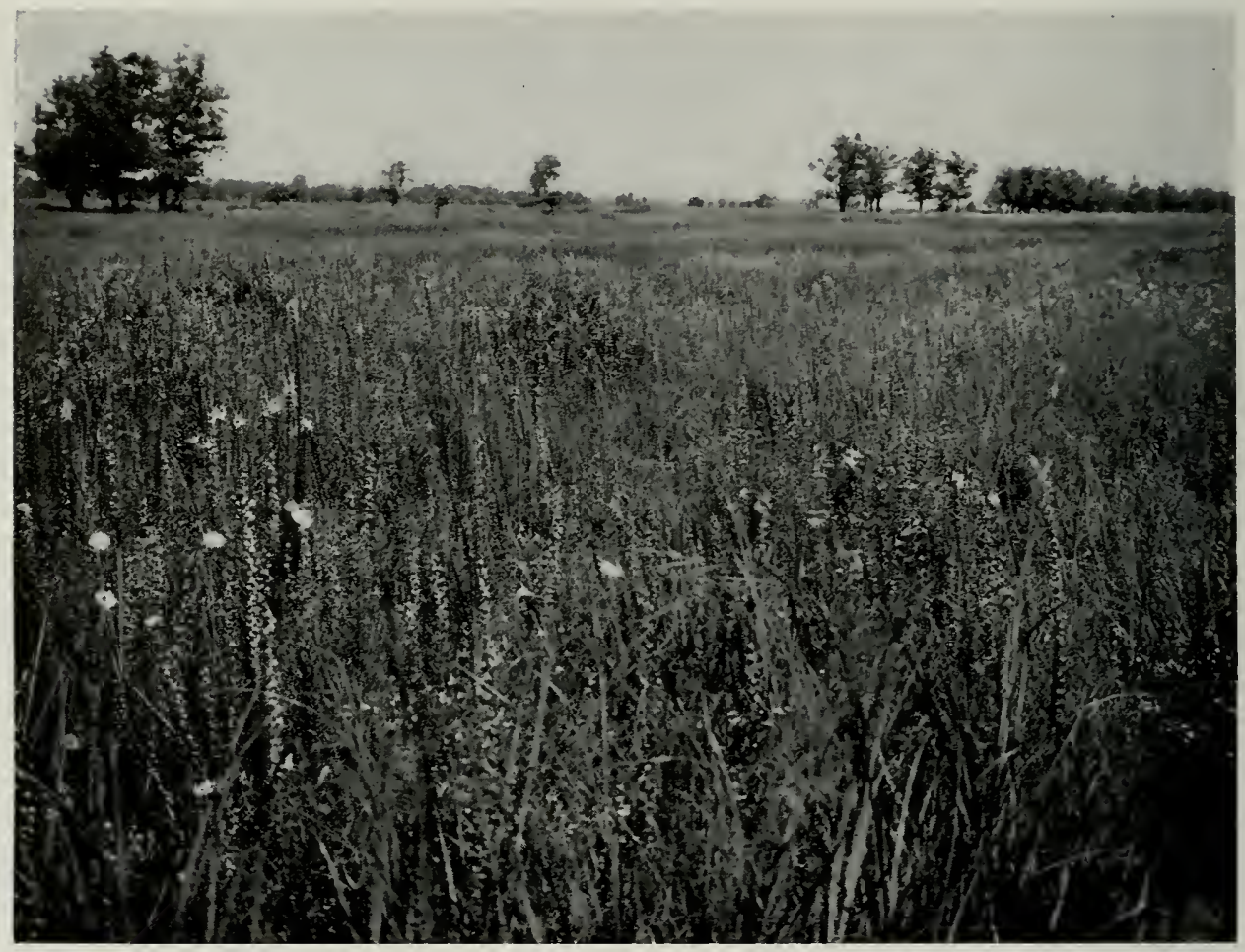

Fig. 6.-Sand prairie vegetation at Beach, Ill., growing on the beaches left by receding Lake Michigan. Note the luxuriant growth of grass and herbs.

been taken in Illinois only in the extreme southern tip, fig. 10 .

\section{Forest Mirids}

Species of deciduous forest trees, especially ash, oak, hickory and members of the birch family, serve as host for a wide variety of Miridae the distribution of which in general follows that of our forested areas.

A decided peculiarity of the tree-inhabiting Miridae is their preference for forestedge conditions. A given species will generally be taken in abundance on only those host

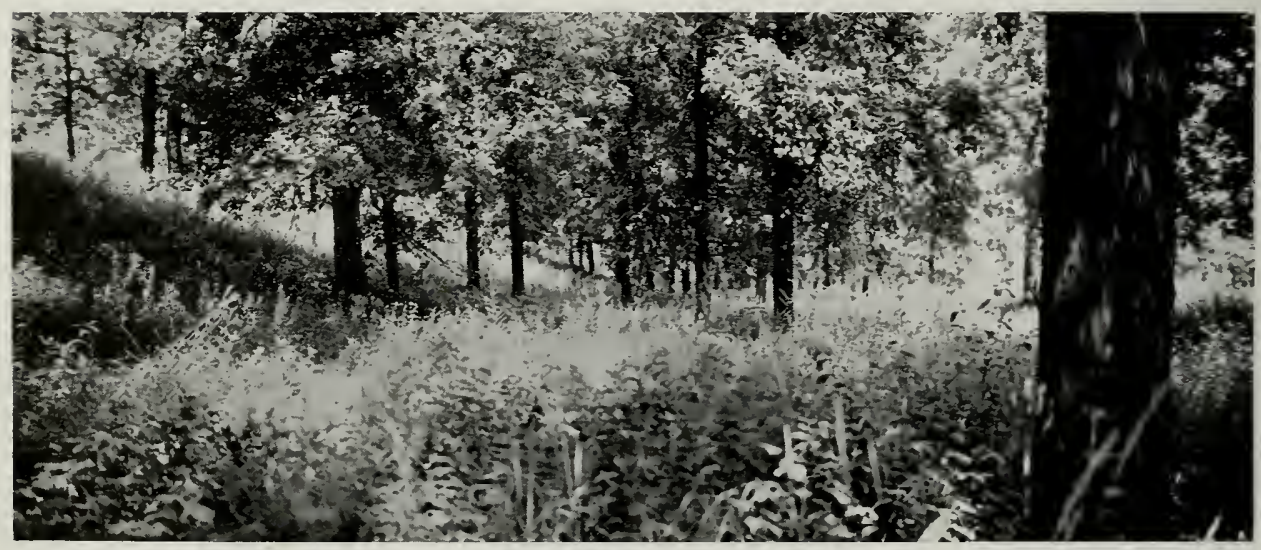

Fig. 7.-Older beaches of the sand prairie area near Zion, Ill. Here the forest-edge conditions, with luxuriant vegetation, offer an ideal habitat for many species of Miridae. This area was formerly one of bare, shifting sand. 


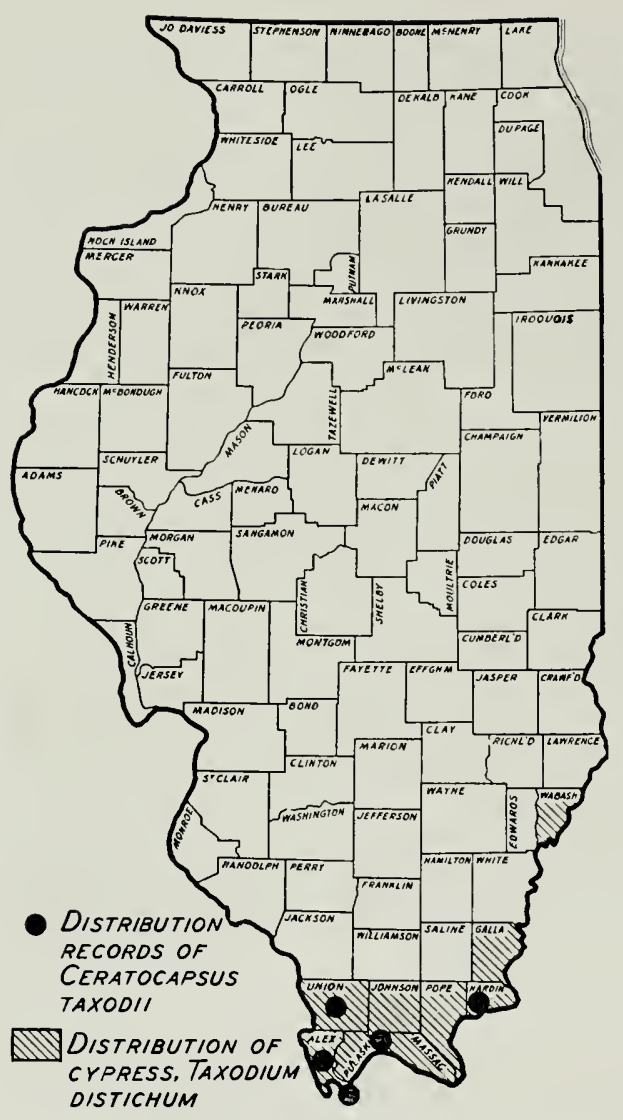

Fig. 10.- Outline map of Illinois showing the distribution of Ceratocapsus taxodii and its exclusive host, cypress.

individuals that are at the edge of a clearing, right at the edge of a woods or isolated in the surrounding herbaceous growth. This condition has been found true especially of the species infesting oak and ash. Sweeping in dense woods seldom netted many specimens, but that at odd trees at the edge of the woods frequently resulted in the collection of great numbers of the bugs. This behavior characteristic probably explains why Miridae sometimes become very abundant in street and ornamental plantings of such trees as ash.

Certain forest Miridae are exceptions to this general habit. One of our best examples is Dicyphus gracilentus Parshley, which feeds on the herb Polymnia canadensis; this bug inhabits deep, shady woods, to which its host is also confined.

We have found collecting of mirids infesting trees and shrubs especially profitable in the Jo Daviess hills, fig. $3 A$, in extreme northwestern Illinois, and in the Ozark hills, fig. $3 H$, in extreme southern Illinois. The Jo Daviess hills are forested and rolling, contain species of Crataegus not found farther south and support a flora more varied in nature than most other Illinois areas.

The Ozark hills of southern Illinois are a continuation of the Ozarkian uplift of Oklahoma, Arkansas and Missouri, and have many species of trees, shrubs and herbs that are much more luxuriant there than in other Illinois areas. These species include such forms as alder, red cedar and cane.

Wooded glens especially profitable for mirid collecting occur in several places near the eastern border of the state, fig. $3 G$.

\section{Grass and Marsh Mirids}

Certain groups of Miridae, notably the subfamily Mirinae, feed on grasses and some of the sedges and rushes. Some of these

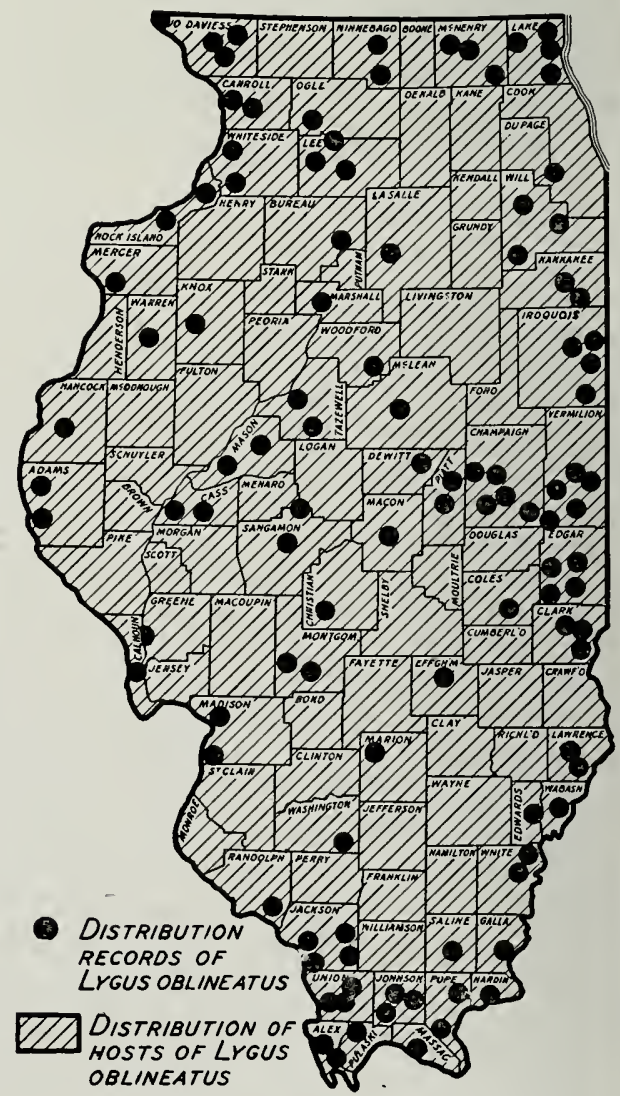

Fig. 11.-Map of Illinois showing distribution of the tarnished plant bug, Lygus oblineatus, which feeds on a wide variety of plants. 


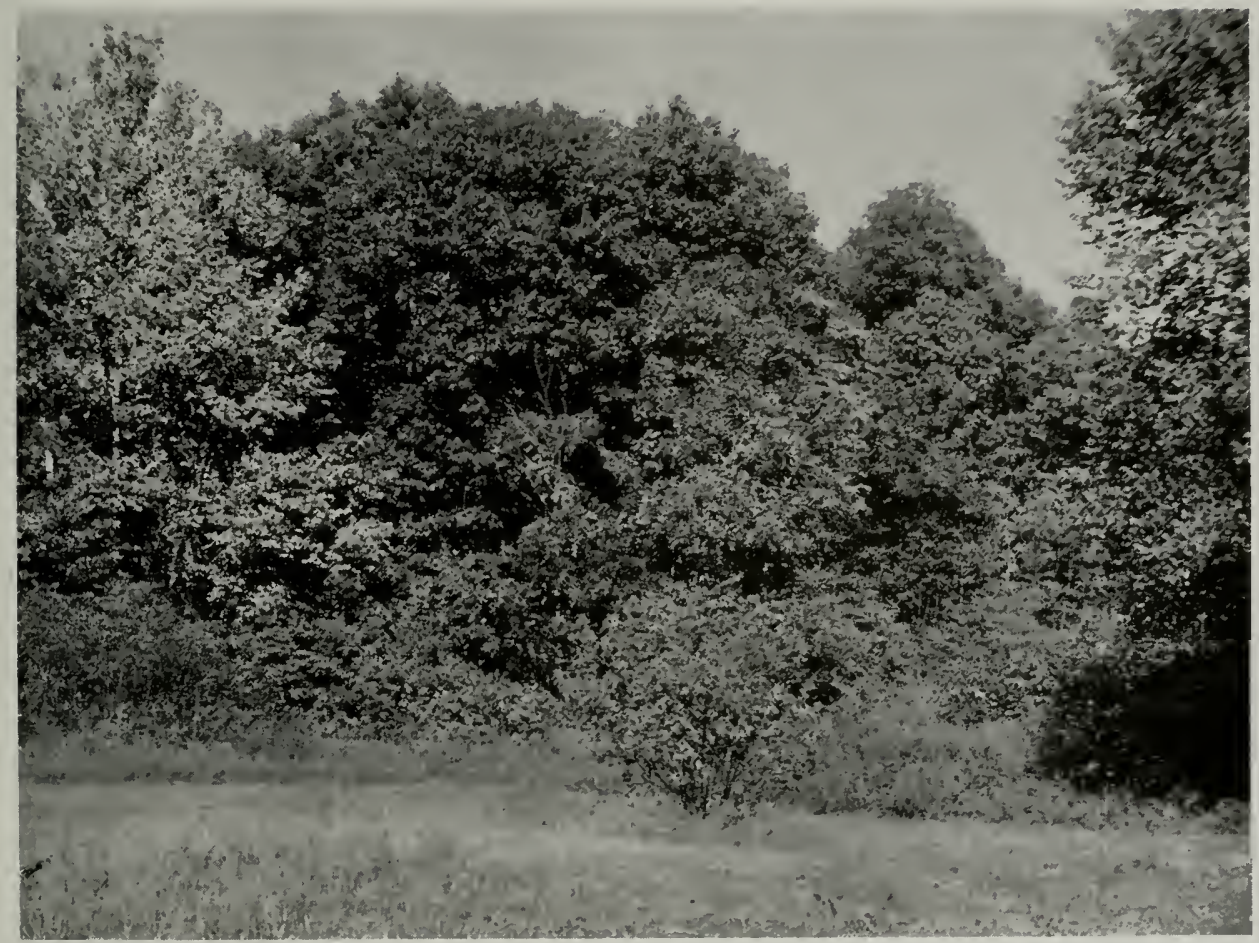

Fig. 12.-Forest edge near Charleston, Ill. Places such as this, with a large variety of trees and shrubs growing near the forest edge, offer good collecting for many species of Miridae.

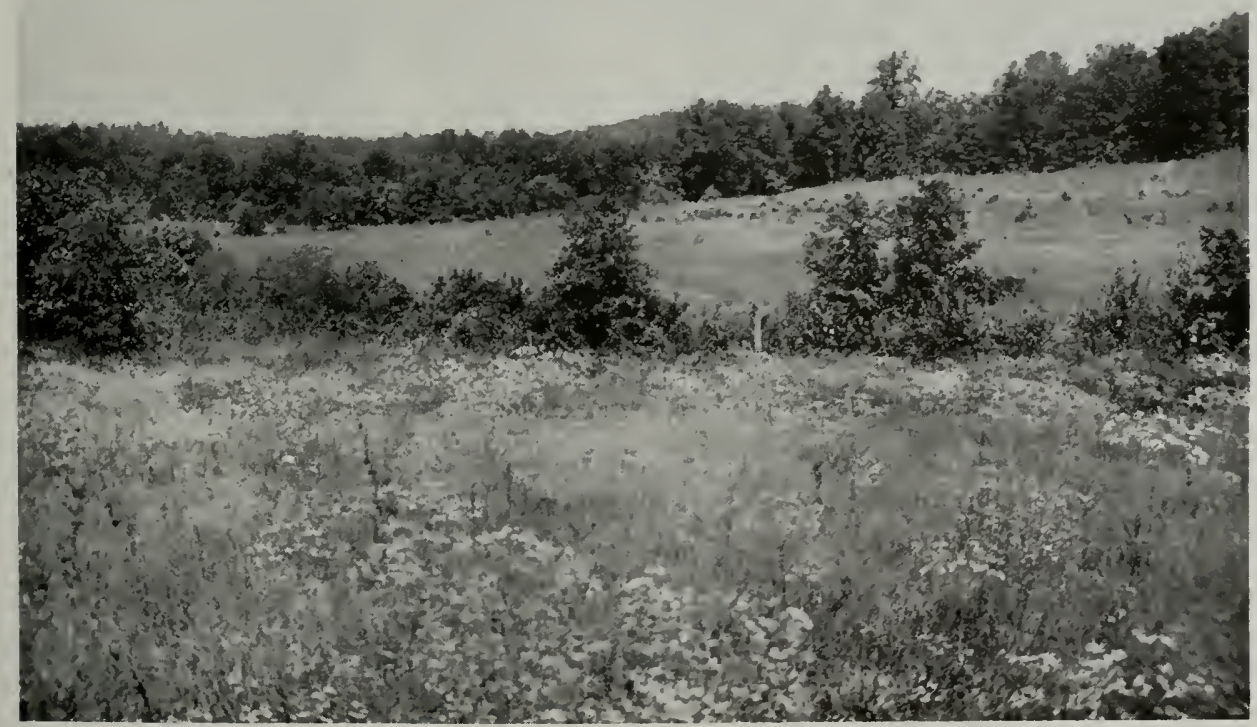

Fig. 13.-Meadows and rolling hills near Herod, III. Fencerows, forest edge and meadows combine in many localities in the Ozark hills to give excellent mirid collecting. Several species, such as Plagiognathus gleditsiae and Lepidopsallus nyssae, known previously only from Gulf Coast states, have been rollected in the Illinois Ozarks. Other species, typically northern in distribution, have been collected in this state only in the Ozark hills. 
species, such as Miris dolabratus (Linnaeus) are widely distributed and feed only on grasses. The range of such species extends over most of the state.

Other plant bugs of this subfamily feed on sedges and rushes, as for example, Mimoceps insignis Uhler and Teratocoris discolor Uhler, and these are restricted to such local areas as have marsh conditions.

In the bog region of northeastern Illinois, we have many marshes which are excellent collecting grounds for these mirids. While these mirids are not restricted to this region, they are found there more frequently and in greater abundance than in other localities of the state. The sand area along the shore of Lake Michigan combines a great variety of grass, sedge and rush species, and offers excellent collecting for some of the rarer Mirinae.

\section{Widely Distributed Species}

A number of favorite plant bug hosts grow in almost every locality in Illinois, and include such familiar forms as ragweeds, cocklebur, willows and some of the grasses. In this category are a large number of weeds, herbs and shrubs. Many of the Mir- idae feeding on these hosts have an equally wide distribution: Lygus oblineatus (Say), feeding on a great variety of herbs and shrubs; Reuteroscopus sulphureus (Reuter), feeding on the cut-leaf ragweeds ( $A$ mbrosia spp.) ; Ilnacora stalii Reuter, feeding on cocklebur; and many others. The distribution map of L. oblineatus, fig. 11 , shows the wide distribution of this species and serves as a check map for comparing the distribution of other Miridae.

\section{Collecting Notes}

It will be seen from the above that the Miridae inhabit practically all the plant communities in Illinois, showing a preference for areas that are borderline between prairie and forest, and that are in the developmental stages approaching the climax forest.

Profitable collecting for a large variety of plant bug species may therefore be found in the forest edge around clearings, fig. 12, or in country with fields, fencerows and woods intermingled, fig. 13. A second equally profitable type of area is that along small streams where a floodplain forest is growing. In both types of situation, many host species are concentrated in a small area.

\section{Economic Status and Control*}

The past 25 years have witnessed a decided increase in the number of Miridae that are recognized as economic pests. These are sucking insects which pierce plant tissues and feed on cell liquids, fig. 14 .

One of the Miridae of greatest economic importance in Illinois is the tarnished plant bug, Lygus oblineatus (Say). This insect causes serious damage to the peach crop. The adult insects hibernate in the fall and leave their winter quarters early in the spring. They feed on the newly set peaches just at the time when the peach petals have fallen, and they are responsible for the blemish commonly known as catfacing, fig. 15. The area surrounding each feeding puncture in the side of the peach grows very little, and on it ordinary peach fuzz does not develop. The result is that when the peach is ripe there is a bare, sunken area, sometimes as much as a half inch across, in the

*W. P. Flint, Chief Entomologist, Illinois Natural History Survey and Agricultural Experiment Station, cooperated in writing this section, supplementing it with his knowledge of economic insect control methods in Illinois over a long period of years. side of the peach. Although these blemishes do not affect the quality of the peach very much, they throw the fruit out of grade. In certain years as much as 7 to 8 per cent of all peach fruit in an orchard is affected.

Dusting with very fine sulfur at the time petals are falling has shown some benefits in peach orchards.

This insect also feeds on the new shoots of nursery stock, causing what is called "stopback" or "dieback." It injures a number of fruits by feeding on the buds. The feeding punctures of this species may cause malformation in the flowering buds of asters and strawberries. In orchards the insect may attack the buds and young fruits of apples and peaches. It also feeds on beet, chard, celery, bean, potato, cabbage, cauliflower, turnip, salsify, cucumber, cotton, tobacco, alfalfa, many flowering plants, and most deciduous and small fruits-more than 50 economic plants, besides many weeds and grasses.

The tarnished plant bug is such a general feeder and so widely distributed, and is at 
the same time such an active insect, that no satisfactory method of control has been developed.

The garden flea hopper, Halticus bracteatus (Say), is a pest of considerable importance on white clover and other leguminous crops in Illinois. In Missouri, it sometimes destroys garden bean crops completely. In South Carolina and neighboring states this tiny bug occasionally destroys 50 to 60 per cent of the alfalfa crop.

The cotton flea hopper, Psallus seriatus (Reuter), is a serious pest of cotton, more important in Texas, Oklahoma, Georgia and South Carolina than in Illinois. In some years it is reported as causing greater losses than the boll weevil. Both nymphs and adults of this flea hopper feed on the tiny flower buds of cotton, causing them to drop; the feeding habits of the bugs may also cause the plant to grow tall and spindly, resulting in a light set of cotton squares. This insect may be controlled in cotton fields by fine sulfur dusts. Almost complete freedom from damage may be obtained by the use of these materials. The abundance of this insect is dependent on certain ecological factors, particularly any condition that favors abundant growth of the wild hosts, the various species of Croton.

The apple redbug, Lygidea mendax Reuter, a potential pest of apples in Illinois, has not yet been found in this state. In parts of the East it is very abundant. Its feeding causes dents or dimples in the apple, and areas of hardened tissue which throw the fruit out of grade. It also damages the apple crop by feeding on small fruit, causing excessive shedding of the apples, with scars and malformed fruit if growth continues. Some infested orchards have had at picking time 25 to 30 per cent of the fruits culled out as a result of malformations caused by the redbug.

This species is easily controlled by adding nicotine sulfate to the pink bud spray or by nicotine dusts, since the nymphs are delicate and very sensitive to these materials, but in Illinois it is not now necessary to put on an application for their control.

The four-lined plant bug, Poecilocapsus lineatus (Fabricius), attacks many cultivated plants, such as currant, gooseberry, parsnip, mint and some other truck crops, as well as dahlia and rose. In Illinois, it fluctuates greatly in abundance. In certain years it pays to apply a nicotine dust for its control.
The bright red nymphs puncture leaves and tender shoots, sucking sap; every puncture produces a reddish spot, the leaves curling as the growth of the plant is checked.

The pear plant bug, Neolygus communis Knight, may leave its natural host, dogwood (Cornus sp.), and colonize on pear trees. The nymphs feed on the small pears, causing

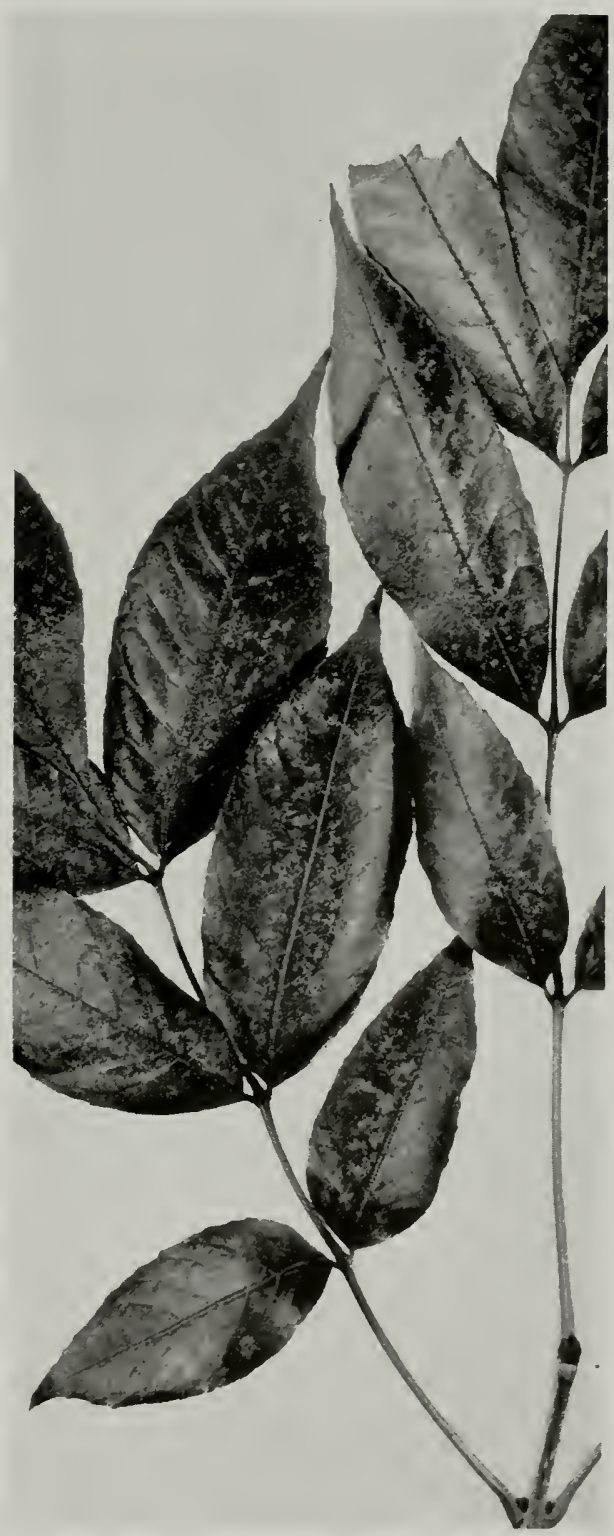

Fig. 14.-Mirid injury. White spots on leaves of ash (Fraxinus sp.) are feeding punctures of plant bugs, in this case Neoborus amoenus. This type of injury is typical of most mirid feeding. 
knotty, malformed fruit. Although the Illinois pear crop is not of great commercial importance, the insect causes an appreciable amount of damage. As is the case with the tance on cultivated onions in Illinois, but in other states it often becomes so abundant on Bermuda onions that the plants are killed before growth is completed. It is very com-

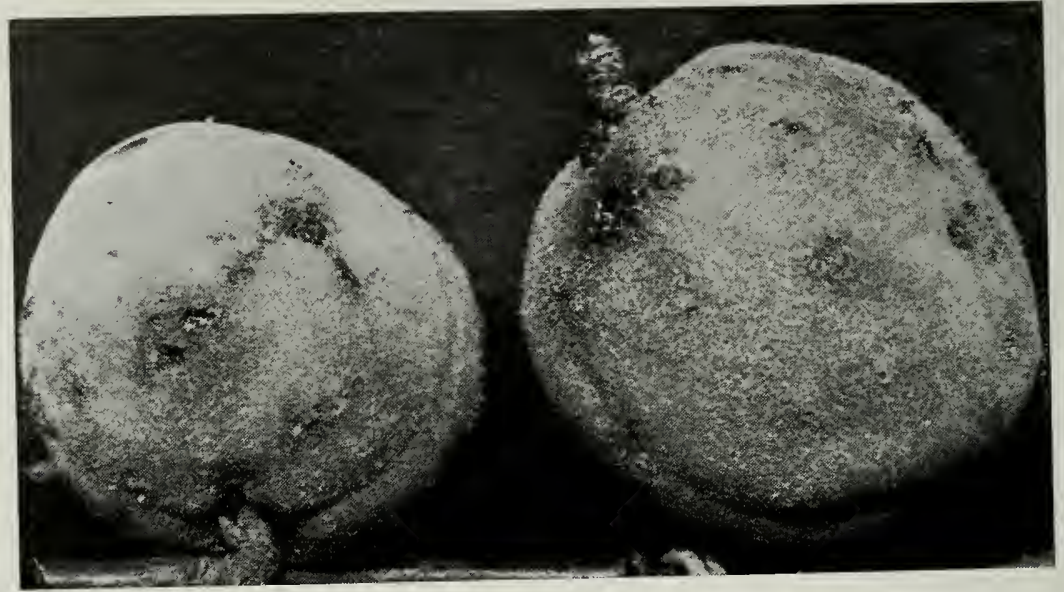

Fig. 15--Mirid injury. Catfacing of peaches caused by Lygus oblineatus. A similar type of injury by plant bugs is common in various fruits in Illinois.

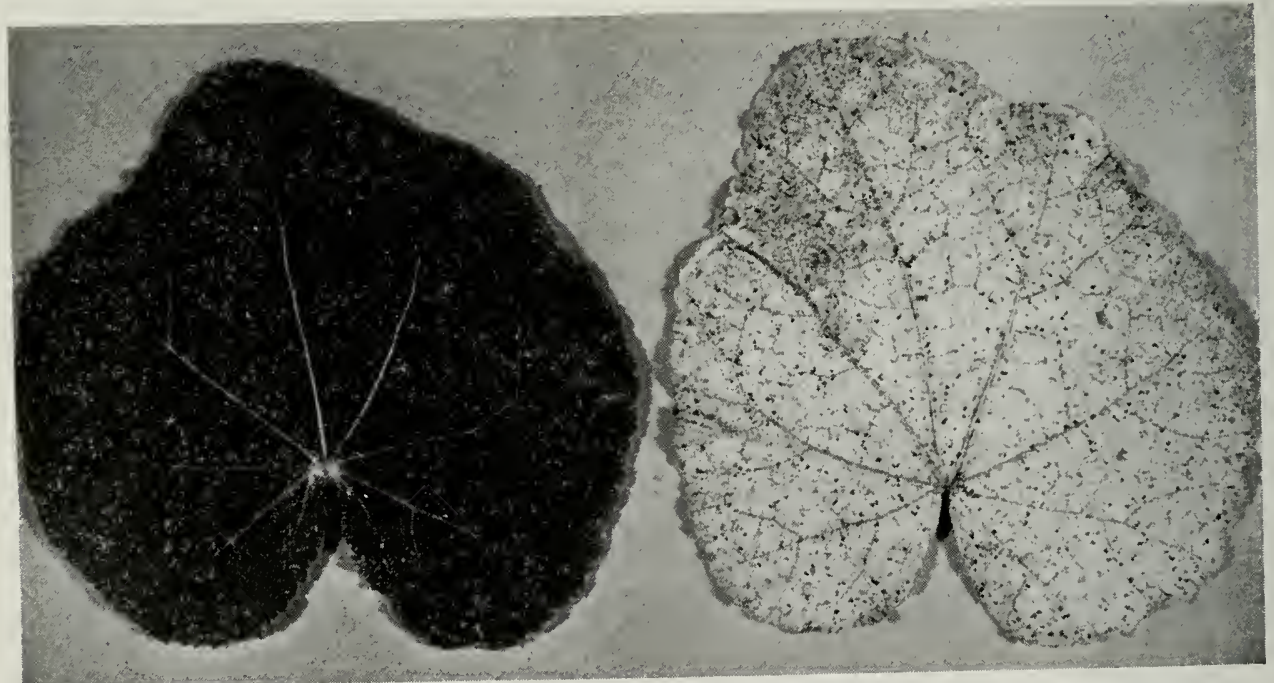

Fig. 16.-Mirid injury. Extreme injury to hollyhock foliage by the plant bugs Melanotrichus Falticus bracteatus. Note in leaf at right almost complete etiolation or destruction of green coloring matter, caused by feeding of these bugs. Similar damage frequently occurs on grasses, onions, phlox, clover and other plants by various mirid species.

tarnished plant bug, no really satisfactory method of control under Illinois conditions has been developed.

Brittain (1917) describes serious injury to apples in Nova Scotia by the green apple bug, Neolygus communis var. novascotiensis Knight.

The onion plant bug, Labopidea allii Knight, is not usually of any great impor- mon on wild onions and wild garlic, but perhaps may be considered a beneficial insect in this respect rather than a plant pest.

The phlox plant bug, Lopidea davisi Knight, breeds on wild phlox but is often found colonizing on cultivated phlox and causing serious injury to these ornamental plants. The bug can be controlled by the use of a nicotine spray or dust, or by pyrethrum 
sprays or dusts. It is an insect that should be looked for every year.

The hickory plant bug, Neolygus caryae Knight, may migrate from its natural host to peach trees, where the adults puncture and suck sap from the young fruit. It causes some injury to peaches, which is similar to that of the tarnished plant bug. Serious damage by this insect has been reported from New York and Ohio.

In several western states the legume bug, Lygus hesperus Knight, causes considerable loss in alfalfa seed due to puncturing and feeding by the bugs on the flower buds. The pale legume bug, L. elisus Van Duzee, does similar damage, but in most localities this species is outnumbered by L. hesperus. In the upper Mississippi River valley the alfalfa plant bug, Adelphocoris lineolatus (Goeze), is extremely abundant on alfalfa and sweet clover and may prove to be a pest where these crops are grown for seed production.

Other species of Miridae that are from time to time reported as pests are hop plant bug, Paracalocoris hawleyi Knight, on hops; hollyhock plant bug, Melanotrichus althaeae (Hussey), fig. 16; meadow plant bug, Miris dolabratus (Linnaeus), on timothy and other grasses; and the rapid plant bug, Adelphocoris rapidus (Say), on cotton in the South.

\section{Taxonomy}

The Miridae are distinguished by foursegmented antennae, a four-segmented rostrum of which the first segment is as long as or longer than the head, three-segmented tarsi (except Peritropis in which they are two-segmented), wing membrane with only two cells or areoles, one longitudinal vein (anal vein), a well-developed cuneus on the wing, and by absence of ocelli, fig. 17. The four-segmented antennae are usually slender, nearly linear or the second segment only slightly thickened apically, but in a few genera strongly thickened as in Capsus, Atractotomus and Teleorhinus; third and fourth segments usually slender but in some forms distinctly thickened as in Ceratocapsus. The hemelytra are typically separated into clavus, corium, cuneus and membrane, the embolium usually not clearly separated from corium; veins of membrane forming two cells, a small and larger areole; however, in a number of species the hemelytra may be abbreviated (brachypterous), the membrane almost absent or reduced to a narrow band with veins poorly indicated. Modifications of the arolia, the pulvillaelike structures between the tarsal claws, furnish the most reliable characters for separating the subfamilies.

In general, the Miridae are small to medium in size, from 2.0 to $9.5 \mathrm{~mm}$. in length, usually rather fragile, broader than high and longer than broad; as viewed from above, ovate to oblong, but in a few genera rather slender, as in Trigonotylus. The male is usually more slender than the female. The body is variously clothed with fine hairs or pubescence, sometimes modified to form sericeous or scalelike hairs, which are easily shed; frequently the dorsum is practically glabrous and strongly shining. The numerous species exhibit the greatest variety of color patterns, ranging from the most obscure to forms that are vivid red. Color varieties within the species are frequent, and the two sexes are more often differently colored, the male usually darker colored than the female.

Brachypterous and apterous forms occur throughout the family, and individuals of a single species may exhibit variation in this respect, as in Halticus bracteatus (Say) and Miris dolabratus (Linnaeus). Usually the male is macropterous even when the female is apterous, but in rare cases the male may be apterous. Ant mimic forms are rather numerous among the Miridae, especially in species of Coquillettia, Sericophanes and Pilophorus. In such forms the abdomen is constricted at the base while the head and thorax are so modified the resemblance to ants is unmistakable. The species of Sericophanes and Coquillettia are generally found upon the ground running about among ants, but the biological relationship, if any, has not been determined. In Iowa the writer has found Sericophanes heidemanni Poppius rather abundant on the ground among short grasses and weeds of closely cropped pasture land; the bugs running about where the little brown ants, Lasius niger alienus var. americanus Emory, were very abundant. At Fort Snelling, Minnesota, in an area of little disturbed, high, prairie vegetation, particularly among the shorter grasses, the writer found and collected a large series of Coquil. 


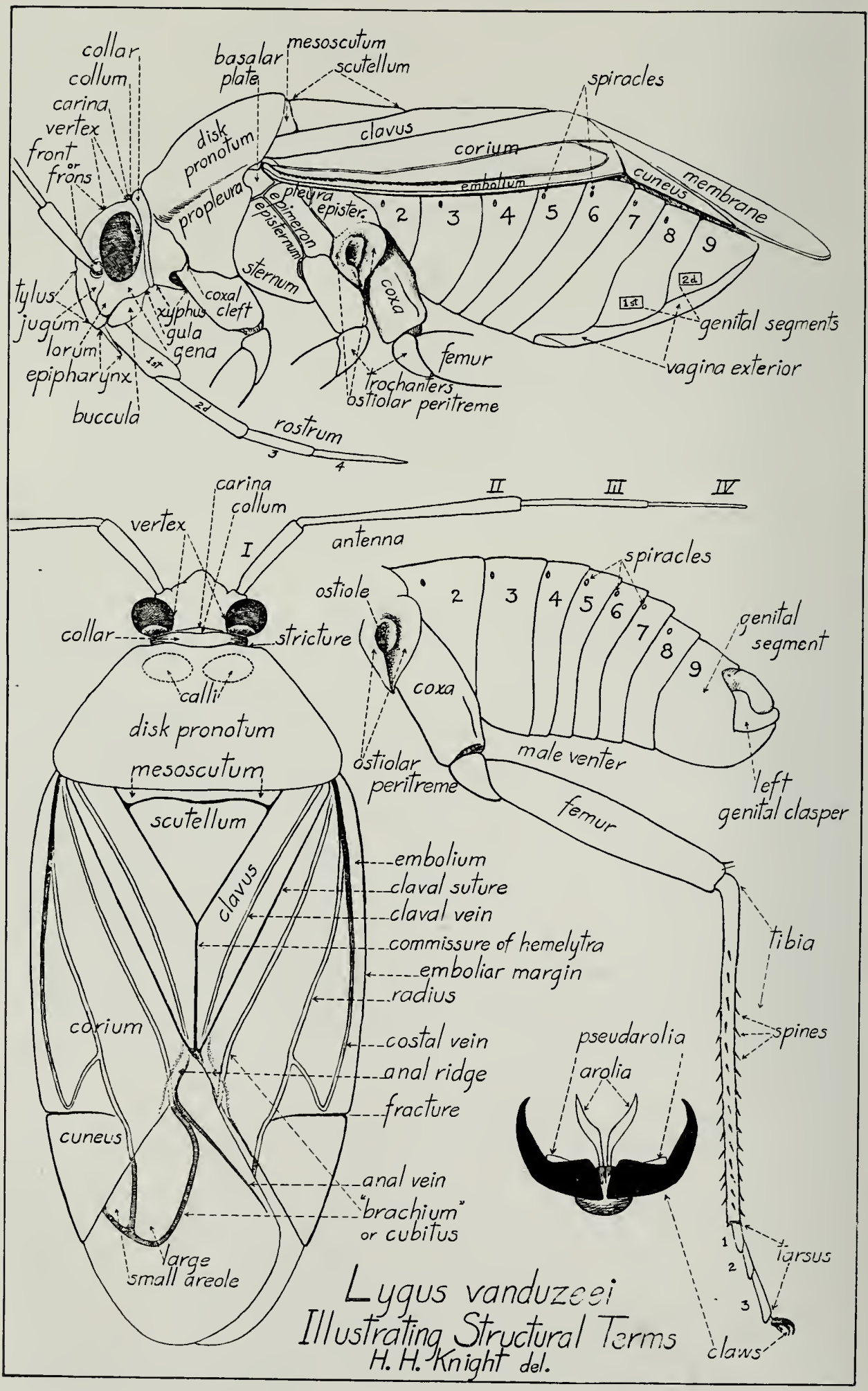

Fig. 17.-Lygus vanduzeei, showing typical mirid structures and illustrating structural terms. 
lettia amoena (Uhler) from an area which abounded with the ant, Formica (Neoformica) pallide-fulva var. incerta Emory. The wingless females so resemble this ant in form and color that one must look rather closely to separate them. Miridae of the above species of Sericophanes and Coquillettia are extremely agile and very rapid of movement, especially when they happen to meet face to face with ants. While they seem not to fear the ants, they appear to avoid close contact with them.

\section{Systematic Characters}

The most important character for separation of subfamilies is found in the structure of the arolia, situated between and at the base of claws, fig. 17. In the subfamilies Phylinae and Deraeocorinae the arolia are represented by a pair of erect bristles that are difficult to see in the smaller species. The arolia are erect and well developed in the Orthotylinae, Mirinae and Capsinae; arolia converging at tips in Orthotylinae and diverging apically in the Mirinae and Capsinae. Pseudarolia are clear to white in color and occur on inner curvature of claw near base. The pseudarolia are found in the Phylinae but are larger and more prominent in the Dicyphinae and Bryocorinae.

The form of the male genital segment is rather distinctive in the subfamily Phylinae; the genital claspers are relatively small, with tip of right clasper resting in a notch across the middle of the $V$-shaped left clasper; both oedagus and claspers are twisted somewhat to the left side. The author believes this particular form of genital segment is a fundamental character of this subfamily. In other subfamilies the male genital segment often presents good characters for the separation of genera as well as species. Specific differences are more likely to be found in the male claspers, which are asymmetrical in form and differ among the species in many genera. It is fortunate that in several of the largest genera the numerous species may be identified by the form of the genital claspers, as in Phytocoris, Neo!ygus, Lopidea, Orthotylus, Ceratozapsus and Deraeocoris. On the other hand, in several sizable genera such as Paraca!ocoris, Neurocolpus and Neoborus the male genital claspers appear to be of little value for distinguishing species. Fortunately, in Paracalocoris and Neurocolpus the length of antennal segments and form of pubescence offer very good characters for separating species. Thus it appears that a particular set of characters may not have equal value throughout the family.

Among the Miridae, pubescence often provides useful characters; it varies from simple, fine hairs, erect or recumbent, to silky, slightly curled pubescence, or even flattened, scalelike hairs. The scalelike pubescence found on several species of Phytocoris and in the genus Halticus is easily shed or lost; hence specimens should be collected and preserved with great care.

The shape of the head and thorax is much used for generic characters; minor differences may indicate species. The length of the rostrum may be of generic value but more frequently it differs among the species and may form good distinctions, as in $\mathrm{Po-}$ lymerus and Lygus. The antennae are generally linear in form with the last two segments very slender. However, some genera may be separated by the exceptional form of the different segments; the second segment is strongly thickened in Capsus, Atractotomus and Teleorhinus; the third and fourth segments are usually slender, but in some genera, as Ceratocapsus, they are distinctly thickened.

\section{Phylogeny}

Nine subfamilies of Miridae are recognized from North America and all of them are found in the state of Illinois. The

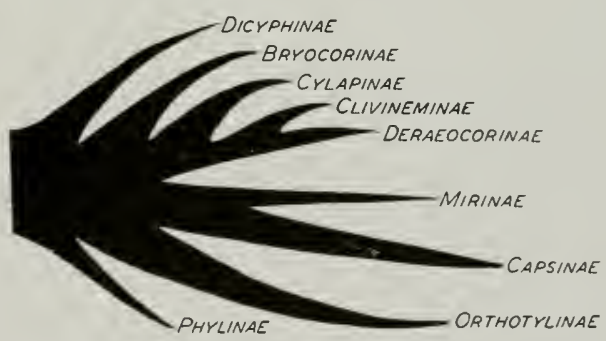

Fig. 18.-Genealogical tree showing relationship of mirid subfamilies.

phylogeny of these subfamilies does not present a linear series of development, but more of a progression upward in several directions, which perhaps may best be represented by a genealogical tree, fig. 18, to express the relationships within the family. These relationships are based on the following characters, which are listed in the order of their relative importance: (1) arolia, (2) 
genital structures, (3) biology, (4) modifications of the thorax.

The position and height of the tree branches indicate the evolutionary relationships of the subfamilies, while the width of the branches indicates the relative number of species. For instance the Mirinae are highly developed structurally but very old and decadent in number of species; the genera and species are few in number but most of them are very widely distributed. The host plants of the Mirinae are confined to the grasses and sedges, families that are among the oldest and most widely distributed plant groups. On the other hand the Capsinae are more recent in development, structurally more specialized with arolia and genital structures highly developed; the species are very abundant, often limited in distribution, and for host plants utilize all the more recent plant families. Species of the subfamily Orthotylinae resemble the Phylinae most by absence of the thoracic collar, but the erect incurved arolia come nearest in form to the Capsinae; the genital claspers are highly modified and specialized.

\section{Present Holders of Material: Symbols}

If not otherwise noted the material listed in this paper belongs to the Illinois Natural History Survey. Material in the collections of other institutions or individuals is so designated by the use of the following symbols.

FM-Field Museum of Natural History, Chicago, Ill.

Kc-Knight Collection, Iowa State College, Ames, Iowa.

UI-University of Illinois, Urbana, Ill.

UsNM-United States National Museum, Washington, D. C.

\section{Measurements and Records}

Measurements given in this paper, e.g., "length 5.80 , width 2.48 ," are uniformly in millimeters. These are standard with other literature on insect taxonomy.

In any previously described species in which more than 10 Illinois records are available, the places are listed and the dates summarized.

\section{Tarsal Claw Key Characters}

The student wishing to identify Miridae should acquaint himself with the structures of the tarsal claws. These claws are used in identifying most of our forms to subfamily and sometimes to genus. It is highly desirable that the student examine a selection of different kinds of mirids to acquaint himself with the various conditions of the arolia and pseudarolia on the tarsal claws.

The claws are best examined at high magnifications against a dark background. If possible, it is well to examine them with both compound microscope and stereoscopic binocular.

The tarsal claws are situated at the extreme end of the third tarsal segment, fig. 23. The simplest type is shown in fig. 24 , which has a pair of hairlike arolia arising from the area between the base of the claws. In some groups, these arolia are membranous and thickened; in such cases, they are either convergent at apex, fig. 25, or divergent at apex, fig. 26. These two membranous types are generaly readily visible without any doubt as to their structure. ln other groups are cushionlike or flaplike membranous areas called pseudarolia attached to the claw itself. These may be very small; they may be present in instances where the arolia are either hairlike or membranous. In Illinois species, they are never large if the arolia are membranous. Among the species in which the arolia are hairlike, these pseudarolia are often quite large. Fig. 27 shows an example in which the pseudarolia are large and joined to the claw over a large surface; figs. 28 and 29 illustrate an example in which the pseudarolia are flaplike and attached to the claw only at its base. 


\section{KEY TO SUBFAMILIES}

1. Scutellum with a dorsal projection, figs. $137,181 \ldots \ldots \ldots \ldots \ldots \ldots 2$

Scutellum without a dorsal projection. 3

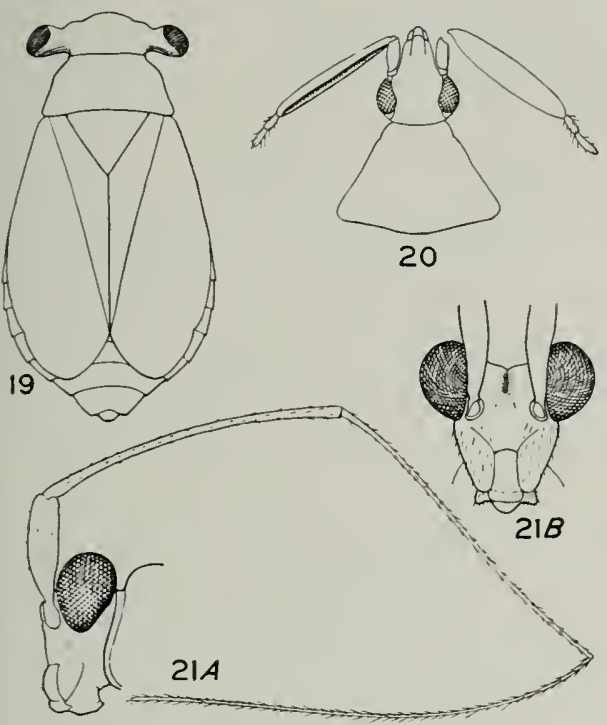

Fig. 19.- - Head and body of Labops hirtus.

Fig. 20.- Head and pronotum of Hesperophylum heidemanni showing dorsal view of antenna at left, anterior flat view at right.

Fig. 21.- Head of Cylapus tenuicornis: $A$, lateral view; $B$, dorsal view.

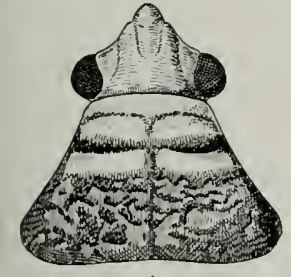

A

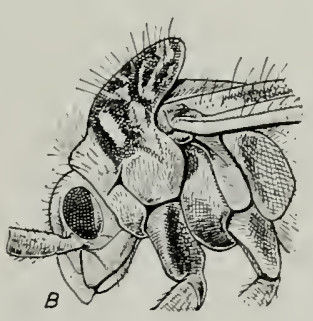

Fig. 22.- Head and pronotum of Semium hirtum: $A$, dorsal view; $B$, lateral view.

2. Pronotum with anterior half flat, posterior half swollen, fig. 181 (Barberiella, p. 209) . . . Capsinae, p. 131

Pronotum with only anterior fifth flat, posterior four-fifths forming a high, swollen area, fig. 137 (Cyrtopeltocoris, p. 117) ....... Orthotylinae, p. 74

3. Eyres attached to a stalk formed by a round lateral projection of head; head very wide and short, fig. 19

Labopini, p. 81
Eyes not stalked, figs. 20, 113 ... . . t

4. Eyes rising a considerable distance above dorsum of head; head deep, with a furrow down the meson and the ventral margin wide and truncate, fig. 21........Cylapini, p. 61

Eyes not rising appreciably above dorsum of head............ 5
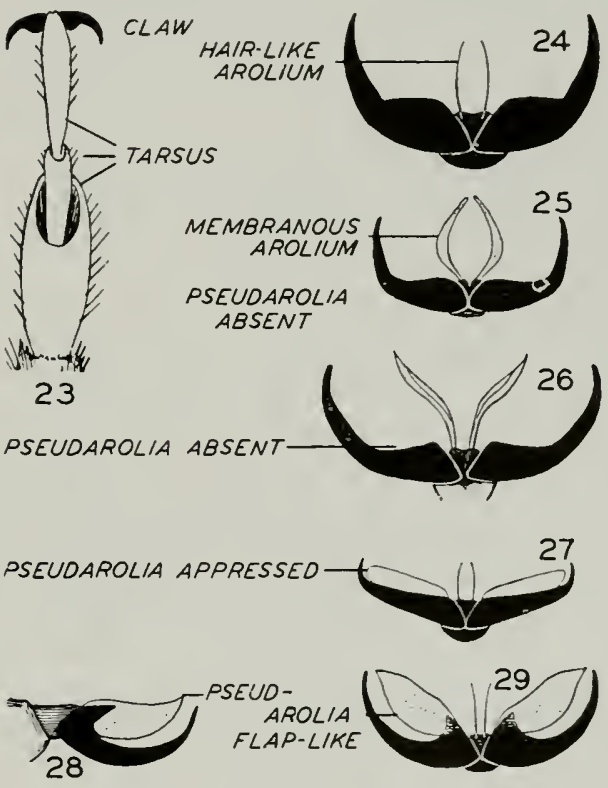

MIRID TARSAL CLAW'S

Fig. 23.-Monalocoris filicis.

Fig. 24.-Largidea davisi.

Fig. 25.-Diaphnidia pellucida.

Fig. 26.-Pithanus maerkelii.

Fig. 27.-Teleorhinus davisi.

Fig. 28.-Dicyphus agilis.

Fig. 29.-Dicyphus agilis.

5. Pronotum as in fig. 22, with anterior fourth membranous, remainder velvety and dark, with a pair of conspicuous, narrow membranous areas near anterior margin of dark portion; pleural area separated from notum by a suture (Semium, p. 75)

Orthotylinae, p. 74

Pronotum otherwise, without a pair of narrow, membranous areas on a velvety area; seldom with a suture separating pleural areas and notum . 6

6. Antennae with second segment bilaterally compressed, foliaceous, nearly 
three times as high as wide, and black; third and fourth segments very short, fig. 20 (Hesperophylum, p. 19) . . . . . . Deraeocorinae, p. 64

Antennae with second segment cylindrical or almost so, or third segment three-fourths as long as second, fig. $92 \ldots \ldots \ldots \ldots \ldots \ldots \ldots$

7. Tarsal claws with only a pair of straight hairs between them, figs. 30-41, sometimes also with a small, inconspicuous, membranous area appressed to inner margin of claw, figs. 38$41 \ldots \ldots \ldots \ldots \ldots \ldots \ldots \ldots \ldots$

Tarsal claws with a pair of prominent, whitish, membranous lobes between them; these lobes either curved and fingerlike, figs. 54-67, or flaplike, figs. $42-53 \ldots \ldots \ldots \ldots \ldots \ldots$. 8

8. Tarsal claws with membranous lobes fingerlike and arising from between bases of claws (true arolia); these either divergent, figs. 63-67, or convergent, figs. 54-62, at apex. ...... . 9

Tarsal claws with membranous lobes flaplike (pseudarolia), arising from inner margin of claw itself, figs. 4253; frequently hooked to form a recess from which the pseudarolia appear to arise, fig. $52 \ldots \ldots \ldots 18$

9. Arolia convergent at apex, figs. 54-62.

Orthotylinae, p. 74

Arolia divergent at apex, figs. $63-67 \ldots 10$

10. Pronotum with a prominent ridge running from the postero-lateral corner of the pronotum almost to the anterior corner, fig. 69; and with pleural suture situated some distance from anterior margin and terminating under ridge......... Mirinae, p. 124

Pronotum with this ridge either absent or represented for only a short distance......................11

11. Posterior portion of head elongate, fig. 143 , so that the eyes are situated their own length from pronotum (Collaria, p. 126)...Mirinae, p. 124

Posterior portion of head short so that the eyes almost touch or do touch the pronotum, fig. $154 \ldots \ldots 12$

12. Pronotum markedly widest at posterior margin, figs. 155, 180; hemelytra with corium and cuneus distinctly defined as sclerotized areas and set off from the apical membrane......

.Capsinae, p. 131
Pronotum swollen at middle, this portion as wide as or wider than hind margin, fig. 142; hemelytra with corium and cuneus merging so imperceptibly with the membrane, which is partially sclerotized, that there is no line of distinction between them; includes both macropterous and brachypterous forms.........

Mirinae, p. 124

13. Calli greatly enlarged into a pair of broad humps occupying the anterior two-thirds of the central area of the pronotum, fig. 68 .... Fulviini, p. 61

Calli much smaller, fig. 70; pronotum not humped anteriorly, but usually considerably humped posteriorly. . 14

14. Anterior margin of pronotum with a distinct, even, ringlike collar set off by a definite, deep groove, fig. 70 . 15

Anterior margin of pronotum without a ringlike collar, fig. 77 ; at most with a flattened area, fig. $78 \ldots \ldots 17$

15. Pronotum narrowed to a distinctly necklike anterior portion; head narrowed posteriorly and appearing stalked; hemelytra colorless, transparent and glassy with a $\mathbf{Y}$-shaped red or fuscous mark, fig. 98 (Hyaliodes, p. 57)....... Dicyphinae, p. 52

Pronotum not greatly narrowed anteriorly, figs. 70, 71; head sometimes narrowed posteriorly but not stalked, fig. 71; hemelytra not colorless and glassy................. 16

16. Eyes distinctly removed from posterior margin of head, fig. 71 ; pronotum with calli represented by a smooth, depressed shining area forming a second "collar," fig. 71 . .

Clivinemini, p. 64

Eyes bordering on posterior margin of head, figs. 70, 105; pronotum with calli not depressed below level of adjacent area of pronotum........

Deraeocorinae, p. 64

17. Anterior portion of pronotum set off by a dark, impressed line running from antero-lateral corner to posterior margin of calli, fig. 72 .

Largideini, p. 63

Anterior portion of pronotum without such a line, figs. $77,79 . \therefore$

Phylinae, p. 22

18. Dorsal outline almost circular, fig. 99 , and pronotum with narrow, ringlike 

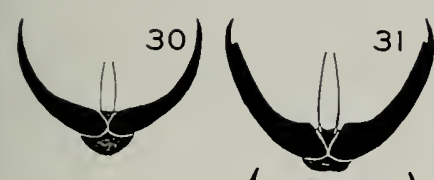

$\left(\begin{array}{c}33 \\ 1^{3}\end{array}\right)$
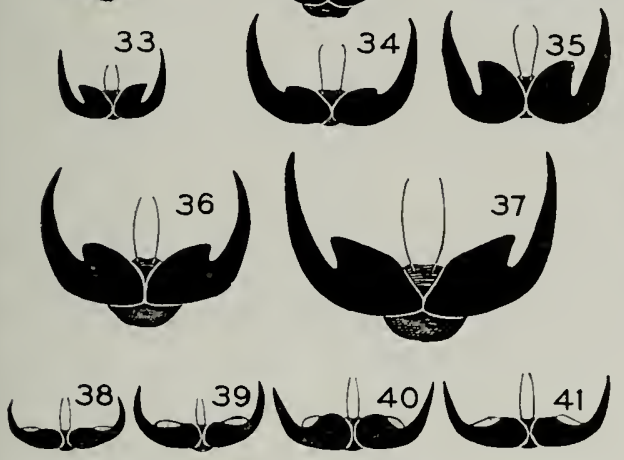
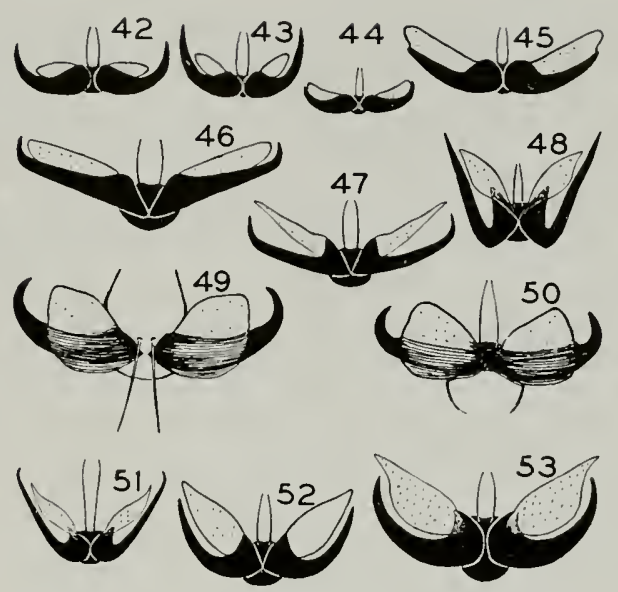

MIRID TARSAL CLAWS

Fig. 30.-Fulvius brunneus.

Fig. 31.-Cylapus tenuicornis.

Fig. 32.- Hyaliodes vitripennis.

Fig. 33.-Deraeocoris nebulosus.

Fig. 34.-Deraeocoris pinicola.

Fig. 35.-Deraeocoris ruter.

Fig. 36.-Eurychilopterella luridula.

Fig. 37.-Eustictus venatorius.

Fig. 38.-Microphylellus modestus.

Fig. 39.-Psallus ancorifer.

Fig. 40.-Rhinocapsus vanduzeei.

Fig. 41.-Criocoris saliens.
Fig. 42.-Microsynamma bohemanni.

Fig. 43.- Reuteroscopus ornatus.

Fig. 44.-Chlamydatus associatus.

Fig. 45.- Lopus decolor.

Fig. 46.-Orectoderus obliquus.

Fig. 47.- Coquillettia mimeica.

Fig. 48.-Dicyphus famelicus.

Fig. 49.-Pycnoderes dilatatus.

Fig. 50.-Sixeonotus insigris.

Fig. 51.-Dicyphus discrepans.

Fig. 52.-Macrotylus sexguttatus.

Fig. 53.-Macrolophus separatus.
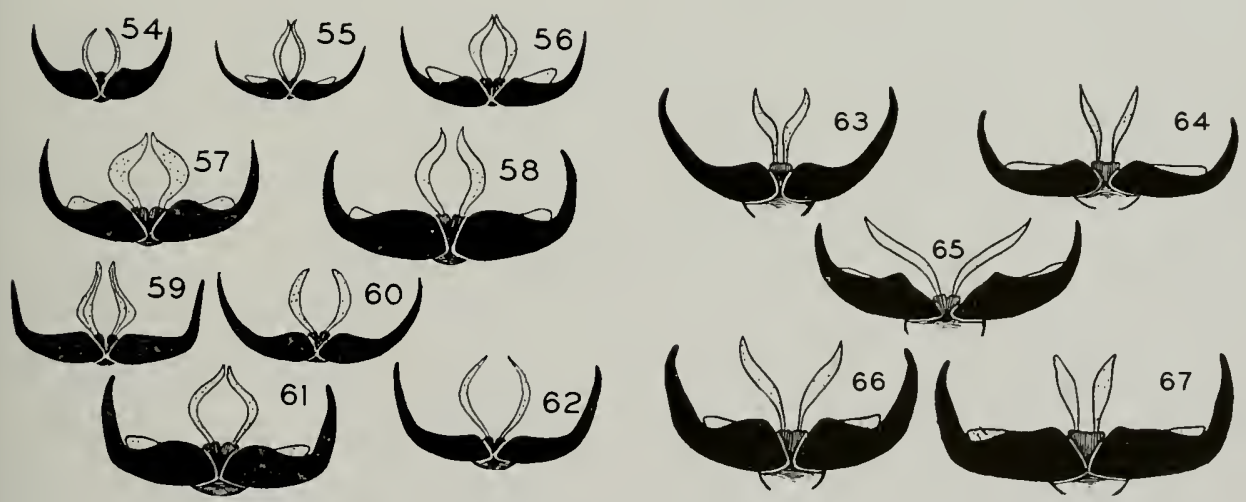

MIRID TARSAL CLAIIS

Fig. 54.- Parthenicus vaccini.

Fig. 55.- Halticus bracteatus.

Fig. 56.- Halticus intermedius.

Fig. 57.-Strongylocoris stygicus.

Fig. 58.- Heterocordylus malinus.

Fig. 59.-Ceratocapsus modestus.

Fig. 60.-Labops hirtus.
Fig. 61.-Ilnacora malina.

Fig. 62.-Orthotylus flavosparsus.

Fig. 63.- Stenodema trispinosum.

Fig. 64.-Phytocoris lasioneris.

Fig. 65.- Barberiella apicalis.

Fig. 66.-Lygus vanduzeei.

Fig. 67.-Platylylellus insitivus. 
collar well marked, fig. 73 (Monalocoris, p. 58)...... Bryocorinae, p. 58

Either dorsal outline much more elongate, fig. 97 , or pronotal collar absent, fig. $77 \ldots \ldots \ldots \ldots \ldots \ldots$

19. Tibiae without spines, only hair. Short, robust species, figs. 100 , 101, with the pronotum greatly swollen posteriorly and the areole demarked by a single, angulate, thick vein (Sixeonotus, p. 59, and Pycnoderes, p. 60)

Bryocorinae, p. 58

Tibiae with spines which project beyond hair, fig. 17; either more elongate, slender species, fig. 97; or pronotum only moderately enlarged posteriorly, fig. 87; or areole divided into large and small parts, fig. 17 . . 20

20. Pronotum wide, without collar or collarlike area, figs. $77,87 \ldots \ldots \ldots$.

$\ldots \ldots \ldots \ldots$ Phylinae, p. 22

Pronotum narrower, anterior portion somewhat necklike, with a collar or collarlike flat area, figs. $78,97 \ldots 21$

21. Hind tarsi very long and slender, fig. 74 ; second segment very long, claws small. . .

Dicyphinae, p. 52

Hind tarsi stouter, figs. 75, 76; second segment not much longer than third. 22

22. Hind tibiae with a few black spines at apex, fig. 76; tarsal segments robust; tarsal claws long, figs. 46,47 , sharply curved at extreme apex..........

Phylinae, p. 22

Hind tibiae with no black spines at apex, fig. 75; tarsal segments bilaterally compressed; tarsal claws short, figs. 52, 53, evenly curved from base

Dicyphinae, p. 52

\section{PHYLINAE}

\section{KEY TO GENERA}

1. Pronotum nearly triangular with a more or less flattened apical collar, but this collar not set off from disk of pronotum by a distinct carina, fig. 78; abdomen usually constricted at base, as in fig. $136 \ldots \ldots \ldots 2$

Pronotum wider without a flattened apical collar, figs. 77-79; abdomen never constricted at base........ 4

2. Second antennal segment strikingly clavate, its thickness at apex more than twice that at base; beak reach- ing almost to hind coxae; hemelytra fully developed in both sexes... ............. Teleorhinus, p. 52

Second antennal segment linear or slightly thickened at apex, fig. 80; beak reaching middle coxae; females brachypterous or wingless....... 3

3. Second antennal segment linear; pseudarolia attached at base of claw, free apically, fig. 47; females wingless........ Coquillettia, p. 52

Second antennal segment slightly thickened at apex, fig. 80; pseudarolia completely jointed to claw, fig. 46; females brachypterous........

$\ldots \ldots \ldots \ldots$ Orectoderus, p. 52

4. Cuneus white or very light yellow, with transverse black bar across middle; membrane dark brown or black, with prominent white marginal spots, fig. 93; pseudarolia large, attached only at basal angles and extending free and parallel with claws to tips, fig. $52 \ldots \ldots \ldots \ldots \ldots$ ............Macrotylus, p. 51

Wings not marked as in fig. 93; pseudarolia large and completely united with claws, fig. 46; or pseudarolia minute or wanting, figs. $38-43 \ldots 5$

5. Vertex and pronotum bearing silvery, scalelike hairs, these hairs sometimes in tufts............. 6

Vertex and pronotum not bearing silvery, scalelike hairs.........11

6. Head transverse, front vertical, not protruding in front of antennal bases as seen from dorsal aspect...

Rhinacloa, p. 50

Head produced in front of antennal bases, fig. $89 \ldots \ldots \ldots \ldots \ldots \ldots 7$

7. Tylus sharply produced, apex acute, fig. $91 \ldots \ldots \ldots$ Criocoris, p. 49

Tylus not produced, apex blunt.... 8

8. Second antennal segment strongly thickened..... Atractotomus, p. 51

Second antennal segment linear, not thicker than first segment...... 9

9. Length of second antennal segment less than width of head across eyes

Lepidopsallus, p. 46

Length of second antennal segment greater than width of head across eyes.................. 10

10. Pseudarolia attached only at base of claw, tip free and extending to middle of claw, fig. 43; color green- 

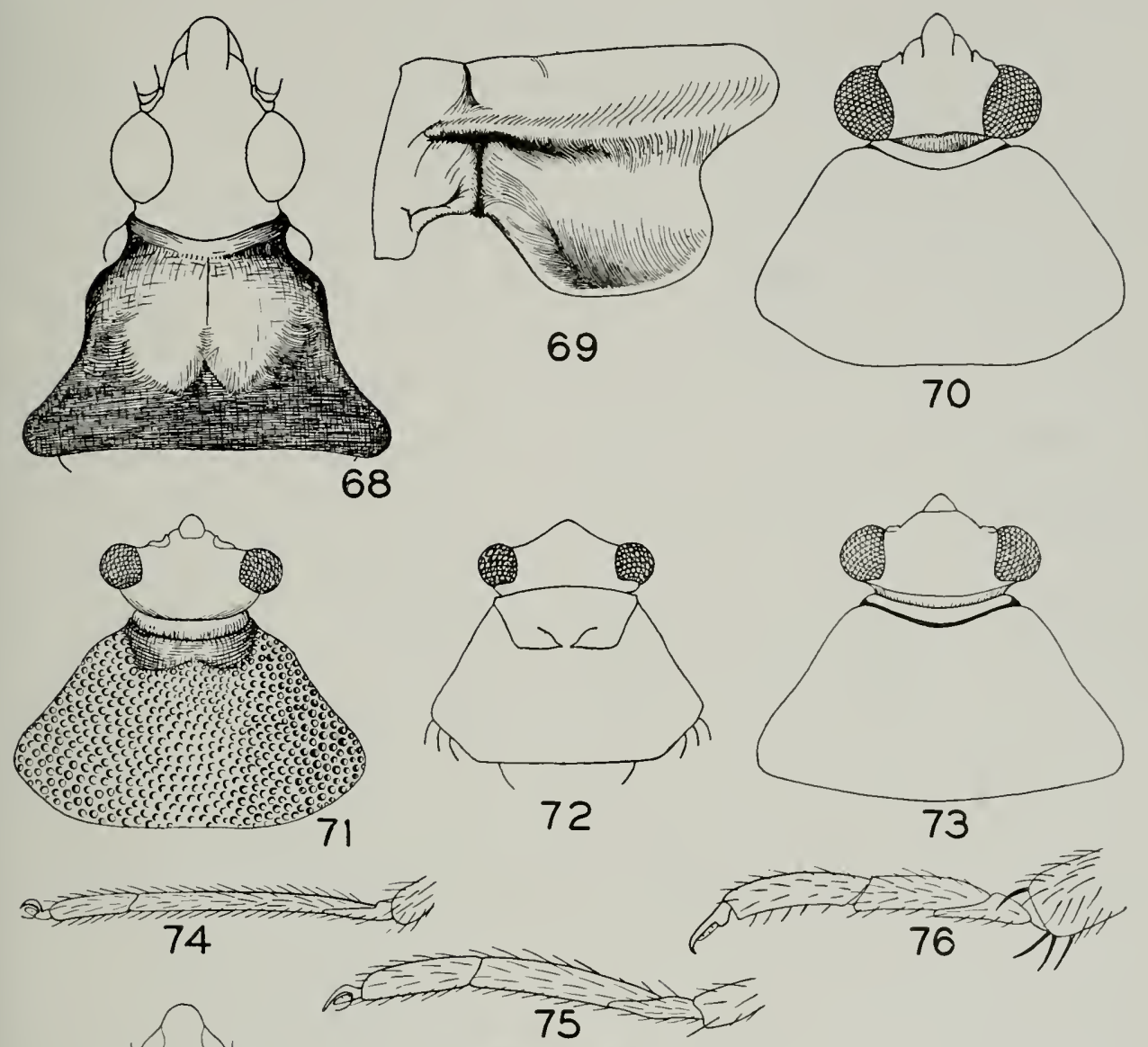

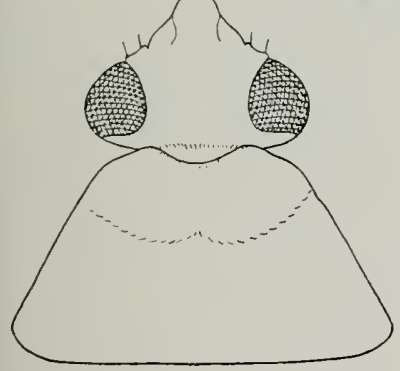

77

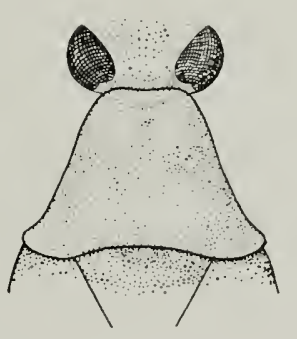

78

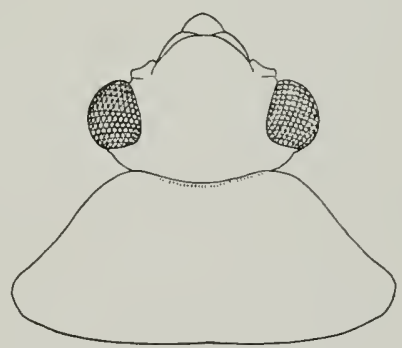

79
Fig. 68.- Head and pronotum of Fulvius brunneus.

Fig. 69.- Prothorax of Miris dolabratus, lateral aspect, showing the prominent lateral ridge characteristic of the Mirinae.

Fig. 70.-Head and pronotum of Deraeocoris nubilus.

Fig. 71.- Head and pronotum of Bothynotus modestus.

Fig. 72.- Head and pronotum of Largidea grossa.
Fig. 73.- Head and pronotum of Monalocoris filicis.

Fig. 74.-Tarsi of Macrolophus tenuicornis.

Fig. 75.-Tarsi of Dicyphus vestitus.

Fig. 76.-Tarsi of Orectoderus obliquus.

Fig. 77.- Head and pronotum of Plagiognathus albifacies.

Fig. 78.-Pronotal disk of Orectoderus obliquus, ơ.

Fig. 79.- Head and pronotum of Macrotylus amoenus. 
ish yellow, with large, well-marked, dark brown areas.............

Reuteroscopus, p. 48

Pseudarolia united with claw, fig. 39; color dark brown, or yellow with minute, darker markings........

$\ldots \ldots \ldots \ldots \ldots$ Psallus, p. 43
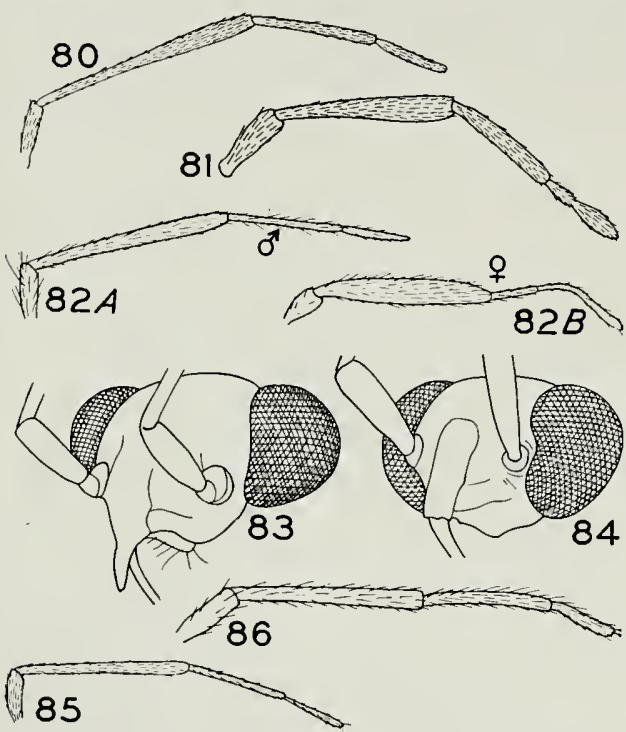

Fig. 80.-Antenna of Crectoderus obliquus, $\sigma^{7}$.

Fig. 81.-Antenna of Rhinacloa forticornis,

Fig. 82.-Antenna of Atractotomus magnicornis. $A, \sigma^{7} ; B, \%$.

Fig. 83.- Head of Microsynamma bokemanni, $\sigma^{7}$. $\sigma^{7}$.

Fig. 84.- Head of Plagiognathus blatchleyi,

Fig. 85.-Antenna of Rhinocapsus vanduzeei. tus.

Fig. 86.-Antenna of Microphylellus modes-

11. Length of second antennal segment less than width of head across eyes; in species in which the two are almost equal, hind femora not light with numerous dark spots......12

Length of second antennal segment greater than width of head across eyes; in species in which the two are almost equal, hind femora light with numerous dark spots........... 14

12. Femora light colored, with conspicuous black spots on ventral surface.

Campylomma, p. 25

Femora dark brown to black or entirely light, without dark spots. . . 13
13. Hemelytra black, with a transverse light mark extending across middie of clavus, fig. 92; male antennae with first and second segments greatly thickened, fig. $92 \ldots \ldots \ldots$. . ........... Leucopoecila, p. 50

Hemelytra uniformly dark brown to black, never with a pale mark extending across clavus; male antennae slender, scarcely thicker than in female....... Chlamydatus, p. 25

14. Pseudarolia large, projecting slightly beyond apices of claws, as in fig. 45 ; disk of prosternal xyphus depressed, and with elevated margins.......15

Pseudarolia minute, not reaching tips of claws, figs. 40, 42; disk of prosternal xyphus convex, margins not elevated..................16

15. Rostrum not extending beyond hind coxae; head only moderately, obliquely produced....... Lopus, p. 51

Rostrum extending to middle of venter; head strongly produced anteriorly...........Amblytylus, p. 51

16. Margin of compound eye well separated from antennal fossa, minimum space between the two more than one-third as great as diameter of antennal fossa; margin of compound eye near antennal fossa almost straight, fig. 83 ......... Microsynamma, p. 42

Margin of compound eye almost or quite touching antennal fossa, minimum space between the two not more than one-eighth as great as diameter of antennal fossa; margin of compound eye more or less emarginate near antennal fossa, fig. $84 \ldots \ldots \ldots \ldots \ldots \ldots \ldots \ldots$

17. Hind tibiae with dark spines, these spines without dark spots at bases 18

Hind tibiae with light yellow to almost colorless spines, or with dark spines having dark spots at bases.......20

18. General color bright yellowish green, with large, well-marked, dark brown areas; pseudarolia attached at base of claw, tip free and extending to middle of claw, fig. $43 \ldots \ldots \ldots \ldots$. . .

Reuteroscopus, p. 48

General color dark red; or brown to black; pseudarolia completely united with claw, figs. $38-40 \ldots \ldots 19$

19. General color dark red; second anten- 
nal segment slightly swollen at apex, so as to become as wide as first segment, fig. $85 \ldots \ldots \ldots \ldots \ldots$

Rhinocapsus, p. 40

General color brown to hlack; second antennal segment linear, not so wide as first segment, fig. $86 \ldots \ldots$. .

Microphylellus, p. 40

20. Mesopleuron with flattened, scalelike pubescence......... Psallus, p. 43 Mesopleuron always without flattened, scalelike pubescence....... ......... Plagiognathus, p. 26

\section{Campylomma Reuter}

\section{Campylomma verbasci (Meyer)}

Capsus verbasci Meyer (1843, p. 70).

MALE.-Fig. 87. Length 2.50, width 1.10 . General color pale testaceous to yellowish, mesoscutum and base of scutellum becoming

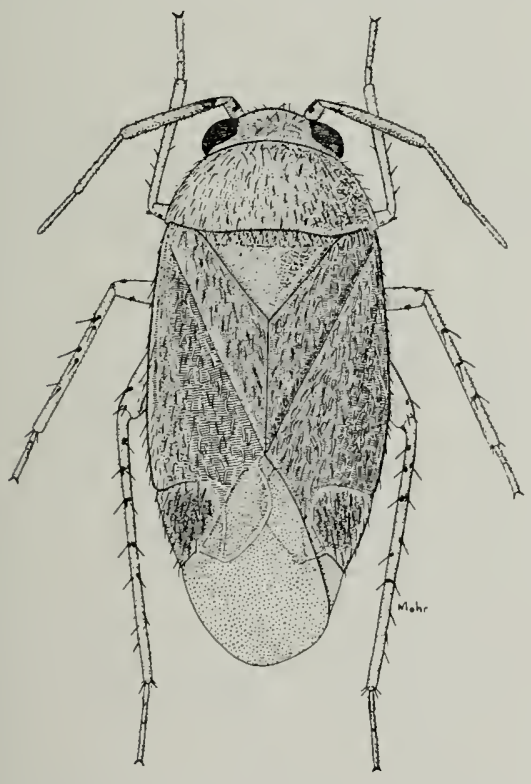

Fig. 87.-Campylomma verbasci, ठ․

fulvous, disk of cuneus pale fuscous. Tylus, apical half of first antennal segment and slender area at base of second, large spots on femora and tibiae, black. Body beneath dark brown; clothed with simple, dusky to blackish pubescence. Membrane uniformly pale smoky.

Female.-Length 2.90 ; width 1.30 .

Host Plants.-In Illinois the commonest host is mullein (I'erbascum sp.). This insect has been taken also on l'erbena stricta and Brassica nigra. It is known to breed occasionally on apple (Pyrus malus); sometimes it is attracted to colonies of aphids, where it feeds on their honeydew.

Known Distribution.-A common species in the eastern United States and Canada. This species came originally from Europe, but has long been established in North America. It is quite common almost everywhere mullein grows.

Illirois Records. - One hundred seven males and $8+$ females, taken May 30 to Aur. 1, are from An:ioch, Arcola, Bloomington, Delavan, Galena, Kankakee, Monticello, Mount Carroll, Starved Rock State Park, Urbana.

\section{Chlamydatus Curtis}

\section{KEY TO SPECIES}

1. All femora black, with narrow areas at tips light yellowish; length 2.00 $2.30 \ldots \ldots$. . . . . suavis, p. 26

Front and middle femora more or less yellow.....

2. Front and middle femora clear yellow, hind femora black with apex yellow; length 2.50 . associatus, p. 25

All femora black with apical one-third yellow. pulicarius, p. 26

\section{Chlamydatus associatus (Uhler)}

Agalliastes associatus Uhler (1872, p. 419).

Adults.-Length 2.50, width 1.00. Body mostly black. Front and middle legs, hind tibiae and first two segments of all tarsi, yellowish. Third and fourth antennal segments pale fuscous.

Food Plant.-Ragweed (Ambrosia sp.).

KNown Distribution.-Commonly found in the United States and Canada wherever ragweed grows.

Illinois Records. - Ninety-nine males and 86 females, taken May $1+$ to Nov. 1, are from Algonquin, Allerton, Alton, Amboy, Antioch, Bloomington, Centralia, Champaign, Chicago, Decatur, Delavan, Dubois, Elizabethtown, Galena, Galesburg, Grafton, Grand Detour, Grand Tower, Hardin, Harrisburg, Havana, Herod, Keithsburg, Lawrenceville, Monticello, Murphysboro, Normal, Oak Lawn, Oakwood, Oquawka, Oregon, Quincy, Rockford, Rockton, St. Anne, St. Joseph, Savanna, Springfield, 
Starved Rock State Park, Tremont, Urbana, Zion.

\section{Chlamydatus suavis (Reuter)}

Agalliastes suavis Reuter (1876, p. 92).

Adults.-Length 2.28, width 0.97; slightly smaller than associatus (Uhler); entirely black except the tibiae, which are pale yellow.

Food Plant.-Ragweed (Ambrosia sp.).

Known Distribution.-Connecticut, IIlinois, Iowa, Kansas, New York and southward.

Illinois Records. - Tiventy-one males and 35 females, taken June 5 to Sept. 19, are from Algonquin, Alto Pass, Carbondale, Champaign, Darwin, Dixon, Dubois, Elizabeth, Evergreen Park, Fountain Bluff, Freeport, Galesburg, Grand Tower, Havana, Herod, Metropolis, Mount Carmel, Murphysboro, Rockford, Savanna, Starved Rock State Park, Urbana.

\section{Chlamydatus pulicarius (Fallen)}

Lygaeus pulicarius Fallen (1807, p. 95).

Not as yet collected in Illinois; known from Michigan, Minnesota, New York.

\section{Plagiognathus Fieber}

\section{KEY TO SPECIES}

1. Tibial spines pale, without black spots at bases.................. 2

Tibial spines dark, with a black spot at base of each, these spots sometimes obsolete near a pices of tibiae. 3

2. Almost colorless; first antennal segment with two black lines; a black line near apices of dorsal and ventral margins of femora; hind femora with single black spot on anterior aspect ..........nigrolineatus, p. 34

Color yellowish, antennae and femora without black lines; hind femora with a few small fuscous points on anterior face......... sericeus, p. 34

3. Second antennal segment dark fuscous to black, sometimes slightly paler at middle, but always with more area black than light............ 4

Second antennal segment chiefly pale, blackish only at base..........31

4. Cuneous partly or entirely black, never chiefly brown.......... 5
Cuneus pale, or uniformly fulvous to dark brown, sometimes dusky at apex, but never distinctly black. . 20

5. Cuneus more or less pale at base.... 6 Cuneus uniformly black like corium, rarely somewhat pale at fracture...13

6. Scutellum partly or completely pale, sometimes pale only at apex or along lateral margins......... 7

Scutellum uniformly black. . . . . . . 10

7. Scutellum black along median line, with variable light-colored areas at margins

obscurus var. obscurus, p. 32

Scutellum pale along median line, sometimes pale only at apex, or almost entirely light colored with only basal angles blackish......8

8. Rostrum short, scarcely reaching bases of middle coxae; pronotal disk with broad, dark stripes, leaving median line and lateral margins pale yellow.......... gleditsiae, p. 37

Rostrum extending to hind coxae....9

9. Femora pale to light yellowish brown, hind pair with two rows of prominent black spots, these spots sometimes obscured with darker color; hind femora never noticeably black at base and pale in middle; cuneus pale at base and along outer margin; length $3.90-4.50 \ldots \ldots \ldots \ldots$

flavoscutellatus, p. 32

Femora pale to black, usually black at base and pale in middle; in dark specimens femora black with only apices pale; cuneus pale at base, but not along outer margin; length 3.80 -4.00 . politus var. flaveolus, p. 29

10. Pronotum and hemelytra black; cuneus with a small, light-colored spot at base, or with apex paler than base.....................11

Pronotum pale at posterior margin, corium chiefly light yellowish brown or ivory white, but with a large, somewhat ovate, fuscous spot on apical half; cuneus pale, with a small black spot at apex.........

... obscurus var. fraternus, p. 32

11. Femora yellowish, with one or two rows of black spots on anterior face, pubescence yellowish to golden; length 4.00 .........cuneatus, p. 34

Femora black, pale at apices.......12 
12. Cuneus pale only on base; pubescence white; length $3.50 \ldots \ldots \ldots \ldots$.

politus var. politus, p. 29

Cuneus pale at apex and along outer margin; pubescence yellowish to golden............. cuneatus, p. 34

13. Rostrum and legs chiefly yellowish, femora with black spots, or with black spots and lines..........14

Rostrum and legs black or obscured with very dark brown ..........16

14. Hind femora with black line above and one on ventral margin of apical half, also four or five black spots on anterior aspect

annulatus var. annulatus, p. 34

Hind femora without black lines above and below................ 15

15. Length 3.80-4.00; legs orange yellow, hind femora with four or five black spots on antero-dorsal line, a second, less conspicuous row of dots just beneath, and a single spot just below at middle of apical half.

negundinis, p. 33

Length 3.00 ; legs yellowish, femora with small, rather inconspicuous, fuscous dots arranged in series on anterior face.... repetitus, p. to

16. Femora, tibiae and antennae very dark brown; third antennal segment dusky to fuscous, scarcely paler than second segment; hemelytra very dark brown, somewhat translucent, pubescence yellowish to dusky; length 4.00 .

laricicola, p. 39

Femora black except at extreme tips; tibiae pale, with prominent black spots.................. 17

17. Length of second antennal segment less than width of head plus width of vertex.................. 18

Length of second antennal segment greater than width of head plus wid th of vertex. . . . . . . . . . . 19

18. Deep black, strongly shining, with white pubescence; length $3.00 \ldots$. .

nigronitens, p. 30

Very dark brown, moderately shining, with golden yellow pubescence; length $3.50 \ldots \ldots$ cornicola, p. 38

19. Rostrum extending to hind coxae; very dark brown, sometimes slightly translucent at cuneal fracture.... latus var. nigrofemoratus, p. 34 Rostrum extending only to middle of intermediate coxae; black, cuneus uniformly black like corium.......

nigritus, p. 34

20. Rostrum short, not attaining posterior margin of sternum or hase of middle coxae; frons with quadrate black spot on either side

gleditsiae, p. 37

Rostrum extending to or beyond middle coxae.

21. Length of second antennal segment equal to or less than width of pronotum at base

Length of second antennal segment greater than width of pronotum at base....................26

22. Rostrum not extending beyond middle coxae.........brevirostris, p. 33

Rostrum extending heyond middle coxae..................23

23. Femora very dark brown, without definite spots.... cornicola, p. 38

Femora with fuscous spots on anterior face, or uniformly pale with spots indistinct or absent

24. Hind femora with two rows of fuscous spots on anterior face; body dull yellowish brown, with lower half of head and under surface of body black........... fulvidus, p. 37

Hind femora with fuscous spots either grouped on distal half, or absent, a dark line forming above; hody pale to greenish yellow, ventral surface not darker.

25. Pronotum and hemelytra uniformly light yellowish brown or greenish.

blatchleyi var. blatchleyi, p. 35

Basal half of pronotal disk, apical half of corium, and disk of clavus darkened with dark yellowish brown or black

... . blatchleyi var. nubilus, p. 35

26. First antennal segment mostly pale; narrow area at base and two setigerous spots on apical half hlack.

albifacies, p. 35

First antennal segment entirely black. 27

27. Rostrum not extending beyond middle coxae.................28

Rostrum extending beyond middle coxae... . . . . . . . . . . . . . . 29

28. Body and wings uniformly straw 
colored or slightly tinged with yellow............atricornis, p. 35

Body dark; hemelytra black, basal one-third to one-half of embolium and corium pale, rarely dark; cuneus pale to fulvous, apex frequently dusky; length $4.30-4.70 \ldots \ldots$.

brevirostris, p. 33

29. Hemelytra without pale areas; general color light yellowish brown; tylus, lora and sternum black.....

rosicola, p. 36

Hemelytra fuscous with pale areas. . . 30

30. Pale area of corium limited by claval suture; smaller forms, length 3.704.60 .

obscurus var. albocuneatus, p. 32

Pale area of corium limited by radial vein; females with fuscous area on apical half of corium divided into two spots by pale stripe which extends along radius and joins that of cuneus; larger forms, length 4.50$4.90 \ldots \ldots$. . . alboradialis, p. 31

31. Scutellum, and usually entire dorsum as well, black...............32

Scutellum pale or light yellowish brown, sometimes dark brown, trequently the median line blackish, but the basal angles distinctly paler; hemelytra more or less pale, in darkest forms very dark brown, but always somewhat translucent . .42

32. Hemelytra uniformly brownish and translucent; thorax and scutellum black....... suffuscipennis, p. 40

Hemelytra uniformly black, or blackish with paler areas.............33

33. Cuneus very light yellow or reddish. .34 Cuneus chiefly black.............36

34. Femora mostly black, only bases and narrow area at tips pale..... albonotatus var. albonotatus, p. 31

Femora pale or reddish, with two rows of prominent black spots on anterior face; posterior aspect also spotted with black................ 35

35. Cuneus and femora more or less reddish.....tinctus var. tinctus, p. 31

Cuneus straw colored or yellowish... tinctus var. debilis, p. 31

36. Femora pale or fulvous, usually spotted with black...........37

Femora black, pale only at apices. . . 40

37. First antennal segment mostly pale, black only on base; hind femora pale, a single black spot on lower margin near apex..... davisi, p. 38

First antennal segment mostly black, small area at apex pale; hind femora with two rows of prominent black spots on anterior face...........38

38. Rostrum not extending beyond middle coxae.......... punctatipes. p. 39

Rostrum extending beyond middle coxae.....................39

39. Cuneus pale at base............

dispar var. dispar, p. 39

Cuneus uniformly black.

dispar var. crataegi, p. 39

40. Length of second antennal segment just equal to width of head across eyes, first and second segments equally thick...... syrticolae, p. 31

Length of second antennal segment distinctly greater than width of head....................41

41. Cuneus pale at base; second antennal segment with basal one-fourth black; body narrower........... pallidicornis, p. 30

Cuneus uniformly black like corium; second antennal segment with a narrow black area at base, apex dusky; body more ovate, deep black, strongly shining..........

flavicornis, p. 30

42. Dorsum uniformly greenish yellow, clothed with prominent black pubescence; bases of first and second antennal segments black, a second black annulus present near apex of first segment........... ..............chrysanthemi, p. 31

Dorsum darkened or marked with fuscous; pubescence pale; antennae not marked as above.........43

43. Second antennal segment uniformly pale, sometimes with a narrow dusky area at base...........44

Second antennal segment black at base..................46

44. First antennal segment pale; dorsum pale, thickly dotted with minute reddish brown or dusky brown spots..........guttulosus, p. 40

Fitst antennal segment black; scutellum and cuneus pale; femora with black spots..............45

45. Scutellum and cuneus pale.........

.......albatus var. albatus, p. 36 
Median line of scutellum and apical half of cuneus blackish..........

albatus var. vittiscutis, p. 36

46. Scutellum uniformly colored, or with median line paler than basal angles .47

Scutellum with median line blackish, darker than lateral areas, which are yellowish or light brown. .

47. Femora rather uniformly dark except at apices, black spots indistinct; scutellum uniformly colored, usually dark yellowish brown or walnut colored, similar to dorsum.

cornicola, p. 38

Femora pale or light yellowish brown, with distinct lines of black spots... 48

48. Length of rostrum less than width of pronotum; length of second antennal segment only slightly greater than width of head; length $3.30 \ldots$

delicatus, p. 37

Length of rostrum distinctly greater than basal width of pronotum; length of second antennal segment nearly equal to width of head plus width of vertex; length $4.10 \ldots . .49$

49. Calli and two longitudinal stripes on corium black; cuneus black, with margins pale...

. . . salicicola var. salicicola, p. 36

Dorsum uniformly pale, brownish markings only very faintly indicated.

....salicicola var. depallens, p. 36

50. Cuneus uniformly light colored......51

Cuneus brownish or black at apex. ..52

51. Rostrum scarcely attaining hind margins of middle coxae; propleura clothed only with slender pubescence; femora distinctly spotted with black although these dots at times are slightly obscured at apex.

... . repletus var. repletus, p. 38

Rostrum extending beyond middle coxae; propleura clothed with silky pubescence; femora more or less black on apical half, but black areas scarcely forming distinct spots...

albonotatus var. compar, p. 31

52. Rostrum attaining hind margins of posterior coxae; basal half of corium and more or less broad area on either side of claval suture white; paler areas never brownish, darker areas distinctly black...........
Rostrum not attaining hind margins of posterior coxae............53

53. Hemelytra, except along basal half of radius, dark brown or yellowish brown; most of dorsum dull yellowish brown to tawny, sides of pronotal disk and median line of scutellum dark brown . . . . . caryae, p. 38

Hemelytra black, outer half of clavus, basal half of corium and area extending along claval suture to apex pale and translucent.

. repletus var. apicatus, p. 38

\section{Plagiognathus politus Uhler}

Plagiognathus politus Uhler (1895, p. 52).

MALE.-Length 3.50 , width 1.30 ; ovate, shining black; clothed with simple, pale or white pubescence. Femora dark fuscous to black, apices pale. Rostrum yellowish at middle, apex slightly surpassing hind coxae. Antennae black, tip of first segment pale, third and fourth pale or tinged only with fuscous. Tibiae pale or yellowish, with bases darker, and tibial spines with black spots surrounding their bases.

Fenale.--Length 3.80 , width 1.60 ; very similar to male but more robust.

Adults appearing after July, apparently of the second brood, are lighter in color, usually having the scutellum and mesal areas of the pronotum straw colored. They do not differ structurally from the typical form and belong to the variety flaveolus Knight (1923d, p. 434).

Food Plants.-Ragweed (A mbrosia sp.), goldenrod (Solidago sp.) and other herbaceous plants, particularly composits; reared from apple (Pyrus malus), where the nymphs fed on the tender foliage. In Illinois, specimens have been taken also on hickory (Carya sp.), willow (Salix sp.), birch (Betula sp.), cypress (Taxodium distichum), oak (Quercus sp.), hazelnut (Corylus sp.), red cedar (Juniperus virginiana), coralberry ( $S_{y}$ mphoricarpos orbiculatus), locust (Robinia pseudoacacia) and pine (Pinus strobus).

Known Distribution.-Commonly distributed east of the 100th meridian.

Illinois Records.-Four hundred fortysix males and 505 females, taken June 2 to Nov. 1, are from Albion, Algonquin, Allerton, Alton, Alto Pass, Amboy, Anna, Antioch, Beverly Hills, Bloomington, Bluff Springs, Browns, Bureau, Carbondale, 
Champaign, Charleston, Chicago, Cypress, Danville, Darwin, Decatur, Delavan, Dolson, Dubois, Eichorn, Elizabethtown, Equality, Forest Park, Fountain Bluff, Fox Lake, Freeport, Galena, Galesburg, Glencoe, Golconda, Grand Detour, Grand Tower, Grandview, Grayville, Hamilton, Hardin, Harrisburg, Havana, Herod, Hillsboro, Homer, Joliet, Jonesboro, Kampsville, Kankakee, Kansas, Kappa, Karnak, Keithsburg, Lawrenceville, Mahomet, Makanda, Marshall, Mason City, McClure, Meredosia, Metropolis, Monticello, Mounds, Mount Carmel, Mount Forest, Muncie, New Milford, Newton, Normal, Oakwood, Oquawka, Oregon, Palos Park, Paxton, Quincy, River Forest, Rockford, Rockton, St. Anne, St. Joseph, Seymour, Shawneetown, Sparland, Springfield, Starved Rock State Park, Ullin, Urbana, Vienna, Volo, Ware, Warren, Warsaw, Waukegan, West Union, White Heath, White Pines Forest State Park, Willow Springs, York, Zion.

\section{Plagiognathus pallidicornis Knight}

Plagiognathus politus var. pallidicornis Knight (1923d, p. 435).

This species is allied to politus Uhler, but is easily to be distinguished by its pale antennae and shorter rostrum.

MaLE.-Length 3.50, width 1.47. Head width 0.71 , vertex 0.37 . Antennae, first segment, length 0.24 , black; second, 0.91, pale, black at base; third, 0.65, pale; fourth, 0.39 , pale. Rostrum, length 1.21 , reaching only to middle of hind coxae. General color black, moderately shining, pubescence pale, base of cuneus with a narrow, pale area; ventral margin of propleura, mesoepimera and ostiolar peritremes white.

FEMALE.-Length 3.40, width 1.56 ; slightly more robust but very similar to male in color and pubescence.

Known Distribution.-Connecticut, 11linois, Maine, Massachusetts, Minnesota, New Hampshire, New York, Ontario.

Illinois Records.-Antioch : July 5-7, 1932, Frison et al., 1 우 ; Aug. 1, 1930, Frison, Knight \& Ross, $1 \hat{\delta}, 1$ 오.

\section{Plagiognathus nigronitens Knight}

Plagiognathus nigronitens Knight (1923d, p. 435).

This species is slightly smaller than politus Uhler, with a shorter rostrum; the body is shining black, with the cuneus uniformly black like the corium.

MALE.-Length 3.00, width 1.20. Head width 0.64 , vertex 0.33 . Rostrum scarcely attaining posterior margin of middle coxae. Antennae, first segment, length 0.22 , black; second, 0.78, black, extreme tip pale; third, 0.66 , pale; fourth, 0.45 , dusky. Pronotum, length 0.53 , width at base 1.03 . Hemelytral margins very slightly arcuate; uniformly black, shining; cuneus never pale at base; clothed with pale yellowish pubescence. Membrane uniformly pale fuscous, a pale triangular spot bordering cuneus. Legs black, femora light in color at extreme tips; tibiae yellowish, spines with black spots at bases, hind pair becoming infuscated on basal one-third.

Female.-Length 3.00 , width 1.30 ; very slightly more robust than male but very similar in coloration.

Food Plant.-Ragweed (Ambrosia sp.), sunflower (Helianthus sp.).

Known Distribution.-Colorado, Illinois, Michigan, Minnesota, Mississippi, New Jersey, New York, Ohio, Ontario, South Dakota.

Illinois Records.-Eighteen males and 28 females, taken May 12 to Aug. 1, are from Antioch, Champaign, Dubois, Fountain Bluff, Goreville, Grand Tower, Metropolis, Muncie, Oakwood, Vienna, Volo.

\section{Plagiognathus flavicornis Knight}

Plagiognathus flavicornis Knight (1923d, p. 436).

This is larger and more robust than nigronitens Knight and about the same size as politus Uhler, but the second antennal segment is pale except for a narrow area at the base; the cuneus remains uniformly black like the corium.

Male.-Length 3.50, width 1.60. Head width 0.73 , vertex 0.38 . Rostrum scarcely attaining hind margins of middle coxae. Antennae, first segment, length 0.28 , black, apex pale; second, 1.16 ; third, 0.83 , fuscous; fourth, 0.55 . Pronotum, length 0.61 , width at base 1.16. General color black, shining, including basal margin of cuneus; clothed with yellowish to dusky pubescence. Membrane and veins uniformly dark fuscous. Legs black, tips of femora pale; tibiae pale; knees and spot at base of spines black; spots much reduced or absent on apical one-third.

Female.-Length 3.30 , width 1.60 ; very 
similar to male in coloration but more robust in form.

Food Plant.-Sweet gale (Myrica gale).

Known Distribution.-lllinois, Massachusetts, Minnesota, New York.

Illinois Records.-Antioch: July 5-7, 1932, T. H. Frison, 1 of ; Aug. 1, 1930, Frison, Knight \& Ross, 3 o . Cedar Lake: Aug. 4, 1906, bog, 3 q. Sun Lake: Aug. 9, 1906, bog, 1 ㅇ.

\section{Plagiognathus chrysanthemi (Wolff)}

Miris chrysanthemi Wolff (1804, p. 157).

Plagiognathus viridulus Reuter (1878, p. 74).

Known only from eastern Canada, New England states, New York, Pennsylvania; Europe. Feeds on the oxeye daisy, Chrysanthe mum leucanthemum.

\section{Plagiognathus alboradialis Knight}

Plagiognathus alboradialis Knight (1923d, p. 439$)$.

Known from British Columbia, Connecticut, Maine, Newfoundland, New Hampshire, New York, Ontario, Vermont.

\section{Plagiognathus syrticolae new species}

This runs to favicornis Knight in my key (Knight 1923d, p. 431), but is distinguished by the shorter and thicker second antennal segment which, in length, just equals the width of the head.

MaLE.-Length 3.30, width 1.25. Head width 0.69 , vertex $0.3+$. Rostrum, length 1.08 , reaching close to hind margins of hind coxae, dark fuscous, paler at middle. Antennae, first segment, length 0.19 , black; second, 0.69 , equal in thickness to first, yellowish, hlack at base, with close, pale pubescence; third, 0.43, yellowish; fourth, 0.31 , pale. Pronotum, length 0.52 , width at base 1.00 . General color black, moderately shining; pubescence pale, with a few fuscous hairs on corium and cuneus. Legs fuscous, tips of femora paler, tibiae pale yellow, spines black, fuscous spots at bases of spines sometimes rather small, tarsi pale, apices fuscous.

Fenale.-Length 3.60, width 1.50. Head width 0.69 , vertex 0.36 . Antennae, first segment, length 0.22 ; second, 0.69 , third, 0.43 ; fourth, 0.30 . Very similar to male in form, color and pubescence.

Host Plant.-Sand willow (Salix syrticola), a willow known only from the shores of the Great Lakes.
Holotype, male.-Waukegan, Ill.: July 6. 1932, on Salix syrticola, T. H. Frison et al.

Allotype, female. - Same data as for holotype.

Paratypes.- Same data as for holotype, 2 of, 18 \%.

\section{Plagiognathus albonotatus Knight}

Plagiognathus albonotatus Knight (1923d, p. 437 ).

This is nearly the same size as politus Uhler, but is slightly more robust; the second antennal segment, except for its base, the cuneus, and the basal one-third or more of the corium, are pale.

MaLE.-Length 3.50, width 1.50. Head width 0.71 , vertex 0.36 . Rostrum reaching hind coxae. Antennae, first segment, length 0.28 , black; second, 1.00 ; third, 0.70 ; fourth, 0.47 . Pronotum, length 0.57 , width at base 1.11. General color black, basal one-third of embolium and corium, and portion of the adjacent area on clavus, pale; membrane uniformly fuscous; body clothed with pale yellowish pubescence. Legs black; tibıae pale; knees, spines and spot at base of each spine, black; spots ahsent or much reduced on apical one-third of tibiae.

Female.-Length 3.40, width 1.60. Very similar to male, but slightly more robust. Pronotal disk frequently with pale spot on middle. Sides of venter more or less pale.

Specimens with more extensive pale areas than the typical have been designated compar Knight (1923d, p. 438); the two have been found to occur together in Illinois.

Food Plant. - Meadow-sweet (Spiraea salicifolia).

Known Distribution.-Colorado, Illinois, Maine, Minnesota, New York, North Dakota, Ohio.

Illinois Records.-Antroch: July 5-7. 1932, Frison et al., $1 \hat{\delta}, 1$ ㅇ. NORTHERN ILLINOIS: 1 \% .

\section{Plagiognathus tinctus Knight}

Plagiognathus albonotatus var. tinctus Knight (1923d, p. 437).

The size and color in this species are suggestive of albonotatus Knight, but the pale areas are tinged red.

Male.-Length 3.70, width 1.50. Head width 0.69 , vertex 0.30 . Rostrum just reaching hind margins of middle coxae. Antennae. 
first segment, length 0.22 ; second, 0.86 , pale, narrow area at base black; third, 0.53 , pale; fourth, 0.34. Pronotum, length 0.58 , width at base 1.08. Body black; basal one-third of corium and embolium, adjacent area of clavus, cuneus and vertex, pale, but hypodermis tinged reddish; clothed with pale yellowish pubescence. Membranes fuscous, pale on veins and near apex of cuneus. Legs pale to reddish, hind femora with two rows of black $X$ markings.

Female.-Length 3.50 , width 1.50 ; very similar to male in form and coloration.

Paler specimens lacking red in the hypodermis, referable to variety debilis Blatchley $(1926 b$, p. 941$)$, were taken in company with the typical form.

Host Plaxt.-Sandbar willow (Salix longifolia). A single Illinois specimen was taken on red cedar (Juniperus virginiana), but probably did not feed on that plant.

Knowr Distributiox.-Illinois, Iowa, Minnesota, Ohio, Pennsylvania.

Illinois Records. - Galesburg: June, 1ㅇ. Grand Detour: July 2, 1932, on Salix sp., Dozier \& Mohr, tô, 6 \%. HAvarixa: June 23, 1926, Frison \& Hayes, 1 ô. Kampsville: June 10, 1932, on $J u$ niperus virginiana, H. L. Dozier, $1 \delta$. Marshall: June 14, 1933, Frison \& Ross, 1 ô, 1 ․ Monticello: July 19, 1932, on Salix sp., T. H. Frison, 1 . ProphetsTown: July 7, 1925, T. H. Frison, 1 of. ROCKFORD: July 5, 1932, on Salix sp., Dozier \& Mohr, 1 ㅇ. Urbana: Sept. 1, 1930, T. H. Frison, 1 t .

\section{Plagiognathus flavoscutellatus Knight}

Plagiognathus flavoscutellatus Knight (1923d, p. 440 ).

This may be distinguished by its pale scutellum and fulvous femora with two rows of black spots.

Male.-Length 4.40, width 1.67. Head width 0.80 , vertex 0.36 . Rostrum reaching to middle of hind coxae. Antennae black; first segment, length 0.31 ; second, 1.43 ; third, 0.88 ; fourth, 0.47. Pronotum, length 0.68 , width at base 1.29. General color black; basal half of embolium and corium, apex of embolium, base and outer margin of cuneus, pale to yellow, pale color on corium limited by radial vein. Membrane uniformly fuscous, spot bordering apex of cuneus and veins pale or yellowish. Legs fulvous to dark brown; femora with two rows of black spots on anterior face, irregularly spotted on posterior face.

Fevale.-Length 4.30 , width 1.70 ; more robust than male, usually pale areas broader. Scutellum except base, area just before calli, and slight vitta on median line at base of pronotal disk, pale. Embolium, claval suture, anal ridges joining with base of cuneus, pale. Legs more fulvous than in male.

Food Plaxt.-Sandbar willow (Salix longifolia).

Krowx Distribution.-New England states westward to Iowa, Minnesota and Nebraska.

Illinois Records.-Eighteen males and 12 females, taken June 1 to July 8 , are from Beardstown, Elizabeth, Freeport, Grand Tower, Mount Carmel, Oakwood, Prophetstown, Thebes, West Union, White Heath.

\section{Plagiognathus obscurus Uhler}

Plagiognathus obscurus Uhler (1872, p. 418).

Female.-Fig. 88. Length 4.40, width 1.69; larger and more elongate than albonotatus Knight, moderately shining, with pale yellowish pubescence. Rostrum scarcely reaching hind margins of posterior coxae. Antennae fuscous to black, first segment

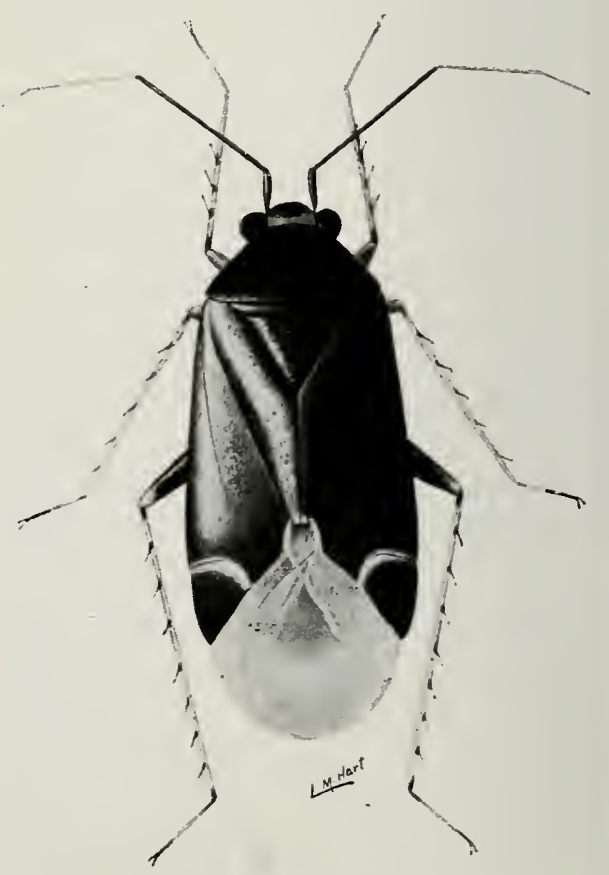

Fig. 88.-Plagiognathus obscurus. 
pale at extreme apex. Pronotum blackish, calli and central area of disk pale; scutellum black, lateral margins more or less pale; sternum, pleura and ostiolar peritremes black. Hemelytra mostly black; basal onethird of embolium and corium, and adjacent area of clavus, pale; cuneus pale, but apex distinctly blackish. Legs pale to yellowish; base of hind coxae, line on apical half of dorsal margin of femora, and two rows of spots just beneath, black. Venter blackish, more or less pale on sides.

Known Distribution.-Colorado, Illinois, Massachusetts, Michigan, Minnesota, New York, Nova Scotia, Quebec.

An extremely light form of this species in which the cuneus is uniformly pale or yellowish, and in which broad, pale areas are sometimes present on the dorsum, is the variety albocuneat us Knight (1923d, p. 438). Those specimens of this species having the scutellum entirely black may be designated variety fraternus Uhler (1895, p. 51). This variety was originally described as a species, but the examination of a large amount of material, from Colorado as well as the eastern states, has led to the conclusion that fraternus is nothing more than a variety of obscurus. In Illinois material, intergrades occur between all these varietal forms, which are found together in the field.

Illinois Records.-Fifty-four males and 60 females collected June 2 to Sept. 13 are from Algonquin, Antioch, Elizabeth, Fox Lake, Frankfort, Galena, Mason City, Rockton, Rosiclare, Savanna, Starved Rock State Park, Urbana, Volo, Waukegan, Zion.

\section{Plagiognathus negundinis Knight}

Plagiognathus negundinis Knight (1929d, p. 263).

This species is allied to annulatus Uhler, but differs in having a longer second antennal segment which, in the male, equals or slightly exceeds the width of the pronotum at its base.

Male.-Length 4.00, width 1.36. Head width 0.72 , vertex 0.37 . Rostrum reaching to middle of hind coxae. Antennae black; first segment, length 0.27 ; second, 1.20; third, 0.75 ; fourth, 0.35 . Pronotum, length 0.62 , width at base 1.17. General color black, vertex pale. Legs orange yellow, hind femora with a row of four or five black spots on antero-dorsal line, also one spot on median line of anterior face at middle of apical half, sometimes with two or three smaller dots, and two subapical black spots beneath; tibiae yellow; knees, spines, and spots at bases of spines, black. Clothed with recumbent, yellowish to dusky brown pubescence.

Female.-Length 3.80 , width 1.40 ; very similar to male in pubescence and coloration.

A variety, fulvotinctus Knight (1929d, p. 264), is known from Iowa; it differs from the typical negundinis in that the embolium, basal half of corium, outer margin of clavus on basal half, and basal half of cuneus are pale to orange yellow

Food Plant.-Box Elder (Acer negundo).

Known Distribution.-Illinois, Iowa, Minnesota.

Illinois Records.-Fox LAKE: June 10, 1936, Ross \& Burks, 1 o . Galena: June 30, 1932, Dozier \& Mohr, $1 \hat{\delta}, 1$ o. HAVAnNa: May 31, 1933, C. O. Mohr, $2 \hat{o}$, 3 q. Oquawka: June 13, 1932, H. L. Dozier, 2 ․ Putnam: June 2, 1933, Mohr \& Townsend, 2 o , 1 ㅇ. Urbana: June 20, 1932, Frison \& Ross, 1 ‥ Volo: July 8, 1932, Ross, Dozier \& Mohr, $1 \delta$.

\section{Plagiognathus brevirostris Knight}

Plagiognathus brevirostris Knight (1923d, p. 441 ).

The general aspect of this species is very similar to that of obscurus var. albocuneatus Knight, but it is larger and more elongate and the cuneus usually is tinged with fulvous; it is distinguished by the short rostrum, which does not reach the hind margins of the middle coxae.

Male.-Length 4.60, width 1.80. Head width 0.79 , vertex 0.37 . Rostrum reaching middle of intermediate coxae. Antennae, first segment, length 0.35 ; second, 1.t3; third, 1.00; fourth, 0.54. Pronotum, length 0.63 , width at base 1.26. General color black, moderately shining, embolium and basal half of corium pale, dark color frequently invading apical half of embolium, sometimes pale color extending along claval suture to anal ridge; cuneus pale, usually tinged with fulvous; apex sometimes dusky. Legs black, femora frequently with rather broad, pale area at base; tibiae pale; knees, spines and spots at base black.

Female.-Length 4.00 , width 1.89 ; shorter and more robust than male; legs with broader pale areas. 
KNown Distribution. - Newfoundland and the New England states, westward to Michigan, Illinois and Minnesota.

Illinois Record.-ANTioch: June 10, 1933, Mohr \& Townsend, 2 ô, 3 ㅇ.

\section{Plagiognathus cuneatus Knight}

Plagiognathus annulatus var. cuneatus Knight (1923d, p. 442).

This form is allied to the typical annulatus Uhler, but the cuneus is pale at the base and sometimes at the lateral margin; the femora are yellowish and spotted with black, but the spots do not form black lines.

MALE.-Length 4.00, width 1.50. Head width 0.75 , vertex 0.36 . Rostrum extending to posterior margins of hind coxae. Antennae black; first segment, 0.30 ; second, 1.22 ; third, 0.83 ; fourth, 0.47 . Pronotum, length 0.61 , width at base 1.16. General color black; cuneus pale to yellowish at base and lateral margin; clothed with yellowish to golden pubescence. Membrane fuscous. Legs pale to yellow; hind femora with two rows of small fuscous spots on anterior face, sometimes clouded with fuscous.

FEMALE.-Length 4.20, width 1.70; more robust than male but very similar in coloration.

Food Plant.-Wild aster (Aster sp.).

Known Distribution.-Georgia, Illinois, New Hampshire, New York, Texas, Vermont.

Illinois Record.-ELIZAветнтоWN : May 27-31, 1932, H. L. Dozier, 1 ㅅ, 1 ㅇ.

\section{Plagiognathus nigritus Knight} 441).

Plagiognathus nigritus Knight (1923d, p.

Known only from Colorado, Connecticut, Ohio.

\section{Plagiognathus sericeus (Heidemann)}

Psallus sericeus Heidemann (1892, p. 226).

Plagiognathus tiliae Knight (1926h, p. 252).

This species is distinguished by its uniformly pale yellow color and by a few small, fuscous points on the anterior face of its hind femora.

MalE.-Length 3.30, width 1.34. Head width 0.74 , vertex 0.31 . Antennae uniformly yellowish; first segment, length 0.21 ; second, 1.08; third, 0.51; fourth, 0.31. Pronotum, length 0.57, width at base 1.10. Body uni- formly pale yellow, the same color as the Tilia blossoms among which the insect retreats; indistinct fuscous points on femora arranged in a double row, tibial spines pale to brownish. Body clothed with soft, recumbent, simple pubescence of pale to golden yellow color.

Female.-Length 3.50 , width 1.50 . Coloration and pubescence similar to those of male.

Host Plant.-Basswood (Tilia americana); a single specimen was taken on elm (Ulmus americana), but may not have been feeding on that tree.

The adult stage is attained just as the basswood flowers come into full bloom, and the yellow color of the mature bugs matches the color of the flowers perfectly. When disturbed the bugs hide among the petals and are then difficult to see.

Known Distribution.-District of Columbia, Illinois, Iowa, Minnesota.

Illinois Records.-Antioch: July 5-7, 1932, on Tilia sp., T. H. Frison et al., $2 \hat{o}$, 3 ㅇ. Kampsville: June 10,1932, on Tilia sp., H. L. Dozier, 5 o , 2 ㅇ. Muncie: July 22, 1932, Dozier \& Park, 1 o , 1 \%. New Milford: July 3, 1936, Ross \& Burks, 1 o . Urbana: July 2, 1914, at light, 1 o ; June 27, 1932, on elm, Frison \& Ross, 1 q . WAUKegAN : July 6, 1932, on Tilia sp., T. H. Frison et al., 11 o , 8 \%.

\section{Plagiognathus annulatus Uhler}

Plagiognathus annulatus Uhler (1895, p. 51)

Neither the typical form of this species nor the variety nigrofemoratus Knight (1923d, p. 443) has yet been taken in Illinois; known from Colorado, Connecticut Massachusetts, Montana, New York.

\section{Plagiognathus nigrolineatus Knight}

\section{Plagiognathus nigrolineatus Knight (1923d, p. 443 ).}

This is uniformly pale greenish, with pale pubescence; it may be distinguished by the black lines on the antennae and femora.

MALE.-Length 4.30, width 1.58. Head width 0.75 , vertex 0.33 . Rostrum reaching to middle of hind coxae. Antennae, first segment, length 0.28 , pale, two longitudinal black lines on dorsal surface; second, 1.38, pale, a slender black line on anterior surface extending from base to near middle; third, 0.69 , pale; fourth, 0.31. Pronotum, length 
$0.6+$, width at base 1.22. General color uniformly pale green, translucent. Legs pale; slender line on dorsal margin of femora, line on apical half of postero-ventral margin of hind femora, and a single dot on anterior face, black.

Fexiale.-Length 4.30 , width 1.66 ; similar to male in coloration.

Food Plant.-Bur oak (Quercus macrocarpa).

KNown Distribution.-Connecticut westward to Minnesota and southward to Texas, its distribution nearly coinciding with the range of its host tree.

Illinois Records. - DuboIs: May 15, 1916, 1 o , 1 \% ; May 22, 1917, + o, $1 \%$; May 23, 1917, 1 o. Frankfort: June 8, 1933, Mohr \& Townsend, 1 ․ MontiCELlo: June 11, 1934, Frison \& DeLong, 19 . White Pines forest State Park: on Quercus sp., Dozier \& Mohr, 2 q.

\section{Plagiognathus albifacies Knight} 11).

\author{
Plagiognathus albifacies Knight (1927b, p
}

This species is allied to blatchleyi Reuter, but is distinguished by its pale first antennal segment, black sternum, longer head and differently formed male genital claspers.

Male.-Length 4.40, width 1.50. Head width 0.81 , vertex 0.35 . Rostrum just reaching posterior margins of hind coxae. Antennae, first segment, length 0.39 ; second, 1.55 ; third, 1.1t; fourth, 0.58. Pronotum, length 0.74 , width at base 1.28. Hemelytra pale yellow, inner half of clavus and apical half of corium dusky to pale fuscous; cuneus pale to dusky, translucent. Legs pale, femora with two rows of black spots on anterior face, hind femora with antero-dorsal row composed of six larger black spots. Genital claspers distinctive, the left clasper with lateral or basal lobe much larger than in blatchleyi.

Fexale.-Length 4.70 , width 1.68. Very similar to male in coloration and pubescence.

Food Plant.-Leafcup (Polymnia canadensis).

Krow Distribution.-Illinois, Indiana, Maryland.

Illinois Records.-Aldridge: May 8 , 1932, H. L. Dozier, 1 . Bloomington: July 18, 1932, T. H. Frison, 7 o , 1 . DAxithe: Aug. 17, 1934, DeLong \& Ross, 2 ․ Golconda: July 25, 1930, on Polymnia canadensis, Knight \& Ross, 48 ô, 68 ㅇ.
Hardin: June 5-9, 1932, H. L. Dozier, 11 o. 13 o. KarNaK: June 23, 1932, Ross, Dozier \& Park, 1 \% Urbaxa: 1930, on Polyminia sp., T. H. Frison, 2 o, 6 \% ; Aug. 25, 1930, H. H. Knight, 8 ô, 1 \%.

\section{Plagiognathus atricornis Knight}

p. 9).

Plagiognathus atricornis Knight (1926a,

This species is distinguished by its pale color, pale pubescence and black antennae.

MaLE.-Length 3.50, width 1.20. Head width 0.77 , vertex 0.27 . Eyes prominent, black. Rostrum just attaining posterior margins of middle coxae. Antennae uniformly black; first segment, length 0.24 ; second, 1.07 ; third, 0.66; fourth, 0.34. Pronotum, length $0.5+$, width at base 1.03 . General color pale greenish testaceous, pronotum distinctly green, calli yellowish; hemelytra somewhat translucent, membrane and veins uniformly pale fumate. Legs pale, hind femora with a double row of prominent black spots; knees, tibial spines, and large spots at base of spines, black.

Female.-Length 3.40, width 1.34. Form and coloration similar to those of male.

Host Plaxt.-Specimens were taken in Illinois on red birch (Betula nigra).

KNowx Distributiox.-Previously known only from Pennsylvania.

Illinois Record.-HARRiSBURG: June 25, 1932, on Betula nigra, Ross, Dozier \& Park, 2 o , 1 ㅇ.

\section{Plagiognathus blatchleyi Reuter}

61). Plagiognathus blatchleyi Reuter (1912a, p.

MaLE.-Length 4.60, width 1.70 ; pale greenish and yellowish brown; clothed with pale yellowish pubescence, hairs becoming dusky on cuneus and apical half of corium and embolium. Antennae black, third and fourth segments pale fuscous, extreme apex of first and second segments pale. Tylus black. Basal and apical segments of rostrum almost black. Legs nearly as in chrysanthemi (Wolff) but black spots on femora less conspicuous. Membrane fuscous, central area of apical half, veins and area invading each side, paler.

Fendale.-Length 4.40, width 1.70 ; very similar to male in coloration, although membrane, and sometimes antennae, slightly paler. 
All but one or two of the lllinois specimens are darker than the typical form, with a brown band developed across the basal half of the pronotum and the apical half of the clavus. These belong to the variety nubilus Knight (1923d, p. 444).

Food Plant.-Several specimens were taken in Illinois on ragweed (A mbrosia sp.).

Known Distribution.-District of Columbia, Illinois, Maine, Maryland, Massachusetts, New Jersey, New York, Ohio, Virginia.

Illinois Records. - Nineteen males and 19 females, taken Aug. 10 to Oct. 6, are from Algonquin, Carbondale, Charleston, Elizabethtown, Havana, Jonesboro, Mounds, Oakwood, Rockford, Sparland, Urbana.

\section{Plagiognathus salicicola Knight} 69).

Plagiognathus salicicola Knight (1929b, p.

This species is suggestive of delicatus (Uhler) but is easily distinguished by its larger size and black markings; the cuneus is black with pale margins.

Mal.E.-Length 4.10, width 1.50. Head width 0.83 , vertex 0.33 . Rostrum extending to middle of hind coxae. Antennae, first segment, length 0.27 ; second, 1.09 , pale, base and apex black; third, 0.77 ; fourth, 0.45 . Pronotum, length 0.65 , width at base 1.26 . Clothed with pale to yellowish simple pubescence. General color black; anterior margin of pronotum, disk behind calli, lower half of propleura, scutellum except at base, areas along claval suture and radial vein, embolium, all margins of cuneus, sides of sternum, epimera, and apical area of genital segment, pale to yellowish. Legs pale, with two rows of spots on femora; apex of inner face of femora, knees, spots and spines on tibiae, black.

Female.-Length 3.90 , width 1.70 ; very similar to male in pubescence and coloration, but with pale areas on dorsum broader.

The fuscous markings on the dorsum vary considerably in intensity and size; the extremely light form, in which these markings are very indistinct, is referable to the variety depallens Knight (1929b, p. 70).

Food Plant.-Sandbar willow (Salix longifolia).

Known Distribution.-Illinois, Indiana, Iowa, Minnesota.
Illinois Records.-Alton: July 19-21, 1932, on Salix sp., Ross \& Dozier, 2 q. Anna: June 6, 1884, 19 . Savanna: July 23, 1892, on sandbar in Mississippi River, McElfresh, Hart \& Forbes, 5 q; July 25, 1892, from sandy island in Mississippi River, McElfresh, Hart, Shiga \& Forbes, $1 \delta, 5$ o ; July 26, 1892, along railroad in bottomlands, McElfresh, Hart \& Forbes, 1 \% ; July 27, 1892, at light and sugar, McElfresh, Shiga, Forbes \& Hart, 1 ô, $1 \%$; Aug. 1, 1892, from willow, F. M. McElfresh, $1 \hat{\delta}$. WEst Union: June 26, 1932, on Salix sp., Ross, Dozier \& Park, $2 \hat{\delta}$.

\section{Plagiognathus rosicola Knight} 446).

Plagiognathus rosicola Knight (1923d, p.

This species is fulvo-testaceous, with the antennae, tylus, sternum, and prominent spots on the femora, black; the rostrum reaches to the middle of the venter.

MALE.-Length 4.30, width 1.64. Head width 0.75 , vertex 0.33 . Antennae black; first segment, length 0.31 ; second, 1.42 ; third, 1.00; fourth, 0.44. Pronotum, length 0.66 , width at base, 1.22. Color fulvo-testaceous to fusco-brownish, clothed with yellowish or golden pubescence; scutellum slightly darker than pronotum, disk of cuneus darker. Legs pale yellow and tinged with brown, femora with two rows of very prominent black spots on anterior face; tibiae with large and prominent black spots at base of spines.

Female.-Length 4.40 , width 1.70 ; more robust than male, but very similar in coloration.

Food Plant.-Wild rose (Rosa sp.).

Known Distribution.-Illinois, Kansas, Maryland, Missouri.

Illinois Record.-Monticello: July 19, 1932, T. H. Frison, 1 ô.

\section{Plagiognathus albatus (Van Duzee)}

Psallus albatus Van Duzee (1915, p. 116).

Adults.-Length 4.20, width 1.40. General color whitish. Tylus, basal segment of antennae, more or less broad area at lateral margins of pronotal disk, inner half of clavus, subapical spot on corium or, in darker specimens, spot covering apical half of corium, sternum and venter, black. Calli and second antennal segment frequently yellowish. Membrane pale, a distinct fus- 
cous ray along margin just beyond clear spot at tip of cuneus. Hind femora with a group of black spots on apical half, sometimes with a subdorsal row of spots extending over basal half. Tibiae with small and sometimes indistinct spots at bases of spines; female with pale areas broader than those of male.

The variety vittiscutis Knight (1923d, p. +45) differs from the typical in having the apical half of the cuneus black; it has not yet been collected in Illinois. It occurs on butternut ( $J$ uglans cinerea).

Food Plant,-Sycamore (Platanus occidentalis); specimens were also taken on walnut (Juglans nigra).

Known Distribution.-Connecticut, District of Columbia, Georgia, Illinois. Iowa, Massachusetts, Michigan, Minnesota, New York, Ohio, Pennsylvania, Quebec.

Illinois Records.-Forty-seven males and 49 females, taken June 13 to Aug. 9, are from Alton, Ashley, Danville, Dolson, Eichorn, Herod, Kansas, Monticello, Oakwood, Putnam, Rockford, Urbana, Vienna.

\section{Plagiognathus similis Knight}

Plagiognathus albatus var. similis Knight (1923d, p. 445).

The coloration of this form is suggestive of albatus (Van Duzee), but it may be distinguished by the black base of its second antennal segment and the two rows of black spots on the hind femora.

Male.-Length 3.90, width 1.38. Head width 0.78 , vertex 0.30 . Rostrum extending almost to hind margin of posterior coxae. Antennae, first segment, length 0.23 ; second, 1.08; third, 0.72; fourth, 0.43. Pronotum, length 0.62 , width at base 1.14. General color black, varied with pale; scutellum pale, with a rather broad, black, median line; hemelytra pale, inner half of clavus, apical half of corium and area invading embolium, black; cuneus pale, translucent, apical half black. Legs pale yellow; hind femora with two rows of black spots, anterior pairs with three or four spots forming a line; tibial spines black with prominent black spot around base of each.

FeMALE.-Length 3.50 , width 1.50 ; very similar to male in form and coloration.

Food Plant,-Red birch (Betula nigra). Taken also on alder $(A \ln u s)$ in Michigan and on birch in Maryland.

Illinois Records.-EICHORN : June 24, 1932, Hicks Branch, on Betula nigra, Ross,
Dozier \& Park, 1 ô. Galeva: June 30, 1932, on Betula nigra, Dozier \& Mohr, 2 s, 3 \%. HARRISBURg: June 25, 1932, on Betula nigra, Ross, Dozier \& Park, 20 ๙ิ, 24 우; June 15, 1934, DeLong \& Ross, 1 우.

\section{Plagiognathus fulvidus Knight} 447)

Plagiognathus fulvidus Knight (1923d, p.

Known from Connecticut, Maryland, New Jersey, North Carolina, Ohio.

\section{Plagiognathus delicatus (Uhler)}

\section{Psallus delicatus Uhler (1887b, p. 34).}

Adults.-Length 3.30, width 1.40. General color reddish yellow to brownish. First antennal segment except extreme tip, and a ring at base of second segment, dark fuscous; front of head more or less dark either side of median line. Hemelytra, sternum and abdomen shaded with fuscous, sometimes basal margins of calli quite dark; scutellum yellowish, usually with basal angles dark, thus leaving a median pale line; membrane lightly shaded with fuscous; cuneus with area near middle and spot on either side adjacent to apex clear. Legs pale yellow to fulvous, with two rows of spots on femora; tibial spines and spots around their bases, and apex of tarsi and claws, black.

Host Plant.-Honey locust (Gleditsia triacanthos).

Knowy Distribution.-Illinois, Indiana, Iowa, Missouri, New York, Ohio, Pennsylvania, Virginia.

Illinois Records.-ELIZAветн тоWN : May 27-31 1932, H L. Dozier, 1 ㅅ, 9 우. Grand Tower: May 12, 1932, Frison, Ross \& Mohr, 18 o, 11 . URBANA: June 7, 1916, on tree trunk, 1 ; J June 9, 1916, on tree trunk, 1 우 ; June 27, 1917, on tree trunk, 7 ; J June 1, 1933, H. H. Ross, 1 ㅇ․

\section{Plagiognathus gleditsiae Knight}

Plagiognathus gleditsiae Knight (1929d, p. 265).

This species is allied to delicatus (Uhler), hut is distinguished by its broader head and shorter rostrum; the scutellum is black with a median pale line, and the frons has a quadrate black spot on either side of the median line.

MALE.-Length 3.00, width 1.17. Head 
width 0.69 , vertex 0.34 . Rostrum reaching only to middle of sternum. Antennae dark fuscous to black; first segment, length 0.17 ; second, 0.78 , third, 0.39 ; fourth, 0.22. Pronotum, length 0.52 , width at base 1.04 . General color dark fuscous to black; vertex, median line of frons, median line and lateral margins of pronotal disk, claval suture, and base of cuneus, straw colored to yellowish. Legs straw colored to yellowish, femora dusky but with small, darker spots showing through; tibial spines and spots around their bases black. Body clothed with fine, short, pale to dusky pubescence.

Female.-Length 3.00, width 1.29. Rather similar to male in form and pubescence, but color much paler; pronotum yellowish with only calli black; frons with quadrate black spot on either side; median line of scutellum pale; hemelytra pale yellowish with fuscous confined to inner angles of clavus and apical half of corium, and with cuneus uniformly pale.

Food Plant.-Honey locust (Gleditsia triacanthos).

Known Distribution. - Illinois and Texas.

Illinois Records. - Dolson: June 25, 1932, Rocky Branch, Frison \& Mohr, 1 웅. Fountain Bluff: May 15, 1932, Frison, Ross \& Mohr, $1 \hat{\delta}$. Grand Tower: May 12, 1932, Frison, Ross \& Mohr, 5 q ; May 12, 1932, H. L. Dozier, 1 of. Makanda: Giant City State Park, May 21, 1932, H. L. Dozier, 1 q .

\section{Plagiognathus caryae Knight}

Plagiognathus caryae Knight (1923d, p. 448). Occurs on hickory (Carya ovata) and pecan ( $C$. illinoensis). Not yet taken in Illinois; known from Mississippi, New York and Texas.

\section{Plagiognathus repletus Knight} 449).

Plagiognathus repletus Knight (1923d, p.

This species is suggestive of albatus var. vittiscutis Knight but has the rostrum distinctly shorter.

Male.-Length 3.70, width 1.25. Head width 0.69 , vertex 0.30 . Rostrum extending only to middle of intermediate coxae. Antennae, first segment, length 0.26 ; second, 1.10 third, 0.69; fourth, 0.34. Pronotum, length 0.56 , width at base 1.10 ; black; area occupy- ing center of disk and extending between calli, pale yellowish. Scutellum yellowish; median line black. Hemelytra black; basal one-third of corium, embolium and cuneus, yellowish, translucent; membrane fuscous, veins paler. Clothed with simple yellowish pubescence. Legs yellowish; hind femora brownish on apical half except at extreme apex; two rows of black spots on anterior face; front and middle femora showing only three or four spots.

Female.-Length 3.90 , width 1.40 ; more robust than male and rather similar in coloration, but frequently with the pale areas broader. Very pale specimens may fail to show dark line on scutellum.

The variety apicatus Knight (1923d, p. 449 ) is generally darker on the dorsum than is the typical form; repletus apicatus has not been collected in Illinois.

Food Plants.-Walnut (Juglans nigra) and butternut (Juglans cinerea).

Known Distribution.-Connecticut, Illinois, Iowa, New York, Ohio.

Illinois Records.-Nineteen males and 36 females, taken June 5 to July 17, are from Alton, Freeport, Galena, Galesburg, Grand Detour, Hardin, Harvard, Marshall. Monticello, Palos Park.

\section{Plagiognathus davisi Knight}

Plagiognathus davisi Knight (1923d, p. 452).

Known from Iowa and New York, but not yet taken in Illinois.

\section{Plagiognathus cornicola Knight} 450).

Plagiognathus cornicola Knight (1923d, p.

The general coloration of this species is fusco-brownish or ligneous with the calli darker; the second antennal segment is fusco-brownish and black at the base.

Male.-Length 3.40, width 1.24. Head width 0.69 , vertex 0.32 . Rostrum reaching near hind margin of middle coxae. Antennae, first segment, length 0.21 ; second, 0.82 ; fusco-brownish to fuscous, black at base; third, 0.60 ; fourth, 0.34. Pronotum, length 0.54 , width at base 1.10. General color fusco-brownish or ligneous, somewhat translucent on hemelytra; cuneus evenly colored like corium; membrane fuscous, veins pale brownish. Body clothed with yellowish to golden pubescence. Legs fusco-brownish to black; tip of femora pale; tibial spines with 
prominent black spots around the base of each.

Fenale.-Length 3.10 , width 1.33 ; slightly more robust than male, but very similar in coloration.

Food Plants.-Dogwoods (Cornus amomu $m$ and $C$. stricta).

Known Distribution-Illinois, Massachusetts, New York, Virginia.

Illinois Records.-FrankFORT: June 8, 1933, Mohr \& Townsend, $1 \delta, 1 \%$. ST. Joseph: June 17, 1932, T. H. Frison, 1 o. Urbana: June 20, 1932, T. H. Frison, $4 \delta$, 3 \%.

\section{Plagiognathus laricicola Knight} 452).

Plagiognathus laricicola Knight (1923d, p.

This species is black, with fuscous legs; small black spots show through the obscuration on the legs; the body is clothed with yellowish and dusky pubescence.

MaLE.-Length 3.90, width 1.40 . Head width 0.66 , vertex 0.33 . Rostrum reaching to middle of hind coxae. Antennae, first segment, length 0.27 ; second, 1.03 , fusco-brownish with black at base; third, 0.66 ; fourth, 0.36 . Pronotum, length 0.55 , width at base 1.11. Body fuscous black; base of cuneus scarcely paler than corium. Legs dark fuscous; small black dots visible on anterior and posterior faces of femora; tibiae fuscous, but black setigerous spots showing through infuscation.

Female.-Length 3.60 , width 1.55 ; more ovate and rohust than male, but very similar in coloration.

Food Plant.-Larch (Larix laricina).

Known Distribution. - Canada, Illinois, Maine, Minnesota, New York.

Illinois Records.-Antloch: July 5-7, 1932, on Larix, Frison et al., $44 \hat{\delta}, 78$ ㅇ. Grand Detour: July 2, 1932, Dozier \& Iohr, 1 .

\section{Plagiognathus punctatipes Knight}

Plagiognathus punctatipes Knight (1923d, p. 450$)$.

This species is black, with the second antennal segment biack at base, pale beyond; the legs are yellowish, and the hind femora have two rows of black spots on each anterior face.

Male.-Length 3.80 , width 1.70 . Head width 0.72 , vertex 0.37 . Rostrum reaching middle of hind coxae. Antennae, first segment, length 0.25 ; second, 0.97 ; third, 0.66 ; fourth, 0.39. Pronotum, length 0.67 , width at base 1.28. Body black, moderately shining, clothed with pale yellowish pubescence; cuneus uniformly black, scarcely translucent at base. Legs pale yellowish to fulvous; hind femora with two rows of prominent black spots on anterior faces; tibial spines with rather small black spots around bases.

Fenale.-Length 3.70 , width 1.70 ; slightly more robust than male, but very similar in coloration.

Food Plant, - Black walnut (Juglans nigra). A single Illinois specimen was taken on apple.

Known Distribution.-Illinois, Michigan, New York, Ohio, Ontario, Pennsylvania.

Illinois Records.-Twenty-six males and 28 females, taken May 27 to July 6, are from Elizabethtown, Freeport, Galena, Hardin, Kampsville, Keithshurg, Urbana, Warsaw, White Heath, White Pines Forest State Park, Zion.

\section{Plagiognathus dispar Knight}

Plagiognathus punctatipes var. dispar Kright (1923d, p. 451).

This species is smaller and more slender than punctatipes Knight; the two are very similar in coloration, but dispar has a narrow, pale area at base of cuneus. This species was originally described as a variety of punctatipes Knight, but more recent examination of the genital characters reveals a distinct difference in structure of the left genital clasper.

Male.-Length 3.50, width 1.28. Head width 0.67 , vertex 0.31 . Rostrum reaching middle of hind coxae. Antennae, first segment, length 0.22 ; second, 0.90 , yellow with narrow black area at base; third, 0.58 ; fourth, 0.36. Pronotum, length 0.53 , width at base 1.05. Body black, moderately shining; base of cuneus yellowish, translucent. Legs straw colored to yellow; hind femora with two rows of fuscous spots on anterior face and a group of five or six spots on posterior surface near apex; tibiae with very small fuscous spots around hase of spines.

Female.-Length 3.30, width 1.39 ; slightly more robust than male but very similar in coloration.

The cuneus varies considerably in color; specimens in which it tends to he entirely. 
rather than partly, black belong to the variety crataegi Knight (1929d, p. 264).

Food Plants.-Hickory (Carya sp.), hawthorn (Crataegus sp.); Illinois specimens were taken also on ash (Fraxinus sp.).

Known Distribution. - Illinois, Iowa, Michigan, New England, New York.

Illinois Records.-Sixty-three males and 67 females, taken May 31 to July 4, are from Champaign, Dixon, Frankfort, $\mathrm{Ha}$ vana, Joliet, Lacon, Sparland, Urbana, White Pines Forest State Park.

\section{Plagiognathus suffuscipennis Knight}

Plagiognathus suffuscipennis Knight (1923d, p. 454 ).

This species is distinguished by its translucent, pale yellowish brown hemelytra; the second antennal segment is pale yellowish brown, darker at the base.

MaLE.-Length 3.40, width 1.30. Head width 0.68 , vertex 0.36 . Rostrum reaching hind coxae. Antennae, first segment, length 0.23 ; second, 0.81 ; third, 0.54 ; fourth, 0.36 . Pronotum, length 0.45 , width at base 0.98 . Body blackish brown; pubescence yellowish to dusky; scutellum black; cuneus uniformly translucent yellowish brown like corium. Legs yellowish testaceous; femora with two series of fuscous dots on anterior face and a group of six or eight spots on apical half of posterior face.

Female.-Length 3.20 , width 1.37 ; very similar to male in coloration, but more robust in form.

Food Plant.-Spruce (Picea mariana).

Known Distribution.-Illinois, Maine, Minnesota, New York.

Illinois Records.-Antioch: July 5-7, 1932, Frison et al., 1 . Galena: June 30 , 1932, on spruce, Dozier \& Mohr, 10 ๙ิ, 8 ㅇ. Keithsburg: June 15,1932 , on spruce, $\mathrm{H}$. L. Dozier, $6 \hat{o}, 8$ q

\section{Plagiognathus guttulosus (Reuter)}

Psallus guttulosus Reuter (1876, p. 89).

This species is distinguished by its pale color and its numerous reddish brown dots. It has been placed in the genus Psallus up to the present time, but the possession of a single type of simple pubescence refers it to Plagiognathus.

Male.-Length 3.00, width 1.20. Head width 0.69 , vertex 0.30 . Rostrum reaching posterior margins of hind coxae. Antennae, first segment, length 0.21 ; second, 0.99 ; thickness equal to that of first segment; third, 0.34; fourth, 0.26. Pronotum, length 0.52 , width at base 0.99 . Body pale, thickly dotted with reddish brown to dusky brown points; calli shaded brown; median line of pronotal disk paler. Body clothed with pale to yellowish simple pubescence. Legs pale; femora thickly dotted with brown, hind pair darker; tibial spines pale, but with black dot around base of each.

Female.-Length 3.00 , width 1.40 ; very similar to male in color and pubescence.

Food Plant.-Oak (Quercus sp.)

Known Distribution. - Florida, Illinois, Mississippi, Texas.

Illinois Records.-Champaign: June 6, 1888, at electric light, 1 ô. Dubors: May 21, 1917, 1 of ; May 22, 1917, 5 ㅇ․

\section{Plagiognathus repetitus Knight} 453).

Plagiognathus repetitus Knight (1923d, p.

Breeds on cranberry (Vaccinium) in Massachusetts. Not yet collected in Illinois, but occurs in Massachusetts, Michigan, New Jersey, New York.

\section{Rhinocapsus Uhler}

No Illinois species; Rhinocapsus vanduzeei Uhler occurs from New England west to Michigan and south to North Carolina.

\section{Microphylellus Reuter}

\section{KEY TO SPECIES}

1. Hemelytra more or less pale; embolium, cuneus and basal half of corium almost colorless or yellowish; scutellum light, with median line black.............. 2

Hemelytra uniformly blackish..... 3

2. Second antennal segment and femora uniformly pale..........maculipennis var. maculipennis, p. 41 Second antennal segment dark brown to black, femora with fuscous dots .

macu -

lipennis var. fuscicornis, p. 41

3. Second antennal segment black, first segment pale on apical half......

nigricornis, p. 41

Second antennal segment pale, or fuscous at base only.........4 
4. Length of second antennal segment less than width of pronotum at base 5

Length of second antennal segment equal to or greater than width of pronotum at base........... 7

5. First antennal segment yellowish, fuscous at base only; femora usually with fuscous dots on anterior face although these at times absent; length $3.30 \ldots \ldots$ modestus, p. 41

First antennal segment black, or mostly black. .

6. Smaller, length $2.60-2.80$; rostrum not extending beyond hind margins of middle coxae........tsugae, p. 42

Larger, length 3.30 ; rostrum nearly attaining hind margins of posterior coxae........tumidifrons, p. 42

7. Rostrum long, extending beyond hind coxae, reaching to near middle of venter; hind femora uniformly pale yellowish...... longirostris, p. 42

Rostrum shorter, reaching only to middle of hind coxae; hind femora with fuscous spots on anterior face.

elongatus, p. 42

\section{Microphylellus modestus Reuter} 62).

Microphylellus modestus Reuter (1912a, p.

Adults.-Length 3.30-3.50, width 1.30 . Body ligneous black. Antennae and legs yellowish; first antennal segment fuscous at base, dark area sometimes extended from base toward middle. Hind femora usually with three or four fuscous dots near dorsal margin on anterior face, although these spots are frequently indistinct. Hemelytra mostly black, with membrane fuscous; apex of cuneus slightly paler, and veins pale fuscous.

Host Plants.-Elm (Ulmus) and white oak (Quercus alba). In Illinois, specimens have been taken also on hazelnut (Corylus americana), hawthorn (Crataegus mollis) and hickory (Carya sp.). On elm the bugs are found most frequently among leaves curled by aphids, where they feed to some extent on honeydew. I have observed this species feeding on eggs of the elm leaf beetle, Galerucella luteola Mullsant.

Known Distribution. - From Minnesota to Texas and in all states eastward.

Illinois Records.-Fifty-one males and 57 females, taken May 23 to July 6, are from Algonquin, Dolson, Elizabethtown, Frankfort, Freeport, Galena, Galesburg,
Grand Detour, Hardin, Havana, Homer, Keithsburg, Maywood, Meredosia, Monticello, Mounds, Rockford, Rogers, Savanna, Ullin, Urbana, Waukegan, White Heath. White Pines Forest State Park, Willow Springs, Zion.

\section{Microphylellus nigricornis Knight}

Microphylellus nigricornis Knight (1923d, p. 457 ).

Not yet collected in Illinois; known to occur in Minnesota, New York, Ontario. It breeds on aster (Aster macrophyllus).

\section{Microphylellus maculipennis Knight}

Microphylellus maculipennis Knight (1923d, p. 456).

This is similar in size to modestus Reuter, but is distinguished by having pale markings on the dorsum.

Male.-Length 3.40, width 1.30. Head black, width 0.69 ; vertex pale, 0.33. Rostrum yellowish, dark at base and apex and reaching hind margins of middle coxae. Antennae, first segment, length 0.30 , yellow, fuscous at base; second, 0.86 , yellow, fuscous at base and dusky at apex; third, 0.47, yellowish with dusky tinge; fourth, 0.33 , pale fuscous. Pronotum, length 0.55 , width at base 1.11 ; black, moderately shining; central area of disk and basal angles pale to yellowish; clothed with fine, yellowish pubescence. Scutellum pale yellowish; rather broad median line of scutellum and mesoscutum black. Hemelytra mostly black; with embolium, cuneus, and basal half of corium, usually straw colored to yellow but sometimes distinctly reddish; membrane fuscous, paler bordering apex of cuneus, veins pale only at apex of areoles. Legs pale to yellowish; basal half of hind coxae and tips of tarsi fuscous.

Female.-Length 3.40, width 1.39 ; slightly more robust than male but very similar in coloration.

A form of this species having the antennae very dark, almost black, rather than light is known only from Maine; it has been described as maculipennis fuscicornis Knight (1923d, p. 457).

Food Plant, - White oak (Quercus alba).

Known Distribution. - Illinois, Iowa, Maine, Minnesota, Texas.

Illinois Records.-Frankfort: June 8, 
1933, Mohr \& Townsend, 1 . KeIthsBURG: June 8, 1932, Ross \& Mohr, 1 ô. Mounds: May 23, 1932, H. L. Dozier, 6 q. Urbana: May 28, 1934, Crystal Lake Park, Ross \& Mohr, $1 \delta$. White Heath : May 29, 1933, H. H. Ross, 1 ô.

\section{Microphylellus tsugae Knight}

Microphylellus tsugae Knight (1923d, p. 456). Known only from New York; breeds on hemlock (Tsuga canadensis).

\section{Microphylellus elongatus Knight}

Microphylellus elongatus Knight (1923d, p. 458).

This species is larger and longer than modestus Reuter; the length of the second antennal segment is equal to the width of the pronotum at its base.

Male.-Length 4.00, width 1.4t. Head width 0.68 ; vertex 0.33 ; head black, slightly paler at base of vertex. Rostrum reaching to middle of hind coxae. Antennae, first segment, length 0.28 , yellowish, fuscous at base; second, 1.19, yellow, sometimes slightly dusky at base ; third, 0.77 , yellowish ; fourth, 0.33 , yellowish. Pronotum, length 0.62 , width at base 1.16 ; black, pubescence pale to dusky. Scutellum, sternum and pleura black. Hemelytra black, strongly shining; emboliar nargins nearly straight; pubescence pale to dusky. Legs straw colored to yellow; bases of hind and middle coxae, and tips of tarsi, black; hind femora with a row of fuscous spots on anterior face near dorsal margin. Venter black, shining.

Female.-Length 3.80, width 1.42 ; very similar to male.

Food Plant.-Sugar maple (Acer saccharum).

Known Distribution.-Illinois, Minnesota, New York.

Illinois Record.-ZIoN: July 6, 1932, Frison et al, 1 ô, 1 \%.

\section{Microphylellus longirostris Knight}

Microphylellus longirostris Knight (1923d, p. 458 ).

This species is very similar to elongatus Knight, but has the rostrum distinctly longer: it extends beyond the hind coxae to near the middle of the venter.

MaLE.-Length 3.80, width 1.25. Head black, width 0.61 ; vertex and area border- ing eyes paler, 0.32. Rostrum reaching to middle of venter; yellowish, apex and basal segment black. Antennae, first segment, length 0.28 , fuscous at base; second, 1.22, yellow; third, 0.86, yellowish to dusky; fourth, 0.44, dusky. Pronotum, length 0.64 , width at base 1.11 ; black, strongly shining. Scutellum and ventral surface black. Hemelytra uniformly black, strongly shining; clothed with minute, dusky to black pubescence: emboliar margins nearly straight. Membrane and veins uniformly fuscous, apex of cuneus scarcely paler. Legs straw colored to yellowish, devoid of black spots; bases of hind coxae and apices of tarsi fuscous. Venter black, strongly shining.

Female.-Length 3.90 , width 1.34 ; very similar to male in form and coloration.

Food Plant.-Hazelnut (Corylus americana); a single specimen was collected on hickory (Carya ovata).

Known Distribution. - Illinois, Iowa, Minnesota, New England, New York.

Illinois Records.-Thirty-two males and 42 females, taken June 3 to July 27, are from Algonquin, Antioch, Dolson, Elizabeth, Galena, Galesburg, Grandview, Hardin, Monticello, Oregon, Palos Park, White Pines Forest State Park.

\section{Microphylellus tumidifrons Knight}

Microphylellus tumidifrons Knight (1923d, p. 455).

Known only from Nova Scotia.

\section{Microsynamma Fieber}

\section{Microsynamma bohemanni (Fallen)}

Phytocoris bohemanni Fallen (1829, p. 106).

This species is distinguished from others by its broad, flat vertex with a basal carina.

MALE.-Length 4.00, width 1.60. Head width 0.84 , vertex 0.43 ; vertex flat, basal carina distinct, an impressed mark evident on either side near eye; head mostly black, with juga and a broad area bordering front of eyes and sides of vertex, yellowish. Rostrum, length 1.51 , extending nearly to tips of hind coxae. Antennae, first segment, length 0.23 ; second, 1.03 ; third, 0.52 ; fourth, 0.30 ; black. Pronotum, length 0.64 , width at base 1.21; black, with area between and behind calli, and spot on either side in front of calli, pallid to yellowish. Dorsum clothed with fine, short, yellowish, simple pubes- 
cence. Hemelytra pallid, translucent; apex of cuneus, apical half of corium and embolium, and clavus except in central area near tip of scutellum, dark brown to black; membrane pale brown, areoles and veins clear to yellowish. Legs black; tips of coxae, bases and tips of femora, and tibiae except for setigerous spots and spines, pale yellowish.

Fenale.-Length 3.80, width 1.62. Head width, 0.86 , vertex 0.45 . Antennae, first segment, length 0.22 ; second, 0.92 ; third, 0.56 ; fourth, 0.39. Pronotum, length 0.62 , width at base 1.21. More robust than male and usually lighter in color.

Host Plant.-Willow (Salix sp.).

Known Distribution.-British Columhia, Colorado, Illinois, Indiana, Iowa, Michigan, Newfoundland, New Jersey, New York, Ohio, Oregon, Vermont, Washington; Europe.

Illinois Record.-NORTHERN IlLINOIS: $1 \hat{\delta}, 2$ ㅇ․

\section{Psallus Fieber}

\section{KEY TO SPECIES}

1. Second antennal segment with four or five black spots, fig. 89; membrane with a conspicuous black mark on margin behind apex of cuneus; dorsum thickly covered with pale fuscous dots.......... seriatus, p. 45

Second antennal segment either black, or pale without distinct black spots. ?

2. Second antennal segment yellowish, black only at base... amorphae, p. 44

Second antennal segment black..... 3

3. Dorsum chiefly red; head, pronotal disk and scutellum flecked with fuscous; cuneus red with a narrow area at base light; length 3.60 .

alnicola, p. 44

Dorsum black o-fuscous, never distinctly flecked............. $t$

4. Femora pale or fulvous, or pale with black spots, but without black line on dorsal margin............ 5

Femora black, or pale to yellowish with spots and a dark line on dorsal margin.

5. Femora uniformly pale or yellowish; dorsum uniformly black; length $3.50 \ldots \ldots$. . . strobicola, p. 45

Femora fulvous, becoming dusky, with one or two black dots on dorsal aspect near apex, hind femora obscured with fuscous; length 2.60$3.00 \ldots \ldots \ldots \ldots$ bakeri, p. 45

6. Length of second antennal segment more than three-fourths width of pronotum at base........... 7

Length of second antennal segment less than three-fourths width of pronotum a base ............11

7. Scutellum more or less pale at lateral margins, rarely entirely black; if scutellum black, cuneus paler or dusky at apex only; cuneus usually pale, sometimes slightly infuscated at apex; pale areas of legs and hemelytra tinged with reddish yellow.... .....alnicenatus, p. 44

Scutellum black; cuneus always partly black, frequently paler at base; pale areas of legs and hemelytra never tinged with reddish yellow...... 8

8. Rostrum reaching hind margins of posterior coxae; hemely tra uniformly black; femora black with pale apices; length $3.60 \ldots \ldots \ldots \ldots$.

morrisoni, p. 45

Rostrum scarcely surpassing hind margins of middle coxae....... 9

9. Femora pale, a dark line forming on dorsal margin, anterior face with black spots and occasionally becoming uniformly dusky; tip of embolium and spot on base of corium almost colorless; length 4.50 .

parshleyi, p. 44

Femora black but with light-colored apices.................. 10

10. Length 2.90-3.10; deep black, with scalelike, silvery white pubescence.

astericola, p. 45

Length $3.50-4.00$; very dark brown, hemelytra sparsely clothed with silvery, silky hairs intermixed with more erect, yellowish pubescence.

fuscatus, p. 44

11. Antennae entirely pale, pubescence dusky; legs black; apices of femora and tibiae pale, spines with small fuscous spots at bases

piceicola, p. 44

Antennae black, or at least first segment black................. 12

12. Legs dull yellow brown to dark brown; femora sometimes nearly black but never paler at apices, always tinged with brownish and reddish, hind 
pair strongly thickened; coxae and tibiae dull yellow brown to dark brown, more or less tinged with reddish.......... ancorifer, p. 46

Legs chiefly black; femora more slender, black, apices of front and middle pairs pale; coxae deep black; tibiae very light yellow to dull yellow brown, black spots at bases of spines......drakei, p. 46

\section{Psallus parshleyi Knight}

Psallus parshleyi Knight (1923d, p. 465).

The color aspect of this species is suggestive of Plagiognathus obscurus fraternus Uhler, but Psallus parshleyi is to be distinguished by the sericeous, semiscalelike pubescence on its pleura and dorsum.

MALE.-Length 4.50, width 1.70. Rostrum just reaching hind margins of middle coxae. Second antennal segment, length 1.26. Pronotum, width at base 1.37. Body black, basal half of cuneus, tip of embolium, and a small translucent spot near base of corium, pale. Legs pale yellowish; coxae fuscous at base; femora with dark line forming above and below on apical half, anterior face with three or four spots on apical half.

Female.-Length 4.00, width 1.66 ; more robust than male but very similar in coloration.

Food Plant.-Birch (Betula pumila).

Known Distribution.-Illinois, Massachusetts, Minnesota, New York.

Illinois Record.-Antioch: July 5-7, 1932, Frison et al., 23 ô, 16 ․

\section{Psallus fuscatus Knight}

Psallus parshleyi var. fuscatus Knight (1923d, p. 466).

This species is allied to parshleyi Knight, but is distinguished by its smaller size and uniformly black femora and hemelytra.

MALE.-Length 3.70, width 1.40. Rostrum reaching posterior margins of hind coxae. Second antennal segment, length 0.95 , black. Pronotum, width at base 1.08. Body sparsely clothed with silvery, silky hairs intermixed with more erect yellowish pubescence. Body black, paler areas appearing very dark brown, cuneus uniformly black like corium. Legs black, tips of femora and tibiae yellowish, tibial spines with prominent black spots at bases.
Female.-Length 3.30 , width 1.40 ; very similar to male in color and pubescence.

Host Plant.-Alder (Alnus rugosa).

Known Distribution. - Illinois and Minnesota.

Illinois Records. - DoLson: June 25, 1932, Rocky Branch, Frison \& Mohr, 1 \% EICHORN: June 24, 1932, on Alnus rugosa, Ross, Dozier \& Park, 6 ô, 10 \% ; June 13, 1934, DeLong \& Ross, 2 ô , 1 우.

\section{Psallus amorphae Knight}

Psallus amorphae Knight (1930b, p. 125).

This species is black, with the second antennal segment yellow except at the base.

Adults.-Length 3.00-3.20, width 1.201.30. Rostrum extending to hind margins of middle coxae. Second antennal segment, length 0.87 , yellow, black at base; pronotum, width at base 0.99. Body black, dorsum and sides clothed with rather closely appressed silvery, silky to scalelike pubescence.

Food Plants. - Lead plant (Amorpha canescens and A. fruticosa).

Known Distribution.-Previously known only from Iowa and Minnesota.

Illinois Records.-Grand Detour: July 2, 1932, Dozier \& Mohr, 5 \%. Mounds: May 23, 1932, H. L. Dozier, $1 \hat{\delta}$. OQuawKA: June 13, 1932, H. L. Dozier, 2 o . Starved Rock State Park: July 14, 1932, Dozier \& Park, 1 ㅇ.

\section{Psallus alnicola Douglas \& Scott}

Psallus alnicola Douglas and Scott (1865, p. 414).

Not taken in Illinois; known from Colorado, Idaho, Michigan, Minnesota, New Hampshire, New York, Oregon, Washington; Europe. Breeds on alder (Alnus rugo$s a)$ in cool, humid surroundings.

\section{Psallus alnicenatus Knight}

Psallus alnicenatus Knight (1923d, p. 466).

Not taken in Illinois; known from Michigan, Minnesota and New York.

\section{Psallus piceicola Knight}

Psallus piceicola Knight (1923d, p. 469).

This species is very dark brown, almost black; the hemelytra are more brownish than the rest of the dorsum, and the antennae and base of the cuneus are pale. 
MaLe.-Length 3.00, width 1.08. Head width 0.60 , vertex at basal margin 0.34 , narrowest point on front 0.27 ; strongly inclined vertically. Rostrum extending behind posterior coxae. Antennae with first segment pale; second, 0.66 in length, pale with dusky tinge. Pronotum, width at base 0.91 . Hemelytra fusco-brownish to black, base of cuneus pale; clothed with golden to dusky pubescence intermixed with more closely appressed, silvery, woolly pubescence. Legs very dark brown, apices of femora and tibiae pale; tibial spines black, a fuscous spot at base of each.

FeMale.-Length 2.90, width 1.30 ; more robust than male, but very similar in coloration; hemelytra usually more brownish.

Food Plant.-Spruce (Picea sp.).

Known Distribution.-Illinois, Minnesota, New York.

Illinois Record.-Anrioch: July 5-7, 1932, on spruce, Frison et al., $2 \delta, 2$.

\section{Psallus strobicola Knight}

Psallus strabicola Knight (1923d, p. 467).

This species is very dark fuscous, almost black; the antennae and the legs, except for the coxae, are yellow; the body is clothed with closely appressed, silvery, silky pubescence.

Male.-Length 3.50, width 1.33. Head width 0.72 , vertex 0.33 measured across posterior corners of eyes; black; eyes reddish brown. Rostrum, length 1.25 , reaching hind margins of posterior coxae, yellow, basal segment black. Antennae yellow; first segment, length 0.17 ; second, 0.97 ; third, 0.62; fourth, 0.39, slightly dusky. Pronotum, length 0.53 , width at base 1.08 . Hemelytra uniformly very dark fuscous; clothed with closely appressed, silvery, silky pubescence intermixed with more erect dark pubescence similar to that of the pronotum and scutellum; emboliar margins very slightly arcuate; membrane and veins uniformly fuscous, border of cuneus not perceptibly paler. Legs yellow, coxae almost black except at apex; tibial spines black without dark spots at bases.

Female.-Length 3.10 , width 1.36 ; more robust than male, but otherwise very similar.

Food Plant.-Pine (Pinus strobus).

Known Distribution.-Illinois, Minnesota, New York, Ohio, Quebec.

Illinois Records. - Galena: June 30, 1932, on Pinus strobus, Dozier \& Mohr,
3 ó, 4 q. Keithsburg: June 15, 1932, $\mathrm{H}$. L. Dozier, 1 o , 4 . Mount Carroll: June 15, 1932, on Pinus strobus, Frison \& Mohr, 2 o, 1 q. Urbana: June 11, 1915, $1 \%$. White Pines Forest State Park: July 4, 1932, on grasses, Dozier \& Mohr, 1 o ; July 4, 1932, on Pinus strobus, Dozier \& Mohr, 2 .

\section{Psallus astericola Knight}

Psallus astericola Knight (1930b, p. 125).

Known only from lowa. Breeds on prairie aster (Aster sericeus), which grows only on undisturbed, native prairie.

\section{Psallus morrisoni Knight}

\section{Psallus morrisoni Knight (1923d, p. 464).}

Not taken in Illinois; known from Massachusetts, Minnesota, New York.

\section{Psallus bakeri (Bergroth)}

Agalliastes signatus Uhler $(1895$, p. 55). Preoccupied.

Chlamydatus bakeri Bergroth (1898, p. 35).

This species has previously been placed in the genus Chlamydatus, but its two types of pubescence, its longer antennae, and the form of its pseudarolia place it in Psallus.

Adults.-Length 2.60-2.90. General color fuscous to black, two spots on vertex and frequently base of cuneus paler. Legs yellowish to dusky yellow; hind femora frequently dark fuscous; femora with two or three black dots on dorsal surface before apex; tibiae pale, spines black with a prominent black spot at base of each. Clothed with pale, simple hairs intermixed on dorsum with some silky, silvery pubescence.

Food Plant. - Sage brush (Artemisia sp.).

Known Distribution. - Occurs frequently in the states west of the Mississippi River.

Illinois Records.-Grand Detour: July 12, 1934, DeLong \& Ross, 3 o , 2 \%. OreGoN: July 4, 1932, on Artemisia canadensis, Dozier \& Mohr, 10 s, 33 o. Rockton: July 5, 1932, Dozier \& Mohr, 2 ㅇ.

\section{Psallus seriatus (Reuter)}

Alomoscelis seriatus Reuter (1876, p. 91).

This is the well-known cotton flea hopper, distinguished by its pale color, the black 
spots on its second antennal segment, and the conspicuous black marks on the margin of the membrane, fig. 89 .

Male.-Length 3.10, width 1.30. Head width 0.69 , vertex 0.34 . Rostrum reaching

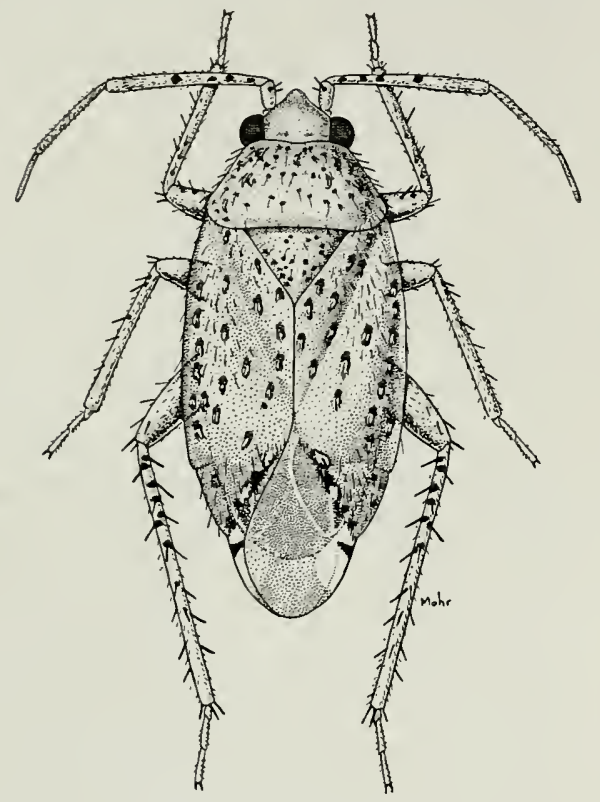

Fig. 89.-Psallus seriatus, $\circ$.

behind posterior coxae to third ventral segment. Antennae, first segment, 0.17 , pale, a group of three setigerous black spots before apex, some of which form narrow annulations; second, 0.82 , pale, with four or five conspicuous black spots on dorsal aspect. Pronotum, length 0.56 , width at base 1.09 ; pale, finely dotted with fuscous. Hemelytra pale, dotted with small and a few larger fuscous spots. Dorsum clothed with simple fuscous hairs intermixed with deciduous, silvery scalelike pubescence which in part is arranged in tufts at posterior edge of larger fuscous spots; roughly handled specimens or old living adults may lose pubescence. Membrane clear and shaded with fuscous; a clear spot surrounding black mark on margin behind cuneus; veins white. Legs pale; femora dotted with fuscous; tibiae with two rows of black spines, each with a prominent black spot around base.

FEMALE.-Length 2.80 , width 1.40 ; slightly more robust than male, but very similar in color and pubescence.

Host Plants. -The nymphs and adults feed on the tiny flower buds of cotton just as they appear, causing the buds to drop. The wild hosts of this insect may be several herbaceous weeds, but the preferred food plants appear to be several species of Croton, especially $C$. texensis. In Illinois, specimens have been taken on snowberry ( $S_{y}$ mphoricarpos orbiculatus), horse mint (Monarda punctata) and daisy (Chrysanthemum sp.), as well as on cotton and Croton capitatus.

Known Distribution.-P sallus seriatus is known from all the southern states and ranges northward into Nebraska and Colorado and westward into Arizona and southern California. Its range coincides rather closely with the distribution of the various species of Croton.

Illinois Records. - One hundred one males and 57 females, taken June 15 to Sept. 6, are from Centralia, Fulton, Golconda, Harrisburg, Havana, Keithsburg, Meredosia, Metropolis, Patoka, St. Anne.

\section{Psallus ancorifer (Fieber)}

Apucremnus ancorifer Fieber (1859, p. 336).

Not taken in Illinois; known only from New York and Pennsylvania.

\section{Psallus drakei Knight}

Psallus drakei Knight (1923d, p. 464).

Not taken in Illinois; known only from Colorado and New York.

\section{Lepidopsallus Knight}

\section{KEY TO SPECIES}

1. Rostrum extending beyond posterior coxae.................. 2

Rostrum not extending beyond posterior coxae................ 3

2. First and second antennal segments pale yellowish; sides of venter without scalelike pubescence.........

claricornis, p. 47

Fi:st antennal segment black, base of second dusky; sides of venter and pleura bearing scalelike pubescence . . . . . . . . . rostratus, p. 47

3. First antennal segment pale yellow. . 4 First antennal segment very dark brown or black............. 5

4. First antennal segment short, second segment six times as long as first segment; reddish color dominant, 
darkest forms brownish red......

miniatus, p. 47

First antennal segment longer, second segment four times as long as first segment; color brown to fuscous, never reddish ........ nyssae, p. 48

5. Combined lengths of third and fourth antennal segments greater than length of second segment; second antennal segment thickened in both sexes, cylindrical and as thick as first segment; black, length 2.60

minusculus, p. 47

Combined lengths of third and fourth antennal segments less than or scarcely equal to length of second segment; second antennal segment more slender in female, distinctly thinner on basal half and not so thick as first segment.........6 6

6. Color uniformly black; second antennal segment always black; scalelike pubescence silvery white..... ..... rubidus var. atricolor, p. 47

Color black with reddish areas; second antennal segment usually light at apex, scalelike pubescence yellowish ...... rubidus var. rubidus, p. 47

\section{Lepidopsallus rubidus (Uhler)}

Sthenarus rubidus Uhler (1895, p. 41).

MALE.-Length 3.20 , width 1.50 ; ground color black; hemelytra reddish brown with fuscous; embolium and cuneus strongly reddish; membrane uniformly fuscous. Body clothed with pale yellowish, closely appressed, scalelike pubescence intermixed with more erect, dusky, simple pubescence. Femora fusco-brownish, tinged with reddish; tibiae brownish to reddish, beset with prominent black spines. Antennae fuscous to ferruginous; first segment, length 0.16 ; second, $0.6+$, its length two-thirds as great as width of head, apical three-fourths equal in thickness to first segment, but more slender on basal one-fourth, usually paler on apical half; third, 0.36; fourth, 0.31. Pronotum, length 0.62 , width at base 2.38 .

Fexlale.-Length 3.50 , width 1.53 ; head narrower than in male; second antennal segnent gradually becoming thicker toward apex, but not quite attaining thickness of first segment.

Specimens which are uniformly black in color, rather than not quite so, and having silvery rather than yellowish pubescence, have been named rubidus atricolor Knight (1923d, p. 472). These were taken in company with typical specimens at Dolson.

Food Plants.-Willow (Salix sp.). A few specimens were taken in Illinois on plantain (Plantago aristata) and black locust (Robinia pseudoacacia).

Knowy Distribution.-Common in the eastern United States and Canada; also known from California, Colorado, Idaho, Texas, Utah, Washington.

Illinois Records. - Twenty-two males and 49 females, taken June 22 to Aug. 19, are from Browns, Decatur, Dolson, Eichorn, Elizabethtown, Galesburg, Golconda, Grand Detour, Grand Tower, Havana, Herod, Kansas, Meredosia, Savanna, Shawneetown, Starved Rock State Park, York.

\section{Lepidopsallus claricornis Knight} 471).

Lepidopsallus claricornis Knight (1923d, p.

Not taken in Illinois; known from New Jersey.

\section{Lepidopsallus rostratus Knight} 470).

Lepidopsallus rostratus Knight (1923d, p.

Not taken in Illinois; known from lowa and Minnesota.

\section{Lepidopsallus minusculus Knight} 472).

Lepidopsallus minusculus Knight (1923d, p.

Not taken in Illinois; known from New York.

\section{Lepidopsallus miniatus Knight} 226).

Lepidopsallus miniatus Knight (1926b, p.

This species is distinguished by its reddish color and relative lengths of the first two antennal segments.

MaLE.-Length 2.70, width 1.60. Head width 0.73 , vertex 0.30 . Rostrum reaching to middle of hind coxae. Antennae uniformly pale yellowish; first segment, length 0.13 ; second, 0.78 ; third, $0.3+$. Pronotum, length 0.56 , width at base 1.21 . General color uniform red to red with fuscous shading; membrane fuscous, veins red. Legs fusco-reddish; tips of femora and tibiae pale; spines and spots at bases black.

Fenale.-Length 2.80, width 1.50. Head 
width 0.77 , vertex 0.36 . Antennae pale yellowish; first segment, 0.17; second, 0.69. Pronotum, length 0.58 , width at base, 1.23. Color more reddish than in male, sometimes pronotum and scutellum more fuscous than red. Clothed with silvery white, scalelike pubescence intermixed with simple, yellowish to fuscous pubescence.

Food Plant.-Post oak (Quercus stellata).

Known Distribution.-Described from Florida, and now known from Illinois, Mississippi, Texas.

Illinois Records.-Dongola: May 1012, 1917, 1 of, 1 ㅇ․ . Dubors: May 21-24, 1917, 2 ô, 6 q. Meredosia: May 29, 1917, 2 ㅇ․

\section{Lepidopsallus nyssae Johnston} 299).

Lepidopsallus nyssae Johnston (1930, p.

This is allied to miniatus Knight, but is distinguished by its pale brownish color and the relative lengths of the first and second antennal segments.

Male.-Length 3.00 , width 1.40 . Head width 0.73 , vertex 0.30 . Rostrum just attaining posterior margins of middle coxae. Antennae pale yellowish, last two segments dusky; first segment, length 0.21 ; second, 0.82 ; third, 0.34 ; fourth, 0.23 . Pronotum, length 0.61 , width at base 1.21. General color pale brown to fuscous, never reddish as in miniatus; head, pronotum and scutellum dark fuscous to black; hemelytra pale brownish, sometimes darker; cuneus uniformly translucent like the corium. Clothed with silvery, scalelike pubescence intermixed with pale yellowish to fuscous simple pubescence. Legs dark brown; tibiae pale with black spines arising from brown spots.

Female.-Length 3.00, width 1.60 . Head width 0.79 , vertex 0.37 . Antennae uniformly pale yellowish; first segment, length 0.14 ; second, 0.67. Pronotum, length 0.67 , width at base 1.26. Color much paler than in male, dorsum uniformly pale brownish except anterior half of pronotum and head, which are fuscous to blackish. Legs uniformly pale.

Food Plant.-Black gum (Nyssa sylvatica).

Known Distribution.-Described from Texas. Now known in Illinois also.

Illinois Record.-ELIZAB ETH TOWN : May 27-31, 1932, H. L. Dozier, $1 \hat{\delta}$.

\section{Reuteroscopus Kirkaldy}

\section{KEY TO SPECIES}

Membrane uniformly fuscous except for clear spot at apex of cuneus and smaller spot just beyond; scutellum and clavus black, fig. $90 \ldots \ldots \ldots$ ornatus, p. 48

Membrane with many small, fuscous marks; scutellum and clavus yellowish, dotted with fuscous...sulphureus, p. 49

\section{Reuteroscopus ornatus (Reuter)}

Episcopus ornatus Reuter (1876, p. 90).

Adults.-Fig. 90. Length 3.40, width 1.30 ; general color yellowish green, pronotum with darker green; scutellum, clavus,

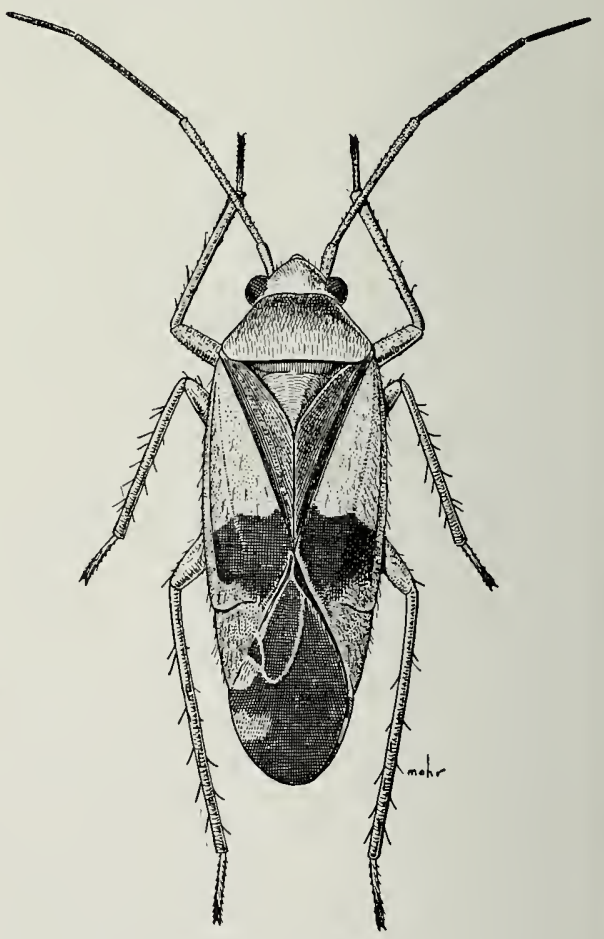

Fig. 90.-Reuteroscopus ornatus, .

membrane, and bar across apex of corium, fuscous, dark color forming a well-marked Greek cross.

Food Plants.-Ragweed (Ambrosia sp.). A few Illinois specimens were taken also on red cedar (Juniperus virginiana), basswood (Tilia sp.) and lamb's quarter (Chenopodium album); the first two are undoubtedly "sitting" records.

Known Distribution. - Common in 
North America east of the 100th meridian.

Illinois Records.-One hundred three males and 77 females, taken May 27 to Sept. 24, are from Albion, Alto Pass, Ashley, Bloomington, Cave-in-Rock, Champaign, Chicago, Darwin, Decatur, Delavan, Dolson, Dubois, East St. Louis, Elizabethtown, Fountain Bluff, Galena, Galesburg, Golconda, Grafton, Grand Detour, Grand Tower, Grandview, Grayville, $\mathrm{Hardin}, \mathrm{Ha}$ vana, Herod, Kampsville, Kankakee, Kansas, Kappa, Karnak, Keithsburg, Lawrenceville, Metropolis, Monticello, Mounds, Mount Carmel, Muncie, Murphysboro, Oquawka, Palos Park, Pulaski, St. Joseph, Snyder, Springfield, Starved Rock State Park, Ullin, Urbana, York.

\section{Reuteroscopus sulphureus (Reuter)}

Psallus sulphureus Reuter (1907, p. 23).

ADults.-Length 3.30, width 1.18. General color yellow, sometimes with a greenish tinge. Inner apical angles of corium, tip of clavus, anal area of membrane, and spot on inner angle of cuneus, fuscous. Body clothed with yellowish to fuscous pubescence, base of each hair with a small fuscous spot, also sparsely set with small tufts of silvery scalelike hairs, arranged in series on median line and outer margins of head and pronotal disk, and present to some extent on clavus and corium; membrane with dark spots on a clear background, fuscous color forming a short transverse bar touching margin just beyond tip of cuneus, each side of this clear but with another, larger fuscous area situated just before apex; femora thickly speckled with small, pale fuscous spots.

Host Plants.-I have collected this species on ragweed (A mbrosia sp.) and found it breeding on Sida spinosa in Georgia. Specimens were collected in Illinois on lamb's quarter (Chenopodium album) and snowberry (Symphoricarpos orbiculatus) as well as on ragweed.

Known Distribution.-This species is common in the southern states and appears to find its northern limits of distribution in central Illinois.

Illinois Records. - Twenty-two males and 29 females, collected June 5 to Oct. 2, are from Alton, Alto Pass, Ashley, Cave-inRock, Darwin, Dolson, Dongola, Dubois, Elizabethtown, Fairfield, Golconda, Hardin, Havana, Herod, Lawrenceville, Metropolis, Oquawka, Shawneetown, Vienna, York.

\section{Criocoris Fieber}

\section{Criocoris saliens (Reuter)}

Strongylotes saliens Reuter (1876, p. 88).

MaLE.-Fig. 91. Length 2.70, width 1.40 . Head and body black, shining, clothed with white scalelike pubescence intermixed with

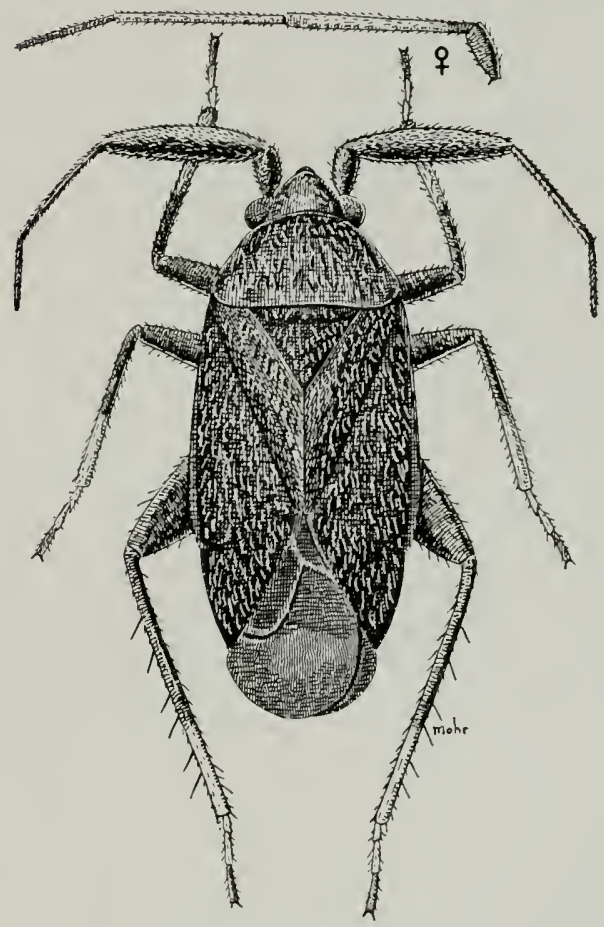

Fig. 91.-Criocoris saliens, $\sigma^{7}$.

more erect pubescence; first and second antennal segments strongly thickened, thickness of second segment half as great as width of vertex.

Ferale.-Length 3.00 , width 1.40 ; black, pubescence similar to that of male; antennae yellowish brown, entire first segment and base of second, black; second segment slender, scarcely more than half as thick as first.

Host Plant.-Bedstraw (Galium aparine.)

Known Distribution.-California, Idaho, Illinois, Iowa, Kansas, Maryland, Massachusetts, Minnesota, New Jersey, New York, Ontario, Pennsylvania, Texas, Virginia, Washington.

Illinois Records.-Anтıон: July 5-7, 1932, Frison et al., $1 \delta$. Elizabethtown: May 27-31, 1932, H. L. Dozier, 1 . Grand Tower : May 12, 1932, Frison, Ross 
\& Mohr, 6 \&. Herod: May 29, 1935, Ross \& Mohr, +q. Jonesboro: May 6, 1932, on Galium aparine, H. L. Dozier, 16 ô, 5 ㅇ. Texas City: May 12, 1936, Ross, Mohr \& Burks, 1 ô.

\section{Rhinacloa Reuter}

\section{Rhinacloa forticornis Reuter}

Rhinacloa forticornis Reuter (1876, p. 89).

This species is distinguished by its small size, scalelike pubescence and thickened second antennal segment.

MalE.-Length 2.20, width 0.95. Head width 0.65 , vertex 0.26 . Rostrum reaching apices of hind coxae, length 0.86. Antennae, first segment, length 0.13 , thickness 0.06 , black; second, length 0.56 , thickness 0.07 , cylindrical, clothed with fine, short pubescence, black; third, length 0.28 , pale, slender; fourth, length 0.21 , fuscous. Pronotum, length 0.36 , width at base 0.85 , clothed with fine, closely appressed, silvery, scalelike pubescence intermixed with dusky to black simple pubescence. General color fuscous to black, hemelytra paler at base, embolium with reddish spot at apex; membrane dusky. Legs brownish to fuscous; tibiae pale with spines and dots at bases of spines black.

Female.-Length 0.21 , width 1.00 . Head width 0.60 , vertex 0.30 . Antennae, first segment, length 0.13 , thickness 0.06 ; second, length 0.47 , slender on basal half, clavate apically (thickness 0.07 ) ; third, length 0.30 , slender, pale; fourth, length 0.20 , fuscous. Pronotum, length 0.39 , width at base 0.86 . Color and pubescence very similar to those of male.

Known Distribution. - Common in Texas and westward. Rare in Illinois, Iowa and Missouri.

Illinois Record. - Urbana: June 29, 1914, C. A. Hart, 1 \&.

\section{Leucopoecila Reuter}

\section{Leucopoecila albofasciata Reuter} 26).

Lencopoecila albofasciata Reuter (1907, p.

This species is distinguished by its peculiar antennae, fig. 92. The dorsum is dark with a pale fascia across the clavus.

MALE.-Fig. 92. Length 2.40, width 0.95 . Head width 0.74 , vertex 0.39 , strongly vertical in position. Rostrum reaching slightly beyond hind coxae or to fourth ventral seg- ment, length 1.04. Antennae, first segment, length 0.26 , width 0.11 , constricted at base, black; second, length 0.43 , somewhat flattened, broader at base, width 0.12 , clothed with short, black pubescence, ventral aspect black with an elongate, pale sensory pit which occupies nearly whole length of seg-

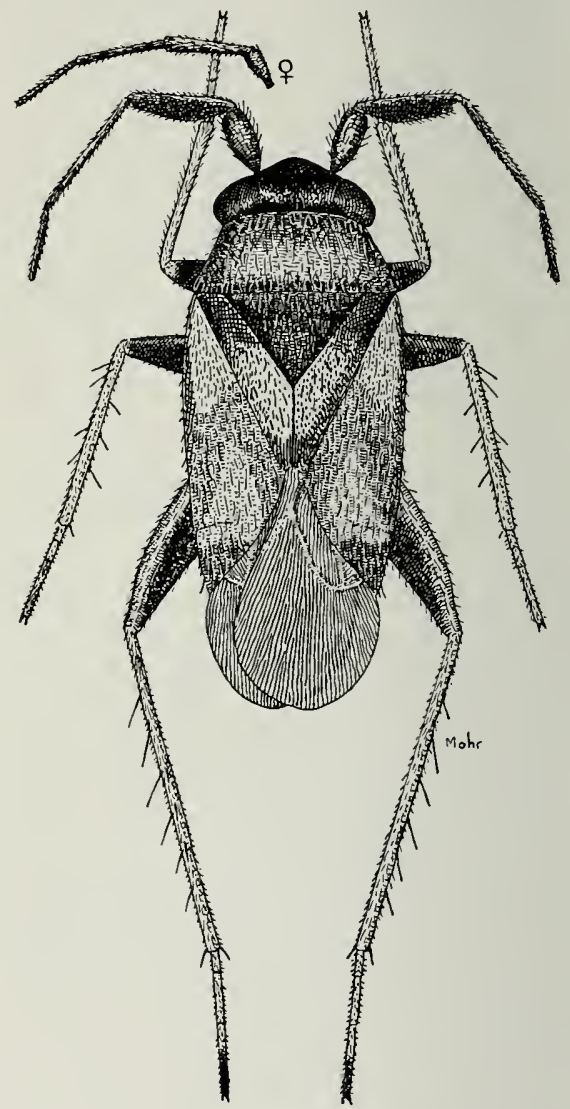

Fig. 92.-Leucopoecila albofasciata, $\sigma^{7}$.

ment; third, length 0.52 , slender, black; fourth, length 0.43 , black. Pronotum, length 0.43 , width at base 0.91. Scutellum distinctly convex above level of clavus. Dorsum clothed with pale, simple pubescence. General color black; a prominent, slightly irregular pale band extends across middle of clavus and basal half of corium; base of cuneus and a triangular spot just before on corium, pale; membrane fuscous, paler at base. Legs black, front and middle femora yellowish at apex, tibiae pale, spines black but without spots at bases, tarsi pale to fuscous, apical segment darker.

Female.-Length 2.60, width 1.08. Head width 0.73 , vertex 0.38 . Antennae, first seg- 
ment, length 0.17 , width 0.06 ; second, length 0.49 , width 0.06 , more slender on basal half, no sensory pit evident; third, length 0.43 ; fourth, length 0.35 , black. Form slightly more robust than that of male, but very similar in pubescence and coloration.

Known Distribution.-This species is widely distributed in the southern and southwestern United States. It has been reported as injurious to grass on golf greens at St. Louis, Mo., and about New York, N. Y.

Illinois Records. - Alton: June 26, 1934, DeLong \& Ross, 1 o . Carbondale: Aug. 17, 1891, sweepings from grape, G. H. French, 1 9. Cave-In-Rock: Oct. 2, 1934, Frison \& Ross, 1 o. Fountain Bluff: Aug. 10, 1891, Hart \& Shiga, 1 o . Metropol.1s: Aug. 18, 1891, sweepings from Coreopsis sp., etc., C. A. Hart, 1 ․

\section{Lopus Hahn}

No Illinois species; Lopus decolor (Fallen) occurs in Connecticut, District of Columbia, Maine, Maryland, Massachusetts, New Jersey, New York, Ontario, Quebec, $V$ irginia. It breeds on sedges (Juncus dudleyi and other species).

\section{Amblytylus Fieber}

No Illinois species; Amblytylus nasutus (Kirschbaum) occurs in Indiana, Massachusetts, Michigan; Europe.

\section{Atractotomus Fieber}

No llinois species; Atractotomus crataegi Knight is known from lowa.

\section{Macrotylus Fieber}

\section{KEY TO SPECIES}

Chiefly green, ventral surface yellowish, femora black along dorsal margin, fig. 93 ; length $2.30 \ldots \ldots$ amoenus, p. 51 Uniformly black, membrane with four white spots; length 3.00 .

sexguttatus, p. 51

\section{Macrotylus amoenus Reuter}

Macrotylus amoenus Reuter (1909, p. 75).

Adults.-Fig. 93. Length 2.30, width 0.80 ; yellowish green, hemelytra darker green; first and second antennal segments black, apices white; tibiae black; femora with black bar on dorsal margin; cuneus opaque white with greenish tint, an oblique

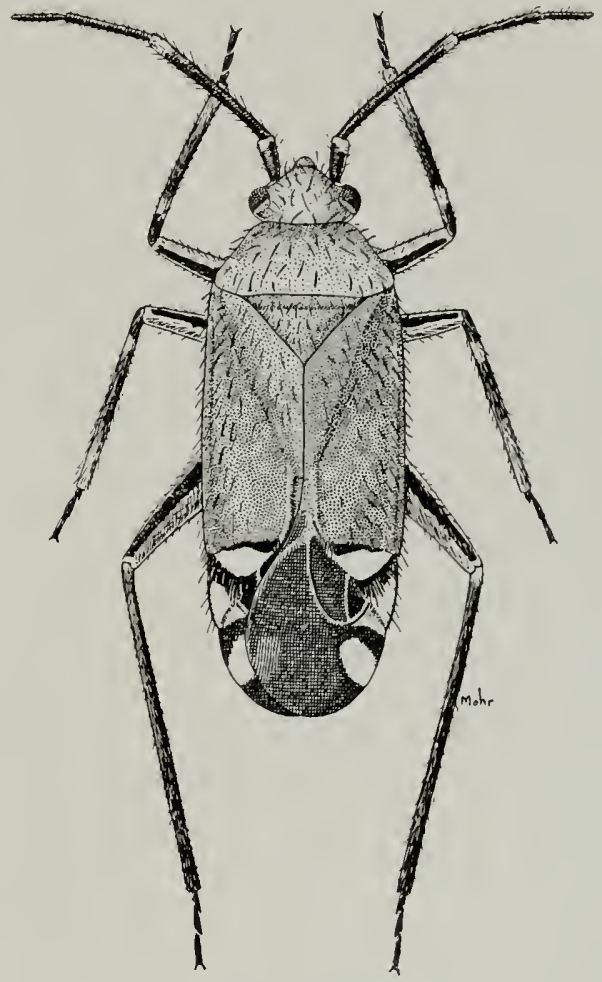

Fig. 93.-Macrotylus amoenus, ㅇ.

black bar across middle; membrane fuscous, a clear spot on either side near margin.

Host Plant.-New England aster ( $A s$ ter novae-angliae).

Known Distribution.-Originally described from Connecticut and later found in Rhode Island and the Delaware Water Gap.

Illinois Records. - Evergreen PARK: July 1, 1935, Ross \& DeLong, 1 \% ; Aug. 23, 1934, Ross \& DeLong, 1 ㅇ. Grayslake: June 10, 1936, breeding on Aster novaeangliae, Ross \& Burks, 59 of 51 ‥ OAK LAw : July 1, 1936, DeLong \& Ross, 3 o + +

\section{Macrotylus sexguttatus (Provancher)}

Amblytylus sexguttatus Provancher (1887, p. 150$)$.

Not taken in Illinois; known from Connecticut, Michigan, Minnesota, New York, Ontario, Pennsylvania. Host plant, aster (Aster undulatus). 


\section{Orectoderus Uhler}

\section{Orectoderus obliquus Uhler}

Orectoderus obliquus Uhler (1876, p. 320).

MaLE.-Length 8.00 , width 2.30. Head elongate, inclined, width 1.22 , vertex 0.60 . Rostrum extending to near apex of middle coxae. Antennae with first segment yellowish, length 0.47 ; second, 2.42, apical one-third distinctly thickened, yellowish to orange, thick part black; third, 1.55; fourth, 0.86 ; last two segments orange. Pronotum, length 1.30 , width at base 1.81 ; lateral margins rounded, slightly concave. General color black, shining; legs yellowish to orange colored. Body sparsely clothed with short, yellowish pubescence. A color variation has the basal half of cuneus and basal one-third of corium white.

Female.-Length 6.00, width of abdomen 2.40. Brachypterous, antlike in form, head broader than pronotum; hemelytra greatly reduced, extending to base of abdomen, there turning upward, the tips vertical and tapering to a point; two basal segments of abdomen constricted into a pedicel, the remaining segments forming a globose portion, the pleural fold prominent. General color piceous to black; antennae yellowish to orange, tips of second and third segments blackish.

HaBiTs.-Occurs on the ground among grasses and associated with ants.

Known Distribution.-Alberta, Colorado, Connecticut, Illinois, Maine, Manitoba, Massachusetts, Montana, New Brunswick, New Mexico, New York. Uhler (1876, p. 320) records this species from Illinois.

\section{Teleorhinus Uhler}

No Illinois species; Teleorhinus tephrosicola Knight is known from Missouri, New Jersey, New York, and may eventually be taken in Illinois. It breeds on hoary pea (Tephrosia sp.).

\section{Coquillettia Uhler}

\section{Coquillettia amoena (Uhler)}

Orectoderus amoenus Uhler $(1877$, p. 426$)$.

MALE.-Length 6.40, width 1.77. Head width 0.90 , vertex 0.41 . Antennae dark brown; first segment, length 0.38 ; second, 2.20 ; third, 2.00; fourth, 0.95. Pronotum, length 0.99 , width at base 1.43. General color dark orange brown; abdomen, tarsi and second antennal segment becoming fuscous; basal half of corium transparent, apical part bright orange brown, but with a slender dark brown margin; basal onethird of cuneus white, slightly translucent; membrane and apical two-thirds of cuneus very dark brown, almost black.

Female.-Length 5.50, wingless; antlike in form, head wider than pronotum; abdomen with first two segments constricted to form a pedicel, remaining segments forming a globose, polished, minutely and sparsely haired gaster with conspicuous pleural fold. General color brown; third and fourth antennal segments and apex of second, tarsi, and apices of tibiae, fuscous to black; globose portion of abdomen, and tergite of second segment, dark chestnut to pitchy black.

Known Distribution. - Florida, Illinois, Iowa, New Mexico, North Carolina, Texas. The only Illinois record is that in the original description where Uhler stated: "Other specimens have been secured in ... Illinois."

Occurs on high prairie among grasses and appears to be associated with ants, such as Formica (Neoformica) pallide-fulva var. incerta Emory. The wingless female bugs resemble this ant in form and color so nearly that one must look rather closely to separate them.

\section{DICYPHINAE}

\section{KEY TO GENERA}

1. Eyes large, postocular space of head less than half lateral width of an eye; first antennal segment always short, fig. 94 ....Cyrtopeltis, p. 53 Eyes small, postocular space much longer, figs. 95, 97; or first antennal segment very long, fig. $98 \ldots \ldots .2$

2. Hemelytra hyaline, completely transparent and glassy, with a well-defined, red or fuscous $Y$-shaped mark, fig. 98; pseudarolia absent, fig. 32 ; form broader...........

Hyaliodes, p. 56

Hemelytra opaque or at least milky, and with brown, scattered spots or widely suffused brownish areas; pseudarolia prominent, figs. 29,53 ; form narrower, fig. 97 ........ 3

3. Pronotal disk with an arcuate, deep 
furrow across middle at junction of wide and narrow portions, fig. 97 . .

Dicyphus, p. 53

Pronotal disk without such a furrow, fig. $96 \ldots \ldots \ldots \ldots \ldots \ldots \ldots+4$

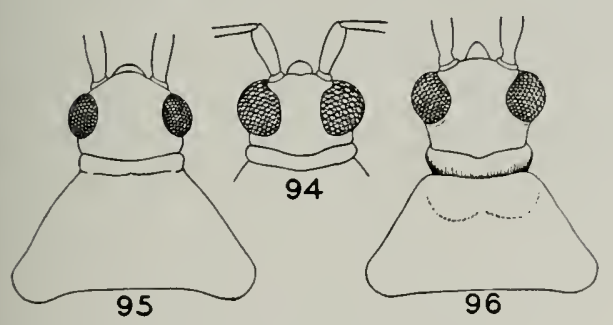

Fig. 94.- Head of Cyrlopeltis tenuis.

Fig. 95.- Head of Macrolophus separatus.

Fig. 96.- Head and pronotum of Dicyphus agilis.

4. Head mostly black; pronotum brown or black, at least on sides........

Dicyphus, p. 53

Head and pronotum almost entirely greenish yellow..........................

Macrolophus, p. 55

\section{Cyrtopeltis Reuter}

No Illinois species; Cyrtopeltis varians (Distant) occurs in Arizona, California, Florida, Georgia, Mississippi, Missouri, South Carolina, Texas; Mexico and Central America; Puerto Rico and Grenada. It is known to breed on cultivated tomatoes, but in the wild state it feeds probably on related plants. It has been reported to be a tomato pest in Arizona, Georgia and Mississippi.

\section{Dicyphus Fieber}

\section{KEY TO SPECIES}

1. Length not over 3.00 ; corium with large black spot near apex.......

. minimus, p. 54

Length more than 4.00 ; corium variously marked but without a large black spot near apex......... 2

2. Head entirely and pronotum mostly dark brown to black; pronotum usually with a pale median stripe. . ................. agilis, p. 53

Head with at least vertex behind eyes pale; pronotum in greater part dull yellow or reddish with only sides darkened ................ 3
3. Length of second antennal segment subequal to both maximum width and maximum length of pronotum. vestitus, p. 53

Length of second antennal segment at least one-third greater than maximum width of pronotum and at least one-half greater than maximum length of pronotum........ 4

4. Second antennal segment uniformly black; scutellum mostly black; femora without reddish dots......

gracilentus, p. 54

Second antennal segment with basal two-thirds pale; scutellum entirely reddish or yellowish; femora with numerous reddish dots........ 5

5. Elytra with numerous reddish streaks; length of postocular space subequal to distance between eyes.........

famelicus, p. 54

Elytra without reddish streaks; length of postocular space slightly more than one-half distance between eyes

discrepans, p. 54

\section{Dicyphus agilis (Uhler)}

Idolocoris agilis Uhler (1877, p. 425).

Male.-Length 3.40 , width 0.90 . General color pale yellowish; head, thorax and second segment of antennae chiefly black; hemelytra pale, lightly marked with fuscous, sometimes tinged with red.

Fenale.-Length 4.50, width 1.10 .

Food Plant.-Raspberry (Rubus odora$t u s$ and doubtless others). In Illinois it was collected on walnut (Juglans nigra) and butternut $(J$. cinerea), but these are certainly "sitting" records.

Known Distributiun. - Maine westward to British Columbia and southward to Virginia, through Illinois and Iowa.

Illinois Records.-Seven males and 16 females, taken June 2 to July 2, are from Algonquin, Dolson, Rocky Branch, Galesburg, Grand Detour, Grand View, Hardin, Manito, Savanna, Sheldon, Urbana.

\section{Dicyphus vestitus Uhler}

Dicyphus vestitus Uhler (1895, p. 46).

Dicyphus notalus Parshley (1922, p. 16).

Adults.-Length 3.80 , width 1.20 . Head width 0.60 , vertex 0.26 . Rostrum reaching to base of hind coxae. First antennal segment, length 0.36 , reddish, black on base; 
second, 0.91, yellowish, apical one-fourth black. Pronotum, length 0.58 , width at base 0.95 , basal margin deeply concave. General color pale, shaded with fuscous, scutellum black, basal angles pale; ventral surface black, shining. Legs pale, femora with small fuscous points.

Known Distribution.-Colorado, Illinois, Iowa, Minnesota, Ohio, South Dakota.

Illinois Records.-Algonquin: Nov. 4, 1895, 1 q ; May 8, 1897, 1 ㅇ. Apple River Canyon State Park: June 2, 1933, Ross \& Townsend, 1 q. Bloomington: July 18 , 1932, T. H. Frison, 1 ô, 3 q. Cary: May 14, 1936, Ross \& Mohr, 1 q. Fountain Bluff: Aug. 10, 1891, Hart \& Shiga, 1 . Urbana: Nov. 2, 1887, sweeping from grass and evergreens in arboretum, C. A. Hart, 1 \% ; April 30, 1892, in woods, Hart \& Marten, 1 . Willow Springs: July 16, 1911, A. B. Wolcott, 2 o , 1 q, FM.

\section{Dicyphus famelicus (Uhler)}

Idolocoris famelicus Uhler (1878, p. 413).

Adults.-Length 4.80, width 1.20. Rostrum extending to second abdominal sternite. First antennal segment, length 0.47 ; second, 1.43, yellowish, apical one-third dark reddish. Pronotum, length 0.62 , width at base 0.86 , strongly sulcate on base. General color pale yellowish; head and thorax dull reddish; hemelytra and scutellum with dull reddish markings; membrane infuscated; veins and tip of cuneus reddish.

Food Plant.-Raspberry (Rubus odoratus).

Known Distribution.-Illinois, Massachusetts, New Hampshire, New Jersey, New York, Ohio, Ontario, Pennsylvania, Vermont, West Virginia, Wisconsin.

Illinois Record. - Savanxa: July 11, 1917,1 \% .

\section{Dicyphus minimus Uhler}

Dicyphus minimus Uhler (1899, p. 59).

Not taken in Illinois; known from California, Colorado, District of Columbia, New Mexico.

\section{Dicyphus discrepans Knight}

Dicyphus discrepans Knight (1923d, p. 477).

Not yet collected in Illinois; known to occur in British Columbia, Michigan, Minnesota, New Hampshire, New York, North
Dakota, Oregon, Washington. Feeds on aster (Aster sp.).

\section{Dicyphus gracilentus Parshley}

Dicyphus gracilentus Parshley (1922, p. 21). Dicyphus vestitus Blatchley (1926b, p. 910) not Uhler. Misidentification.

Adults.-Fig. 97. Length 4.50, width 1.25. Head width 0.60 , vertex 0.21 . Rostrum reaching to second abdominal sternite.

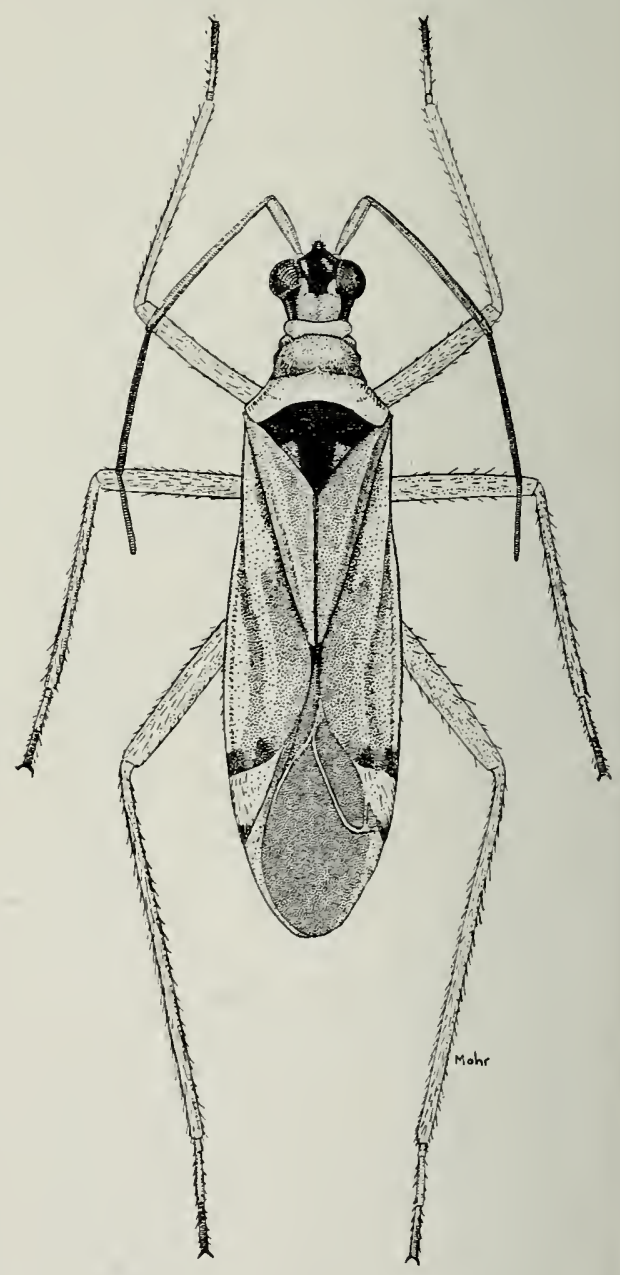

Fig. 97.-Dicyphus gracilentus.

First antennal segment, 0.43; second, 1.25, black. Pronotum, length 0.65 , width at base 0.99 , basal margin deeply concave. General color pale to yellowish, shaded with fuscous; scutellum and mesoscutum dull black, basal angles of scutellum yellowish; sternum and propleura dark brown, strongly shining. 
Legs uniformly pale yellowish, without spots.

Food Plant.-Leafcup (Polymnia canadensis).

Known Distribution.-Originally described from Illinois and known also from Indiana and Ohio.

Illinois Records.-Sixty-seven males and 66 females, taken April + to Oct. 29, are from Apple River Canyon State Park, Bloomington, Cave-in-Rock, Kappa, Oakwood, Savanna, Urbana, Zion.

\section{Macrolophus Fieber}

\section{KEY TO SPECIES}

1. Length of first antennal segment equal to or slightly greater than width of head across eyes; length of second segment distinctly greater than basal width of pronotum........ $\ldots \ldots \ldots$......... tenuicornis, p. 56 Length of firs. antennal segment less than width of head across eyes... 2

2. Postocular space of head nearly equal to lateral width of an eye; a fuscous stripe present at dorsal margin of eye; second antennal segment with apical one-fourth black; basal twothirds of corium without fuscous points at bases of hairs except one row bordering claval suture.......

brevicornis, p. 55

Postocular space of head little more than half lateral width of an eye; second antennal segment with a narrow fuscous area at apex; corium with three or four rows of fuscous points on basal two-thirds .

separatus, p. 55

\section{Macrolophus separatus (Uhler)}

Dicyphus separatus Uhler (1894, p. 194).

Male.-Length 4.30. Head width 0.54 , vertex 0.28 ; lateral width of an eye 0.20 , space between eye and pronotal collar, 0.11 ; without trace of a fuscous vitta behind dorsal margin of eye. Rostrum, length 1.79, scarcely attaining posterior margins of hind coxae. First antennal segment, length 0.38 , black; second, 1.17 , yellowish, narrow area at apex black; third, 1.28, slender, yellowish to dusky; fourth, 0.51 , fusco-brownish. Pronotum, length 0.66 , width at base 1.06 .

Female.-Length 4.20. Head width 0.56 , vertex 0.29 ; lateral width of an eye 0.20 , space between eye and pronotal collar 0.11 . First antennal segment, length 0.34 ; second, 1.00 , practically equal to width of pronotum at base; third, 1.20 ; fourth 0.52 .

Food Plants.-Found breeding on $G e$ rardia pedicularia; also occurs in Illinois on leafcup (Polymnia sp.).

Known Distribution. - Florida, Illinois, Indiana, Maryland, New York, Ohio.

Illinois Records. - Bloomington: July 18, 1932, T. H. Frison, 1 . Chicago: Aug. t, W. J. Gerhard, 1 of, FM. GolconDA: June 22, 1932, Ross, Dozier \& Park, 1 ô. Hardin: June 5-9, 1932, H. L. Dozier, 2 of, 1 o. Kankakee: Sept. 19, 1930, on Gerardia pedicularia, Frison \& Ross, 28 ô, 65 q. St. AnNe: Aug. 4, 1936, Frison \& Burks, 1 ㅇ. Urbana: Aug. 25, 1930 , H. H. Knight, 8 o , 5 \% ; 1930, on Polymnia sp., T. H. Frison, 13 of, 10 ․ Zion: July 6, 1932, T. H. Frison, 6 ô, 5 ․

\section{Macrolophus brevicornis Knight}

Macrolophus brevicornis Knight (1926i, p. $315)$.

This species is suggestive of tenuicornis Blatchley, but the antennae are distinctly shorter, with the first segment not equal to the width of the head; it is distinguished from separatus (Uhler) as shown in the key.

MALE.-Length 3.60, width 0.96. Head width 0.48 , vertex 0.26 ; lateral width of an eye 0.16 , or a trifle greater than space (0.11) between eye and base of head where collar normally fits. Rostrum reaching to middle of hind coxae, length 1.3t. Antennae, first segment, length 0.34 , scarcely equal to width of vertex plus dorsal width of an eye; second, 0.88 , being a trifle greater than width of pronotum at base, apical onefourth black; third, 1.03 ; fourth, 0.43. Pronotum, length 0.54 , width at base 0.84 .

General coloration usually lemon yellow, sometimes greenish yellow; head with a fuscous stripe behind dorsal margin of eye; hemelytra with fuscous points more distinct than in tenuicornis, basal two-thirds of corium without fuscous points at bases of hairs, except one row bordering claval suture.

Fenale.-Head width 0.47 , vertex 0.25 ; lateral width of an eye 0.16 , space between eye and pronotal collar 0.11 . Antennae, first segment, length 0.33 ; second, 0.75 , not equal to width of pronotum at base; third, 1.03 ; 
fourth, 0.38 . Pronotum, length 0.54 , width at base 0.84 .

Food Plant.-In Iowa found breeding on an unidentified milkweed (Asclepias sp.).

Known Distribution. - Illinois, Iowa, Kansas, Maryland, New Jersey.

Illinois Records. - Hardin: June 5-9, 1932, H. L. Dozier, 2 ô, 1 ㅇ. Vienna: May 18, 1932, H. L. Dozier, 3 ․

\section{Macrolophus tenuicornis Blatchley}

Macrolophus tenuicornis Blatchley (1926b, p. 913).

Male.-Length 4.20, width 0.91. Head width 0.47 , vertex 0.26 ; lateral width of an eye 0.17 , space between eye and pronotal collar 0.13 . Rostrum reaching to near posterior margin of hind coxae. Antennae, first segment, length 0.56 , pale, apex black; second, 1.43, pale, apex black, length greater than basal width of pronotum plus width of head. Pronotum, length 0.60 , width at base 0.78 . General coloration greenish yellow, darkened with fuscous, nearly as in separatus (Uhler), but fuscous points on corium much fainter and confined to inner half; longitudinal fuscous stripe behind dorsal margin of each eye.

Female.-Length 4.00, width 1.00. Head width 0.43 , vertex 0.26 . Antennae, first segment, length 0.47 ; second, 1.17. Pronotum, length 0.60 , width at base 0.82 . Very similar to male in form and coloration.

Food Plant.-Leafcup (Polymnia canadensis).

Known Distribution,-Illinois and Indiana.

Illinois Records.-Algoneuin: Aug. 7, 1930, on Polymnia canadensis, Frison \& Knight, 1 ô. Fern Cliff: Aug. 3, 1934, DeLong \& Mohr, 1 ô, 3 q. Golconda: July 25, 1930, on Polymnia canadensis, Knight \& Ross, 52 oิ , 5 q . Morris: July 19, 1883, Webster, 1 o. Urbana: 1930, on Polymina sp., T. H. Frison, 1 ô, 1 ․

\section{Hyaliodes Reuter}

\section{KEY TO SPECIES}

1. Collar, calli and areas lateral to calli very dark brown or black, median pronotal line always light, fig. 98; length of first antennal segment of male equal to maximum width of pronotum; length of first antennal segment of female four-fifths as great as maximum width of pronotum............harti, p. 57

Entire pronotum almost colorless; or pronotum with collar, calli, and a broad median mark extending from anterior to posterior margins, dark brown or black; or pronotum with a vague dark mark on median line at posterior margin; length of first antennal segment in either ex not more than three-fourths as great as maximum width of pronotum.... 2

2. Broad, median, dark brown or black mark extending from anterior to posterior margins of pronotum.... vitripennis var. discoidalis, p. 56

Pronotum without broad, median, longitudinal, dark mark....... 3

3. Length of first antennal segment equal to or only slightly greater than width of head measured across eyes............brevis, p. 58

Length of first antennal segment much greater than width of head across eyes; at least two-thirds as great as maximum width of pronotum..... vitripennis var. vitripennis, p. 56

\section{Hyaliodes vitripennis (Say)}

Capsus vitripennis Say (1832, p. 24).

Length 4.80 , width 1.70 ; hemelytra hyaline, glassy, with black or red marks bordering scutellum, inner edge of clavus and corium, and extending across apex of corium to lateral margin; also dark on membrane, veins and tip of cuneus; pronotum usually almost entirely colorless; antennae variously marked with red.

In some specimens the median area of the posterior portion of the pronotum tends to be fuscous; in others it may be dark brown or black. Other specimens may have this dark mesal area extending the full length of the pronotum. These dark extremes constitute the variety discoidalis Reuter (1909. p. 61).

Habits.-Occurs on several plants; frequent on grape (Vitis sp.); predacious on plant lice.

Known Distribution. - Originally described from Indiana and Pennsylvania and since recorded from several eastern states and southern Canada.

Illinois Records.-Forty-eight males and 95 females, taken May 24 to Sept. 10, are 
from Alton, Antioch, Ashley, Bluff, Cairo, Clay City, Danville, Darwin, De Soto, Dolson, Dongola, Dubois, Eichorn, Elizabethtown, Evanston, Fairfield, Fort Sheridan, Galesburg, Grantsburg, Hardin, Harrisburg, Havana, Herod, Kampsville, Karnak, Marshall, McHenry, Meredosia, Metropolis, Monticello, Olive Branch, Oregon, Parker, Pulaski, Quincy, Rock lsland, Shawneetown, Starved Rock State Park, Urbana, West Pullman, White Heath, Willow Springs, Zion.

\section{Hyaliodes harti new species}

This is distinguished from vitripennis (Say) by the longer first antennal segment,

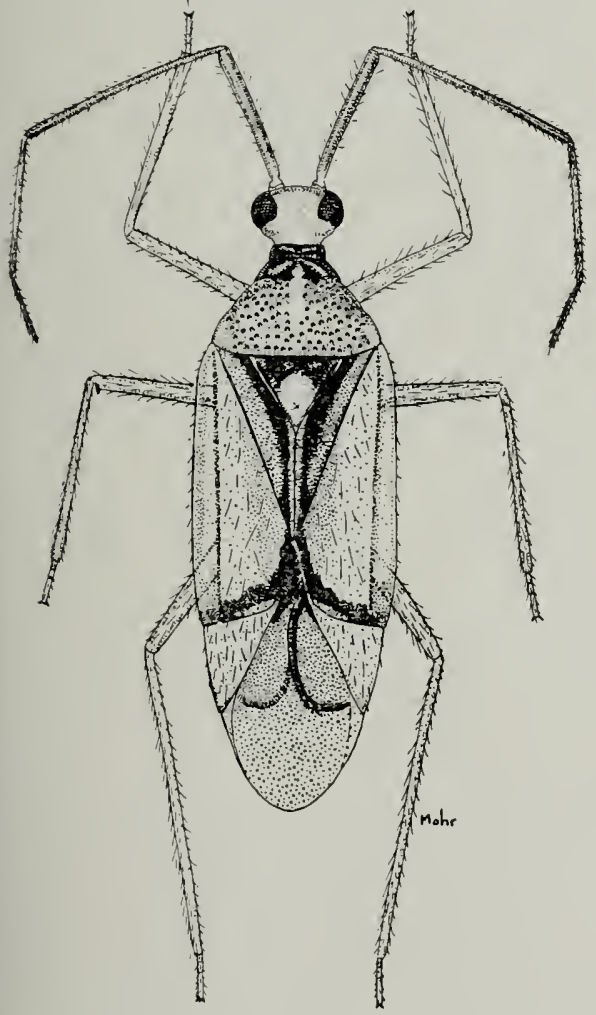

Fig. 58.-Hyaliodes harti.

which, in the male, is equal to the width of the pronotum at base.

MALE.-Length 4.40, width 1.40. Head, width 0.73 , vertex 0.26 . Rostrum just attaining posterior margins of middle coxae, length 1.20. Antennae, first segment, length 1.10 , bright red; second, 1.69 , reddish to black; third, 1.12 , black; fourth, 0.60. Pro- notum, length 0.82 , width at base 1.12 . General color pale, translucent; head and body yellowish; calli, collar, scutellum except apex, mesoscutum, and inner margin of clavus, black; apex of scutellum white; apex of corium, and tip of embolium, red; cuneus and membrane clear, anal angles fuscous, veins red to fuscous. Legs pale to yellowish.

Female.-Fig. 98. Length 4.90, width 1.60. Head width 0.71 , vertex 0.32 . Antennae, first segment, length 1.08; second, 1.77. Pronotum, width at base 1.34 . Very similar to male in form and coloration.

Holotype, male. - Harrisburg, Ill.: June 25, 1932, Ross, Dozier \& Park.

Allotype, female. - Same data as for holotype.

Paratypes. - Illinois. - Same data as for holotype, $11 \hat{\delta}, 3$. Northern IlliNois: 1 s, 3 o. Alton: July 19-21, 1932, Ross \& Dozier, 1 \%. Anva: June 27, 1909, 2 \%. Ashley: Aug. 7, 1917, 3 s , 3 ㅇ. Beverly Hills: Sept. 11, 1907, E. B. Chope, 1 q ; July 13, 1908, W. J. Gerhard, 1 ô. Dixon Springs: June 23, 1932, Ross, Dozier \& Park, 1 o . Dolson: Sept. 30, 1935, T. H. Frison, 1 q. Durois: July 2, 1909, 2 of . Eichorn: June 24, 1932, Hick's Branch, on Alnus rugosa, Ross, Dozier \& Park, 1 o . Elizabethtown: June 22-24, 1932, Ross, Dozier \& Park, 1 ô ; July 8, 1935, Ross \& DeLong, 2 q. Galena: June 30, 1932, Dozier \& Mohr, 1 \% Galesburg: July 24 , 1892, Stromberg, 2 of , 2 q. GefF: June 12, 1934, DeLong \& Ross, 1 \%. Glenview: July 19, 1931, A. R. Park, 1 \% . Herod: June 23, 1927, T. H. Frison, 1 of ; June 24, 1932, Ross, Dozier \& Park, 1 q. Joliet: July 31, 1930, Frison \& Knight, 2 \%. KarNAK: June 23, 1932, Ross, Dozier \& Park, 1 q. La Grange: Sept. 11, 1907, 1 of. La Rue: July 11, 1935, DeLong \& Ross, 1 o , 1 \&. Lawrenceytlle: Sept. 7, 1933, Ross \& Mohr, 1 9 . Makanda: June 26, 1909, 1 of Marshall: July 23, 1932, Dozier \& Park, 1 ô. Metropolis: Aug. 20, 1916, 1 $q$. Monticello: June 28, 1914, 1 q. Normal: July 22, 1884, on black walnut, 1 \% ; July 26, 1884 , on leaves of maple, 1 9 . OAKwoon: July 22, 1930, Hottes \& Tauber, 1 o ; Oct. 6, 1930, T. H. Frison, 1 q. Olive Branch: Oct. 2, 1909. W. J. Gerhard, 1 to. Quincy: Aug. 14, 1889. "sweeping along shore of Mississippi R.," C. A. Hart, 1 9 . Rockford: July, 1932, Dozier \& Mohr, 1 q. Rock IsLand: July 7, 1934, DeLong \& Ross, 1 f . Sт. 
ANve: July 22, 1935, Ross \& DeLong, 1 q SPRINGField: July 12, 1932, T. H. Frison, on Quercus sp., 3 ô, 7 ㅇ. Starved Rock State Park: July 14, 1932, Dozier \& Park, 5 ô, 16 q. TAmaroa: Sept. 22, 1882, 1 q. Temple Hill: June 24, 1936, DeLong \& Ross, 1 o , 2 ㅇ. Urbana: Sept. 27, 1892, C. A. Hart, 1 ; July 21, 1889, "sweeping in Univ. forestry," C. A. Hart, 1 \% ; Oct. 8 , 1889, in woods, Marten, 1 \% ; June 23, 1908, 1 \% Aug. 23, 1917, 1 \% ; Aug. 11, 1932, Knight \& Ross, 1 ô, 1 \% ; Sept., 1932, T. H. Frison, 1 o. Warren: Aug. 22, 1935, DeLong \& Ross, 1 . White HeAth: July 11, 1915, 1 \% ; July 4, 1933, H. H. Ross, $1 \hat{\delta}$. Willow Springs: June 27, 1905, A. B. Wolcott, 1 ô.

Georgia.-Experiment: Aug. 6, 1929, T. L. Bissell, 1 ô.

Iowa.-Ames: July 31, $1 \%$; Aug. 1, 1932, F. Andre, 1 \% .

Missouri.-Springfield: July 18, 1915, H. H. Knight, 4 .

New YORK.-Batavia: July 30, 1916, H. H. Knight, 2 o. IтнACA: July 23, 1 \% ; July 26, 1916, H. H. Knight, 2 ô.

North Carolina.-Ralejgh : July, 1909, F. Sherman, 1 o .

North Dakota.-Dickenson County: July 23, 1925, E. D. Ball, 1 . Trait County: July 19, 1923, A. A. Nichol, 1 ㅇ.

Ontario.-Parry Sound: Aug. 7, 1915, H. S. Parish, 1 o , 2 \% .

Wisconsin.-Hayward: Aug. 15, 1932, Moose Lake, T. H. Frison, 1 ô.

\section{Hyaliodes brevis new species}

This species is distinguished by its short first antennal segment which, in the female, does not exceed the width of the head across the eyes and, in the male, exceeds the width of the head only very slightly; the body is shorter and more nearly ovate than in vitripennis (Say).

Male.-Length 4.00, width 1.80 . Head width 0.69 , vertex 0.32 . Rostrum scarcely reaching base of middle coxae, length 0.95 . Antennae, first segment, length 0.70 , pale yellowish, becoming reddish at apex; second, 1.43 , fuscous to black, slightly paler at middle; third, 0.74 ; fourth, 0.26 , black. Pronotum, length 0.86 , width at base 1.16 . General color pale to yellowish; scutellum white; hemelytra clear, translucent; tip of cuneus, veins in membrane, narrow inner margin of clavus, narrow band across apex of corium, and tip of embolium, fuscous to black. Legs and ventral surface pale, apex of hind femora becoming reddish.

Fenale.-Length 4.00, width 1.55 . Head width 0.69 , vertex 0.31 . First antennal segment, length 0.65 , scarcely equal to width of head. Pronotum, length 0.86 , width at base 1.20. Very similar to male but black areas much reduced, apex of corium and tip of cuneus still retaining black.

Holotype, male. - Urbana, Ill., Aug. 10, 1932, on bur oak, Quercus macrocarpa, H. H. Knight.

Allotype, female. - Same data as for holotype.

Paratypes. - Illunois. - Same data as for holotype, 11 ô, 22 o. Starved Rock State Park: July 14, 1932, Dozier \& Park, 1 ô, 5 o. Urbana: Aug. 3, 1932, H. H. Ross, 1 ô ; Aug. 10, 1932, H. H. Ross, 5 ô, 3 역 Aug. 11, 1932, H. H. Ross, 1 ô, 2 ㅇ, H. H. Knight, 4 ô, 6 \% .

IowA.-Ames: Aug. 1, 1 \% ; Aug. 9, 1932, F. Andre, 2 ô.

Minnesota.-St. Anthony Park: Aug. 5, 1920, H. H. Knight, 1 .

\section{BRYOCORINAE}

\section{KEY TO GENERA}

1. Pronotum with a distinct collar and not gibbous posteriorly; sparsely punctured, figs. 73,99 . .

Monalocoris, p. 58

Pronotum without a distinct collar, and posteriorly inflated and enlarged, often very much so; coarsely punctured, figs. $100,101 \ldots \ldots 2$

2. Pronotum posteriorly greatly inflated, with a longitudinal crease at least in middle; embolium broadly expanded and flat, not thickened, fig. $101 \ldots \ldots \ldots$. . . . .

Pronotum posteriorly moderately inflated, without longitudinal impressions; embolium narrow, thickened, fig. 100 .... Sixeonotus, p. 59

\section{Monalocoris Dahlbom}

\section{Monalocoris filicis (Linnaeus)}

Cimex flicis Linnaeus (1758, p. 443).

Adult.-Fig. 99 . Length 2.50, width 1.40 ; short oval, convex. General color brown to dark brown, shining. Pronotum 
finely punctured; legs and antennae pale yellowish brown.

Host Plants.-Occurs on shield fern (Aspidium spinulosum) and cinnamon fern (Osmunda cinnamonea).

KNown Distribution. - A European species known also from Canada, Florida,

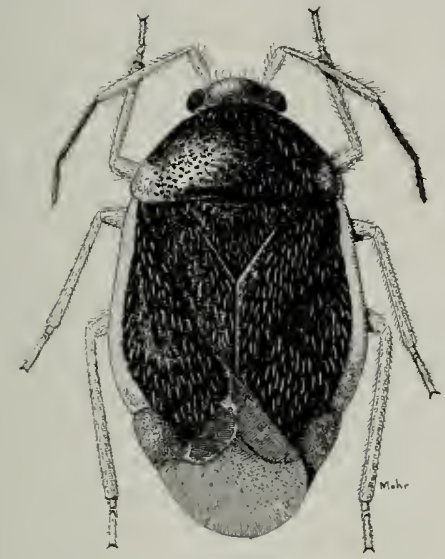

Fig. 99.- Monalocoris filicis, o.

Illinois, Minnesota, New England states, Wisconsin.

Illinois Records. - Antioch: Aug. 1, 1924, tamarack bog, T. H. Frison, 2 ; Aug. 1, 1930, on Osmunda cinnamonea, Frison, Knight \& Ross, 49 o, 50 \& ; July $5-7,1932$, T. H. Frison, 2 . Galena Junction: July 8, 1917, 1 \&. Volo: July 8, 1932, Ross, Dozier \& Mohr, 1 \& ; Aug. 24, 1935, DeLong \& Ross, 1 ô.

\section{Sixeonotus Reuter}

\section{KEY TO SPECIES}

1. Legs black; membrane uniformly fuscous to black.... unicolor, p. 59

Legs entirely pale with brownish areas on hind femora......... 2

2. Antennae and legs uniformly pale; membrane with basal half black.

insignis, p. 59

Antennae black; hind femora and basal halves of tibiae fuscous; membrane pale, veins black.

areolatus, p. 60

\section{Sixeonotus insignis Reuter}

Sixeonotus insignis Reuter (1876, p. 78). Adult.-Fig. 100. Length 3.10, width
1.50. Head width 0.73 , vertex 0.43 . Rostrum reaching to middle of sternum. First antennal segment, length 0.25 ; second, 0.54 . Pronotum, length 0.86 , width at base 1.30 . General color black; legs and antennae very light yellowish; membrane hlack, apical half pale, veins black.

Knowy Distribution.-Texas eastward to Florida, north to Virginia and west to Illinois.

Illinois Records.-Alton: July 19-21, 1932, Ross \& Dozier, 1 . Champaigx: July 26, 1889, electric light, C. A. Hart,

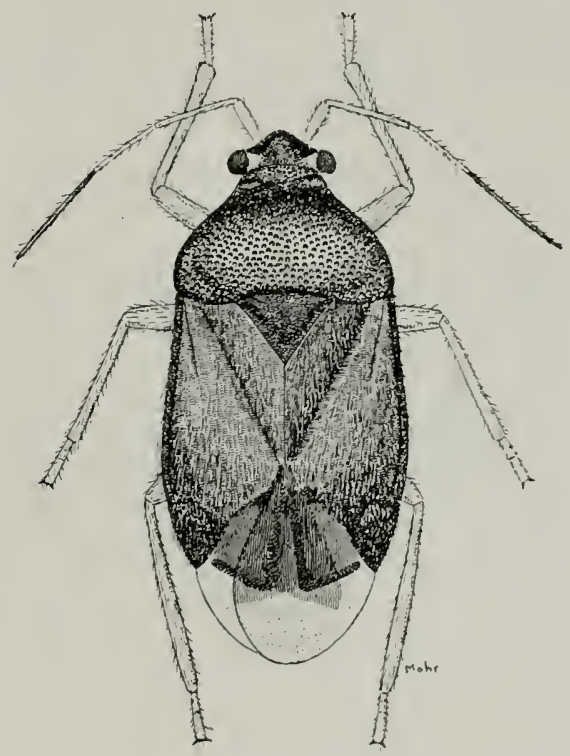

Fig. 1C0.--Sixeonotus insignis, ?.

1 j. Dongola: Aug. 22, 1916, at light, 1 ‥ Galesburg: Stromberg, 1 i . HAVANA: Sept. 2t, 1895, Matanzas Lake, C. A. Hart, $2 \hat{\delta}, 1 q$; July 2, 1934, DeLong \&. Ross, 1 q. Metropolis: Aug. 20, 1916, at light, 2 . Pulaski: May 1t, 1910, cypress swamp, $1 q$. WOLF LAKE: July 30, 1934, DeLong \& Ross, 1 q.

\section{Sixeonotus unicolor Knight}

Sixeonotus unicolor Knight (1929a, p. 247).

This species may be distinguished by being uniformly black, including the membrane; the pubescence is prominent, erect and white.

MaLE.-Length 3.20, width 1.48. Head width 0.75 , vertex 0.47 . Rostrum extending slightly beyond middle of sternum, black; length 0.65 . Antennae, first segment, length 
0.26 ; second, 0.56 ; black. Pronotum, length 0.89 , width at base 1.30 ; basal margin very slightly sinuate along middle, obscuring base of scutellum; disk moderately and evenly convex, coarsely and closely punctate, shining. Scutellum coarsely punctate, apical area rather distinctly convex and with finer punctures. Uniformly black, trochanters somewhat pale; membrane uniformly dark fuscous or black; veins black. Clothed with prominent, erect, stiff, white pubescence.

Feadie.-Length 2.90, width 1.48. Head width 0.73 , vertex 0.47 . Antennae, first segment, length 0.25 ; second, 0.53 . Pronotum, length 0.90 , width at base 1.27 . Very similar to male in form, punctation and pubescence, but generally slightly darker in color.

Known Distribution. - Originally described from Mississippi. Now known also from Illinois.

Illinois Records. - Galesburg: Sept., Stromberg, 1 o ; Aug. 29, 1888, Stromberg, 1 오.

\section{Sixeonotus areolatus Knight}

Sixeonotus areolatus Knight (1929a, p. 243).

Not as yet taken in Illinois; known from Alabama, Arkansas, Mississippi, Texas.

\section{Pycnoderes Guerin}

\section{KEY TO SPECIES}

1. Legs black; tibiae paler apically; embolium with large pale spot near base and a slightly smaller one near apex.

convexicollis, p. 60

Legs pale; hind femora fuscous on apical half only...............

2. Emboliar margins strongly arcuate; a large pale spot on basal half of embolium, apical half black........ . drakei, p. 61

Emboliar margins very slightly arcuate; embolium with small pale spot near base and also near apex, fig. $101 \ldots$. .

medius, p. 60

\section{Pycnoderes convexicollis Blatchley}

Pycnoderes convexicollis Blatchley (1926a, p. 166).

This is allied to medius Knight, but is larger, with the pronotum more strongly gibbous; the femora are all black except at the bases, and the tibiae are very dark brown or nearly black, and with the apices almost white.

MaLE.-Length 3.40 , width 1.50 . Head width 0.67 , vertex 0.39 ; front partly yellowish brown. Rostrum just reaching posterior margins of middle coxae. Antennae, first segment, length 0.30 ; second, 0.65 ; third, 0.56; fourth, 0.61; pale yellowish, last two segments fuscous. Pronotum, length 1.04 , width at base 1.25 , height from basal angle 0.65 ; disk clothed with distinct white hairs, emboliar margins strongly arcuate, edge sharp; basal one-third with large translucent white spot, a small one just before apex; cuneus clear. Membrane lightly infuscated; veins black.

Known Distribution.-Described from Indiana. Now known also from Illinois.

Illinois Records.-Marshall: Sept. 27, 1934, Frison \& Ross, 1 ô. Urbana: July 4, 1938, 1 ô ; Aug. 15, 1936, Sarah Jones, 1 ô , $\mathrm{KC}$.

\section{Pycnoderes medius Knight}

Pycnoderes medius Knight (1926e, p. 105).

This is allied to dilatatus Reuter, but differs in its smaller size, fuscous membrane and broader, more heavily gibbous, bilobed pronotal disk, fig. 101; it differs from quadrimaculatus Guerin and incurvus (Dis-

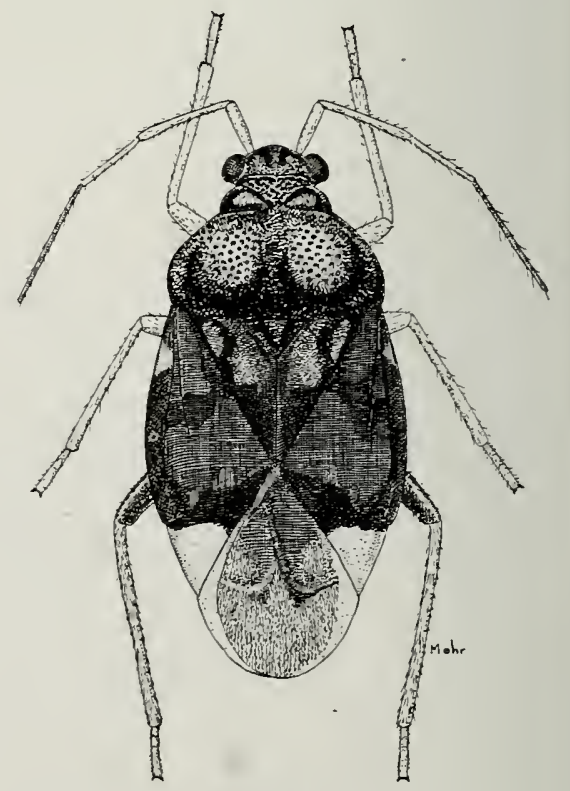

Fig. 101.-Pycnoderes medius, ㅇ. 
tant) by the sharp outer edge of its embolium.

Male.-Length 2.90, width 1.37. Head width 0.63 , vertex 0.37 . General color black; juga and lora more brownish. Rostrum, reaching hind margin of mesosternum, length 0.67 . Antennae, first segment, length 0.27 ; second, 0.60 ; third, 0.57 ; fourth, 0.68 ; first three segments pale, fourth fuscous. Pronotum, length 0.86 , width at base 1.20 , height from basal angle 0.53 . Punctation, pubescence and coloration nearly as in dilatatus, but hemelytra not so broadly dilated; apical pale spot on embolium sometimes nearly obsolete. Membrane and veins distinctly fuscous, darker at base and on veins, apical margins paler and more brownish. Legs pale; front coxae except apex, and apical half of femora, fuscous to black.

Fenale.-Fig. 101. Length 2.80, width 1.36; similar to male in form and coloration.

Known Distribution.-Described from the Ozarks of Missouri, and now found in southern Illinois.

Illinois Records.-Alton: July 19-21, 1932. Ross \& Dozier, 1 of ; June 27, 1934, DeLong \& Ross, 1 ô. Elizabethtown: May 22-24, 1932, Ross, Dozier \& Park, 1 .

\section{Pycnoderes drakei Knight}

Pycnoderes drakei Knight (1926e, p. 106).

Not yet collected in Illinois; known only from Mississippi.

\section{CYLAPINAE}

Represented in Illinois by two tribes, the Cylapini and Fulviini keyed out on pp. 19 and 20.

\section{CYLAPINI}

\section{Cylapus Say}

\section{Cylapus tenuicornis Say}

Cylapus tenuicornis Say (1832, p. 26).

Adults.-Length 5.50-6.00, width 2.20. General color brownish gray, marked with white. Distinguished by the long, slender antennae and prominent, protuberant eyes.

HaBits.-This is a very active species, usually to be found on dead and funguscovered tree trunks.

Known Distribution. - Originally described from Indiana, and since recorded from Illinois, Maryland, New York, Pennsylvania, Ontario, Virginia.

Illinois Records. - Mount Carmel: June 30, 1906, 1 ô. Oregon: July 9, 1925, T. H. Frison, 1 of. Savanna: July 29, 1892, base of bluff, 1 .

\section{FULVIINI}

\section{KEY TO GENERA}

Tarsi three-segmented; lateral margins of pronotum rounded near anterior angles, not shelflike, fig. 68 ..... Fulvius, p. 61

Tarsi two-segmented; lateral margins of pronotum sharp and shelflike for their entire length, fig. 102...Peritropis, p. 62

\section{Fulvius Stål}

\section{KEY TO SPECIES}

Second antennal segment uniformly pale yellow; scutellum brown with a pale spot at apex........... brunneus, p. 61

Second antennal segment brown, white at apex; scutellum uniformly brown..... ................ imbecilis, p. 61

\section{Fulvius brunneus (Provancher)}

Lygus brunneus Provancher (1872, p. 104). Adults.-Length 3.+0, width 1.10. General color brown, marked with yellowish and white. Second antennal segment pale yellowish; femora brown like pronotum, basal half of cuneus white; apex of scutellum and an area on hemelytra pale.

KNown Distribution. - Originally described from Ontario, and since reported from Colorado, District of Columbia, Illinois, Iowa, Kansas, Massachusetts, Virginia.

Illinois Records.-Olive Branch : Sept. 29, 1909, W. J. Gerhard, 1 \%, FM. WEst Pullian: July 13, 1902, W. J. Gerhard, 1 ô ; Oct. 27, 1912, A. B. Wolcott, 1 q, FM. Willow Springs: Aug. 4, 1912, W. J. Gerhard, 1 , FM.

\section{Fulvius imbecilis (Say)}

Capsus imbecilis Say (1832, p. 25).

Adults.-Length 4.09, width 1.20. Very similar to brunneus (Provancher), but larger. Second antennal segment brown with apical third white; femora yellowish brown: scutellum dark brown. 
Known Distribution.-Described from Indiana and since reported from Alabama, Florida, Illinois, Minnesota, Missouri, North Carolina, Pennsylvania, Tennessee.

Illinois Records.-Beverly Hills: Aug. 27, 1908, W. J. Gerhard, 1 ô. CarbonDAlE: Aug. 21, 1891, Hart \& Shiga, I nymph. Dubors: June 21, 1905, 1 오. Galesburg: Sept., Stromberg, 1 i , 1 . Havana: Aug. 16, 1883, 1 nymph. Mount Carmel: June $30,1906,2 \hat{\delta}$. Olive Branch: Sept. 29, 1909, W. J. Gerhard, 1 q, FM. Urbana: June 16, 1887, electric light, C. A. Hart, 1 . . White Heath: June $25,1916,1$ i .

\section{Peritropis Uhler}

\section{KEY TO SPECIES}

Coxae brown; clavus and corium thickly dotted with pale flecks.....husseyi, p. 62 Coxae pallid; clavus and corium brown to fuscous, without pallid flecks.......

saldaeformis, p. 62

\section{Peritropis saldaeformis Uhler}

Peritropis saldaeformis Uhler (1891, p. 122). Peritropis saldiformis Bergroth $(1920$, p. 74). Emended name.

Diagnostic color characters: general color brownish black, alutaceous, head and pronotum thickly dotted with pale yellowish, clavus and corium unspotted, coxae pallid.

Female.-Length 2.90, width 1.51. Head width 0.65 , vertex 0.32 , length from front margin of eyes to tip of tylus 0.28 . Rostrum, length 1.51 , reaching to base of sixth ventral segment. Antennae, first segment, length 0.22 , brown, a white annulus on basal half, a pallid dot on dorsal aspect of apical half; second, 0.88 , dark brown, a white spot at middle on dorsal side, somewhat paler near base. Pronotum, length along median line 0.49 , width at base 1.29 . anterior width 0.45 ; lateral margins nearly straight, shelflike, very slightly reflexed; basal margin with small tubercle at median line, each side of this a distinct scallop, then sinuate to basal angle, the basal edge whitish; calli strongly convex, separated at median line by a foveate depression. Scutellum moderately convex, dark brown, apex white; mesoscutum broadly exposed for a longitudinal space equal to threefourths the length of scutellum. Sternum and pleura dark brown, a white spot on mesepimeron. Hemelytra dark brown to blackish, a few white dots on costal edge of embolium; width 1.50; emboliar margins very slightly arcuate, moderately reflexed; cuneus triangular, narrow white area at apex and at inner basal angle. Membrane and veins uniformly pale brown. Legs brownish black; coxae pallid to white; tibiae with three white spots on basal half, apical one-third pallid; tarsi pale fuscous. Venter dark brown.

MaLE.-Length 3.20 , width 1.47 ; somewhat more slender than the female but very similar in color. Head width 0.60 , vertex 0.29 . Rostrum, length 1.60 , reaching upon seventh abdominal sternite. Antennae, first segment, length 0.19 ; second, 1.12. Pronotum, length 0.47 , width at base 1.21 .

Known Distribution.-Described from the District of Columbia and Illinois. Uhler states: "Others have been captured near Chicago and in other parts of northern Illinois." Known from District of Columbia, Illinois, Iowa, Maryland, Oklahoma, Pennsylvania and Texas. The only record for Illinois is that in the original description.

\section{Peritropis husseyi Knight}

Peritropis husseyi Knight (1923a, p. 50).

Female.-Fig. 102. Length 3.20. Head width 0.62 , vertex 0.31 , length from front margin of eyes to tip of tylus 0.31 ; front

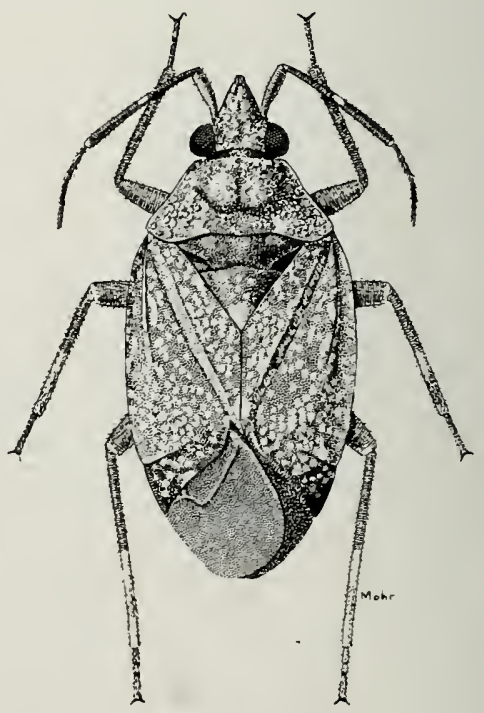

Fig. 102.-Peritropis husseyz. 
more porrect and more nearly cone shaped than in saldaeformis Uhler. General color brownish black, irregularly marked with small pale spots; three or four larger spots on the strongly flattened tylus; bucculae tinged reddish. Rostrum brownish black, length 2.22, nearly attaining the hind margin of the first genital segment. Antennae, first segment, length 0.28 , black; second, 1.00 , nearly cylindrical, but slightly thickened toward apex, black, a small pallid spot on dorsal side near middle, the extreme tip slightly paler, clothed with very fine, short pale pubescence; third, 0.29 ; fourth, 0.34 ; last two segments slender, black. Pronotum brownish black; length along median line 0.51 , width at base 1.17 ; anterior width 0.61 ; lateral margins practically straight, shelflike, extreme edge reflexed; anterior angles prominent, forming right angles; basal margin with a broad sulcus which rounds distally; margin without tubercles, practically transverse on the middle onethird; calli less prominent than, and not so abruptly convex as, in saldaeformis, separated by a foveate groove at the median line of disk; disk rather closely dotted with whitish spots that are frequently confluent; slender area at lower margin of propleura, and a line extending distad from the top of coxal cleft, pallid. Scutellum nearly as in saldaeformis, more extensively white at apex, a few pale dots adjoining; mesoscutum exposed for a longitudinal space equal to two-thirds the length of scutellum, a curved pale mark near each basal angle. Sternum and pleura brownish black; basalar plate, and posterior and ventral margins of epimera, pale; ostiolar peritreme pallid.

Hemelytra brownish black, rather closely spotted with pallid, the spots frequently elongate or confluent, each pale point with a minute, short, scalelike hair; tip of clavus and spot at inner basal angle of cuneus rendered pallid by the fusion of several small points; cuneus black, a few pale points near base; width 1.54 , emboliar margins arcuate, somewhat reflexed basally. Membrane uniformly pale fuscous, the veins scarcely darker, slightly paler areas bordering margin of cuneus. Legs brownish black; coxae scarcely paler at apices; middle and hind tibiae paler apically, a narrow pallid annulus near middle; front and middle tarsi pale fuscous, hind pair lighter. Venter brownish black, with pale yellowish pubescence.

I ALE.-Length 3.00 , width 1.40 ; slightly smaller than the female but very similar in structure and color; genital claspers prominent and distinctive.

Habits.-Collected by R. F. Hussey from beneath bark of white oak logs cut for fence posts.

Known Distribution. - Alabama, Illinois and Michigan.

Illinois Record.-Meredosia: Aug. 21, 1917, sand pit, 1 \% .

\section{CLIVINEMINAE}

Represented in Illinois by two tribes, the Largideini and Clivinemini, keyed out on p. 20.

\section{LARGIDEINI}

\section{Largidea Van Duzee}

\section{Largidea grossa Van Duzee}

Largidea grossa Van Duzee (1916c, p. 238).

This species is allied to davisi Knight, but is distinguished by the thick, more inflated form of its second antennal segment.

Fenale.-Length 5.30, width 2.60. Head width 1.34 , vertex 0.86 . Rostrum extending slightly beyond middle of sternum, length 1.50. Antennae, first segment, length 0.35 , thickness 0.17 ; second segment, 1.73, strongly inflated, thickness 0.30 at middle, tapering off at either end. Pronotum, length 1.60, width at base 2.20 , disk moderately convex, with coarse, rugulose punctation. Scutellum moderately convex, finely punctate. Clavus and corium with shallow, rugulose punctation. Clothed with short, recumbent, pale to dusky pubescence. General color reddish brown, calli black, membrane fuscous, veins darker.

Known Distribution. - Originally described from Lake Tahoe, California, and later found in Oregon and the Santa Catalina Mountains of Arizona. It occurs on pines.

Illinois Record.-A single female specimen in the Illinois Natural History Survey collection bears the data, "Havana, Ill. Sept. 21, 1895, at lights in town, collected by Hempel." This specimen can be identified only as Largidea grossa, although this species has always been considered to be restricted to the far western states. This surprising distribution record cannot at the present time be explained. 


\section{GLIVINEMINI}

\section{KEY TO GENERA}

Membrane distinctly pubescent; collar not distinctly hooded over head.........

Bothynotus, p. 64

Membrane glabrous, or with extremely fine pubescence only; collar hooded or somewhat elevated above head.......

Clivinema, p. 64

\section{Clivinema Reuter}

No Illinois species; Clivinema villosa Reuter occurs in Montana, Oklahoma, Texas.

\section{Bothynotus Fieber}

\section{Bothynotus modestus (Wirtner)} 34).

Neobothynotus modestus Wirtner (1917, p.

This species is distinguished from the other known American species by its large size and longer antennae; also, the length

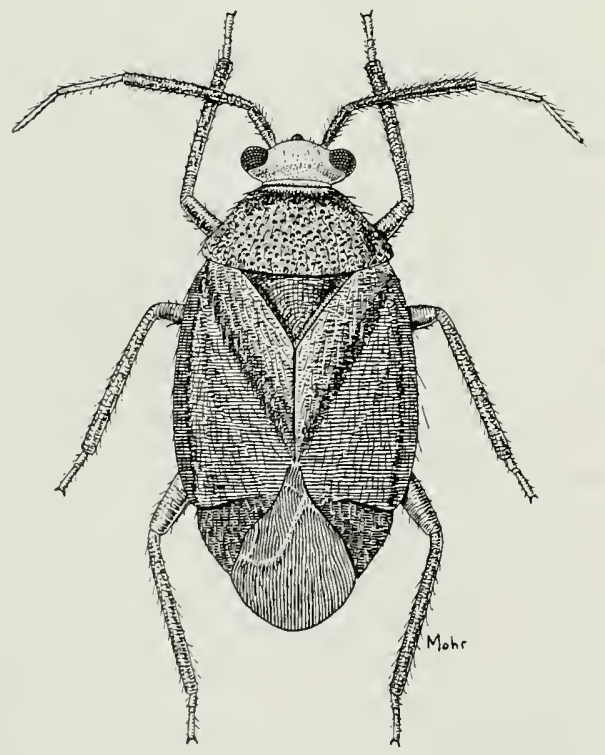

Fig. 103.-Bothynotus modestus, $\sigma^{7}$.

of the second antennal segment is much greater than the width of the head.

MALE.-Fig. 103. Length 5.10, width 2.40. Head width 0.99 , vertex 0.56 . Rostrum reaching to bases of hind coxae, length 1.60. Antennae, first segment, length 0.49 , fusco-brownish, strongly pubescent; second segment, 1.50, black, cylindrical, equal in thickness to first segment, thickly clothed with suberect pubescence; third, 0.69 , slender, pale to dusky, clothed with long pubescence; fourth, 0.35 , slender, fuscous. Pronotum, length 1.30 , width at base 1.90 ; disk convex, coarsely and closely punctate, clothed with long fuscous pubescence. Scutellum strongly convex, impunctate, pubescent. Hemelytra with emboliar margins subparallel, with sharp edge, clavus and corium strongly, transversely rugulose; membrane and veins uniformly dark fuscous, thickly clothed with erect fuscous pubescence. Body black, distinctly shining, head red, tylus black, legs very dark brown, tibiae somewhat paler and translucent.

Female.-Length 4.80 , width 2.60 ; emboliar margins distinctly arcuate. Head width 1.01 , vertex 0.65 . Antennae, first segment, length 0.51 ; second, 1.20 , more slender than first segment, black, paler on basal half, clothed with long pubescence; third, 0.73 ; fourth, 0.56. More robust than male, but similar in color and pubescence.

Known Distribution.-Described from Pennsylvania, where it was found on pine trees. Single specimens are now known from Illinois, Kansas, Maryland, Ohio. Apparently this is a rare but widely distributed species.

Illinois Record.-NortherN IlLINOIS: 1 .

\section{DERAEOCORINAE}

\section{KEY TO GENERA}

1. Second antennal segment broad and distinctly flattened, fig. $20 \ldots \ldots$. . .........Hesperophylum, p. 74 Second antennal segment cylindrical, fig. $105 \ldots \ldots \ldots \ldots \ldots \ldots 2$

2. Antennae linear, very long and of nearly equal thickness throughout, fig. 105 ; vertex transversely striate and longitudinally sulcate, fig. 104; second segment of hind tarsus much shorter than either first or third segments; usually large, elongate species ............. Eustictus, p. 65

Antennae not so long or linear, second segment slender at base and slightly enlarged toward apex, third segment slender, fig. 107; vertex usually polished; second segment of hind tarsus 
as long as either first or third segments, or nearly so........... 3

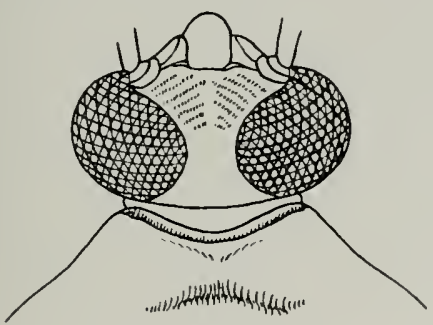

Fig. 104.- Head and pronotum of Eustictus salicicola.

3. Head strongly produced and nearly horizontal, facial angle acute, tylus projecting beyond apex of first antennal segment, fig. 108; emboliar margin thin and broadly expanded, sides nearly parallel............

. Eurychilopterella, p. 73

Head less produced, scarcely surpassing middle of first antennal segment, fig. 107, facial angle either one of 90 degrees or only slightly less; embolium not as above. .

Dera eocoris, p. 66

\section{Eustictus Reuter}

\section{KEY TO SPECIES}

1. Hind tibiae with long, fine hairs on basal half, these hairs distinctly longer than true spines......... 2

Hind tibiae with minute pubescence on basal half, these hairs not so long as true spines................ 3

2. Pronotal disk uniformly very dark brown; legs chiefly reddish, tibiae without paler bands; length $8.00-$ $11.00 \ldots \ldots$.......filicornis, p. 66

Pronotal disk black, but paler near basal margin; legs pale testaceous and marked with black, tibiae distinctly marked with four alternating pale and fuscous bands..........

venatorius, p. 66

3. Pronotal disk with median portion black; broad, pale areas with dark punctures present at lateral margins; width of vertex of male only slightly greater than thickness of first antennal segment; length, male 6.90 , female $7.40 \ldots \ldots$. . salicicola, p. 65

Pronotal disk chiefly dark brown, not paler at lateral margins; width of vertex of male twice as great as thickness of first antennal segment; length, male 5.50-6.00, female 7.00

necopinus, p. 66

\section{Eustictus salicicola Knight}

Eustictus salicicola Knight (1923d, p. 482).

This is allied to renatorius Van Duzee, but differs in the form of its antennae, its tibial pubescence and the color pattern of the dorsum.

Male.-Fig. 105. Length 6.90 , width 2.40. Head width 1.19 , vertex 0.08 , height of eye 0.77 ; eyes prominent, projecting above

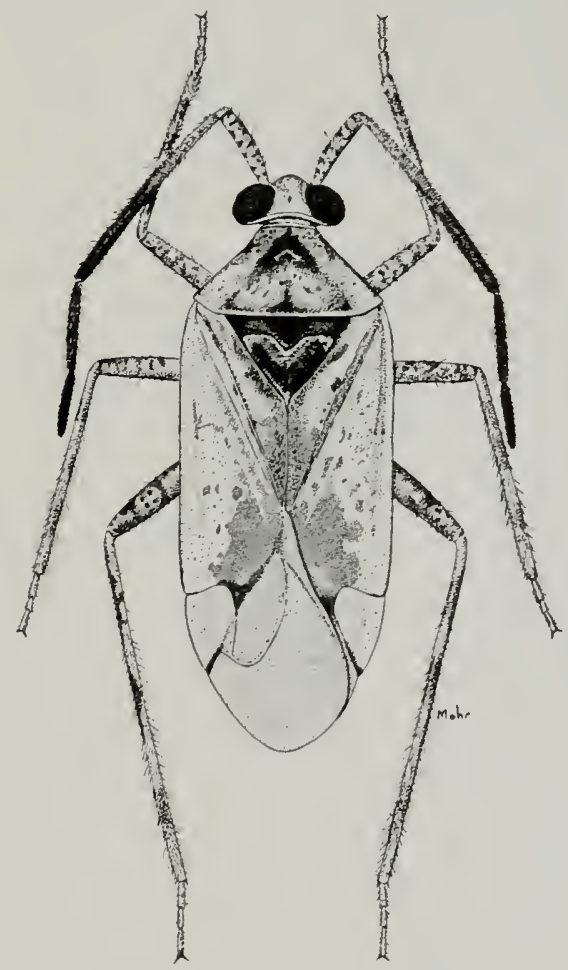

Fig. 105.-Eustictus salicicola, $\sigma^{7}$.

vertex and below gula. Rostrum, length 2.77, attaining posterior margins of hind coxae. Antennae, first segment, length 0.81 , pale, marked with black; second, 2.31, dark fuscous, paler on basal one-sixth but with faint dark spots, extreme apex paler, rather densely covered with fine, short, pale pubescence, a few hairs slightly longer, but none exceeding thickness of segment; third, 1.05, black, paler apically; fourth, 0.91, black. Pronotum, length 1.25 , width at base 2.00 ; 
median portion of disk black, broad pale areas with dark punctures present at lateral margins; propleura very dark brown, lower margins pale. Scutellum black, basal angles paler; minutely, sparsely pubescent. Hemelytra glabrous, pale, translucent and marked with fuscous, but without large spots on basal half as in venatorius; clavus black on either side of commissure, slender dark markings bordering claval veins; corium with punctures; radius, and large spot on inner apical angle, dark fuscous to black; embolium scarcely darkened at apex, extreme outer edge black, width 2.50. Cuneus pale, translucent, inner apical margin blackish. Membrane pale, smoky within areoles, veins slightly darker, a fuscous mark bordering apical margin of larger areole. Legs pale and marked with black; femora with apical half marked and spotted with black, an irregular pale but spotted subapical annulus; tibiae with four paler bands but more or less interrupted with dark spots, pubescence short, not attaining length of true spines. Venter pale greenish with reddish marks.

Fevale.-Length 7.40 , width 2.77 ; very similar to male in coloration, but differs in pilose character of antennae.

Habits.-This species occurs on the bark of willow trees where it may be predacious on aphids and other small insects.

KNown Distribution. - Illinois, Iowa, Kansas, Minnesota, Mississippi, Nebraska, Oklahoma, South Dakota, Texas.

Illinois Records.-Five males and $8 \mathrm{fe}-$ males, taken June 17 to Sept. 7, are from Alton, Chicago, Galesburg, Havana, Lawrenceville, Metropolis, Mount Carmel, Rosiclare, Savanna.

\section{Eustictus filicornis (Walker)}

Capsus filicornis Walker (1873, p. 96).

Megacoelum grossum Uhler (1887c, p. 70).

Not taken in Illinois; known from District of Columbia, Florida, Maryland, Massachusetts, New Jersey, New York, Pennsylvania, Virginia; occurs on yellow pine (Pinus echinata).

\section{Eustictus venatorius Van Duzee} 479).

Eustictus venatorius Van Duzee (1912, p.

Not taken in Illinois; known from New York, where it occurs on hickory trees.

\section{Eustictus necopinus Knight}

Eustictus necopinus Knight (1923d, p. 481). Not taken in Illinois; known from British Columbia, District of Columbia, Massachusetts, New York, Ontario; occurs on aspen.

\section{Deraeocoris Fieber}

\section{KEY TO GROUPS AND SUBGENERA}

1. Claws not cleft or only slightly cleft, fig. $34 \ldots \ldots$. . . Group C, p. 72 Claws deeply cleft near base, figs. 33,

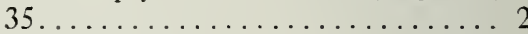

2. Scutellum punctate......... Group A, Subgenus Camptobrochis, p. 66 Scutellum impunctate............ 3

3. Dorsum practically glabrous, at most only sparsely and finely pubescent (not rubbed specimens), rarely with a few hairs at anterior angle of pronotum; hind tibiae with a row of spines or heavily chitinized hairs on anterior face........ Group B, p. 69

Dorsum heavily pubescent or hairy, at least with long hairs at anterior angles of pronotum; hind tibiae without distinct spines on anterior face, usually closely set with prominent long hairs........... Group D, Subgenus Euarmosus, p. 73

\section{Group A}

\section{KEY TO SPECIES}

1. Dorsum bright red; clavus, a pair of large spots on corium and pronotum black.............histrio, p. 69

Dorsum not red and black as above... 2

2. Cuneus red or stained with reddish; membrane hyaline or with only a fuscous spot at apex, or a point either side of middle............... 3

Cuneus infuscated or marked with black, rarely reddish; if reddish, membrane distinctly black; membrane usually heavily marked with fuscous; if not, cuneus without a trace of reddish............ 4

3. Length of second antennal segment not equal to length of pronotum; two fuscous spots on apical half of membrane, darkest specimens developing 
a brownish cloud distad of spots...

ornatus, p. 67

Length of second antennal segment at least equal to length of pronotum; membrane infuscated at apex.....

poecilus, p. 67

4. Membrane nearly clear, but having two small fuscous points, one at either side on apical half...nebulosus, p. 67

Membrane with apical half heavily infuscated..........nubilus, p. 69

\section{Deraeocoris nebulosus (Uhler)} 417).

Camptobrochis nebulosus Uhler (1872, p.

Adult.-Length 3.50-3.90, width 1.75 2.00; ovate, shining; olivaceo-testaceous, darkened with black, or fuscous to black with pale markings; membrane clear, a pair of small fuscous points on apical half, one on either side of middle. Male genitalia as in fig. 106.

Habits.-Predacious; occurs most frequently on bur oak (Quercus macrocarpa) and maple (Acer sp.), but also on other trees.

Known Distribution.-Common in the eastern states and westward to Texas and Colorado.

Illinois Records. - One hundred fifty males and 175 females, taken May 11 to Nov. 1, are from Algonquin, Allerton, Alton, Antioch, Cary, Centralia, Champaign, Chicago, Cohden, Danville, De Soto, Dolson, Dubois, Eichorn, Elizabeth, Ernst, Fairmount, Frankfort, Galena, Galesburg, Giant City, Grafton, Grand Tower, Harrisburg, Havana, Kansas, Lawrenceville, Meredosia, Metropolis, Milford, Monticello, Muncie, Normal, Oquawka, Palos Park, Paris, Quincy, Rockford, Rockton, Springfield, Starved Rock State Park, Urbana, Warsaw, White Heath, White Pines Forest State Park, Willow Springs, Zion.

\section{Deraeocoris ornatus Knight}

Deraeocoris (Camptobrochis) ornatus Knight (1921, p. 99).

This species is very similar to poecilus (McAtee), but the second antennal segment is shorter in proportion to the length of the pronotum and the punctures on the disk are finer; the two rounded fuscous spots on the apical half of the membrane are suggestive of nebulosus (Uhler), but the darkest specimens of ornatus may develop a brownish cloud distad of the spots.

Male.-Length 4.50, width 2.08. Head width 1.01, vertex 0.40 . Antennae, first segment, length 0.34 ; second, 1.11 , scarcely equal to length of pronotum, thickness 0.08 , black, brown annulus indicated at middle; third, 0.40 ; fourth, 0.40. Pronotum, length 1.14 , width at base 1.92 ; calli black, a reddish brown stripe extends around posterior margin and more or less toward anterior angles of disk; grayish testaceous, paler near margins of disk and at median line, not so distinctly brownish as in poecilus. Scutellum reddish brown to piceous, punctures black, apex and lateral margins ivory white, median line usually indicated. Hemelytra grayish, translucent; punctures, frenal margin, areas bordering commissure, spot at middle, and stripe along apical margin of corium, piceous; tip of embolium translucent, reddish. Cuneus red, translucent, paler at inner angle and outer margin; several very fine, black punctures evident. Membrane pale, brachium infuscated, more or less invading membrane on both sides; a pair of rounded fuscous spots present on apical half, one either side of middle, darkest specimens developing a brownish cloud distad of spots. Genitalia as in fig. 106.

Female.-Length 4.80, width 2.34; very similar to male. Second antennal segment, length 1.08; slightly shorter than length of pronotum, which is 1.20 , black, middle onethird testaceous or brownish; all other segments black.

Known Distribution. - Illinois, Iowa, Missouri, Nebraska, South Dakota.

Illinois Records.-Dixon SPRINGs: May 9, 1935, C. O. Mohr, +o. EICHorN: May 11, 1933, C. O. Mohr, 1 ㅇ. Golconda: May 10, 1935, C. O. Mohr, 1 o . PIkE: June 28, 1937, Delong \& Ross, 2 \%. Vienna: June 14, 1934, DeLong \& Ross, 1 q. One female labeled "III." in the C. $V$. Riley collection, USNM.

\section{Deraeocoris poecilus (McAtee)} 246).

Camptobrochis poecilus McAtee (1919, p.

Deraeocoris cuneatus Knight (1921, p. 96).

Adults.-Length $4.00-5.00$, width 2.00 2.50 ; slightly larger than, but structurally very close to, nebulosus (Uhler); olivaceotestaceous to brownish and black, cuneus red, membrane clear, a rather distinct, some- 


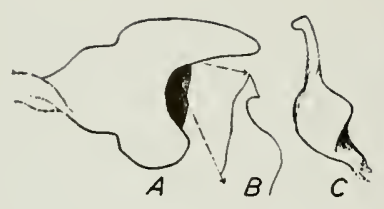

ALNICOLA

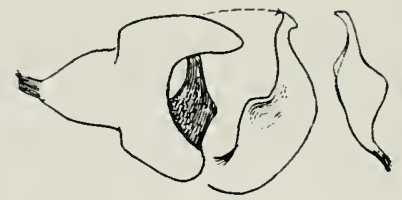

ALBIGULUS

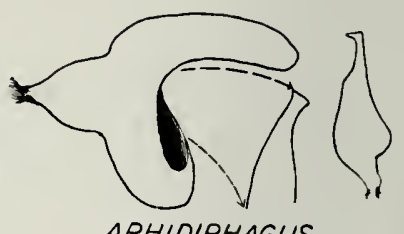

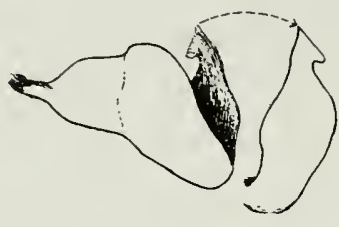

BOREALIS
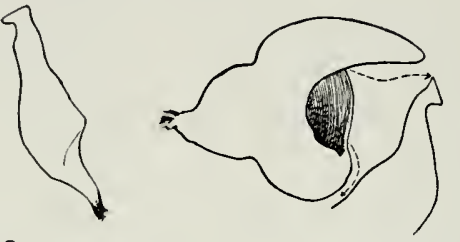

BETULAE
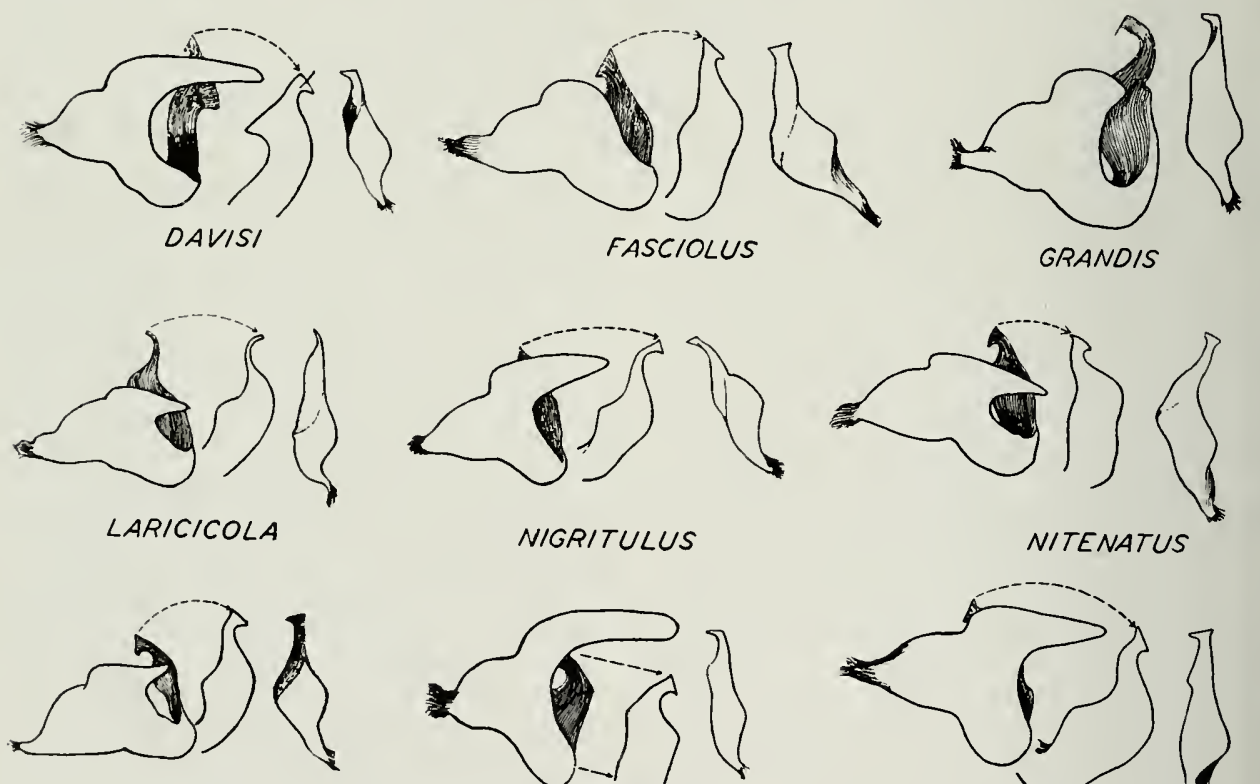

PINICOLA

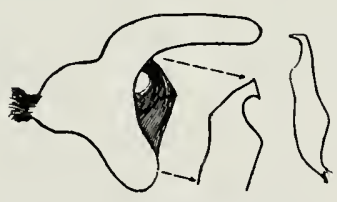

QUERCICOLA
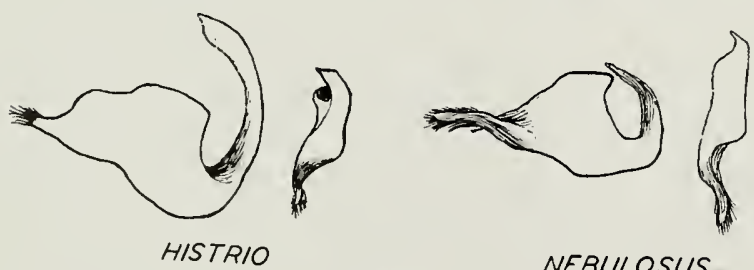

NEBULOSUS
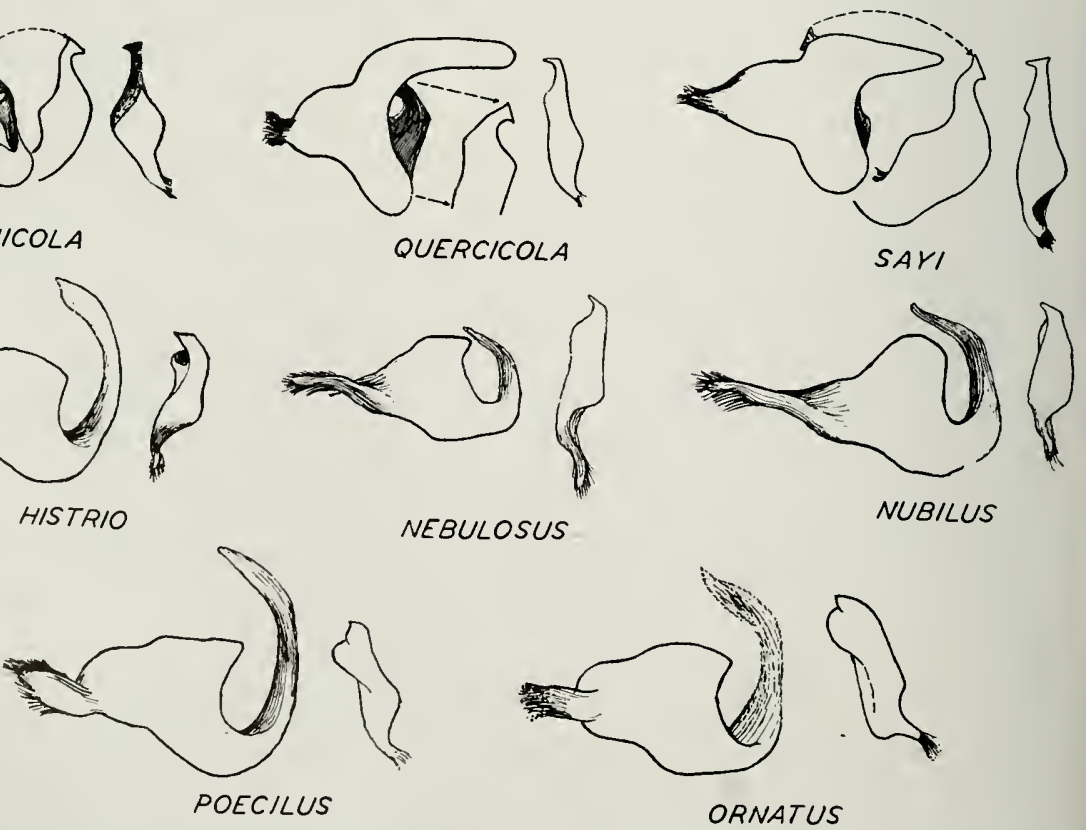

Fig. 106.- Male genital claspers of Deraeocoris. $A, B$, left clasper; $C$, right clasper. 
what oval-shaped, fuscous spot at apex. Male genitalia as in fig. 106.

Habits.-Predacious; occurs most frequently on alder (Alnus rugosa) and red birch (Betula nigra).

Known Distribution.-Illinois, Minnesota, New York, Pennsylvania, West Virginia.

Illinois Records.-Thirty males and 25 females, taken May 1 to July 26, are from Antioch, Carmi, Charleston, Eichorn, Elizabethtown, Galena, Grafton, Grand Tower, Harrisburg, Havana, Herod, Lawrenceville, Metropolis, Pike, Quincy, Rock Island, Starved Rock State Park, West Union.

\section{Deraeocoris histrio (Reuter)}

Callicapsus histrio Reuter (1876, p. 75).

Adults.-Length $4.50-5.00$, width 2.00 2.30 ; dorsum bright red; clavus, a pair of large spots on corium and pronotum black. Male genitalia as in fig. 106.

HaBits. - Found breeding on smartweed (Polygonum muhlenbergii) in Minnesota and Colorado, where it appeared to be predacious in part on certain Fulgoridae.

Illinois Records.-Sixty-two males and 51 females, taken May 4 to Nov. 10, are from Algonquin, Argo, Bath, Canton, Champaign, Chicago, Galesburg, Grand Tower, Havana, Homer Park, Kampsville, Metropolis, Normal, Palos Park, Putnam, Quincy, Savanna, Savoy, Starved Rock State Park, Urbana.

\section{Deraeocoris nubilus Knight}

Deraeocoris (Camptobrochis) nubilus Knight (1921, p. 106).

AdulTs.-Length 4.20-4.80, width 2.00 2.30 ; male more elongate than female, apical half of membrane usually heavily infuscated ; disk of pronotum fuscous to black behind calli, median line pale; femora biannulate with apical half pale. Male genitalia as in fig. 106 .

Habits.-Occurs on pine (Pinus strobus) ; probably predacious.

Known Distribution.-Illinois, Minnesota, Nebraska, New England states, New York, North Carolina, Virginia.

Illinois Records.-Starved Rock State PARK: July 14, 1932, on Pinus strobus, Dozier \& Park, 1 o ; Sept. 17, 1935, Delong \& Ross, 1 ㅇ. White Pines Forest State Park: July 4, 1932, on Pinus strobus, Dozier \& Mohr, $66 \delta, 57$ \& ; July 12, 1934, DeLong \& Ross, 2 ㅇ.

\section{Group B}

\section{KEY TO SPECIES}

1. Tibiae with fuscous or pale bands... 2 2 Tibiae uniformly pale or yellowish... 7

2. Membrane with a distinctly rounded fuscous spot on apical half, frequently connected at base br a fuscous streak extending down from between areoles, thus leaving a large pale spot on either side of middle and on area bordering apex of cuneus................ 3

Membrane usually somewhat infuscated, but not as above........ 4

3. Calli solid black, a broad piceous ray behind each; in pale specimens, calli may be somewhat brownish, but, in such cases, median line and margins of disk distinctly pale, leaving a dark brown ray behind each callus; hemelytra with clavus and corium piceous, embolium pale

borealis, p. 71

Calli more or less invaded with brownish, or pale, distinct rays not apparent behind calli; hemelytra and pronotum more uniformly colored, either dull yellowish brown or dark brown.

fasciolus var. fasciolus p. 70

4. Rostrum extending slightly beyond posterior margins of hind coxae; membrane with apical half scarcely infuscated; femora pale but with two distinct black bands near apex; hind tibiae with two fuscous annuli on basal half........grandis, p. 71

Rostrum scarcely attaining posterior margins of hind coxae; membrane, femora and hind tibiae not having above combination of characters. . 5

5. Femora uniformly dark on apical half, likewise basal part in darkest specimens; venter distinctly reddish, sometimes dark chestnut red, shining............ betulae, p. 70

Femora with apical half distinctly banded or entirely pale... ...66

6. Second antennal segment provided with prominent, pale, erect hairs, their length equal to three times thickness of segment; pronotum 
with discoidal margins pale, calli and posterior part of disk black, forming a ray behind each callus, thus leaving median line pale.....

alnicola, p. 70

Second antennal segment without prominent, exserted hairs or, if such hairs present, their length never more than twice thickness of segment; pronotal disk without distinct rays, sometimes black, but lateral margins not distinctly paler.....

aphidiphagus, p. 71

7. Hind femora with two brown or fuscous bands near apex; apical half of membrane with a distinctly rounded fuscous spot, usually connected at base by a fuscous streak that extends up between large areoles................. 8

Hind femora with but one fuscous band; apical half of membrane pale or clouded with fuscous, but fuscous area not forming a rounded spot on apical half........... 9

8. Calli solid black, a broad piceous ray behind each; in pale specimens, calli may be somewhat brownish, but, in such case, median line and margins of disk distinctly pale, leaving a dark brown ray behind each callus; hemelytra with clavus and corium piceous, embolium pale...

borealis, p. 71

Calli more or less invaded with brownish or pale areas, distinct rays not apparent behind calli; hemelytra and pronotum more uniformly colored, fulvo-testaceous to dark brownish.

.... fasciolus var. castus, p. 70

9. Dorsum uniformly very dark brown; calli and scutellum black........ .............. davisi, p. 72

Dorsum pale to testaceous and brownish, frequently becoming fuscous or black but always with some pale areas; calli margined with black or entirely black. .

10. Calli black only around margins, dorsum rich brownish to deep brown, shining.......nitenatus, p. 72

Calli entirely black, or, if not, dorsum pallid and with three darkened spots on each hemelytron, one at apex, one at middle and one at base. 11

11. Dorsum fuscous to black, usually with a pale median line running over disk and scutellum; hemelytra darkened to such an extent that three blotchlike, fuscous spots are not apparent

quercicola var. quercicola, p. 71

Dorsum pallid brown with three dark spots, one at base, one at middle and one at apex of each hemelytron; calli usually entirely black, but, in pale specimens, calli only margined with black................

quercicola var. pallens, p. 71

\section{Deraeocoris betulae Knight}

Deraeocoris betulae Knight (1921, p. 129).

No Illinois specimens; known from the New England and Middle Atlantic states; occurs on birch (Betula lutea). Male genitalia as in fig. 106.

\section{Deraeocoris alnicola Knight}

Deraeocoris alnicola Knight (1921, p. 132).

No Illinois specimens; known from Connecticut, Ontario, New York; occurs on alder (Alnus incana). Male genitalia as in fig. 106.

\section{Deraeocoris fasciolus Knight}

Deraeocoris fasciolus Knight (1921, p. 123).

Adults.-Length 6.50, width 2.80-3.10; usually slightly smaller than borealis ( $V$ an Duzee), disk of pronotum more uniformly colored, calli more or less invaded with brownish or pale and without distinct rays behind; left genital clasper very similar to that of borealis, but right clasper distinctive, fig. 106.

In the variety fasciolus castus Knight (1921, p. 125) the tibiae are uniformly yellowish rather than partly dark, as in the typical form; castus has not been taken in Illinois.

Habits.-Occurs on hawthorns ( $\mathrm{Cra}$ taegus sp.) and apple trees, where it feeds on the rosy aphid, Macrosiplium rosae (Linnaeus). In New York the author found the white, wax-coated nymphs of $D$. fasciolus frequenting the aphid-curled leaves, feeding on aphids and their honeydew excretions.

Illinois Records.-NORTHERN IlLINOIS: July, 1 ô, 1 o. Antioch: Aug. 1, 1930, Frison, Knight \& Ross, $1 \%$. Galena: June 30, 1932, Dozier \& Mohr, 1 . Monticello: June 11, 1934, Frison \& De- 
Long, $1 \delta, 1 \%$. WAUKEGAN : July 6, 1932, on Tilia sp., T. H. Frison, 1 \% . Willow Springs: July 8, 1906, W. J. Gerhard, 1 ㅇ, FM.

\section{Deraeocoris borealis (Van Duzee)}

Camptobrochys borealis Van Duzee (1920, p. 354).

Not taken in Illinois; known from Michigan, Minnesota, Ohio, Wisconsin; occurs on alders. Male genitalia as in fig. 106.

\section{Deraeocoris grandis (Uhler)}

Camprobrochis grandis Uhler (1887a, p. 230). Adults.-Length 6.40-7.00, width 2.903.10. Distinguished by its long rostrum, which reaches the second abdominal sternite. Dorsum rather uniformly dark brown; median line of pronotal disk with a rather broad, pale stripe, but this area only slightly paler than that behind calli. Legs pale; apical half of hind femora and basal half of tibiae with two black annulations. Membrane uniformly pale smoky on the apical half. Male genitalia as in fig. 106.

HaBits.-Occurs on hickory (Carya sp.).

Known Distribution. - Illinois, Iowa, Maryland, New York, Ontario.

Illinois Records.-NORTHERN IlLINOIS: 1 . Champaign: June 15,1888 , at electric light, C. A. Hart. Frankfort: June 8, 1933, on Carya sp., Mohr \& Townsend, 2 o, 3 o.

\section{Deraeocoris aphidiphagus Knight} 134)

Deraeocoris aphidiphagus Knight (1921, p.

Adults.-Fig. 107. Length 5.80-6.10, width 2.90-6.10. Fusco-grayish to black, paler and translucent parts not stained with brownish; apical half of membrane infuscated; tibiae with three black annulations; left genital clasper with a long horn at dorsal extremity, internal arm slender, fig. 106.

HABITS.- I have found this species breeding only on elm (Ulmus sp.), in curled leaves infested with Eriosoma americanum (Riley). Both nymphs and adults feed on the aphids and their honeydew excretions. The nymphs are coated with a white, waxlike material similar to that which covers the aphids, and in the early stages, at least, they are rather inconspicuous, as they live among the aphids and their excretory products. This species of mirid must be regarded as a beneficial species, as it reduces the numbers of elm aphids.

Known Distribution.-Several eastern states; taken as far west as Arkansas, Colorado, Minnesota, North Dakota, South Dakota.

Illinois Records. - Twenty-one males and 13 females, taken June 5 to July 18, are

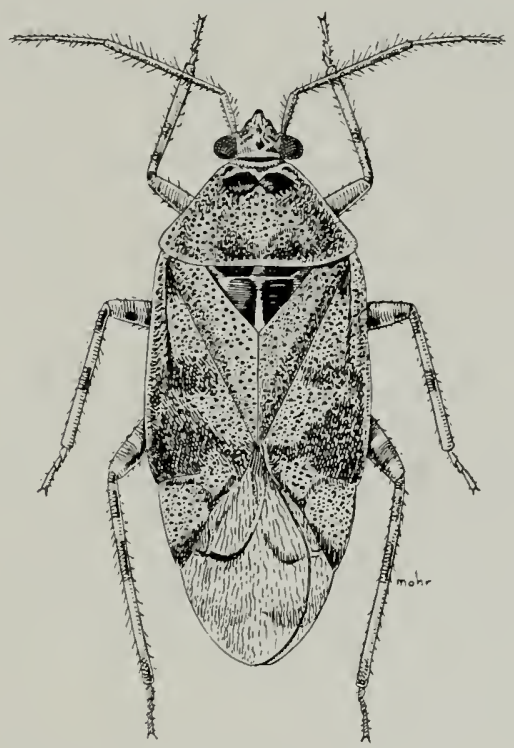

Fig. 107.-Deraeocoris aphidiphagus, ơ.

from Alto Pass, Antioch, Augerville, Champaign, Elgin, Frankfort, Galesburg, Grand Detour, Hardin, Lacon, Normandy, Urbana, Willow Springs.

\section{Deraeocoris quercicola Knight}

Deraeocoris quercicola Knight (1921, p. 138). Adults.-Length 5.50-5.80, width 2.402.80. General color fuscous to black. Calli black; apical half of membrane smoky, rarely as pale as in nitenatus Knight. Left genital clasper with a long dorsal horn that is very distinctive when contrasted with the form of the internal arm, fig. 106.

Specimens of this species in which the calli are more or less pale, the hemelytra are pallid or yellowish, and the corium has a black spot in the middle, have been designated variety pallens Knight (1921, p. 140). This variety and the typical one occur together in Illinois.

Habits.-Occurs on white oak (Quercus 
alba), bur oak (Quercus macrocarpa), basswood (Tilia sp.) and hawthorn (Crataegus sp.).

Known Distribution.-A common species in the northeastern states; known also from Colorado, Iowa, Minnesota, New Mexico, and southeastward into Georgia and North Carolina.

Illinois Records.-Thirty-two males and 36 females, taken June 2 to July 16, are from Antioch, Apple River Canyon State Park, Champaign, Chicago, Elizabethtown, Frankfort, Galena, Galesburg, Grand Detour, Keithsburg, Manito, Monticello, Mount Carroll, Urbana, Waukegan, White Pines Forest State Park, Willow Springs, Zion. Blatchley (1926b, p. 900) also records this species from Glen Ellyn.

\section{Deraeocoris davisi Knight}

Deraeocoris davisi Knight (1921, p. 140).

Adults.-Length 5.30, width 2.50. General color uniformly brownish black; legs and antennae chiefly pale, hind femora with an incomplete dark annulus on apical half; membrane with apical half very faintly but uniformly stained with brownish, veins and areoles darkened with brownish; closely related to quercicola Knight, but the internal arm of left clasper more highly developed, fig. 106.

Known Distribution. - An uncommon species, known only from Alabama, Illinois, New York, North Carolina, Texas.

Illinois Records.-PoLo: May 31, 1933, Ross \& Townsend, 1 ô. Vienna: June 14, 1934, savanna grasses, DeLong \& Ross, 1 ㅇ.

\section{Deraeocoris nitenatus Knight}

Camprobrochis nitens Reuter (1909, p. 56). Preoccupied.

Deraeocoris nitenatus Knight (1921, p. 141).

ADULTs.-Length 5.70-6.00, width 2.002.90. General aspect very similar to quercicola Knight, but more highly polished, calli black around margins only. Dorsum rich brownish to dark brownish and piceous, frequently brownish on scutellum, but rarely black each side of median line. Brachium and apex of areoles dark fuscous, apical half of membrane practically clear; male genital claspers distinctive for species, fig. 106.

Habits.-Breeds on elm (Ulmus sp.), basswood (Tilia americana), and other trees, where it is predacious on the woolly aphid, Eriosoma lanigerum (Hausmann), and, probably, other aphids.

Known Distribution.--District of Columbia, Illinois, Iowa, Maryland, Minnesota, New England, North Carolina, Quebec, Virginia.

Illinois Records.-Antioch: July 5-7, 1932, on Tilia sp., T. H. Frison et al., 1 ô. Galesburg: July 24, 1892, 1 ô, 1 q .

\section{Group C}

\section{KEY TO SPECIES}

1. Dorsum practically glabrous, at most only sparsely and finely pubescent (not rubbed specimens), rarely with a few hairs at anterior angles of pronotum.............. 2

Dorsum heavily pubescent, at least with long hairs at anterior angles of pronotum................ 3

2. Second antennal segment of female with prominent exserted hairs, length of hairs one and one-half times the thickness of segment where they occur. Second antennal segment of male as thick at middle as on the apical half, and length of exserted hairs equal to one and one-half times the thickness of segment.........

laricicola, p. 73

Second antennal segment of female with erect hairs but length of hairs barely equal to twice the thickness of segment where they occur. Second antennal segment of the male slender on basal half, distinctly thicker on apical half than at middle; length of hairs not greater than maximum thickness of second segment.......

pinicola, p. 73

3. Pronotum, hemelytra and legs uniformly dark, sepia brown or black, semitranslucent areas stained with brownish; hind tibiae usually with distinct annulated pale bands on apical half........nigritulus, p. 73

Pronotum usually fusco-grayish or black; hemelytra fuscous to black, becoming paler in certain areas but not stained with brownish; legs very dark brown, hind tibiae sometimes with indistinct pale bands on apical half; front coxae, xyphus, lower margins of propleura, gula, and sides of tylus, pale.........albigulus, p. 73 
Deraeocoris pinicola Knight

Deraeocoris pinicola Knight (1921, p. 162).

Adulrs.-Length 5.70-6.00, width 2.602.90 ; calli margined or lined with black, antero-lateral angles invaded by light-colored areas; median line of front and areas just anterior to calli pale to ivory white: general color pale to grayish, darkened with black, not at all tinged with brownish. Male genitalia as in fig. 105.

Habits.-Occurs on white pine (Pinus strobus) ; predacious on Chermes pinicorticis (Fitch). This species may also attack aphids, such as Cinara strobi (Fitch) and Eulachnus rileyi (Williams), which commonly occur on white pines growing in Illinois.

Known Distribution. - Iowa, Minnesota and states to the east where white pine grows.

Illinois Records.-White Pines Forest State Park: July 4, 1932, on Pinus strobus, Dozier \& Mohr, 1 \& ; June 4, 1933, on Pinus strobus, Ross \& Townsend, 13 .

\section{Deraeocoris Jaricicola Knight}

Deraeocoris laricicola Knight (1921, p. 164). Adults.-Length 6.00-6.50, width 2.702.80 ; very suggestive of pinicola Knight, but slightly larger and more elongate. Antennae with prominent, exserted hairs; male genital claspers distinctive, fig. 106.

Habits.-Occurs on larch (Larix laricina).

KNown Distribution. - Illinois, Indiana, Minnesota, New York.

Illinois Records.-Antoch: July 5-7, 1932, T. H. Frison et al., 6 \% . VoLo: June 11, 1936, Ross \& Burks, 2 ô, 2 q.

\section{Deraeocoris nigritulus Knight}

Deraeocoris nigritulus Knight (1921, p. 170).

Not taken in Illinois. Breeds on Virginia pine (Pinus virginiana); known from District of Columbia, Maryland, Ohio, Virginia. Male genitalia as in fig. 106.

\section{Deraeocoris albigulus Knight}

Deraeocoris albigulus Knight (1921, p. 171).

Not yet collected in Illinois. Occurs on pine; known from Indiana, Iowa, Michigan, Minnesota, New York; will surely be found in Illinois eventually. Male genitalia as in fig. 106.

\section{Group D}

\section{Deraeocoris sayi (Reuter)}

Euarmosus sayi Reuter (1876, p. 76).

Adults.-Length 7.40-7.90, width 3.403.80 ; distinctly hairy. Color chiefly black, with considerable variation in the color of the head, pronotum and scutellum. In the darkest form, var. unicolor Knight (1921, p. 177), these parts are mostly or entirely black; in the lightest form, var. sayi, most of them are reddish. Various intermediate conditions occur between these extremes, these taken in Illinois representing var. marginata Knight (1921, p. 176), frontalis Inight (1921, p. 177) and costalis Knight (1921, p. 177). Male genitalia, fig. 106.

Habits.-Occurs on oaks (Quercus sp.).

Known Distribution.-Described from Texas and since found in Florida, Georgia, Illinois, Iowa, Massachusetts, Michigan. Minnesota, Mississippi, New York, North Carolina.

Illinois Records.-NORThern IllinoIs: $2 \hat{o}$. Southern Illinois: 1 . AlgonQUiN: May 27, 1899, 1 ô; June 8-12, 1900, 2 б; June 13, 1905, Nason, $1 \hat{\delta}$. Chicago: June 9, 1 o . Galesburg: Stromberg, 1 o , 1 o ; June 12-14, 1 o , 1 \& ; July 17, 1892, 1 \% ; June 14-19, 1893, Stromberg, 1 o , 1 \%. Glen Ellyy: June 18-19, W. J. Gerhard, $1 \hat{\delta}$, FM, $2 \hat{\delta}, 1$.

\section{Eurychilopterella Reuter}

\section{KEY TO SPECIES}

Dorsum of body fuscous to black on a pale background........... luridula, p. 73 Dorsum of body uniformly fuscous brown

$$
\text { ................ brunneata, p. } 74
$$

\section{Eurychilopterella luridula Reuter} $60)$.

Eurychilopterella luridula Reuter (1909, p.

Male.-Fig. 108. Length t.50, width 1.80 ; fuscous to black on a pale background; pronotum coarsely punctured; dorsum clothed with stiff, erect pubescence.

Female.-Length 4.40, width 1.03 ; more robust than male, but very similar in coloration.

Habits.-Occurs on apple (Pyrus malus) and elm (Ulmus sp.); evidently predacious in habits. 
Known Distribution.-District of Columbia, Illinois, Iowa, Minnesota, New York, South Carolina, Virginia.

Illinois Records. - Illinors: July 9, 1892, 1 ㅇ. Northern Illinois: $2 \hat{o}$. Chi-

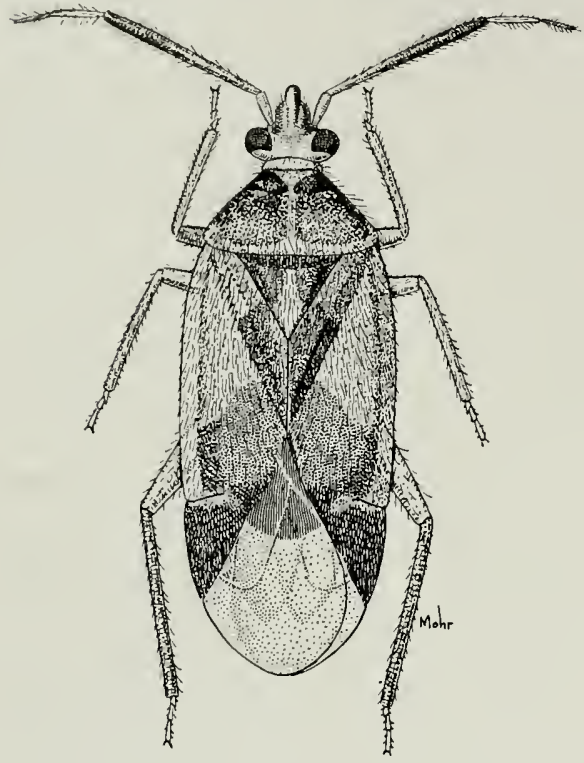

Fig. 108.-Eurychilopterella luridula, $\sigma^{7}$.

CAGo: Aug. 10, 1909, A. B. Wolcott, $1 \%$, FM; Sept. 12, 1919, on elm, W. J. Gerhard, 1 \%, FM. URBANA: July 7, 1915, tree trunk. 1 \% ; Sept. 28, 1915, tree trunk, 1 ô.

\section{Eurychilopterella brunneata Knight}

Eurychilopterella brunneata Knight (1927d, p. 141).

This species is distinguished from luridula Reuter by its uniformly fuscous-brown coloration, longer head and larger size.

Male.-Length 4.70 , width 2.10 . Head width 0.86 , vertex 0.38 , head length 0.71 , extending 0.44 beyond front of eyes; horizontal, flattened beneath; gula slightly sulcate; lower margins of eyes extending slightly below gula. Rostrum, length 3.20 , reaching to base of genital segment. Antennae, first segment, length 0.29 , more slender on basal half; second, 1.26, cylindrical, equal to thickness of first segment; third, 0.44 ; fourth, 0.36; last two segments slender. Pronotum, length 1.18, width at base 1.77 ; disk more distinctly flattened than in luridu$l a$, coarsely and closely punctate; calli confluent, smooth, smaller than in luridula.
General color dark, fuscous brown; pronotum slightly darker; head, collar and legs more yellowish brown; membrane and veins uniformly brownish. Clothed with thickly set, erect, rather long, yellowish brown pubescence.

Illinois Record.-Clay City: Aug. 17, 1911, C. A. Hart, 1 ô.

\section{Hesperophylum Reuter}

\section{Hesperophylum heidemanni Reuter}

Hesperophylum heidemanni Reuter (1912b, p. 17).

This is a rare species, yet widely distributed as indicated by the few records. Originally described from a New Hampshire specimen, it was later taken at Washington, D. C. (Heidemann). H. G. Barber (1914, p. 170) recorded it from Arizona. The most recent record is a female specimen, taken June 26, 1931, in Ames, Iowa ( $H$. H. Knight); it was collected while sweeping under trees. This species has not been found in Illinois, but doubtless it will be eventually. The male is unknown.

In previous books this genus has frequently been considered in a separate family, the Termatophylidae.

\section{ORTHOTYLINAE}

\section{KEY TO TRIBES}

1. Eyes pedunculate, head very broad, fig. $19 \ldots \ldots$. . . . LABOPINI, p. 81

Eyes not pedunculate, head not unusually broad, figs. 109, 113..... . 2

2. Pronotum with pleural area separated from dorsal part by a distinct suture, fig. 22; pronotal disk raised posteriorly and projecting above scutellum; clothed with dense, bristly pubesscence............ SEMIINI, p. 75

Pronotum without a distinct lateral suture; pronotal disk not projecting above scutellum.............. 3

3. Antlike species with abdomen constricted at base, figs. $137-141 \ldots \ldots 4$

Body not antlike in form, figs. 112, 1135

4. Second and third segments of antennae equal in thickness, fig. $137 \ldots \ldots$. .

.......SYSTELLONOTINI, p. 116

Second segment of antennae considerably thicker than third, fig. 141 .

PILOPHORINI, p. 118 
5. Small, light-colored species clothed with intermixed erect pubescence and scalelike hairs, and with vertex not carinate, fig. 110 .. HALTICINI, p. 75

Not having that combination of characters: if scalelike hairs present, vertex carinate............... 6

6. Small, compact, black species with saltatorial femora, figs. 111, 112, 115

HALTICINI, p. 75

Not compact, black species with saltatorial femora.............. 7

7. Second and third segments of antennae equal in thickness, fig. $135 \ldots \ldots$....

CERATOCAPSINI, p. 107

Second segment of antennae considerably thicker than third, fig. $129 \ldots$

ORTHOTYLINI, p. 81

\section{SEMIINI}

\section{Semium Reuter}

\section{Semium hirtum Reuter}

Semium hirtum Reuter (1876, p. 80).

Adults.-Fig. 109 . Length 2.80, width 1.00 ; legs and antennae red; head, apex of

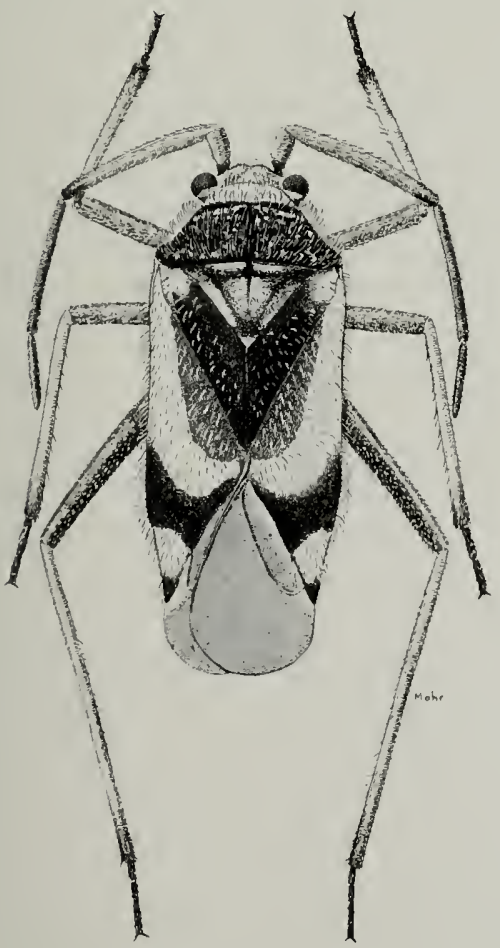

Fig. 109.--Serium hirtum, ㅇ. pronotum, and sides of thorax, rosy red; basal half of pronotum, clavus, bar across apex of corium, and tip of cuneus, velvety brown, remaining parts of corium and cuneus white; body densely clothed with erect, bristly pubescence.

Food Plants.-Spurges (Euphorbia adenoptera and E. humistrata); lives on the red undersides of the leaves; two 1llinois specimens were taken on sugar beet (Beta vulgaris), but may not have been feeding there.

Known Distribution.-Described from Texas, and now known also from California, District of Columbia, Illinois, Indiana, Iowa, Kansas, New Jersey, New York, Ohio, Pennsylvania.

Illinois Records.-Twenty-three males, 65 females and 2 nymphs, taken July 3 to Oct. 13, are from Borton, Centralia, Chicago, Dongola, Dubois, Fountain Bluff, Galesburg, Green Valley, Jewett, Lawrenceville, Monticello, Savanna, Urbana.

\section{HALTICINI}

\section{KEY TO GENERA}

1. Head without a well-defined, sharp, posterior margin, fig. 110; head and dorsum thickly clothed with closely appressed, scalelike hairs interspersed with more nearly erect, long hairs; small species, varying in color from pale to dull black.

Parthenicus, p. 76

Head with well-defined, sharp, posterior margin, fig. 113; color black....... 2

2. Antennae very long and slender, second segment four or more times as long as first segment, fig. 111 ; brachypterous forms common and have oval body, strongly convex, fig. $112 \ldots$. .

Halticus, p. 77

Antennae shorter, second segment little more than three times as long as first segment, fig. $113 \ldots \ldots \ldots \ldots 3$

3. Length of hairs on third antennal segment three times as great as thickness of segment; antennae and head with long, coarse, black hairs.

Orthocephalus, p. 81

Antennae with much shorter pubescence, fig. 115; head and body in most species nearly glabrous

Strongylocoris, p. 78 


\section{Parthenicus Reuter}

\section{KEY TO SPECIES}

1. Body color fuscous to black; first antennal segment black, second segment pale........nigrellus, p. 77

Body straw colored to yellowish; antennae pale............... 2

2. Body and legs uniformly pale yellowish or pinkish, without flecks or dots taxodii, p. 76

Body more or less pale, hind femora pale fuscous, usually sprinkled with reddish dots; scutellum fuscous; cuneus tinted with red..........

juniperi, p. 76

\section{Parthenicus juniperi (Heidemann)}

Psallus juniperi Heidemann (1905, p. 49).

MaLE.-Fig. 110. Length 3.00, width 1.00. General color pale yellowish. Cuneus, apical one-third of corium and base of head tinged with reddish, color sometimes separating into specks; femora pale fuscous, sprinkled with reddish; scutellum and base of clavus darkened with fuscous. Body clothed with fine, erect, golden pubescence,

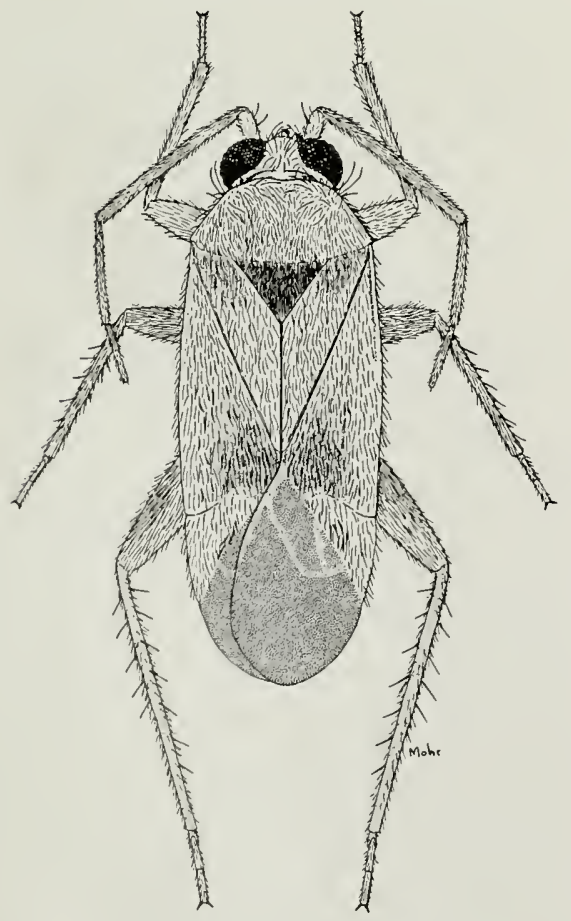

Fig. 110.--Parthenicus juniperi, $\sigma^{7}$. intermixed with more closely appressed, scalelike, golden hairs, the hairs tending to silvery on scutellum and on transverse area extending across corium at tip of clavus: pubesence becoming black across apex of corium and forming a spot on inner edge of cuneus at middle and at base; membrane uniformly infuscated and iridescent.

Female.-Very similar to male in form and color.

Food Plant.-Red cedar (Juniperus virginiana).

Known Distribution.-Ranges widely east of the 100th meridian, occurring nearly everywhere red cedar grows in natural stands.

Illinois Records. - Twenty-one males and 108 females, taken June 10 to July 25, are from Alton, Antioch, Eichorn, Ernst, Galena, Golconda, Grayville, Hillsboro, Kampsville, Karnak, Keithsburg, Oquawka, Starved Rock State Park, Urbana, White Pines Forest State Park.

\section{Parthenicus taxodii new species}

This may be distinguished from allied species by its small size, its uniformly yellowish salmon color and its pale fuscous membrane.

MALE.-Length 2.00, width 0.90 . Head width 0.54 , vertex 0.17 . Rostrum, length 0.73 , extending very slightly behind posterior coxae. Antennae yellowish to dusky; length of first segment, 0.13 ; second, 0.73 ; third, 0.43 ; fourth, 0.30 . Pronotum, length 0.34 , width at base 0.73 . Dorsum clothed with deciduous, silvery to golden, sericeous pubescence intermixed with more nearly erect, simple, pale pubescence. General coloration rather uniformly yellowish to salmon; strongly colored specimens may have scutellum dusky and clavus tinted salmon pink; membrane uniformly pale fuscous; veins yellowish.

Female.-Length 2.20, width 0.91. Head width 0.47 ; vertex 0.26 . Pronotum, length 0.32 , width at base 0.75 . Antennae, length of first segment, 0.13 ; second, 0.70 ; third, 0.40 ; fourth, 0.29. Form more robust than that of male, but very similar in pubescence and coloration.

Food Plant.-Bald cypress (Taxodium distichum).

Holotype, male.-Karnak, Ill.: July 26, 1930, on Taxodium distichum, Knight \& Ross. 
Allotype, female.-Same data as for holotype.

Paratypes. - lluinois. - Same data as for holotype, 39 oे, 42 q. Cairo: July 27, 1930, on Taxodium distichum, Knight \& Ross, 2 o , 6 \% . Jonesboro: Aug. 2, 1932 , H. L. Dozier, 17 \& , 34 q. Karnak: June 23, 1932, Ross, Dozier \& Park, 1 of, 1 \%; June 14, 1934, on Taxodium distichum, DeLong \& Ross, 3 of, 10 \&. Shawneetown : June 14, 1934, DeLong \& Ross, 1 nymph. UrbaNa: Aug. 28, 1917, 1 f , 3 q, 1 nymph.

\section{Parthenicus nigrellus Knight}

Parthenicus nigrellus Konight (1939a, p. 23).

This species is distinguished from the other members of the genus by its black color and pale second antennal segment.

MalE.-Length 3.30, width 1.60 . Head width 0.73 , vertex 0.34 . Rostrum, length 1.40 , just attaining hind margins of posterior coxae. Antennae, first segment, length 0.39 ; black; second, 1.18 , pale, tinged with reddish, clothed with pale and dusky pubescence; third, 0.91 , pale; fourth, 0.60 , fuscous. Pronotum, length 0.60 , width at base 1.25 . Form ovate, robust; general color fuscous black with a tinge of red in hypodermis which is more pronounced on ventral surface, tips of femora, and base and apex of cuneus; membrane uniformly fuscous; veins reddish. Legs black, tibiae pale except basal one-third; tarsi pale, apices fuscous. Clothed with pale to yellowish pubescence intermixed with silvery, scalelike hairs. Genital claspers distinctive, right clasper spatulate at apex and curved so as to form a $V$-shaped loop which turns back over middle of genital segment.

Female.-Length 3.50, width 1.70. More robust than male, but very similar in form, color and pubescence.

Known Distribution. - Georgia, Illinois, Iowa, Texas.

Illinois Records.-Monticello: June 11, 1934, Frison \& DeLong, 1 f , 2 ㅇ. SEYMiour: July 7, 1937, Mohr \& Burks, 1 के 2 ㅇ.

\section{Halticus Hahn}

\section{KEY TO SPECIES}

1. Body devoid of scalelike pubescence; length of second antennal segment only slightly exceeding width of pronotum at posterior margin.......

apterus, p. 77

Body above with spots of deciduous, scalelike pubescence, figs. 110, 111; length of second antennal segment considerably greater than width of pronotum at posterior margin ..... 2

2. Second antennal segment yellow, apex with a narrow fuscous area; length $3.50 \ldots \ldots \ldots$ intermedius, p. 77

Second antennal segment black, or, at least, with base and apex black; length $2.00-2.20 \ldots$ bracteatus, $p .77$

\section{Halticus apterus (Linnaeus)}

Cicada aptera Linnaeus (1758, p. 438).

Not taken in Illinois; known from Maine, Nova Scotia, Ontario.

\section{Halticus intermedius Uhler}

Halticus intermedius Uhler (1904, p. 360).

Not taken in lllinois; known from Colorado, Mississippi, New York, North Dakota, Ohio, Ontario, Pennsylvania; breeds on virgin's bower (Clematis virginiana).

\section{Halticus bracteatus (Say)}

\section{Garden Flea Hopper}

Cylapus bracteatus Say (1832, p. 26).

Rhinacloa citri Ashmead (1887, p. 155).

Male.-Fig. 111. Length 1.90-2.00, width 0.70. General color black, slightly shining; antennae fuscous, middle of second segment and base of third pale; usually first antennal segment pale also. Apices of femora, tibiae (except bases of posterior pair), and all tarsi, pale. Body clothed with very fine, pale pubescence, with deciduous, tomentose patches that give silvery and greenish reflections.

Fenale.-Fig. 112. Length (brachypterous) 1.50 , width 1.00 ; length (macropterous) 2.20 ; first antennal segment dark; usually brachypterous, but frequently winged like male.

Food Plants.-White clover (Trifolium repens), beans (Phaseolus sp., etc.), plantain (Plantago lanceolata); also recorded on many other plants. This is a pest of considerable importance on leguminous crops.

KNown Distribution.-Common through states of Middle West and East. 


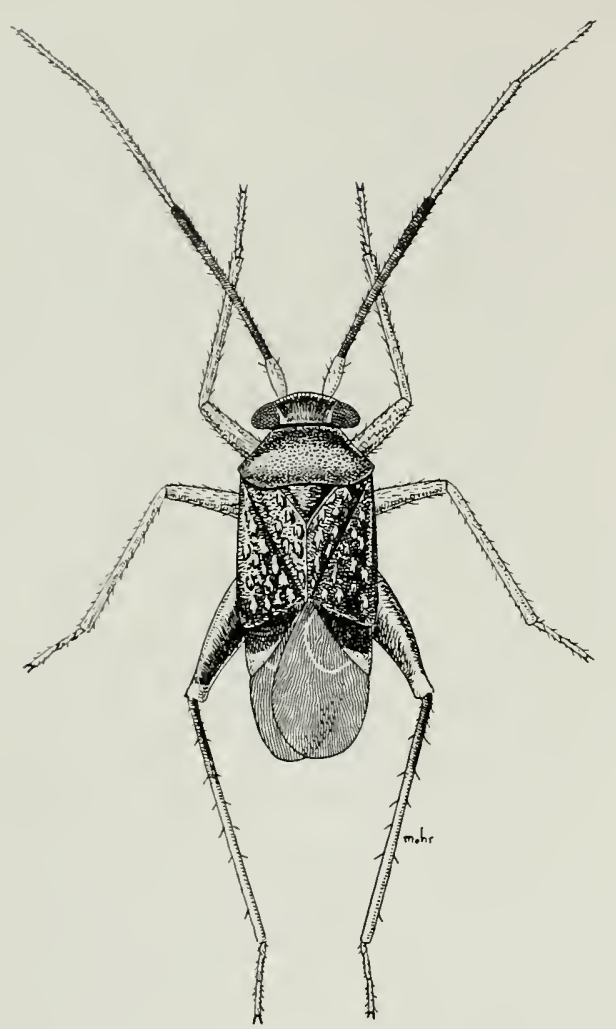

Fig. 111.- Halticus bracteatus, $0^{7}$.

Illinois Records.-Forty-two males and 86 females, taken May 29 to Oct. 3, are from Aldridge, Alton, Alto Pass, Anna, Bluffs, Carmi, Dolson, Dubois, Fountain Bluff, Freeport, Galena, Glen Ellyn, Golconda, Grand Tower, Grandview, Grayville, Henry, Karnak, Muncie, Normal, Paxton, Shawneetown, Starved Rock State Park, Tremont, Villa Ridge, Willow Springs, Wolf Lake, Urbana.

\section{Strongylocoris Blanchard}

\section{KEY TO SPECIES}

1. Dorsum glabrous or nearly so, fig. 114. 2 Dorsum and body thickly clothed with erect pubescence, fig. $115 \ldots \ldots \ldots 5$

2. Legs uniformly yellow to orange yellow ................. pallipes, p. 79 Legs with femora more or less black... 3

3. Hind tibiae yellow, sometimes dusky on basal half; second antennal segment yellow with narrow fuscous band at base and apex.... breviatus, p. 79

Hind tibiae black or fuscous, at least

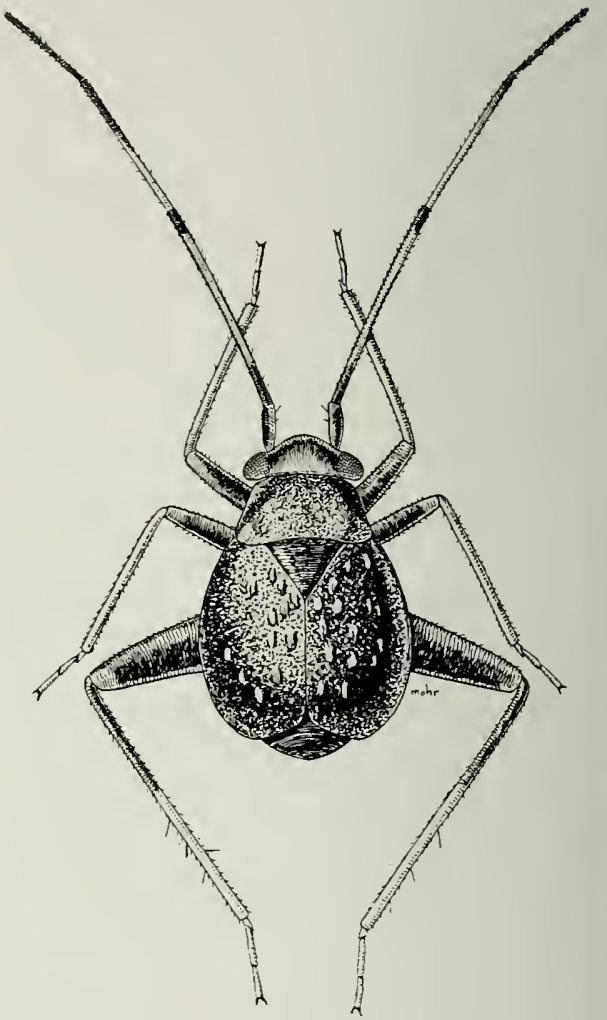

Fig. 112.-Halticus bracteatus, ㅇ․

with more area black than pale; second antennal segment sometimes yellowish at middle, but broad fuscous area always present at base... .4

4. Hind tibiae uniformly black; emboliar margins of hemelytra strongly arcuate........... atritibialis, p. 80

Hind tibiae fuscous, becoming paler on distal half; emboliar margins only moderately arcuate...stygicus, p. 79

5. Length of second antennal segment greater than width of head.......

hirtus, p. 80

Length of second antennal segment less than width of head...........6 6

6. Basal segments of tarsi pale, apical segment black; tibiae brownish, hind pair very dark brown; broad area on second antennal segment pale; costal margin of hemelytra strongly arcuate; length $4.30 \ldots \ldots$ mohri, p. 81

Tarsi entirely black; tibiae uniformly pale; antennae uniformly black; costal margin of hemelytra only slightly arcuate; length 3.50 .

ambrosiae, p. 81 


\section{Strongylocoris stygicus (Say)}

Capsus stygicus Say (1832, p. 24).

Male.-Fig. 113. Length 4.20, width 2.00. Head width 0.99 , vertex 0.54 . Rostrum, length 1.04, reaching to middle of intermediate coxae. Antennae black; length of first segment, 0.30 ; second, 1.12 ; third, 0.86 ; fourth, 0.47. Pronotum, length 0.91 , width at base 1.50. Form ovate, black, shining, finely but densely punctate, somewhat rugulose, nearly glabrous, sparsely set with fine, short pubescence; apices of femora, two anterior pairs of tibiae, all except apical segment of tarsi, and bases of trochanters, pale yellowish; hind tibiae fuscous to black, becoming paler on distal half. Male genital claspers distinctive, fig. 114.

Female.-Length 4.40 , width 2.10. More ovate and robust than male, but very similar in color, puncturation and scanty pubescence.

Food Plant-Goldenrod (Solidago sp.).

KNowx Distribution.-Commonly distributed in the eastern United States

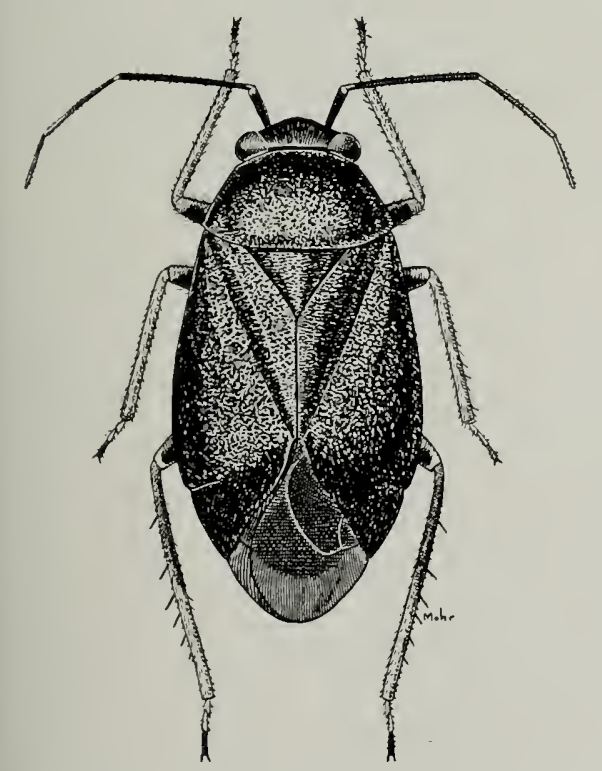

Fig. 113. - Strongylocoris stygicus, $\sigma^{7}$.

and Canada and extending westward to Alberta, Colorado, Montana.

Illinois Records.-One hundred fortyfive males, 36 females and 12 nymphs, taken May 6 to Sept. 21, are from Anna, Bloomington, Bluff Springs, Carbondale, Champaign, Charleston, Chicago, Cypress, Dan- ville, Dolson, Edgebrook, Elizabethtown, Galena, Galesburg, Golconda, Goreville, Grand Detour, Grandview, Hamilton, Herod, Joliet, Jonesboro, Keithsburg, Makanda, Monticello, Mount Carmel, Muncie, Odin, Oquawka, Palos Park, Pulaski, Sheldon, Springfield, Urbana, Vienna, Warsaw, West Union, Willow Springs.

\section{Strongylocoris pallipes Knight} 254).

Strongylocoris pallipes Knight (1926h, p.

Not taken in Illinois; known from Maryland and Virginia. Male genitalia as in fig. 11 .

\section{Strongylocoris breviatus Knight}

Strongylocoris breviatus Knight (1938, p. 1.)

This species is allied to stygicus (Say), but is distinguished by the yellowish first and second antennal segments, the latter having a distinct black band at the base; male genital claspers are distinctive for this species, fig. 114.

Male.-Length 4.30, width 2.00. Head width 1.06 , vertex 0.56 . Antennae, first segment, length 0.35 , yeliowish brown, black at base; second, 1.30 , brownish on basal half and black at base; third, 0.95 , black; fourth, 0.47 , black. Pronotum, length 0.91 , width at base 1.51 . Hemelytra with costal margin moderately arcuate. Dorsum finely and closely rugulose punctate, sparsely clothed with short, pale pubescence, this pubescence more apparent on lateral margins of hemelytra, paracuneus with three or four long hairs. General coloration deep black, shining; femora black, apices yellowish; tibiae uniformly yellowish, except hind pair, which have apices and variable area at base fuscous; tarsi yellowish, apical segment black.

FeMale.-Length 4.10, width 2.20 ; hemelytra more sharply arcuate than in male. Head width 1.20 , vertex 0.64 . Antennae, first segment, length 0.36 , yellow, base black; second, 1.17, yellow, apical one-fourth and narrow ring at base black; third, 0.86 , black, yellowish at base; fourth, 0.44 , black.

Food Plant.-Goldenrod (Solidago altissima).

Known Distribution. - Nova Scotia and Maine to District of Columbia, and westward to Alberta, Minnesota, Montana.

Illinois Records. - Nineteen males and 22 females, taken May 21 to Aug. 25, are 
from Anna, Antioch, Beach, Browns, Bureau, Champaign, Dolson, Golconda, Grand Detour, Herod, Makanda, Marshall, Mount
Illinois Records.-Thirty-five males and 44 females, taken May 12 to July 15, are from Algonquin, Antioch, Browns, Charles-
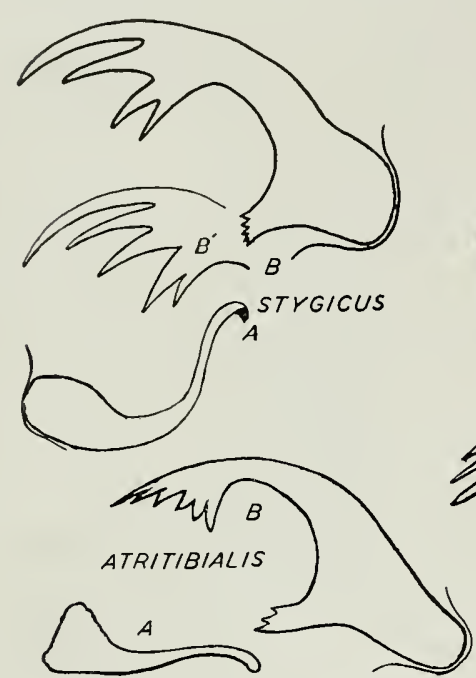

Fig. 114.- Male genital claspers of Strongylocoris. $A$, left clasper; $B$, right clasper.

Carmel, Oakwood, Oregon, Pulaski, Shawneetown, Urbana, West Union.

\section{Strongylocoris atritibialis Knight}

Strongylocoris atritibialis Knight (1938, p. 2).

This species is distinguished from stygicus (Say) by its more arcuate hemelytra, black tibiae and the structure of the male genital claspers, fig. 114.

MAL.E.-Length 4.60, width 2.40. Head width 1.21 , vertex 0.65 . Antennae black: length of first segment, 0.34 ; second, 1.26; third, 1.00 ; fourth, 0.43. Pronotum, length 1.12 , width at base 1.77 . Hemelytra with costal margin strongly arcuate. Dorsal surface nearly glabrous, rugulose, punctate, sparsely clothed with fine, short pubescence, which is more evident on cuneus and embolium. General coloration deep black; membrane very dark brown; legs black; tibiae and tarsi sometimes very dark brown, but hind tibiae always black. Genital claspers distinctive for species, fig. 114.

Female.-Length 4.50, width 2.50; emboliar margins more strongly arcuate than in male. Form more robust than in male, but very similar in coloration.

Known Distribution.-Widely distributed in eastern United States and ranging westward into Alberta, Colorado, Wyoming. ton, Dolson, Dongola, Fountain Bluff, Galena, Galesburg, Grand Detour, Grayslake, Havana, Herod, Joliet, Makanda, Muncie, Pulaski, St. Anne, Shawneetown, Sheldon, Volo.

\section{Strongylocoris hirtus Knight}

Strongylocoris hirtus Knight (1938, p. 4).

This is distinguished from allied species with erect pubescence by the longer second antennal segment, which exceeds the width of the head across the eyes; the tibiae and first antennal segment are pale and the male genital claspers are distinctive, fig. 114.

Male.-Length 4.60, width 2.20. Head width 1.12 , vertex 0.56 . Antennae, first segment, length 0.38 , pale, base fuscous; second, 1.43, black, basal one-fifth pale; third, 0.86 , black; fourth, 0.47, black. Pronotum, length 0.98 , width at base 0.16 . Hemelytra with costal margin moderately arcuate on distal half. Clothed with thickly set, erect, goldenbrown to black pubescence. General coloration black, shining slightly; legs mostly black, with tibiae, all but apical segment of tarsi, and apices of femora, pale; tibial spines fuscous.

Female.-Length 4.30, width 2.40. More robust than male, but very similar in color and pubescence. 
Food Plant.-Cup plant (Silphium perfoliatum).

Known Distribution.--Illinois, Iowa, Kansas.

Illinois Records.-Charleston: June 14, 1931, H. H. Ross, 1 o. Hardin: June 5, 1932, H. L. Dozier, 1 o. West Union: June 14, 1930, on Silphium sp., T. H. Frison, tô, 1 q ; June 26, 1932, Ross \& Dozier, $1 \hat{\delta}, 1 \%$.

\section{Strongylocoris mohri new species}

This species is allied to hirtus Knight, but is distinguished by its longer pubescence, more arcuate hemelytra, and shorter second antennal segment, which does not equal the width of the head across the eyes.

Fenale.-Fig. 115. Length 4.30 , width 2.50. Rostrum, length 1.00 , reaching to

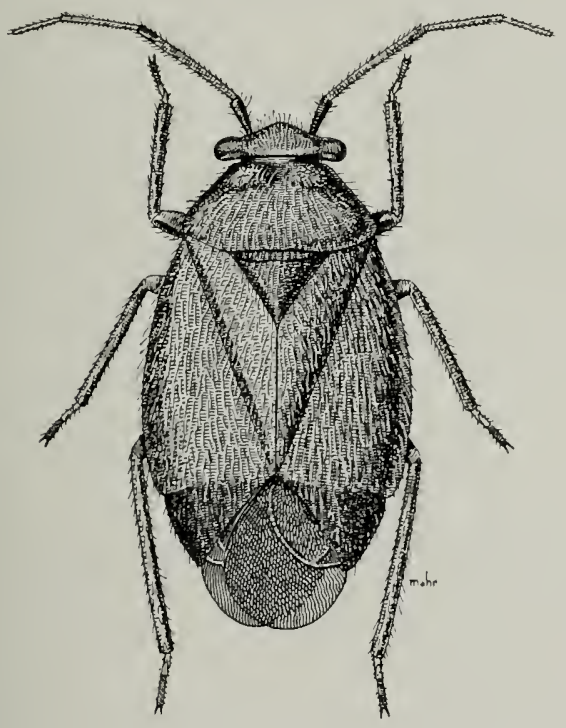

Fig. 115.-Strongylocoris mohri, ㅇ.

middle of intermediate coxae, black, with second segment pale. Antennae, first segment, length 0.30 , black, slightly pale on apex; second, 0.99, cylindrical, tapering to become more slender on basal than on apical half, pale, apex black, base brownish, pubescence pale; third, 0.65 , black, pale on base; fourth, 0.43 , black. Pronotum, length 0.95 , width at base 1.73 . Hemelytra strongly arcuate, costal edge sharp, slightly reflexed, cuneus approximately triangular.

General coloration black, moderately shining, clothed with long, rather fine, erect, pale to brownish pubescence. Legs mostly black, with tips of femora slightly paler; tibiae pale to brownish, darker on basal half, hind pair nearly black; tarsi pale, apical segment black.

Holotype, female.-Hamilton, Ill.: June 9, 1932, Ross \& Mohr.

Paratype.-Central llinois: 19 .

Named for Dr. Dr. Carl O. Mohr, who made many of the illustrations for this work.

\section{Strongylocoris ambrosiae Knight}

Strongylocoris amlrosiae Knight (1938, p. 5). Not yet collected in Illinois; known from Iowa, Kansas, South Dakota, Texas. Male genital claspers as in fig. 11 .

\section{Orthocephalus Fieber}

No Illinois species; Orthocephalus mutabilis (Fallen) occurs in Maine, New York, Pennsylvania.

\section{LABOPINI}

\section{Labops Burmeister}

No Illinois species; Labops hirtus Knight is known from Colorado, Maine, Massachusetts, Montana, New York, Ontario.

\section{ORTHOTYLINI}

\section{KEY TO GENERA}

1. Posterior margin of vertex with a high, transverse ridge extending from eye to eye and bearing stout, black bristles, fig. 116 .

Hadronema, p. 84

Posterior margin of vertex not having a ridge extending from eye to eye which bears stout, black bristles... 2

2. A well-defined, oblique suture on gena extending from antennal fossa to beneath eye, fig. 117, this suture frequently outlined by a dark stripe; red-orange and black species.

Lopidea, p. $8 t$

Genal suture absent, or extending directly from antennal fossa to eye, fig. 118 , or present, but vague and not outlined by a dark stripe..... 3

3. Base of tylus markedly produced and located considerably ventrad of the 
level of ventral margins of eyes, fig. $118 \ldots \ldots$. . . . . In . Inacora, p. 82

Base of tylus less angularly produced, not located ventrad of level of ventral margins of eyes, fig. 119; on a line with or considerably dorsad of level of ventral margins of eyes. . 4

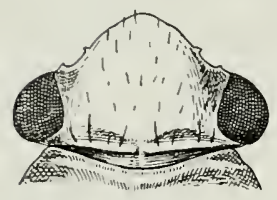

116

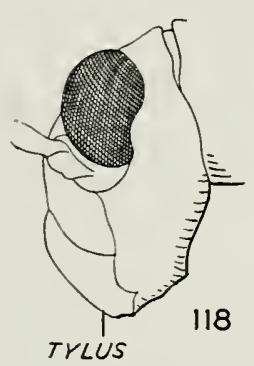

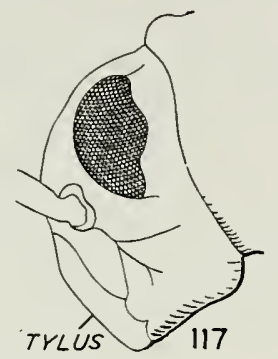

Fig. 116.--Head of Hadronema militare.

Fig. 117.--Head of Lopidea confluenta.

Fig. 118.- Head of Ilnacora stalii.

Fig. 119.--Head of Mecomma gilvipes.

4. Second antennal segment thickened at apex, fig. 133 .

.........Heterocordylus, p. 107

Second antennal segment linear, fig. $125 \ldots \ldots \ldots \ldots \ldots \ldots \ldots$. . . . . 5

5. First antennal segment with a longitudinal black line on either side, these lines connected on ventral side near apex..... Reuteria, p. 92

First antennal segment not marked with longitudinal black lines...... 6

6. Eyes rounded behind and set at or near middle of head, well removed from anterior margin of pronotum, fig. 123 ....... Diaphnidia, p. 91

Eyes relatively straight behind and set close to anterior margin of pronotum, fig. 129 .

7. Body clothed with scalelike hairs intermixed with more nearly erect bristles................ 8

Body clothed with simple pubes- cence only; sometimes with a few silky hairs............... 9

8. Pronotum and corium thickly clothed with black and white, scalelike pubescence, with a few bristles; venter very dark, almost black; third antennal segment equal to three times the length of fourth segment; large fuscous species, length 5.50-6.00. .

Noctuocoris, p. 105

Pronotum and corium bearing numerous erect bristles intermixed with scattered scalelike pubescence, fig. 152; venter light; third antennal segment not equal to three times the length of fourth segment; small species, length less than $5.00 \ldots .$.

Melanotrichus, p. 95

9. Vertex with a carina at posterior margin..................... 10

Vertex without a carina at posterior margin..................11

10. Head broad; width of vertex three times as great as dorsal width of an eye, fig. 130 ......Labopidea, p. 105

Head not so broad; width of vertex not more than two times as great as dorsal width of an eye, fig. 129....

Orthotylus, p. 97

11. Head vertical, strongly compressed apically, fig. 119; as viewed from the side, tip of tylus projecting below posterior end for a distance equal to one-half height of eye; pronotum sinuate at base and slightly so at sides; male and female dissimilar in form; female brachypterous, abdomen very broad, macropterous forms rare.............

Mecomma, p. 95

Head inclined, more prognathous; as viewed from side, tip of tylus not projecting below posterior end of gula for a space equal to half the height of eye; both sexes macropterous........... Cyrtorhinus, p. 95

\section{Ilnacora Reuter}

\section{KEY TO SPECIES}

1. Length of first antennal segment exceeding width of vertex......... 2

Length of first antennal segment less than width of vertex........... 3 
spines black. Dorsum clothed with erect, simple pubescence intermixed on hemelytra with patches of deciduous, black, scalelike hairs; spot behind each callosity, median line between callosities, and spot on base of scutellum formed by masses of black, scalelike pubescence. Male genital claspers distinctive for species, fig. 120 .

FeNIALE.-Length 4.70 , width 1.80. Form slightly more robust than that of male, but color and pubescence very similar.

Food Plaxt.-A single Illinois specimen was collected on milkweed (Asclepias sp.).

KNowy Distribution.-Colorado, Illinois, Iowa, Minnesota, North Dakota, Texas.

Illinois Records.-One male and $17 \mathrm{fe}-$ males, taken March 8 to Aug. 17, are from Bloomington, Champaign, Dubois, Galena, Galesburg, Teheran, Urbana.

\section{Ilnacora stalii Reuter}

Ilnacora stalii Reuter (1876, p. 86).

Male.-Length 5.20, width 1.60. Head width 0.95 , vertex 0.49 . Rostrum, length 1.30 , just attaining apices of middle coxae, pale, with apical segment black. Antennae, first segment, length $0.5+$, exceeding width of vertex, pale, apical half and ring at base black; second, 1.95, dusky, more fuscous on apex; third, 1.60, black; fourth, 0.65, black. Pronotum, length 0.82 , width at base $1.3+$. General coloration pale or whitish; hemelytra and legs tinged with greenish; membrane pale; veins greenish. Dorsum clothed with erect, pale hairs sparsely intermixed with patches of black, deciduous scalelike hairs; a round, black spot behind each callosity and a median basal spot on scutellum formed by black, deciduous hairs. Male genital claspers distinctive, right clasper terminating in a slender, dorsally projecting point, fig. 120 .

Female.-Length 5.40, width 1.80. More robust than male, but very similar in pubescence and color.

Food Plants. - Breeds on cocklebur (Ianthium sp.), sunflower (Helianthus sp.), artichoke (H. tuberosus) and perhaps on other weeds. A single specimen was collected on wild grape ( Vitis sp.).

Known Distribution.-Colorado, Montana, Texas, eastward to District of Columbia, New York, North Carolina.

Illinois Records. - Ninety-eight males and 146 females, taken May 23 to Sept. 22, are from Algonquin, Alton, Alto Pass, Antioch, Beardstown, Browns, Cairo, Camargo, Carbondale, Champaign, Charleston, Chicago, Cornland, Decatur, De Soto, East St. Louis, Effingham, Elizabeth, Elizabethtown, Fountain Bluff, Freeport, Galena, Galesburg, Hardin, Harrisburg, Ingleside, Kampsville, Kankakee, Karnak, Keithsburg, Law renceville, Meredosia, Metropolis, Monticello, Mounds, Mount Carmel, Oquawka, Palos Park, Rockford, Rockton, Rosiclare, St. Joseph, Seymour, Shawneetown, Starved Rock State Park, Teheran, Urbana, Ware, Warren, West Pullman, Willow Springs, York.

\section{Hadronema Uhler}

No Illinois species; Hadronema militare Uhler is known from Colorado, Kansas, Michigan, New York, South Dakota and westward.

\section{Lopidea Uhler}

\section{KEY TO SPECIES}

1. Apex of abdomen with a pair of claspers (males); all characters in couplets $2-14$ are illustrated in fig. $121 \ldots \ldots \ldots \ldots \ldots \ldots \ldots \ldots \ldots \ldots$

Apex of abdomen without claspers (female $\approx$ )................

2. Left clasper with a plainly visible, baso-mesal, flat-hooked tooth.... ............. staphyleae, p. 90

Left clasper without such a tooth.... 3

3. Tip of right clasper short, large and somewhat rounded, with a short, serrate, dorsal tooth just before apex...........media, p. 89

Tip of right clasper without such a dorsal tooth at apex........... 4

4. Base of right clasper produced into a long, dorsal, curved arm.

robiniae, p. 89

Base of right clasper without a long, basal, dorsal projection........ 5

5. Right clasper ending in a curved tooth which is either long, e.g., instabilis or blunt, e.g., lathyri.........6 6

Right clasper ending in a serrate lobe, e.g., amorphae-salicis.......... 8

6. Right clasper with a preapical hook which may be reduced to a small swelling. ......... instabilis, p. 91 
Right clasper with a preapical enlargement which is somewhat rectangular and produced into an apical point, e.g., incura, lathyri. . 7

7. Apical hook of right clasper long and sharp, fig. 121 ....... incurva, p. 88

Apical hook of right clasper shorter and with tip slightly serrate...... $\ldots \ldots \ldots \ldots$ lathyri, p. 91

8. Right clasper with base bulbous, center constricted and apex expanded into an upturned, serrate lobe, e.g., amorphae, reuteri............ 9

Right clasper otherwise, without an upturned, apical lobe, e.g., minorsalicis................... 10

9. Serrate margin of apical lobe more irregular and truncate.

amorphae, p. 90

Serrate margin of apical lobe regular, curving back on to inner curve of lobe. reuteri, p. 91

10. Apex of right clasper obliquely truncate, flat and serrate, e.g., minor. .11

Apex of right clasper pointed or irregular, with a second row of serrations on dorsal or mesal side, e.g., cuneata-salicis..............13

11. Left clasper with dorsal tooth small. . minor, p. 88

Left clasper with dorsal tooth large, e.g., davisi...............12

12. Right clasper with both dorsal and ventral corners expanded and sharp davisi, p. 87

Right clasper with ventral corner round and not expanded.

confluenta, p. 87

13. Right clasper with apex rounded and curved ventrad...... cuneata, p. 89

Right clasper with apex horizontal and pointed, e.g., salicis.........14

14. Apex of right clasper with a double row of dorsal serrations.

heidemanni, p. 88

Apex of right clasper with second row of dorsal serrations separated mesad as a definite lobe......salicis, p. 89

15. Length of first antennal segment equal to or greater than width of vertex between eyes...........16

Length of first antennal segment less than width of vertex between eyes. 22

16. Bases of first and second antennal segments equal in thickness, second segment tapering apically to become more slender than first segment..................17

Base of second antennal segment not so thick as base of first........ 18

17. Length of second antennal segment approximately twice width of head across eyes; length $5.80 \ldots \ldots \ldots$.

instabilis, p. 91

Length of second antennal segment distinctly greater than twice width of head across eyes; length $6.70 \ldots$. .

$\ldots \ldots \ldots \ldots$ reuteri, p. 91

18. Corium bearing both simple and sericeous pubescence; pronotal disk with erect, stiff, black hairs; general color yellowish to orange; scutellum and inner half of corium and clavus blackish; length $6.40 \ldots \ldots \ldots \ldots$.

robiniae, p. 89

Corium with only simple pubescence; or, if a few minute, sericeous hairs present, pronotal disk without erect hairs................ 19

19. Length of second antennal segment more than twice width of head across eyes; length 7.00 .

..............staphyleae, p. 90

Length of second antennal segment less than twice width of head across eyes.................... 20

20. Scutellum with a few black, bristlelike hairs; juga red; dorsum also with a broad, reddish area; length $5.20-5.40 \ldots \ldots \ldots \ldots$ media, p. 89

Scutellum with minute, soft pubescence only; juga pale.........21

21. Second antennal segment clothed with very short, recumbent, golden pubescence.........cuneata, p. 89

Second antennal segment clothed with prominent, semierect, black, bristlelike hairs...........salicis, p. 89

22. Second antennal segment thickened, diameter near base equal to that of first segment although tapering apically to become more slender. . .reuteri, p. 91

Second antennal segment slender, its greatest thickness not approaching that of first segment..........23

23. Length of second antennal segment equal to twice width of head across eyes; length $6.50 \ldots \ldots \ldots \ldots \ldots$. ............ confluenta, p. 87 
Length of second antennal segment less than twice width of head across eyes...................24

24. Corium with outer half bearing suberect, black hairs.............25

Corium with outer half bearing pale hairs; or, if dark, pubescence minute and closely appressed........26

25. Corium bearing simple pubescence intermixed with more closely appressed, sericeous pubescence..... ............heidemanni, p. 88 Corium bearing only suberect, bristly pubescence.........davisi, p. 87

26. Length not over $5.20 \ldots \ldots \ldots \ldots 27$

Length 5.60 or more..........28

27. Corium infuscated across its full width; pubescence very short, appressed; length $5.00-5.20 \ldots \ldots$.

incurva, p. 88

Corium reddish on its outer half; pubescence suberect, pale in color; length $4.20-4.30 \ldots$ minor, p. 88

28. Outer half of corium fuscous to black cuneata, p. 89

Outer half of corium orange to red...29

29. Pubescence on dorsum minute, closely appressed; embolium never pale, yellowish to red like outer half of corium......... amorphae, p. 90

Pubescence on dorsum suberect; embolium usually pale or white....

lathyri, p. 91

\section{Lopidea confluenta (Say)}

Capsus confluentus Say (1832, p. 23; 1859, p. 341).

Male.-Length 6.30, width 2.10. Yellowish orange, tinged with reddish; broad area on either side of commissure, entire membrane, scutellum, and variable area on pronotal disk, fuscous; antennae, tylus, rostrum, base of head, and a stripe each side of front, black; legs mostly blackish, with trochanters and apices of coxae yellowish; genital claspers, fig. 121, distinctive for species.

Female.-Fig. 122. Length 6.50, width 2.40 ; more robust than male, but very similar in coloration.

Food Plants.-Leafcup (Polymnia uvedalia and probably $P$. canadensis); in Illinois specimens were collected also on sweet William (Phlox sp.), daisy (Chrysanthemum sp.), red clover (Trifolium pratense), persimmon (Diospyros virginiana), willow (Salix sp.), snowberry (Symphoricarpos orbiculatus), locust (Robinia pseudoacacia)

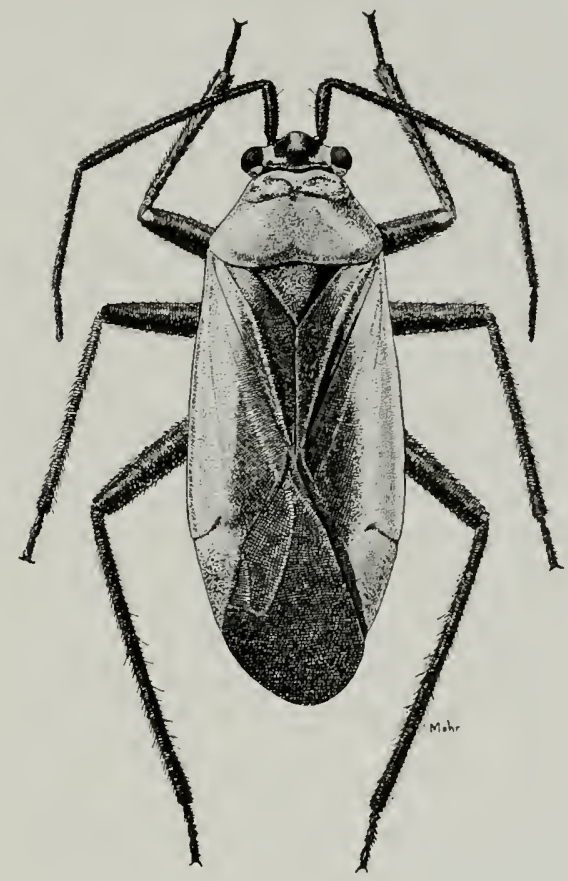

Fig. 122.-Lopidea confuenta, o.

and cypress (Taxodium distichum). Several of these plants undoubtedly are not hosts of this mirid.

Known Distribution.-Widely distributed in the eastern United States, but more abundant in the upper Mississippi valley.

Illinois Records. - Ninety-four males and 97 females, taken June 10 to Aug. 21, are from Anna, Beardstown, Bloomington, Dolson, Dubois, Elizabethtown, Ernst, Galesburg, Golconda, Grafton, Grand Tower, Grantsburg, Grayville, Havana, Herod, Kansas, Law renceville, Monticello, Muncie, Palos Park, Pike, Pulaski, Shawneetown, Starved Rock State Park, Urbana, Walnut Prairie, White Heath, Willow Springs.

\section{Lopidea davisi Knight \\ Phlox Plant Bug}

\section{Lopidea davisi Knight (1917d, p. 458.)}

Male.-Length 5.50, width 2.00. Yellowish orange to reddish; antennae, legs, front of head, and rostrum, black; calli, base 
of pronotum, scutellum, clavus, inner half of corium, and membrane, fuscous; genital claspers, fig. 121, distinctive for species.

Fearale.-Length 5.60, width 2.10; more robust than male, but very similar in color and pubescence.

Food Plants. - When the original description appeared the food plant of this species was unknown, but as early as 1925 the insect had appeared as a serious pest of cultivated phlox in Arkansas, Missouri, Minnesota and West Virginia. This insect breeds on the wild species of phlox and may fly to the cultivated varieties within reach. The bug overwinters as an egg in the dead stems of phlox; it hatches in the spring and crawls upon the new growth to suck nourishment from the leaves. The feeding punctures cause brown spots to develop; the leaves curl, dry out and finally drop. Control of this pest may be obtained by destroying all dead plant tops before spring, when the eggs would hatch. Toward the end of the season, this species is often found on a wide range of herbs, but it does not breed on them.

Illinois Records.-One hundred thirtyseven males and 117 females, taken June 3 to Sept. 30, are from Ashland, Beach, Champaign, Charleston, Cobden, Dolson, Eichorn, Eldorado, Equality, Galena, Grandview, Herod, Jacksonville, Jerseyville, Norris City, Oak Lawn, Oakwood, Quincy, St. Anne, Schuyler County, Tolono, Urbana, Waterman, Watseka, Waukegan.

\section{Lopidea minor Knight}

Lopidea minor Knight (1918b, p. 213).

MALE.-Length 4.50, width 1.60. Fuscous; exterior half of corium, cuneus, sides of body and head, reddish; embolium paler; clothed with fine, suberect, pale pubescence, a few hairs brownish on darker areas. Genital claspers distinctive for species, fig. 121; showing a close relationship to davisi Knight, which species is, however, much larger.

Female.-Length 4.20, width 1.60. More robust than male, but very similar in color and pubescence.

Host Plant.-Prairie clover (Petalostemum purpureum).

Known Distribution,-Alberta, Colorado, Illinois, Iowa, Mississippi, New York, North Dakota.

Illinois Record.-OAK LAWN: Sept. 6, 1935, T. H. Frison, 3 o , 1 \%.

\section{Lopidea incurva Knight}

Lopidea incurva Knight (1918b, p. 214).

Male.-Length 5.00, width 1.60 . Second antennal segment slightly thickened at middle and tapering toward base and apex. Dorsum fuscous, with only exterior margins of corium, pronotum and cuneus reddish; membrane, antennae, eyes, rostrum and most of face fuscous. Legs mostly pale fuscous; coxae and basal half of femora pale to yellowish and pink; tarsi fuscous to black. Clothed with minute, closely appressed, fuscous pubescence. Genital claspers as in fig. 121.

Fenale.-Length 5.00-5.20, width 1.80 , slightly more robust than male, but very similar in color and pubescence.

Host Plant.-Honey locust (Gleditsia triacanthos).

Known Distribution. - Illinois, Indiana, Iowa, Missouri, Nebraska, Ohio.

Illinois Records.- Ten males and $35 \mathrm{fe}$ males, taken July 3 to July 30 , are from Alton, Champaign, Darivin, Dubois, Fountain Bluff, Galesburg, Grafton, Kansas, Monticello, Muncie, Paxton, Urbana.

\section{Lopidea heidemanni Knight}

Lopidea heidemanni Knight (1917d, p. 456).

MaLE.-Length 6.70, width 2.14. Dark red, with more fuscous on pronotum and scutellum than in media (Say); larger and more elongate than media. Hemelytra of dry specimens always having a strong tendency to shrivel and wrinkle longitudinally. Dorsum clothed with simple, black hairs sparsely intermixed with more closely appressed, silvery, sericeous pubescence. Genital claspers distinctive, fig. 121, right clasper showing a close relationship with cuneata Van Duzee and salicis Knight.

Female.-Length 6.20 , width 2.08 ; slightly more robust than male, otherwise very similar. Costal margins of hemelytra frequently pale, as in media; in certain color phases, becoming dull orange red with fuscous. Head width 1.08 , vertex 0.65 . Antennae, length of first segment, 0.56 ; second, 1.90.

Food Plants. - Elm (Ulmus sp.); nymphs have been reared from common yarrow (Achillea millefolium). Occasional specimens were collected in Illinois on honey locust (Gleditsia triacanthos), willow (Salix sp.), snowberry (Symphoricarpos 
orbiculatus) and bedstraw (Galium aparine).

KNown Distribution.-Iowa and Minnesota to Connecticut and southward to North Carolina.

Illinois Records.-Eighty-two males and 121 females, taken May 6 to July 3, are from Aldridge, Carlinville, Charleston, Dolson, Dongola, Dubois, Elizabethtown, Fountain Bluff, Galesburg, Golconda, Goreville, Grayslake, Hardin, Harvard, Herod, Homer, Jacksonville, Jonesboro, Kampsville, Keithshurg, Makanda, Muncie, Murphysboro, Oakwood, Ozark, Palos Park, Pulaski, Rock Island, St. Joseph, Seymour, Shawneetown, Urbana, Vienna, West Union, Zeigler.

\section{Lopidea cuneata Van Duzee}

Lopidea cureata V'an Luzee (1910, p. 79).

Male.-Length 5.80, width 2.00. Dorsum dark fuscous on a background of orange red; cuneus, embolium and base of radial vein more strongly reddish; pronotum dark fuscous, lateral margin of disk pale to reddish; antennae, head and legs chiefly black; mark along front margin of eyes, juga, genae, trochanters, and apices of coxae, pale; propleura, except area surrounding coxal cleft, pale reddish; venter reddish, darkened with fuscous; genital segment blackish ; genital claspers, fig. 121, distinctive for species.

Fenale.-Length 6.00 , width 2.10 ; similar to male, but reddish coloration replaced chiefly by pale, frequently inner margin and apical angles of corium becoming pale.

Food Plants.-Poplars (Populus deltoides, P. balsamifera).

Known Distribution.-New York, Illinois, Minnesota.

Illinois Records.-Galesburg: Sept. 2, 1892, Stromberg, 1 ․ Harvard: July 17, 1936, C. O. Mohr, 1 o. PIkE: June 28, 1934. DeLong \& Ross, 1 .

\section{Lopidea robiniae (Uhler)}

Capsus robiniae Uhler (1861, p. 24).

MALE.-Length 6.30, width 2.10. General color usually orange yellow, rarely reddish; scutellum, apical area of clavus, inner half of corium, broad central area on pronotal disk, inner halves of calli, and membrane, fuscous to black; antennae, tylus, rostrum, tibiae, and tarsi, black; femora fuscous, coxae partly yellowish. Clothed with closely appressed, silvery, sericeous pubescence intermixed with simple, erect hairs; setae on pronotal disk stiff and prominent; dark-colored areas provided with dark pubescence. Structures of male genital claspers distinctive for species, fig. 121.

FEMALE.-Length 6.40 , width 2.10 ; slightly more robust than male, but very similar in pubescence and coloration.

Food Plant. - Black lozust (Robinia pseudoacacia). Also, two Illinois specimens were collected on peach (Prunus persica).

Known Distribution.-Commonly distributed in the eastern United States nearly everywhere the black locust grows.

Illinois Records.-Eighty-four males and 105 females, taken June 10 to Aug. 30, are from Algonquin, Alton, Anna, Antioch, Bishop, Bluff Springs, Bridgewater, Browns. Carbondale, Effingham, Elizabethtown, Galena, Galesburg, Havana, McClure, Monticello, Mound City, Normal, Rosiclare, Shawneetown, Springfield, Stonefort, Union Grove, Villa Ridge, West Union.

\section{Lopidea salicis Knight}

Lopidea salicis Knight (1917d, p. 457).

M ALE.-Length 5.70, width 2.00. Mostly black; propleura and basal angles of pronotal disk orange; embolium and cuneus, except inner apical margin, yellowish to orange. Genital claspers, fig. 121, distinctive for species.

FeMALE.-Length 6.20, width 2.10. Very similar to male in size and coloration, sometimes slightly more robust.

Food Plant.-Black willow (Salix nigra); a single specimen was taken in Illinois on elm (Ulmus), but it probably had not fed there.

Known Distribution. - Illinois, Iowa, Kansas, Minnesota, New York.

Illinois Records.-Illivors: Stromberg, 3 ㅇ. Elizabethtowx: May 27-31, 1932, H. L. Dozier, 1 đ̊. Galexa: June 30, 1932, on elm, Dozier \& Mohr, 1 ㅇ. OQuawka: June 13, 1932, H. L. Dozier, 1 .

\section{Lopidea media (Say)}

Capsus medius Say (1832, p. 22; 1859 , p. $3+1)$.

MALE.-Length 5.60, width 1.70. Orange red to bright red, scutellum and rather broad area either side of commissure more or less darkened with fuscous, reddish color 
always showing through this infuscation; legs fusco-brownish to blackish; femora exhibiting one or two rows of darker spots both above and below. Clothed with short, pale pubescence; a few stiff, black hairs on scutellum. Genital claspers very distinctive for species, fig. 121.

Female.-Length 5.70, width 1.80; usually colored very similarly to male, but sometimes with embolium and outer edge of cuneus pale or white as in heidemanni Knight.

Food Plants.-Goldenrod (Solidago rugosa) and several other plants. Illinois specimens were collected on spiderwort (Tradescantia sp.), hazelnut (Corylus sp.), willow (Salix sp.), ash (Fraxinus sp.) and red birch (Betula nigra).

Known Distribution.-A common and widely distributed species east of the Rocky Mountains.

Illinois Records. - One hundred four males and 104 females, taken May 25 to July 24, are from Champaign, Dixon Springs, Galena, Geff, Golconda, Grand Detour, Grand Tower, Hardin, Harrisburg, Havana, Homer Park, Kankakee, Keithsburg, Lilly, Muncie, Oakwood, Oquawka, Oregon, Palos Park, Princeton, Pulaski, Shawneetown, Starved Rock State Park, Urbana.

\section{Lopidea staphyleae Knight}

Lopidea staphyleae Knight (1917d, p. 460). MALE.-Length 6.50, width 2.05. Antennae, first segment, length 0.71 , thickness 0.15 ; second, 2.48 , thickness 0.10 , tapering to become slightly smaller on apical half; third, 1.82, slender and almost linear ; fourth, 0.52 . General color mostly orange yellow, with calli, narrow area at base of pronotum, scutellum, apical two-thirds of clavus, inner half of corium, and membrane, fuscous; antennae, tylus, two bars on front, base of head, rostrum, and legs, black; fuscous shading on dorsum much paler than in robiniae (Uhler); genital claspers, fig. 121, distinctive for species.

FEMALE,-Length 6.80, width 2.20. Similar to male in structure and coloration, but usually slightly larger; sometimes very similar in size and coloration to female of confluenta (Say), but length of first antennal segment in confluenta is shorter than width of vertex, while in staphyleae its length is as great as, or slightly greater than, width of vertex. Head width 1.29 , vertex 0.78 . Antennae, length of first segment, 0.81 ; second, 2.64 .

Specimens in which the orange yellow areas become red constitute var. sanguinea Knight (1917d, p. 461), taken in Illinois chiefly in northern localities.

Food Plant. - American bladder nut (Staphylea trifolia); a single Illinois specimen was collected on willow (Salix sp.), but that tree was probably not its host.

Known Distribution.-Connecticut, Illinois, Iowa, Kansas, Maryland, Massachusetts, Minnesota, New York, Oklahoma, South Carolina, Virginia.

Illinois Records.- Thirty-two males and 47 females, taken June 2 to Aug. 22, are from Apple River Canyon State Park, Bloomington, Decatur, Dolson, Glendon Park, Grafton, Grand Tower, Hardin, Havana, Homer Park, Kampsville, Karnak, Monticello, Parker, Seymour, Urbana, Willow Springs.

\section{Lopidea amorphae Knight}

Lopidea amorphae Knight (1923c, p. 65).

MALE.-Length 5.90, width 2.00. Head width 1.10 , vertex 0.34 . Antennae, length of first segment, 0.60 ; second, 2.09 , thickness 0.11 , tapering to become more slender on apical half; third, length 1.20 ; fourth, length 0.40 . Pronotum, width at base 1.84 . Hemelytra with red areas bearing fine, yellowish pubescence, while in reuteri Knight these areas bear black pubescence. Smaller than reuteri and more yellowish in color, majority of specimens more yellowish than red. Genital claspers, fig. 121, indicate a close relationship with reuteri, but in the large series examined distal portion of right clasper shows constant differences.

Female.-Length 6.30 , width 2.30 ; very similar to male in form, pubescence and coloration.

Food Plant.-False indigo (Amorpla fruticosa); a single specimen was also taken in Iilinois on red clover (Trifolium pratense).

Known Distribution. - Illinois, Iowa, Kansas, Minnesota, Nebraska, South Dakota, but may be expected from other states where the host plant grows in abundance.

Illinois Records.-AnNa: July 17, 1883, 1 ․ Beardstown: June 10, 1932, Ross \& Mohr, 1 of. Grand Tower: June 27, 1906, $3 q$; June 30, 1909, sweeping from grass, 
1 of, 1 ; J June 1, 1913, 1 ․ OQuawka: June 13, 1932, H. L. Dozier, 1 \% . SavanNA: July 21, 1892, from sweet clover, McElfresh, 1 ㅇ․

Lopidea lathyri Knight. Emended name.

Lopidea lathyrae Knight (1923c, p. 66). MALE.-Length 5.90, width 1.90. Head width 1.11 , vertex 0.65 . Antennae, length of first segnient, 0.65 ; second, 2.00 , cylindrical. Pronotum, width at base 1.71. Size, form and color very suggestive of confluenta (Say) ; mostly deep red; legs, antennae, pronotal disk (except lateral and anterior margins), scutellum, broad stripe on either side of commissure, and membrane, black; clothed with fine, yellowish pubescence on red areas, but pubescence black over dark surface, with a few sericeous, yellowish hairs about margins of calli. Genital claspers, fig. 121, distinctive for species.

Female.-Length 6.20, width 2.20; very similar to male, but with embolium and outer half of cuneus pale.

Food PLANT.-Vetchling (Lathyrus venosus). In Minnesota I found this species so abundant that its host plants were largely killed. This mirid may be regarded as a potenial pest of cultivated vetches.

Known Distribution.-Illinois, Manitoba, Minnesota, North Dakota, Oklahoma, Saskatchewan.

Illinois Records.-PALOS PARK: July 10, 1912, A. B. Wolcott, 3 o , 3 ㅇ, FM; July 2, 1916, W. J. Gerhard, 1 of, FM; July 4, 1918 , IV. J. Gerhard, 1 \%, FM.

\section{Lopidea reuteri Knight}

Lopidea reuteri Knight (1917d, p. 459).

Male.-Length 7.10, width 2.54. General color a vivid carmine red, with fuscous on calli, scutellum and areas bordering commissure. Very similar to caesar (Reuter), but with fuscous areas on corium and cuneus narrower; genital claspers, fig. 121, distinctive for species. Antennae, length of first segment, 0.65 , thickness 0.17 ; second, length 2.42, greatest thickness 0.16 , tapering from middle to become more slender at apex; third, length 1.60 , linear and slender; fourth, length 0.60 ; black, first two segments clothed with prominent, coarse hairs; almost identical in structure with caesar.

Female.-Length 6.90, width 2.50. Structurally and in color very similar to male; also very similar to female of caesar, which species rarely has calli darkened and usually has less fuscous shading on scutellum. Head width 1.17 , vertex 0.71 . Antennae, length of first segment 0.74 , thickness 0.17 ; second, length 2.62, greatest thickness 0.17 .

Food Plant.-Witchhazel (Hamamelis virginiana).

Known Distribution.-Illinois, Massachusetts, Michigan, Mississippi, Missouri, Pennsylvania, Virginia, West Virginia.

Illinois Records.-Grand Tower: June 27, 1906,1 .

\section{Lopidea instabilis (Reuter)}

Lomatoplenra instabilis Reuter (1909, p. 72).

Male.-Length 5.40, width 2.02. Antennae black, two basal segments clothed with moderately short, black hairs; first segment, length 0.58 , thickness 0.08 ; second, 1.80 , thickness 0.07 at middle, tapering to become smaller at either end; third, length 1.19 , slender; fourth, length 0.52. General color bright red, apical half of clavus and inner half of corium darkened with fuscous; membrane uniformly blackish; tibiae blackish, becoming reddish at base; genital claspers distinctive, fig. 121 .

Female.-Length 6.00, width 2.40 ; similar to male in coloration, pubescence and in structure of antennae. Head width, 1.10, vertex 0.65 . Antennae, first segment, length 0.66, thickness 0.17 ; second, length 2.12, greatest thickness 0.17 .

Food Plant.-Lead plant (Amorpha canescens).

Known Distribution.-Missouri, Nebraska, North Dakota, South Dakota, eastward to Connecticut, southward to Mississippi, Alabama.

Illinois Records.-NORTHERN ILLINoIs: 1 o . LA RuE: July 11, 1935, DeLong \& Ross, 4 \%. SAVANNA: July 24, 1892, along bluff, C. A. Hart, 1 ㅇ.

\section{Diaphnidia Uhler}

\section{KEY TO SPECIES}

1. Head black, first antennal segment very dark................................... p. 92

Head pale.

2. Second antennal segment pale.

pellucida, p. 92

Second antennal segment fuscous to black.........provancheri, p. 92 


\section{Diaphnidia pellucida Uhler}

Diaphnidia pellucida Uhler (1895, p. 44).

Adults.-Fig. 123. Length 4.30, width 1.40. General color uniformly pellucid, greenish white, including antennae; eyes and tips of tarsi fuscous; pubescence simple, pale.

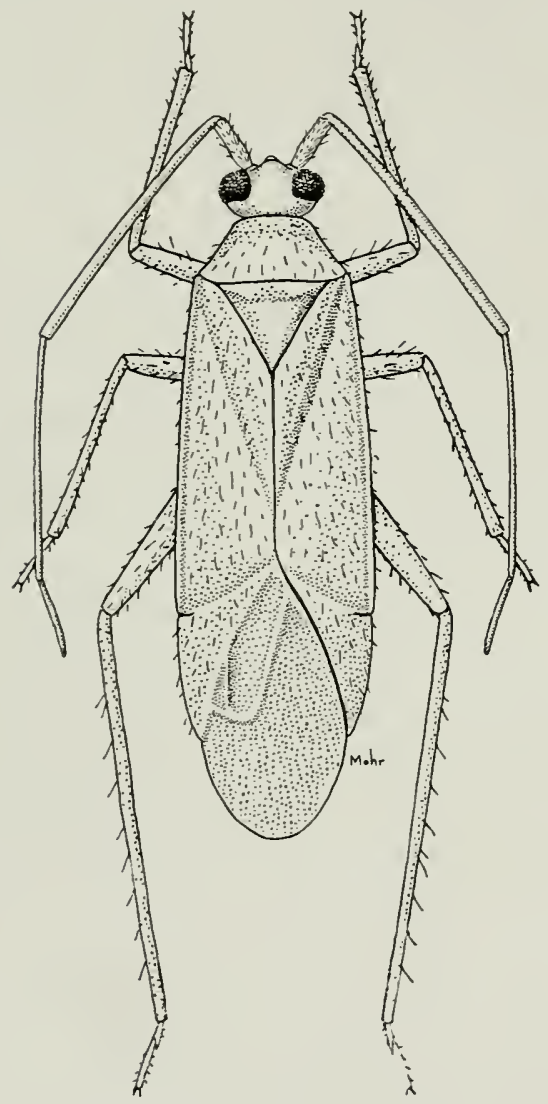

Fig. 123.-Diaphnidia pellucida, ơ.

Host Plaxts. - Hawthorn (Crataegus sp.), apple (Pyrus malus), hop hornbeam (Ostrya virginiana) and several other trees; Illinois specimens were taken also on cottonwood (Populus deltoides), locust (Robinia pseudoacacia), oak (Quercus sp.), maple (Acer sp.), elm (Ulmus sp.), walnut (Juglans nigra), willow (Salix sp.) and alder (Alnus sp.).

Known Distribution.-Throughout the eastern United States and Canada.

Illinois Records.-Sixty-one males and 121 females, taken June 5 to Sept. 20: Danville, Eichorn, Fairfield, Galena, Galesburg, Geff, Grafton, Grand Detour, Hardin, Ha- vana, Kansas, Marshall, Monticello, Muncie, Oakwood, Shawneetown, Urbana, Vienna, White Heath, White Pines Forest State Park.

\section{Diaphnidia provancheri (Burque)} 144).

Malacocoris provancheri Burque (1887, p.

Adults.-Length 4.80, width 1.40. General color pellucid greenish yellow, more green on hemelytra than elsewhere, tibiae lightly infuscated; second antennal segment fuscous to black; following segments fuscous.

Host Plant.-White oak (Quercus al$b a)$ and probably other plants.

Known Distribution.-District of Columbia, Illinois, Minnesota, New Hampshire, New York, Quebec.

Illinois Records.-Monticello: June 28, 1914, 1 o. Urbana: Aug. 26, 1932, Harper \& Park, $6 \delta$; Sept. 16, 1935, DeLong \& Ross, $1 \hat{\delta}$.

\section{Diaphnidia capitata Van Duzee} 490).

Diaphnidia capitata Van Duzee (1912, p.

Adults.-Length 3.00. General color pale; distinguished by its black head and fuscous to black first antennal segment; sometimes second antennal segment is also infuscated, beginning on base and apex.

Host Plant.-Witchhazel (Hamamelis virginiana).

Known Distribution.-District of Columbia, Illinois, Iowa, Maine, Minnesota, New York, Ohio, Ontario.

Illinois Records.-DF Soto: July 28, 1930, Knight \& Ross, 2 . Dongola: Aug. 3, 1916, 1 o . Elizabethtown: Aug. 4, 1932, H. L. Dozier, 1 \&. Metropolis: July 26, 1930, Knight \& Ross, 1 o . MontiCELLO: June 11, 1934, Frison \& DeLong, 2 \&. OAKwood: June 14, 1930, on ironwood, T. H. Frison, 1 .

\section{Reuteria Futon}

\section{KEY TO SPECIES}

1. First antennal segment with inner black line indistinct on basal half; transverse apical portion with outer black line forming a letter $J$.

platani, p. 95 
width 0.67 , vertex 0.36 . Antennae, first segment, length 0.39 ; second 0.95 ; marked as in male. Slightly more robust than male, but very similar in pubescence and coloration.

Host Plaxts.-Chiefly on elm (Ulmus americana); also, two Illinois specimens were taken on cypress (Taxodium distichum).

Knowx Distribution. - Illinois, Indiana, Iowa, Minnesota, New York.

Illinois Records.-Twenty males and 34 females, taken June 24 to Aug. 11, are from Aldridge, Algonquin, Ashley, Champaign, Dubois, Galesburg, Grafton, Harrisburg, Kansas, Karnak, Monticello, Pulaski, Rockford, Starved Rock State Park. Urbana.

\section{Reuteria bifurcata Knight}

Reuteria bifurcata Knight (1939b, p. 130).

This is distinguished from allied species by the bifurcate form of the male genital claspers, fig. 12t; it differs in color from irrorata (Say) and fuscicornis Knight in the absence of green dots on the clavus and the corium.

Male.-Length 4.80, width 1.60. Head width 0.75 , vertex 0.36 . Rostrum, length 1.30 , reaching to middle of intermediate coxae. Antennae, first segment, length 0.44 , black marks typical for genus; second, 1.69 , yellowish, a distinct black ring at base; third, 1.21, yellowish to dusky; fourth, 0.69 , dusky yellow. Pronotum, length 0.62 , width at base 1.25. Clothed with pale, simple pubescence as in irrorata.

Fexiale.-Length 4.30 , width 1.65 . Color and pubescence not differing from those of male.

KNown Distribution.-Illinois, Maryland, New York, Oklahoma.

Illinois Record.-ShawneEtow: June 27, 1936, DeLong \& Mohr, 1 ô.

\section{Reuteria fuscicornis Knight}

Reuteria fuscicornis Knight (1939b, p. 129).

This species is distinguished from irrorata (Say) by the structure of the male genital claspers, fig. 12t, and the fuscous coloration of the second antennal segment.

MaLe.-Fig. 125. Length 4.30, width 1.30. Head width 0.65 , vertex 0.55 . Rostrum, length 1.21, reaching to apices of middle coxae. Antennae, first segment, length 0.43 , pale, a heavy, black, longitudinal line on inner and one on outer margin, the two lines connected apically across ventral aspect; second, 1.53, blackish at base, shading to fuscous on basal half or more, yellowish apically; third, 1.17, yellowish;

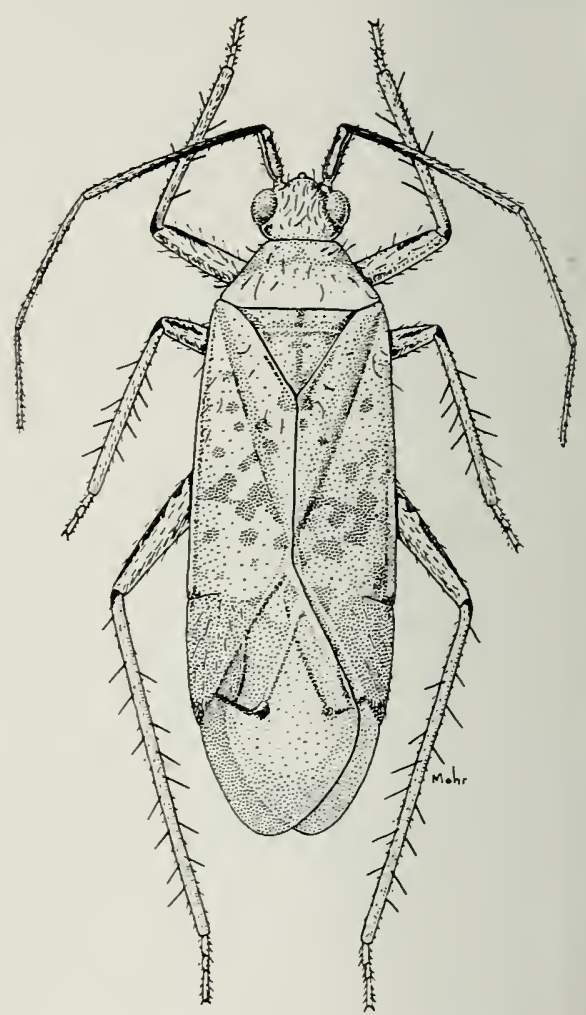

Fig. 125.-Reuteria fuscicornis, $\sigma^{7}$.

fourth, 0.56, dusky. Pronotum, length 0.52, width at base 1.12. Clothed with simple pale pubescence, hairs longer on pronotum, embolium and vertex of head; a few fuscous hairs at the tip of clavus; pubescence more recumbent and silky on clavus and corium. Coloration pale to whitish, hemelytra more translucent; apex and outer basal angle of cuneus, veins at tip of membrane cells, blotch on corium near tip of clavus, bluish green. This differs from irrorata in having much less green on the hemelytra and femora. Ventral surface and legs pale; femora sometimes shaded with greenish but not forming distinct spots; tibiae with a black point at base.

Fexale.-Length 4.30. Color and pubescence not differing greatly from those of the male.

Host Plants.-Hop hornbeam (Ostrya 
virginiana) and water beech (Carpinus caroliniana).

Kyowx Distribution. - Illinois, Iowa, Minnesota, New York, Ontario.

Illinois Records. - Harrisburg: June 25, 1932, Ross, Dozier \& Park, ô ô, $q$ ㅇ. Karnak: June 23, 1932, Ross, Dozier \& Park, 1 oे, 1 ㅇ.

\section{Reuteria querci Knight}

Reuteria querci Knight (1939b, p. 131).

This species is allied to irrorata (Say), but is distinguished by the structure of the male genital claspers, fig. 124; the females of querci and irrorata may be separated by the absence in querci of well-formed green blotches on the corium and the presence of paler veins in the membrane.

MaLE.-Length 4.30, width 1.40. Head width 0.71 , vertex 0.35 . Rostrum, length 1.17 , reaching to near hind margins of middle coxae. Antennae, first segment, length 0.43 . marked with black, as typical for genus; second, 1.51, yellowish, black at base ; third, 0.95, yellowish; fourth, 0.56, dusky yellow. Pronotum, length 0.56 , width at base 1.14. Clothed with pale, simple pubescence, clavus and corium with somewhat sericeous pubescence, a tuft of fuscous hairs at tip of clavus.

Feidale.-Length 4.40, width 1.50. Coloration and pubescence similar to those of male.

Host Plant.-Bur oak (Quercus macrocarpa).

KNow Distribution. - Illinois, Jowa, Maryland, Minnesota, New York, Virginia.

Illinois Records. - Alton: June 23, 1934, DeLong \& 'Ross, 1 s. Dixon Springs: June 23, 1932, Ross, Dozier \& Park, 1 o. Golconda: June 22, Ross, Dozier \& Park, 1 q. KarNaK: June 23, 1932, on Quercus sp., Ross, Dozier \& Park, 2 f. 2 ․ . Rockford: July 5, 1932, Dozier \& Mohr, 3 of. Urbana: June 27, 1932, on oak, Frison \& Ross, $1 \delta$. White Heath : July 4, 1933, H. H. Ross, 2 ô .

\section{Reuteria platani new species}

This is distinguished from other species of the genus by the indistinct inner black line on the first antennal segment, this black line forming a letter $J$ on the ventral aspect.

FeMale.-Length 4.90, width 1.64. Head width 0.73 , vertex 0.41 . Rostrum, length
1.42, reaching to middle of hind coxae. Antennae, first segment, length 0.43 , white, inner black line indistinct on basal half, connecting portion distinct, black lines forming a distinct letter J; second, 1.77 , white, a narrow black annulus at base; third, 1.12 , pale; fourth, 0.65 , pale. Pronotum, length 0.60 , width at base 1.16. Clothed with rather long, white pubescence, longest on thorax, head and base of hemelytra, a tuft of fuscous hairs at tip of clavus and inner angle of paracuneus. General coloration pale to white, hemelytra semitranslucent, devoid of green blotches, cuneus tinged with greenish, but without spots; membrane clear, veins opaque whitish. Legs pale; femora tinged with greenish, but without spots; spot on bases of hind tibiae and at tips of tarsi black.

Host Plant.-Sycamore (Platanus oc(identalis).

Holotype, female.-Snyder, Ill.: July 23, 1932, on sycamore, Dozier \& Park.

Paratype.-Same data as for holotype, 1 오.

\section{Reuteria pollicaris Knight}

Reuteria pollicaris Knight (1939b, p. 131).

Not taken in Illinois; described from Mississippi. Male genital claspers as in fig. 124 .

\section{Mecomma Fieber}

No Illinois species; Mecomma gilripes (Stål) is known from Michigan, New York, Ontario.

\section{Cyrtorhinus Fieber}

No Illinois species; Cyrtorhinus caricis (Fallen) is known from Minnesota.

\section{Melanotrichus Reuter}

\section{KEY TO SPECIES}

1. Dorsum with black, scalelike pubescence, fig. 152; color chiefly deep apple green; veins green; membrane including larger areoles fuscous.....

al thaeae, p. 96

Dorsum with pale, silky, glossy pubescence................. 2

2. Hemelytra and scutellum dusky in color; length of second antennal segment less than width of pronotum 
at posterior margin....catulus, p. 97 Hemelytra and scutellum greenish; length of second antennal segment greater than width of pronotum at posterior margin; membrane dusky; veins and areoles green...........

flavosparsus, p. 96

\section{Melanotrichus flavosparsus (Sahlberg)} 411).

Phytocoris flavosparsus Sahlberg (1842, p.

Male.-Length 4.00, width 1.30. Head width 0.69 , vertex 0.55 . Antennae, first segment, length 0.28 ; second, 1.21. Pronotum,

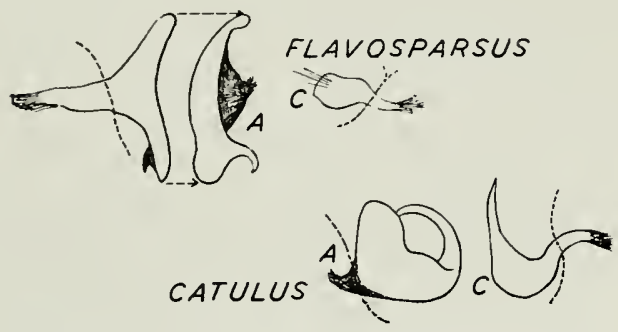

Fig. 126.-Male genital claspers of Melanotrichus. $A$, left clasper; $C$, right clasper.

length 0.45 , width at base 0.95 . General color clear green, becoming yellowish on callosities, head and ventral surface; membrane dusky; areoles and veins green. Clothed with simple, erect, bristlelike, fuscous pubescence, intermixed with spots of silvery, sericeous pubescence. Genital claspers as in fig. 126.

Female.-Length 4.00, width 1.50. Head width 0.80 , vertex 0.43 . Antennae, first segment, length 0.30 ; second, 1.25 . Pronotum, length 0.56 , width at base 1.21 . Color and pubescence similar to those of male.

Food Plants.-Lamb's quarter, known likewise as pigweed (Chenopodium album); also, Illinois specimens were collected on hawthorn (Crataegus sp.), beet (Beta vulgaris), willow (Salix sp.), cypress (Taxodium distichum), spruce (Picea sp.) and sunflower (Helianthus sp.). Some of these records are undoubtedly accidental.

Known Distribution. - Common over the eastern United States.

Illinois Records. - One hundred forty males and 174 females, taken May 12 to Oct. 9, are from Algonquin, Alton, Alto Pass, Anna, Antioch, Arcola, Beardstown, Bloomington, Champaign, Chicago, Clayton, Colona, Delavan, Des Plaines, Dixon, Dol- son, Dongola, Elizabeth, Elizabethtown, Fairmount, Forest City, Galena, Galesburg, Grafton, Grand Detour, Grand Tower, Grandview, Hatton, Havana, Kampsville, Kankakee, Karnak, Keithsburg, Meredosia, Momence, Monticello, Mount Carroll, Quincy, Rising, St. Anne, St. Joseph, Savanna, Starved Rock State Park, Tremont, Urbana, York, Zion.

\section{Melanotrichus althaeae (Hussey)}

\section{Hollyhock Plant Bug}

Orthotylus (Psallus) delicatus Cook (1891, p. 10). Preoccupied.

Orthotylus althaeae Hussey (1924, p. 165).

Male.-Length 4.10, width 1.30. Head width 0.75 , vertex 0.39 . Antennae, first segment, length 0.44 ; second, 1.51. Pronotum, length 0.61 , width at base 1.14. General color deep apple green; calli, head and ventral surface yellowish; membrane, including areoles, fuscous; veins green. Clothed with simple, erect, pale pubescence intermixed with deciduous, black, sericeous or scalelike pubescence.

Female.-Fig. 127. Length 3.80, width 1.34. Color and pubescence similar to those of male.

Host Plant.-Cultivated hollyhock ( $A l$ -

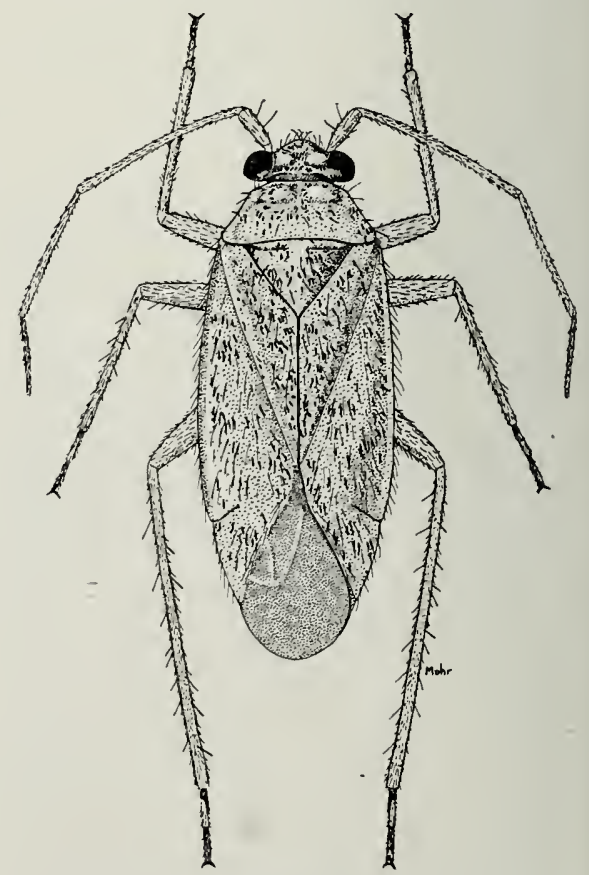

Fig. 127.-Melanotrichus althaeae, ․ 
thaea rosea), where it is often a pest. The nymphs and adults feed on the leaves, causing white spots to appear where the chlorophyll is removed; with severe infestation the leaves may turn yellow and dry out. In Colorado the author found this bug breeding on a wild species of Althaea. In Illinois it was found breeding also on mallow (Malva rotundifolia), a very near relative of the hollyhock.

Known Distribution.-Colorado, Illinois, lowa, Michigan, Minnesota, Wyoming.

Illinois Records.-Sixty-three males and 68 females, taken May 31 to Sept. 30, are from Algonquin, Decatur, Galena, La Harpe, Monticello, Urbana.

\section{Melanotrichus catulus (Van Duzee)}

Orthotylus catulus Van Duzee (1916b, p. 106). Mal.E.-Length 4.50, width 1.60. Head width 0.82 , vertex 0.43 . Antennae, first segment, length 0.27 ; second, 1.00. Pronotum, length 0.56 , width at base 1.20. General color whitish to testaceo-grayish; head and calli tinged with yellowish; hemelytra sometimes slightly infuscated; membrane fumate. Clothed with simple, erect, fuscous hairs, intermixed with recumbent, silvery, glossy pubescence. Genital claspers distinctive for species, fig. 126.

Female.-Length 3.90, width 1.50. Color and pubescence similar to those of male.

Host Plant.-Low cudweed (Gnaphalium uliginosum).

KNown DISTR1BUtion.-Connecticut, lllinois, lowa, Maine, Minnesota, New York, Ontario.

Illinois Record.-Marshal..: May 25, 1928, T. H. Frison, $2 \delta, 4$.

\section{Orthotylus Fieber}

\section{KEY TO SPECIES}

1. Ground color green; dark markings, if present, not clouding corium.... 2

Ground color pale testaceous to black, sometimes greenish, but, in that case, hemelytra marked with fuscous and black areas, fig. 129...11

2. Small, length not over $4.00 \ldots \ldots \ldots 3$ Larger, length 4.50 or more....... 7

3. Rostrum not reaching posterior margin of mesosternum, extending very little beyond middle; pubescence fuscous .......... chlorionis, p. 98

Rostrum attaining or surpassing posterior margin of mesosternum.... 4

4. Length of second antennal segment less than three times width of vertex between eyes. . robiniae, p. 100

Length of second antennal segment equal to or more than three times width of vertex........... 5

5. Length of third antennal segment three-fourths length of second segment; hemelytra with soft, simple pubescence intermixed with a limited number of minute, golden, silky hairs...............ulmi, p. 100

Length of third antennal segment not more than two-thirds length of second segment; hemelytra with only stiff, simple pubescence..... 6

6. Length of second antennal segment distinctly greater than width of pronotum at posterior margin; hemelytra and veins in membrane deep blue green........taxodii, p. 101

Length of second antennal segment not exceeding width of pronotum at posterior margin; hemelytra and veins of membrane yellowish green, veins often pale..... ramus, p. 100

7. Tylus with small fuscous spot at base. 8 Tylus without small fuscous spot at base.................... 9

8. Membrane pale, darkest specimens pale fuscous; clavus never infuscated.......... viridis, p. 101

Membrane uniformly dark fuscous or black; clavus sometimes with a dusky cloud.

modestus var. immaculatus, p. 104

9. Length of second antennal segment twice width of head across eyes; first antennal segment fuscous; length $5.70 \ldots$ basicornis, p. 102

Length of second antennal segment less than twice width of head across eyes.................... 10

10. Length 5.80-6.10; rostrum extending upon middle coxae; first antennal segment may be fuscous to black beneath, but always paler above...

Length $6.70-7.30$; rostrum just attaining posterior margin of mesosternum; first antennal segment uniformly black..... notabilis, p. 100 
11. Ground color green, apical half of clavus, spot on apical half of corium, and broad spot or vitta either side of pronotal disk behind calli, black; length $6.70-7.00$ (male)........ ..............notabilis, p. 100 Ground color not green, or, if so, then length less than $6.50 \ldots \ldots .12$

12. Pronotal disk partly orange colored; sometimes hemelytra also partly orange................. 13

Pronotal disk without orange coloring................ 14

13. Hemelytra chiefly orange or salmon colored; black either side of commissure and on embolium........

submarginatus, p. 103

Hemelytra black; a broad, pale stripe extending full length of corium and connecting with pale cuneus; legs fulvous; apical halves of hind femora black.......knighti, p. 102

14. General color pale yellow brown, hemelytra translucent and with fuscous markings very faint or nearly lacking in female; median line of head and scutellum, lateral margins of pronotum, and sides of body, black; antennae black; membrane slightly infuscated, veins brown.........

candidatus, p. 102

Ground color sometimes pale greenish or yellowish, but dark markings of hemelytra distinct; other markings not as above.............. 15

15. Cuneus black, slightly translucent at base; dorsum blackish; slender, pale areas present only at base of corium and of embolium; pale median line present on pronotal disk, this line sometimes continued upon scutellum; length $6.80 . \ldots \ldots \ldots$. ...........necopinus, p. 103

Cuneus pale, or fuscous on inner half only; length not over $6.00 \ldots \ldots 16$

16. Lateral margins of pronotal disk and propleura, except ventral margin, black; median area of disk and scutellum pale.............. 17

Pronotum with different coloring..... 18

17. Length of female second antennal segment slightly greater than twice the width of head across eyes; for males see figure of genital claspers, fig. $128 \ldots \ldots \ldots \ldots$ nyctalis, p. 104 Length of female second antennal seg- ment scarcely equal to twice the width of head across eyes; for males see figure of genital claspers, fig. 128 ............ lateralis, p. 104

18. Length of second antennal segment less than twice width of head across eyes................... 19

Length of second antennal segment twice width of head across eyes. . . 20

19. Legs green or yellowish, not infuscated; light-colored areas of dorsum greenish or fading to yellowish, never tinged with salmon.....

... modestus var. modestus, p. 104

Legs pale to greenish, but hind femora fuscous on apical half; light-colored areas of dorsum tinged with salmon....... ornatus, p. 103

20. Female calli with outer half black; male genital claspers as in fig. 128 . .

serus, p. 102

Female calli, at least the outer half, pallid; for males see figures of genital claspers................ 21

21. Juga black; smaller, length $5.20 \ldots \ldots$ ............. dorsalis, p. 100

Juga yellowish; larger, length 5.80 . . ...........neglectus, p. 105

\section{Orthotylus chlorionis (Say)} 346).

Capsus chlorionis Say (1832, p. 25; 1859, p.

This species is distinguished by its small size, short rostrum, green color and simple, fuscous pubescence.

MALE.-Length 3.70, width 1.25. Rostrum, extending very slightly beyond middle of mesosternum, green, apex black. Antennae, greenish yellow, last two segments dusky to fuscous. General color green, head and ventral surface yellowish; membrane pale, veins green. Clothed with simple, short, fuscous pubescence, this paler on embolium. Male genital claspers distinctive, fig. 128.

Female.-Length 3.80 , width 1.40 . Head width 0.73 , vertex 0.38 . Antennae, first segment, length 0.30 ; second, 1.04 ; third, 0.90 ; fourth, 0.31. Pronotum, length 0.51 , width at base 1.12. More robust than male, but very similar in color and pubescence.

Host Plants.-Honey locust (Gleditsia triacanthos) and black locust (Robinia pseudoacacia).

Known Distribution.-Connecticut, District of Columbia, Illinois, Indiana, 
September, $19+1$ Knight: Plant Bugs, or Miridae, of Illinois

99

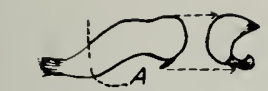

CHLORIONIS
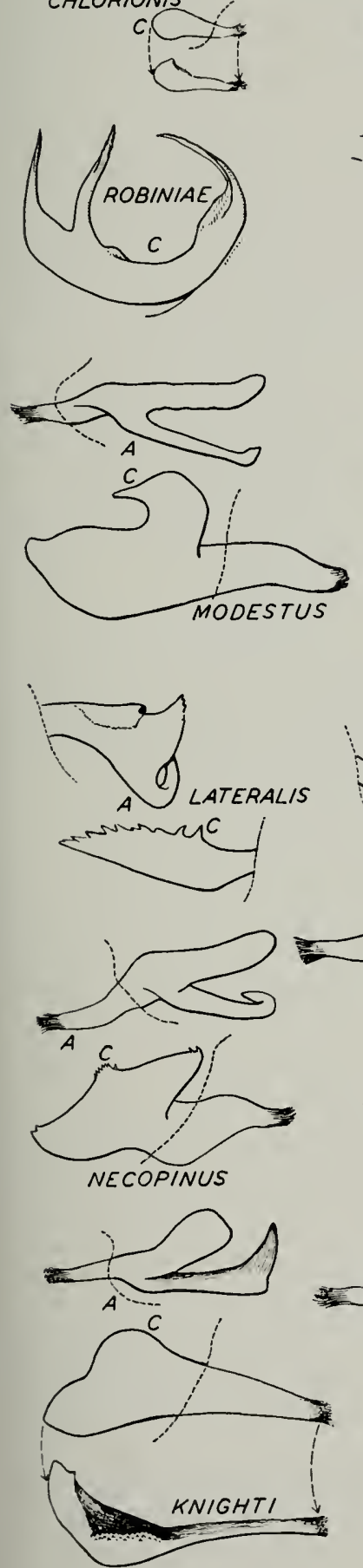
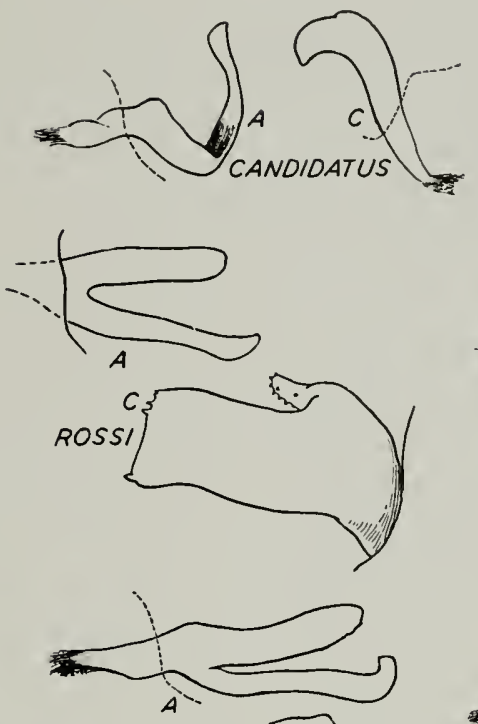
RAMOS
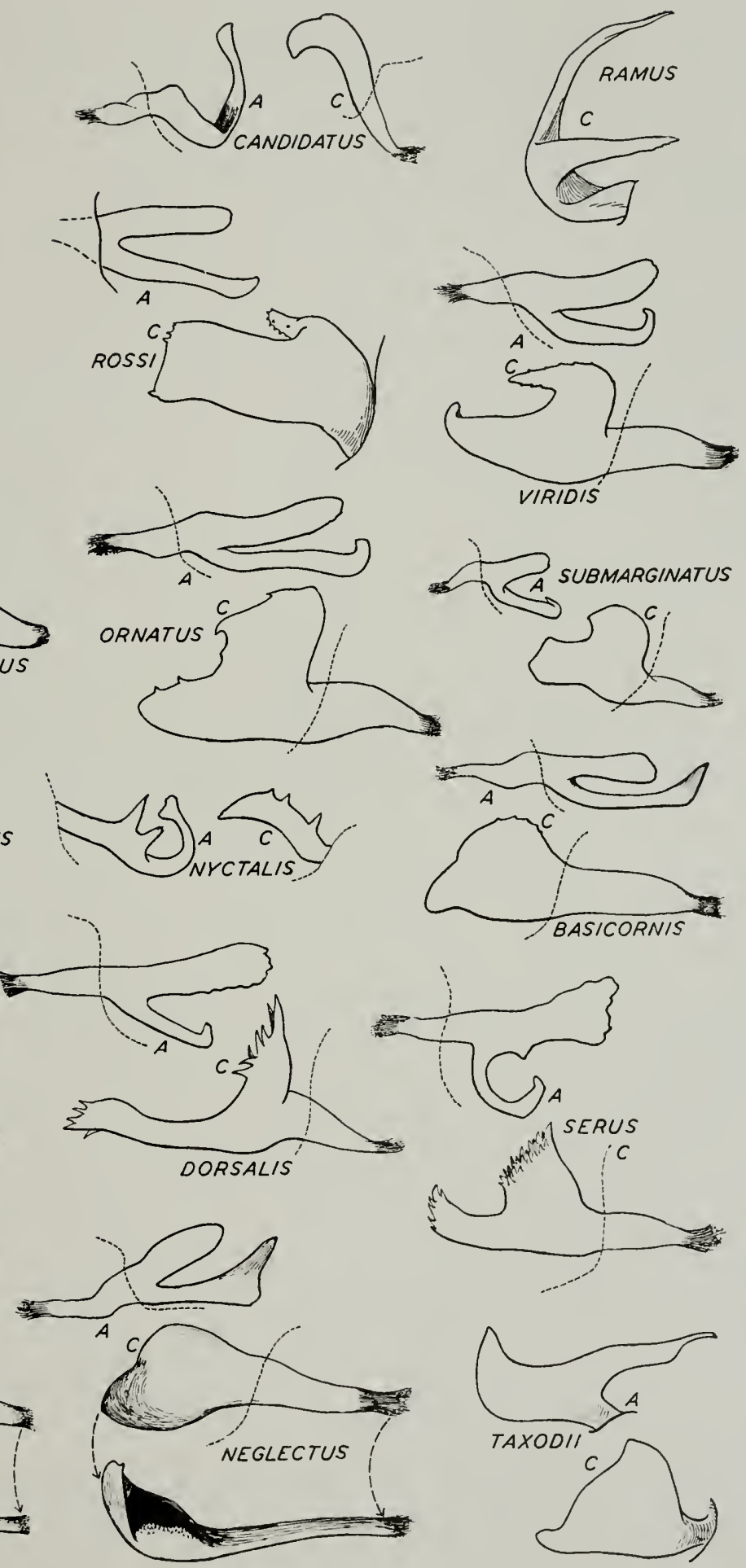

Fig. 128.- Male genital clappers of Orthotylus. $A$, left clasped, lateral aspect; $C$, right clasper, lateral aspect. 
Iowa, Mississippi, Ohio, Texas, Virginia.

Illinois Records.-ELIZABETHTOWN : May 27-31, 1932, on Robinia pseudoacacia, H. L. Dozier, 24 우. Mason City: June 2, 1933, C. O. Mohr, 3 of, 9 ㅇ․ Muncie: June $8,1917,1 \%$. OAkwood: June 1t, 1930, T. H. Frison, 1 ㅇ. White Heath: May $30,1915,1 \hat{\delta}$.

\section{Orthotylus ramus Knight}

Orthotylus ramus Knight (1927e, p. 178).

This species is suggestive of chlorionis (Say), but is somewhat larger, with pale yellowish pubescence.

MALE.-Length 3.90, width 1.50. Eyes and shape of head about as in female of chlorionis. Antennae yellowish green, last segment dusky. General color uniformly green or yellowish green, membrane pale, veins green. Genital structures distinctive, fig. 128 , right clasper forked near base and forming two long, curved, acuminate arms; dorsal margin of genital segment with a strong chitinous spine projecting posteriorly.

Female.-Length 4.10, width 1.54. Very similar to male in form, pubescence and coloration.

Host Plants.-Hickory (Carya sp.) and pecan (Carya illinoensis); according to Johnston these insects feed largely on the catkins or male flowers and but very little on the pistillate flowers. A single specimen was taken in Illinois on wild grape ( $I$ itis sp.), but that record is probably accidental.

Known Distribution.-Georgia, Illinois, Iowa, Michigan, Mississippi, New York, Texas.

Illinois Records.-Danville: June 8. 1902, Titus \& Kahl, 1 우 Elizabethtown : May 27-31, 1932, H. L. Dozier, 2 \& , 5 ․ Mason City: June 2.1933, C. O. Mohr, 5 ๙ , 10 ㅇ. Monticello: June 11, 1934, Frison \& DeLong, $2 \delta$. Mound City: May 24, 1932, H. L. Dozier, 2 f , 4 ㅇ. Mounds: May 23, 1932, on wild grape, H. L. Dozier, $1 \delta$. Springfield: June 27, 1885, in woods, C. A. Hart, $1 \delta$.

\section{Orthotylus robiniae Johnston}

Orthotylus robiniae Johnston (1935, p. 15).

Male.-Length 3.60 , width 1.30 . Rostrum slightly surpassing hind margin of mesosternum. Antennae yellowish green, last two segments dusky. General color uniformly green or yellowish green; mem- brane pale to dusky, veins green. Clothed with simple, pale to yellowish pubescence. Genital claspers distinctive, fig. 128; right clasper forked near apex, forming two short, flattened, acuminate arms curving inward and upward to near middle of genital segment, the apex of each flattened and with short, blunt teeth; dorsal margin of genital segment with a slender chitinous spine projecting postero-ventrally.

Female.-Length 3.60, width 1.47. More robust than male, but very similar in color and pubescence.

Host Plant. - Black locust (Robinia pseudoacacia).

Known Distribution.-Described from $M$ ississippi and now recorded from Illinois.

Illinois Records.-EIchorN: June 13, 1934, Hicks Branch, DeLong \& Ross, 1 ô. Fairfield: June 12, 1934, DeLong \& Ross, 2 ô. Mason City: June 2, 1933, C. O. Mohr, $1 \hat{\delta}$.

\section{Orthotylus notabilis Knight}

Orthotylus notatilis: Knight (1927e, p. 176). Not taken in Illinois; known from lowa, Kansas, Minnesota, South Dakota; Saskatchewan. Host unknown.

\section{Orthotylus ulmi Knight}

Orthotylus ulmi Knight (1927e, p. 179).

Not taken in Illinois; known from Minnesota and New York; breeds on elm (Ulmus sp.) and should eventually be found in Illinois.

\section{Orthotylus dorsalis (Provancher)}

Lygus dorsalis Provancher (1872, p. 104).

MALE.-Length 4.90, width 1.50. Rostrum reaching upon bases of middle coxae. Form elongate, costal margins of hemelytra nearly parallel. General color black. Cuneus, embolium, base of corium, and rather broad area along radius, greenish translucent; median line of pronotum frequently paler; rostrum, except apex, and legs, green; coxae paler; membrane fuscous, veins slightly paler. Genital claspers as in fig. 128.

Female.-Fig. 129. Length 5.20, width 1.60. Pale green to greenish yellow; juga, arc or spot on either side of front, stripe either side of median line, stripe extending from inner basal angles of calli to basal margin of disk, scutellum except median line 
(usually), all but base of clavus and large spot on inner apical angles of corium, dark fuscous to black; pale area of corium extending along claval suture and thus tending to separate dark apical area from that of

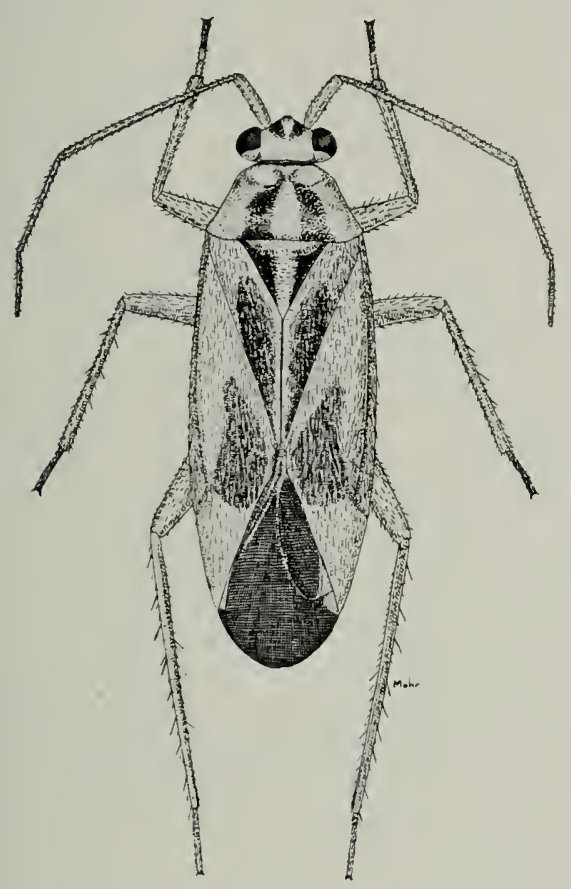

Fig. 129.--Orthotylus dorsalis, ㅇ.

clavus; membrane infuscated, veins distinctly paler. Legs green, femora yellowish; tip of rostrum and apices of tarsi blackish.

Host Plant.-Willow (Salix sp.).

Known Distribution.-Connecticut, Illinois, Iowa, Maine, Michigan, Minnesota, New York, Ohio, Ontario, Quebec.

Illinois Records.-NORThERN IllinoIs: to. Antioch: July 5-7, 1932, Frison et al., 1 ô, 2 q. FREEPORT: July 2, 1917, 1 o. Grandview: June 24, 1932, Frison \& Mohr, $1 \hat{\delta}$.

\section{Orthotylus taxodii new species}

This species is allied to robiniae Johnston, but is distinguished by the longer second antennal segment.

MALE.-Length 3.30, width 1.10. Head width 0.62 , vertex 0.30 . Rostrum reaching to bases of hind coxae. Antennae yellowish green, with pale pubescence; last two segments fuscous; length of first segment 0.26 ; second, 1.00 , cylindrical, nearly equal to thickness of first; third, 0.5t; fourth, 0.30 . General color green; with mesoscutum, calli and vertex yellowish; hemelytra slightly translucent; cuneus uniformly green like corium; membrane pale fumate, veins green. Clothed with simple, pale yellowish pubescence. Legs yellowish green; tibial spines dark. Genital claspers distinctive for species, fig. 128.

Fenale.-Length 3.40, width 1.20. Slightly more robust than male, but very similar in color and pubescence. Head width 0.64 , vertex 0.3 t. Antennae, first segment, length 0.27 ; second, maxinum width, 1.14 , tapering to become more slender on basal half; third, length 0.56 ; fourth, length 0.37 . Pronotum, length 0.48 , width at base 1.00 .

Host Plant.-Bald cypress (Taxodium distichum).

Holotype, male. -Grantsburg, Ill., June 22, 1932, on cypress, Ross, Dozier \& Park.

Allotype, female.-Same data as for holotype.

Paratypes. - Illinors. - Same data as for holotype, $7 \delta, 36$ o . Elizanethtown : June 22-24, 1932, Ross, Dozier \& Park, 2 ㅇ. Golconda: June 22, 1932, Ross, Dozier \& Park, 6 o. Karnak: June 14 , 1934, on cypress, DeLong \& Ross, 12 o. 26 o. ShawneEtown: June 14, 1934, DeLong \& Ross, 1 \%

\section{Orthotylus viridis Van Duzee}

Orthotylus viridis Van Duzee (1916b, p. 103).

Mal.E.-Length 4.60, width 1.50 . Rostrum reaching to middle of intermediate coxae. Antennae dusky yellow, last two segments pale fuscous. General color green; head, pronotum anteriorly, embolium, and femora, yellowish; base of tylus with a small fuscous spot; membrane pale to fumate. Clothed with simple, recumbent, pale pubescence. Genital claspers as in fig. 128.

Female.-Length 4.80 , width 1.55 . Slightly more robust than male, but very similar in color and pubescence.

Host Plant.-Black willow (Salix nigra) and perhaps other willows.

KNown Distribution.-Connecticut, District of Columbia, Illinois, Iowa, Maryland, Michigan, Mississippi, New York, North Carolina, Ohio, Pennsylvania, Quebec, Tennessee, Virginia.

Illinois Records.-Sixty-three males and 60 females, taken June it to Aug. 1, are 
from Elizabethtown, Galesburg, Golconda, Grand Detour, Herod, Kansas, Rockford, St. Joseph, Savanna, Starved Rock State Park, White Heath.

\section{Orthotylus candidatus Van Duzee} 124).

Orthotylus candidatus Van Duzee (1916b, p.

Not taken in Illinois; known from Minnesota, New Hampshire, New York; breeds on American aspen (Populus tremuloides). Male claspers as in fig. 128.

\section{Orthotylus knighti Van Duzee}

Orthotylus knighti Van Duzee (1916b, p. 121).

Not taken in Illinois; known from Indiana, New York, Ohio; breeds on American aspen (Populus balsamifera) and balm of Gilead ( $P$. candicans). Male claspers as in fig. 128 .

\section{Orthotylus serus Van Duzee}

Orthotylus serus Van Duzee (1921, p. 131).

MALE.-Length 5.30, width 1.58. General color black; median line of pronotal disk and scutellum pale; embolium, outer margin of corium and cuneus pale greenish, translucent; genae, gula, bucculae, rostrum except apex, sternum, and legs, greenish yellow; membrane and veins uniformly dark fuscous. Male genital claspers as in fig. 128.

Female.-Length 5.56, width 1.61 ; very similar to male in form and coloration; hemelytra with costal margins nearly parallel; sometimes the pronotal disk, vertex and front bordering eyes with broader pale mark than in male.

HaBiTs.-Breeds on hawthorns (Crataegus punctata and C. tomentosa).

Known Distribution. - Illinois, Iowa, New York.

Illinois Record.-Frankfort: June 8, 1933, on Crataegus tomentosa, Mohr \& Townsend, $19 \hat{o}, 32$ \&.

\section{Orthotylus basicornis Knight}

Orthotylus basicornis Knight (1923d, p. 515). Male.-Length 5.60, width 1.66. Rostrum reaching to middle of intermediate coxae. Antennae with first segment black, second yellowish to pale fuscous, third pale fuscous, fourth fuscous. General color green; embolium and outer edge of corium yellowish green; membrane pale, veins green. Clothed with prominent, suberect, rather coarse, pale pubescence. Suggestive of viridis Van Duzee, but distinguished by the black, first antennal segment and structure of the male genital claspers, fig. 128.

Female.-Length 5.60, width 1.70. Very similar to male in form, color and pubescence.

Host Plant. - Sandbar willow (Salix longifolia).

Known Distribution. - Illinois, Indiana, Iowa, Michigan, Minnesota, New York, Quebec, South Dakota.

Illinois Records.-Thirty-nine males and 30 females, taken June 9 to Aug. 24, are from Antioch, Beardstown, Bureau, Fulton, Freeport, Galena, Grand Detour, Kampsville, Keithsburg, McHenry, Normal, Oquawka, Quincy, Savanna, Urbana, Warsaw, Waukegan, West Union.

\section{Orthotylus rossi new species}

This species is allied to basicornis Knight, but differs in its shorter second antennal segment; the first segment is always paler or greenish above; the structure of the male genital claspers is distinctive, fig. 128. Orthotylus rossi is also allied to the western species, fuscicornis Knight, but differs in being larger, having a longer first antennal segment and short, recumbent pubescence, and in details of the genital claspers.

Male.-Length 6.10, width 1.80. Head width 1.18 , vertex 0.43 . Rostrum, length 1.56 , extending slightly beyond middle of intermediate coxae. Antennae, first segment, length 0.56 , fuscous to black beneath, yellowish to green above; second, 1.95, yellowish green, length less than twice width of head; third, 1.08, fuscous; fourth, 0.56, fuscous. Pronotum, length 0.99 , width at base 1.65. Clothed with rather short, recumbent, pale pubescence. General color uniformly yellowish green to clear green; eyes, first antennal segment beneath, tip of rostrum, and tips of tarsi, blackish; membrane pale, veins yellowish to greenish. Genital claspers distinctive, right clasper differs from that of basicornis by having a broad, truncated apex.

Female.-Length 6.30, width 2.16. Head width 1.12 , vertex 0.56 . Antennae, first segment, length 0.54 , fuscous to blackish beneath; second, 1.86 ; third, 1.08 ; fourth, 
0.56. Pronotum, length 1.08 , width at base 1.78. More robust than male, but very similar in color and pubescence.

Host Plant.-Willow (Salix sp.).

Holotype, male.-Warsaw, Ill.: June 9, 1932, on Salix sp., Ross \& Mohr.

Allotype, female. - Same data as for holotype.

Paratypes. - Illinors. - Same data as for holotype, $5 \hat{\delta}, 5 q$. Champaign: June 15, 1888, at light, C. A. Hart, 1 q. Grand Tower: June 27, 1906, on willow, C. A. Hart, 7 ô, 13 . Kampsville: June 25, 1932, Frison, Betten \& Ross, 2 o . KeithsBURG: June 8, 1932, on Salix sp., Ross \& Mohr, 2 of. Savanna: July 23, 1892, on sandbar in Mississippi River, McElfresh, Hart \& Forbes, $1 \delta, 2$ ㅇ.

Iowa.-Ames: Aug., 1940, 1 \%. CounCIL Bluffs: July 16, 1940, $1 \hat{\delta}$. DavenPORT: June 27, 1940, 3 ô. Dubuque: June 27, 1 ô ; July 5, 1 ô ; July 9, 1940, 1 ô. Muscatine: July 27, 1940, trap light, 1 o . All Iowa paratypes, Kc.

\section{Orthotylus necopinus Van Duzee} 125).

Orthotylus necopinus Van Duzee (1916b, p.

MALE.-Length 6.60, width 2.11. General color brownish black; juga, vertex, area extending along front of eyes, median line of pronotal disk and frequently anterior part of median line of scutellum, base of embolium, slender area at base of radius, areas bordering cuneal fracture, pale to pale translucent; basal half of venter, and coxae, pale; femora and tibiae testaceous to fuscous; genital claspers, fig. 128, distinctive for species.

FeMale.-Length 6.80, width 2.20; very similar to male, but frequently with pale areas broader.

Host Plant.-Yellow birch (Betula lutea) in cool, damp, shaded situations.

Known Distribution. - Illinois, New Hampshire, New York, Ontario.

lllinois Record. - NORTHERN l LLINOIS, UI.

\section{Orthotylus submarginatus (Say)}

Capsus submarginatus Say (1832, p. 23; 1859 , p. 244).

Male.-Length 4.60, width 1.33. Dorsum pale salmon to orange; antennae, front of head, lateral margins of pronotal disk, scutellum, rather broad area on either side of commissure, embolium, area at apex of corium, apex of cuneus, and membrane, blackish or black; rostrum, except apex, pale; legs mostly pale, with hind femora dusky and tibiae almost black. Genital claspers as in fig. 128.

Female.-Length 4.80, width 1.44; very similar to male, but salmon yellow areas more broad above; venter white with dorsolateral margins black; ostiolar peritreme fuscous, epimera and sternum blackish.

Host Plant. - Black locust (Robinia pseudoacacia).

Known Distribution.-Connecticut, Illinois, Indiana, Maryland, Missouri, New York, Ohio, Pennsylvania, Virginia.

Illinois Records.-Bluff Springs: June 10, 1932, Ross \& Mohr, 1 \%. McClure: June 25, 1931, Frison, Betten \& Ross, 1 ㅇ․

\section{Orthotylus ornatus Van Duzee} 122).

Orthotylus ornatus Van Duzee (1916b, p.

Male.-Length 5.60, width 1.78. Rostrum extending to bases of middle coxae. Body clothed with moderately short, recumbent, simple, pale yellowish pubescence. General color black or very dark brown; tip of scutellum, basal angles of corium, and cuneus, pale to pale translucent; membrane fuscous, veins and spot on middle of apical half slightly paler; legs pale to dusky, front and middle femora very dark brown, posterior pair darker. Genital claspers as in fig. 128.

Female.-Length 6.00, width 2.05. General color chiefly pale, tinged with reddish, varied with fuscous. Base of tylus and spot just above, sometimes an arc on front, basal margins of calli, pronotal disk, except median line and lateral margins, basal angles of scutellum, apical half of corium, and part of clavus, fuscous to blackish; antennae pale fusco-brownish, first segment darker; hind femora very dark brown. Sometimes this sex may have blackish areas broader and paler parts not at all tinged with reddish.

Host Plant.-Crack willow (Salix fragilis).

Known Distribution.-Colorado, Connecticut, Illinois, Indiana, Iowa, Minnesota, New York, Ohio, Ontario, South Dakota, Texas.

Illinois Records.-Eight males and 11 females, taken May $1+$ to July 8, are from 
Algonquin, Antioch, Apple River Canyon State Park, Dubois, Elizabeth, Galena, Meredosia, Muncie, Oregon, Valley City.

\section{Orthotylus nyctalis Knight}

Orthotylus nyctalis Knight (1927e, p. 181).

This species is very similar to lateralis $V$ an Duzee in color, but its form is more slender; the two differ chiefly in the structure of the male genital claspers.

MALE.-Length 5.10, width 1.40. Rostrum extending slightly beyond middle of intermediate coxae. Antennae very dark fuscous, with second segment uniformly dusky yellow. Coloration nearly as in lateralis, but darker. Clothed with simple, suberect, bristly, pale hairs. Ground color pale, with lateral margins of pronotal disk, dorsal halves of propleura, and all but narrow area st apex of first antennal segment, black; outer half of corium, base of clavus, apical half of cuneus, episterna, and dorso-lateral margins of venter, fuscous to blackish; membrane pale fuscous with veins and narrow areas of membrane bordering veins, clear. Genital claspers as in fig. 128.

Female-Length 4.80, width 1.64. Antennae dusky yellow, third segment pale to dusky, fourth dusky. More robust than male, but very similar in color and pubescence.

Known Distribution. - Illinois, Iowa, Minnesota, New York, Wisconsin.

Illinois Records. - OAKwOOD: July 5, 1936, Mohr \& Burks, 1 ㅇ. Willow SPrings: July 21, 1912, on poplar, W. J. Gerhard, 1 우, kc.

\section{Orthotylus lateralis Van Duzee} 120).

Orthotylus lateralis Van Duzee (1916b, p.

Male.-Length 4.60, width 1.47. Head pale yellowish, frons and tylus blackish. Rostrum, length 1.30, extending upon tips of middle coxae, yellowish, apex black. Antennae with first segment black; second cylindrical, black, clothed with fine, short, dusky pubescence; third and fourth black. Pronotum black; ventral margins of propleura pallid; disk behind calli and the anterior margin, pale to yellowish; calli brownish to black. Scutellum pallid, lateral margins narrowly fuscous; mesoscutum yellowish to fuscous. Hemelytra dark fuscous; base of corium, embolium and base of cu- neus pale translucent. Membrane and veins pale fuscous, central area paler. Body beneath pale to yellowish; sides of thorax and venter dark fuscous. Dorsum clothed with simple, suberect, pale to dusky pubescence. Legs pale greenish; apical half of hind femora fuscous; tibiae dusky; tarsi fuscous.

Female.-Length 4.80, width 1.50. More robust than the male; similar in color but pallid areas more extensive.

Known Distribution.-Described from Colorado and since recognized from Illinois, Iowa, Minnesota and Oklahoma.

Illinois Records.-Galesburg: July 16, 1892 , on "cottonwood," Stromberg, 3 . Monticello: June 28, 1914, C. A. Hart, 1 ㅇ․

\section{Orthotylus modestus Van Duzee} 109).

Orthotylus modestus Van Duzee (1916b, p.

MaLE.-Length 4.40, width 1.44. Rostrum reaching to middle of intermediate coxae. Antennae fusco-brownish, first segment darker. General color fuscous to blackish. Head and paler parts of hemelytra tinged with yellowish; embolium pale, base of corium, rather broad area along radius, and cuneus, greenish yellow; membrane uniformly infuscated, veins scarcely paler. Body clothed with moderately prominent, simple, pale yellowish pubescence. Genital claspers distinctive for species, fig. 128.

Female.-Length 4.50, width 1.47. General color pale greenish. Legs darker; dorsum marked with blackish; spot at base of tylus, transverse mark across bases of calli, mark paralleling basal margin of pronotal disk which approaches but does not attain lateral angles, basal angles and median spot at base of scutellum, all but basal angles of clavus, and spot on inner apical angle of corium, fuscous to black; membrane uniformly dark fuscous.

The black markings vary greatly in extent and intensity, in some cases being indistinct or absent. The uniformly green-colored specimens of this species constitute the variety immaculatus Knight (1923d, p. 520).

Host Plants.-Willows (Salix fragilis and $S$. nigra).

Known Distribution.-Connecticut, District of Columbia, Illinois, Indiana, Iowa, Michigan, Minnesota, New Jersey, New York, Ohio, Ontario, Pennsylvania. 
Illinois Records.-Eighty-nine males and 106 females, taken $\mathrm{M}$ ay 22 to Aug. 1, are from Alton, Antioch, Beardstown, Bureau, Danville, Decatur, Elizabethtown, Freeport, Galena, Galesburg, Golconda, Grand Detour, Grand Tower, Hardin, Havana, Herod, Homer, Keithsburg, Mahomet, Marshall, Monticello, Mount Carmel, Oquawka, Oregon, Quincy, Quiver Lake, Rockford, St. Joseph, Savanna, Seymour, Springfield, Urbana, Warsaw, White Heatl.

\section{Orthotylus neglectus Knight}

Orthotylus neglectus Knight (1923d, p. 515). MALE.-Length 5.40, width 1.75. In color pattern similar to dorsalis (Provancher), but genital claspers, fig. 128 , indicate it is more closely related to basicornis Knight and knighti Van Duzee. Color black, rostrum except apex, slender lateral margin of pronotal disk, cuneus, embolium, and outer margin of corium, greenish; legs greenish, darkened at bases of coxae and tips of tarsi; membrane and veins uniformly blackish. Rarely, pale forms may occur having median line of pronotum and scutellum pale.

Female.-Length 5.80, width 1.90 ; more robust than the male, usually pale areas more extensive.

Foon P LanT.-Black willow (Salix nigra).

Known Distribution.-Connecticut, Illinois, New York, Nova Scotia.

Illinois Record. - Avтіосн: June 12, 1936, Ross \& Burks, 1 \&.

\section{Noctuocoris Knight}

No Illinois species; Noctuocoris fumidus (Van Duzee) occurs from Colorado eastward to New York and Massachusetts. It will likely be found in Illinois eventually.

\section{Labopidea Uhler}

\section{KEY TO SPECIES}

1. Pubescence very short, recumbent, with just a few odd, erect, fuscous hairs scattered over pronotum and mesoscutum........ainsliei, p. 105

Pubescence prominent, dorsum clothed with erect, pale hairs.......... 2

2. Anterior margin of pronotum not raised above flat surface of the disk.

planifrons, p. 105
Anterior margin of pronotum and calli slightly arched, raised above flat, central area of disk...... allii, p. 105

\section{Labopidea planifrons Knight}

Labopidea planifrons Knight (1928a, p. 234).

Not taken in Illinois; known from lowa and South Dakota.

\section{Labopidea ainsliei Knight}

Labopidea ainsliei Knight (1928a, p. 235).

This species is allied to allii Knight, but differs in having a wider vertex, shorter pubescence and pale yellowish green color; ainsliei is also distinguished by the form of the male genital claspers.

MALE.-Length 3.50, width 1.15. Antennae, greenish yellow, last two segments brownish. Body clothed with very short, fine, pale pubescence; a few silvery, silky hairs also evident on pronotum. General color greenish yellow, hemelytra more green, but not blue green as in perfect specimens of allii; membrane and veins evenly shaded with pale fumate. Genital claspers distinctive, left clasper more slender than in allii, basal lobe produced above to form an acuminate spine; right clasper slender, widened at base to form a dorsal, subtriangular lobe; apical half slender, incurved and acuminate.

Female.-Length 3.50, width 1.34. More robust than male, but very similar in color and pubescence.

Host Plants.-Wild onion (Allium cer$n u u m$ ) and cultivated onions in lowa.

Known Distribution. - Illinois and lowa.

Illinois Records. - Fountaln Bluff: May 15, 1932, Frison, Ross \& Mohr, $1 \delta$. Giant City State Park: May 21, 1932, H. L. Dozier, 1 o . Muncie: June 10, 1919, 1 \&.

\section{Labopidea allii Knight}

\section{Onion Plant Bug}

Labopidea allii Knight (1923b, p. 31).

This is a small, blue green species with fine, erect, simple, pale pubescence, figs. 130 , 131.

Male.-Length 4.00, width 1.28. Head width 0.86 , vertex 0.49 . Rostrum, length 0.75 , scarcely reaching to middle of sternum. 
Antennae, first segment, length 0.34 ; second, 1.05 , yellowish brown, green at base; third, 1.01 , dusky brown; fourth, 0.43 , fuscous. Pronotum, length 0.48 , width at base 1.08 ; disk rather flat, anterior margin and calli

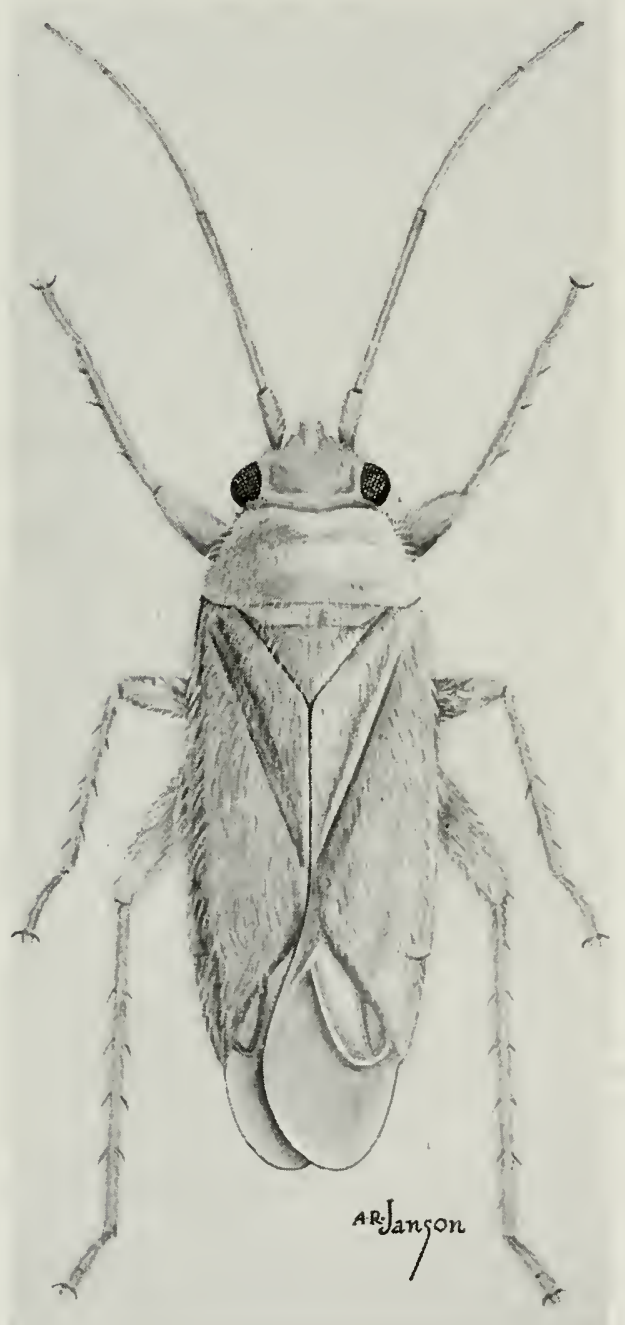
form.

Fig. 130.-Labopidea allii, the long-winged

slightly arched. Body clothed with fine, erect, simple, pale hairs, this pubescence longest on clavus, base of embolium, margins of pronotum, and frons; on pronotum and hemelytra minute, silvery, sericeous hairs which shine in certain lights also present. General color a pale blue green; antennae, except first segment, brownish; membrane uniformly pale fumate, veins about smaller areole green; tip of rostrum black. Male genital claspers distinctive for species, fig. 132.

Female.-Length 4.10, width 1.48. More robust than male, but very similar in color and pubescence. Brachypterous females are at hand from Iowa; in these the last two segments of abdomen are exposed, cuneus short and membrane lacking.

Host Plants.-Wild garlic (Allium canadense) and wild onion (Allium cernuum);

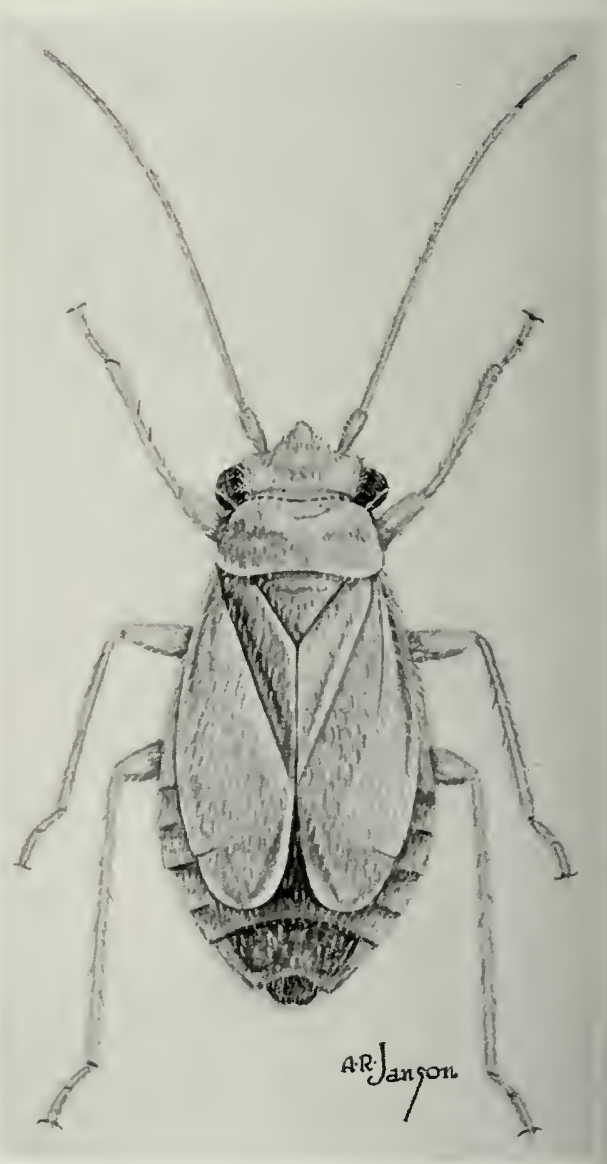

Fig. 131.-Labopidea allii, the short-winged form.

this species often migrates to cultivated onions, where it becomes exceedingly abundant, often killing the plants. In southern Missouri from $193+$ to 1936 , many plantings of Bermuda onions were destroyed. Labopidea allii is also reported as a pest in southern Iowa and eastern Kansas. The bug winters as an egg in old onion stems. Destroying the old onion tops and eradicat- 
ing the nearby stands of the wild host should keep the pest under control.

Known Distribution. - Illinois, Indiana, Iowa, Kansas, Missouri, Oklahoma.

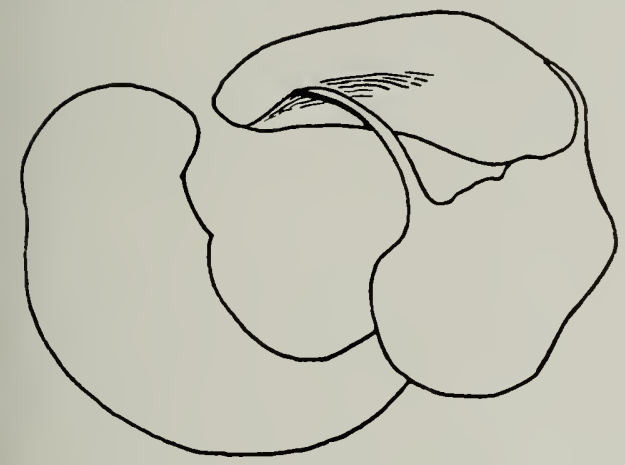
allii.

Fig. 132.- Male genital claspers of Iabopidea

Illinois Records.-Sixteen males and 15 females, taken May 7 to October, are from Green County, Alto Pass, Anna, Cache, Cobden, Dongola, Elizabethtown, Fountain Bluff, Grand Tower, Olney, Rattlesnake Ferry, Urbana.

\section{Heterocordylus Fieber}

\section{Heterocordylus malinus Reuter}

Heterocordylus malinus Reuter (1909, p. 71). Male.-Length 6.20, width 2.20. Head width 1.12 , vertex 0.58 . Antennae, first segment, length 0.47 ; second, 1.80 , maximum thickness equal to that of first segment, pubescence prominent, black; third, length 0.73 , moderately slender; fourth, length 0.52 , slender. Pronotum, length 1.12, widtil at base 1.95. General color black, usually with a patch of red on basal angles of pronotum and hemelytra. Clothed with very fine, yellowish to dusky, simple pubescence, intermixed with rather sparsely placed tufts of white, deciduous, tomentose pubescence.

Female.-Fig. 133. Length 6.20, width 2.40. Antennae with second segment nearly as thick as first segment but more slender on basal half. Red areas often broader than those of male; usually with basal half of pronotum, embolium, inner half of corium, base and exterior margin of clavus, and cuneus, red; more rarely entirely black, as in male. Pubescence as in male.

Foon PLANTs. - Hawthorn (Crataegus sp.) is the original host, but in many locali-

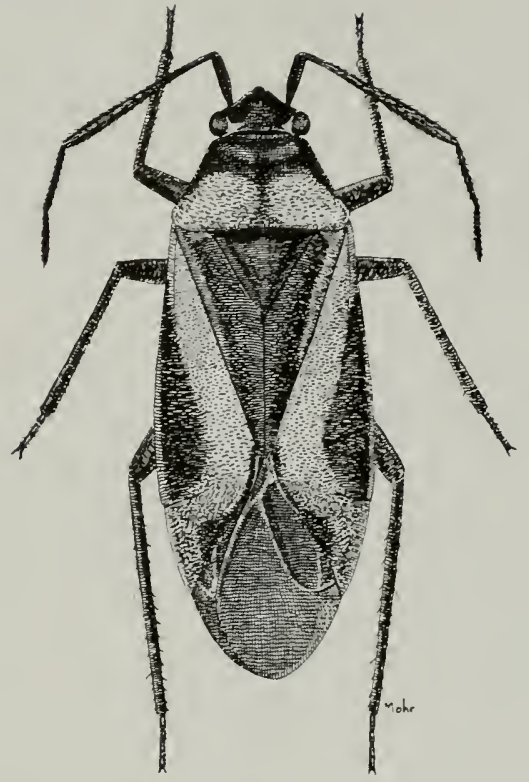

Fig. 133.- Heterocordylus malinus, ㅇ.

ties the species migrates and breeds on cultivated apple (Pyrus malus). A single Illinois specimen was collected on locust (Robinia pseudoacacia). Known as a pest of apple in New York where the nymphs have been observed to puncture the small fruits; this species is not, however, so serious a pest as Lygidea mendax Reuter.

Known Distribution. - Illinois, Indiana, Iowa, Michigan, Minnesota, Mississippi, Missouri, New Hampshire, New York, Ohio, Ontario, Pennsylvania, W isconsin.

Illinois Records. - Twenty-one males and 33 females and 7 nymphs, taken May 23 to June 27, are from Eldorado, Elizabeth, Galena, Galesburg, Glen Ellyn, Manito, Pegrim, Willow Springs.

\section{GERATOCAPSINI}

\section{KEY TO GENERA}

Pronotum anterior to middle nearly cylindrical, rather abruptly flaring behind middle, basal half of disk strongly convex; emboliar margins sulcate on basal half............. Pamillia, p. 108

Pronotum regularly narrowed anteriorly, its sides not constricted at middle; emboliar margins not sulcate, fig. 197.

Ceratocapsus, p. 108 


\section{Pamillia Uhler}

No Illinois species; Pamillia davisi Knight is known from New Jersey.

\section{Ceratocapsus Reuter}

\section{KEY TO SPECIES}

1. Clothed only with simple pubescence, although sometimes also with prominent, long, pilose hairs........ 2

Clothed with two types of pubescence; bearing either more or less closely appressed, silky, tomentose pubescence, or scalelike pubescence, and in addition intermixed, more erect pubescence..............6 6

2. Head and antennae chiefly red; dorsum uniformly yellowish........ 3

Head and antennae not distinctly red; dorsum more or less darkened.... . 4

3. Antennae entirely red.

rubricornis, p. 109

Antennae with first segment and basal part of second yellowish......... ........... lutescens, p. 111

4. Dorsum dark brown, a broad pale or yellowish mark extending across hemelytra just beyond tip of scutellum..........fasciatus, p. 109

Dorsum without transverse pale fascia 5

5. Robust; head and thorax not, or scarcely, darker than hemelytra, which are very dark brown with basal half frequently paler; length $4.30 \ldots \ldots \ldots$ modestus, p. 111

Slender; head and thorax black, hemelytra yellowish with a fuscous cloud on corium; sometimes brachypterous; length 4.50 .

nigrocephalus, p. 111

6. Dorsum dark brown, a broad, pale mark extending across hemelytra just beyond tip of scutellum; this pale area in cuticula, not formed by pubescence....... pilosulus, p. 109

Dorsum without transverse pale mark 7

7. Pronotum impunctate, sometimes with vague, minute cracks...... 8

Pronotum punctate, these punctures sometimes rather minute, but always distinctly present. ......14

8. Clavus bearing long, pilose hairs... .9 9 Clavus without Jong, pilose hairs... 11

9. Length of first antennal segment equal to not more than three-fourths width of vertex in male, in female less than three-fourths; male slender, length of second antennal segment only slightly exceeding width of head; female brachypterous, disk of corium swollen, convex ............... camelus, p. 114

Length of first antennal segment approximately equal to width of vertex..................... 10

10. Second antennal segment fuscous at apex; male best distinguished by structure of genital claspers, fig. 134 husseyi, p. 113

Second antennal segment uniformly pale yellowish; male best distinguished by structure of genital claspers, fig.134...... sericus, p. 113

11. Length of third antennal segment not equal to width of vertex plus dorsal width of one eye; color uniformly yellowish, antennae brownish apically............ luteus, p. 111

Length of third antennal segment greater than width of vertex plus dorsal width of one eye........12

12. Length of second antennal segment approximately equal to or greater than width of pronotum at base; color very dark brown, almost black; length 4.50 ...nigellus, p. 111

Length of second antennal segment less than width of pronotum at base . 13

13. Third and fourth antennal segments approximately equal in length; total length $3.10 . \therefore$ taxodii, p. 111

Third antennal segment distinctly longer than fourth; total length $3.40 \ldots \ldots \ldots \ldots$ vicinus, p. 112

14. Length of third antennal segment greater than width of vertex plus dorsal width of one eye........15

Length of third antennal segment equal to or less than width of vertex plus dorsal width of one eye.....17

15. Length of third antennal segment equal to width of head; female ovate, brachypterous, length 2.50 ; male length $3.10 \ldots$ setosus, p. 115

Length of third antennal segment less than width of head . . . . . . . . 16

16. Pronotum with a fuscous spot behind each callus; scutellum and clavus bearing a few long, pilose hairs....

complicatus, p. 114 
Pronotum with calli and anterior area of disk dark fuscous to black; scutellum and clavus rather thickly clothed with suberect, yellowish pubescence, but without long, pilose hairs.

pumilus, p. 112

17. Length of second antennal segment greater than width of head plus dorsal width of one eye ..........

incisus, p. 113

Length of second antennal segment not exceeding width of head plus dorsal width of one eye.......18

18. Membrane uniformly pale, darkest specimens with membrane slightly smoky; length 2.80 .

quadrispiculus, p. 114

Membrane dark. . . . . . . . . . . . . . 19

19. Second and third antennal segments uniformly pale yellowish. $\ldots \ldots \ldots \ldots$. . . . . . . . 113 dish brown.

20. Dorsum densely clothed with erect, rather bristly pubescence.........

digitulus, p. 115

Dorsum more sparsely clothed with semierect pubescence.

21. Membrane uniformly fuscous.......

decurvatus, p. 116

Membrane pale, fuscous on apical onethird only ...... fuscinus, p. 115

\section{Ceratocapsus fasciatus (Uhler)}

Megacoelum fasciatum Uhler (1877, p. 421). MaLE.-Length 3.00, width 1.30. Head width 0.65 , vertex 0.28 . Antennae, first segment, length 0.26 ; second, 0.91 ; third, 0.60 ; fourth, 0.48 . Pronotum, length 0.56 , width at base 1.04. General color dark chestnut brown with legs and antennae paler; hemelytra with a broad, transverse, pale yellowish band behind tip of scutellum; clothed only with fine recumbent, yellowish pubescence. Genital claspers as in fig. 134.

Fenale.-Length 3.10, width 1.40. Head width 0.67 , vertex 0.33 . Antennae, first segment, length 0.29 ; second, 0.99 ; third, 0.61 ; fourth, 0.52. Pronotum, length 0.56 , width at base 0.67 . Very similar to male in color and pubescence.

Host Plant.-Hickory (Carya sp.).

K nown Distribution.-District of Columbia, Illinois, Indiana, Iowa, Maryland, Massachusetts, Michigan, Minnesota, Mis- sissippi, New York, North Carolina, Ohio, Virginia.

Illinois Records.-IllinoIs: July 16, 1892, 1 oิ ; 1 oิ, 2 o. Argo: Aug. 13, 1916, W. J. Gerhard, 1 ô, FM. DuboIs: July 2, 1909, beating from tree, 1 \%. GALESBURG: June 27, 1892, 2 \%. PALos PARK: July 27, 1913, on hickory, W. J. Gerhard, 1 \&, FM.

\section{Ceratocapsus rubricornis Knight} 145)

Ceratocapsus rubricornis Knight (1927c, p.

MAlE.-Length 4.30, width 1.70. Antennae deep red, last two segments somewhat darker red. Clothed with simple, yellowish pubescence; a few longer, more nearly erect hairs on base of clavus, scutellum and disk of pronotum. Color uniformly pale yellowish; antennae, head, propleura above middle of coxal cleft, and hind tibiae, bright red. Genital claspers distinctive, fig. 134; differ from those of lutescens Reuter by long, decurved, sickle-shaped apical half of right clasper and by broader basal spine.

Female.-Length 4.40, width 1.90. In coloration and pubescence similar to male.

Food Plants.-Collected on linden (Tilia americana).

Known Distribution.-District of Columbia, Illinois, Mississippi.

Illinois Record.-Galesburg: August, on linden, 1 \%

\section{Ceratocapsus pilosulus Knight}

Ceratocapsus pilosus Knight (1923d, p. 526). Preoccupied. 198).

Ceratocapsus pilosulus Knight (1930c, p.

This species is very similar to fasciatus (Uhler) in size and coloration but is readily to be distinguished by the long, pilose hairs on the head and the dorsum, and by the claspers, fig. 134 .

MaLE.-Length 3.40, width 1.30. Front beset with several prominent, erect hairs. Rostrum attaining hind margins of posterior coxae. Antennae with second segment becoming gradually thicker from base to apex, yellowish brown; third brownish; fourth dark brown. Pronotum clothed with fine, yellowish pubescence, margins of disk beset with prominent pilose hairs. General color dark brown; hemelytra with a broad, transverse, pale yellowish fascia just behind apex of scutellum. Hemelytra clothed with very 
fine, closely appressed, sericeous pubescence, intermixed with longer recumbent pubescence and sparsely set, erect, pilose hairs, pubescence taking color of surface beneath.

Female.-Length 3.60, width 1.60. More robust than male, but very similar in color and pubescence.

Food Plants.-Collected on hop horn- beam (Ostrya virginiana), bur oak (Quercus macrocarpa) and hazelnut (Corylus americana).

Known Distribution.-Illinois, Iowa, Massachusetts, Minnesota, New York.

Illinois Records.-NorthERN IllinoIs: July, 1 우 ; 1 s, 1 ㅇ. . Algonquin: June 10, 1896, 2 of, 1 ㅇ. Galena: June 30, 1932,
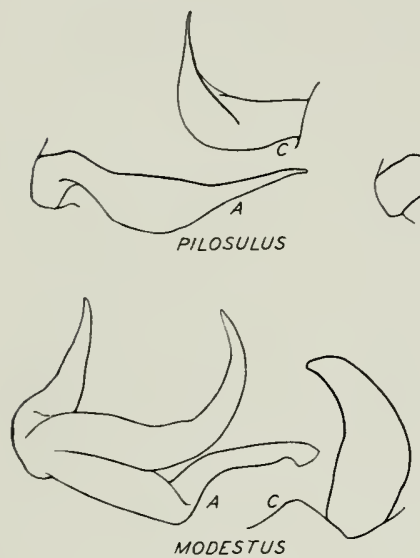

MODESTUS
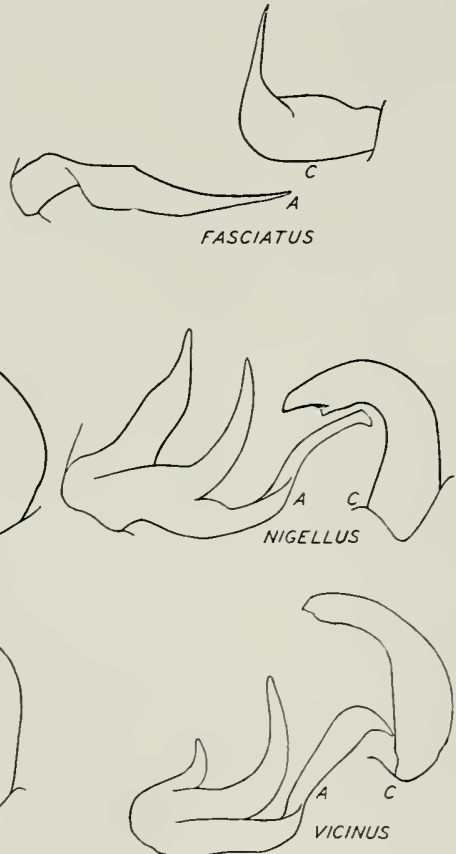

HUSSEY
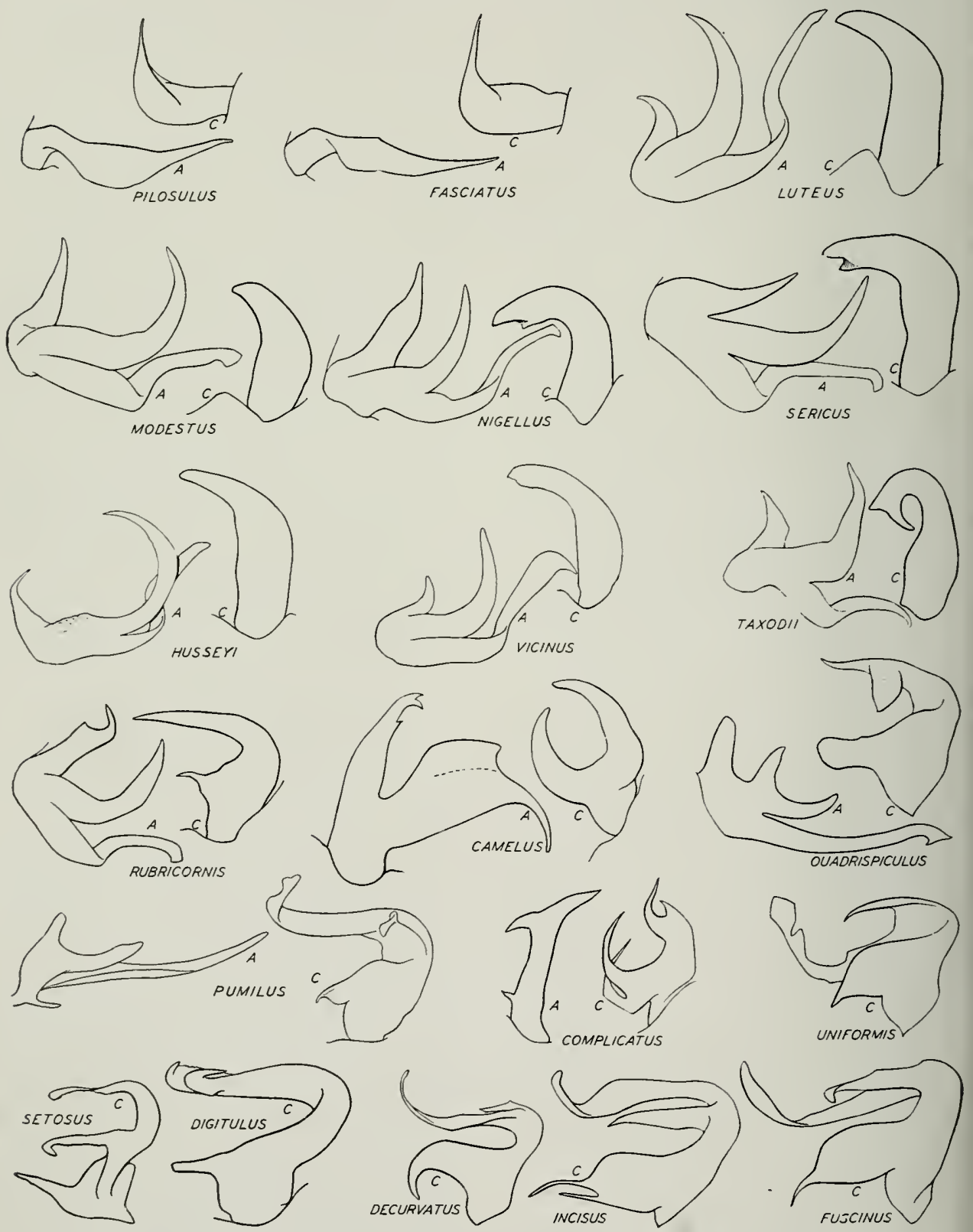

Fig. 134.- Male genital claspers of Ceratocapsus. $A$, left clasper, lateral aspect; $C$, right clasper, lateral aspect. 
Dozier \& Mohr, on Corylus sp., 9 s, 5 q. Willow Springs: June 28, 1903, W. J. Gerhard, 1 o, 2 q , FM; June 26, 1904, IV. J. Gerhard, 1 \&, FM; July 8, 1906, W. J. Gerhard, 1 o, FMI July 18, 1909, A. B. Wolcott, 1 ô, F.I.

\section{Ceratocapsus lutescens Reuter}

Ceratocapsus lutescens Reuter (1876, p. 87).

Not taken in Illinois; known from Florida, Kansas, Long Island, New York, Texas.

\section{Ceratocapsus nigrocephalus Knight}

Ceratocapsus nigrocephalus Knight (1923d, p. 534).

Not taken in Illinois; known from Iowa, Michigan, Minnesota, New Hampshire, Ontario, Quebec, South Dakota.

\section{Ceratocapsus modestus (Uhler)}

Melinna modesta Uhler (1887c, p. 69).

MaLE.-Length 4.00, width 1.40. General color yellowish brown to dark fuscous brown. Dorsum impunctate, surface very finely alutaceous; scutellum, clavus and inner apical margin of corium heset with a few long erect hairs, but devoid of closely appressed, sericeous pubescence. Genital claspers as in fig. $13+$.

Feviale.-Length 4.40, width 1.70. Similar to male in general color.

Food Plants. - Occurs on basswood (Tilia americana), oak (Quercus sp.), alder (Alnus rugosa) and grape (I'itis sp.).

Known Distribution.-Extensive over the eastern United States.

Illinois Records.-Thirty males and 22 females, taken June $2+$ to Sept. 4 , are from Algonquin, Antioch, Argo, Cary, Chicago, De Soto, Eichorn, Fox Lake, Galesburg, Glen Ellyn, Havana, Pulaski, Starved Rock State Park, Urbana, Waukegan, West Pullman, Willow Springs.

\section{Ceratocapsus nigellus Knight}

Ceratocapsus nigellus Knight (1923d, p. 528).

This resembles the dark forms of modestus (Uhler), but is readily distinguished by the pubescence of the scutellum.

MaLE.-Length 4.50, width 1.70. Antennae clothed with short, closely set pubescence; dark reddish brown to blackish. Pronotum alutaceous, finely and sparsely pu- bescent, a few, more nearly erect hairs also present. Scutellum, clavus and basal half of corium clothed with closely appressed. scalelike pubescence sparsely intermixed with simple puhescence. General color very dark brown, almost black; cuneus frequently more reddish hrown; tihiae yellowish brown. Membrane and veins uniformly fuscous, area bordering apex of cuneus slightly paler. Genital claspers as in fig. 134.

Female.-Length 4.60 , width $1.8+$. Very similar to male in color and pubescence.

Habits.-Collected on hickory (Carya sp.), the nymphs frequently found on the trunk and larger limbs of the trees; perhaps predacious.

Known Distribution. - Georgia, Illinois, Iowa, Maryland, Minnesota, New Jersey, New York, North Carolina, Ohio, Virginia.

Illinois Records.-Nineteen males and 22 females, taken June 11 to Aug. 9, are from Galena, Galesburg, La Rue, Monticello, Oakwood, Round Lake, Shawneetown, Urbana, Waukegan, White Pines Forest State Park, Zion.

\section{Ceratocapsus luteus Knight}

Ceratocapsus luteus Knight (1923d, p. 527).

Male.-Length 3.80, width 1.46. Antennae with first segment yellowish, second yellowish, brownish on apical half, third fusco-brownish, fourth very dark brown. Pronotum impunctate, somewhat alutaceous. Dorsum clothed with very fine, simple, yellowish pubescence, intermixed with closely appressed, silvery, scalelike pubescence on scutellum, clavus and inner half of corium. General color uniformly yellowish, tinged with brownish; membrane uniformly pale fumate, veins tinged with yellowish. Claspers as in fig. $13+$.

Fenale.-Length 4.00 , width $1.6+$. Very similar to male in color and pubescence.

Known Distribution. - Illinois, New York, West Virginia.

Illinois Record.-BЕACH: Aug. 7, 1935, DeLong \& Ross, 1 i, 1 .

\section{Ceratocapsus taxodii Knight}

Ceralocapsus taxodii Knight (1927c, p. 143).

This species is allied to luteus Knight but is distinguished hy its smaller size, longer second antennal segment, and yellow anten nae with a reddish fourth segment. 
Male.-Length 3.20, width 1.30. Antennae with all segments nearly equal in thickness; all but fourth yellow; the fourth segment reddish. Pronotum impunctate, alutaceous. Dorsum clothed with fine, simple, yellowish pubescence, intermixed on scutellum, clavus and inner half of corium with closely appressed, silvery, scalelike pubescence. General color light reddish; hemelytra more or less translucent, old specimens may become brownish red; membrane pale fuscous, becoming gradually paler toward base. Genital claspers distinctive, fig. 134.

Female.-Length 3.10, width 1.30 . Very similar to male in pubescence and coloration.

Food Plant.-Cypress (Taxodium distichum).

Known Distribution. - Florida, lllinois, Louisiana, Mississippi, Tennessee.

Illinois Records.-CaIro: July 27, 1930, on Taxodium distichum, Knight \& Ross, 4 4, 2 \%. Elizabethtown: July 25, 1930, on Taxodium distichum, Knight \& Ross, 1 ô, 8 o. Horseshoe LAKe: July 11, 1935, DeLong \& Ross, 11 하 22 우. Jon esboro: Aug. 2, 1932, on Taxodium distichum, H. L. Dozier, 2 o , 6 q. KARNAK: July 26, 1930, on Taxodium distichum, Knight \& Ross, 4 o, 13 우; June 23, 1932, Ross, Dozier \& Park, 1 ô.

\section{Ceratocapsus pumilus (Uhler)}

Melinna pumila Uhler (1887c, p. 69).

MALE.-Length 3.70, width 1.50. Antennae with first segment yellowish, a red mark present near base; second yellowish, third yellowish, apical half reddish brown; fourth brownish. Dorsum with fine, black punctures; thickly clothed with prominent, simple, yellowish pubescence intermixed with shorter, closely appressed, silvery yellow, sericeous pubescence. General color yellowish brown to dark brown, calli and anterior third of pronotum almost black; dark specimens with the whole dorsum very dark brown, almost black; membrane fuscous, paler on basal half. Genital claspers distinctive, fig. 134 .

Female.-Fig. 135. Length 3.90, width 1.70. More robust than male, but very similar in color, pubescence and puncturation.

Food Plants.-Occurs most frequently on grape (I'itis sp.) and willow (Salix sp.); also taken on red birch (Betula nigra).
Known Distribution.-Extensive over the eastern United States and Canada.

Illinois Records. - One hundred one males and 81 females, taken June 10 to Sept. 20 , are from Algonquin, Alton, Antioch, Apple River Canyon State Park, Beardstown, Browns, Carbondale, Des Plaines, Dolson, Eichorn, Elizabethtown, Galesburg, Golconda, Hardin, Harrisburg, Herod, Homer Park, Kampsville, Kankakee, Kansas,

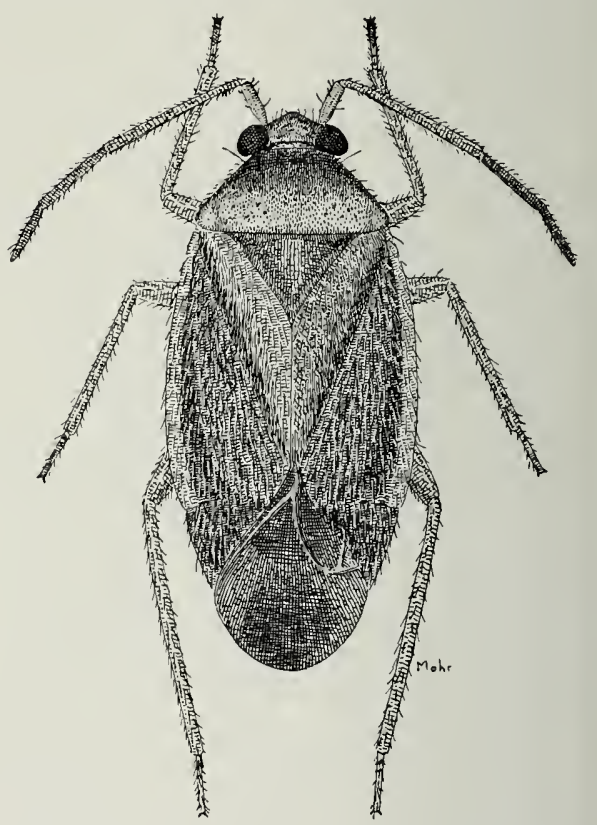

Fig. 135.-Ceratocapsus pumilus, ๆ.

Metropolis, Monticello, Muncie, Pike, Putnam, Savanna, Seymour, Starved Rock State Park, Topeka, Vienna, Walnut Prairie, West Union, White Heath, York.

\section{Ceratocapsus vicinus Knight}

Ceratocapsus vicinus Knight (1923d, p. 529)

MALE.-Length 3.40 , width 1.40 . Antennae with first segment yellowish, frequently a red mark on ventral surface; second yellowish, brownish at apex; third reddish brown; fourth reddish brown. Pronotum impunctate, alutaceous, sparsely clothed with fine, yellowish pubescence. Scutellum, clavus and basal half of corium covered with closely appressed, silvery, scalelike pubescence. General color fulvous to reddish; scutellum and apical half of hemelytra dark brownish to blackish; legs yellowish; membrane pale, apical half fus- 
cous. Genital claspers distinctive, fig. 134.

Fenale.-Length 3.60, width 1.60. More robust than male, but very similar in color and pubescence.

Known Distribution. - Illinois, New Jersey, New York.

Illinois Records. - Ashley: Aug. 7, 1917, 1 \%. Meredosia: Aug. 22, 1917, sand pit, 1 ㅇ.

\section{Ceratocapsus sericus Knight}

Ceralocapsus sericus Knight (1923d, p. 530).

Male. - Length 3.90, width 1.56. Dorsum clothed with rather sparsely set, erect, yellowish, pilose hairs; scutellum, clavus and inner half of corium covered with closely appressed, sericeous or scalelike pubescence. General color very dark brown; legs and antennae yellowish; third and fourth antennal segments dark reddish brown. Membrane and veins uniformly pale fuscous, a small clear spot bordering apex of cuneus. Genital claspers distinctive, fig. 134.

FeMale.-Length 4.10, width 1.66. Very similar to male in color and pubescence.

Known Distribution.-Illinois, Michigan, New Jersey, New York, Pennsylvania, Wisconsin.

Illinois Records. - Galesburg: $1 \hat{o}$; July 16, 1892, 1 ㅇ.

\section{Ceratocapsus incisus Krnight}

Ceratocapsus incisus Knight (1923d, p. 532).

MaLE.-Length 3.70, width 1.50. Antennae with second segment slender at base and gradually thickened toward apex; third brownish, nearly equal in thickness to second segment; fourth brownish, equal in thickness to third segment. Disk with fine, black punctures similar to those on clavus and corium. Dorsum clothed with prominent, suberect, yellowish pubescence, intermixed on scutellum, clavus and corium with closely appressed, silvery, sericeous or scalelike pubescence. General color very dark brown, more yellowish on clavus, embolium and base of pronotum: membrane and veins pale fumate, apical half fuscous, margins slightly paler. Legs yellowish to greenish; femora scarcely darker. Genital claspers distinctive, fig. 134 .

Fenale.-Length 4.00, width 1.70 . Antennae with second segment slender, slightly thicker apically, yellowish; third brownish, paler at base; fourth brownish. Very simi- lar to male in pubescence and coloration.

Food Plants.-Occurs on willow (Salix sp.), alder (Alnus rugosa) and hornbeam (Carpinus caroliniana).

KNown Distribution. - Illinois, Iowa, New York, Ohio.

Illinois Records.-Northern IlLINOIS: 1 ㅇ. Eichorn: June 24, 1932, Hicks Branch, on Alnus rugosa, Ross, Dozier \& Park, 1 \%. Elizabethtown: June 22-24, 1932, Ross, Dozier \& Park, 2 o , 2 ․ HaRRISBURG: June 25, 1932, on Carpinus caroliniana, Ross, Dozier \& Park, $6 \hat{\jmath}, 7 \%$. KARNAK: June 14, 1934, DeLong \& Ross, $+\delta$.

\section{Ceratocapsus husseyi Knight}

Ceratocapsus husseyi Knight (1930c, p. 196). MaLE.-Length 4.00, width 1.57. Antennae with second segment yellowish, fuscous on apical one-third; third fuscous with a narrow yellowish area at base; fourth fuscous. Pronotum impunctate, alutaceous. Dorsum clothed with two types of pubescence; sparsely set with rather long, erect hairs; and scutellum, clavus and corium also bearing closely appressed, silvery, scalelike hairs. General color very dark brown; inner half of clavus, narrow area at base of corium, entire emholium, and base of pronotum, yellowish. Membrane uniformly fuscous, paler within areoles and on areas bordering cuneus. Genital claspers distinctive, fig. 13t, differing from sericus Knight particularly in left clasper.

Fenale.-Length 4.40, width 1.60. Very similar to male in color and pubescence.

Known Distribution. - Illinois and Michigan.

Illinois Record.-Galesburg: July 16, 1892. Stromberg, 2 .

\section{Ceratocapsus uniformis Knight} 147).

Ceratocapsus uniformis Knight (1927c, p.

The dorsum of this species is more sparsely covered with yellowish, simple pubescence than in pumilus (Uhler), and the pubescence in uniformis is intermixed with silvery, sericeous hairs; the punctation in uniformis is stronger and more distinct than in pumilus.

Male.-Length 3.00, width 1.50. Rostrum reaching middle of hind coxae. Antennae yellowish, with fourth segment brownish. General color uniformly dark reddish 
brown; darker at anterior half of pronotum and somewhat paler at basal margin. Membrane and veins uniformly fuscous, a pale spot present near apex of cuneus. Genital claspers distinctive, fig. 134.

Female.-Length 3.00, width 1.50. Similar to male in punctation, pubescence and coloration.

Food Plant.-Collected on walnut ( $J u$ glans nigra).

Known Distribution.-District of Columbia, Illinois, Maryland, Mississippi, Missouri, Ohio, Virginia, West Virginia.

Illinois Records. - DE Soto: July 28, 1930, Knight \& Ross, $1 \hat{\delta}$. Grafton: July 20, 1932, on Juglans nigra, Ross \& Dozier, 2 \&, 2 o. Metropolis: July 26, 1930, Knight \& Ross, 1 .

\section{Ceratocapsus camelus Knight}

Ceratocapsus camelus Knight (1930c, p. 187). Male.-Length 3.80, width 1.08. Form slender. Head width 0.73 ; vertex 0.38 , convexly rounded, basal edge thin, slightly overlapping collar. Pronotum, length 0.82 , width at base 1.08 ; nearly campanulate in form, lateral margins sulcate, coxal clefts visible from above; disk strongly convex, smooth, shining; calli scarcely evident. General color dark brown to almost black; pronotal disk and cuneus darker and shining; ostiolar peritreme white, somewhat protruding laterally. Hemelytra dark brown, translucent, strongly shining, emboliar margins sinuate; a silvery, sericeous, pubescent band extending across middle of corium and clavus near apex; also with similar pubescence at base of clavus and across middle of scutellum; scutellum, clavus and inner angle of corium beset with several erect, moderately long, yellowish, bristlelike hairs; cuneus scarcely deflexed, uniformly very dark brown. Membrane uniformly dark fuscous, area bordering cuneus, and spaces between and within larger areoles, pale. Genital structures distinctive, right clasper bifurcate, each half curving in a semicircle, tips nearly in contact, fig. 134.

FEMALE. - Length 2.80; brachypterous, width across abdomen 1.12. Head width 0.80 , vertex 0.52 ; large, eyes rather small, frons, vertex and tylus forming an arcuate line as viewed from side. Antennae, first segment, length 0.22 , pale brownish; second, 1.77, becoming progressively larger from base to apex, very dark brown. Pronotum, length 0.65 , width at base 0.67 ; disk strongly convex, base strongly depressed below level of anterior margin, sides rounded and slightly sinuate, coxal clefts visible from above. Scutellum depressed, small, triangular, mesoscutum visible, sharply declivent. Hemelytra abbreviated, reaching to middle of abdomen, depressed at base, corium tumidly convex on apical area, shining, apical and inner margins thickly clothed with silvery, sericeous pubescence and also beset with several erect, fine, long hairs; cuneus and membrane absent. Basal abdominal sternite with a frosted spot just posterior to each hind coxa.

Known Distribution.-Illinois.

Illinois Records.-Algoneuin: July 17, 1896, 1 specimen. Urbana: Aug. 21, 1926, Vera Smith, $1 \hat{\delta}, 1 \%$.

\section{Ceratocapsus complicatus Knight} 148).

Ceratocapsus complicatus Knight (1927c, p.

Male.-Length 3.80, width 1.50. Antennae with first segment yellowish, a red mark near base; second yellowish; third redish brown; fourth dark reddish. General color and punctation nearly as in pumilus (Uhler), but dorsum is clothed with silvery, sericeous pubescence sparsely intermixed with long, erect, pilose hairs and usually has two fuscous spots visible on the pronotal disk, one behind each callus. Craspers as in fig. 134.

Female.-Length 3.10, width 1.40. Very similar to male in pubescence, puncturation and coloration.

Known Distribution.-Florida, Illinois, Maryland, Mississippi, Missouri, Texas, Virginia.

Illinois Records. - - Harrisburg: June 15, 1934, DeLong \& Ross, 1 \% Havana: Aug. 30, 1917, 1 ô. Herod: Aug. 4, 1934, DeLong \& Ross, 1 ô. Quincy: Aug. 11, 1889, C. A. Hart, 2 oे.

\section{Ceratocapsus quadrispiculus Knight}

Ceratocapsus quadrispiculus Knight (1927c, p. 148).

This species is allied to uniformis Knight, and is very similar to it in size and coloration, but differs in having strongly arcuate emboliar margins, a somewhat shorter rostrum and a uniformly pale, smoky membrane; the genital claspers are distinctive, fig. 134 . 
MaLe.-Length 2.90, width 1.50. Antennae yellowish; first segment with red mark near base; fourth segment reddish. Dorsum with irregular, fine, black punctations; clothed with prominent, erect, pale hairs intermixed with appressed, silvery, sericeous pubescence that appears to arise from punctures on hemelytra and scutellum. General color dark reddish brown, more blackish on scutellum and on anterior portion of pronotum; punctures black; legs uniformly yellowish; membrane and veins uniformly pale dusky.

Female.-Length 3.20 , width 1.50 . More robust than male, but very similar in pubescence and coloration.

Food Plant. - Collected on hornbeam (Carpinus caroliniana).

Known Distribution.-Illinois, Louisiana, Texas.

Illinois Records. - Dongola: July 2, 1916, 1 ô. Herod: July 24, 1930, on Carpinus sp., Knight \& Ross, 2 oे, 3 q.

\section{Ceratocapsus digitulus Knight} 533).

Ceratocapsus digitulus Knight (1923d, p.

Male.-Length 3.40, width 1.60. Antennae with first segment yellowish; second yellowish, thickened on apical half, but not attaining thickness of first segment; third scarcely equal in thickness to second segment, yellowish, apical half brownish; fourth brownish. Pronotum punctate, dark brownish, almost black on calli. Dorsum rather densely clothed with erect, somewhat bristly pubescence, intermixed on scutellum and hemelytra with closely appressed, silvery, scalelike pubescence. General color dark brown with a reddish tinge; cuneus reddish brown, embolium translucent yellowish; legs greenish or yellowish; membrane uniformly fusco-brownish. scarcely paler on areas bordering cuneus. Genital claspers distinctive, fig. 134 .

Fexale.-Length 3.50, width 1.70. Antennae with second segment slender, gradually thickened apically; third nearly equal in thickness to that of apex of second segment, yellowish to brownish; fourth brownish. Hemelytra more arcuate than in male, but pubescence, punctation and coloration very similar.

Known Distribution.-Illinois, Maryland, Massachusetts, New York, North Carolina, Ontario, Virginia.
Illinois Records.-Durors: July 2, 1909. beating from trees, 1 q. VIENNA: June 14 , 1934, DeLong \& Ross, 2 t.

\section{Ceratocapsus setosus Reuter}

Ceratocapsus setosus Reuter $(1909$, p. 70$)$.

Male.-Length 2.80, width 1.10. Antennae with first segment yellowish, a red mark near base; second yellowish; third fuscous, paler at base; fourth fuscous. Pronotum with disk finely punctate. Dorsum clothed with sparsely set, erect, pilose hairs, intermixed on hemelytra and scutellum with closely appressed, silvery, sericeous pubescence. General color dark brownish, shining; head paler; legs yellowish. Genital claspers distinctive, fig. 134.

FeMale.-Length 2.60, width 1.43 ; brachypterous, ovate. Hemelytra rounded at apex, membrane absent or only a mere trace of it remaining at anal angle. Color, puncturation and pubescence similar to those of male. Macropterous females occur in southern states, but appear rarer farther north.

FOOD Plants. - Occurs frequently on ferns.

Known Distribution.-District of Columbia, Georgia, Illinois, Indiana, Kentucky, Maryland, Mississippi, New Jersey, Ohio, Pennsylvania, Virginia.

Illinois Records.-Eleven males and two females, taken May 19 to Aug. 23, are from Anna, Bluff Springs, Danville, Dongola, Elizabeth, Hardin, Herod, Muncie, Rockton. Union County State Forest, Urbana.

\section{Ceratocapsus fuscinus Knight}

Ceratocapsus fuscinus Knight (1923d, p. 531).

MALE.-Length 3.70, width 1.61. Antennae with first segment yellow, a red spot on inner side at base; second slender at base and becoming gradually thicker apically, attaining thickness of first segment, yellowish; third yellowish, becoming fuscous on apical half; fourth equal in thickness to third segment, fusco-brownish. Dorsum punctate, clothed with suberect, yellowish pubescence, this pubescence longer and more prominent than in pumilus (Uhler) and intermixed with closely appressed, silvery, sericeous pubescence. General color yellowish brown to very dark brown, almost black; calli and anterior portion of pronotum usually blackish; hemelytra yellowish brown, often infuscated; cuneus reddish. Legs yellowish; 
femora reddish on apical half; membrane pale fumate, a distinct fuscous cloud occupying middle of apical half. Genital claspers distinctive, fig. 134 , both right and left claspers composed of three prongs each.

Female.-Length 3.60, width 1.60. Very similar to male in pubescence and punctation, but emboliar margins more strongly arcuate; pronotum yellowish, only calli and a ray across top of coxal cleft blackish; venter reddish to brownish.

HaB1Ts.-Occurs on willows (Salix nigra and $S$. amygdaloides). Evidently predacious in habits.

Known Distribution.-District of Columbia, Illinois, Iowa, Louisiana, Maryland, Minnesota, Mississippi, Missouri, New York, Ohio.

Illinois Records.-Forty males, $49 \mathrm{fe}-$ males and 1 nymph, taken May 25 to Aug. 30 , are from Algonquin, Alton, Antioch, Eichorn, Galesburg, Golconda, Grand Detour, Grand Tower, Havana, Homer Park, Kampsville, Lawrenceville, Meredosia, Metropolis, Monticello, Muncie, Paxton, Putnam, Quincy, St. Joseph, Savanna, Topeka, Urbana, West Union.

\section{Ceratocapsus decurvatus Knight} 194).

Ceratocapsus decurvatus Knight (1930c, p.

Male.-Length 3.70, width 1.64. Antennae pale yellowish, segments three and four reddish. Dorsum punctate, clothed with prominent, nearly erect, yellowish pubescence intermixed on scutellum and hemelytra with silvery, sericeous pubescence; more strongly pubescent than pumilus (Uhler), although fuscous punctures on dorsum are very similar. General color yellowish to brownish, calli and propleura dark brown; cuneus reddish, except on outer margin; legs uniformly yellowish; membrane uniformly fuscous. Genital claspers distinctive for species, fig. 134.

Femal.e.-Length 3.80 , width 0.88 . Very similar to male in pubescence, punctation and coloration.

HaBITs.-Predacious; collected on alder (Alnus rugosa).

Known Distribution.-Illinois, Maryland, New York, Pennsylvania.

Illinois Records.-Eichorn: June 24, 1932, on Alnus rugosa, Ross, Dozier \& Park, 3 of, 1 q ; June 13, 1934, DeLong \& Ross, 6 ô, 1 우.

\section{SYSTELLONOTINI}

\section{KEY TO GENERA}

Scutellum conically produced, fig. 137; hemelytra with a transverse white fascia across middle of clavus and base of corium..... Cyrtopel tocoris, p. 117

Scutellum only moderately convex, fig. 136; hemelytra with a pale spot on clavus, or white spot at base of corium, but, in either case, these white marks not forming a complete transverse fascia...

Sericophanes, p. 116

\section{Sericophanes Reuter}

\section{Sericophanes heidemanni Poppius}

Sericophanes ocellatus Osborn (1898, p. 238) not Reuter.

Sericophanes heidemanni Poppius (1914b, p. 260).

Sericophanes noctuans Knight (1917a, p. 4).

MaLE.-Length 3.40, width 1.00. General color dark chestnut to black. Legs yellowish brown; tibiae darker, posterior coxae pale; antennae yellowish brown, darker on third and fourth segments, fourth segment slightly compressed. Hemelytra velvety brown, darker at base of clavus; two trans-

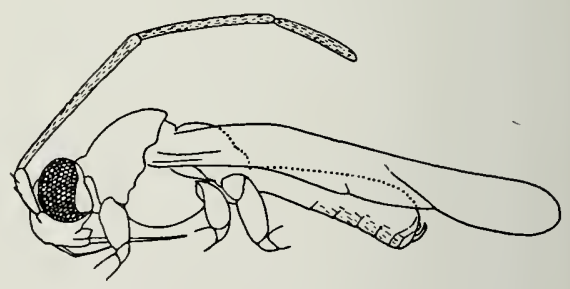

Fig. 136.-Sericophanes keidemanni.

verse, irregular, silvery bars over brown; a cream-colored round spot on clavus just beyond scutellum; membrane light smoky, pale areas bordering apical third of cuneus.

Fenale.-Brachypterous. Length 3.10, width of abdomen 0.97. Antlike in form. General color yellowish brown. Prothorax subglobose; hemelytra much reduced, reaching only base of third abdominal tergite; cream-colored spot present just beyond scutellum; abdomen subglobose, pleural margins prominent, fourth to seventh segments dark brownish to piceous; sternites paler on areas bordering ovipositor.

Habits.-This species, fig. 136, has been found to occur on grassy ridges. Males are 
frequently collected at light. In New York, Dr. C. P. Alexander in letter reports this species as flying up in large numbers from the grass after sundown. In Iowa I found this species abundant in closely cropped pasture land where the little brown ants Lasius alienus var. americanus Emery were abundant.

Known Distribution.-Connecticut, Mllinois, Iowa, Maryland, Massachusetts, Michigan, Minnesota, Montana, New York, North Carolina, Ohio, Ontario, Pennsylvania, South Dakota, Utah, Washington, Wyoming.

Illinois Records.-Seventeen males, taken May 10 to Aug. 22, are from Algonquin, Chicago, Oak Lawn, Palos Park, Urbana, Willow Springs.

\section{Cyrtopeltocoris Reuter}

Cyrtopeltocoris illini new species

This species is to be distinguished from allied species by the pointed, conical development of the scutellum, fig. 137.

Male.-Fig. 137. Length 3.60, width 0.91 . Head width 0.75 , vertex 0.52 ; eyes scarcely raised above contour of frons, a sharp carina at base of vertex. Rostrum, length 1.40 , reaching to middle of hind coxae. Antennae, first segment, length 0.28 , pale to white; second, 1.25, nearly cylindrical, fuscous brown, with fine, pale pubescence; third, 0.86, equal in thickness to second segment, dark brown; fourth, 0.60 , thickness equal to that of preceding segments, dark brown. Pronotum, length 0.73 , width at base 0.95 , disk strongly convex on basal half, collar distinctly narrowed, not equal to width of vertex. Scutellum remarkably developed into a vertical cone with an acuminate point, mesoscutum broadly exposed and sloping downward to base of scutellum. General color medium brown to dark brown, smooth or only very minutely punctate, mod-

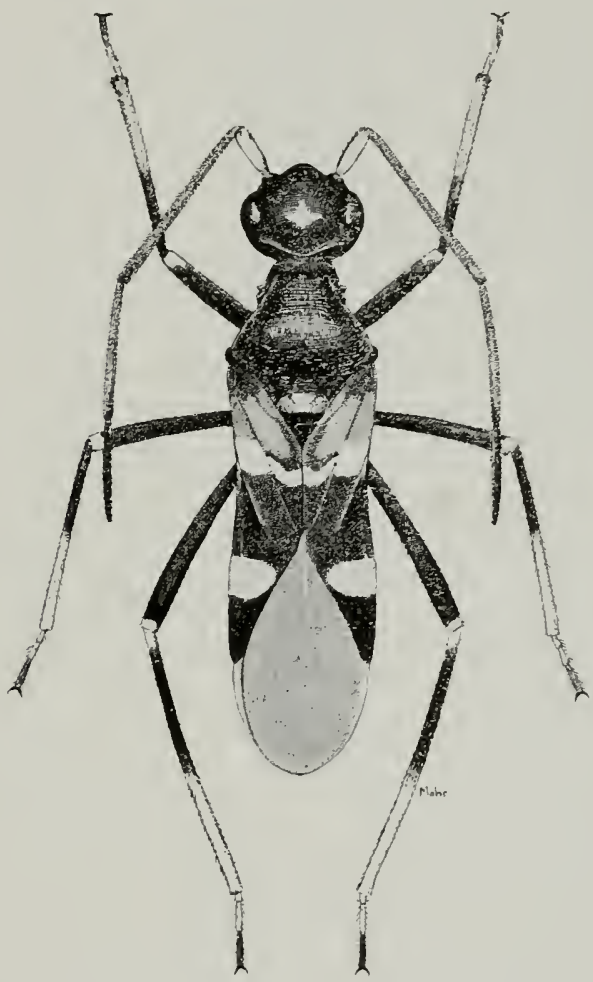

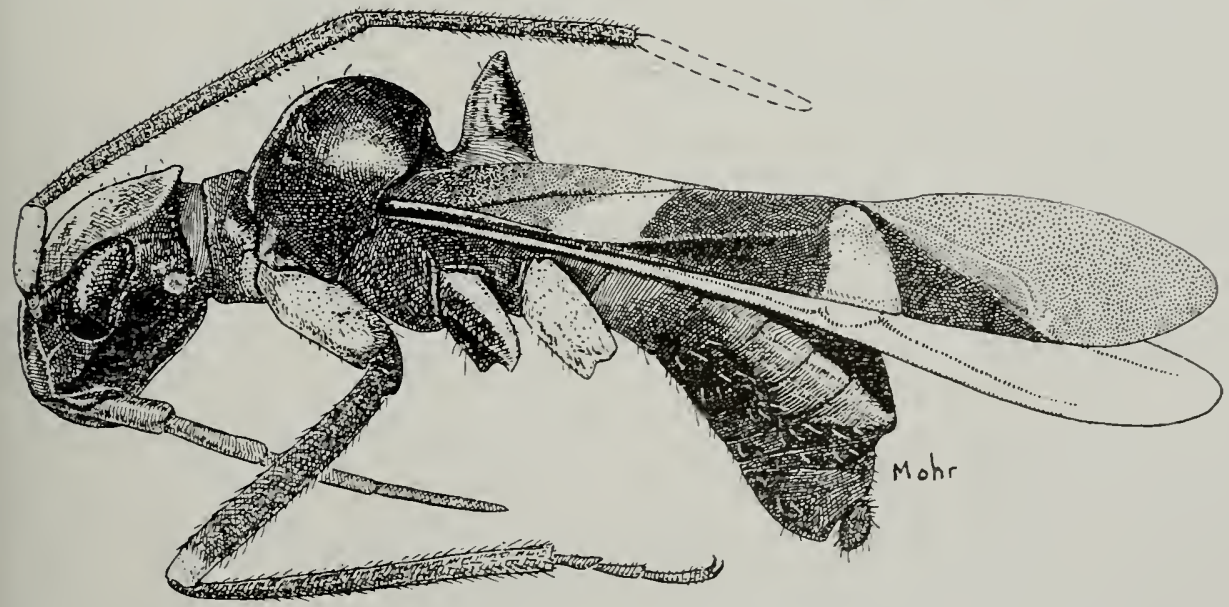

Fig. 137.-- Cyrtopeltocoris illini, dorsal and lateral aspects. 
erately shining; with sparse and very fine, pale pubescence. Hemelytra slightly constricted near middle, dark brown, strongly shining; clavus paler brown on basal half, crossed on apical half by a clear white band that becomes wider on corium and reaches costal margin; a white spot present on cori-
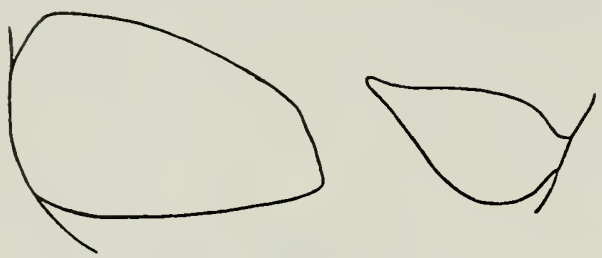

Fig. 138.-Cyrtopeltocoris illini, male claspers.

um bordering base of cuneus; membrane uniformly fuscous, slightly paler at tip of cuneus. Legs mostly medium brown to dark brown; coxae white, middle pair reddish brown at base; apex of hind femora and base of tibiae pale; tibiae paler on apical onethird. Genital segment distinctive, fig. 138.

Holotype, male — Dolson, Ill., Rocky Branch: June 25, 1932, Frison \& Mohr.

Paratypes.-Illixois.-Geff: June 12, 1934, DeLong \& Ross, 1 o . Morton: July 22, 1928, A. R. Park, 1 o . Urbaxa: July 10, 1940, in building, C. O. Mohr, $1 \hat{\delta}$.

Missouri.-ST. Louis: June 25, 1939, R. C. Froeschner, $1 \delta$.

\section{PILOPHORINI}

\section{KEY TO GENERA}

1. Vertex not compressed posteriorly, fig. 139 ; length of first antennal segment nearly equaling width of head; anterior half of pronotum constricted, its sides at that point nearly parallel

Pseudoxenetus, p. 118

Vertex compressed posteriorly, slightly overlapping anterior edge of pronotum, fig. 140; length of first antennal segment not exceeding width of vertex................. 2

2. Second antennal segment scarcely thickened toward apex; width of head across eyes equal to or greater than posterior width of pronotum, fig. 140; hemelytra with emboliar margins parallel. ... Alepidia, p. 119 Second antennal segment thickened toward apex; width of head less than width of posterior margin of pronotum, fig. $141 \ldots \ldots \ldots \ldots \ldots \ldots .3$

3. Lateral margins of hemelytra slightly constricted and recurved ventrad, bearing white pubescent bands, fig. $141 \ldots \ldots \ldots$ Pilophorus, p. 119

Lateral margins of hemelytra slightly arcuate, bearing silvery pubescence, but this pubescence not forming distinct bands......Alepidiella, p. 119

\section{Pseudoxenetus Reuter}

\section{KEY TO SPECIES}

Entire pronotum and prosternum dark brown or black......scutellatus, p. 118 Disk of pronotum and prosternum orange or reddish...... regalis, p. 119

\section{Pseudoxenetus scutellatus (Uhler)}

Xenetus scutellatus Uhler (1890, p. 81).

Adults.-Fig. 139. Length 6.50, width 1.20. Black; scutellum yellow, except for

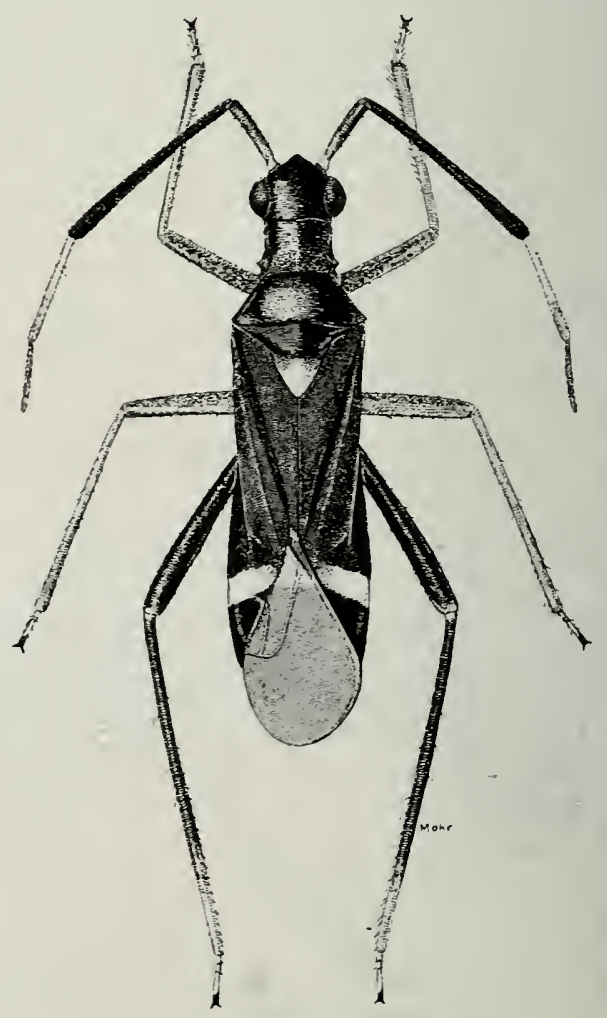

Fig. 139.-Pseudoxenetus scutellatus. 
narrow area at base; cuneus with white translucent band at base; posterior coxae pale, legs mostly dark brownish, anterior and middle tibiae yellowish.

Food Plants.-Oaks (Quercus muhlenbergii, $Q$. rubra and $Q$. alba) ; occasionally ash (Fraxinus sp.). A single specimen was taken on apple in Illinois.

Known Distribution.-Connecticut, Illinois, Maryland, Massachusetts, Minnesota, New York, North Carolina, Ohio, Ontario, Pennsylvania, Virginia.

Illinois Records.-Thirty-nine males and 38 females, taken May 9 to July 8 , are from Antioch, Bluff Springs, Champaign, Dongola, Dubois, Elizabeth, Fox Lake, Galesburg, Glen Ellyn, Grand Detour, Havana, Keithsburg, Meredosia, Muncie, Oregon, St. Anne, Summerfield, Urbana, Willow Springs.

\section{Pseudoxenetus regalis (Uhler)}

Yenetus regalis Uhler $(1890$, p. 80$)$.

Adults.-Length 6.50, width 2.00. General color black; very similar to scutellatus (Uhler), but with basal half of pronotum, sternum and pleura largely red.

Food Plants.-Usually live oak (Quercus virginiana); collected also on other oaks (Q. alba, Q. rubra and $Q$. marilandica) in Illinois.

Known Distribution.-Florida, Georgia, Illinois, Maryland, Mississippi, North Carolina, Oklahoma.

Illinois Records.-Ten males and 11 females, taken May 15 to June 15, are from Dubois, Galesburg, Havana, Keithsburg, Meredosia, St. Anne.

\section{Alepidia Reuter}

\section{Alepidia gracilis (Uhler)}

Pilophorus gracilis Uhler (1895, p. 42).

ADults.-Fig. 140. Length 4.20, width 1.30. General color black, slightly shining; hemelytra ferruginous black, membrane pale fuscous; a darker spot on either side covering apex of brachium; pale area present bordering cuneus; antennae and legs pale yellowish; femora sometimes darkened; abdomen with a patch of silvery scales on either side near base.

Host Plants.-Red pine (Pinus resinosa), Scotch pine (P. sylvestris) and Austrian pine ( $P$. nigra var. austriaca).
A single female of this spceies from Galena shows a greater development of spots of silver pubescence on the hemelytra and is referable to the variety squamosa Knight (1926d, p. 26).

Known Distribution.-Alabama, Colorado, District of Columbia, Florida, Geor-

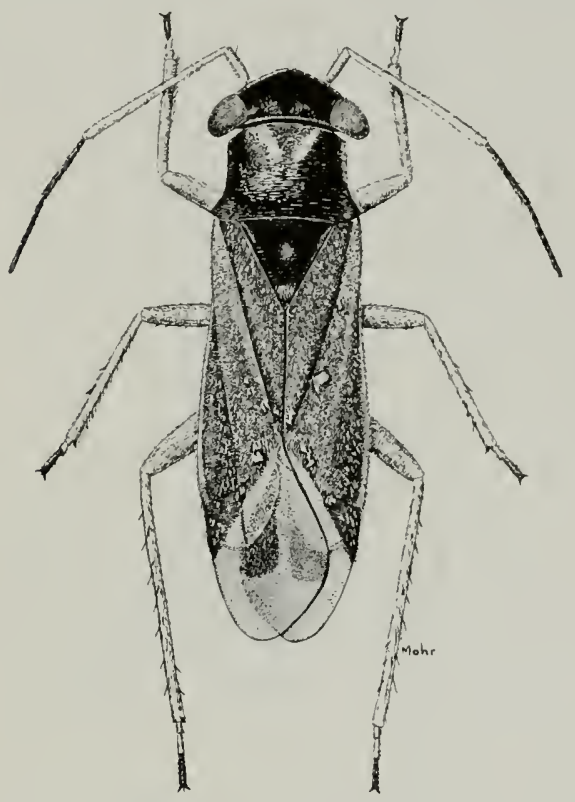

Fig. 140.- Alepidia gracilis.

gia, Illinois, Indiana, Iowa, Maryland, Massachusetts, New Jersey, New York, West Virginia.

Illinois Records. - Galena: June 30 , 1932, on Austrian pine, Dozier \& Mohr, 1 $\$$. Galesburg: July 23, 1893, Scotch pine, 6 \%. Urbana: July 20, 1889, sweepings, Hart \& Terrill, 5 of. 1 \% ; July 21, 1889 , sweepings in forest, C. A. Hart, $2 \delta$, 1 ․

\section{Alepidiella Poppius}

No Illinois species; Alepidiella heide manni Poppius is known from District of Columbia, Maryland, Oklahoma; occurs on scrub pine (Pinus virginiana).

\section{Pilophorus Westwood}

\section{KEY TO SPECIES}

1. Hemelytra polished over entire width behind posterior silvery line ..... 2 
Hemelytra behind posterior silvery line polished on area exterior to radial vein only............ 8

2. Hemelytra with erect, short, black bristles................. 3

Hemelytra clothed only with fine, recumbent pubescence, this pubescence sometimes black, but not erect and bristlelike...........4

3. Third antennal segment black, nearly as thick as first segment.........

vanduzeei, p. 120

Third antennal segment pale, with apical half infuscated, slender, scarcely thicker than fourth segment...........uhleri, p. 122

4. Pronotum with silvery, silky and tomentose pubescence; length $5.00 \ldots$

strobicola, p. 122

Pronotum without silvery, silky and tomentose pubescence......... 5

5. Length 4.50 ; posterior silvery line not interrupted on corium, but slightly dislocated at claval suture; second antennal segment gradually thickened toward apex..amoenus, p. 122

Length not exceeding 3.90; posterior silvery line interrupted on corium but not dislocated at claval suture. 6

6. Second antennal segment strongly clavate on apical one-third........

laetus, p. 121

Second antennal segment gradually thickened from middle to apex.... 7

7. Third antennal segment dark brown; fourth segment pale. .taxodii, p. 121

Third antennal segment pale with apex darkened; fourth segment fuscous..........juniperi, p. 123

8. Transverse silvery line of clavus and corium continuous and straight, that of clavus bent slightly forward but never disconnected. .

perplexus, p. 121

Transverse silvery line of clavus and corium dislocated at claval suture or on corium at radial vein.

9. Posterior silvery band widely dislocated at radial vein, inner portion set forward and forming a straight, transverse line with that on clavus; length $3.20 \ldots$ geminus, p. 122

Posterior silvery band not widely dislocated on corium at radial vein, of ten sloping forward to join band on clavus, but not forming a straight, transverse line with claval

band................... 10

10. Hemelytra clothed with fine, soft, recumbent pubescence only.......11

Hemelytra bearing sparsely set, erect, short, stiff hairs intermixed with soft, recumbent pubescence......12

11. Length of second antennal segment less than distance between tip of tylus and posterior margin of pronotum; length 3.50 . walshii, p. 123

Length of second antennal segment equal to or slightly greater than distance between tip of tylus and posterior margin of pronotum; length $4.00 \ldots \ldots \ldots$ brunneus, p. 123

12. Length of second antennal segment distinctly greater than distance between tip of tylus and posterior margin of pronotum; clavus with a distinctly darker area bordering scutellum and commissure; length 4.50$5.00 \ldots \ldots \ldots$. . . . . . 124

Length of second antennal segment equal to or only slightly greater than distance between tip of tylus and posterior margin of pronotum; clavus same brown color as corium; length $3.70-3.90 \ldots$ setiger, p. 124

\section{Pilophorus vanduzeei Knight}

Pilophorus vanduzeei Knight (1923d, p. 540).

MALE.-Length 5.00, width 1.66. Head width 1.25 , vertex 0.66 , from tip of tylus to basal margin of head 1.11; sharp basal margin of vertex beset with six black bristles, front sparsely clothed with silvery, deciduous and scalelike hairs, which are interspersed with erect bristles. Rostrum, length 2.27, scarcely attaining hind margin of middle coxae. Antennae, first segment, length 0.44 , thickness 0.11 ; second, length 2.22, gradually thickened from base toward apex ( 0.15 thick), dark brownish black, clothed with short black pubescence; third, length 0.80 , thickness 0.08 , uniformly black; fourth, length 0.72 , pale, infuscated apically. Pronotum, length 0.94 , width at base 1.53 , anterior angles 0.83 ; anterior half of disk sparsely clothed with silvery, deciduous pubescence quite similar to that on front of head. Scutellum with apical half and slender lateral margins flat, abruptly convex on basal half but flattened basally, flattened apical half more or less covered with silvery, scalelike pubescence. Hemelytra, dark fus- 
co-brownish, opaque anterior to posterior silvery line, basal half with a silvery sheen apparent in certain lights; beset with erect, short, black bristles; posterior silvery line nearly straight, slender, behind this distinctly polished, apex of clavus included. Membrane uniformly darkened with fuscous, an opaque black cloud bordering apex of larger areole. Legs uniformly brownish black, a pale spot on anterior aspect of front coxae near base; hind tibiae strongly flattened and distinctly curved. Venter with a patch of silvery, scalelike pubescence laterally on third segment.

Female.-Length 5.30, width 1.80 ; very similar to the male, but third antennal segment perceptibly thicker $(0.10$ thick $)$, nearly equal to thickness of first segment.

Habits.-Occurs on pines (Pinus sylvestris and P. resinosa).

Knowy Distribution. - Alabama, Illinois, Iowa, Maryland, Massachusetts, Minnesota, New Jersey, New York, Pennsylvania.

Illinois Records.-Antioch: July 5-7, 1932, T. H. Frison, et al., 1 . Grand Detour: July 2, 1932, Castle Rock, Dozier \& Mohr, 1 o. Staried Rock State Park: July 14, 1932, on Scotch pine, Dozier \& Park, 3 ô. Urbana: June 20, 1932, T. H. Frison, 1 .

\section{Pilophorus laetus Van Duzee}

Pilophorus laetus Van Duzee (1918, p. 294).

Not taken in Illinois; breeds on scrub pine (Pinus virginiana). Known from Alabama, District of Columbia, Maryland, Massachusetts, New York, Tennessee, Virginia.

\section{Pilophorus perplexus Douglas \& Scott}

Pilophorus perplexus Douglas \& Scott (1875, p. 101).

Not taken in Illinois; known from Connecticut, New York, Nova Scotia, Ontario.

\section{Pilophorus taxodii new species}

This species is allied to juniperi Knight, but is distinguished by the dark third antennal segment and pale fourth segment.

MALE.-Fig. 1+1. Length 3.70, width 1.30. Head width 1.03 , vertex 0.52 . Rostrum, length 1.56, dark brown, reaching to posterior margin of middle coxae. Antennae, first segment, length 0.30 , yellowish brown; second, 1.25, yellowish brown, darker on apex, clothed with fine, short, black pubescence; third, 0.47 , uniformly brown; fourth, 0.52 , pale. Pronotum, length 0.74 , width at base 1.12 , very dark brown, paler on anterior half, finely rugulose. Mesoscutum and scutellum very dark brown, disk of scutellum strongly convex; bordered with silvery, scalelike pubescence. Hemelytra fulvous to brown, hut black behind posterior sil-

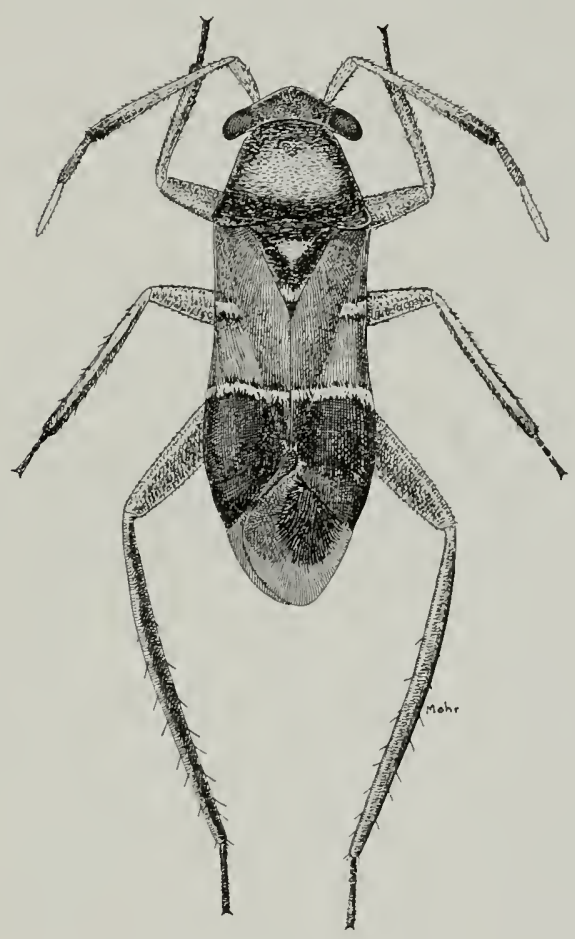

Fig. 141.-Pilnphorus taxodii.

very line; clothed with fine, short, recumbent, black pubescence; posterior silvery line transverse, nearly straight, not interrupted; basal silvery line restricted to corium and embolium; surface behind posterior silvery line polished, black; pubescence fine, black, cuneus very similar; membrane pale fuscous, an opaque, dull, very dark brown spot covering larger areole and an equal area extending toward middle of membrane. Legs yellowish brown; hind tibiae dark brown, strongly compressed, edges carinate, spines rather short; tarsi fuscous. Venter very dark brown, polished, fulvous brown at base and with a patch of silvery scales on either side at margin of dark color. 
Female.-Length 3.90 , width 1.30 . Slightly more robust than male, but very similar in color and pubescence.

Host Plant.-Cypress (Taxodium distichum).

Holotype, male.-Karnak, Ill.: June 23, 1932, on cypress, Ross, Dozier \& Park.

Allotype, female.-Same data as for holotype.

Paratypes.-Illinois.-Same data as for holotype, $7 \hat{\delta}, 2$.. Horseshoe LAKE: July 11, 1935, on cypress, DeLong \& Ross, 3 , 4 ㅇ.

\section{Pilophorus geminus Knight}

Pilophorus geminus Knight (1926d, p. 22).

Not taken in Illinois; known only from Minnesota and $W$ isconsin.

\section{Pilophorus strobicola Knight}

Pilophorus strobicola Knight (1926d, p. 19).

MaLE.-Length 5.10. Head width 1.06, vertex 0.50 . Antennae, first segment, length 0.39 ; second, 1.94, gradually thickened apically ( 0.13 thick), dark fusco-brownish, apical half black; third, 0.66 , pale fuscous at apex; fourth, 0.61, pale fuscous. Front of head and pronotum clothed with fine, silvery pubescence, that on hemelytra more nearly golden; scutellum clothed with silvery, scalelike pubescence, this pubescence denser at basal angles and apex; hemelytra polished behind posterior silvery line, but rather thickly clothed with recumbent golden pubescence; posterior tibiae distinctly compressed; venter with an oblique patch of silvery, scalelike pubescence on either side of third to sixth sternites.

Female. - Length 5.00, width 1.61. Length of second antennal segment, 2.19, greatest thickness 0.17 , more distinctly thickened on apical one-third than in male.

Host Plants.-White pine (Pinus strobus) and Scotch pine (P. sylvestris), but may be in part predacious.

Known Distribution. - Illinois, Iowa, Minnesota, New Hampshire, New York, North Carolina, Ohio.

Illinois Records.-BEACH: Aug. 7, 1935, Delong \& Ross, $1 \hat{\delta}, 1$. Galesburg: July 23, 1893, on Scotch pine, $1 \hat{\delta}, 3 q$. Quincy: Aug. 13, 1889, in street, 1 of. Urbana: July 20,1889, sweepings, Hart \& Terrill, 1 \% ; June 20, 1892, swept from bluegrass, F. McElfresh, 1 o . White
Pines Forest State Park: July 4, 1932, on Pinus strobus, Dozier \& Mohr, $29 \hat{\sigma}$, 15 ㅇ ; July 12, 1934, DeLong \& Ross, 5 ô, 8 ㅇ.

\section{Pilophorus amoenus Uhler}

Pilophorus amoenus Uhler (1887b, p. 30).

Male.-Length 5.00, width 1.64. Antennae, first segment, length 0.39 , fuscous; second, 1.83 , greatest thickness 0.12 , gradually thickened from base to apex, black, fusco-brownish on basal half; third, length 0.72 , slender, pale; fourth, length 0.64 , pale, dusky on apical half. Hemelytra anterior to posterior silvery line cinnamon fulvous in color; distad of this, polished and piceous; posterior silvery line nearly straight, not inter rupted on corium. Hind tibiae distinctly compressed.

Female.-Length 4.80 , width 1.70 ; very similar to male in structure and coloration.

Host Plant.-Scrub pine (Pinus virginiana).

Known Distribution.-District of Columbia, Georgia, Illinois, Maryland, Massachusetts, New Jersey, New York, North Carolina, Ohio, Pennsylvania, Virginia.

Illinois Record.-Illinois: 1 ㅇ․

\section{Pilophorus uhleri Knight}

Pilophorus uhleri Knight (1923d, p. 541).

MALE.-Length 5.00, width 1.90. Head width 1.14 , vertex 0.53 . Rostrum, length 1.80 , nearly attaining hind margins of middle coxae. Antennae, first segment, length 0.38 ; second, 1.86, gradually thickened apically ( 0.14 thick), brownish to black; third, 0.66 , thickness 0.06 , pale, apical half infuscated, sometimes tinged with pink; fourth, 0.61 , pale, apex dusky. Pronotum, length 0.83 , width at base 1.44 , uniformly black, bearing a few short, erect bristles. Scutellum covered with silvery, scalelike pubescence on sides and base. Hemelytra dark brown; black and polished behind posterior silvery line; beset with erect, short, black bristles, posterior silvery line transverse, broader than in vanduzeei Knight; membrane fusco-brownish, a darker, cloudlike spot covering larger areole and surrounding area.

Female.-Length 4.80 , width 1.77 ; very similar to male in color and pubescence.

Habits.-Occurs on larch (Larix laricina) and Scotch pine (Pinus sylvestris). 
Known Distribution. - Illinois, Iowa, New Jersey, New York, Ontario.

Illinois Records.-Antioch: July 5-7, 1932, on Larix sp., T. H. Frison et al., 6 \% . Yolo: Aug. 24, 1935, DeLong \& Ross, 1 o .

\section{Pilophorus juniperi Knight}

Pilophorus juniperi Knight (1923d, p. 543). This species is allied to laetus Van Duzee, hut is darker in coloration; it differs in the shorter and more gradually thickened second antennal segment; also in the narrower head.

Male.-Length 3.70, width 1.30. Head width 0.91 , vertex 0.49 . Rostrum, length 1.06 , attaining middle of intermediate coxae. Antennae, first segment, length 0.28 , brownish; second, 1.11, gradually thickened from middle toward apex $(0.10$ thick $)$, length not equal to distance between tip of tylus and base of pronotum, brown, apical half black; third, length 0.44 , pale, infuscated apically; fourth, length 0.42 , infuscated. Pronotum, length 0.71 , width at base 1.11 ; very dark brown, sides more gradually sulcate than in laetus. General color very dark brown, almost black; hemelytra nearly as in laetus, but darker; membrane blackish on basal half, pale fuscous on apical half and on area bordering cuneus; legs fusco-brownish, venter very dark brown, a patch of silvery hairs present on either side of third to fifth sternites.

Female.-Length 3.50, width 1.12. Very similar to male in structure and coloration.

HaBITs.-Breeds on red cedar ( $J_{\text {unip- }}$ erus virginiana) and may be predacious in habits.

Known Distribution.-District of Columbia, Illinois, Maryland, Massachusetts, Minnesota, New Jersey, New York, South Dakota.

Illinois Record.-Starved Rock State PARK: July 14, 1932, on Juniperus virginiana, Dozier \& Park, 27 o , 57 ㅇ.

\section{Pilophorus walshii Uhler}

Pilophorus walshii Uhler (1887b, p. 30).

Male.-Length 3.20, width 1.17; head width 0.82 , vertex 0.41 . Rostrum, length 0.95 , reaching only to near posterior margin of mesosternum. Antennae, first segment, length 0.22 , pale, brownish ahove; second, 0.97 , cylindrical, slightly more slender hasally, mostly brown; blackish on apical third; third, 0.35, mostly pale, apex fuscous; fourth, 0.32, fuscous. Pronotum, length 0.64 , width at base 1.05 ; from tip of tylus to hasal margin of pronotal disk, 1.14. General color dark brown; hemelytra lighter brown; corium behind posterior silvery band and exterior to radial vein dark brown and polished; membrane pale fuscous, a brown cloud covering larger areole and area just behind. Dorsum clothed with short, soft pubescence except for bands; posterior silvery band slightly irregular, widely disconnected at claval suture, that portion on clavus set well forward but transverse in position; basal band thick, just opposite tip of scutellum, extending from costal edge to claval suture; sides of venter with arcuate band of dense, silvery pubescence extending from second to sixth sternites; paracuneus with two spots of silvery pubescence.

Female.-Length 3.70, width 1.30. More robust than male, but very similar in color and pubescence.

Habits.-Breeds on honey locust (Gleditsia triacanthos), but may be in part predacious. A single, probably accidental, specimen was taken in Illinois on apple.

Known Distribution,-District of Columbia, Illinois, Indiana, Iowa, Maryland, Missouri, Ohio, Virginia.

Illinois Records.-Nineteen males and 31 females, taken June 22 to Sept. 24 , are from Darwin, Dubois, Elizabethtown, Galesburg, Kansas, Lawrenceville, Metropolis, Monticello, Murphysboro, Paxton, Pike, Quincy, Rock Island, Savanna, Starved Rock State Park, Urbana, White Heath, Willow Springs. Blatchley (1926b, p. 815) records it also from Palos Park.

\section{Pilophorus brunneus Poppius}

\section{4). \\ Pilophorus brunneus Poppius (1914a, p. \\ Male.-Length 4.00 , width 1.40 ; from} tip of tylus to basal margin of pronotum, 1.38. Antennae, first segment, length 0.28 , fusco-brownish; second, 1.47 , dark brownish, more nearly black at apex; third, 0.61, fuscous, basal one-fourth pale; fourth, 0.61 , fuscous, narrow pale area at hase. Pronotum, length 0.73 , width at base 1.21 .

Female.-Length 3.80 , width 1.51 ; from tip of tylus to basal margin of pronotum, 1.33 ; more robust than male but very similar in pubescence and coloration. Second antennal segment, length 1.33 , slightly thicker 
toward apex but scarcely exceeding thickness of first segment.

Habits.-Occurs on willow (Salix sp.).

KNown Distribution.-Illinois, Indiana, Iowa, Maryland, Minnesota, Missouri, New York, Ohio, Ontario.

Illinois Records.-Ten males and $16 \mathrm{fe}-$ males, taken May 29 to Aug. 23, are from Algonquin, Alton, Antioch, Byron, Champaign, Dubois, Eichorn, Kankakee, Meredosia, Savanna, Urbana, Waukegan.

\section{Pilophorus clavatus (Linnacus)}

Cimex clavatus Linnaeus (1767, p. 729).

MALE.-Length 4.60 , width 1.53 ; from tip of tylus to basal margin of pronotum, 1.50. Rostrum, length 1.73 , reaching to middle of hind coxae. Antennae, first segment, length 0.33 , fusco-brownish; second, 1.75, gradually thickened from base toward apex, greatest thickness 0.11 , slightly greater than thickness of first segment, dark brownish black, more nearly black on apical half; third, length 0.66 , fuscous, pale on basal half; fourth, length 0.39 , fuscous, paler at base. Pronotum, length 0.73 , width at base 1.40. General color very dark brown, almost black; hemelytra brown; clavus darker than corium except for area bordering claval suture; polished only behind posterior silvery line exterior to radial vein. Dorsum clothed with fine, short, golden and yellowish pubescence intermixed with short, erect, stiff bristles; posterior silvery line dislocated at claval suture, but not disconnected with portion on clavus.

FeMale.-Length 4.60 , width 1.67 ; from tip of tylus to basal margin of pronotum, 1.55 ; very similar to male in form, color and pubescence.

Habits.-Occurs on oaks (Quercus spp.).

Known Distribution.-This is a European species known in America from British Columbia, Colorado, Illinois, Iowa, Massachusetts, Michigan, Minnesota, New York, North Dakota, Ontario.

Illinois Records.-IllunoIS: 2 o . CARY: Aug. 27, 1905, on oak, W. J. Gerhard, 1 s , 2 ㅇ, fir. Kankakee: Aug. 1, 1933, Ross \& Mohr, 1 \%.

\section{Pilophorus setiger new species}

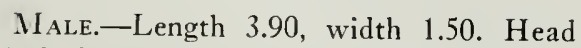
width 0.91 , vertex 0.45 . Rostrum, length 1.51, reaching base of hind coxae. Antennae, first segment, length 0.30 , yellowish brown; second, 1.34, yellowish, apical one-fourth very dark brown, slender, slightly thicker apically; third, 0.48, pale, apical half fuscous; fourth, 0.39, fuscous. Pronotum, length 0.73 , width at base 1.23 ; from tip of tylus to basal margin of pronotum 1.38. Dorsum clothed with fine, simple, yellowish pubescence intermixed with sparsely set, suberect, bristlelike hairs; posterior silvery band dislocated at claval suture, but still making contact with that part on clavus; basal band thick, extending from costal edge to claval suture at a point very slightly behind tip of scutellum; paracuneus with two silvery patches. General color dark brown to almost black, hemelytra brown, corium dark brown and shining on area behind posterior silvery line and exterior to radial vein, cuneus also dark brown and shining; membrane pale fuscous, a large brown cloud covering larger areole and central area of membrane; legs brown; coxae partly paler; hind tibiae very slightly curved.

Female.-Length 3.90, width 1.50. Very similar to male in general proportions, color and pubescence.

Holotype, male.-Kings Bluff, Winona County, Minn.: June 30, 1922, H. H. Knight, кc.

Allotype, female. - Same data as for holotype, кc.

Paratypes.-l lllinoIs.-Galena: June 30, 1932, Dozier \& Mohr, 2 q ; July 10, 1934, Delong \& Ross, 1 o. Palos Park: May 31, 1914, W. J. Gerhard, 1 q. WILLow Springs: June 9, 1912, 1 ô ; June 28, 1903, 1 ; ; Sept. 4, 1904, W. J. Gerhard, 1 오, FM.

South Dakota.-Trail County: Aug. 19, 1923, A. A. Nichol, 1 ô, Kc.

\section{MIRINAE}

\section{KEY TO GENERA}

1. Pronotum distinctly swollen at middle as wide as or wider than hind margin, fig. $142 \ldots \ldots \ldots \ldots \ldots \ldots \ldots 2$

Pronotum widest at hind margin, not noticeably swollen at middle, fig. 1453

2. Length of first antennal segment less than width of vertex; pronotum not extending back to basal angles of hemelytra; base of scutellum poorly defined..........Pithanus, p. 125 Length of first antennal segment 
greater than wid th of vertex, fig. 142: pronotum extending back to basal angles of hemelytra, and hemelytra usually depressed near base and tip of scutellum, arched over middle of abdomen.........Mimoceps, p. 125

3. Head strongly exserted with eyes placed near middle, thus far removed from anterior of pronotum, fig. 143 .

Collaria, p. 126

Head not or only slightly exserted; eyes in contact with pronotum or nearly so, fig. $144 \ldots \ldots \ldots \ldots \ldots$. . . .

4. Pronotum impunctate or nearly so.... 5 Pronotum coarsely and deeply punc-

tured................... 8

5. Antennal segments thickly covered with long, erect, black hairs, fig. 14t; body covered with fine, long, erect pubescence; eyes slightly removed from anterior angles of pronotum. .

Miris, p. 127

Antennal segments clothed with very short pubescence, fig. 145; body nearly glabrous, at most with very short pubescence............6 6

6. Head short and greatly Hattened, front scarcely protruding beyond bases of antennae, fig. 145; head with a broad and shallow median basin; first antennal segment slender and curved, thickest near base, tapering to become slender at middle, then becoming slightly enlarged at a pex....... .......... Teratocoris, p. 128

Head long and pointed, front projecting sharply beyond bases of antennae, compare fig. 14t; first antennal segment not formed as above..... 7

7. Rostrum not extending behind middle coxae....... Trigonotylus, p. 129

Rostrum extending to base of abdomen

Megaloceroea, p. 125

8. First antennal segment with very short pubescence, practically glabrous; pronotum and scutellum sparsely covered with deep punctures......

Mesomiris, p. 131

First antennal segment thickly covered with long pubescence; punctures of pronotum and scutellum deep and closely placed.... Stenodema, p. 130

\section{Megaloceroea Fieber}

No Illinois species; Megaloceroea recticornis (Geoffroy) is apparently an imported
European species which has been recognized in British Columbia, Idaho, Iowa, Ontario. Wisconsin. It has not as yet been collected in Illinois, but most likely it will be found here eventually.

\section{Pithanus Fieber}

No Illinois species; Pithanus maerkelii (Herrich-Schaeffer) is known from British Columbia, Maine, New York, Washington.

\section{Mimoceps [hler}

\section{Mimoceps insignis Uhler}

Mimoceps insignis Uhler (1890, p. 84).

MaLE.-Length 3.50, width 0.91. Head width 0.82 , vertex $0 .+3$. Rostrum, length 1.25 , reaching to base of middle coxae. Antennae, first segment, length 0.60 , pale, black on base ; second, 1.70, pale ; third, 1.21, fuscous; fourth, 0.95, fuscous. Pronotum, length 0.78 , width at base 0.73 ; calli large, convex, smooth, occupying middle of disk.

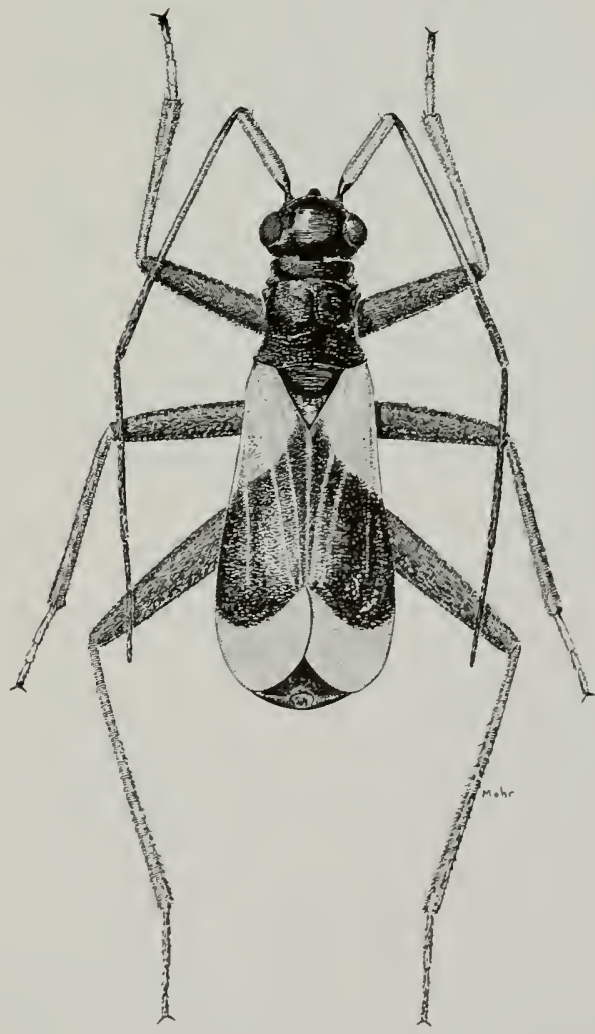

Fig. 142.-Mimoceps insignis, brachypterous】? 
Hemelytra short, membrane absent, apices rounded, covering three-fourths of abdomen, depressed at base, apical half more convex; dorsum glabrous, shining. General color black; white spot present on either side at base of hemelytra; legs pale, femora reddish except at base; coxae fuscous at bases; rostrum pale, except at base and apex.

Female.-Brachypterous: Fig. $1+2$. Length 4.50 , width 1.30 . Head width 0.95 , vertex 0.52. Antennae, first segment, length 0.61 ; second, 1.77. Pronotum, length 0.91 , width at base 0.82 . Form of hemelytra and coloration similar to male. Macropterous: Length 4.80 , width 1.34 . Head width 0.82 , vertex 0.43 . Antennae, first segment, length 0.61 ; second, 1.78. Pronotum, length 0.82 , width at base 1.08 . Hemelytra with membrane developed, fuscous; hrachium distinct; cuneus large, outer margin arcuated. Color black; basal half of clavus and corium pale yellowish; legs and rostrum as in male. The macropterous form is rare.

Paler specimens of this species, in which the hemelytra are almost entirely creamy white, belong to the variety gracilis Uhler (1890, p. 85).

Food Plaxts. - Sedges.

KNowy Distribution.-Colorado, Idaho, Illinois, Iowa, Minnesota, Montana, New Mexico, New York, North Dakota, Ohio, Ontario, Utah, Wisconsin.

Illinois Records.-Four males and 11 females, taken June 10 to Aug. 26, are from Algonquin, Argo, Beach, Champaign, Fox Lake, Galesburg, Grayslake, Palos Park, Rock Island, Volo, Zion.

\section{Collaria Provancher}

\section{KEY TO SPECIES}

Pronotal disk brown to fuscous, conspicuous black spot present on either side of basal half of disk...... oculata, p. 127 Pronotal disk black, black spots obscure meilleurii, p. 126

\section{Collaria meilleurii Provancher}

Collaria meilleurii Provancher (1872, p. 79; 1886, p. 102).

Male.-Length 6.00-7.00, width 1.70 . Head width 1.08 , vertex 0.48 . Antennae, first segment, length 0.78 , yellowish brown, base blackish; second, 4.11, black; third, 2.64; fourth, 1.56. Pronotum, length 0.99, width at base 1.17 ; calli strongly convex, nearly as high as base of pronotum; basal

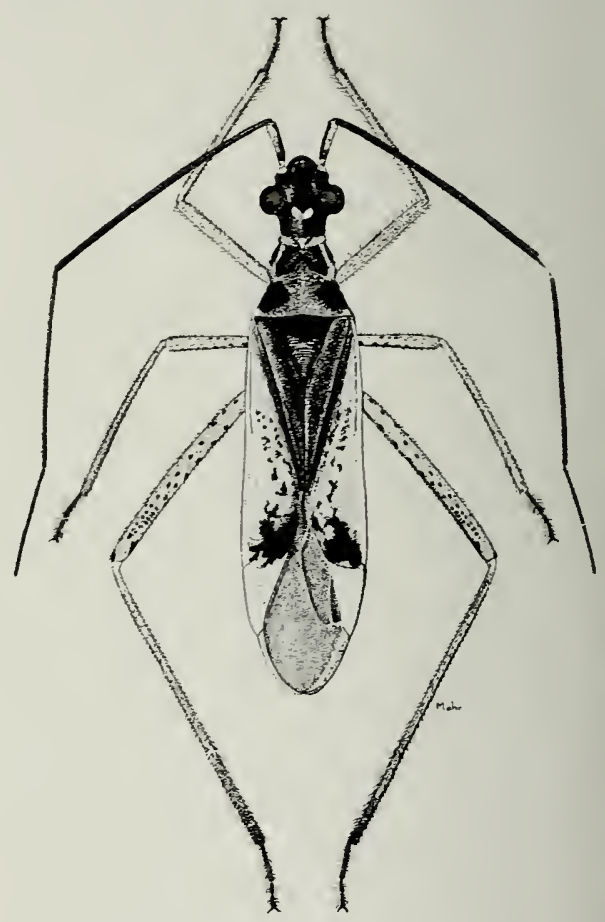

Fig. 143.-Collaria meilleurii,

half of disk with an opaque black spot on either side near basal angle, these spots inconspicuous on the black background. General color black; front of head shining; legs yellowish brown; femora with small, black spots; hemelytra translucent, yellowish; clavus and irregular area on apical half of corium, fuscous to black.

Female.-Fig. 143. More robust than male, but very similar in color and scarcity of pubescence.

Host Plants.-Bluejoint grass (Calamagrostis canadensis) and other grasses in damp situations.

Knowx Distribution.-Alberta, Connecticut, Illinois, Indiana, Maine, Massachusetts, Michigan, Minnesota, New Brunswick, New Hampshire, New York, North Dakota, Ohio, Ontario, Pennsylvania, West Virginia, Wisconsin, Vermont.

Illinois Records. - Twenty-four males and 16 females, taken June 14 to Aug. 4, are from Algonquin, Antioch, Browns, Ce- 
dar Lake, Dug Hill, Homer Park, Oakwood, Urbana, Volo, West Union.

\section{Collaria oculata (Reuter)}

Trachelomiris oculatus Reuter (1876, p. 61). MALE.-Length 6.00, width 1.50 . Head width 0.93 , vertex 0.39 . Antennae, first segment, length 0.95 ; second, 2.84 ; third, 1.94; clothed with long, pilose hairs. Pronotum, length 0.99 , width at hase 1.30 ; disk brownish, a large opaque, black spot each side near basal angle; calli only moderately convex. General color brownish with fuscous; hemelytra chiefly brown; legs pale to brownish yellow; hind femora with seriate fuscous spots on anterior aspect.

Fexiale.-Length 6.75, width 1.75. More robust than the male but very similar in general form and color.

Host Plants.-Occurs on grasses in dry sandy meadows; this species found breeding on panic grass (Panicum huachucae) in $V$ irginia.

KNowx Distribution.-Common in the southern United States and known from as far north as Connecticut, Illinois, Indiana, Iowa, New York, Ohio.

Illinois Records.-Thirty-two males and 54 females, taken May 15 to Sept. 30, are from Ashley, Carbondale, Chautauqua Bluff, Clay City, Dixon Springs, Dolson, Dongola, Dubois, Elizabethtown, Fulton, Herod, Mahomet, Meredosia, Murphysboro, Norris City, Odin, Palos Park, Pulaski, St. Anne, Saratoga, Shawneetown. Thebes, Waukegan.

\section{Miris Fabricius}

\section{Miris dolabratus (Linnaeus)}

\section{Meadow Plant Bug}

Cimex dolabratus Linnaeus (1758, p. 449).

Adults.-Fig. 14t. Length 7.30-8.50, width 2.40. General color pale greenish with fuscous and black markings; pronotum with two black stripes that run over the scutellum; clothed with fine, long, erect pubescence. Brachypterous females common. Females have the second antennal segment uniformly slender, which distinguishes them from ferrugatus Fallen.

Darker males of this species, in which the hemelytra are tawny brown, are referable to the variety aurantiacus Reuter (1875, p. 16). These and the lighter specimens occur together in Illinois.

Food Plants.-Bluegrass (Poa pratensis), timothy (Phleum pratense) and frequently other grasses. A series of specimens was taken in this state on spiderwort ( Tradescantia sp.). These bugs puncture grass stems, causing the tops of the plants to wilt.

KNown Distribution.-This is a common European species which is now widely distributed in the eastern United States and

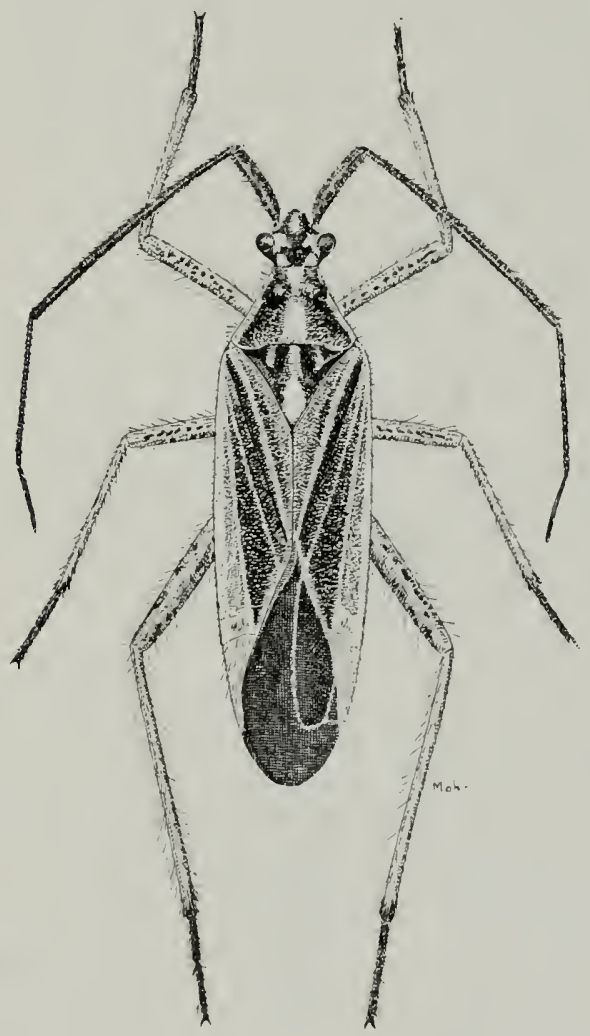

Fig. 144.-Miris dolabratus, $\sigma^{7}$.

Canada. The fact that this bug is not evenly distributed through the states where it occurs lends evidence to the view that it may have arrived here after the advent of white men.

Illinois Records.-One hundred fortynine males, 122 females and 2 nymphs, taken May 18 to July 11, are from Algonquin, Amboy, Antioch, Aurora, Custer Park, Danvers, Dixon, East Dubuque, Erie, Freeport, Galena, Glendon Park, Grand Detour, Grandview, Hamilton, Hardin, Harvard, 
Joliet, Keithsturg, Lyndon, Mahomet, Marengo, Mount Carroll, Muncie, Oakwood, Oregon. Palos Park, Peoria, Putnam, Quincy, Rock lsland, Rockton, St. Anne, St. Joseph, Savanna, Seaton, Seymour, Sheldon, Urbana, Watseka, Waukegan, White Heath, White Pines Forest State Park, Willow Springs, Zion.

\section{Teratocoris Fieber}

\section{KEY TO SPECIES}

Scutellum and clavus fuscous to black. . . discolor, p. 128 Scutellum and clavus uniformly green... . paludum, p. 128

\section{Teratocoris discolor Uhler}

Teratocoris discolor Uhler (1887c, p. 68).

Male.-Length 4.80, width 1.25 . Head width 0.86 , vertex 0.38 . Rostrum, length 1.17 , reaching slightly beyond middle of

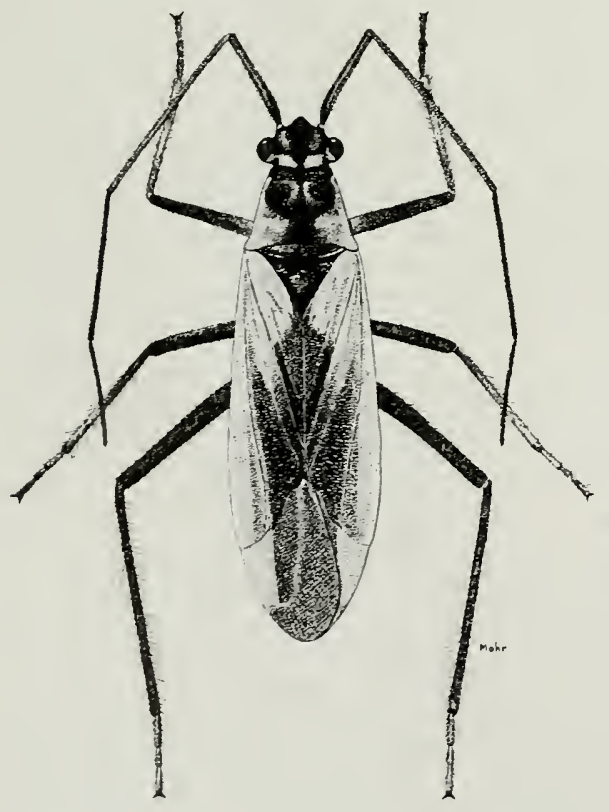

Fig. 145.- Teratocoris discolor, $\circ$.

sternum. Antennae, first segment, length 1.04, thicker on basal half, reddish, blackish at base; second, 2.07, reddish; third, 1.47 , fuscous; fourth, 0.99, blackish. Pronotum, length 0.77 , width at base 1.04 . Tibiae and ventral margins of femora bearing long, pilose hairs. General color pale greenish with fuscous and black areas; basal angles of pronotum, base of hemelytra, and full length of embolium, pale or greenish; legs reddish, bases of femora and tips of coxae paler.

Fenale.-Fig. 145. Length 5.60, width 1.64. More robust than male, hemelytra and venter much paler in color; usually only slightly fuscous along claval suture and inner angles of corium, sometimes tinged with reddish.

Host Plants.-Occurs on sedges (Scirpus and Carex). Frequently collected at lights.

Known Distribution.-Colorado, Illinois, Indiana, Iowa, Massachusetts, Michigan, Missouri, Ohio, Ontario, Quebec, South Dakota, Utah.

Illinois Records.-Eleven males and 42 females, taken May 30 to Sept. 8, are from Champaign, Chicago, Galena, Grayslake, Havana, Momence, Odin, Urbana.

\section{Teratocoris paludum J. Sahlberg} 291)

Teratocoris paludum J. Sahlberg (1871, p.

Male.-Length 5.40, width 1.21. Head width 0.78 , vertex 0.39 . Rostrum, length 1.17 , just reaching middle of sternum. Antennae, first segment, length 1.43 , thicker on basal half, reddish; second, 2.81 , reddish; third, 1.47, fuscous; fourth, 1.08 , black. Pronotum, length 0.74 , width at base 1.02 . General color light green, yellowish on head and mesoscutum; legs green; hind tibiae and tips of femora bright red; hind tibiae with long, pilose hairs.

Female.-Length 5.80, width 1.34. More robust than male, but very similar in coloration.

Host Plant,-Occurs on sedge (Carex resicaria), which probably is the plant on which this species breeds. Frequently collected at lights.

Known Distribution.-Illinois, Iowa, Minnesota, New York, Ontario, South Dakota; Finland.

Illinois Records.-Chicago: May 23, W. J. Gerhard, 3 o, FM; June 13, W. J. Gerhard, 1 \%, FM; May 25, 1906, at light, W. J. Gerhard, 3 o , 1 o, FM; May 31, 1906, at light, W. J. Gerhard, 1 o , FM ; July, 1915, W. J. Gerhard, 2 o , FM. Grayslake: Aug. 27, 1932, Ross \& Mohr, $2 \hat{o}$. Havana: May 29, 1936, Mohr \& Burks, $1 \hat{\delta}$. URBANA: May 20, 1887, at light, 1 우. 


\section{Trigonotylus Fieber}

\section{KEY TO SPECIES}

1. Posterior tarsi and apices of posterior tib:ae black.......... tarsalis, p. 129

Posterior tarsi and apices of posterior tibiae pale or reddish............ 2

2. Length of first antennal segment less than width of head across eyes.

brevipes, p. 129

Length of first antennal segment exceeding width of head across eyes... 3

3. Clavus and corium roseate; second antennal segment pale to yellowish. .

pulcher, p. 129

Clavus and corium pale to dusky or greenish; antennae reddish.

ruficornis, p. 130

\section{Trigonotylus pulcher Reuter}

Trigonotylus pulcher Reuter (1876, p. 59).

MALE.-Length 4.50, width 0.99 . Head width 0.62 , vertex 0.31 . Rostrum, length 1.38 , reaching to near apices of middle coxae. Antennae, first segment, length 0.64 , thickness 0.15 , pale, tinged with roseate; second, length 1.49 , pale; third, length 1.31 , pale; fourth, length 0.65 , brownish. Pronotum, length 0.52 , width at base 0.86 . General color pale, clavus and corium tinged with roseate; two brown, longitudinal lines on middle of pronotum and scutellum; a roseate to fuscous line present on either side of head along inner margin of eye and extending to basal margin of pronotum.

Fenale.-Length 5.40, width 1.25. More robust than male, but very similar in coloration.

Known Distribution.-Recorded from Minnesota south to Texas and eastward.

Illinois Record.-ANNA: Oct. 11, 1933, Frison \& Ross, 1 ㅇ.

\section{Trigonotylus tarsalis (Reuter)}

Callimiris tarsalis Reuter (1876, p. 60).

MALE.-Length 5.40, width 1.12. Head width 0.75 , vertex 0.43 . Rostrum, length 1.38 , reaching nearly to posterior margin of sternum. Antennae, first segment, length 0.80 , green; second, 2.34 , green, apical halt pink; third, 2.60, pink; fourth, 0.95, pink. Pronotum, length 0.65 , width at base 0.97 . Pubescence very short, dorsum nearly glabrous; tibial spines weak. General color medium green to bright green; apices of posterior tibiae, and tarsi, black; antennae pink to reddish on apical half; membrane pale, veins green.

Female.-Length 6.30, width 1.51. More robust than male, but very similar in form and coloration.

Food Plaxt. - Slough grass (Spartina michauxiana).

Known Distribution.-Connecticut, Illinois, Iowa, Kansas, Manitoba, Massachusetts, Minnesota, New Hampshire, North Dakota, South Dakota, Texas, Wisconsin.

Illinois Records.-Fifty-five males and 122 females, taken $\mathrm{May} 15$ to Oct. 1, are from Allerton, Antioch, Argo, Beach, Bondville, Champaign, Chicago, Grayslake, Moline, Momence, Oak Lawn, Ogden, St. Anne, Savanna, Seymour, Urbana, Watseka, Waukegan, Zion.

\section{Trigonotylus brevipes Jakovlev}

Trigonotylus brevipes Jakovlev (1880, p. 215). Male.-Length 4.10, width 0.95 . Head width 0.60 , vertex 0.28 . Rostrum, length 1.25 , reaching to near tips of middle coxae. Antennae, first segment, length 0.51 , thickness 0.13 , usually greenish yellow, sometimes pink, clothed with short fuscous pubescence; second, length 1.51, cylindrical, 0.07 thick, usually pale yellowish, sometimes pink, clothed with very short, minute pubescence; third, length 1.30, pallid to dusky; fourth, length 0.47 , fuscous. Pronotum, length 0.47 , width at base 0.82 , basal margin broadly concave; disk minutely rugulose, median line slightly elevated, pallid, dusky on each side; calli distinct, a foveate puncture on each inner angle. Dorsal surface nearly glabrous, claval vein and brachium on corium, distinctly elevated. General color pallid to greenish yellow; hemelytra subtranslucent; cuneus nearly clear; membrane sometimes dusky, veins pale to greenish.

Female.-Length 4.85, width 0.96. Slightly larger than the male but very similar in form and coloration.

Food Plaxts.-Bermuda grass (Cynodon dactylon) and perhaps related grasses.

Known Distribution.-Alabama, Arizona, California, Colorado, Connecticut, Florida, Georgia, Illinois, Kentucky, Maryland, New York (coastal), North Carolina, South Carolina, Tennessee, Texas, Utah. Virginia; also Cuba and Mexico. 
Illinois Records.-Metropolis : Aug. 17, 1891, Shiga \& Hart, 2 ㅇ ; Aug. 20, 1916, C. A. Hart, $1 \delta, 1$.

\section{Trigonotylus ruficornis (Geoffroy)}

Cimex ruficornis Geoffroy (1785, p. 209).

MaLE.--Length 5.30, width 1.17. Head width 0.69 , vertex 0.36 . Rostrum, length 1.56, reaching to middle of intermediate coxae. Antennae red, first segment often more or less pale; first segment, length 0.73 ; second, 2.31 ; third, 1.95 ; fourth, 0.56. Pronotum, length 0.65 , width at base 0.95 . Pubescence short on antennae and legs; dorsum practically glabrous. General color pale yellowish green to green; pronotum with four longitudinal, fuscous stripes, median pair extending to apex of scutellum and separated by a slender, pale line; membrane pale to dusky, veins green.

Female.-Length 6.00, width 1.34. More robust than male, but very similar in form and coloration.

Food Plants.-Cultivated oats (Avena sativa) and closely related wild grasses.

Known Distribution.-This is a Holarctic species, widely distributed in the United States and Canada, most abundant in the Boreal region.

Illinois Records. - Twenty-two males and 64 females, taken May 22 to Aug. 28, are from Amboy, Antioch, Chicago, Elizabeth, Frankfort, Galena, Grand Detour, Havana, Hoopeston, Macomb, Orangeville, St. Anne, Savanna, Starved Rock State Park, Urbana, Warren, White Pines Forest State Park, Zion.

\section{Stenodema Laporte}

\section{KEY TO SPECIES}

Hind femora with three strong spines on apical half of posterior margin, fig. 146 .

.............trispinosum, p. 130

Hind femora without spines..........

vicinum, p. 130

\section{Stenodema trispinosum Reuter} 8).

Stenodema trispinosum Reuter (1904, pp. 4,

Adults.-Length 7.00-7.50, width 1.70 .

General color pale yellowish to greenish; hemelytra sometimes bright green; membrane pale, veins green. Dorsum clothed with short, pale pubescence; antennae with prominent pale hairs, first segment more thickly clothed. Pronotum thickly and rather coarsely punctate; median line raised into

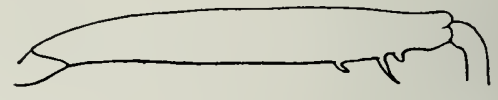

Fig. 146.-Stenodema trispinosum, hind femur.

a callus. Posterior margin of hind femora with three spines, one of them much reduced in size.

Food Plants. - Occurs on grasses in moist meadows; adults hibernate.

Known Distribution. - A Holarctic species that is widely distributed in the northern United States and Canada.

Illinois Records.-Fifty-one males and 37 females, taken April 15 to Oct. 6, are from Algonquin, Allerton, Alto Pass, Anna, Antioch, Apple River Canyon State Park, Carbondale, Carmi, Champaign, Chicago, Dubois, Elizabethtown, Fern Cliff, Fountain Bluff, Golconda, Grand Tower, Herod, Jonesboro, Kampsville, Lawrenceville, Mahomet, Mount Carmel, Muncie, Palos Park, Parker, Pulaski, Quincy, Robinson, Shawneetown, Snyder, Springfield, Thebes, Urbana, Vienna, Waukegan.

\section{Stenodema vicinum (Provancher)}

Miris vicinus Provancher (1872, p. 77).

Adults.-Length 7.00-7.50, width 1.70. Femora devoid of spines; pronotum and scutellum coarsely and closely punctate, a callous median line evident; first antennal segment thickly clothed with long pubescence, second segment with short pubescence only. General color yellowish to greenish with fuscous markings; dorsum with a median pale stripe and fuscous areas on either side extending from tylus back over pronotum, scutellum and hemelytra; clavus and inner half of corium dark fuscous to blackish in male; antennae reddish, in dark specimens dusky red.

Food Plants.-Occurs on grasses in moist meadows; adults hibernate.

Known Distribution.-This is a common species in the eastern United States and Canada.

Illinois Records.-Fifty-two males, 35 females and 2 nymphs, taken April 26 to Nov. 26, are from Algonquin, Amboy, Apple 
River Canyon State Park, Argo, Bowmanville, Chicago, Elizabeth, Fort Sheridan, Galesburg, Geneseo, Ingleside, Lake Villa, Normal, Oquawka, Palos Park, Port Byron, Riverside, Roby, Rockford, Savanna, Urbana, Waukegan, White Pines Forest State Park.

\section{Mesomiris Reuter}

No Illinois species; Mesomiris curtulus Reuter is known from Colorado eastward to Pennsylvania and Connecticut. It has not yet been collected in Illinois, but should be found here eventually.

\section{GAPSINAE}

\section{KEY TO TRIBES}

1. Elongate antlike species, figs. 180,181 ; abdomen constricted at base; lateral margins of pronotum indistinct, more or less sinuate; emboliar margins of hemelytra recurved ventrad....... ............. Myrmecorini, p. 209

Not antlike, figs. 154, 155; abdomen not distinctly constricted at base; pronotum with lateral margins distinct, frequently finely carinate; hemelytra with emboliar margins straight or slightly arcuate, not recurved ventrad.................
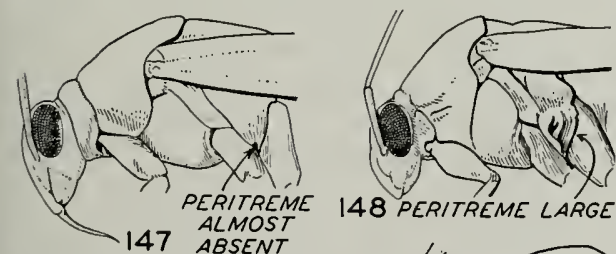

Fig. 147.- Thorax of Opistheuria clandestina.

Fig. 148.-Thorax of Lygus oblineatus.

Fig. 149.-Prothorax of Platytylellus fraternus.

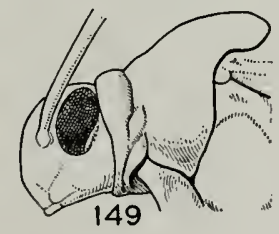

2. Ostiolar peritreme small, indistinct, fig. 147 , its dorsal margin scarcely extending dorsad as far as ventral margin of mesepimeron; body impunctate; pronotal collar broad, strongly convex, mesal length of collar usually as great as width of calli......... ............Resthenini, p. 131
Ostiolar peritreme prominent, fig. 148 , its dorsal margin extending well above ventral margin of mesepimeron; dorsum frequently punctate; pronotal collar not so broad and prominent as above. . Capsini, p. 136

\section{RESTHENINI}

\section{KEY TO GENERA}

Stricture of pronotal collar joining base of coxal cleft, fig. 147; head oblique as viewed from side; gula rather long, oblique........... Opis theuria, p. 131

Stricture of pronotal collar interrupted at side, not joining directly with base of coxal cleft, fig. 149; head short, vertical; gula short, scarcely apparent.......

............. Platytylellus, p. 132

\section{Opistheuria Reuter}

\section{Opistheuria clandestina Van Duzee}

Opistheuria clandestina Van Duzee (1915, p. 110).

MALE.-Length 7.00 , width 2.80 . Head width 1.30 , vertex 0.61 . Rostrum, length 1.90 , reaching to middle of intermediate coxae. Antennae black; first segment, length 1.08 , slender, 0.13 thick, clothed with long, suberect, fuscous hairs; second, length 2.20, cylindrical; third, 1.70 ; fourth, 1.08. Pronotum, length 1.43 , width at base 2.20 . Emboliar margins distinctly arcuate on apical half. Clothed with erect, rather short, pale pubescence, longer and more fuscous on legs and antennae. Color orange red; antennae, front and tylus, all but central area of disk of scutellum, all but outer margins of hemelytra, and genital segment, black; legs black; coxae reddish; femora more or less pale at hase.

Fenale.-Length 7.10, width 3.00. More robust than male, but very similar in color and pubescence.

All our Illinois specimens but one have the pronotal disk variously marked with black and are referable to the variety dorsalis Knight (1918d, p. 115); the exception is the single female from West Pullman which has the venter more or less fuscous or black and belongs to the variety ventralis Knight (1918d, p. 115).

Habits.-Occurs on willow (Salix sp.) and beans (Phaseolus spp.). 
Known Distribution.-Florida, Illinois, Louisiana, Minnesota, New York, North Dakota, Ohio, Oklahoma, Ontario, Wisconsin.

Illinois Records.-Golconda: June 22, 1932, on Salix sp., Ross, Dozier \& Park, 1 o. Grand Detour: June 27, 1906, on willow, 1 合, 2 \&; June 30, 1909, sweeping grass, 1 क ; July 24, 1905, 2 ๙ : Aug. 26, 1889, C. A. Hart, 2 o . West Pullman: July 10, 1910, A. B. Wolcott, 1 \& , FM.

\section{Platytylellus Reuter}

\section{KEY TO SPECIES}

1. Length of first antennal segment less than width of vertex. . . 2

Length of first antennal segment equal to or greater than width of vertex.. 4

2. Pronotal disk without median red vitta; length of first antennal segment twice lateral width of an eye.

nigricollis, p. 133

Pronotal disk with median red vitta that extends to join red area on scutellum................ 3

3. Hemely tra uniformly black; scutellum red; length $5.00-5.30$.

.......... rubrovittatus, p. 133

Hemelytra with lateral margins pale to orange colored; commissure pale; scutellum black with a broad, red median line; length 6.20-6.60.

zonatus, p. 133

4. Pronotum yellow to orange yellow... 5

Pronotum red, or red with black, or chiefly black.

5. Scutellum black; male genital segment with a prominent tubercle at base of each clasper, as in fig. 150 . nigroscutellatus, p. 134

Scutellum orange yellow; male genital segment without tubercles.......6 6

6. Width of pronotal collar slightly greater than width of head; length 8.70 . insitivus var. insitivus, p. 133

Width of pronotal collar less than width of head; length $6.80-8.00$... insitivus var. angusticollis, p. 133

7. Male with a prominent lateral tubercle near base of left genital clasper, fig. 150; both sexes with pronotal disk uniformly red, or red and black; in latter case, black always present along median line, but sometimes black spreads to cover all but narrow area along lateral margins; latteral margins of hemelytra frequently red or pale............. 8

Male without tubercle near base of left genital clasper; both sexes usually with pronotal disk black; frequently pronotal disk red and with black, but, in that case, red color present along median line, thus leaving a black ray present on either side; these rays may be reduced to spots near basal margin; lateral margins of hemelytra sometimes red, but, in that case, median line of pronotum red with a black vitta on either side..............11

8. Hemelytra uniformly black........

fraternus var. fraternus, p. 134

Hemelytra with lateral margins pale or red ................ 9

9. Scutellum uniformly bright red.....

fraternus var. regalis, p. 134

Scutellum black..............10

10. Calli black............frater-

nus var. rubromarginatus, p. 134 Calli red.

fraternus var. discifer, p. 134

11. Hemelytra with red lateral margins; pronotal disk red at median line, thus leaving a black or fuscous vitta at either side; vitta sometimes reduced to a black spot near basal margin..... circumcinctus, p. 135

Hemelytra uniformly black........12

12. Length of first antennal segment equal to width of vertex plus onethird dorsal width of an eye; length $7.90 \ldots . . .$. rubellicollis, p. 136

Length of first antennal segment only slightly greater than width of vertex, less than width of vertex plus one-third dorsal width of an eye; length 7.70 , or less.........13

13. Head black, basal margin of vertex with a narrow red line; pronotal collar red, with usually a black area above; base of venter red beneath; gula never red; surface coarsely granulate....... borealis, p. 136

Head red, tylus and variable areas on juga and lora black; surface very finely granulate............. 14

14. Venter black, with not more than a red tinge at base; scutellum red, lateral margins black; pronotal disk 
with a broad central red area, this area not forming a clearly defined vitta; length $6.70-7.50 \ldots \ldots \ldots$.

insignis, p. 135

Venter red; scutellum black; basal half of pronotal disk black; length $5.10-5.80 \ldots$ fraterculus, p. 136

\section{Platytylellus rubrovittatus (Stål)}

Resthenia rubrovittata Stål (1862, p. 318).

Male.-Length 5.00, width 1.70; emboliar margins moderately arcuate; surface distinctly granulate. Head width 1.08 , vertex 0.51. Antennae, first segment, length 0.44 ; second 1.71 , cylindrical, nearly as thick as first; third, 1.26; fourth, 0.81. General color black; head except tylus and eyes, basal segment of rostrum, pronotum except a flaring ray extending from callus to basal margin on either side of disk, scutellum, mesoscutum except outer angles, sternum except cloud on either side, pleura, venter except vagina exterior, coxae, femora except narrow area at base and apical onethird, red or orange red.

Female.-Length 5.30 , width 2.00 ; very similar to male in coloration; second antennal segment slightly more slender and less cylindrical.

Host Plant.-Collected on willow (Salix sp.).

Known Distribution.-Originally described from a single male specimen with the locality given as "boreal America." Now known from Nova Scotia southward to Florida and westward to Texas.

Illinois Records.-Aldridge: Aug. 11, 1891, sweepings, Mississippi bottoms, Hart \& Shiga, $1 \hat{\delta}$. Golconda: June 22, 1932, on Salix sp., Ross, Dozier \& Park, 5 o , 3 q. Grand Tower: July 12, 1909, on willow, 1 ơ. KarNak: July 10, 1935, DeLong \& Ross, 1 o. Urbana: Aug. 17, 1916, 1 oे.

\section{Platytylellus nigricollis (Reuter)}

Resthenia nigricollis Reuter (1876, p. 65).

Male._Length 6.00, width 2.30. Head width 1.14 , vertex 0.66 , lateral width of eye 0.28 . Rostrum, length 2.20 , reaching to middle of hind coxae. Antennae, first segment, length 0.58 ; second, 1.76; third, 1.14; fourth, 0.90 . Pronotum, length 1.04 , width at base 1.82. Surface rather coarsely and thickly granulate, clothed with short, black pubescence. General color black; head ex- cept tylus, collar, xyphus, and sides of pronotum, scutellum except basal angles, sternum except cloud on either side of median line, pleura, venter except beneath on genital segment, red; legs black; coxae and basal one-third of hind femora pale to red.

Female.-Length 6.40 , width 2.60 ; very similar to male in color, pubescence and surface granulation.

Known Distribution.-Connecticut, Illinois, Indiana, Iowa, Massachusetts, New Hampshire, New Jersey, New York, Ohio, Ontario, Pennsylvania, Texas, Virginia.

Illinois Records.-Antioch: July 5-7, 1932, T. H. Frison et al., 1 o , 1 o. Grand Detour: July 2, 1932, Dozier \& Mohr, 1 o .

\section{Platytylellus zonatus Knight}

Platytylellus zonatus Knight (1926h, p. 254).

Male.-Length 6.20, width 2.40. Head width 1.26 , vertex 0.68 . Rostrum, length 2.20, just attaining bases of hind coxae. Antennae, first segment, length 0.58 ; second, 2.00 ; third, 1.46; fourth, 0.77. Pronotum, length 1.31, width at base 2.10. General color black; vertex except for lunate marks, lower half of face except tylus and apex of lora, collar, lateral margins and median line of pronotum, and median one-third of scutellum, orange red; embolium and narrow outer margin of corium, outer half of cuneus, and commissure of hemelytra, orange colored. Variable areas on pleura and sides of venter orange obscured with blackish. Femora yellowish to orange, with anterior and posterior faces obscured with fuscous. Body surface covered with fine granules, and thickly clothed with fine, short, yellowish to fuscous pubescence. Genital segment without tubercles.

Fenale.-Length 6.60, width 2.60. Slightly more robust than male, but very similar in coloration and pubescence.

Known Distribution.-1llinois, Manitoba, Michigan, Minnesota, North Dakota, Wisconsin.

Illinois Records.-Antioch: July 5-7, 1932, T. H. Frison et al., 3 o .

\section{Platytylellus insitivus (Say)} $340)$.

Capsus insitivus Say (1832, p. 21; 1859, p.

MAI.E.-Length 8.70, width 3.60. General color black, pronotum and scutellum orange yellow; surface very finely granulate, 
opaque, with short pubescence; width of collar greater than width of head. Head width 1.36 , vertex 0.81 . Width of collar 1.49. Rostrum, length 2.40 , attaining tips of middle coxae. Antennae, first segment length 1.07 ; second, 3.00 , nearly cylindrical, length of hairs not equal to thickness of segment; third, 1.98 ; fourth, 0.94 . Pronotum, length 1.73 , width at base 2.77

Female.-Length 8.70 , width 3.50 ; very similar to male in form and coloration.

The single male from Palos Park, listed below, which is smaller in size and has the width of the head greater than the width of the collar, belongs to the variety angusticollis Knight (1923d, p. 556). It may prove to be biologically distinct from the typical form.

Known Distribution.-Connecticut, Florida, Illinois, Indiana, Iowa, New Jersey, New York, Ontario, Pennsylvania.

Illinois Records.-Galena: June 27, 1928, T. H. Frison, 1 o ; June 30, 1932, Dozier \& Mohr, 2 o . Galesburg: June 21, 1892, Stromberg, 2 q ; June 27, 1893, Stromberg, 2 ㅇ․ Hardin: June 5-9, 1932, H. L. Dozier, 2 o, 2 ᄋ. Palos Park: June 19, 1933, Ross \& Mohr, 1 o . Rock Island: 1880, 1 ㅇ. Willow Springs: July 12, 1903, W. J. Gerhard, 1 oิ , FM.

\section{Platytylellus nigroscutellatus Knight}

Platytylellus nigroscutellatus Knight (1923d, p. 557).

Male.-Length 9.20, width 3.70. Head width 1.71 , vertex 0.94 ; black with gula, genae, bucculae, and margins of lora and juga, orange yellow. Rostrum black, length 3.10 , extending slightly beyond hind margins of middle coxae. Antennae black; first segment, length 1.19 , clothed with erect, almost pilose hairs, length of hairs not exceeding thickness of segment; second, 3.43, cylindrical, strongly pubescent, a few erect hairs near base as long as thickness of segment ; third, 1.66; fourth, 0.94. Pronotum, length 1.89 , width at base 2.94 , collar 1.36; uniformly orange yellow, finely granulate, clothed with short, erect, pale pubescence. Scutellum black; sternum blackish; pleura orange yellow, becoming fuscous on central area of metepisternum. Hemelytra, emboliar margins very slightly arcuate for most of their length; black, faintly shining, clothed with very fine, short pubescence. Legs black; tibiae clothed with erect, prom- inent hairs, length of many hairs exceeding thickness of segment; spines not evident. Venter black, with a velvety luster; clothed with erect, fine, dusky pubescence.

Fenale.-Length 9.70, width 3.50. Very similar to male in form and color.

KNown Distribution.-Illinois, Michigan, New York, North Carolina, Pennsylvania.

Illinois Record.-Heyworth: Aug. 14, 1909, A. B. Wolcott, 1 ㅇ, FM.

\section{Platytylellus fraternus Knight} 557).

Platytylellus fraternus Knight (1923d, p.

The color pattern of this form is suggestive of that of confraternus (Uhler), but this is larger, and the length of the first antennal segment is equal to the width of the vertex plus one-half the dorsal width of an eye.

Male.-Length 9.40, width 3.50. Head width 1.56 , vertex 0.86 ; red, with tylus, front and vertex chiefly black. Rostrum, length 2.85, reaching to middle of hind coxae. Antennae, first segment, length 1.06; second, 3.23, thickest near base and tapering to become more slender at apex, clothed with short, stiff, black hairs and fine pubescence, length of longest hairs not exceeding thickness of segment; third, 1.71 ; fourth, 1.28. Pronotum, length 1.74, width at base 2.92 , collar 1.31 ; surface very slightly shining, thickly clothed with short, pale pubescence; red, with dorsal area of collar, calli except at outer angles, and a broad band extending to basal margin of disk, black. Scutellum black; sternum blackish, median line red; pleura red or becoming dusky. Hemelytra with emboliar margins only slightly arcuate; black, opaque, surface somewhat scabriculous, clothed with

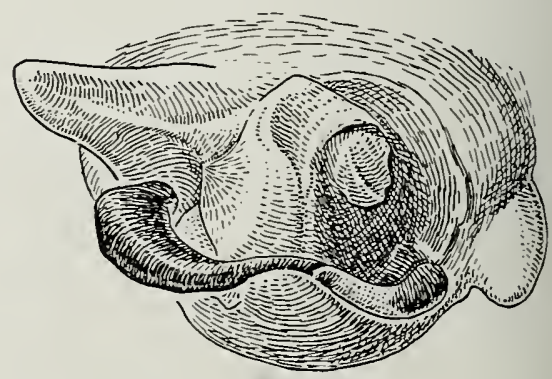

Fig. 150.--Male genitalia of Platytylellus fraternus. 
short, dusky pubescence, hairs somewhat decumbent on apical half. Legs black, thickly clothed with prominent, erect hairs. Venter red; genital segment becoming black; a large, prominent, erect tubercle present just

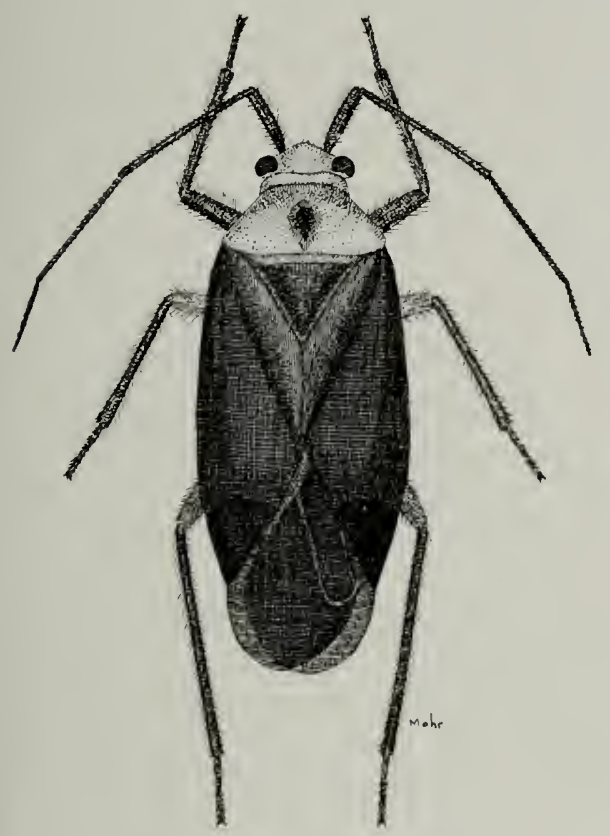

Fig. 151.-Platytylellus fraternus,

above base of left genital clasper, and another, smaller tubercle directed distad from near base of right clasper, fig. 150.

Female.-Fig. 151. Length 9.10, width 3.50. Pronotum, length 1.52 , width at base 2.6t. Similar to male in form and color.

This species varies greatly in color, and many color combinations have been given varietal names. The typical form and variety rubromarginatus Knight (1923d, p. 558 ) have been recognized in Illinois material; varieties regalis Knight (1923d, p. 559 ) and discifer Knight (1923d, p. 559) have not.

Host Plant.-Apparently breeds on sumach (Rhus aromatica).

Known Distribution.-Connecticut, District of Columbia, Florida, Georgia, Illinois, Maryland, Michigan, Minnesota, New Hampshire, New Jersey, New York, North Carolina, Pennsylvania, Tennessee, Virginia, West Virginia.

Illinois Records.-Bishop: June 23, 1906, 1 ô, 1 \%. Bluff Springs: June 10, 1932, Ross \& Mohr, $+\delta, 10 \%$. Forest
City: June 6, 1905, 1 o . Hardin: June 5-9, 1932, H. L. Dozier, 2 q. Havana: June 3, 1918, 1 ㅇ ; June 8, 1905, Devil's Hole, 2 of ; June 23, 1926, Devil's Hole, Frison \& Hayes, 22 ô, 12 \&. Kerthisburg: June 15, 1932, on Rhus aromatica, H. L. Dozier, 22 of, 7 \&. MaKanda: June 26, 1909, sweepings, $1 \hat{\delta}$. NORMaL: $1 \hat{\delta}$.

\section{Platy tylellus circumcinctus (Say)}

Capsus circumcinctus Say (1832, p. 23; 1859, p. 343).

MALE.-Length 7.10, width 2.70. Head width 1.28 , vertex 0.71 . Antennae, first segment, length 0.77 ; second, 2.3t; third, 1.5t; fourth, 0.95. Head red, with front and tylus blackish and juga and lora more or less black; pronotum red; calli blackish, a flaring black ray located behind each callus and extending to basal margin of disk; scutellum and mososcutum red, basal angles black; pleura red; sternum reddish, but becoming blackish on either side of median line; hemelytra black; embolium, outer margin of corium and cuneus red; legs black, tinged with reddish near bases of femora; venter chiefly red with genital segment and variable areas at sides black.

Feriale.-Length 7.40, width 2.70. More robust than male, but very similar in coloration.

Known Distribution.-Originally described from Indiana, and now known from District of Columbia, Illinois, Maine, Massachusetts, New Hampshire, New Jersey, New York, North Carolina, Pennsylvania, Virginia.

Illinois Records. - Dolsox: June 25, 1932, Rocky Branch, Frison \& Mohr, $1 \delta$. OAKwood: June 16, 1925, T. H. Frison, $1 \delta$.

\section{Platytylellus insignis (Say)} 342).

Capsus insignis Say (1832, p. 22; 1859, p.

Male.-Length 6.70, width 2.60. Head width 1.19 , vertex 0.67 . Antennae, first segment, length 0.74 ; second, 2.20 ; third, $1.5+$; fourth, 0.97. General color black, opaque; finely granulate; head red, tylus and variable areas on juga and lora blackish; pronotum red, basal half of disk largely blackish, but broad central area of disk red, this red area not forming a clearly defined vitta; scutellum red, lateral margins blackish; ven- 
ter black with not more than a red tinge at hase.

Fenale.-Length 7.60 , width 2.80. Larger and more robust than male, but very similar in coloration.

KNown Distribution.-Common over the eastern United States.

Illinois Record.-West Pullman: July 13, 1902, W. J. Gerhard, 1 \&, FM.

\section{Platytylellus fraterculus Knight}

Platytylellus insignis fraterculus Knight (1923d, p. 554).

Male.-Length 5.10, width 1.90. Head width 1.00 , vertex 0.51 ; red, tylus blackish. Rostrum, length 1.69 , black, basal segment red. Antennae, first segment, length 0.51 ; second, 1.90 ; third, 1.43 ; fourth, 0.80 . Pronotum, length 0.90 , width at base 1.60 ; bright red; disk black from just behind calli to basal margin and with a very slight indication of median vitta. Scutellum black; sternum and pleura red. Hemelytra hlack, very slightly shining; thickly clothed with fine dusky pubescence, hairs recumbent on apical half. Legs black with red coxae. Venter uniformly red and genital claspers black.

Female.-Length 5.60, width 2.00. Slightly larger and more robust than male, but similar in coloration.

Known Distribution. - lllinois, Indiana, Michigan, Minnesota, Ontario, Pennsylvania, Wisconsin.

Illinois Record.-NORTHERN IlLINOIS: Bolter, 1 .

\section{Platytylellus borealis Knight}

Platytylellus borealis Knight (1923d, p. 553).

Not taken in Illinois; known from "Alberta, Maine, Manitoba, Michigan, Minnesota, New York, North Dakota, Ontario, Vermont.

\section{Platytylellus rubellicollis Knight} 555).

Platytylellus rubellicollis Knight (1923d, p.

Not taken in lllinois; known from British Columbia, Maine, Michigan, Minnesota, Nebraska. Nymphs and adults of this species have been collected on the figwort (Scrophularia leporella), but it has not been proved that this plant is normally their host.

\section{CAPSINI}

\section{KEY TO GENER.4}

1. Pronotum punctate, sometimes only very finely punctate but usually distinctly so; strongly shining, calli usually prominent, figs. 152, 153.. 2

Pronotum impunctate, or with fine aciculate punctures only.......11

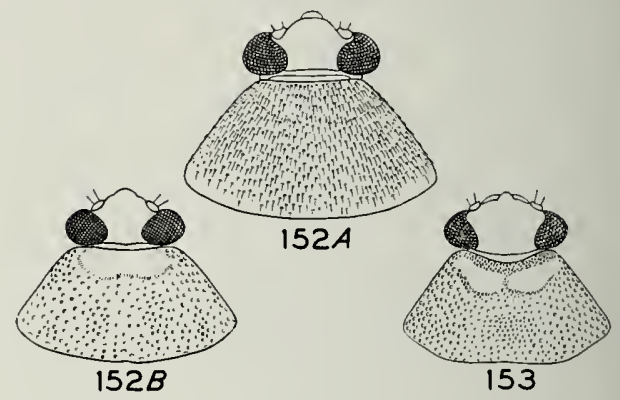

Fig. 152. - $A$, head and pronotum of Neolygus invitus; $B$, head and pronotum of Lygus oblineatus.

Fig. 153.-- Head and pronotum of Neoborus glaber.

2. Second antennal segment clavate, fig. 154; juga tumidly convex; vertex broad, transversely striolate on either side near eyes; short oval, convex, chiefly black species...... $\ldots \ldots \ldots$........... Capsus, p. 138

Second antennal segment linear or practically so, fig. $155 \ldots \ldots \ldots 3$

3. Pronotum punctate between calli and posterior to collar............ 4

Pronotum impunctate between calli and posterior to collar........6 6

4. Lateral margins of pronotum not carinate; form more elongate and subparallel.......Xenoborus, p. 143

Lateral margins of pronotum carinate or at least with a calloused line; form ovoid.............. 5

5. First antennal segment distinctly thicker than second segment and both segments black; body color red and black.................

Tropidosteptes, p. 139

First antennal segment slender, scarcely equaling thickness of second segment at apex; if body colored reddish, first and second antennal segments pale or yellowish. ............. Neoborus p. 139 
6. First and second antennal segments thickly clothed with heavy black pubescence, fig. 155; large red species, length $8.00 \ldots \ldots \ldots \ldots \ldots$

Coccobaphes, p. 138

First antennal segment more sparsely clothed with pale pubescence, fig. 156 ; size less than $7.50 \ldots \ldots \ldots .7$

7. Pronotum with lateral margins sharply angulate, carinate near posterior angle; body red and black, fig. 159

.Neocapsus, p. 147

Pronotum with lateral margins rounded or angulate, but not carinate... 8

8. Rostrum extending to fourth or fifth abdominal sternite; dorsum glabrous......... Platylygus, p. 147

Rostrum rarely extending beyond tips of hind coxae; if so, then dorsum distinctly pubescent.......... 9

9. Pronotum very finely punctate, fig. $152 A$; body integument more thinly chitinized, more fragile.

Neolygus, p. 154

Pronotum coarsely, or at least distinctly punctate, fig. 152B; body integument heavily chitinized . . . . 10

10. Second antennal segment distinctly more slender at base, fig. 162; lateral margins of pronotum angulate.

Lygus, p. 148

Second antennal segment cylindrical, scarcely more slender at base, fig. 158 ; lateral margins of pronotum rounded.

Lygidea, p. 145

11. First antennal segment thickened, clothed with numerous flattened hairs, fig. 172. Neurocolpus, p. 181

First antennal segment devoid of flattened hairs, fig. $170 \ldots \ldots \ldots 12$

12. Pronotum with two subexcavated, dull, black spots situated behind the callosities, fig. 170; first antennal segment clothed with long black hairs and setae.

Paracalocoris, p. 176

Pronotum without black spots, or with only superficial ones, and with first antennal segment without prominent, long, black setae; length of hairs on first antennal segment rarely exceeding thickness of segment.

13. Second antennal segment thickened; somewhat spindle shaped, fig. 171

Garganus, p. 181
Second antennal segment linear, or only very slightly thickened at tip, fig. $168 \ldots \ldots \ldots \ldots \ldots \ldots \ldots \ldots$

14. Hind femora long, extending much beyond tip of abdomen, and flattened, broadest before middle and more slender at apex, fig. $177 \ldots \ldots$. . . . ............Phytocoris, p. 184

Hind femora shorter, not or scarcely extending beyond tip of abdomen, fig. $169 \ldots \ldots \ldots \ldots \ldots \ldots \ldots \ldots$

15. First segment of hind tarsus distinctly longer than third.........

Stenotus, p. 175

First segment of hind tarsus shorter than third................ 16

16. Dorsal surface distinctly pubescent, dull, fig. $166 \ldots \ldots \ldots \ldots \ldots \ldots$

Dorsal surface glabrous, highly polished, fig. 167

17. Body above and below clothed with silky or woolly pubescence.

Polymerus, p. 166

Body clothed only with simple pubescence, never woolly.

18. Head broad, eyes practically in contact with pronotal angles, hind margins of eyes somewhat flattened and forming an arcuate line with base of vertex, fig. 166 .

Dichrooscytus, p. 165

Head not unusually broad, eyes convex behind and well removed from pronotal angles, fig. 168

19. Thickness of fourth antennal segment almost equal to that of base of second segment; mesal length of collar subequal to thickness of fourth antennal segment, fig. 168

Ad eiphocoris, p. 174

Fourth antennal segment distinctly thinner than base of second segment; mesal length of collar distinctly greater than thickness of fourth segment....Calocoris, p. 137

20. Rostrum short, scarcely surpassing anterior coxae.

Poecilocapsus, p. 172

Rostrum longer, at least reaching posterior margins of middle coxae.

Horcias, p. 172

\section{Calocoris Fieber}

No Illinois species; Calocoris norvegicus (Gmelin) is a European species now known 
from Connecticut, Maine, Massachusetts, New Jersey, New York, Nova Scotia, Quebec, where it occurs on grasses.

\section{Capsus Fabricius}

\section{KEY TO SPECIES}

Second antennal segment strongly clavate on apical half, thickness nearly twice that of first segment, fig. $154 \ldots \ldots \ldots$. . ater, p. 138

Second antennal segment only moderately clavate on apical half, thickness only slightly greater than that of first segment............... simulans, p. 138

\section{Capsus ater (Linnaeus)}

Cimex ater Linnaeus (1758, p. 447).

MALE.-Length 5.70, width 2.60. Head width 1.43 , vertex 0.75 . Antennae, first segment, length 0.65 , thickness 0.13 ; second,

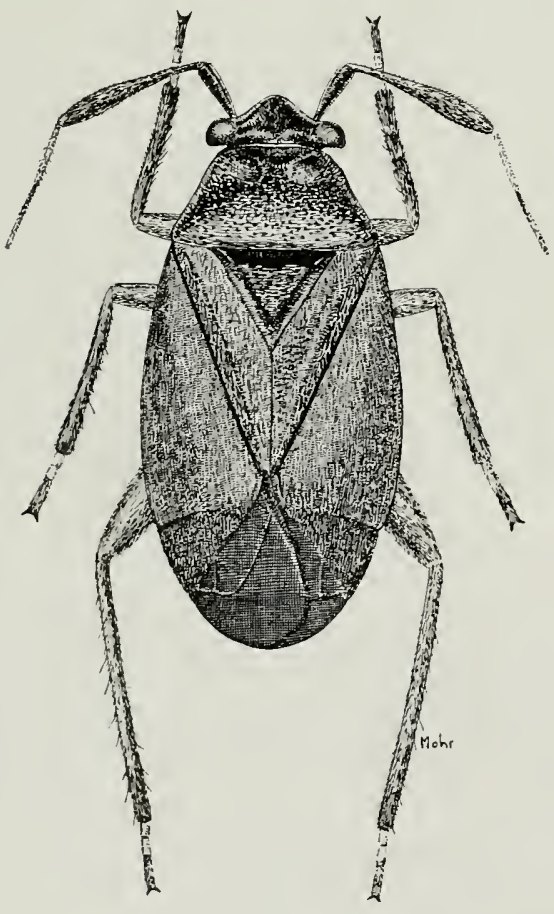

Fig. 154.-Capsus ater,

1.86, strongly clavate, greatest thickness 0.22 ; third, 0.73 , slender; fourth, 0.91 . Pronotum, length 1.21 , width at base 2.03 . Head and body uniformly black, moderately shining; the pronotum shallowly, but rather coarsely, punctate; clothed with pale to yellowish pubescence.

Female.-Fig. 154. Length 5.80, width 3.10. Very similar to male in color, pubescence and punctation.

The typical form of this species has black legs, variety tyrannus (Fabricius) (1794, p. 177) has yellow brown or reddish legs, and variety semiflavus (Linnaeus) $(1767$, p. 725$)$ has the legs, head and pronotum reddish. All three forms and their intergrades have been taken together in Illinois. All Illinois specimens with the reddish head and pronotum are females.

Food Plants.-Canada bluegrass ( $\mathrm{Poa}$ compressa), couch grass (Agropyron repens); occasionally other grasses, such as timothy (Phleum pratense).

Known Distribution.-This European species is common throughout the eastern United States and Canada.

Illinois Records.-One hundred fifteen males, 67 females and 1 nymph, taken May 13 to Aug. 12, are from Algonquin, Amboy, Antioch, Aurora, Bloomington, Chicago, Des Plaines, East Dubuque, Edgebrook, Elizabeth, Erie, Fort Sheridan, Frankfort, Freeport, Galena, Galesburg, Glendon Park, Glen Ellyn, Grayslake, Harvard, Havana, Joliet, Monticello, Normal, Oregon, Palos Park, Pecatonica, Rock Island, Savanna, Starved Rock State Park, Urbana, Willow Springs.

\section{Capsus simulans (Stål)}

Deraeocoris simulans Stål (1858, p. 186).

This species is distinguished from ater (Linnaeus) by its more slender second antennal segment. It is a palearctic form that feeds on brome grass (Bromus inermis) and has been found in Alaska, Alberta, Iowa, Minnesota, Montana, South Dakota, Wyoming. Not as yet found in Illinois, but it should be taken here eventually.

\section{Coccobaphes Uhler}

\section{Coccobaphes sanguinareus Uhler} 401).

Coccobaphes sanguinareus Uhler (1878, p.

Adults.-Fig. 155. Length 7.50, width 3.40. General color bright 'red with a dusky space either side of hemelytral commissure: membrane, first two segments of antennae, tibiae, and apices of tarsi, black; third an- 
tennal segment pale; fourth segment fuscous.

Food Plants.-Sugar maple (Acer saccharum) and occasionally red maple ( $A$.

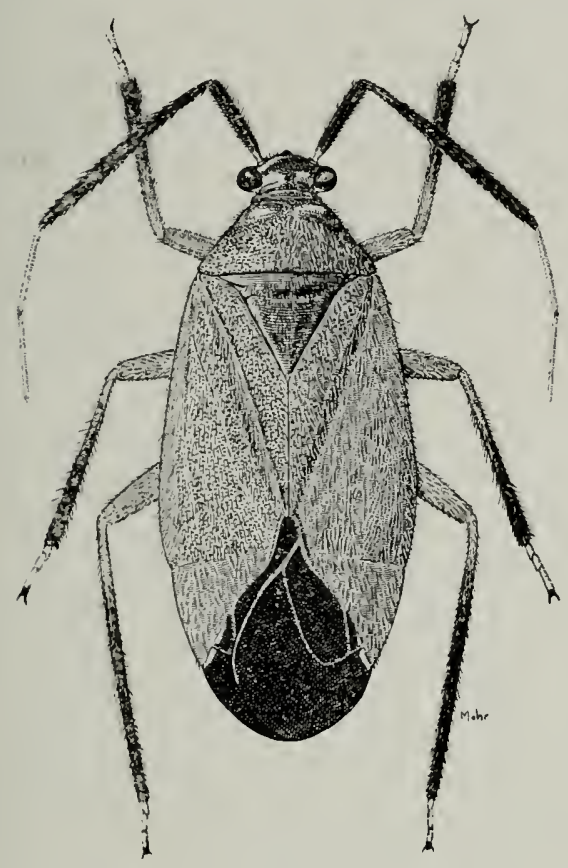

Fig. 155.-Coccobaphes sanguinareus.

rubrum); breeds most abundantly on second growth or young trees.

Known Distribution.-Connecticut, Illinois, Indiana, Iowa, Maine, Massachusetts, Michigan, Minnesota, New Hampshire, New Jersey, New York, North Carolina, Ohio, Ontario, Pennsylvania, Tennessee, Vermont, Wisconsin.

Illinois Records. - Nine males and $7 \mathrm{fe}$ males, taken May 24 to Aug. 9, are from Carbondale, Champaign, Elizabethtown, Hardin, Herod, Makanda, Urbana.

\section{Tropidosteptes Uhler}

\section{Tropidosteptes cardinalis Uhler}

Tropidosteptes cardinalis Uhler (1878, p. 404)

Adults.-Length 5.50, width 2.60; general color bright red with antennae, tylus, legs except apices of front and middle femora, space on either side of commissure of hemelytra, and membrane, black.

Food Plant.-White ash (Fraxinus americana) and occasionally other species of ash; occurs most frequently on young trees.

Known Distribution.-Connecticut, Florida, Illinois, Iowa, Massachusetts, Michigan, Mississippi, New Hampshire, New Jersey, New York, Ohio, Ontario, Pennsylvania, Texas, Vermont.

Illinois Records.-Dubors: May 14, 1916, 1 우 ; May 15, 1916, 2 o ; May 21,

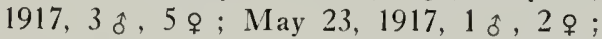
May 24, 1917, 1 of. Frankfort: June 8, 1933, Mohr \& Townsend, 4 $\delta, 2$ q, Herod: May 29, 1936, Ross \& Mohr, 1 q. Urbana: June 3,1906 , on elder, 1 o .

\section{Neoborus Reuter}

\section{KEY TO SPECIES}

1. Dorsum practically glabrous....... 2 Dorsum strongly pubescent....... 8

2. Rostrum attaining hind margins of middle coxae; a black line bordering outer margin of radius and curving mesad across apical area of corjum............ palmeri, p. $1+1$

Rostrum not extending beyond posterior margin of mesosternum.... . 3

3. Antennae very dark brown; scutellum dark brown, basal angles pale; hemelytra dark brown to pitch black, pale or yellowish at base of corium and embolium and on areas extending along radius......glaber, p. 140

First antennal segment pale, rarely somewhat dusky............ 4

4. Dorsum uniformly black with cuneus pale, except apically, and membrane black; sometimes with a small pale spot at base of corium .

geminus, p. 140

Dorsum more or less pale, frequently marked with red; scutellum usually with some pale or yellow, but, if black, then membrane and cuneus pale................. 5

5. Chiefly pale, with apical area of corium reddish. ..

amoenus var. amoenus, p. 140

Chiefly black or very dark brown, almost black.............. 6

6. Membrane slightly smoky, paler on area bordering apex of cuneus....

...amoenus var. scutellaris, p. 140

Membrane entirely pale......... 7

7. Very dark brown, almost black; lateral 
and median vittae on pronotal disk, all of scutellum except basal angles and median line at base, and corium, more or less pale..........

amoenus var. signatus, p. 140

Black; only cuneus and membrane pale.

amoenus var. atriscutis, p. 140

8. First antennal segment black....... 9

First antennal segment pale.......11

9. Scutellum very dark brown on either side of median line, basal angles paler; hemelytra translucent reddish brown; cuneus colored similarly to corium...... rufusculus, p. 143

Scutellum testaceous, sometimes brownish on middle at base, never black with median line paler..... 10

10. Second antennal segment yellowish brown, sometimes black near base; cuneus translucent yellowish to brownish.......canadensis, p. 141

Second antennal segment uniformly black; cuneus clear and translucent populi, p. 142

11. Dorsum uniformly black, cuneus clear, legs pale.....tricolor, p. 143

Dorsum more or less pale, scutellum always partly yellowish........12

12. Scutellum with a median black line extending from base to apex; female with embolium and outer margin of corium black and inner apical angle of corium dull yellow brown.....

vittiscutis, p. 142

Scutellum yellow, sometimes dark at middle of base, but never with a median black line; female with inner apical angle of corium black and embolium chiefly pale........

pubescens, p. 141

\section{Neoborus geminus (Say)} 344).

Capsus geminus Say $(1832$, p. 24; 1859, p.

Adults.-Length 4.80-5.30, width 2.20 . General color deep black, shining; legs, first antennal segment and base of second, and cuneus except apex, pale; front of head usually with pale marks.

Food Plant.-White ash (Fraxinus americana). Usually occurs with amoenus (Reuter) during June.

Known Distribution.--Described from Indiana and since recognized from Illinois, Ohio, Ontario, New York.
Illinois Records. -Galesburg: June 8, 1893, 1 q. Shawneetown: May 27, 1928, T. H. Frison, 1 ô.

\section{Neoborus amoenus (Reuter)}

Tropidosteptes amoenus Reuter (1909, p. 48).

Adults.-Length 4.30-5.00, width 2.00. General color pale yellowish, marked with reddish and fuscous, and sometimes with black; pronotum with five to seven fuscous or reddish rays, clavus and apical area of corium marked with bright red, sometimes tinged with fuscous; apex of second antennal segment and sometimes third and fourth fuscous.

The typical form of this species is mostly pale; darker specimens may be designated by varietal names. Of these, amoenus signatus (Reuter) (1909, p. 49) and scutellaris (Reuter) (1909, p. 49) and intergrading forms have been taken together in Illinois; variety atriscutis Knight (1929c, p. 10) has not yet been taken in the state.

Food Plants. - White ash (Fraxinus americana) and red ash ( $F$. pennsylvanica), especially the latter. Nymphs occur on the trees from May to September; there are apparently two broods per year.

Known Distribution.-Common from Texas and Kansas northward to North $\mathrm{Da}$ kota and eastward to the Atlantic Coast.

Illinois Records.-Ninety-six males, 107 females and 2 nymphs, taken May 24 to Oct. 2, are from Antioch, Chicago, De Soto, Dubois, Elizabeth, Elizabethtown, Evanston, Gibsonia, Glen Ellyn, Golconda, Harrisburg, Havana, l roquois, Kappa, Keithsburg, Monticello, Mound City, Normal, Oregon, Pinkstaff, Quincy, St. Joseph, Savanna, Shawneetown, Starved Rock State Park, Ullin, Urbana.

\section{Neoborus glaber Knight}

Neoborus glaber Knight (1923d, p. 563).

Male.-Length 4.60, width 1.90. Pronotum grabrous, shining, coarsely punctate, lateral margins sharply defined, but not prominently carinate; yellowish testaceous with a large, flaring, dark brown ray extending from each callus to posterior margin. Hemelytra with emboliar margin slightly sinuate, widest behind middle; very dark brown to piceous, shining, coarsely and rather closely punctate, glabrous or with only a minute hair set in pit of coarse punctures; 
area at base of corium and embolium, and areas extending for a space along radius, yellowish testaceous: cuneus yellowish translucent, apical half and area extending along inner margin to basal angle, fuscobrownish. Membrane and veins uniformly fuscous, a small pale spot bordering apex of cuneus. Legs pale yellowish; femora with two subapical brownish bands, these bands lacking on front pair. Venter yellowish, two subdorsal lateral lines dark brownish, genital segment brownish; fine, pale pubescence present on venter, hairs more prominent on genital segment.

FeMale.-Length 4.80, width 2.20. More robust than male and usually with pale areas broader; basal half of corium and more than basal half of cuneus yellowish.

Food Plant.-White ash (Fraxinus americana); often found associated with amoenus (Reuter). A single Illinois specimen was taken on hickory (Cary'a sp.).

Known Distribution.-Connecticut, Illinois, Iowa, Michigan, Minnesota, New York, North Dakota, Ohio, Ontario, South Dakota.

Illinois Records.-NORTHERN IlLINOIS: 1 o. Champaign: June 9, 1888, at light, C. A. Hart, 1 of . Frank fort: June 8, 1933, Mohr \& Townsend, 2 o , 11 q. OQuawka: June 13, 1932, on Carya sp., H. L. Dozier, 1 9. Rago: May 6, 1932, swamp, H. L. Dozier, 1 of. Urbana: May 16, 1887, C. A. Hart, $1 \hat{\delta}$.

\section{Neoborus palmeri Reuter}

Neoborus amoenus palmeri Reuter in Van Duzee (1908, p. 112).

Adults.-Length 5.70, width 2.40. General color pale yellowish with a brown shellaclike gloss; each callus with a transverse mark; line along lateral margin of pronotal disk, and usually a second one parallel to it, line along outer margin of radius which widens apically and crosses corium to inner angle of cuneus, fuscous to black; in pale specimens, black color showing only on corium; sides of pleura frequently black; apex of second antennal segment and entire third and fourth segments fuscous to black.

Food Plant.-White ash (Fraxinus americana) and probably other ash trees.

Known Distribution.-Illinois, Minnesota, New York, South Dakota.

Illinois Records. - BEVERLY HILLS:
Aug. 2, 1920, W. J. Gerhard, $1 \delta$, FM. Elizabeth: July 7, 1917, 1 ô. Freeport: July $4.1917,1$ ㅇ. .

\section{Neoborus pubescens Knight}

Neoborus pubescens Knight (1917c, p. 81).

Adults.-Length 4.60, width 1.70. General color very dark brown marked with pale; clothed with prominent, erect pubescence; more coarsely punctured than in amoenus (Reuter). Pronotum, lateral margins distinctly carinate only on anterior half; black with top of collar, rather wide median stripe on disk, one and sometimes two rays behind each callus, pale yellow. Scutellum yellow, black at middle of base: mesoscutum black; sternum and pleura black; ostiolar peritreme pale; hemelytra pale; inner half of clavus, area along claval suture, large apical spot on corium and small area at edge of embolium, black; membrane mostly pale; in female, dark fuscous to black within cells and on areas margining veins; in male, dark fuscous extending to include middle of membrane: venter black, sometimes less dark in female.

Food Plant.-White ash (Fraxinus americana); found developing only on young plants growing in the shade.

Known Distribution.- 1 llinois, Massachusetts, Michigan, New Hampshire, New York, Ohio, Ontario, Pennsylvania, Quebec.

Illinois Record.-PALOS PARK: July 4, 1910, W. J. Gerhard, 1 of, FM.

\section{Neoborus canadensis (Van Duzee)}

Tropidosteptes canadensis Van Duzee (1912, p. 486).

MaLE.-Length 4.70, width 2.00. Head width 1.08 , vertex 0.41 . Antennae with first segment black; second fusco-brownish, more nearly black at base, pubescence dusky, cylindrical, constricted at base, nearly attaining the thickness of first segment; third fuscous; fourth fuscous. General color yellowish testaceous; clavus, apical area of corium, two subapical bands on hind femora, and calli, very dark brown; pronotal disk obscure brownish to fuscous on either side of median line; base of scutellum at middle brownish, brown color somewhat notched by paler on median line; dorsum coarsely and rather closely punctate, clothed with erect, yellowish pubescence.

FEMALE,-Length 5.30, width 2.40 ; more 
robust than male; dark color more brownish than black.

Food Plaxt.-White ash (Fraxinus americana).

KNow: Distributiox.-lllinois, Iowa, Michigan, Minnesota, Ohio, Pennsylvania, Quebec, South Dakota, Texas.

Illinois Records.-NORTHERN ILLINOIS: June, 3 q. Frankfort: June 8, 1933, on Fraxinus sp., Mohr \& Townsend, 7 ó, 35 q. Palos PARK: June 19, 1909, A. B. Wolcott, 1 o , FM. Rock Ford: June 11, 1933, Mohr \& Townsend, 1 $q$. Urbana: June 1, 1889, 1 s , 1 \% .

\section{Neoborus populi Knight}

Neoborus populi Knight (1929c, p. 4).

MALE.-Length 4.20 , width 1.70 . Head yellowish; tylus, spot above each antennal socket, and mark either side of median line of frons, black. Rostrum, length 1.06, nearly attaining hind margin of sternum, yellowish, apex black. Antennae with first and second segments black, third brownish, fourth yellowish. Calli prominent, black, surrounded by yellowish, posterior half of disk black, but this not joined with black on calli; lateral margins of disk slightly sinuate, not distinctly carinate. Body clothed with prominent, erect, pale pubescence, hairs longer

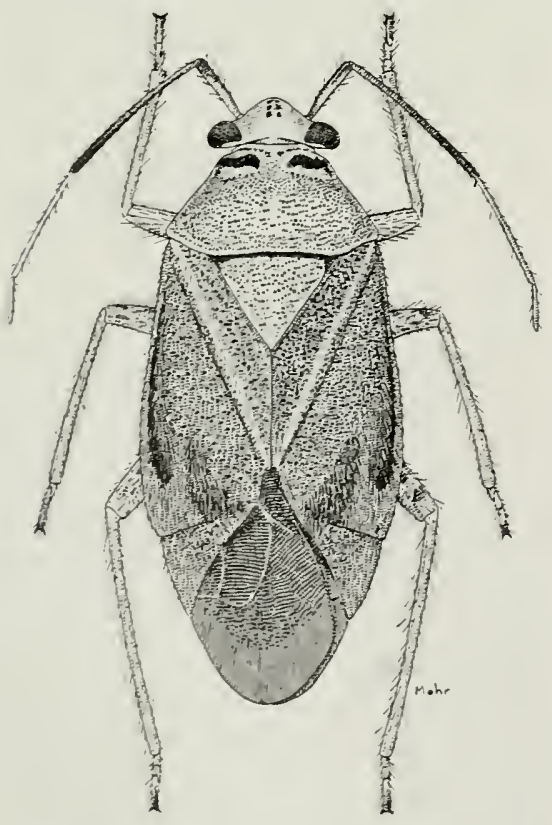

Fig. 156.-Neoborus populi, ㅇ. and more prominent than in pubescens Knight. General color pale to yellowish, shaded with black; scutellum yellow, without vitta; calli, mesoscutum, inner apical half of clavus, all except apex of embolium, outer margin of corium exterior to radial vein, line extending across apical area of corium to inner angles, pleura, and sternum, black. Cuneus clear; membrane and veins very dark, almost black. Legs yellowish, apical halves of hind femora and bases of tibiae becoming almost black.

Fenale.-Fig. 156. Length 4.60 , width 1.90. Very similar to male in pubescence and coloration, except black areas somewhat reduced; hind femora each with two incomplete, subapical black annuli; membrane fuscous to almost black.

Food Plant.-Cottonwood (Populus sp.).

Known Distribution.-Illinois.

Illinois Records.-IlLINoIS: $1 \hat{\delta}, 3$ ㅇ․ GalesBurg: July 16, 1892, 2 of, 2 q. URBANA, BRownfield Woods: July 19, 1926, Vera G. Smith, 1 o , 1 \& , Kc; July 28, 1889 , C. A. Hart, 1 .

\section{Neoborus vittiscutis Knight}

Neoborus vittiscutis Knight (1923d, p. 566). MaLe.-Length 4.00, width 1.86. Head almost black; bucculae, and margins of juga and lora, paler. Rostrum, length 1.16, reaching to middle of intermediate coxae, pale, apex black; antennae pale except second segment, which is reddish or dusky apically. Pronotum coarsely punctate, with an erect, pale hair arising from each puncture; black, shining, spot on median line, an indistinct ray behind each callus, and carinate lateral margin, pale. Scutellum pale with a narrow, black area at base and a median black line, median line more slender apically; mesoscutum black, clothed with pale pubescence; sternum and pleura black. Hemelytra with emboliar margins slightly sinuate; black, shining, coarsely punctate, slightly paler and somewhat translucent along claval veins at a spot near base of corium; cuneus pale translucent, apex with a narrow fuscous area. Membrane uniformly fuscous, scarcely paler near apex of cuneus. Legs uniformly pale.

Female.-Length 5.00, width 2.30. Antennae pale. Pronotal disk yellowish testaceous with a black line bordering lateral carina and an indistinct, fuscous line be- 
hind outer margin of callus. Scutellum colored similarly to that of male, median black line broader near base. Hemelytra pale testaceous with embolium and outer margin of corium exterior to radial vein black and tip of embolium pale; membrane pale, areoles except small spot near basal angle of cuneus, veins, and area bordering areoles, dark fuscous. More robust than male and with pale areas broader.

Food Plant.-Ash (Fraxinus sp.).

KNow Distribution.-District of $\mathrm{Co}$ lumbia, Illinois, Maryland, Mississippi, Missouri, Virginia.

Illinois Records.-DARwix: July 23, 1932, on Fraxinus americana, Dozier \& Park, 1 \&. Elizabethtown: June 22-24, 1932, on Fraxinus americana, Ross, Dozier \& Park, 1 of, 2 q. Hardin: June 5-9, 1932, on Fraxinus americana, H. L. Dozier, 5 s, 3 q. HARRISBURG: June 25, 1932, on Fraxinus americana, Ross, Dozier \& Park, 1\%. KARNAK: June 23, 1932, on Fraxinus americana, Ross, Dozier \& Park, 2 . Lill.y: June 11, 1914, Mackinaw River, 1 o. 1 \&. Willow Springs: June 27, 1909. A. B. Wolcott, 1 \&, Fu.

\section{Neoborus tricolor (Van Duzee)}

Tropidosteptes tricolor Van Duzee (1912, p. 487 ).

Adults.-Length 5.70, width 2.80. Antennae pale, second segment pale with apex fuscous. Dorsum rather coarsely punctured, with an erect, prominent, pale hair arising from each puncture. General color black with rostrum except apex, legs, ostiolar peritreme, and cuneus, pale; front of head reddish to brownish.

Kxow Distribution.-Described from New Jersey, and since recognized only from Illinois, Indiana, Mississippi, Missouri.

Illinois Records.-Urbana: Aug. 9. 1920, J. R. Malloch, 1 o. Vienna: June 14. 1934, DeLong \& Ross, 1 .

\section{Neoborus rufusculus Knight}

Neoborus rufusculus Knight (1923d, p. 564). Adults.-Length 4.60, width 1.86. General color of head yellowish; tylus, median line of front and joining arc above, and juga except sutural margins, blackish. Antennae, first segment black; second fuscoblackish; third and fourth fuscous. Pronotum, length 0.94 , width at base 1.69 ; coarse- $\mathrm{ly}$ and rather closely punctate, shining, clothed with erect, pale yellowish pubescence; brownish black; collar, median line of disk that narrows near basal margin, spot behind outer angle of each callus, and slender basal margin. yellowish testaceous; carinate lateral margins of disk only moderately distinct, slightly more sulcate than in canadensis ( $V$ an Duzee). Scutellum coarsely punctate, clothed with erect, yellowish pubescence; brownish black, median line and basal angles paler; mesoscutum brownish with prominent pubescence. Sternum brownish black, median line yellowish, pleura blackish, clothed with prominent puhescence; ostiolar peritreme pale. Hemelytra, emboliar margins nearly straight, but curved at each end; reddish brown, translucent, darker on clavus bordering scutellum and commissure; rather coarsely and closely punctate, shining, clothed with prominent, erect, yellowish pubescence; cuneus reddish brown, translucent, scarcely paler at base. Membrane and veins fusco-brownish, a small pale spot bordering apex of cuneus. Legs yellowish; apical half of hind femora, somewhat on apex of middle pair, base of tibiae and somewhat on middle of hind pair, blackish; apices of tarsi fuscous. Venter blackish; ventral surface except on genital segment, yellowish; pubescence pale.

Food Plant.-Ash (Fraxinus americana).

Known Distribution.--Illinois, Minnesota, Mississippi, New York, Texas.

Illinois Record.-White Pines Forest State Park: June 4,1933 , Ross $\mathbb{k}$ Townsend, 10 .

\section{Xenoborus Reuter}

\section{KEY TO SPECIES}

1. Membrane pale or, if fuscous, paler on middle.................. 2

Membrane uniformly fuscous or black. 3

2. Dorsum uniformly pale greenish yellow, fuscous along commissure of hemelytra; length 6.40

commissuralis, p. 144

Dorsum with black areas broader; calli, spot either side of median line on pronotal disk, clavus except along claval vein, and spot on apical area of corium, very dark fuscous, almost black; membrane fuscous, with an oval spot on middle of apical half; 
within areoles, distinctly paler; length $5.00 \ldots \ldots$. plagifer, p. $1+4$

3. Posterior tiliae uniformly pale; femora pale or only rarely dusky near apex; embolium and basal half of corium pale in both sexes...neglectus, p. 144

Posterior tibiae fuscous, almost black near base; posterior femora black apically or with dark color forming two bands; embolium and basal half of corium pale in some female specimens.............. pettiti, p. $1+5$

\section{Xenoborus commissuralis Reuter}

Xenoboruscommissuralis Reuter in Van Duzee (1908, p. 112).

Adults.-Length 6.40, width 2.30. General color uniformly pale greenish, becoming yellowish after death; antennae, a narrow streak along commissure of hemelytra, tips of tarsi, and tip of rostrum, very dark fuscous, almost black; membrane pale translucent; brachium and a streak beyond apex of larger areole dusky.

Food Plant.-Black ash (Fraxinus nigra); occurs during July and August.

Known Distribution.-Illinois, Iowa, Minnesota, New York, Nova Scotia, Ontario, Quebec.

Illinois Records.-NORTHERN ILLINOIS: 1 o , 4 ․ Galesburg: July 16, 1892, 2 우.

\section{Xenoborus plagifer (Reuter)}

Tropidosteptes plagifer Reuter (1909, p. 51).

Adults.-Length 5.00, width 1.90. General color pale yellowish testaceous; antennae, calli, male usually with a spot either side of median line on pronotal disk, clavus except claval vein, and spot on apical area of corium, very dark brown, almost black; scutellum yellow; membrane fuscous, with an oval spot on middle of apical half, and area within areoles, distinctly paler; female with pale areas broader, infuscation on apical half of membrane forming a ray at either side behind areoles. Male claspers as in fig. 157.

Food Plant,-Black ash (Fraxinus nigra); occurs during August and September.

Know Distribution.--lllinois, Minnesota, New York, Ontario, Wisconsin.

Illinois Records.-Northern IllinoIs: 2 子, 6 우. Galesburg: Sept. 12, 1888, 2 \%, 2 \&.

\section{Xenoborus neglectus Knight}

Xenoborus neglectus Knight (1917c, p. 82). Male.-Length 5.40, width 2.10. General color black with pale areas; antennae almost black, paler on base of first segment; head with lower half of face fuscous; front pale, flecked with reddish; carina and a small median dash at middle of vertex almost black. Pronotum not carinate, punctation and pubescence nearly as in plagifer (Reuter); collar and large median spot or ray on disk white or pale yellow; pale ray extending from outer angle of callus

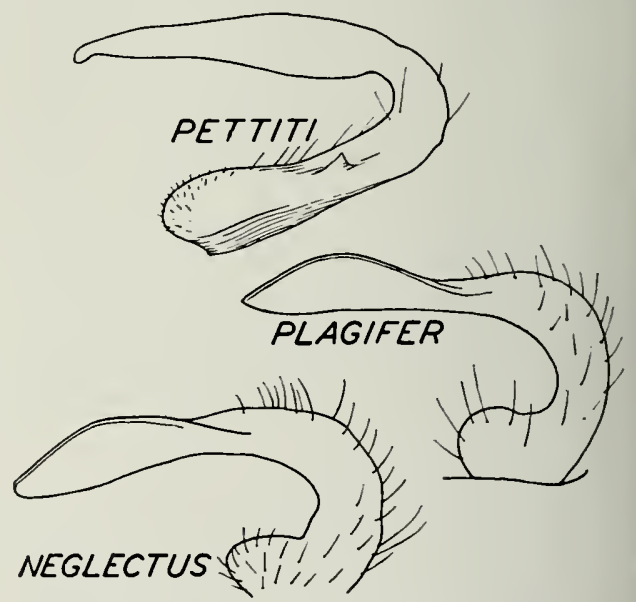

Fig. 157.-Male left genital claspers of Yenoborus.

along lateral margin of disk to basal angle: scutellum pale yellowish, mesocutum almost black. Hemelytra very dark brown, almost black; embolium, basal angle of corium and cuneus, pale translucent; membrane uniformly fuscous. Legs pale yellowish; hind femora sometimes dusky near apices, but never distinctly banded. Claspers as in fig. 157.

FEMALE.-Membrane slightly paler on middle; a black ray present behind each callus; lateral margin and basal angle of disk remaining yellowish.

Food Plants.-Occurs during June and probably breeds on black ash (Fraxinus nigra). Found on pignut (Carya glabra) in Illinois.

Krown Distribution.-Illinois, Michigan, New York, Ohio, Ontario.

Illinois Record.-East Dubuque: June 1, 1933, on Carya glabra, Ross \& Townsend, 2 \%, 8 f. 


\section{Xenoborus pettiti (Reuter)}

Tropidosteptes pettiti Reuter (1909, p. 50). Adults.-Length 5.70, width 2.10. General color black; scutellum yellow; sometimes with embolium, basal half of corium, and all of cuneus except apex, pale; front of head and pronotal disk sometimes reddish; lateral margins and basal angles of disk never so pale as median line, except in teneral specimens killed before any black color develops on pronotum; legs pale, with posterior femora almost black apically, or with dark color forming two subapical bands. Male claspers as in fig. 157.

Food Plaxt.-Wh ite ash (Fraxinus americana); occurs during $M$ ay and June.

Known Distribution.-Iowa, Kansas, Minnesota and eastward.

Illinois Records.-NorThERN IllinoIS: 1 f. Algonquin: June 12, 1897, 1 우 ; June 29, 1907, W. A. Nason, 1 ô, 1 o. Chicago: June 5, 1908, at light, W. J. Gerhard, 1 ô, Fil. Frankfort: June 8, 1933, Mohr \& Townsend, $+q$. PAlos PARK: June 20, 1909, at light, W. J. Gerhard, 4 of, FM. Urbana: May 19, 1889, C. A. Hart, 1 ô ; May 31,1889 , C. A. Hart, 1 \%. White Pines Forest State Park: June 4, 1933, Ross \& Townsend, 1 ㅇ.

\section{Lygidea Reuter}

\section{KEY TO SPECIES}

1. Rostrum scarcely attaining posterior margin of intermediate coxae...... ?

Rostrum reaching to near apices of hind coxae.

2. Length of first antennal segment equal to width of vertex plus one-half dorsal width of an eye; hemelytra with pubescence chiefly suberect, set moderately close; cuneus chiefly pale, red only along inner margin and at apex............. viburni, p. 145

Length of first antennal segment less than or scarcely greater than width of vertex................ 3

3 Second antennal segment provided with several erect hairs that in length exceed thickness of segment; length $6.00-6.30 \ldots . . .$. . . rosacea, p. 145

Second antennal segment provided only with short hairs that in length are less than thickness of segment; length $5.60-5.90 \ldots$.... salicis, p. 146
4. Color orange red with basal margin of pronotum and variable areas of outer margins of hemelytra fuscous to almost black.......mendax, p. 146

Color chiefly fuscous to almost black with ground color pale to greenish, never reddish........obscura, p. 145

\section{Lygidea rosacea Reuter} 46).

Lygidea rubecula rosacea Reuter (1909, p.

MaLE.-Length 6.70, width 2.00. Head width 1.26 , vertex 0.63 . Rostrum, length 1.85, reaching to middle of intermediate coxae. Antennae, first segment, length 0.60 ; second, 2.10, pubescence dense and intermixed with several erect hairs which in length exceed thickness of segment; third, 0.88 ; fourth, 0.57. Hemelytra densely clothed with closely appressed, golden yellow pubescence; clavus and apical half of corium fuscous to black, basal half of corium and embolium yellowish translucent. Cuneus red with a yellowish area at base and extending to middle along outer margin.

Fenale.-Length 6.50, width 2.60. Head width 1.34 , vertex 0.68 . Antennae, first segment, length 0.60 ; second, 1.90 ; third, 0.80 ; fourth, 0.60. Dorsum chiefly red, although in dark forms clavus and apical half of corium hecoming infuscated.

Food Plant.-Sandbar willow (Salix longifolia).

Known Distribution. - Illinois, Iowa, Minnesota, Ohio, South Dakota.

Illinois Records.-Fifteen males and 32 females, taken June 1 to July 7, are from Champaign, Chicago, Elizabethtown, Freeport, Grand Tower, Grayslake, I roquois, Kampsville, Keithsburg, New Milford, Pike, Prophetstown, Savanna, Urbana, Vienna, Willow Springs.

\section{Lygidea viburni Knight}

Lygidea viburni Knight (1923d, p. 569).

No Illinois specimens; known from Massachusetts, New Hampshire, New York. Breeds on nannyherry (I iburnum lentago).

\section{Lygidea obscura Reuter}

Lygidea rubecula obscura Reuter (1909, p. 46). MALE.-Length 6.00, width 2.20. Smaller and darker colored than rubecula (Uhler). 
General color dark fuscous to black with genae, apices of juga, median line on frons, median line and slender area along basal margin of pronotum, lateral margins and apical two-thirds of median line of scutellum, thoracic sternum, and lower half of abdominal venter except on genital segment, coxae, hasal halves of femora, and tibiae except base and apex, pale to yellowish; cuneus pale translucent, inner half reddish, apex dark red to almost black.

FeMale.-Length 6.00 , width 2.40 ; very similar to male, but with dark areas smaller. General color yellowish to brownish, darkened with fuscous; head yellowish with bases of juga, and broad mark on frons either side of median line, black; pronotum brownish, a broad black line at either lateral margin and a black ray behind callus on either side of pale median line; hemelytra rather uniformly fusco-brownish; hind femora with very dark brown bands before apices, anterior face more or less black on apical half.

Food Plant.-Black willow (Salix nigra).

Known Distribution.-Illinois, Michigan, New York, Nova Scotia, Ontario, Pennsylvania.

Illinois Records.-Eleven males and 11 females, taken June 3 to July 5, are from Champaign, Chicago, Grand Detour, Homer, Kampsville, Keithsburg, Mount Carmel, Rockford, Urbana, Warsaw, White Heath.

\section{Lygidea salicis Knight}

Lygidea salicis Knight (1939a, p. 22).

Male.-Length 5.60, width 2.20. Rostrum pale, apex black. Antennae with first segment black, slender apex pale; second fusco-brownish, basal one-fourth black, pubescence rather short and recumbent; third fuscous; fourth almost black. Pronotum with disk punctate, transversely rugulose; black, collar except behind eyes, median line of disk, two blotches behind outer halves of calli, disks of calli, narrow area along basal margin, and dorsal margin, pale; ventral one-third of propleura pale. Scutellum pale with a wedge-shaped, very dark brown mark on either side of median line, mesoscutum black. Hemelytra very dark brown, embolium except apically, cuneus except reddish spot on apex, pale translucent. Membrane uniformly dark fuscous, less dark on area bordering apex of cuneus; veins pale. Clavus and corium clothed with pale to silvery, somewhat silky pubescence. Ventral surface white to yellowish; a broad, lateral, longitudinal stripe on thoracic pleura and sides of venter, reddish brown to black. Legs pale; hind femora with two subapical reddish brown annuli; tibial spines yellowish; apical segment of each tarsus fuscous.

Female.-Length 5.90, width 2.30. Very similar to male in color and pubescence, but pale area on disk of pronotum broader.

Food Plant.-Peach-leaved willow ( $S a-$ lix amygdaloides).

Known Distribution.-Illinois, Michigan, Minnesota, Ontario.

Illinois Record.-Galena: June 30 , 1932, Dozier \& Mohr, 1 o, 1 ㅇ.

\section{Lygidea mendax Reuter}

\section{Apple Redbug, fig. 158.}

\section{Lygidea mendax Reuter (1909, p. 47).}

While not as yet collected in Illinois, this bright, orange red species undoubtedly will be found along the Rock River and vicinity.

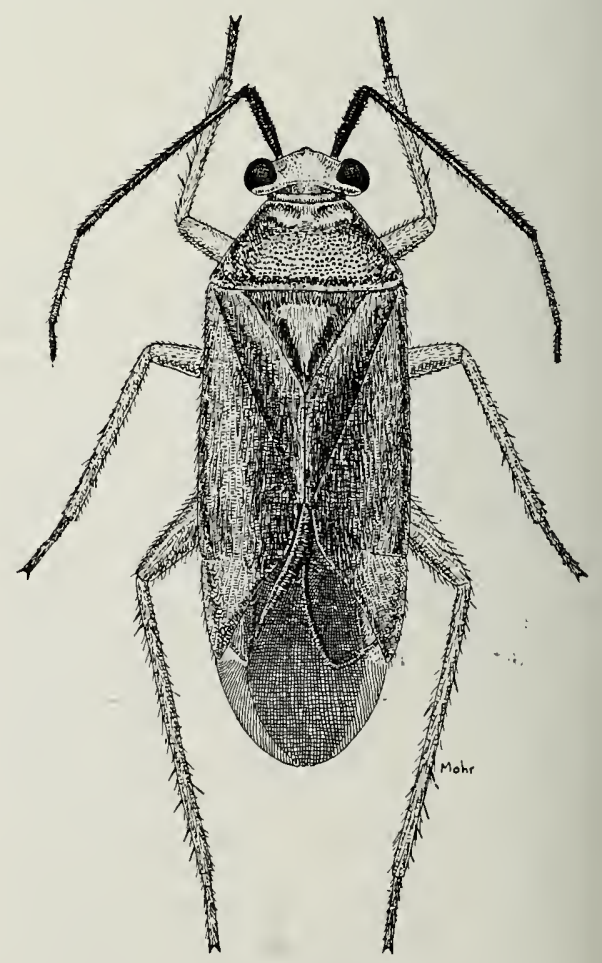

Fig. 158.-Lygidea mendax, ㅇ. 
This assumption is based on the fact that mendax has been collected near Davenport and Bentonsport, Iowa. Occurs on hawthorn (Crataegus sp.), American crabapple (Pyrus coronaria), cultivated apple (Pyrus malus) and to some extent on cultivated quince (Cydonia oblonga). This insect is now regarded as a serious pest on apples in New York, Pennsylvania and Michigan. Known from Connecticut, Indiana, Iowa, Maine, Michigan, New York, Nova Scotia, Ohio, Ontario, Pennsylvania.

\section{Neocapsus Distant}

\section{Neocapsus cuneatus Distant}

Neocapsus cuneatus Distant (1893, p. 438).

Male.-Length 4.80, width 2.60. Head width 1.17 , vertex 0.52 . Rostrum, length 1.73 , reaching to apices of middle coxae.

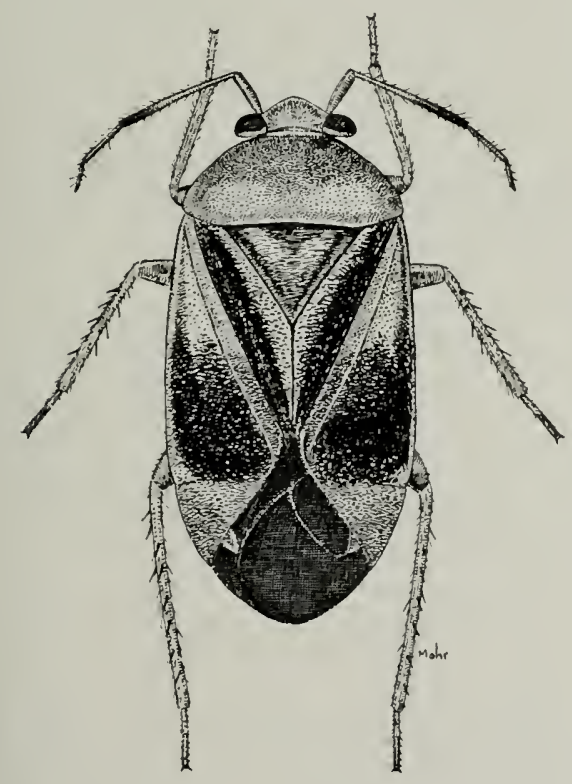

Fig. 159.- Neocapsus cuneatus, 9.

Antennae very short, black, with fine pubescence; first segment, length 0.47 ; second 1.38 , cylindrical, slightly more slender near base; third, 0.56 ; fourth, 0.35 . Pronotum, length 1.25 , width at base 2.25 ; finely, shallowly punctate. Scutellum transversely rugulose, orange red, rarely partly black. Dorsum practically glabrous; hemelytra with minute pubescence in some of the shallow punctures. General color black; prono- tum, except calli and basal angles, femora, and sometimes cuneus, red; head yellowish to red; tylus usually darker.

Fenale.-Fig. 159. Length 5.60, width 2.80. More robust than male and usually with red areas broader; pronotum, scutellum, cuneus, femora and ventral surface of body orange to red; basal area of corium usually pale; tibiae and second antennal segment largely pale.

Food Plant.-Post oak (Quercus stel. lata), according to Dr. H. G. Johnston.

KNown Distribution. - Arizona, Illinois, Mississippi, Missouri, North Carolina, Oklahoma, Texas; Mexico.

Illinois Records.-Dubols: May 15, 1917, 1 o ; May 22, 1917, 1 o ; May 23, 1917, 2 \&, 7 \% May 24, 1917, + $\delta, 3 q$.

\section{Platylygus Van Duzee}

\section{Platylygus luridus (Reuter)}

Lygidea rubecula var. lurida Reuter (1909, p. 46).

MALE.-Fig. 160. Length 6.50, width 2.40. Minutely pubescent; dorsum practi-

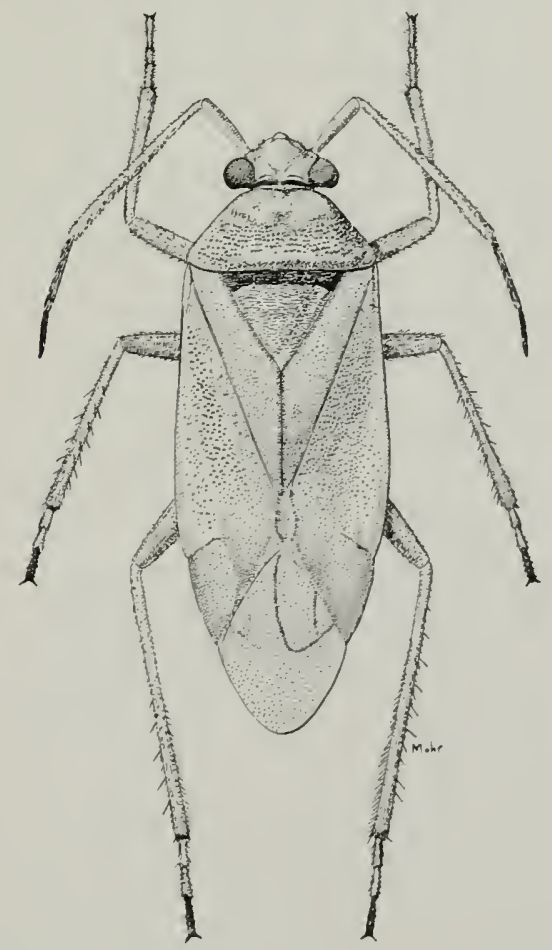

Fig. 160.-Platylygus luridus, $0^{x}$. 
cally glabrous. General color pale yellowish brown; hemelytra translucent; collar and tip of scutellum pale to white; apex and inner half of cuneus, brachium, disk of scutellum, apices of femora, and area on venter, somewhat reddish; third and fourth antennal segments infuscated; apex of rostrum piceous; membrane fumate or pale brownish.

FEMALE.-Length 7.00, width 2.70; more robust than male, but otherwise very similar in structure and coloration.

Food Plant.-White pine (Pinus strobus). The nymphs are yellowish with a tinge of brownish, and thus very closely match the color of the bud scales of their host plant.

Known Distribution. - Illinois, New Hampshire, New York.

Illinois Record. - NorThere IllinoIs: 1 ㅇ․

\section{Lygus Hahn}

\section{KEY TO SPECIES}

1. Length of second antennal segment less than width of head; body ovate, robust, yellowish brown to dark reddish brown, darkened with fuscous...... rubicundus, p. 153

Length of second antennal segment greater than width of head........ 2

2. Basal carina of vertex lacking in middle, visible only at corners of eyes; green or greenish yellow, preserved specimens fading to dull yellowish; $Y$-shaped fuscous mark formed by anal areas of membranes; usually with a longitudinal cloud distad of areoles. pabulinus, p. 153

Basal carina of vertex entire; variously colored................. 3

3. Rostrum just attaining posterior margins of middle coxae; scutellum bright yellow or green..........

campestris, p. 154

Rostrum reaching to or slightly beyond hind coxae.

4

4. Hind tibiae deep black...........

atritibialis, p. 152

Hind tibiae more or less pale...... 5

5. Color chiefly pale or green, sometimes with darker markings..........6 6

Color yellowish brown to black, or reddish. .
6. Tibiae uniformly pale greenish, without bands at base; eyes large; color of body chiefly green. . apicalis, p. 154

Tibiae spotted, often with red and. black bands at base......... 7

7. Rostrum almost, but not quite, reaching tips of hind coxae; abdomen uniformly green; area along claval vein and spot on apical area of corium fuscous...........elisus, p. 152

Rostrum attaining or slightly exceeding apices of hind coxae; abdomen marked with black; hemelytra of female uniformly pale, of male darkened with red and black......

hesperus, p. 151

8. Hemelytra black and irregularly mottled with greenish yellow; head and anterior part of pronotum yellowish green, usually with two black rays behind each callus

plagiatus, p. 153

Hemelytra sometimes dark but not mottled with pale spots; head and pronotum not colored as above... . 9

9. Length 6.50-7.30; nearly glabrous, strongly shining . vanduzeei, p. 150

Length 4.80-6.30; distinctly pubescent................... 10

10. Second antennal segment three times as long as first segment; frons uniformly yellowish, without black lines; length 6.00-6.30. frisoni, p. 151

Second antennal segment less than three times as long as first segment; frons with median line dark; length $5.00-5.50 \ldots \ldots$ oblineatus, p. 148

\section{Lygus oblineatus (Say)}

\section{Tarnished Plant Bug}

Capsus oblineatus Say (1832, p. 21).

This species has passed in American literature under the name Lygus pratensis (Linnaeus) for many years. It differs, however, from the European pratensis in the structure of the right genital clasper, fig. 161; oblineatus is darker in color and has definite stripes.

Adults.-Fig. 162. Length 4.90-5.50, width 2.50 ; ovate. General color shining, yellowish brown with more or less blackish marking, or reddish brown and fuscous areas; pronotum with yellowish and blackish rays; scutellum margined with blackish leaving a $Y$ - or heart-shaped yellowish 
chorn, Elizabeth, Elizabethtown, E r i e, Ernst, Evanston, Fairmount, Farmer City, Fountain Bluff, Fox Lake, Frankfort, Fulton, Galena, Galesburg, Georgetown, Giant City State Park, Glencoe, Glen Ellyn, Glenview, Golconda, Grand Detour, Grand

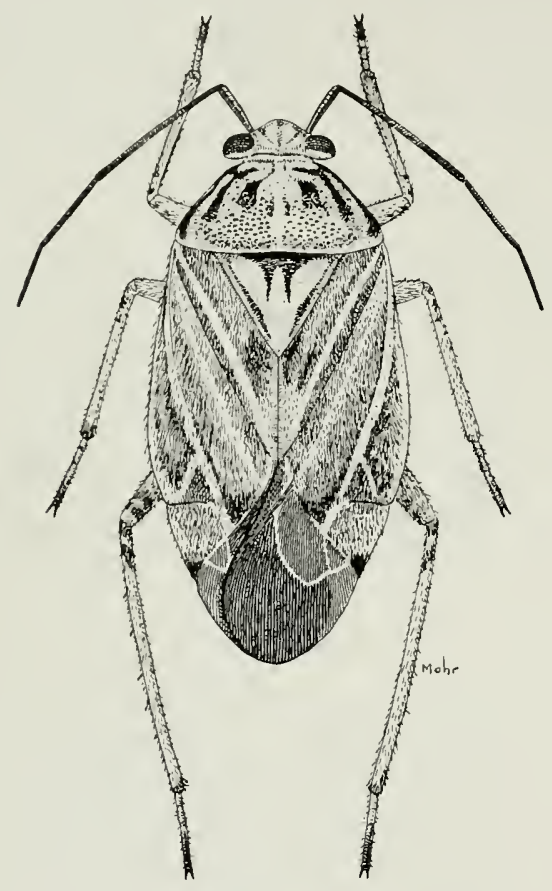

Fig. 162.-Lygus oblineatus.

Tower, Grand View, Grayville, Hamilton, $\mathrm{Hardin}, \mathrm{Harrisburg,} \mathrm{Harvard,} \mathrm{Hatton}, \mathrm{Ha}-$ vana, Henry, Herod, Hillsboro, Hillsdale, Homer, Horseshoe Lake, Iroquois, Joliet, Kampsville, Kankakee, Kansas, Kappa, Karnak, Keithsburg, Lawrenceville, Lima, Litchfield, Mahomet, Makanda, Marshall, Mason City, Maywood, McClure, Metropolis, Milford, Monmouth, Monticello, Mounds, Mount Carmel, Mount Carroll, Muncie, New Columbia, New Milford, Normal, Oak Lawn, Oakwood, Olive Branch, Ozark, Palmer, Palos Park, Paris, Parker, Patoka, Pekin, Philadelphia, Pulaski, Quincy, Riverdale, River Forest, Rockford, Rock Island, Rockton, St. Anne, Savanna, Savoy, Seymour, Shawneetown, Sheldon, Sherman, Sparland, Springfield, Starved Rock State Park, Temple Hill, Union County State Forest, Urbana, Vienna, Ware, Warsaw, Watseka, Waukegan, West Union, White Heath, White Pines
Forest State Park, Willow Springs, Woodstock, York, Zion.

\section{Lygus vanduzeei Knight}

Lygus vanduzeei Knight (1917b, p. 565).

Mat.E.-Length 7.10, width 3.30. Head width 1.25 , vertex 0.50 . Rostrum, length 2.93, just attaining posterior margins of hind coxae, yellowish brown, apex blackish. Antennae, first segment, length 0.85 , reddish brown to black; second, 2.22 , reddish brown, apex blackish; third, 1.31, blackish, narrow pale area at base; fourth, 1.00 , fuscous; all segments with fine pubescence. Pronotum, length 1.70 , width at base 2.82 ; nearly glabrous, strongly shining, punctures deep and irregularly placed; a small black spot present behind each callus, usually two in darkest specimens; basal angles with a black spot just inside the narrow, pale margins; in darkest specimens, dark lines extending along lateral margins of disk; a snall black spot present just above coxal cleft; dark specimens have dark brown rays behind black spots on disk. Scutellum transversely rugose and sparsely punctate; yellowish brown, with apex and dash on either side at base paler. Hemelytra strongly shining, with minute pubescence, nearly glabrous; punctures coarse and deep, somewhat crowded; color rich dark brown, darker on clavus and at apex of corium; claval vein and cubitus pale; embolium translucent yellowish except at apex; cuneus translucent yellowish, dark brownish to blackish at base and on extreme apex. Membrane fuliginous, a pale spot present in center and on either side just behind apex of cuneus; veins at apices of cells and in area bordering apex of cuneus also pale. Legs yellowish brown, apical halves of posterior femora brownish to blackish, with two pale rings near each apex; tibiae greenish yellow, each apex and spines dark brownish, a dark spot on base and, in some cases, a dark stripe; tarsi dark brownish, tips blackish. Venter yellowish brown, a dark brownish, longitudinal stripe on either side; some specimens brownish beneath, thus forming a pale stripe beneath dark lateral one. Genital claspers, fig. 161, typical for this group, but shape of claw on right clasper and internal arm on left distinguishes this species.

Female.-Length 6.70 ; width 3.40 ; more robust than male, but very similar in color and general structural characters. 
Food Plant.-Goldenrod (Solidago canadensis and perhaps other species of the genus). The adults hibernate and come forth in early spring to feed on the tender goldenrod plants. The eggs are doubtless inserted in the goldenrod stems where the nymphs appear and feed during July. In New York, most of the adults mature by the middle of August, and continue to feed until the cool September nights make them seek hibernation quarters.

Known Distribution.-Illinois, Iowa, Minnesota, Ontario, Wyoming and eastward, perhaps everywhere its host plant grows freely.

Illinois Records.-Northern llLinoIs: 1 f . Apple River Canyon State Park: July 11, 1934, DeLong \& Ross, 1 o, 2 q . Galesburg: Sept. 13, 1888, 1 \% . Rock IsLAND: May 19, 1934, Ross \& Mohr, 1 ô. SavanNa: June 13, 1917, 1 q. White Pines Forest State Park: July 12, 1934, DeLong \& Ross, 1 ô.

\section{Lygus frisoni new species}

This is to be distinguished from oblineat us (Say) by its larger size and longer second antennal segment; it is smaller than vanduzeei Knight, but the second antennal segment is relatively longer than in that species.

MALE.-Length 6.10, width 3.00. Head width, 1.18 , vertex 0.48 ; yellowish without dark marks, collum black. Rostrum, length 2.60, extending to tips of hind coxae, yellowish, apex black. Antennae, first segment, length 0.73 , yellowish brown, becoming blackish beneath; second, 2.20, brownish, apical one-fourth black; third, 1.04 , black; fourth, 0.91, black. Pronotum, length 1.38, width at base 2.38; disk rather coarsely punctate; yellowish brown; two small spots present behind each callus, large spot at either basal angle, and ray behind top of coxal cleft, black. Scutellum pale to yellowish, darker on median line at base; coarsely punctate; transversely rugulose. Hemelytra punctate, with rather fine pubescence, this pubescence more distinct than in vanduzeei; pale translucent yellow; apical area of corium and area on middle of clavus fuscous to black. Cuneus pale, translucent; extreme tip black. Membrane dark fuscous, veins yellowish; marginal spot beyond tip of cuneus and basal half of cells clear. Venter very dark brown with a broad lateral, longitudinal, yellowish stripe. Legs yellowish brown; apical half of each hind femur very dark brown, with three rather irregular, pale fasciae on anterior aspect; tibiae pale; spot at base and elongate mark just beneath black. Genital claspers rather similar to those of randuzeei.

Holotype, male.-Urbana, Ill.: S e p t. 1932, T. H. Frison.

Paratype. - Same data as for holotype, $1 \delta$.

\section{Lygus hesperus Knight}

Legume Bug 575).

Lygus elisus hesperus Knight (1917b, p.

MaLe.-Length 6.50. Head width 1.22, vertex 0.45 . Rostrum, length 2.68 , slightly exceeding posterior margin of hind coxae. Antennae, first segment, length 0.65 , pale reddish brown, fuscous on ventral side; second, 2.11, reddish, apex and ventral side at base very dark brown; third, 1.00 , dark reddish brown to fuscous; fourth, 0.63 , fuscous. Pronotum, length 1.34 , width at base 2.30 ; yellowish; outer half of calli and a small round spot behind each inner margin, a spot within basal and anterior angles of disk, and a small spot behind coxal cleft, black. Hemelytra more pallid than yellowish; apex of clavus and suture, apical half of corium, and tip of embolium, reddish or marked with red; cuneus with inner margin and apex reddish. Membrane pale, faintly shaded with brownish in areas bordering veins, a darker mark at inner apical angles of larger areoles. Legs yellowish, more or less shaded with reddish; two annuli present near apex of each femur; tibiae yellowish, apices reddish, spines black. Venter fuscous beneath, sides yellowish. Genital claspers as in fig. 161.

Fenale.-Length 6.40. More uniformly yellowish than male, pronotum entirely yellow except for a small black dot behind inner margin of each callus; hemelytra uniformly pallid, without reddish; markings on femora more reduced than in male; venter yellow. Rostrum attaining or slightly exceeding posterior margins of hind coxae.

Food Plants. - This species is an important pest of beans and alfalfa in Idaho and Utah and on cotton in Arizona. Shull (1933) has published a work on the biology and economic status of this species and has given it the common name "legume bug."

KNow Distribution.-This is a west- 
ern species that finds its eastern limits of distribution in Illinois, lowa, Michigan and Minnesota.

Illinois Record. - NORTHERN IllinoIs: 1 ㅇ.

\section{Lygus atritibialis new species}

This species is allied to hesperus Knight and related western species, but is easily to be distinguished by its uniformly black antennae and posterior tibiae, fig. 163.

MaLE.-Length 5.40, width 2.50. Head width 1.17 , vertex 0.45 ; yellow, collum black. Rostrum, length 2.30, extending slightly beyond hind coxae, yellow, apex very dark brown. Antennae uniformly black; first segment, length 0.52 ; second, 1.56; third, 0.87; fourth, 0.65. Pronotum, Iength 1.25 , width at base 2.16 ; yellow; a lateral. submarginal line joining outer half of callus. two rays behind each callus (in dark specimens these rays joining to form a submarginal line), and ray behind top of coxal cleft, black. Scutellum yellow; a geminate mark on middle of base, lateral edges and mesoscutum, black. Hemelytra pale, translucent yellowish; middle of clavus and outer apical angle of corium fuscous. Cuneus pale, trans-

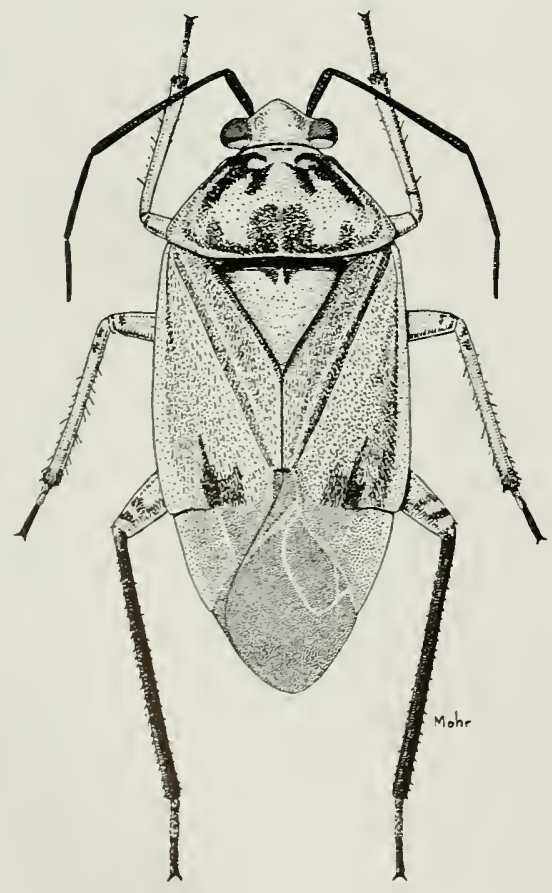

Fig. 163.-Lygus atritibialis, . .
Iucent; outer margin yellowish, but not darker on apex. Membrane pale fuscous, veins pale. Dorsum clothed with fine, short, pale pubescence. Ventral surface uniformly yellow. Legs mostly yellowish, but hind femora with two subapical black annuli; hind tibiae black; middle and front pairs pale, fuscous at apices and each one with a black ring at base, spines black; tarsi fuscous, apices and claws very dark brown. Genital claspers as in fig. 161.

FeMale.-Length 5.20, width 2.50. Head width 1.17 , vertex 0.52 . Antennae, first segment, length 0.49 ; second, 1.51. Slightly more robust than male, but very similar in coloration; black marks on pronotum usually more reduced.

Food Plant.-Apparently breeds on wormwood (Artemisia canadensis).

Holotype, male.-Oregon, Ill.: July 4, 1932, on Artemisia canadensis, Mohr \& Dozier.

Allotype, female. - Same data as for holotype.

Paratypes.-Illinois.-Oregon: Same data as for holotype, 32 ๙ , 48 $q$. RockFord: June 11, 1933, Mohr \& Townsend, 2 s. Zion: July 6, 1932, T. H. Frison et al., $1 \hat{\delta}$.

Michigan.-Pentwater: July 17, 1916, E. Liljeblad, 1 o .

Minnesota.-St. Paul: St. Anthony Park, June 18, 1921, at light, H. H. Knight. 1 ㅇ, KC.

\section{Lygus elisus Van Duzee}

\section{Pale Legume Bug} 20).

Lygus pratensis elisus Van Duzee (1914, p.

MaLe.-Length 4.80-5.80. Head width 1.20, vertex 0.45 . Rostrum, length 2.11, scarcely attaining posterior margins of hind coxae. Antennae, first segment, length 0.52 , pale yellowish to brown, very dark brown on ventral surface; second, 1.98, dusky brown, lower side at base and extreme apex darker; third, 0.85 , brownish, apex fuscous; fourth, 0.60 , dusky brown. Pronotum, length 1.40 , width at base 2.20 ; coarsely, deeply and closely punctate, with minute, pale pubescence. General color pale greenish with pronotum and scutellum bright green, a small black spot present behind each callus. Scutellum bright green, two black dashes in middle at base; roughly, transversely rugose. Mesoscutum black, 
scarcely exposed. Hemelytra pale, translucent; clavus with a dusky cloud in middle, divided by pale claval vein; apex of corium with two small, fuscous patches; cuneus pale, extreme tip fuscous; membrane clear, veins pale. Legs pale yellowish; femora with a wide, fuscous band in middle on ventral side, also with two annuli near each apex; tibiae with a spot on knee and a ring just below, fuscous; spines very dark brown. Venter yellowish green; genital claspers distinctive, fig. 161.

Food Plants.-This species is an important pest on beans and altalfa in ldaho, Utah and Arizona and perhaps other western states. Shull (1933) has discussed the biological and economic status of this species and has given it the common name "pale legume bug."

KNown Distribution.-This is a westtern species which migrated eastward during the drought years of 1930 to 1936. It is now known from Illinois, Iowa. Minnesota and all the states westward.

Illinois Record.-IllinoIs: 1 .

\section{Lygus plagiatus Uhler}

Lygus plagiatus Uhler (1895, p. 35).

MALE.-Length 5.30, width 2.80. More robust than oblineatus (Say). General color black with greenish yellow mottling; head and anterior part of pronotum yellowish or olive green, hemelytra irregularly mottled with black and less dark spots. Right genital clasper distinctive, fig. 161.

FEMaLE.-Slightly more robust than male and usually not so dark in color; second antennal segment shorter; pronotum yellowish, black rays behind calli frequently not reaching black basal margin; venter greenish yellow, blackish on the vagina exterior. dark specimens with black more extended.

Food Pl.ANTs.-Giant ragweed (Ambrosia trifida); a few Illinois specimens were collected on fleabane (Erigeron sp.), smartweed (Polygonum sp.), willow (Salix sp.) and hickory (Carya glabra). The last is undoubtedly a "sitting" record.

Illinois Records.-One hundred thirtyone males and 107 females, taken Feb. 12 to Dec. 1, are from Algonquin, Allerton, Alton, Anna, Antioch, Apple River Canyon State Park, Ashley, Beardstown, Bloomington, Borton, Browns, Calvin, Carbondale, Champaign, Charleston, Danville. Darwin, Decatur, De Soto, Dubois, East
Dubuque, East St. Louis, Elizaheth, Elizabethtown, Forest City, Fountain Bluff, Freeport. Galena, G a le sburg, Grand Tower, Harvard, Havana, Hillsboro, Hillsdale, Homer Park, Kansas, Kappa, Keithsburg. Lawrenceville, Mahomet, Monticello, Mounds, Muncie, Murphysboro, Niota, Oakwood, Oquawka, Oregon, Palos Park, Parker, Pekin, Philadelphia, Prophetstown, Quincy, Rock Island, Rockford, Rockton, St. Francisville, St. Joseph, Sherman, Starved Rock State Park, Springfield, Urbana, Warsaw, Waukegan, West Pullman, White Heath, White Pines Forest State Park, Willow Springs, York.

\section{Lygus rubicundus (Fallen)}

Phytocoris rubicundus Fallen (1829, p. 92).

Male.-Length 4.50, width 2.14. Ovate, robust. General color dark reddish brown to fuscous; second antennal segment shorter than width of head; genital claspers distinctive for species, fig. 161 .

Fenale.-Very similar to male in structure, but usually not so darkly colored.

Host Plants.-Peach-leaved willow (Salix amygdaloides); occurs also to some extent on other willows.

KNowy Distribution.-A com mon, Holarctic species.

Illinois Records.-Seventy-four males and 70 females, taken April 15 to Nov. 15, are from Alton, Antioch, Beardstown, Bloomington, Browns, Cairo, Carbondale, Chicago, Dongola, Elizabeth, Elizabethtown, Freeport, Galena, Galesburg, Geff, Golconda, Grafton, Grand Detour, Grand Tower. Harrisburg, Hatton, Havana, Herod, Hopedale, Kankakee, Lilly, Marshall, Meredosia, Monticello, Mount Carmel, Oquawka, Oregon, Putnam, Quincy, Rockford, Savanna, Springfield, Starved Rock State Park, Thebes, Urbana, Volo, West Union. White Pines Forest State Park, York.

\section{Lygus pabulinus (Linnaeus)}

Cimex pabulinus Linnaeus (1761, p. 253).

MALE.-Length 5.50, width 2.00; body elongate. General color pale green or greenish yellow, frequently fading to dull yellowish; carina of vertex indistinct in middle; a fuscous $Y$-shaped mark formed at extreme anal area of membrane; usually a spot present within apices of areoles, and 
a longitudinal cloud extending beyond areoles to tip of membrane. Genital claspers as in fig. 161.

FEMALE. - Length 6.10, width 2.22 ; slightly larger and more robust than male, but not differing in coloration.

Host PlaNT,-Touch-me-not (Impatiens biflora).

Known Distribution. - Europe and Boreal America; apparently Holarctic in distribution.

Illinois Records.-Eight males and 11 females, taken May 7 to Oct. 6, are from Antioch, Bloomington, Bowmanville, Dubois, Elizabethtown, Evanston, Fountain Bluff, Herod, Karnak.

\section{Lygus campestris (Linnaeus)}

Cimex campestris Linnaeus (1758, p. 448).

Male.-Length 4.10, width 1.77. Ovate, rather small. General color greenish brown or brownish yellow with fuscous areas; scutellum bright yellow or green; genital claspers, fig. 161, distinctive for species.

Female.-Slightly more robust than male; second antennal segment more slender; very similar to male in coloration.

Food Plants.-Poison hemlock (Conium maculatum) and other plants of the family Umbelliferae; Illinois specimens have been collected on wild parsnip (Pastinaca sativa) and cow parsnip (Heracleum lanatum). Reported in Massachusetts and New Brunswick as a pest on celery plants.

Known Distribution.-Common in the northern states and Canada; Holarctic in distribution.

Illinois Records. - Seventy-one males and 83 females, taken April 12 to Oct. 9, are from Algonquin, Allerton, Antioch, Browns, Champaign, Elizabeth, Lawrenceville, Oregon, Palos Park, St. Joseph, Seymour, Spring Grove, Urbana, Waukegan, Willow Springs, Worth.

\section{Lygus apicalis Fieber}

Lygus apicalis Fieber (1861, p. 275).

Lygus Carolinae Reuter (1876, p. 71).

Lygus carolinae Reuter has remained an enigma to American Hemipterists up to the present time. Mr. W. L. McAtee visited the Stockholm museum in 1927 and at the writer's request examined the type of carolinae and drew the genital claspers. These distinctive structures leave no doubt about the identity of the species and its synonymy with apicalis Fieber.

MaLE.-Length 4.50-5.00, width 2.00 ; body oblong; head broad, width 1.12 , vertex 0.29 , eyes unusually large. General color greenish, dark green, or yellowish green; membrane, and, in some cases, corium, marked with fuscous; genital claspers distinctive for species, fig. 161.

Female.-Length 4.60, width 2.05; width of head 1.05 , vertex 0.37 ; uniformly green or greenish yellow; eyes dark brown; tip of tarsi and apex of rostrum very dark brown.

Host Plant.-Fleabane (Erigeron canadensis).

Known Distribution.-Throughout the eastern United States, and known also from Europe, Mexico, Central America and islands of the Pacific.

Illinois Records. - Twenty-seven males and 32 females, taken June 24 to Nov. 11, are from Cypress, Grand Tower, Hardin, Lawrenceville, McClure, Monticello, Mounds, Quincy, Shawneetown, Ullin, Urbana, Villa Ridge, Ware.

\section{Neolygus Knight}

\section{KEY TO SPECIES}

1. Pronotal disk greenish, or yellowish to brownish, but without distinct dark rays.............. 2

Pronotal disk black or marked with dark rays............... 23

2. Color chiefly greenish, old specimens frequently fading to yellowish; sometimes darkened on clavus and at tip of corium, but ground color green.................. 3

Color distinctly yellowish or brownish, more brownish than green.......9

3. Tibial spines with fuscous spots at base; corium never infuscated, but inner half faintly bronzed; clavus and basal half of pronotum usually bronzed.............alni, p. 157

Tibial spines without fuscous spots at base................... 4

4. Dorsum uniformly greenish, with a small, fuscous mark beginning at inner apical angles of corium and extending transversely across anal area of membrane; length 5.20$5.70 \ldots \ldots \ldots$ neglectus, p. 162 
Dorsum partly brownish; apical area of corium and usually clavus distinctly brownish, sometimes dark brown or even fuscous......... 5

5. Membrane with apical half infuscated along median line, this darkened area forming a distinct, longitudinal ray which may be widened apically; corium with a triangular dark brownish spot just before apex, clavus usually brownish; length $5.60-6.00 \ldots \ldots$. . belfragii, p. 162

Membrane never forming a median, longitudinal fuscous ray; smaller forms................ 6

6. Apical one-fifth of second antennal segment infuscated............ canadensis var. canadensis, p. 164

Second antennal segment uniformly colored................. 7

7. Scutellum partly fuscous; clavus also more or less darkened: corium with a triangular dark patch before apex ................tiliae, p. 161

Scutellum pale; clavus and apex of corium usually darkened....... 8

8. Area of clavus bordering scutellum dark brown; apical half of membrane clear, a fuscous spot at margin either side of middle, a spot also bordering tip of cuneus.......... ........... inconspicuus, p. 161

Area of clavus bordering commissure as well as along scutellum dark brown; apical half of membrane rather uniformly infuscated.....

cla vigen italis, p. 163

9. Rostrum scarcely attaining apices of intermediate coxae; color rich yellowish brown, darker on clavus and apex of corium............. 10

Rostrum extending beyond apices of intermediate coxae...........11

10. Second antennal segment darkened at apex, its length greater than width of pronotum at basal margin ............... viburni, p. 159

Second antennal segment not infuscated, its length less than width of pronotum at base. nyssae, p. 164

11. Apical half of tylus black; two reddish bands present near apices of hind femora; sides of body red......... ..............atritylus, p. 157

Tylus not black, or, if so, then body and bands on femora not reddish. .12
12. Hind femora without two distinct bands near apices; when dark, paler only at tip; second antennal segment rarely darkened, if so, bands on femora indistinct...........13

Hind femora with distinct dark or light bands near apices; second antennal segment darkened a pically . . 21

13. Scutellum dark, with a pale, median stripe on apical half; dorsum dark greenish brown to almost black, a lateral, dark fuscous stripe extending full length of body; femora dark with pale tips....... invitus, p. 157

Scutellum sometimes dark, but without any indication of a pale median line.....................14

14. Color distinctly reddish; head, pronotum, femora and veins of membrane red.........tinctus, p. 157

Color not reddish. . . . . . . . . . . 15

15. Hemelytra uniformly rich brownish, or brownish pink; clavus and apical half of hemelytra not appreciably darker.....................

Hemelytra not uniformly colored; clavus and apical half of corium darker than scutellum and basal half of corium .............. 18

16. Hemelytra and femora brownish pink; membrane distinctly darkened. . .

fagi, p. 161

Hemelytra reddish yellow brown to black, or uniformly rich brownish; membrane dar'sened, or uniformly yellowish............... 17

17. Dorsal prongs of left genital clasper parallel or converging at tips, fig. $164 \ldots \ldots \ldots$.......hirticulus, p. 163

Dorsal prongs of left genital clasper divergent at tips, fig. $164 \ldots$

\section{geminus, p. 163}

18. Second antennal segment darkened apically. .

Second antennal segment uniformly colored, never distinctly darkened apically . . . . . . . . . . 20

19. Length 4.70-5.00; female vertex distinctly wider than dorsal width of an eye; male left genital clasper with basal spine shorter and more slender than posterior spine, fig. 164 carpini, p. 164

Length 5.50-6.00; female vertex narrower than dorsal width of an eye; male left genital clasper with basal 
spine longer and stouter than posterior spine, fig. 164. ostryae, p. 164

20. Length of second antennal segment scarcely exceeding width of posterior margin of pronotum; rostrum scarcely attaining apices of hind coxae; hemelytra greenish yellow with apical spot on corium and inner margins of clavus dark brownish to almost black............ clavigenitalis, p. 163

Length of second antennal segment much exceeding width of posterior margin of pronotum; rostrum extending slightly beyond apices of hind coxae; clavus and corium dark brownish......geneseensis, p. 159

21. Pale greenish yellow; clavus and large spot on apical half of corium very dark brown; femora greenish yellow, with faint, fuscous bands near

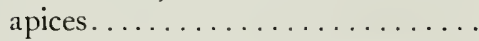

canadensis var. canadensis, p. 164

Color yellowish to brownish; apical half of corium brownish, but this colored area not forming a definite spot; femora brownish or reddish. . 22

22. Femora and, usually, sides of body distinctly reddish; hind femora with dark reddish bands before apices. .

quercalbae, p. 160

Femora and sides of body dark brown to fuscous; hind femora with dark brown bands before apices....... omnivagus, p. 163

23. Pronotal disk dark, but without distinct rays..................24

Pronotal disk with distinct, dark rays or spots behind calli..........27

24. Sides of body and hind femora distinctly reddish; femora with pale and dark red bands near apices....

quercalbae, p. 160

Sides of body and femora not reddish. 25

25. Hind femora black, with paler bands near apices; hemelytra black, costal margin scarcely paler, cuneus clear, apex dark................

caryae var. caryae, p. 161

Hind femora greenish to brownish, without subapical bands........26

26. Embolium greenish, clavus and inner half of corium dark fuscous to almost black.........tiliae, p. 161

Embolium scarcely paler than corium, hemelytra and whole dorsum nearly uniformly dark brown

hirticulus, p. 163

27. Hind femora with two dark brown or pale bands near apices.........2. 28

Apical halves of hind emora dark brown to black, but without two distinct bands, pale only at apices.32

28. First and second antennal segments black; embolium, outer half of corium and cuneus, pale and translucent..........johnsoni, p. 162

First antennal segment pale or only slightly brownish; apex of embolium and outer half of corium darkened; if not, then first antennal segment distinctly pale.

29. Sides of body and usually hind femora distinctly reddish. . communis, p. 159

Sides of body and femora not reddish. 30

30. Embolium and basal half of corium pale, a large black spot on apical half of corium; clavus and a nearly quadrate spot behind each callus black; calli and areas just anterior to them not black............ canadensis var. binotatus, p. 164

Embolıum usually darkened apically; if not, then calli and areas just anterior to them black...........31

31. Apex of median line of scutellum and all but cuneus of hemelytra dark brown to black............... ........ caryae var. caryae, p. 161 Scutellum and basal half of corium and embolium distinctly pale.... ..... caryae var. subfuscus, p. 161

32. Scutellum with a darkened median line; apex and inner margin of cuneus, femora and variable areas on sides of body, reddish........

univittatus, p. 160

Scutellum never with a dark brown median line.................33

33. Pronotal disk with small fuscous mark behind each callus; venter dark brown, with a pale, lateral stripe. . .............semivittatus, p. 163

Pronotal disk with distinct black ray or spot behind each callus; venter without pale, lateral stripe.......34

34. Pronotal disk with two conspicuous, nearly square black spots, one behind each callus; ground color yellowish brown; hind femora black except at tips... atrinotatus, p. 162 
A black stripe traversing outer half of each callus and extending to posterior margin of pronotal disk; ground color pale yellowish, with clavus and apices of corium and embolium black...vitticollis, p. 162

\section{Neolygus invitus (Say)}

Capsus invitus Say (1832, p. 24).

Male.-Length 5.00, width 2.00. General color dark greenish with fuscous or black areas; a lateral, fuscous stripe extending full length of body, including genital segment; apical half of scutellum with a pale, median vitta; disk of pronotum dark brown or black, but never with two distinct rays, as in communis Knight; genital claspers distinctive for species, fig. 164 .

Fenale.-Length 5.10, width 2.20 ; slight$y$ more robust than male, very similar in coloration, but in general lighter colored, with pale vitta on scutellum longer.

Food Plant.-American elm (Ulmus americana); a single specimen was collected in Illinois on hickory (Carya sp.).

Known Distribution.-Connecticut, Illinois, Indiana, Iowa, Massachusetts, Michigan, Minnesota, Missouri, New York, Ohio, Vermont.

Illinois Records.-Illinois: June 21, 1892, 2 ㅇ. Dubols: May 21, 1917, 1 各. Elizarethtown: May 27-31, 1932, on elm, H. L. Dozier, 10 o , $6 q$. Frankfort : June 8, 1933, Mohr \& Townsend, 2 o , 9 \%. Mount Carmel: May 27, 1884, on leaves of Carya sp., 1 \&. Muncie: June 8, 1917, 1 . Savanna: June 1, 1917,1 1 ; June 12, 1917,3 o , 1 \% .

\section{Neolygus tinctus new species}

This species is distinguished from allied ones by its smaller size and reddish coloration; it apparently is most closely related to invitus (Say).

Male.-Length 4.76, width 2.00. Head width 0.99 , vertex 0.30 . Rostrum yellowish, apex reddish brown, length 1.56 , extending slightly beyond middle of hind coxae. Antennae, first segment, length 0.44 , yellowish brown; second, 1.56, yellowish, becoming dusky at apex. Pronotum reddish; basal half of disk fuscous; calli dusky brown; median line of side of pronotum paler just behind calli. Propleuron pale about coxal cleft. Scutellum yellowish, with many red flecks in hypodermis. Hemelytra reddish to fuscous, with clavus and apical half of corium distinctly fuscous; cuneus pale, flecked with red about margins; membrane pale, with red veins and with areas within areoles and along margin behind cuneus fuscous. Dorsum clothed with fine, yellowish, recumbent pubescence; pronotum and scutellum minutely regulose, as in allied species. Venter of body pale yellowish, tinged with reddish and shaded with fuscous; sides of thorax dusky. Legs yellowish green, hypodermis of femora rather uniformly colored with bright red; tarsi darkened. Genital claspers distinctive, fig. 16t; form nearest to invitus, but left clasper thicker at base and right clasper with a much more prominent, protuberant shoulder at middle.

FeMale.-Length 4.63, width 2.20. Head with frons, tylus and juga bright red. Antennae yellowish, first segment becoming reddish at apex, third and fourth segments dusky; first segment, length 0.47 ; second, 1.47 ; third, 0.82 ; fourth, 0.34 . More robust than male, and very similar in coloration. although with less fuscous shading on pronotum and hemelytra.

Holotype, male. - Morgan C o u n ty, Ind.: June 10, 1933, on Gleditsia triacanthos, P. O. Musgrave, Kc.

Allotype, female. - Illinors. - EICHORN, HICK's Branch: June 13, 1934, DeLong \& Ross.

\section{Neolygus atritylus Knight}

Lygus (Neolygus) atritylus Knight (1917b, p. 606).

No Illinois specimens; known from Colorado, Minnesota, New itampshire, New York, Vermont. Feeds on willow (Salix sp.).

\section{Neolygus alni Knight} 607).

Lygus (Neolygus) alni Knight (1917b, p.

MaLE.-Length 5.50-6.00, width 2.00 . Head width 1.00 , vertex 0.33 . Rostrum. length 1.88, just attaining posterior margins of hind coxae. Antennae, first segment, length $0.6+$; second, 2.02, yellowish to brownish, its apex not strongly infuscated; third, 1.0t; fourth, 0.74. Pronotum, length 0.86 , width at base 1.57. Color medium green to light green, fading to yellowish in old specimens; clavus, scutellum and basal 

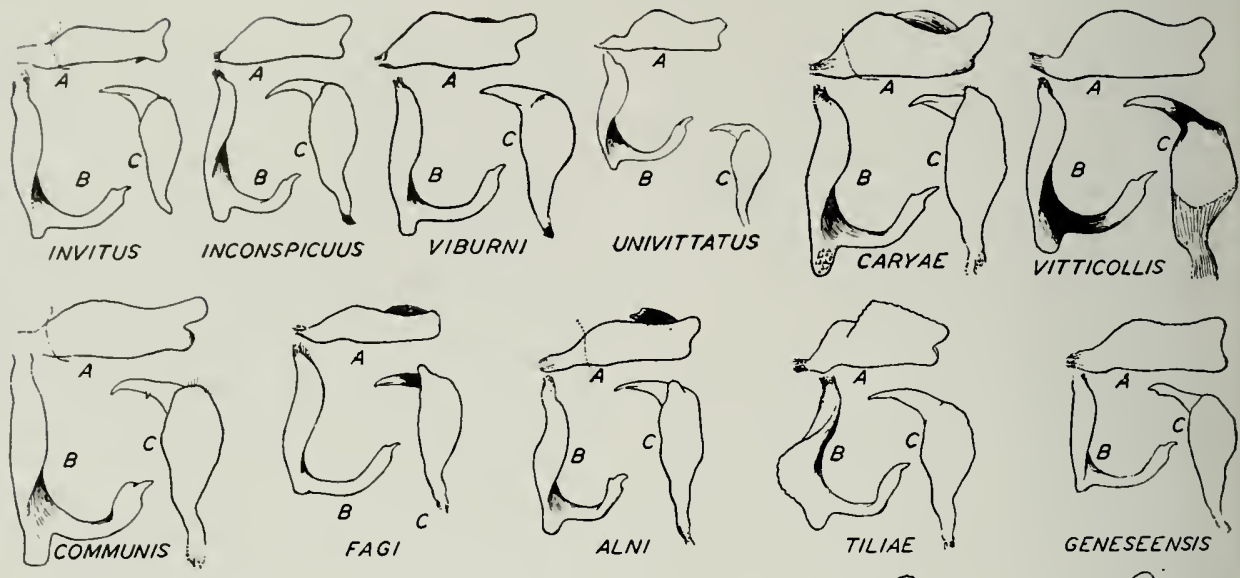

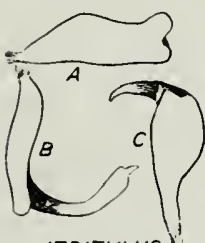

ATRITYLUS
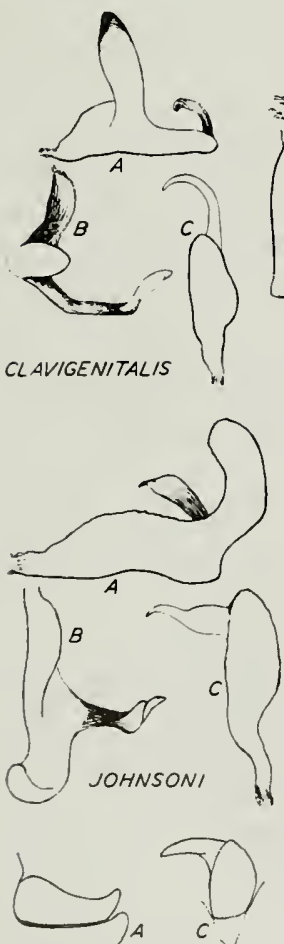

TINCTUS
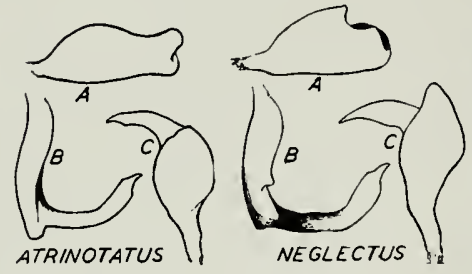

NEGLECTUS

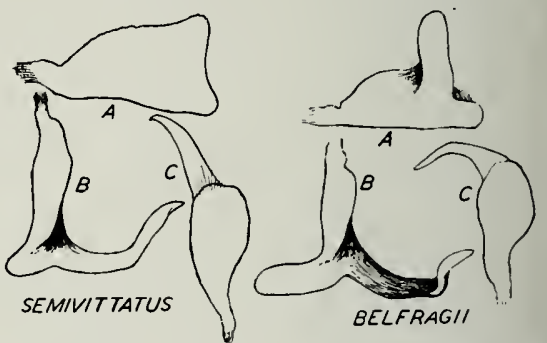

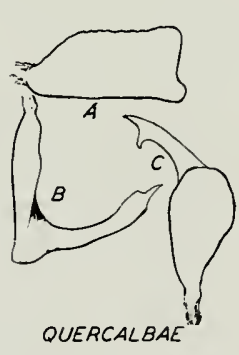
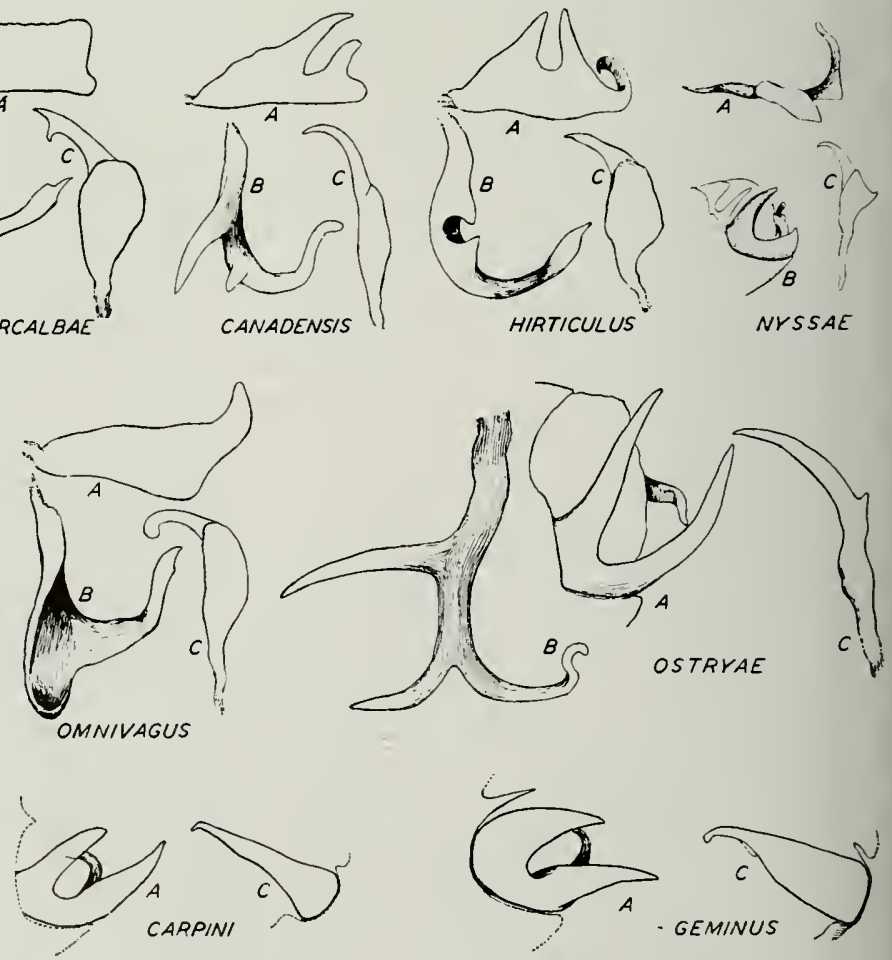

Fig. 164.--Male genital claspers of Neolygus. $A$, left clasper, lateral aspect; $B$, left clasper, dorsal aspect; $C$, right clasper, ventral aspect. 
half of pronotal disk usually distinctly bronzed. Membrane slightly smoky, with apical part of cells and a narrow transverse spot at apex of cuneus darker, veins pale to dusky. Legs greenish, each tibial spine with fuscous spot at base. Venter bright green to yellowish green. Genital claspers, fig. 16t, distinctive for species.

Fenale.-Length 5.50, width 1.95. Form, color and pubescence very similar to those of male.

Host Plant.-Alder (Alnus incana).

Known Distribution.-Illinois, Minnesota, New Hampshire, New York, Nova Scotia, Quebec.

Illinois Record.-Herod: June 20, 1935, DeLong \& Ross, 1 of.

\section{Neolygus geneseensis Knight}

Lygus (Neolygus) geneseensis Knight (1917b, p. 609$)$.

Male.-Length 5.00, width 2.05. General color yellowish brown to dark brown and fuscous. Allied to viburni Knight, having much the same color, but differs in being slightly smaller, having a longer rostrum and differently shaped genital claspers, fig. $16+$.

Fenale.-Length 4.90 , width 2.10 ; very similar to male, but more uniformly yellowish brown; distinguished from viburni by having uniformly yellowish antennae, and by the rostrum, which extends to posterior margins of hind coxae.

Food Plants.-White oak (Quercus alba $)$ and post oak $(Q$. stellata $)$.

Known Distribution. - Georgia, Illinois, Iowa, Maryland, Massachusetts, Michigan, Mississippi, Missouri, New York, Pennsylvania, Virginia.

Illinois Records.-Fifteen males and 13 females, taken May 25 to July $\boldsymbol{t}$, are from Beach, Charleston, Elizabethtown, Frankfort, Galena, Geff, Grand Detour, Harvard, Marshall, Oakwood, Palos Park, St. Joseph, White Heath, White Pines Forest State Park.

\section{Neolygus viburni Knight}

Lygus (Neolygus) viburni Knight (1917b, p. 609).

Male.-Length 5.20, width 2.08; width of head 1.03 , vertex 0.38 . Rostrum short, its apex scarcely attaining posterior margins of mesocoxae. Similar to omnivagus
Knight, but is smaller and more yellowish brown than that species. It also is closely related to geneseensis Knight, but is more robust and has a shorter rostrum; the apical half of the second antennal segment is darkened, and the general coloration is a richer yellowish brown. Claspers, fig. 164, distinctive for species.

Fendale.-Length 5.30, width 2.28; very similar to male in coloration, but usually not so dark.

Food Plant.-Sheepberry ( I'iburnum lentago). In New York state this bug often occurs in such numbers that foliage of its host is badly injured.

Known Distribution.-Connecticut, Illinois, Michigan, Minnesota, New York, Ohio, Pennsylvania.

Illinois Records.-Galena: June 30, 1932, Dozier \& Mohr, 1 ô, 1 ㅇ. GalesBURG: July 16, 1892, 2 ㅇ.

\section{Neolygus communis Knight}

\section{Pear Plant Bug}

Lygus (Neolygus) communis Knight (1916a, p. 346$)$.

This species, fig. 165, is suggestive of invitus (Say), but may easily be distinguished from it by the two black rays on the disk of the pronotum, the reddish lateral stripe on the body and the larger size.

Male.-Length 5.50, width 2.30. Antennae with second segment dark brownish to fuscous, sometimes with basal half paler; third dark brown; fourth fuscous. Pronotum greenish, darkened with brown on basal half; two black rays on disk, one behind each callus and, in the darkest specimens, extending across calli, widened behind and nearly reaching hind margin. Scutellum greenish, darkened with brown; rarely with a longitudinal, median, fuscous line. Hemelytra dark brown to fuscous, darker on apical half of corium and across tip of embolium; cuneus clear, tinged with yellow, extreme tip sometimes slightly darkened; membrane darkened. Legs greenish to yellowish, posterior femora and often intermediate femora with two reddish annulations near each apex; frequently entire apical halves reddish. Venter pale greenish with a broad, lateral band and the genital segment dark brownish red; genital claspers distinctive for species, fig. 164.

Fenale.-Length 5.40, width 2.40. More 
robust than male, but very similar in color and pubescence.

Food Plants and Habits.-Breeds on dogwoods (Cornus stolonifera, C. paniculata and $C$. alternifolia) and cultivated pear (Pyrus communis); also reared from winterberry (Ilex verticillata). The nymphs hatch when the leaves unfold and they feed

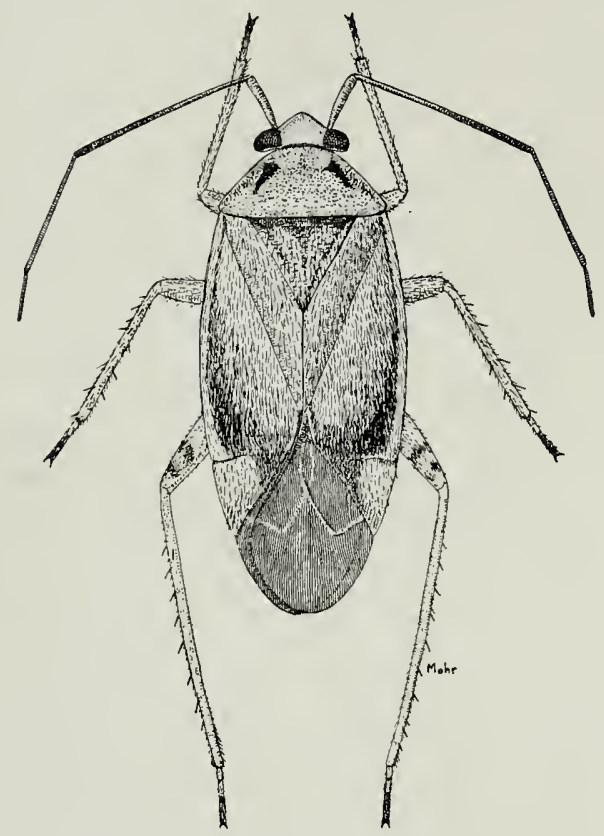

Fig. 165.--Neolygus communis, ㅇ.

on this tender foliage. On pears, the nymphs attack the young fruit as soon as it forms and continue to feed on it in preference to the leaves. All pears thus punctured become knotty and scarred to such an extent that the fruit is unsalable. The nymphs are green, closely matching the color of the young fruit; this makes it difficult to see them. The nymphs mature in about 24 days, or, usually, by the middle of June in central Illinois. The adults, likewise, prefer to feed on the pears and contribute further to the destruction of the fruit. In New York, the author observed that the adult bugs were active agents in distributing pear blight among the trees, the blight developing about feeding punctures made by the bugs. Oviposition occurs during the last week of June and up to the middle of July in New York, a few individuals probably laying after that date. The eggs are inserted under the bark of the new cambium layer (Knight 1915); in one place six eggs were found deposited in a mass. Most of the males die by the middle of July, but many females live until the end of that month. There is only one brood annually; the winter is passed in the egg stage and the nymphs appear again in the spring at the time the leaves unfold. In Nova Scotia a smaller, more slender form, variety novascotiensis Knight (1916a, p. 349 ), is an important pest on apple fruit.

Known Distribution.-Colorado and Idaho northward to Alberta and Minnesota, eastward to Ontario and Maine and southward to North Carolina.

Illinois Records.-Anтroch: Aug. 1, 1924, T. H. Frison, 1 q ; July 5-7, 1932, T. H. Frison, on Ilex verticillata, $4 \hat{o}, 20$ q. Frankfort: June 8, 1933, Mohr \& Townsend, 3 ㅇ. Quincy: June 11-30, 1883, lowlands, 1 \&. St. JosEPH: June 17, 1932, T. H. Frison, 1 \%

\section{Neolygus univittatus Knight}

Lygus (Neolygus) univittatus Knight (1917b, p. 623).

Known only from New York, but intensive collecting on its host plant, hawthorn (Crataegus sp.), should extend its recorded range.

\section{Neolygus quercalbae Knight}

Lygus (Neolygus) quercalbae Knight (1917b, p. 624).

Male.—Length 5.70, width 2.40. Resembles omnivagus Knight, but is deeper reddish brown, more robust, and has a pale stripe on either side of venter; similar to semivittatus Knight in coloration of venter. but does not have distinct, fuscous spots behind calli and is more red in color; genital claspers, fig. 164, distinctive.

Female.-Length 5.60, width 2.60 ; more robust than male, but very similar in coloration; larger and more reddish than omnivagus and semivittatus; distinguished from them by the distinctly reddish hind femora and sides of body.

Food Plant.-White oak (Quercus alba) on which it is often very abundant. This species has been collected on peach trees and hickory (Carya ovata) along with $N$. caryae Knight, but breeds only on white oak so far as the writer has been able to determine. The nymphs hatch with the bursting of the buds and feed thereafter on the 
tender foliage. In times of rain or cold weather the nymphs retreat under the bud scales which remain on the trees. Up to the fourth instar the nymphs are greenish yellow, but later they become tinged with pink; in the last instar the wing pads become brownish while the body is pink. In western New York the nymphs are developing during May and usually begin maturing during the first week of June; the adults may remain on the trees up to the middle of July. Eggs are laid mostly in late June and early July in the oak twigs; there they pass the winter, and the nymphs come forth with the bursting of the buds the following spring.

Known Distribution.-Connecticut, Illinois, lowa, Maryland, Massachusetts, Michigan, Minnesota, Missouri, New York, Ontario, Virginia, Wisconsin.

Illinois Records. - Twenty males and 18 females, taken May 9 to July 6, are from Algonquin, Antioch, Beach, Cedar Lake, Dongola, Dubois, Elizabeth, Frankfort, Galena, Glen Ellyn, Goreville, Grand Detour, Harvard, Meredosia, Oregon, St. Anne, Savanna, Urbana, Willow Springs, Zion.

\section{Neolygus fagi Knight} $603)$

Lygus (Neolygus) fagi Knight (1917b, p.

Not as yet collected in Illinois; known from Massachusetts, New Hampshire, New York, Ohio, Vermont. Feeds on beech (Fagus grandifolia) and birch (Betula lutea).

\section{Neolygus inconspicuus Knight}

Lygus (Neolygus) inconspicuus Knight $(1917 b$, p. 612).

Male.-Length 4.50, width 2.08. General color pale greenish; a transverse brownish spot at apex of corium and on area of clavus bordering scutellum; in general appearance, resembling tiliae Knight and clavigenitalis Knight, but differing greatly from those species in form of genital claspers, fig. 164.

FeNale.-Length 4.80 , width 2.25 ; very similar to male in size and coloration; similar in size and general appearance to clavigenitalis and tiliae; distinguished from the latter by the pale scutellum, and from the former by being more greenish with a paler scutellum.
Food Plant.-Muscadine grape (I'itis rotundifolia).

Known Distribution.-Connecticut, Georgia, Illinois, Indiana, Iowa, Maryland, Michigan, Minnesota, New York, North Carolina, Oklahoma, Virginia.

Illinois Records.-NORTHERN IlLINoIS: June, 1 q. Aldridge: May 8, 1932, H. L. Dozier, 1 q . Elizareth : July 6, 1917, 1 ô. Freeport: July 4, 1917, 1 ô. Oregon: June June 11, 1933, Mohr \& Townsend, 1 \% . Willow Springs: July 3, 1904, W. J. Gerhard, 1 \&, FM.

\section{Neolygus tiliae Knight} 613).

Lygus (Neolygus) tiliae Knight (1917b, p.

MALE.-Length 4.60, width 1.74 ; rather small, scarcely as large as invitus (Say). General color greenish yellow, with base of pronotum darker, and scutellum, clavus and corium dark fuscous to black. Genital claspers distinctive, fig. 164.

Female.-Le ngth 5.00, width 2.00 . Lighter colored than male and usually slightly larger; pronotum yellowish, scutellum and clavus only slightly darkened, apex of corium with a triangular dark patch, much resembling belfragii (Reuter) in this respect; similar in size and general appearance to inconspicuus Knight and clavigenitalis Knight; distinguished from inconspicuus by having front of head more conic and scutellum darker; clavigenitalis differs from this species in being generally more brownish with a paler scutellum.

Food Plant.-Linden (Tilia americana).

Known Distribution.-Connecticut, Illinois, Iowa, Massachusetts, Minnesota, New York, Ohio, Ontario, Pennsylvania, Vermont.

Illinois Records.-Sixty-seven males and 53 females, taken June 8 to July 19, are from Algonquin, Antioch, Elizabeth, Frankfort, Freeport, Galena, Galesburg, Kampsville, Monticello, Oregon, Urbana, Waukegan.

\section{Neolygus caryae Knight}

Lygus (Neolygus) caryae Knight (1917b, p. 615).

MALE.-Length 4.80-5.70, width 2.10 . General color varying from dark brown or black to yellowish brown with more prominent dark areas on pronotum and apex of 
hemelytra. Paler brown forms suggest omnizagus Knight. Genital claspers distinctive, fig. $16+$.

Feviale.-Length 5.00-6.30, width 2.30; more robust than male, frequently with brownish yellow areas between the calli and over posterior part of disk.

Specimens which are towards the pale end of the series with a more or less prominently banded effect represent the variety subfuscus Knight (1917b, p. 616) ; they resemble omniz'agus in coloration. Specimens that show all ranges of color have been taken in Illinois, frequently both extremes and the intergrades together on the same tree.

Food Plants.-Hickory (Carya ovata) and pecan (C. illinoensis). Also, single Illinois specimens were taken on locust ( $R o b i-$ nia pseudoacacia), oak (Quercus sp.) and red cedar (Juniperus virginiana). There is no evidence that they fed on these hosts.

Of recent years this species has been reported several times as causing "cat-facing" on peaches in New York and Ohio. The species may breed on nearby hickory trees and, when mature, fly to the peach trees where they puncture and feed upon the young fruits.

Known Distribution.-Connecticut, Illinois, Iowa, Massachusetts, Michigan, Minnesota, Mississippi, New Hampshire, New York, North Carolina, Ohio, Ontario, Texas.

Illinois Records.--Sixty-two males and 58 females, taken May 15 to July 6, are from Antioch, Bluff Springs, Dubois, Elizabethtown, Fox Lake, Frankfort, Freeport, Galena, Galesburg, Glen Ellyn, Goreville, Grand Detour, Grayslake, Hardin, Harvard, Havana, Kampsville, Manito, Meredosia, Oquawka, Rockford, Savanna, Seymour, Urbana, Waukegan, White Pines Forest State Park, Zion.

\section{Neolygus atrinotatus Knight}

Lygus (Neolygus) atrinotatus Knight (1917b, p. 617).

Known from District of Columbia, North Carolina, Ohio, Pennsylvania; not yet collected in Illinois.

\section{Neolygus vitticollis (Reuter)}

Lygus vitticollis Reuter (1876, p. 71).

MaLe.-Length 5.80, width 2.48; elongate, easily separated from other species by its large size and distinct black markings. General color pale yellowish, with two rays on pronotum ; clavus, apical halves of posterior femora, and apices of corium and of embolium, black; rostrum reaching only intermediate coxae; genital claspers, fig. 164, distinctive.

Female.-More robust than male, but not differing in coloration.

Food Plants.-Sugar maple (Acer saccharum), red maple (A. rubrum) and silver maple ( $A$. saccharinum).

Known Distribution.-Connecticut, Illinois, Indiana, Iowa, Michigan, Minnesota, New Jersey, New York, Ohio, Ontario. In the original description Reuter gave Texas as the type locality for vitticollis, but Mr. W. L. McAtee examined the type in the Stockholm Museum in 1927 and reported that it was labeled "N. Y."

Illinois Records.-Twenty-four males and 37 females, taken May 11 to July 1, are from Algonquin, Antioch, Carlinville, Meredosia, Mount Carmel, Normal, Oakwood, Oquawka, Savanna, Urbana, White Heath.

\section{Neolygus neglectus Knight}

Lygus (Neolygus) neglectus Knight (1917b, p. 619).

Known from Alabama northward to Maine and westerly from Louisiana, Mississippi, Ohio. This species has not as yet been taken in Illinois, but it should be found here eventually. Feeds on American hornbeam (Carpinus caroliniana).

\section{Neolygus johnsoni Knight}

Lygus (Neolygus) johnsoni Knight (1917b, p. 629).

No Illinois specimens; known from New York, Ohio, Virginia. Feeds on hornbeam (Carpinus caroliniana).

\section{Neolygus belfragii (Reuter)}

Lygus belfragii Reuter (1876, p. 71).

MALE.-Length 5.80, width 2.30 ; elongate. General color green or greenish yellow; clavus brownish, tinged with fuscous and bronze; apex of corium with a triangular fuscous or blackish patch, membrane with a median, longitudinal, fuscous area; genital claspers distinctive, fig. 164.

Female.-Length 5.50-5.80; similar to male in coloration, but more robust. 
Host Plants.-Breeds on Acer spicatum and Viburnum acerifolium.

Known Distribution.-Illinois, Maine, Minnesota, New York, Ontario, Pennsylvania, Wisconsin.

Illinois Record.-Dolsov: July 18, 1934, Rocky Branch, DeLong \& Ross, 1 .

\section{Neolygus clavigenitalis Knight}

Lygus (Neolygus) clavigenitalis Knight (1917b, p. 632).

Known from Connecticut, Maine, Maryland, Massachusetts, Ohio, but not yet collected in Illinois. Has been collected on smooth alder (Alnus rugosa).

\section{Neolygus semivittatus Knight}

Lygus (Neolygus) semivittatus Knight (1917b, p. 626$)$.

Not yet taken in Illinois, but it should be found here eventually. Known from Alabama, Florida, Minnesota, Mississippi, New York, Pennsylvania, Texas, Virginia; feeds on white oak (Quercus alba).

\section{Neolygus omnivagus Knight}

Lygus (Neolygus) omnivagus Knight (1917b, p. 627 ).

MALE.-Length 5.40, width 2.20. Yellowish brown with apex of corium dark brown to fuscous; clavus dark brown or black; very much resembling forms of semivittatus Knight and quercalbae Knight; also similar in color to caryae subfuscus Knight, but genital claspers distinctive, fig. 164.

Fenale.-Length 5.40, width 2.50. Usually paler than male, more yellowish brown; never reddish, as in quercalbae, nor with fuscous marks on pronotum as in semivittatus or caryae subfuscus; very similar to canadensis Knight, but that species has apical one-third of second antennal segment distinctly black, fuscous spot on apex of the corium smaller and embolium entirely without fuscous.

Food Plants.-White oak (Quercus $a l b a)$, red oak ( $Q$. rubra), scarlet oak ( $Q$. coccinea) and probably other oaks; breeds occasionally on dogwood (Cornus sp.), chestnut (Castanea sp.) and arrow-wood ( iburnum sp.).

Known Distribution.-Connecticut, Illinois, Iowa, Massachusetts, Michigan, Minnesota, New Hampshire, New York,
North Carolina, Ontario, Pennsylvania, Quebec, Rhode Island, Vermont, Virginia, Wisconsin.

Illinois Records.-Eleven males and 25 females, taken June + to July 31 , are from Dolson, Galena, Glen Ellyn, Grand Detour, Keithsburg, Lilly, Marshall, McHenry, Monticello, Mount Carroll, Oregon, Rockford, St. Anne, Savanna, White Pines Forest State Park, Willow Springs.

\section{Neolygus hirticulus (Van Duzee)}

Lygus tenellus Van Duzee (1912, p. 484), not Hahn.

Lygus hirticulus Van Duzee (1916a, p. 41).

Male.-Length 4.80, width 2.28. General color dark ferrugino-testaceous, sometimes entirely dark fuscous or black, except for the legs and antennae; genital claspers distinctive, fig. 164.

Female.-Length 5.30, width 2.30. Slightly larger and more robust than male. Uniformly colored with yellowish brown or, in some cases, dark brown; hemelytra rarely much darker than pronotum; easily confused with fagi Knight, but membrane is uniformly and faintly tinged with fuliginous color, never dark as in fagi.

Food Plants.-Chestnut (Castanea sp.), sugar maple (Acer saccharum), beech (Fagus sp.), ash (Fraxinus sp.), cottonwood (Populus deltoides) and woodbine (Psedera sp.).

Known Distribution.-Connecticut, Illinois, Iowa, Maryland, Massachusetts, Minnesota, New Hampshire, New Jersey, New York, North Carolina, Ohio, Ontario, Pennsylvania, Rhode Island, Vermont. Always rare.

Illinois Records.-ILLivoIs: $1 \delta$; July 9, 1892, 1 \% ; July 16, 1892, 1 ㅇ. Dubois: June 3, 1919, 1 of. Frankfort: June 8, 1933, on Fraxinus sp., Mohr \& Townsend, 3 ô. UrBANA: June 30,1889 , woods above lake, 1 of ; July 20, 1917, cottonwoods, $1 \hat{\delta}$; July 27, 1917, cottonwood grove, 1 ㅇ․ Willow Springs: July 8, 1906, W. J. Gerhard, 1 , F.I.

\section{Neolygus geminus new species}

This is closely allied to hirticulus ( $\mathrm{V}$ an Duzee), as individuals of the two species are similar in size and coloration, but the males are readily distinguished by the structure of the genital claspers, fig. $16 t$. 
Male.-Length 4.80, width 2.20. Head width 0.91 , vertex 0.34 . Rostrum, length 1.81, almost attaining posterior margins of hind coxae. Antennae, first segment, length 0.58 , pale; second, 1.98 , pale to yellowish brown; third, 1.17, dusky yellow; fourth, 1.21, dusky. Pronotum, length 0.95 , width at base 1.70. Color dusky brown, hemelytra slightly darker; cuneus pale, translucent; membrane pale to smoky, veins yellowish. Legs pale to yellowish; femora tending to yellowish brown. Venter yellowish to brown, darker on sides; genital claspers distinctive.

FeMALE.-Length 5.00, width 2.30. Head width 0.95 , vertex 0.39 ; antennae, first segment, length 0.60 ; second, 1.94 ; third, 1.17 . Pronotum, length 1.08, width at base 1.77 . Slightly more robust than male and more yellowish brown in color. Cannot at present be separated from female of hirticulus.

Holotype, male. - Elizabethtown, Ill.: May 27-31, 1932, H. L. Dozier.

Allotype, female.-Same data as for holotype.

Paratypes.-Illinois. - Same data as for holotype, 4 $\delta, 1$. . Golconda: June 22, 1932, on Trifolium pratense, Ross, Dozier \& Park, 1 ô.

\section{Neolygus nyssae Knight}

Lygus (Neolygus) nyssae Knight (1918c, p. 43 ).

MALE.-Length 5.50 , width 2.50 ; slightly more robust, but in general structure similar to quercalbae Knight; pronotum and scutellum evenly shaded with rich brown; clavus and corium darker brown; genital claspers distinctive for species, fig. 164 .

Female.-Length 5.60 , width 2.57 ; very similar to male in size and coloration.

Food Plant.-Sour gum (Nyssa sp.).

Known Distribution.-Alabama, Connecticut, Illinois, Mississippi, Ohio, Pennsylvania.

Illinois Record.-Dixon Springs: June 24, 1936, DeLong \& Ross, 1 ㅇ.

\section{Neolygus canadensis Knight}

Lygus (Neolygus) canadensis Knight (1917b, p. 634 ).

This species is allied to amnivagus Knight, but is more greenish yellow in color and has a distinct, dark spot on the corium. The only specimen seen from Illinois has a black ray behind each callus extending nearly to the hind margin of the pronotum and would, thus, be referable to the variety binotatus Knight (1917b, p. 635).

Male.-Length 5.50, width 2.08. Second antennal segment, length 2.05 , pale yellowish, apical one-third fuscous to black. Margins of scutellum usually brownish; cuneus pale; legs greenish yellow; hind femora with two pale, fuscous annuli near apices; genital claspers distinctive, fig. 164.

Known Distribution.-Illinois, Minnesota, New Jersey, New York, Ohio, Ontario, Wisconsin.

Illinois Record.-NORTHERN IlLINOIS: July, $1 \hat{\delta}$.

\section{Neolygus ostryae Knight}

\section{Lygus (Neolygus) ostryae Knight (19173,} p. 635).

MALE.-Length 5.80, width 2.36. Head width 1.05 , vertex 0.37 . Rostrum, length 2.08, reaching posterior margins of hind coxae. Antennae, first segment, length 0.74 ; second, 2.25, yellowish, apex fuscous; third, 1.25 , yellowish with apical half slightly infuscated; fourth, 0.71, infuscated. Pronotum, length 1.00, width at base 1.85. Deep yellowish brown in color; embolium and basal half of corium pale yellowish; clavus and apical half of corium light brown to dark brown; cuneus almost colorless, tinged with yellowish. Genital claspers as in fig. 164.

Female.-Length 6.00 , width 2.40 ; similar to male in coloration, but slightly larger and more robust.

Host Plant.-Hop hornbeam (Ostrya virginiana).

Known Distribution.-Illinois, Massachusetts, New York, Ontario, Vermont.

Illinois Record. - North Evanston: Aug. 20, 1905, Gerhard \& Wolcott, 1 \%, FM.

\section{Neolygus carpini Knight}

Neolygus carpini Knight (1939a, p. 21).

Male.-Length 4.70, width 2.00. Head width 0.99 , vertex 0.35 . Rostrum yellowish, apex brownish, length 1.90 , extending slightly beyond hind margins of posterior coxae. Antennae with first segment pale, second pale with apical one-third black, third yellowish, fuscous apically, fourth fuscous. Pronotum yellowish green, tinged with brown, without definite streaks or vittae. 
Scutellum yellowish brown, scarcely darker at sides. Hemelytra translucent, yellowish, with clavus evenly shaded with brownish; apical area of corium dark brown; cuneus uniformly translucent, scarcely tinged with yellow; membrane and veins rather uniformly fuscous brown. Venter of body pale to yellowish, a fuscous band along lateral margins. Fuscous band also extending across pleura of thorax. Legs yellowish to brown; femora uniformly brownish, without bands, apices paler; tibiae pale yellowish, spines brown; tarsi brownish, apices fuscous.

Female.-Length 5.00, width 2.16. More robust than male but very similar in color and pubescence.

Host Plant. - Hornbeam (Carpinus caroliniana).

Known Distribution.-lllinois, lowa, Minnesota.

Illinois Record. - Dolson: June 14 1933, Frison \& Ross, 1 ô.

\section{Dichrooscytus Fieber}

\section{KEY TO SPECIES}

1. Length less than $4.00 \ldots \ldots \ldots \ldots$. 2

Length 4.80 or greater........... 3

2. Width of vertex greater than length of first antennal segment; hemelytra reddish; length $3.50-3.70 \ldots \ldots \ldots$. ...........tinctipennis, p. 165

Vertex narrower, its width less than length of first antennal segment; dorsum uniformly green; length 3.20$3.40 \ldots \ldots \ldots$. viridicans, p. 165

3. Paracuneus pale to white; length of first antennal segment less than width of vertex; length $4.80-5.30 \ldots$ ............suspectus, p. 166

Paracuneus reddish; length of first antennal segment equal to or greater than width of vertex; length 5.50$5.80 \ldots \ldots \ldots$ rufipennis, p. 166

\section{Dichrooscytus tinctipennis Knight}

Dichrooscytus elegans Knight (1923d, p. 597), not Uhler.

Dichrooscytus tinctipennis Knight (1927b, p. 15)

Male.-Length 3.70, width 1.50. Head width 0.83 , vertex 0.36 . Rostrum, length 1.18 , scarcely attaining posterior margins of hind coxae. Antennae, first segment, length 0.33 , less than width of vertex; second
1.36; third, 0.50 ; fourth, 0.42 . Pronotum, length 0.64, width at base, 1.18. Body clothed with soft, brownish, simple pubescence; on embolium and legs pubescence pale brown or yellowish. General coloration yellowish green, more distinctly green on pronotum and tibiae: corium, clavus, and inner apical half of cuneus, reddish; base and outer margin of cuneus paler. Membrane uniformly light fuscous, veins reddish; an opaque, white, callous mark bordering apical angle of larger areole.

Fenale.-Length 3.60 , width 1.60 . Slightly more robust than male, but very similar in pubescence and coloration.

Host Plants.-Red cedar (Juniperus virginiana) and arbor vitae (Thuja occidentalis).

Known Distribution.-District of Columbia, Georgia, Illinois, lowa, Kansas, Maryland, Minnesota, Mississippi, New Jersey, New York, Ohio, Virginia.

Illinois Records.-CAVE-IN-Rock: Oct. 2, 1934, Frison \& Ross, 1 ô, 3 \&. Muncie: Sept. 20, 1935, Frison \& Mohr, 1 ․

\section{Dichrooscytus viridicans Knight}

\section{Dichrooscytus viridicans Knight (1918d,} p. 114).

Male.-Length 3.20, width 1.25. Head width 0.75 , vertex 0.26 . Rostrum, length 0.95 , just attaining posterior margins of hind

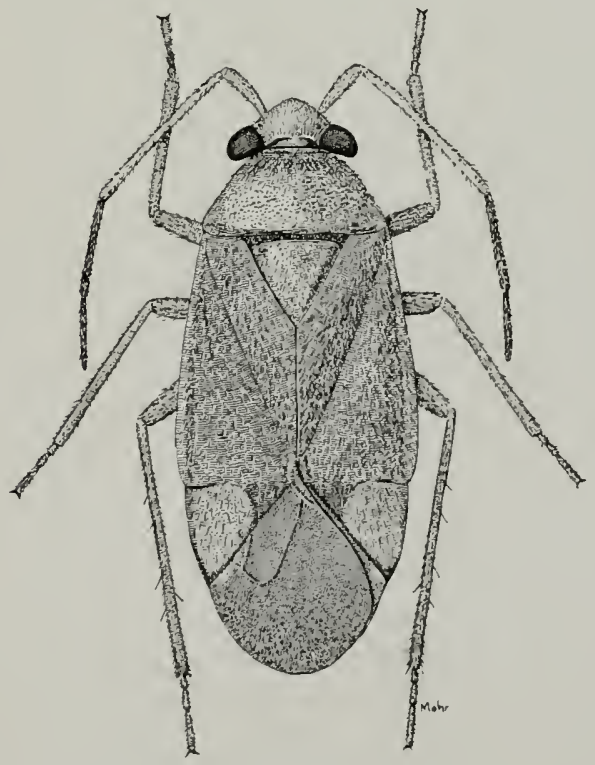

Fig. 166.-Dichrooscytus viridicans, f. 
coxae. Antennae, first segment, length 0.32 ; second, 1.22; third, 0.56; fourth, 0.38. Pronotum, length 0.56 , width at base 1.03 , with black, conspicuous pubescence. General color bright green; head, coxae and femora often becoming pale to brownish; cuneus green, apical halves of margins reddish; membrane fuscous, cell veins sometimes reddish.

FeMAle.-Fig. 166. Length 3.30, width 1.40; slightly more robust than male, but not differing in coloration.

Host Plants.-Red cedar (Juniperus virginiana) and arbor vitae (Thuja occidentalis).

KNown Distribution.-District of Columbia, Illinois, Indiana, Iowa, Minnesota, Mississippi, New York, Ohio.

Illinois Records. - Seventy-one males and 101 females, taken May 27 to Aug. 28, are from Antioch, Apple River Canyon State Park, Elizabethtown, Ernst, Freeport, Ga!ena, Golconda, Grandview, Grayville, Hillsboro, Kampsville, Keithsburg, Lake Villa, Monticello, Oquawka, Starved Rock State Park, Urbana, White Pines Forest State Park.

\section{Dichrooscytus suspectus Reuter}

Dichrooscytus suspectus Reuter (1909, p. 37).

Not yet collected in Illinois, but should occur here. Known from Connecticut, Colorado, District of Columbia, Indiana, Maine, Maryland, Massachusetts, New Jersey, New York. Its host plants are pines (Pinus resinosa and $P$. virginiana).

\section{Dichrooscytus rufipennis (Fallen)}

Lygaeus rufipennis Fallen (1807, p. 84).

A European species known from New York; may have been imported with the Scotch pine (Pinus sylvestris), on which it feeds. Not yet taken in Illinois.

\section{Polymerus Hahn}

\section{KEY TO SPECIES}

1. Rostrum reaching hind coxae, or slightly beyond............. 2

Rostrum not reaching hind coxae.... 4

2. Rostrum scarcely attaining hind margins of posterior coxae; dorsum black and pale brown; femora with apical halves fulvous, tibiae pale...

nigropallidus, p. 167
Rostrum reaching slightly beyond posterior coxae; body yellowish brown, with darkened areas; cuneus usually red, rarely paler........ 3

3. Hemelytra mostly yellowish. ..... basalis var. basalis, p. 167

Hemelytra mostly very dark brown, almost black. .

..... basalis var. fuscatus, p. 167

4. Rostrum reaching beyond anterior margins of middle coxae....... 5

Rostrum not reaching posterior margin of mesosternum .......... 6

5. Rostrum attaining hind margins of middle coxae; dorsum black, narrow area at apex of cuneus and slender line on either side of fracture pale; tibiae uniformly black...... $\ldots \ldots \ldots \ldots$ proximus, p. 168

Rostrum just attaining middle of intermediate coxae; dorsum black and pale brown; tip of scutellum and basal angle of corium pale; cuneus yellowish, red and black......... unifasciatus var. lateralis, p. 167

6. Rostrum nearly attaining posterior margin of mesosternum....... 7

Rostrum not reaching beyond middle of mesosternum........... 8

7. Legs rather uniformly reddish yellow, but hind femora with a small group of fuscous points on anterior face at middle of apical half; cuneus with outer edge pale brown...........

punctipes, p. 169

Tibiae black, femora black on apical half of dorsal aspect; cuneus uniformly red orange.....illini, p. 168

8. Tibiae reddish yellow or with broad, pale areas............. 9

Tibiae black, rarely with some yellowish.................. 12

9. Legs mostly red, with apical one-third of femora black; tibiae yellowish, with apices and variable basal area black; second antennal segment vellowish with apex very dark brown........... venustus, p. 170

Legs orange yellow or fulvous......10

10. Hemelytra uniformly black; length of second antennal segment equal to width of pronotum at posterior margin.........nubilipes, p. 170

Cuneus and embolium of hemelytra pale or fulvous.............11 
11. Pubescence on dorsum deep golden; tibiae without black spot at base...

fulvipes, p. 170

Pubescence on dorsum silvery white; tibiae with black spot at base.... ..............severini, p. 170

12. Rostrum scarcely attaining hind margins of front coxae...........13

Rostrum reaching behind posterior margins of front coxae, or nearly to middle of mesosternum . . . . . 14

13. Hemelytra uniformly black; dorsum clothed with silvery, silky pubescence..........gerhardi, p. 171

Hemelytra with embolium and edge of cuneus pale; dorsum clothed with golden, silky pubescence......... ..........brevirostris, p. 170

14. Cuneus black; second antennal segment of male as thick as first segment; coxae yellow in both sexes; dorsum black with scutellum and hemely tra clothed chiefly with black pubescence.......opacus, p. 170

Cuneus yellowish or red..........15

15. Embolium black; cuneus orange; coxae of male black, of female yellow; dorsum clothed with silvery, silky pubescence. .venaticus, p. 169

Embolium pale brown to red.......16

16. Femora deep red, only narrow band at apices black; tarsi black; embolium and cuneus deep red.........

chrysopsis, p. 171

Femora deep yellow, apical one-third black, a pale fascia showing on anterior aspect; tarsi mostly yellow, with apical segment and claws black; embolium pale brown to yellow; cuneus orange.......... ........flavocostatus, p. 168

\section{Polymerus basalis (Reuter)}

Poeciloscytus basalis Reuter (1876, p. 73).

ADUlTS.-Length 3.70-4.80, width 1.70 2.30. General color pale brown to yellowish, darkened with fuscous and black; hemelytra mostly yellowish, with clavus and apical half of corium chiefly fuscous; scutellum black, variable area at apex not so dark; cuneus red; sometimes embolium and legs tinged with reddish; posterior femora with two subapical fuscous bands; dorsum clothed with silvery, silky pubescence that appears golden yellow in certain lights. A very dark form of this species, variety fuscatus Knight (1926f, p. 167), has not been taken in Illinois.

Food Plants.-Dog fennel (Anthemis cotula); lllinois specimens were collected also on plantain (Plantago aristata), daisy (Chrysanthemum sp.), sunflower (Helianthus sp.), oak (Quercus sp.), tickweed (Coreopsis sp.); the oak record was certainly a "sitting" record.

Known Distribution.-Common in the eastern United States.

Illinois Records.-Two hundred ten males and 176 females, taken May 18 to Oct. 12, are from Albion, Algonquin, Alton, Antioch, Bloomington, Champaign, Chicago, Darwin, Delavan, Dubois, Elizabethtown, Elmira, Farmer City, Freeport, Galesburg, Grand Tower, Grayville, Herod, Karnak, Lawrenceville, M c Henry, Metropolis, Monticello, Mount Carmel, Muncie, Paxton, Rockton, Savanna, Seymour, Shawneetown, Springfield, Starved Rock State Park, Urbana, West Union.

\section{Polymerus nigropallidus Knight} 599).

Polymerus nigropallidus Knight (1923d, p.

Known only from New Jersey.

\section{Polymerus unifasciatus (Fabricius)} 178).

Lygaeus unifasciatus Fabricius (1794, p.

Male.-Length 5.60, width 2.60. Head width 1.04 , vertex 0.47 . Rostrum, length 1.56, reaching to middle of intermediate coxae. Antennae, first segment, length 0.56 ; second, 2.08, black, with basal half dusky brown; third, 0.82; fourth, 0.78. Pronotum, length 1.04 , width at base 1.86 . Clothed with golden, sericeous, tomentose pubescence, intermixed with blackish hairs. Ground color black; apex of scutellum, basal angle of corium, anal ridge and area at inner angle of corium, apex of embolium and area of corium bordering cuneus, base and apex of cuneus, tibiae, apical one-third of front and middle femora, pale to testaceous; cuneus with inner half red, outer margin black except at base and apex; membrane fuscous, veins and central area less dark; a small clear spot bordering apex of cuneus.

Fexale.-Length 5.20, width 2.65; very similar to male in color and pubescence. 
All North American specimens of this species are referable to the variety lateralis Hahn $(1834$, p. 85). The typical unifascia$t u s$ has the pale areas broader than does $u n i-$ fasciatus lateralis; the embolium and corium of this variety are pale brown except for a small fuscous patch on the apical area of the corium.

Food Plant.-Northern bedstraw ( $G a$ lium boreale).

Known Distribution.-This is a European species, now known from Alberta, British Columbia, Colorado, Illinois, Iowa, Maine, Minnesota, New York, North Dakota, Nova Scotia, Quebec. Blatchley $(1926 b$, p. 737$)$ records this from Champaign, Ill., June 14 , at light, under the name Polymerus unifasciatus (Fabricius). Specimens of the typical form from North America have not been seen by the writer.

\section{Polymerus flavocostatus Knight} 165).

Polymerus flavocostatus Knight (1926f, p.

Female.-Length 5.00, width 2.30. Head width 1.06 , vertex 0.54 . Rostrum, length 1.11 , extending slightly beyond anterior coxae, or to middle of mesosternum; first and second segments chiefly yellow. Antennae black, with third segment yellowish; first segment, length 0.51 ; second, 1.80 ; third, 0.86. Pronotum, length 1.02 , width at base 1.70 .

Male.-Length 5.70, width 2.30. Head width 1.06 , vertex 0.46 . Antennae, first segment, length 0.53 ; second, 1.86. Hemelytra colored as in female; coxae orange yellow, or dusky only at base, similar to female.

Food Plant.-Goldenrod (Solidago sp.).

Known Distribution.--Illinois, Iowa, $M$ issouri, Nebraska, North Dakota.

Illinois Records. - ChampaigN : June 15, 1888, C. A. Hart, 1 ô. Galesburg: June 18, 1893, 1 s. OAkwood: June 14, 1930, T. H. Frison, on Solidago sp., $1 \hat{\delta}$, 1 ․ Urbana: June 17, 1889, Marten, 1 \%; June 19, 1889, C. A. Hart, 1 o. WEST Pullman: July 30, 1905, W. J. Gerhard, 1 ㅇ, FM.

\section{Polymerus illini new species}

This differs from flavocostatus Knight by the longer rostrum, and from punctipes Knight by the black tibiae, the partly black femora and the red orange cuneus.
MALE.-Length 4.85, width 2.50. Head width 1.18 , vertex 0.44 ; black, a glabrous, pale spot either side of vertex. Rostrum, length 1.43 , just attaining posterior margin of mesosternum. Antennae black with last two segments yellow; first segment, length 0.44 , thickness 0.15 ; second, length 2.29 , thickness 0.15 , cylindrical; third, length 0.65 ; fourth, 0.62. Pronotum, length 1.17, width at base 2.03 ; black, narrow basal and ventral edge pale. Clothed with silvery, sericeous pubescence intermixed on hemelytra with simple, black pubescence. General color black, embolium pale, cuneus and tip of embolium orange colored; membrane black, narrow pale area bordering cuneus; veins yellowish. Tibiae black, slightly pale near base; femora orange colored, apical half black on dorsal aspect, dark color broken by an incomplete annulus of orange which does not cross dorsal surface; coxae pale to orange, infuscated at base; tarsi yellow, apical segment and claws black.

Female.-Length 5.50, width 2.77. Head width 1.22 , vertex 0.56 . Antennae, first segment, length 0.45 , width 0.16 ; second, 2.08 , thickness 0.10 ; third, 0.77 ; fourth, 0.78 . Pronotum, length 1.21 , width at base 2.25 . More robust than male, but very similar in coloration and pubescence.

Holotype, male.—Oak Lawn, Ill.: July 1, 1935, DeLong \& Ross.

Allotype, female.-Onarga, Ill.: June 8, 1933, Mohr \& Townsend.

Paratypes.-Illinois.-Same data as for holotype, $1 q$; NORTHERN IllinoIs: 2 \&, 1 \% .

\section{Polymerus proximus Knight}

Polymerus proximus Knight (1923d, p. 601). This is closely related to nigritus (Fallen), but may be distinguished from it by the uniformly dark tibiae; the length of the first antennal segment is equal to the width of the vertex, while in nigritus the length of the first segment is less than the width of the vertex.

Male-Length 5.30, width 2.70. Head mostly black with a yellow spot on either side of vertex near eye. Rostrum barely attaining hind margins of middle coxae. Antennae, first segment black; second very dark brown, black at base; third dark brown; fourth black. Pronotum with posterior half of disk strongly convex, transversely wrinkled, uniformly black, slightly 
shining; clothed with yellowish, sericeous pubescence. Scutellum deep black, slender area at apex yellowish. Sternum and pleura black; ostiolar peritreme pale brown to yellowish. Hemelytra black; slender area at tip of embolium, and narrow areas at base and apex of cuneus, pale; slightly shining, clothed with intermixed yellowish and black pubescence; membrane and veins uniformly dark fuscous. Legs usually uniformly black; in paler forms, tibiae uniformly very dark brown, but never with indication of annulations. Venter uniformly black, clothed with pale brown to yellowish pubescence.

Female.-Length 5.30, width 2.80 ; emboliar margins more strongly arcuate than in male, but general coloration similar.

Host Plant.-Bedstraw (Galium aparine).

Known Distribution.-Illinois, Iowa, Kansas, Minnesota, Missouri, Nebraska, Ohio, Ontario, Pennsylvania.

Illinois Record.-Rock City: May 30, 1938, Mohr \& Burks, 2 of.

\section{Polymerus venaticus (Uhler)}

Poeciloscytus venaticus Uhler (1872, p. 414). Male.-Length 5.90, width 2.30. Head width 1.04 , vertex 0.46 . Rostrum, length 1.09 , just attaining middle of sternum; piceous, only slightly paler at joints. Antennae, second segment, length 2.31, cylindrical, not equal in thickness to first segment. Hemelytra elongate, tip of abdomen attaining middle of cuneus, emboliar margins very slightly arcuate; black, moderately shining; thickly clothed with sericeous, pale pubescence, a few black hairs on embolium and cuneus; cuneus fulvous or reddish. Legs black, with basal halves of hind and middle femora, anterior face of front femora except at apex, and two basal segments of tarsi, yellow.

Fenale.-Length 5.00 , width 2.57 ; emboliar margins strongly arcuate; shorter, more ovate and robust than male; coloration very similar to that of male, but coxae always yellowish except for spot at base.

Host Plant.-Goldenrod (Solidago altissima).

Known Distribution.-Alberta, British Columbia, Colorado, Connecticut, District of Columbia, Idaho, Illinois, Iowa, Maine, Maryland, Massachusetts, Michigan, Minnesota, Nebraska, New Hampshire, New York, North Dakota, Ohio, Ontario, Pennsylvania, Quebec, Vermont.
Illinois Records.-Eleven males and 24 females, taken May 17 to July 4 , are from Antioch, Champaign, Cypress, Elizabethtown, Freeport, Galena, Oakwood, Odin, Palos Park, St. Anne, Urbana.

\section{Polymerus punctipes Knight}

Polymerus punctipes Knight (1923d, p. 602). MALE.--Length 4.60, width 2.00. Head width 0.97 , vertex 0.47 ; head black, with a yellow spot on either side of vertex at border of eye; pubescence yellowish. Rostrum, length 1.23, almost attaining hind margin of mesosternum, yellowish, apex black. Antennae, first segment, length 0.51 , black, narrow yellowish area at base; second, 1.85 , nearly cylindrical, slightly thicker at middle, nearly equal in thickness to first segment, black, clothed with mixed black and pale pubescence; third, 0.66, yellowish, with dusky tinge; fourth, 0.80 , dusky. Pronotum, length 1.00 , width at base 1.70 ; black, slightly shining, disk transversely rugulose; clothed with pale and yellowish, sericeous pubescence. Scutellum black, transversely rugulose; clothed with yellowish pubescence, more sericeous on basal angles. Sternum and pleura black; ostiolar peritreme yellow, becoming dusky on anterior lobe. Hemelytra, with emboliar margins slightly arcuate on apical half; black; embolium and outer margin of cuneus yellowish or fulvous; surface scabriculous, slightly shining, clothed with golden, sericeous pubescence intermixed with darker hairs. Membrane rather uniformly fusco-brownish, a small, nearly clear spot bordering apex of cuneus, veins yellowish. Legs fulvous, with spot at apices of femora and apical segment of each tarsus black: hind femora with a group of from two to five fuscous points on anterior face at middle of apical half, a prominent hair rising from each of the two lower points; pubescence pale brown to yellowish, black on apical halves of femora. Venter black, clothed with pale brown to yellowish pubescense.

Female.-Length 5.20, width 2.40 ; emboliar margins strongly arcuate on apical half; pubescence and color similar to those of male. Rostrum, length 1.31 , nearly attaining hind margin of sternum.

Food Plant.-Loosestrife (Lysimachia quadrifolia).

Known Distribution.-District of Columbia, Florida, Georgia, Illinois, Iowa, 
Maine, Maryland, Minnesota, New York, Ohio, Ontario, Quebec.

Illinois Records.-Twelve males and 19 females, taken May 21 to June 24, are from Dolson, Dubois, Elizabethtown, Golconda, Herod, Mound City, Mount Carmel, Oakwood, Pulaski.

\section{Polymerus fulvipes Knight}

Polymerus fulvipes Knight (1923d, p. 603).

Known from Connecticut, Massachusetts, New York, North Carolina, Pennsylvania. Not yet collected in Illinois.

\section{Polymerus severini Knight}

Polymerus severini Knight (1925, p. 247).

No Illinois specimens; known from Alberta, Minnesota, South Dakota.

\section{Polymerus nubilipes Knight}

Polymerus nubilipes Knight (1925, p. 248).

Known only from Minnesota and Wisconsin; not yet taken in Illinois.

\section{Polymerus opacus Knight}

Polymerus opacus Knight (1923d, p. 604).

Not taken in Illinois; known from Maine, Ontario, New York, Vermont. Feeds on aster (Aster umbellatus).

\section{Polymerus venustus Knight}

Polymerus venustus Knight (1923d, p. 605). Male.-Length 5.20, width 2.30. Head width 1.01 , vertex 0.38 ; head black; a yellow spot on either side of vertex bordering eye; lower margin of jugum and upper margin of lorum red; clothed with sericeous, pale pubescence. Rostrum, length 1.14, scarcely exceeding posterior margins of front coxae, piceous, paler at joints. Antennae, first segment, length 0.81 , black, unusually long and thick ( 0.15 thick) ; second, 2.06, cylindrical, thickness 0.07 , yellowish, apical one-third black, pubescence same color as surface beneath; third, 1.02 , slender, yellowish to fuscous, darker apically; fourth, 1.03 , blackish. Pronotum, length 1.03 , width 1.74 ; surface minutely granulate and transversely wrinkled; clothed with yellowish to golden, silky pubescence; black, lower pleural margin with a slender reddish area. Scutellum black, surface and pubescence as on pronotal disk. Sternum and pleura black; ostiolar peritreme yellowish to reddish. Hemelytra with emboliar margins moderately arcuate; black, opaque, surface rather irregularly roughened, somewhat scabriculous; clothed with golden and dusky sericeous pubescence. Membrane uniformly dark fuscous; area bordering apex of cuneus slightly paler, veins yellowish. Legs with coxae and basal half of femora deep, translucent red; lateral areas of coxae, with apex of front pair also, becoming fuscous; apical one-half to one-third of femora black, blackish cloud formed on anterior face of front pair near base; tibiae yellowish to fulvous, basal one-third and apices black; tarsi yellowish, apical half of third segment fuscous. Venter black, clothed with sericeous, silvery pubescence; genital segment with simple, dusky yellowish hairs.

FeMale.-Length 5.70, width 2.60. Emboliar margins more strongly arcuate apically. More robust than male, but very similar in coloration. First antennal segment as thick as that of male, but second segment slightly more slender.

Habits.-Collected on willow (Salix sp.).

Known Distribution. - Florida, Illinois, Michigan, North Carolina, Ohio, South Carolina, Virginia.

Illinois Records.-GolcoNda: June 22, 1932, on Salix sp., Ross, Dozier \& Park, 1 ô, 1 ․ Pulaski: May 28, 1909, cypress swamp, 1 o .

\section{Polymerus brevirostris Knight}

Polymerus brevirostris Knight (1925, p. 246).

Male.-Length 4.50, width 2.20. Head width 0.97 , vertex 0.43 . Rostrum, length 0.88 , not reaching hind margins of front coxae, reddish to fuscous. Antennae, first segment, length 0.46 , thickness 0.14 , black; second, 1.74, thickness 0.11 , cylindrical, slightly constricted near base, black; third, 0.71 , orange yellow, fuscous apically; fourth, 0.93 , fuscous, yellowish at base. Pronotum, length 0.96 , width at base 1.80 ; basal margin with a slender yellowish area; xyphus reddish. Body clothed with golden yellow, sericeous pubescence, silvery beneath, this pubescence intermixed with pale and fuscous, simple hairs; femora with pale pubescence. General color black; embolium and usually slender outer margin of cuneus yellowish; membrane black, veins yellowish. Legs orange to red; tibiae, tarsi and apices 
of femora black; hind femora with indication of a subapical, fuscous band on anterior aspect.

FeMale.-Length 5.03, width 2.60. Very similar to male in pubescence and coloration.

KNowx Distribution.-Illinois, Manitoba, Michigan, Minnesota, North Dakota, South Dakota, Wisconsin.

Illinois Record.-Galesburg: June 28, 1893,1 \% 2 .

\section{Polymerus chrysopsis Knight}

Polymerus chrysopsis Knight (1925, p. 245).

MALE.-Length 5.70, width 3.60. Head width 1.17 , vertex 0.48 ; head black, with a rounded, yellowish spot on either side of vertex near eye. Rostrum, length 1.24, reaching slightly beyond middle of mesosternum; blackish; first and second segments more or less reddish. Antennae black, clothed with short, mixed pale and fuscous pubescence; first segment, length 0.45 , thickness 0.14 ; second, length 2.06 , cylindrical, thickness 0.12 ; third, length 0.66 ; fourth, length 0.63 . Pronotum, length 1.17 , width at base 2.06. Body clothed with silvery white pubescence intermixed with suberect, pale yellowish pubescence. General color black, moderately shining, with embolium and variable area at apex of corium and cuneus, blood red; coxae and femora red; apices of femora and tibiae black; trochanters and extreme bases of coxae sometimes fuscous; posterior femora often with a black patch on dorsal surface before black apex, also two small dots of black on ventral aspect.

Fenale.-Length 5.50, width 2.80. Very similar to male in pubescence and coloration. Antennae black, last two segments dark brownish.

Host Plant.-Golden aster (Chrysopsis villosa).

This is the most beautiful species of Polymerus, the bright red of the embolium, cuneus and femora, standing in brilliant contrast with the black body. Strange to say, the contrasting red and black colors make the insect difficult to see when it is on its host plant. When disturbed, the adult bug usually rushes to the base of a leaf petiole, where it clasps its legs about the reddish stem of the plant in such a way that the black body with its covering of silvery pubescence suggests, at first glance, a bud in the leaf axil of the golden aster. Many other mirids are so colored as to be similarly inconspicuous when they are on their normal host plants.

Known Distribution.-Illinois, Iowa, Manitoba, Minnesota, North Dakota, South Dakota.

Illinois Record.-AldDridge: May 8, 1932, H. L. Dozier, 1 ô.

\section{Polymerus gerhardi Knight}

Polymerus gerhardi Knight (1923d, p. 606).

Female.-Length 6.40 , width 2.80 . Head width 1.16 , vertex 0.51 ; head black, vertex pale on either side; clothed with sericeous, white pubescence. Rostrum, length 1.08 , not attaining hind margins of front coxae, piceous, basal segment and joints reddish. Antennae, first segment, length 0.64 , thickness 0.14 , black ; second, 2.03, thickness 0.09 , cylindrical, black, with rather closely set, black pubescence; third, 0.96, fusco-brownish; fourth, 0.88 , fuscous. Pronotum, length 1.24, width at base 2.14; black, scarcely shining, rather irregularly rugulose; thickly clothed with sericeous, white pubescence; margins of xyphus, and narrow area along lower margins of pleura, yellowish. Scutellum black, pubescent as on pronotal disk. Sternum and pleura black; ostiolar peritreme yellowish. Emboliar margins moderately arcuate. Hemelytra black, thickly clothed with sericeous, white pubescence intermixed with more erect, simple, black hairs. Membrane and veins uniformly very dark brown, slightly paler bordering apex of cuneus. Legs with femora deep red; coxae tending toward yellowish or orange; tips of femora, tibiae, and tarsi, black; tibiae unusually thick, 0.17 ; spines and pubescence also black. Venter black, thickly clothed with sericeous, white pubescence intermixed with more nearly erect, dark hairs.

Male.-Length 4.70, width 2.00. Antennae, first segment, length 0.52 ; second, 2.03 , thickness 0.13 ; third, length 0.82 ; fourth, length 0.86 . Smaller than female, but very similar in pubescence and coloration.

Known Distribution.-Described originally from specimens from Lake County, Indiana, and Texas. Since being described, this species has also been collected in Illinois, Mississippi, Oklahoma.

Illinois Records. - Ashley: Augr. 7, 1917, 1 of, 1 $q$. Savanna: June 29, 1935, DeLong \& Ross, $1 \delta$. 


\section{Poecilocapsus Reuter}

\section{Poecilocapsus lineatus (Fabricius)}

Four-Lined Plant Bug

Lygaeus lineatus Fabricius (1798, p. 541).

Adult. - Fig. 167. Length 7.00-7.50, width 3.50. General color yellow or green yellow, with four black lines on the dor-

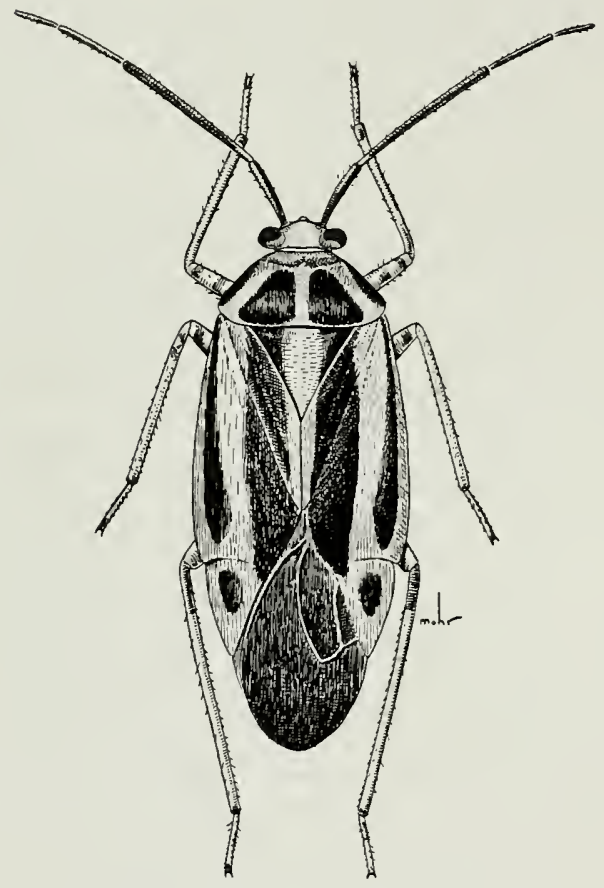

Fig. 167.-Poecilocapsus lineatus.

sum; certain specimens have the yellow of the hemeleytra replaced by bright green.

Host Plants.-A large number of herbaceous plants, especially dock (Rumex sp.); occasionally becomes a pest on currant bushes (Ribes sp.). Large numbers of specimens were collected in Illinois on potato foliage (Solanum tuberosum).

Known Distribution. - Throughout most of the eastern states and Canada.

Illinois Records.-Sixty-eight males, 129 females and 16 nymphs, taken May 7 to September, are from Algonquin, Anna, Antioch, Beach, Bishop, Bluff Springs, Carbondale, Carlinville, Champaign, Chicago, Clarksville, Cypress, Danville, Edgebrook, Elizabethtown, Fountain Bluff, Frankfort, Freeport, Galena, Galesburg, Giant City State Park, Makanda, Glendon Park, Glen Ellyn,
Golconda, Grand Detour, Hardin, Havana, Joliet, Kankakee, Karnak, Manito, Morton Grove, Mount Carmel, Oakwood, Odin, Palos Park, Quincy, Rockford, Rockton, Urbana, Vienna, Villa Ridge, Volo, Warsaw, Waukegan, Willow Springs.

\section{Horcias Distant}

\section{KEY TO SPECIES}

1. Second antennal segment clavate, its maximum diameter exceeding diameter of first segment; embolium white, cuneus rose colored; see frontispiece ............... illini, p. 172

Second antennal segment slightly clavate, but its maximum diameter less than diameter of first segment. .... 2

2. Rostrum not surpassing posterior margins of middle coxae; color black with scutellum frequently red...... ...............fallax, p. 173

Rostrum extending nearly to posterior margins of hind coxae; color variable......... dislocatus, p. 173

Horcias illini new species

This species is allied to dislocatus (Say), but differs from it in being smaller, and in having a narrower vertex and more strongly clavate second antennal segment; in color, it is very similar to dislocatus flavidus Knight, but the cuneus, calli and head are distinctly reddish; the color pattern apparently is not variable.

MALE.-Frontispiece. Length 5.20, width 2.70. Head width 1.12 , vertex 0.43 . Rostrum, length 1.95 , nearly attaining hind margins of middle coxae. Antennae, first segment, length 0.74 , thickness 0.14 , black; second, 1.86 , thickness 0.15 , slender at base ( 0.07 thick), gradually enlarging to clavate on apical half ( 0.15 thick), black, densely clothed with short, velvety, yellowish pubescence; third, length 0.82 , basal one-fourth widened and pale brown, distal part slender and black; fourth, length 1.04, slender, black, with narrow, tan area at base. Pronotum, length 1.21 , width at base 2.04. Surface of body smooth and shining; dorsum with sparse and very fine pubescence. General coloration black and white with lighter areas tinged with reddish. Head yellowish to reddish brown, frons with transverse reddish lines on either side. Pronotum white, a large 
quadrate, black area on either side behind calli, leaving median line, lateral margins of disk, and narrow area at basal edge, white; calli and area extending along lateral margins of disk irregularly marked with reddish; propleura with two reddish rays extending parallel to margins of disk. II esoscutum and scutellum black, median line white. Hemelytra black, broad white area along claval vein; claval suture black only on basal half; embolium, narrow area along radial vein, and wedge-shaped area on inner apical area of corium, white; cuneus reddish, apex blackish, outer basal angle pale. Nembrane uniformly dark brown. Ventral surface reddish brown to black, a white line formed on either side of venter; also white mark extending across dorsal half of ostiolar peritreme and side of sternum. Legs pale to dark brown; coxae reddish brown; femora paler on apical half, annulated with yellowish and brown near apices; tibiae pale, tips and knees dark, spines black; tarsi mostly pale, black apically.

Female.-Length 5.80, width 3.10. Head width 1.25 , vertex 0.49 . Antennae, first segment, length 0.82 ; second, 2.12 , greatest thickness 0.15 , clavate as in male; third, length 0.86 . Pronotum, length 1.38 , width at base 2.42. More robust than male, but very similar in color and pubescence.

Holotype, male. - Dongola, Ill.: May $12,1916$.

Allotype, female. - Same data as for holotype.

Paratypes.-Illinois.-Dongola : May 9, 1916, $1 \delta$; May 12, 1916, 1 \% ; May 13, 1916, 1 ô, 1 o.

The apparently restricted distribution of this beautiful new species seems worthy of remark. Future collections of specimens will be received with great interest.

\section{Horcias dislocatus (Say)}

Capsus dislocatus Say (1832, p. 21).

Adults.-Length 6.20, width 3.00. General color of typical form pale rufo-sanguineous. First and second antennal segments, tylus, juga, base of vertex, two wedgeshaped approximate spots on basal half of pronotal disk, scutellum except median line, inner half of clavus, inner apical angles of corium, membrane, pleura, middle and hind coxae, and the venter, black.

This species varies in color from yellow and brown, through red and black, to en- tirely black. A large number of color combinations of this species have been given varietal names. The Illinois material contains representatives of the following in addition to the typical form: rubellus Knight (1923d, p. 608), goniphorus (Say) (1832, p. 21), gradus Knight (1923d, p. 609), residuus Van Duzee (1912, p. 484), coccineus (Emmons) (1854, pl. 30, fig. 2), limbatellus (Walker) (1873, p. 93), affinis (Reuter) (1876, p. 74), flaridus Knight (1923d, p. 609), scutatus Knight (1923d, p. 609), pallipes Van Duzee (1912, p. 484), and nigritus Reuter (1909, p. 41). Two other varieties, nigriclavus Knight (1923d, p. 609) and marginalis (Reuter) (1876, p. 75 ) have not been recognized in the material collected here.

Food Plants. - False Solomon's seal (Smilacina racemosa), wild geranium (Geranium maculatum), figwort (Scrophularia leporella) and occasionally papoose root (Caulophyllum thalictroides). A few Illinois specimens were collected also on clover (Melilotus sp. and Trifolium sp.), oak (Quercus sp.) and fleur-de-lis (Iris sp.). The different color varieties of this species may occur on any of these food plants.

KNown Distribution.-Known in its various color forms from Maine westward to Minnesota and southward to Pennsylvania and Texas.

Illinois Records. - One hundred forty males, 155 females and 4 nymphs, collected May 21 to June 30, are from Algonquin, Antioch, Beach, Bloomington, Castle Rock, Champaign, Danville, Dubois, Elizabeth, Frankfort, Freeport, Galesburg, Glendon Park, Glen Ellyn, Grand Detour, Herod, Homer, Joliet, Keithsburg, Le Roy, Manito, Monticello, Mount Carmel, Muncie, Oakwood, Oregon, Palos Park, Pecatonica, Riverdale, St. Joseph, Springfield, Stratford, Urbana, Waukegan, White Heath, White Pines Forest State Park, Willow Springs, Zion.

\section{Horcias fallax Reuter}

\section{Horcias fallax Reuter (1909, p. 42$)$.}

Male.-Length 5.10, width 2.10. Head width 1.08 , vertex 0.41 . Rostrum, length 1.86 , just attaining posterior margins of middle coxae. Antennae, first segment, length 0.60 , thickness 0.12 ; second, 1.99 , thickness 0.11 ; third, length 0.80 ; fourth, length 0.95 . Pronotum, length 1.08 , width at base 1.86. General color black, shining, 
nearly glabrous; scutellum either red or black. Propleura yellowish; rarely anterior half of pronotum yellowish. Legs mostly yellowish with basal halves of middle and hind coxae, tips of tibiae, and apical segment of each tarsus, black; hind femora often with two fuscous annulations just be.fore apex; membrane and veins uniformly dark fuscous or black.

Female.-Length 5.40, width 2.43. Somewhat more robust than male, but very similar in coloration.

Host Plants. - A good series of nymphs and adults were taken on wild gooseberry (Ribes oxyacanthoides) in Iowa, May 18 to 25 ; a few Illinois specimens were collected on willow (Salix sp.) and oak (Quercus sp.).

Known Distribution.-Illinois, Indiana, Iowa, Ohio, Pennsylvania, Wisconsin.

Illinois Records.-Five males and $12 \mathrm{fe-}$ males, taken May 9 to June 30 , are from Algonquin, Dongola, Galesburg, Glen Ellyn, Urbana, White Heath, Willow Springs.

\section{Adelphocoris Reuter}

\section{KEY TO SPECIES}

Hemelytra dark brown, broad pale area at costal margin, fig. 168; scutellum uniformly dark brown, leng $h$ 6.80-7.40... $\ldots \ldots \ldots \ldots \ldots \ldots$ rapidus, p. 174 Hemelytra pale, costal edge black; scutellum light with two dark longitudinal lines; usually apical area of corium darkened, fig. 169; length $8.00 \ldots . .$. . ............. lineolatus, p. 175

\section{Adelphocoris rapidus (Say)}

Capsus rapidus Say (1832, p. 20).

Adults.-Fig. 168. Length 6.80-7.40. General color dark brown. Embolium and outer margin of cuneus light brown; pronotum yellowish brown, basal half of disk usually with two black spots; these spots sometimes fuse to form a transverse black mark.

Host Plants.-Ordinarily breeds on dock (Rumex sp.) in the northern states, but may breed on several other plants; Illinois specimens have been collected on clover (Trifolium sp. and Melilotus sp.) and yarrow (Achillea sp.).

Known Distribution.-A common species in the eastern states and those westward to the 100th meridan; farther west it is replaced by superbus Uhler, a quite variable species.

Illinois Records.-Two hundred fortytwo males, 253 females and 1 nymph, collected May 15 to Nov. 4, are from Albion, Algonquin, Allerton, Alton, Anna, Antioch,

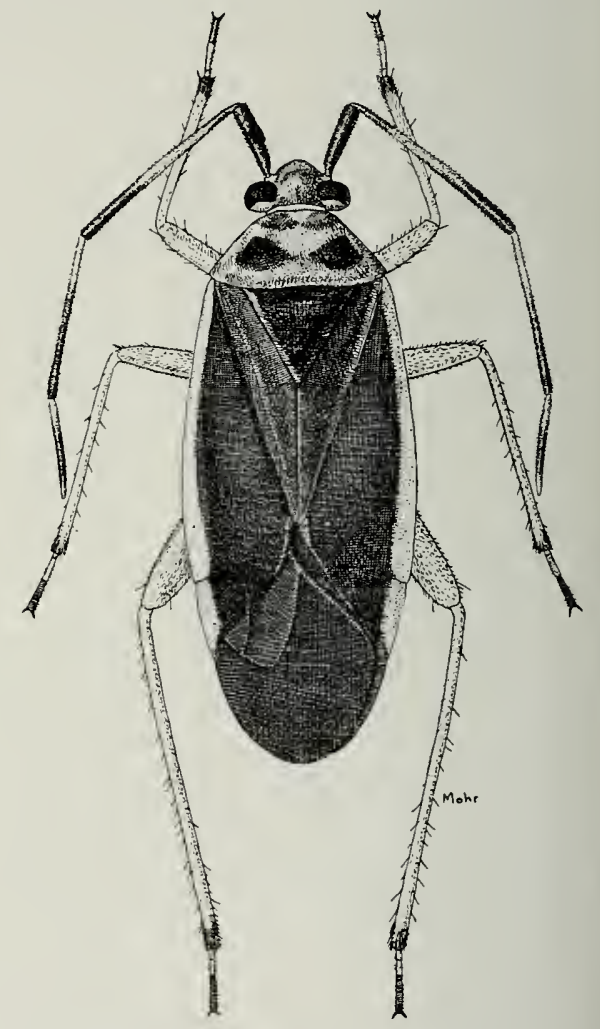

Fig. 168.-Adelphocoris rapidus.

Arcola, Aurora, Beardstown, Beach, Bloomington, Blue Island, Bluff Springs, Borton, Browns, Bushnell, Carbondale, Champaign, Chicago, Darwin, Delavan, Dixon, Dolson, Dubois, Last St. Louis, Elgin, Elizabethtown, Erie, Fairmount, Farmer City, Fountain Bluff, Freeport, Galena, Galesburg, Giant City State Park, Makanda, Glencoe, Glen Ellyn, Golconda, Grand Detour, Grand Tower, Grand View, Hamilton, Hardin, Hartsburg, Havana, Herod, Hilliary, Hinsdale, Homer Park, Iroquois, Jonesboro, Kankakee, Karnak, Keithsburg, Lawrenceville, Mahomet, Marshall, Mason City, Metropolis, Milford, Monticello, Mound City, Mount Carroll, Muncie, Normal, Oak Lawn, Oakwood, Ogden, Oquawka, Oregon, Palos Park, Pecatonica, Princeton, Pulaski, Rockford, Rockton, St. 
Anne, St. Joseph, Savanna, Seaton, Seymour, Shawneetown, Sparta, Springfield, Starved Rock State Park, Sun Lake, Topeka, Ullin, Urbana, Vandalia, Vienna, Virginia, Volo, Ware, Waterman, Watseka, Waukegan, West Union, Willow Springs, York, Zion.

\section{Adelphocoris lineolatus (Goeze)}

\section{Alfalfa Plant Bug}

Cimex lineolatus Goeze (1778, p. 267).

MALE.-Length 8.00 , width 2.80 . Head width 1.36 , vertex 0.42 . Antennae, first segment, length 0.98 ; second, 2.87 ; third, 2.20 ; fourth, 1.30. Pronotum, length 1.30, width at base 2.25. General coloration pale yellowish with a tinge of brown and dusky. Scutellum with two fine, longitudinal fuscous marks on middle; corium usually with a triangular fuscous area on apical half; a fine line along costal edge black; cuneus

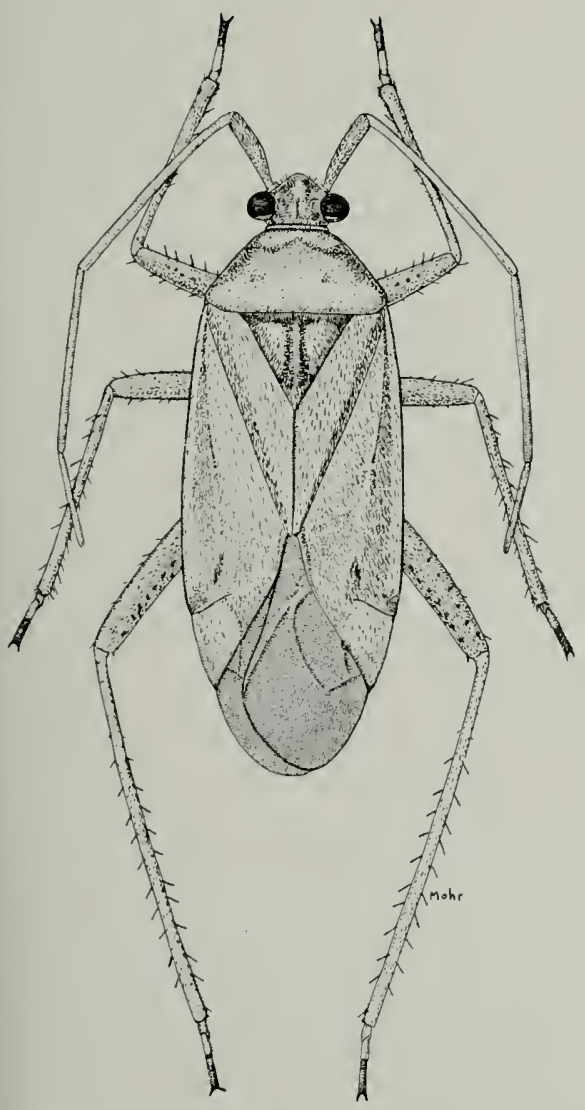

Fig. 169.-Adelphocoris lineolatus. yellowish; membrane fuscous. Antennae yellowish to brown, apical half darker and usually reddish brown. Legs yellowish; femora with many black dots, anterior aspect with two rows of somewhat larger spots; tibial spines black, without distinct spots at bases. Body clothed with simple, pale yellowish pubescence, legs provided with black pubescence.

Female.-Fig. 169. Length 7.50, width 2.90. More robust than male and usually somewhat paler in color, but otherwise very similar in form and coloration.

Host Plants.-Alfalfa (Medicago sativa) and sweet clover (Melilotus sp.) ; occurs in limited numbers on other leguminous plants; also on many other succulent, herbaceous plants. The bugs prefer to feed on flower buds and newly formed seeds, and may prove a pest where alfalfa and sweet clover are grown for seed.

Known Distribution. - A European species first recorded from North America at Cape Breton, Nova Scotia (Knight 1922a), and later from Ames, Iowa, where adults were first collected June 18, 1929. They were probably imported as eggs in seeds, as about 700 samples were imported and grown at the agronomy farm at Ames in 1926 and 1927. The spread of this foreign species to surrounding states is indicated to a certain extent by the collection dates placed in parentheses following the names of these states: Iowa (1929), Minnesota (1934), Illinois (1935), Missouri (1935), South Dakota (1935), Nebraska (1936), Wisconsin (1936), Kansas (1939), Manitoba (1939).

Illinois Records. - FrEePORT: June 28, 1935, DeLong \& Ross, 2 o Richmond: June 25, 1938, at light, Ross \& Burks, $1 \delta$. Savanna: June 29, 1935, DeLong \& Ross, $1 \hat{\delta}$.

\section{Stenotus Jakovlev}

\section{Stenotus binotatus (Fabricius)}

Lygaeus binotatus Fabricius (1794, p. 172). Male.-Length 6.00, width 2.00. Chiefly yellowish green below; pronotum with two broad black rays; hemelytra yellowish orange, with two broad, irregular, longitudinal black stripes.

Fevale.-Length 7.00, width 2.40 ; yellowish green, pronotum with two prominent black spots on disk, one behind each callus; corium with a longitudinal fuscous stripe. 
Host Plants.-Orchard grass (Dactylis glomerata) and, to some extent, other grasses; Illinois specimens have been collected on orchard grass and timothy (Phleum pratense).

Knowx Distribution. - A European species now known from British Columbia, lllinois, Indiana, Iowa, Massachusetts, Michigan, Minnesota, Missouri, New Hampshire, New Jersey, New York, North Carolina, Ohio, Ontario, Oregon, Pennsylvania, $Q$ uebec, Tennessee, Wisconsin.

Illinois Records. -One hundred twentysix males and 158 females, taken June 1 to July 14, are from Antioch, Apple River Canyon State Park, Bureau, Elizabeth, Galena, Hamilton, Hardin, Karnak, Marshall, Mason City, Monticello, Palos Park, Plainview, Putnam, Urbana, Warsaw, Waukegan, Zion.

\section{Paracalocoris Distant}

\section{KEY TO SPECIES}

1. Hind tibiae thickly clothed with long, erect hairs which obscure tibial spines and are easily confused with them........... scrupeus, p. 177

Hind tibiae with shorter and more appressed hairs, especially on inner side; hairs not easily confused with true spines............... 2

2. Length of first antennal segment as great as or greater than maximum dorsal length of pronotum....... 3

First antennal segment shorter than pronotum............... 6

3. Length of first antennal segment less than width of head plus dorsal width of an eye; length $6.00-6.50 \ldots \ldots$.

hawleyi, p. 178

Length of first antennal segment equal to width of head plus dorsal width of an eye, or greater...........4

4. Second antennal segment uniformly black.......... limbus, p. 178

Second antennal segment pale yellowish to brown, sometimes dark brown, but never black; general coloration brownish, with minute pale spots.

5. First antennal segment reddish brown, with pallid spots; gula and genae dark brown.

pallidulus var. pallidulus, p. 178
First antennal segment more pallid than brown; gula and genae pallid pallidulus var. albigulus, p. 178

6. Length of first antennal segment equal to or greater than width of head. . 7

Length of first antennal segment less than width of head .......... 9

7. Pronotum and scutellum with three distinct yellowish stripes; first antennal segmen: black, with few, if any, pale spots....trivittis, p. 178

Pronotum and scutellum without distinct stripes; first antennal segment pallid, marked with brown, or brown with pallid marks........ 8

8. Apical half of second antennal segment black or very dark brown; scutellum with narrow, median, yellowish line, this line sometimes obscured by brownish coloration. .

...........evonymi, p. 178

Second antennal segment rather uniformly yellowish brown, in darkest specimens with black but only at apex; scutellum with light color irregularly distributed; brown largely broken by minute, lightcolored spots.........salicis, p. 177

9. Dorsum dark brown, with several large yellow patches: on apical half of scutellum, apex of clavus, middle of corium, apex of embolium and outer half of corium, and three areas on pronotum............ ........ multisignatus, p. 180

Ground color dark brown, lightcolored areas taking the form of fine lines and small dots........10

10. Basal half of second antennal segment yellowish brown, but without narrow white annulus at middle or base.................

Second antennal segment with a narrow white annulus near the middle which separates black area on apical half from brownish basal half. ....11

11. Rostrum extending beyond hind coxae celtidis, p. 179

Rostrum not extending beyond hind coxae...................... 12

12. Second antennal segment dark, with pale annulus at middle only; femora dark at base, apical half with one large and several smaller white spots.......... gleditsiae, p. 180 Second antennal segment with pale 
annulus both near base and at middle; femora with broad, light-colored areas at base and middle.......

colon, p. 180

\section{Paracalocoris scrupeus (Say)}

Capsus scrupeus Say (1832, p. 23).

MALE.-Length 6.00, width 2.50. Head, width 1.10 , vertex 0.52 . Rostrum, length 2.38 , reaching to middle of hind coxae. Antennae, first segment, length 1.25 ; second, 1.95; third, 0.82; fourth, 0.91. Pronotum, length 1.34 , width at base 2.08. Varying in color from orange and black, through yellow and brown, to almost uniformly brown or tan.

A large number of color combinations of this species have been given varietal names. Of these, besides the typical form, the following varieties, all described by McAtee (1916), have been taken in Illinois: delta, ardens, cunealis, par, sordidus, bidens, nubilus, varius, compar, lucidus, percursus, rubidus and triops.

Host Plants.-Most frequently wild grape (V'itis sp.), but may occur on cultivated varieties of grape and, occasionally, on other woody plants. Illinois specimens were collected on grape, box elder (Acer negundo), willow (Salix sp.), hop tree (Ptelea trifoliata), hickory (Carya sp.), hawthorn (Crataegus sp.), dogbane (Apocynum sp.) and dogwood (Cornus sp.).

Illinois Records.-One hundred males and 150 females, taken May 30 to July 12, are from Algonquin, Antioch, Bureau, Dixon, Dolson, Elizabeth, Elizabethtown, Frankfort, Freeport, Galena, Galesburg, Grand Detour, Harvard, Havana, Joliet, Kampsville, Kankakee, Keithsburg, Kingston, Monticello, Oakwood, Oquawka, Oregon, Palos Park, Putnam, Riverside, Savanna, Urbana, West Union, White Heath, Willow Springs, Zion.

\section{Paracalocoris salicis Knight}

Paracalocoris salicis Knight (1926j, p. 367). Male.-Length 6.00, width 2.50. Head width 1.15 , vertex 0.50 . Rostrum, length 2.36, nearly attaining hind margins of posterior coxae. Antennae, first segment, length 1.18 , slightly greater than width of head; second, 2.22, rather uniformly yellowish brown, somewhat darker at apex; third, 0.89 , black, narrow pale area at base. Pro- notum, length 1.35 , width at base 2.06 . Dorsum clothed with short, yellowish pubescence, more golden on clavus, and with a few sericeous hairs on scutellum and clavus. Ground color pale yellowish, more or less clouded with dark brown; pronotal disk brown with several small, pale spots, some

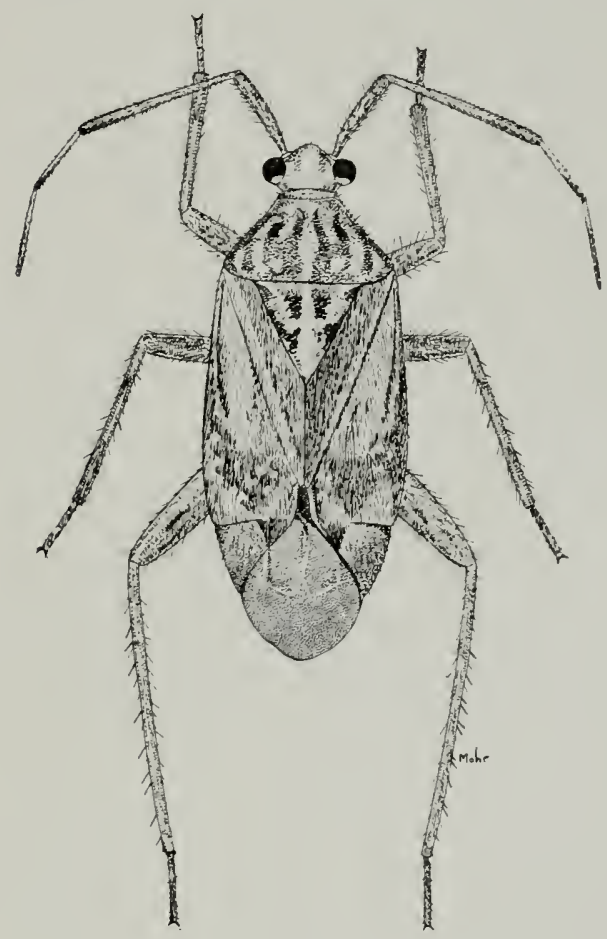

Fig. 170.- Paracalocoris salicis, ㅇ.

of which coalesce behind outer margin of each callus to suggest a ray; pale yellowish median line of pronotum continued on scutellum, where irregular dark color on either side of it is composed of aggregated small dots. Hemelytra medium brown to dark brown, marked with pale dots in longitudinal series, one row along middle of corium, another along radial vein; apex of embolium and inner apical angle of corium with broad, pale areas; clavus with a more or less broad, pale mark along claval vein. Cuneus very light yellow, with inner basal angle, apex, and area extending back along margin of membrane, brownish. Membrane yellowish to brownish, darker at apex and areoles; veins white, brown around smaller areole. Legs tan to yellowish, darkened with brown, this dark color broken by numerous pale dots; basal third of tibiae, band at mid- 
dle, and narrow band at apex, dark brown. Venter yellowish, sides with three indistinct, longitudinal, dark lines separated by three indistinct yellow ones.

Female.-Fig. 170. Length 6.40, width 2.60. Head width 1.14 , vertex 0.50 . Antennae, first segment, length 1.24; second, 2.22 ; third, 1.00 ; fourth, 0.98 . Very similar to male in pubescence and coloration.

Host Plant. - Sandbar willow (Salix longifolia).

Known Distribution.-Colorado, Illinois, Indiana, Iowa, Michigan, Minnesota, Nebraska, Pennsylvania, South Dakota.

Illinois Records. - Twenty-two males and 31 females, taken May 27 to July 26, are from Alton, Bureau, Elizabethtown, Freeport, Golconda, Herod, Kampsville, Lilly, Monticello, Oquawka, Oregon, Palos Park, Pulaski, Rockford, St. Joseph, Savanna, Seymour, West Union, Willow Springs, York.

\section{Paracalocoris hawleyi Knight}

Paracalocoris hawleyi Knight (1916b, p. 377).

Not taken in Illinois; known from Massachusetts, New York, Ohio. Occurs on cultivated hop (Hamulus japonicus).

\section{Paracalocoris limbus McAtee}

Paracalocoris limbus McAtee (1916, p. 380).

Not taken in Illinois; known from Georgia, Maryland, Massachusetts, New York, Ohio, Pennsylvania, Virginia.

\section{Paracalocoris pallidulus McAtee}

Paracalocoris hawleyi var. pallidulus McAtee (1916, p. 380).

Not taken in Illinois; known from Minnesota, New York, North Dakota, Ohio, Ontario; feeds on apple (Pyrus malus) and hawthorn (Crataegus sp.). The variety albigulus Knight (1930d, p. 823) is generally lighter in color than the typical form.

\section{Paracalocoris castus McAtee}

Paracalocoris colon var. castus McAtee (1916, p. 382).

MalE.-Length 5.40, width 2.30. Head width 1.04, vertex 0.45 . Rostrum, length 1.95, just reaching to middle of hind coxae. Antennae, first segment, length 0.88 , dark brown with a few yellowish spots; second,
2.08, yellowish brown, apical two-fifths and narrow area at base dark brown, without any indication of white annuli; third, 0.75 , yellowish, apical half black; fourth, 1.03, fuscous. Pronotum, length 1.21, width at base 1.90. General color dark brown, with a few yellow spots on pronotum, apical area of corium and on cuneus; scutellum with a slender, median yellowish line. Membrane fuscous, with a yellowish spot near tip of cuneus; veins fuscous, pale at apex of larger areole. Dorsum clothed with yellowish to golden, sericeous pubescence intermixed with a lesser amount of simple pubescence. Legs dark brown; femora with rows of small yellowish spots, hind femora each with a large yellowish spot dorsally near middle of apical half; each tibia with a broad, yellowish band at middle and just before apex; tarsi brown to fuscous.

Female.-Length 5.40, width 2.60. Head width 1.11, vertex 0.51. Antennae, first segment, length 1.03; second, 1.99; third, 0.91 ; fourth, 1.12. Pronotum, length 1.38 . width at base 2.12. More robust than male, but very similar in pubescence and coloration.

Host Plant.-Virginia creeper (Psedera quinquefolia).

Known Distribution.-District of Columbia, Florida, Illinois, Iowa, Maryland, Massachusetts, Michigan, Minnesota, New Jersey, New York, Ohio, Vermont.

Illinois Records.-Algoneuin : June 24, 1894, 1 . . Antioch : July 5-7, 1932, T. H. Frison, 1 s , 1 \&. Havana: July 12, 1932 , Dozier \& Park, 1 o. White Pines Forest State Park: July 4, 1932, Dozier \& Mohr, $1 \hat{\delta}$.

\section{Paracalocoris trivittis Knight}

Paracalocoris trivittatus Knight (1926j, p. 371). Preoccupied. 812).

Paracalocoris trivittis Knight (1930d, p.

Known only from Mississippi.

\section{Paracalocoris evonymi Knight} 812).

Paracalocoris evonymi Knight (1930d, p.

MALE.-Length 6.10, width 2.70. Head width 1.13 , vertex 0.54 . Rostrum, length 2.25 , reaching to middle of hind coxae, yellow with apex black. Antennae, first segment, length 1.25 , pale, with reticulated brown marks and spots; second, 2.25, nar- 
row area at base black, bordered by a pale annulus, then yellowish brown to middle, where a slightly paler annulus separates this from the black on apical half; third, 0.97, pale, distal half black; fourth, 1.12, blackish, paler at base. Pronotum, length 1.38 , width at base 2.12 ; dark brown; disk with a few pale spots; median line pale although it may be indistinct near basal margin, basal edge yellowish; discal spots black, inner and outer margins bordered by yellow. Scutellum dark brown, median line with a slender pale mark; small spot near each basal angle, and a few even smaller dots near middle and apex, yellow. Hemelytra dark brown to black; area at inner half of clavus bordering scutellum black; corium with a few vague, yellowish spots; radial vein yellow on basal half. Cuneus mostly dark brown, with outer edge and area extending across middle yellowish; light-colored area on disk appearing more as spots than as uniform color. Membrane dart fuscous to black; a rather large, yellowish spot on margin near apex of cuneus and a smaller one on middle of larger areole; vein at apex of larger areole yellowish. Legs tan, with bases of coxae more or less fuscous and apical halves of femora spotted with brown, this coloration on apical third of hind femora interrupted by a few minute, yellow spots; tibiae each with two brown bands, apices only slightly darkened; tarsi pale, apices black. Venter of thorax dark brown, darker at sides; ventral surface of abdomen yellowish on basal half, sides rather uniformly very dark brown, except on second, or first visible, segment, where two more or less indistinct pale marks occur. Dorsum clothed with yellowish to golden, recumbent, sericeous pubescence intermixed with a few obscure, simple hairs.

Female.-Length 5.80, width 2.80. Head width 1.16 , vertex 0.56 . Antennae, first segment, length 1.21 ; second, 2.20 ; third, 1.00 ; fourth, 1.12. Pronotum, length 1.35 , width at base 2.16. Slightly more robust than male, but very similar in pubescence and coloration.

Host Plant.-Waahoo or burning bush (Evonymus atropurpureus); a single specimen was taken in this state on box elder (Acer negundo); others were taken on redbud (Cercis canadensis).

KNown Distribution.-Illinois, Iowa, Ohio, western New York.
Illinois Records. - Elizabethtown : May 27-31, 1932, on redbud, H. L. Dozier, 3 ô. Oevawka: June 13, 1932, on Acer negundo, H. L. Dozier, 1 ㅇ․

\section{Paracalocoris celtidis Knight}

Paracalocoris celtidis Knight (1930d, p. 810).

Male.-Length 5.70, width 2.60. Head width 1.14 , vertex 0.56 . Rostrum, length 2.70, extending to fifth abdominal segment, tan to yellowish with last two segments black. Antennae, first segment, length 1.00 , dark brown to black, with several small, white, glabrous spots and set with several erect, black setae; second, 2.25, black, with pale annulus at middle; third, 0.91, fuscous to black, yellowish at base; fourth, 0.95, black, with a narrow yellowish area at base. Pronotum, length 1.30, width at base 2.00; disk dark brown to black, with pale spots; calli and areas surrounding discal spots yellow to yellowish brown; area between calli white, this color extending back along median line to base as a white line, basal half of line apparently produced by the joining of several spots. Scutellum brown, with yellowish, more or less confluent spots; median line yellowish, except at apex, but this line joined by so many spots that its outline is largely obscured. Hemelytra black and brown, with minute yellowish spots, these more prominent along radial vein and near apex of embolium. Cuneus largely white due to the numerous and confluent white spots; apex and paracuneus black. Membrane dark fuscous or black, with disk of larger areole, apical half of membrane except large spot bordering apex of larger areole, and spot at middle of outer margin, yellowish. Legs yellow, marked with brown; distal half of femora with black ground color, which is cut into small areas by numerous white spots; hind femora with one much larger white spot on middle of dorsal aspect; tibiae with apex, band at middle, and a broader band at base, brown, the last somewhat broken by white spots; tarsi pale, apices black. Venter dark brown, varied with white and yellowish marks; sides tending toward black, with three rows of obliquely placed, yellow dashes. Dorsum clothed with recumbent, pale to golden yellow, sericeous pubescence, intermixed with less prominent, simple, fus- 
cous hairs; femora with several prominent, bristlelike white hairs, much as in gleditsiae Knight; tibiae with several yellowish, setose hairs which may be longer than true spines, but these spines much thicker and brown in color.

Fexale.-Length 6.00, width 2.60. Head width 1.14, vertex 0.56. Antennae, first segment, length 1.04; second, 2.03; third, 0.95 ; fourth, 1.29. Pronotum, length 1.34 , width at base 2.12. Slightly more robust than male, but very similar in pubescence and coloration.

Hos't Plant.-Hackberry trees (Celtis occidentalis).

Known Distribution. - Illinois and Iowa.

Illinois Records.-IllinoIs: 1 을 URBANA: July 16, 1932, C. O. Mohr, 1 우.

\section{Paracalocoris gleditsiae Knight} 370).

Paracalocoris gleditsiae Knight (1926j, p.

This is allied to colon (Say) by key characters and it is distinguished from colon by having several prominent, erect, bristlelike hairs on the hind femora; the length of each of these hairs is greater than the thickness of a tibia.

Male.-Length 5.40, width 2.20. Head width 1.05 , vertex 0.47 . Rostrum, length 2.04 , reaching to middle of hind coxae. Antennae, first segment, length 0.89 , dark reddish brown with a few small white dots; second, 1.90, dark brown, with a pale annulus at the middle and a somewhat lighte. brown area before annulus; third, 0.81 , dark hrown to fuscous, paler at base; fourth, 0.83 , fuscous, a narrow yellowish area at base. Pronotum, length 1.20 , width at base 1.86; dark brown, basal half of disk black, slender area at hase yellowish, and with seven or eight pale spots on sub-basal margin, area bordering outer margin of black discal spots, and four short, longitudinal marks between, yellow to white. Scutellum dark brown, with slender line and irregular marks on either side near apex pale. Hemelytra dark brown, somewhat paler at base of corium and apex of clavus; embolium, corium and cuneus with several small, yellowish or white dots. Membrane infuscated, veins about apex of larger areole white. Venter with sides dark brown, each segment with three yellow marks which, taken together, suggest broken, longitudinal lines. Legs reddish brown, irregularly marked with white dots; femora much darker at bases; hind pair with a large white spot on dorsal aspect beginning at middle; tibiae with white band at middle.

Female.-Length 5.80, width 2.70. Head width 1.12 , vertex 0.54 . Antennae, first segment, length 0.99 ; second, 1.92 ; third, 0.75 ; fourth, 0.78 . Pronotum, length 1.30 , width at base 2.04 . Very similar to male in pubescence and coloration.

Host Plant.-Honey locust (Gleditsia triacanthos) ; also collected on black locust (Robinia pseudoacacia).

Known Distribution. - Illinois, Indiana, Iowa, Ohio.

Illinois Records.-Danville: June 8, 1902, Titus $\&$ Kahl, 1 of. Elizabethtown : May 27-31, 1932, on Robinia pseudoacacia, H. L. Dozier, $1 \hat{\delta}, 4$. New Holland: May 28, 1936, Mohr \& Burks, 3 ๙ , 4 ㅇ. ST. Joseph: June 17, 1932, T. H. Frison, 1 o .

\section{Paracalocoris multisignatus Reuter}

Paracalocoris multisignatus Reuter (1909, p. 40 ).

Known from District of Columbia, Georgia, Indiana, Maryland, Mississippi, New York, North Carolina, Ohio, Oklahoma, Texas, Virginia. It should eventually be found in southern Illinois. Breeds on wild grape (I itis rotundifolia).

\section{Paracalocoris colon (Say)}

Capsus colon Say (1832, p. 25).

Adulrs.-Length 5.80, width 2.50; length of pronotum 1.33. Antennae, first segment, length 1.10 , brownish, spotted with yellow, spots more or less confluent, clothed with black semierect hairs which are hardly as long as segment is thick; second, 2.22, narrow area at base and apical one-third black, area between brownish, but with pale annulus bordering black, pubescence fine; third, 0.97, pale to fuscous, becoming darker at apex; fourth, 1.08, pale fuscous, darker at apex. Dorsum pale yellowish to grayish or dark brown, spotted with yellow, in paler specimens brown forming large spots; clothed with pale yellowish to golden pubescence; membrane fuscous, with a spot at middle and on either side near tip of cuneus yellowish. Ventral surface brownish, each segment with two or three longitudinal, yellow marks on sides. Legs yellowish; apical third of femora and two bands on tibiae 
brownish, this color spotted with yellow; in dark specimens, hind femora developing a brownish patch on basal half.

Food Plant-Collected on gooseberry (Ribes sp.) in Illinois.

Known Distribution.-District of Columbia, Illinois, Indiana, Michigan, New Jersey, New York.

Illinois Records.-Eleven males and 8 females, taken May 29 to July 14, are from Anna, Forest City, Hardin, Havana, Keithsburg, Manito, Palos Park, Quincy, White Heath, White Pines Forest State Park.

\section{Garganus Stål}

\section{Garganus fusiformis (Say)}

Capsus fusiformis Say (1832, p. 24).

Male.-Fig. 171. Length 5.10, width 1.60. Head width 0.86 , vertex 0.30 . Rostrum, length 1.86 , slightly exceeding posterior margins of hind coxae. Antennae, first segment, length 0.95 , orange colored and with short, fuscous pubescence; second, 1.86, fusiform, thickness 0.13 , black, thickly clothed with

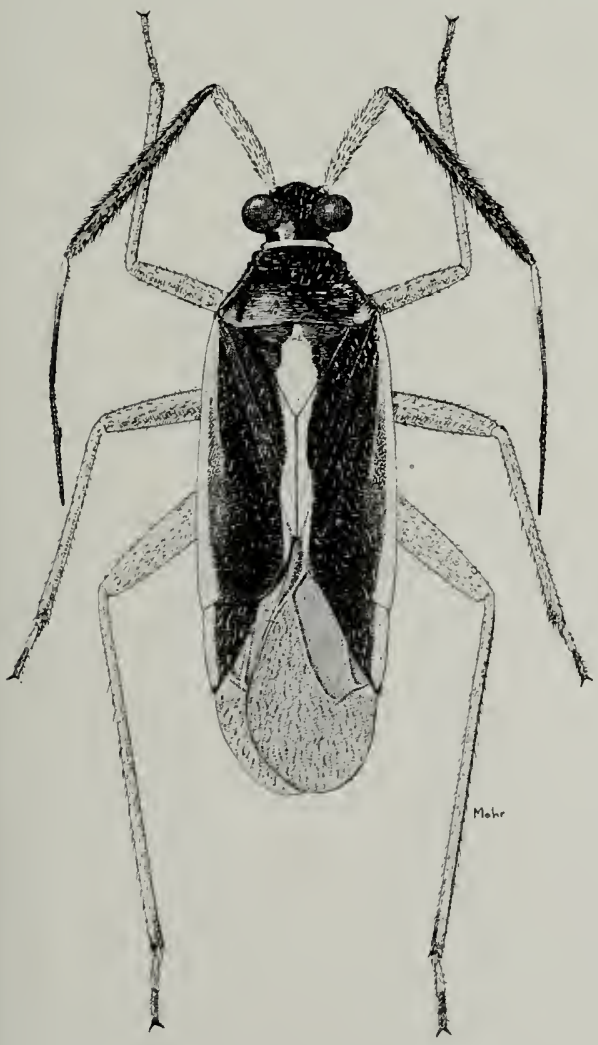

Fig. 171.-Garganus fusiformis, $\sigma^{7}$. slightly flattened, black hairs; third, 0.99 , slender, black, yellowish at base; fourth, 1.00 , black. Pronotum, length 0.78 , width at base 1.22. General color black; collar, broad area on median line of scutellum, inner margin of clavus, embolium, and outer margin of cuneus, yellowish to white; legs and venter, except genital segment, orange colored.

FeMale,-Length 5.40, width 1.81. Head width 0.91 , vertex 0.36 . Antennae, first segment, length 0.86 , yellow to orange ; second, 1.77 , fusiform, greatest thickness 0.17 ; third, 1.00 ; fourth, 1.08. Pronotum, length 0.86 , width at base 1.35. More robust than male, but very similar in pubescence and coloration.

Host Plants. - Coltsfoot (Tussilago farfara); lllinois specimens were taken also on smartweed (Polygonum sp.).

Known Distribution.-Alabama, Connecticut, District of Columbia, Florida, Georgia, Illinois, Indiana, Kansas, Maryland, Massachusetts, Missouri, North Carolina, New Jersey, New York, Ohio, Ontario, Pennsylvania, South Carolina, Tennessee, Virginia.

Illinois Records.-Sixty-six males, 46 females and 1 nymph, taken June 14 to Oct. 6 , are from Algonquin, Alto Pass, Browns, Cairo, Carbondale, Carmi, De Soto, Dixon Springs, Dolson, East St. Louis, Elizabeth, Elizabethtown, Galesburg, Grand Tower, Grandview, Herod, Karnak, Metropolis, Milo, Mount Carmel, Normal, Pulaski, Temple Hill, Urbana, West Pullman.

\section{Neurocolpus Reuter}

\section{KEY TO SPECIES}

1. Length of first antennal segment threefifths or more length of second segment................. 2

Length of first antennal segment not, or only slightly, exceeding one-half length of second segment........ 3

2. Length of first antennal segment nearly three-fourths length of second segment; tip of rostrum surpassing posterior margins of hind coxae. . . . . . .

tiliae, p. 182

Length of first antennal segment not more than two-thirds length of second segment; tip of rostrum reaching posterior margins of hind coxae...........nubilus, p. 182 
3. Hind femora pale with apical onefourth black..........jessiae, p. 183

Hind femora fuscous or reddish on basal half.........rubidus, p. 183

\section{Neurocolpus nubilus (Say)}

Capsus nubilus Say (1832, p. 22).

Male.-Length 6.50, width 2.50. Head width 1.12 , vertex 0.52 . Rostrum, length 2.70, just attaining posterior margins of hind coxae. Antennae, first segment, length 1.34 , moderately compressed, width 0.28 , pale, with irregular brown marks, clothed with prominent, flattened black hairs intermixed with erect, white bristles; second, 2.42, yellowish brown, reddish brown to black on slightly thickened apical one-third; third, 0.88, black, pale at base; fourth, 0.86, blackish. Pronotum, length 1.43 , width at base 2.12 ; pale greenish yellow; disk with it regular brownish marks; basal half clothed with erect, slightly flattened black hairs, intermixed with pale, simple and a few more recumbent, sericeous hairs. Scutellum yellowish, irregularly marked with brown. Hemelytra brownish to fuscous, the darker color broken by minute yellowish dots and irregular spots; cuneus darker at base and apex; membrane fuscous with a pale marginal spot behind cuneus; veins brown, yellowish apically. Legs tan; femora showing brownish markings; hind pair with brownish band at middle of apical half; space before band and at apex, yellowish or white; irregular brownish markings usually breaking paler color; tibiae with band at middle and at apex dark brown or fuscous and with another irregular one of same color near base.

Female.-Length 7.00, width 2.60. More robust than male, but very similar in pubescence and coloration.

Host Plant.-Buttonbush (Cephalanthus occidentalis); Illinois specimens also were collected on cottonwood (Populus deltoides), Kentucky coffee tree (Gymnocladus dioica) and willow (Salix sp.).

Known Distribution.-Common in all the eastern states and southeastern Canada.

Illinois Records.-One hundred twentysix males and 119 females, taken May 24 to Sept. 2, are from Algonquin, Alton, Antioch, Ashley, Browns, Champaign, Chicago, Decatur, Dolson, Dubois, Duncan Mills, East St. Louis, Elizabethtown, Frankfort, Galena, Grand Tower, Havana, Herod, Horseshoe Lake, Karnak, Keithsburg, Lilly,
Monticello, Mound City, Mount Carmel, Muncie, Oakwood, Oregon, Palos Park, Parker, Quincy, Savanna, Seymour, Shawneetown, Urbana, Volo, Wauconda, West Union, Winchester, York.

\section{Neurocolpus tiliae Knight}

Neurocolpus tiliae Knight (1934, p. 162).

MaLE.-Fig. 172. Length 5.70, width 2.30. Head width 1.00 , vertex 0.48 . Rostrum, length 2.55 , exceeding posterior margins of hind coxae, extending to fourth ventral segment. Antennae, first segment, length 1.43, slightly compressed, greatest width 0.24 near middle, clothed with erect, flattened, black hairs, intermixed with erect, slightly longer, simple, yellowish hairs, orange yellow, irregularly marked with reddish or fuscous dots; second, 2.03, slender, becoming clavate on apical third (width 0.15 ), pale, thickened part dark red to blackish; third, 0.78, yellowish, apical third black with a reddish cast; fourth, 0.74 , fuscous. Pronotum, length 1.25 , width at base 1.82 , basal margin distinctly sinuate at middle. Dorsal aspect yellowish to or ange red, hemelytra with a considerable number of yellowish spots which are larger and, in part,

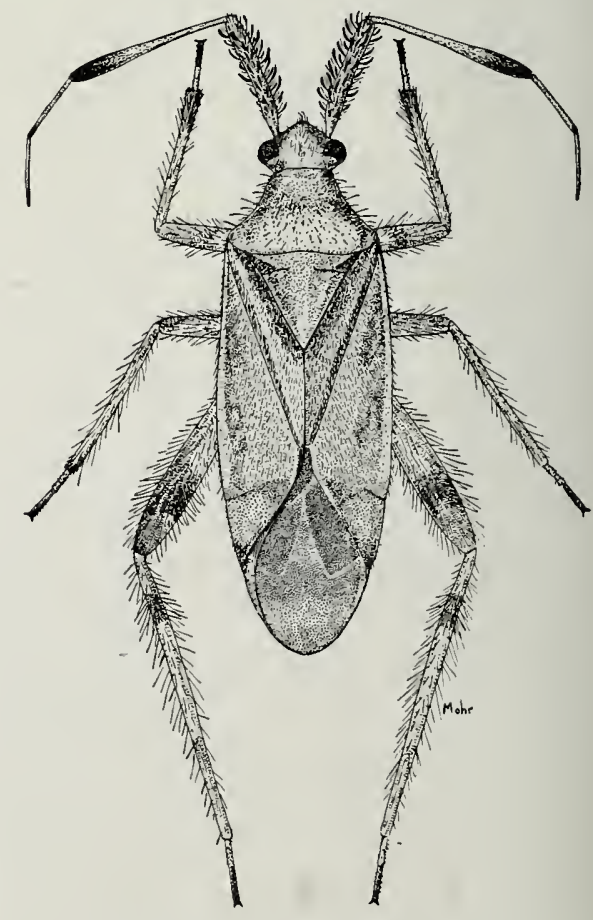

Fig. 172.-Neurocolpustiliae, $\sigma^{7}$. 
confluent on cuneus; scutellum paler, irregularly marked with dark granulate reticulations; pronotum yellowish, usually darkened by hypodermal reddish granulations; propleura pale; coxal cleft crossed by two irregular dark rays. Membrane fuscous, a rounded spot on either side touching margin; discal spot, and areas bordering cuneus within areoles, less dark. Hemelytra clothed with golden, slightly sericeous, recumbent pubescence, intermixed with some simple, pale to fuscous hairs; pronotum with much longer hairs. Body beneath tan to yellowish; sides of thorax and abdomen darkened with reddish and fuscous; two paler longitudinal lines running through dark color. Legs tan to yellowish; hind femora darkened on apical half with reddish and fuscous and provided with a few flattened, black hairs; tibiae pale to reddish, not distinctly banded.

Female.-Length 5.60, width 2.30. Very similar to male in form and coloration.

Host Plant.-Basswood (Tilia ameri(ana).

Known Distribution.-Illinois, Iowa, Minnesota, New York, Ontario.

Illinois Records.-Northern IllinoIs: 3 ㅇ. Algonquin: July 17, 1896, 1 ․ Frankfort: June 8, 1933, Mohr \& Townsend, 1 . Galesburg: July $24,1892,4 \%$. Urbana: July 4, 1915, on tree trunk, $1 \%$.

\section{Neurocolpus jessiae Knight}

Neurocolpus jessiae Knight (1934, p. 163). Male.-Length 6.30, width 2.34. Head width 1.08 , vertex 0.43 . Rostrum, length 2.50, extending nearly to hind margins of posterior coxae. Antennae, first segment, length 1.25, slightly compressed, greatest width (0.22) near middle, the black scalelike hairs only moderately conspicuous, these hairs intermixed with a few more nearly erect, black bristles, this segment very dark brown, closely and irregularly spotted with yellowish; second, 2.64, slender, distal half gradually tapering to become thicker apically, part black, basal half yellowish; third, 1.08 , black, yellowish at base; fourth, 1.11, black. Pronotum, length 1.34 , width at base 1.95. Dorsum chiefly black, with basal half of cuneus, spots on embolium and scutellum, and more or less broad area on anterior half of pronotum, tan to yellowish; body beneath pallid to yellowish, sides of thorax and venter more or less infuscated. Legs pallid; apical one-fourth of hind femora black; front and middle femora with irregular fuscous areas at apices; tibiae pallid; front and middle pairs with bases, apices, and two narrow rings between, fuscous; hind tibiae with basal one-fourth and broad band just below middle, black; apices fuscous; tarsi yellowish, apical segment largely black.

Female.-Length 6.50, width 2.30. Very similar to male in form and coloration.

Habits. - Nymphs and adults were collected "from panicles of elder fruit" at Urbana, by C. A. Hart.

Known Distribution.-Illinois, Iowa, Massachusetts, Missouri, Mississippi, New York, Ontario, Texas.

Illinois Records.-NORTHERN llLinoIS: 1 oे. Galesburg: 1 ô ; July 27, 1892, $1 \hat{\delta}$, 1 ; July 24, 1892, 1 \%. UrbaNa: July 20, 1889. from panicles of elder fruit, C. A. Hart, 11 \& , 16 \% July 21, 1889, in forest, C. A. Hart, $1 \&$; July 24, 1889, on elder (Sambucus sp.), C. A. Hart, 2 of, 9 q.

\section{Neurocolpus rubidus Knight}

Neurocolpus rubidus Knight (1934, p. 164).

MaLe.-Length 6.00, width 2.10. Head width 1.00 , vertex 0.41 . Rostrum, length 2.30 , just attaining posterior margins of hind coxae. Antennae, first segment, length 1.04, compressed, greatest width 0.22 near middle, reddish, irregularly and closely marked with yellowish, usually flattened, black hairs abundant, intermixed with somewhat longer, pale to fuscous, bristlelike hairs; second, 2.16, slender, gradually thickened (width 0.12 ) on apical half, yellowish, apical half reddish; third, 0.82, fuscous, pale at base; fourth, 0.83, black. Pronotum, length 1.12, width at base 1.73. General coloration reddish, in dark specimens fuscous appearing on hemelytra. Embolium and scutellum with several yellowish spots; membrane dark fuscous, a pale spot on either side at margin; veins dark; apical curve of cubitus reddish. Dorsum clothed with golden, sericeous pubescence intermixed with simple yellowish to fuscous hairs; distinct black hairs on pronotum. Femora reddish; hind pair with a distinct yellowish spot above, slightly beyond middle; tibiae yellowish, two narrow reddish rings on front and middle pair; reddish areas on middle and basal onefourth of hind pair.

Female.-Length 6.20, width 2.34. Very similar to male in form and coloration. 
Known Distribution.-Connecticut, Illinois, Kansas, New York, Ohio.

Illinois Record.-NortherN IllinoIs: 2 oิ, 2 \%.

\section{Phytocoris Fallen}

\section{KEY TO GROUPS}

1. Wing membrane confusedly sprinkled with discolored or dark spots, or with numerous, minute, pale spots: median lobe of male genital structure provided with a flagellum that lacks distinct teeth, fig. 175. Group I, p. 184

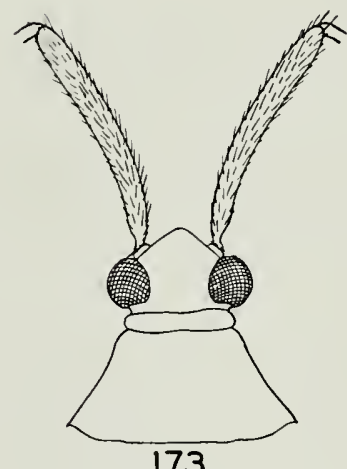

173

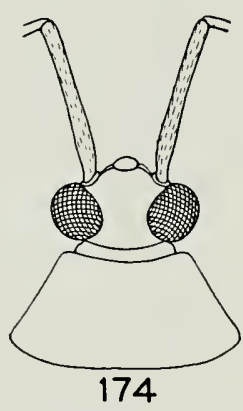

Fig. 173.- - Head and first antennal segment of Phytocoris lasiomerus.

Fig. 174.-- Head and first antennal segment of Phytocoris conspurcatus.

Wing membrane marbled, uniformly dark brown or uniformly light colored, never with many minute spots (except perhaps in some forms of quercicola); margins of dark areas of membrane sometimes separating into small specks, but general effect more mottled than spotted; median lobe of male genital structure with a flagellum bearing distinct teeth, figs. $176,178 \ldots \ldots \ldots \ldots \ldots \ldots \ldots \ldots \ldots \ldots$

2. Length of first antennal segment less than width of head........... 3

Length of first antennal segment greater than width of head..........4

3. First segment of antennae red with yellow spots..... Group IV, p. 201

First segment of antennae not red with yellow spots, but yellow, yellow with dark spots or brown to almost black.......... Group III, p. 199
4. Antennae more black or fuscous than pallid; if second segment has a broad, pale area at middle, then dorsum chiefly dark brown to black; general coloration dark brown or black on a less dark background............

Group II, p. 191

Antennae more nearly pale, yellowish or reddish rather than dark brown or black; second segment sometimes partly brown, but with larger pallid than brown areas; general coloration usually yellowish to reddish on a paler background... Group IV, p. 201

\section{Group I}

\section{KEY TO SPECIES}

1. First antennal segment greatly thickened; thickness nearly equal to dorsal width of an eye, fig. $173 \ldots . .22$

First antennal segment more slender; thickness distinctly less than dorsal width of an eye, fig. $174 \ldots \ldots \ldots 3$

2. Basal three-fou ths of second antennal segment yellowish, apical one-fourth black or very dark brown........

lasiomerus, p. 185

Second antennal segment uniformly yellowish, or very slightly dusky only at apex...pallidicornis, p. 185

3. Second antennal segment dusky yellow to pale brown, white at base; clavus pallid; corium with an oblique, dark brown band on basal half that joins a brown area extending along claval suture; length $3.80-4.00 \ldots$ breviusculus, p. 190

Second antennal segment chiefly black, usually with white bands... 4

4. Second antennal segment black at base, with a light-colored band more distad; length of first antennal segment greater than width of pronotum at base; four small, black, conical projections, two on either side of median line, present near posterior margin of pronotum..... .......... antennalis, p. 185

Second antennal segment with a lightcolored band at base, black beyond 5

5. Third antennal segment with pale band at base and at middle.....6 6

Third antennal segment with pale band at base only, or annuli entirely wanting............ 7 
6. Dorsum bearing both black and white scalelike hairs, which are turned on edge; ventral half of propleura pallid, but no distinct white line present above middle of coxal cleft .......

............ conspurcatus, p. 188

Dorsum without distinct scalelike hairs; propleura white with dorsal margin black and a clear-cut, black line extending across ventral half of coxal cleft to basal margin......

davisi, p. 187

7. Second antennal segment with a broad, pale yellowish to dusky area at middle, dark fuscous only at apex and next to pale band at base; small, slender species, length 5.10 .

minutulus, p. 188

Second antennal segment black with a pale band at base, but, at most, only a narrow, pallid band at middle..................... 8

8. Corium with a longitudinal black vitta on middle of apical half, set on a grayish background, radius indicated by an interrupted series of black dots; length of first antennal segment equal to distance between tylus and basal margin of pronotum; second antennal segment with a light-colored area at base which is interrupted on ventral side by a black line........ vittatus, p. 190

Corium without a distinct longitudinal black vitta on a grayish background................. 9

9. Hind femora very dark brown, apical half with small, pale dots only....

fumatus, p. 188

Hind femora black, with a large lightcolored band or numerous large, pale spots................ 10

10. Lower half of head black, or pallid and marked with black...........11

Lower half of head white; tylus blackish only at base........12

11. Second antennal segment with lightcolored band at middle; mesopleura uniformly black. .

corticevivens, p. 186

Second antennal segment without light-colored band at middle; mesopleura with pallid ray appearing as an extension of that on propleura

purvis, p. 187

12. Length of first antennal segment equal to or greater than width of pronotum at base. albifacies p. 186

Length of first antennal segment not equal to width of pronotum at base 13

13. Femora black; hind pair with an oblique, subapical white band, usually a few small pallid dots nearby; length $6.50 \ldots$ tuberculatus, p. 187

Femora more pallid than black, apical half darkened with fuscous and broken by numerous large and small pallid spots; length 6.00

sulcatus p. 190

\section{Phytocoris lasiomerus Reuter}

Phytocoris lasiomerus Reuter (1909, p. 34).

Known from Colorado, Iowa, Maine, Massachusetts, Minnesota, Montana, New York, Ontario, Quebec, Washington, Wisconsin, Wyoming. Not as yet recorded from lllinois, but should be found in the northern part.

\section{Phytocoris pallidicornis Reuter}

Phytocoris pallidicornis Reuter (1876, p. 69).

Known from British Columbia, Colorado, Maine, Massachusetts, Michigan, Minnesota, Montana, New Hampshire, New York, North Dakota, Wisconsin. Not yet taken in Illinois, but should be found in the northern part.

\section{Phytocoris antennalis Reuter}

Phytocoris antennalis Reuter (1909, p. 32).

MALE.-Length 5.10, width 1.60. Head width 0.90 , vertex 0.42 ; testaceous to very dark brown; tylus white with middle third black. Antennae, first segment, length 1.28, very dark brown, inner surface marked with four or five pale spots; second, 2.56, black, with a narrow, light-colored annulus slightly distad of hase and a second, broader light band slightly beyond middle; third, 1.66, fusco-brownish, pale at base; fourth, 1.44, fuscous. Pronotum, length 0.79 , width at base 1.43, testaceous to brownish and becoming black on area bordering sinuate pale area at posterior margin; two small, conical projections on either side of middle near posterior margin; propleura black, a pale ray extending across top of coxal cleft. Scutellum testaceous to fuscous, with a slender, nearly obsolete, pale median line. Hemelytra testaceous to fuscous and clothed with 
yellowish, black and white pubescence; embolium with an elevated black spot at apex, also with a black area at middle which is broken by pale marks; corium with a darker area bordering clavus and a dark spot at middle on outer margin; cuneus reddish to black along outer margin and at apex, with a black tuft of hairs at middle of inner margin and a second one near inner basal angle. Membrane rather densely marbled with fuscous; more uniformly fuscous apically and at base and with a somewhat light-colored area near apex of cuneus, this spot invaded by fuscous marks; veins fuscous. Coxae white, with small lateral areas at base dusky red. Femora black, less dark at base; hind pair with light spots on ventral aspect and a rather distinct, subapical, light band on dorsal aspect; front pair mostly pale, with a longitudinal black bar on apical half of anterior face. Front tibiae :eddish to black, with a pale annulus at middle of apical half, a narrower one near middle of basal half and a third, nearly obsolete one, near base; intermediate tibiae chiefly light, but marked with dark reddish; hind pair light colored, with variable dark brown marks; tarsi fuscous. Venter black, sides irregularly tinged with reddish; genital segment bearing, above base of left clasper, a broad, erect tubercle with a vague apical notch and another smaller tubercle above base of right clasper; claspers distinctive for species.

Female.-Length 6.20, width 1.90 ; more robust than male, but very similar in coloration.

Habits. - Usually collected at lights; probably predacious.

Known Distribution.-District of Columbia, Illinois, Indiana, Massachusetts, Mississippi, New York, Oklahoma, Virginia.

Illinois Record. - Champaign: June 13, 1888, C. A. Hart, 1 o.

\section{Phytocoris albifacies Knight}

Phytocoris albifacies Knight (1926g, p. 159).

Female.-Length 5.90, width 2.30. Head width 1.11 , vertex 0.46 . Lower half of face, or ventrad to a line running through base of tylus and lower margin of eyes, white; vertex more or less colorless, a curved, white mark touching inner margin of each eye. Rostrum, length 3.43, attaining base of ovipositor, white, with third and fourth segments black. Antennae, first segment, length 1.80 , black, dorsal aspect with two smooth, white spots on apical half and four or five smaller spots on basal half, spines both fuscous and light colored, short, length scarcely equal to thickness of segment; second, 3.30, mostly black, almost colorless at base for a space of 0.23 , and a pale annulus of equal length beginning at middle; third, 1.77, black, paler at base; fourth, 1.31, black. Pronotum, length 1.06 , width at base 1.69 ; black, with lower margin of propleura, xyphus, and collar to a point behind lower margin of eye, white; disk more or less fuscous, basal margin somewhat pale, with two black, elevated spots on either side of median line. Scutellum fuscous to black; basal angles and apex pale. Hemelytra black; with several small spots on embolium, base of cuneus, a triangular spot at apex of corium and spot near middle, tending toward pale. Membrane mostly very dark brown with paler areas sprinkled with fuscous dots; cubitus almost entirely colorless. Sternum and pleura black, margins bordering coxae pale. Venter principally black, with most of ventral area light except on last segment. Legs black with almost colorless marks much as in corticevivens Knight; femora black, with numerous minute, pale spots, a somewhat larger, light-colored spot indicating an oblique, subapical annulus. Dorsum clothed with rather short, black, simple pubescence intermixed with silvery and golden, silky pubescence.

Male.-Length 6.00, width 2.00. Very similar to female in coloration, although generally darker. Genital claspers distinctive and indicating a close relationship to corticevivens.

HaBits.-Occurs on the bark of pecan trees where it is probably predacious.

Known Distribution. - Illinois and $\mathrm{Mississippi.}$

Illinois Record. - Harrisburg: June 15, 1934, at lights, DeLong \& Ross, 1 .

\section{Phytocoris corticevivens Knight}

Phytocoris corticevivens Knight (1920, p. 63, pl. I, fig. 6).

MaLE.-Length 6.60, width 2.30. Head width 1.04 , vertex 0.39 . Rostrum, length 3.03 , reaching fifth abdominal sternite. Antennae, first segment, length 1.60 , black, basal half with five or six small, smooth, white spots, each bearing a few erect, short 
bristles; second, 3.00, very dark brown, with a pallid band at base and another, narrow one at middle; third, 1.69 , black, pallid only at base; fourth, 1.30, black. Pronotum, length 1.16, width at base 1.90. Dorsum clothed with rather short, recumbent, black pubescence intermixed with yellowish to golden, silky hairs. General coloration black, with small, light-colored spots on embolium, between calli, on apical area of corium, and a narrow, pale area at base of cuneus. Membrane almost colorless, thickly and rather uniformly marbled with fuscobrownish. Legs black; hind femora with a few small, light spots; entire coxae light colored, except at bases; tibiae with two pallid hands, those of hind pair becoming obsolete, spots and spines of tibiae almost white. Genital claspers distinctive, fig. 175, a small tubercle present above base of each clasper.

Female.-Length 6.80, width 2.50. More robust than male, but very similar in color and pubescence.

Habits.-Predacious. In Minnesota, I collected a series of nymphs and adults on the bark of sugar maple (Acer saccharum); both nymphs and adults were well concealed as they crouched in crevices of the bark, apparently awaiting their prey.

Known Distribution. - Connecticut, Illinois, Iowa, Maryland, Minnesota, Missouri, New Jersey, New York, Ohio, Ontario, Texas, Wisconsin.

Illinois Records.-NorTHERN IllinoIS: 7 우; July, 1 오. Algoxquix: 1 of ; June 5, 1895, 1 o . Fox Lake: June 10, 1936, Ross \& Burks, 2 . Galesburg: June 21, 1892, 1 f. L̈rbaxa: May 31, 1889, C. A. Hart, $1 \%$.

\section{Phytocoris tuberculatus Knight}

Phytocoris tuberculatus Knight (1920, p. 64.)

MALE.-Length 6.50, width 2.10. Head width 1.10 , vertex 0.39 ; lower half of head white; very dark brown across base of tylus; frons with oblique dark lines. Rostrum, length 3.+2, extending to sixth abdominal sternite. Antennae, first segment, length 1.51, black, dorsal aspect with several smooth, white spots; second, 3.12, black, pallid at base, a yellowish annulus at middle, this band sometimes nearly obsolete; third, 1.86 , black, pallid at base. Pronotum, length 1.16, width at base 1.95. Dorsum clothed with short, black pubescence intermixed with pale yellowish, silky hairs. General color fuscous to black; pronotum and scutellum with paler areas; embolium with small pallid spots. Membrane fuscous, paler areas stippled with small fuscous dots. Legs black, coxae light colored, hind femora with an oblique white band near apex and a few small, pallid spots an apical half. Genital claspers, flagellum, long tubercle above base of left clasper, and shorter one above right clasper, distinctive for species, fig. 175 .

Female.-Length 6.90, width 2.55. More robust than male; very similar in coloration, but dorsum often lighter in color.

Habits.-Collected chiefly at lights.

Known Distribution. - Illinois, Indiana, Michigan, Missouri, New York, North Carolina, Oklahoma, Texas, Wisconsin.

Illinois Records. - Galesburg: $1 \delta$. UrbaNa: June 20, 1909, 1 o .

\section{Phytocoris davisi Knight}

Phytocoris davisi Knight (1923d, p. 624).

Not taken in Illinois; known only from New Jersey and New York.

\section{Phytocoris purvus Knight}

\section{Phytocoris purvus Knight (1927b, p. 17).}

This species is allied to minutulus Reuter, but differs from it in the shorter first antennal segment, the black second antennal segment with a narrow, pale annulus at base only, in the larger eyes and narrow vertex, the distinctive subapical marks on the scutellum, and the structure of the male genital claspers.

Male.-Length 5.50, width 1.90. Head width 1.05 , vertex 0.22 ; eyes large and prominent, vertex chiefly almost colorless, frons with six transverse dark lines, ventral area of frons and tylus black, a $V$-shaped white mark on basal half of tylus, juga white with a transverse black mark on dorsal half, lora black with a light-colored area on lower margin which joins the similarly colored areas on the much reduced genae and gula. Rostrum, length 2.60 , extending to fifth $a b-$ dominal sternite, pale yellowish with apex very dark brown. Antennae, first segment, length 1.11 , only slightly greater than width of head, black, with ventral side light, black area broken by several white spots, a white seta arising from each spot; second, 2.80, black, narrow pale area at base: third, $1 .+5$, 
black, narrow pale area at base; fourth, 1.09, black: Pronotum, length 0.83 , width at base 1.51'; fuscous to black, paler on calli and central area of disk, lower margin of propleura almost' white. Scutellum pale, with a pair of well defined dark brown, subapical, marginal spots. Sternum pale, sides and pleura black. Dorsum rather uniformly dark fuscous, with light-colored spots on embolium and a somewhat paler area at middle of corium. Clothed with fuscous, simple pubescence, intermixed with white, silky hairs in numerous spots. Membrane almost colorless, speckled with numerous small brownish to fuscous spots, the preapical area and margins of areoles more evenly fuscous; veins fuscous, white areas present around apices of areoles. Legs black, marked with more or less confluent, white spots, these spots forming 'a welldefined preapical white annulus. Genital claspers distinctive; left clasper with inner arm much flattened, right clasper shaped much as in quercicola $\mathrm{Knight.}$

FeMALE.-Length 5.30, width 2.00. Very similar to male in pubescence and coloration.

HaBITs.-Collected chiefly about lights ; a single Illinois : specimen was taken on cypress (Taxpdium. distichum).

Know N Distribution.-District of Columbia, Illinois, Iowa, Maryland, South Carolina.

Illinois Record. - KarinaK: July 28, 1930, on Táxodium distichum, Knight \& Ross, 1 우.

\section{Phytocoris minutulus Reuter}

Phytocoris minutulus Reuter (1909, p. 24). Not taken in Illinois; known from Maryland, Massachusetts, New Hampshire, New York, North Carolina, Pennsvlvania, Vir ginia.

\section{Phytocoris fumatus Reuter}

Phytocoris fumatus Reuter (1909, p. 25).

MALE.-Length 7.00 , width 2.30. Head width 1.17 , vertex 0.40 ; front with five oblique black lines on either side of median line and a transverse black area between bases of antennae; lower half of face white: base of tylus, base of jugum, and spot on dorsal margin at base of lorum, black; a rather irregular reddish band extends across middle of tylus. Kostrum, length 4.20 , attaining base of genital segment, pale with apical segment brownish. Antennae, first segment, length 1.57, equal to distance between posterior margin of pronotum and a line drawn through eyes at a point slightly before middle, black, with pale spots on dorsal side, two largest spots on apical half; second, 3.10, dark brown with pallid areas on dorsal side at base and middle, areas at middle vague; third, 1.79, black with almost white area 0.17 wide at base ; fourth, 1.30 , black. Hemelytra fuscous to black; a large yellowish and translucent spot at apex of corium near base of cuneus ; embolium irregularly translucent and darkened with fuscous; cuneus very slightly lighter at base, a tuft of black hair on inner margin near base and a similar tuft at apex of corium; pubescence black, intermixed with pale, silky pubescence. Membrane pale, thickly and rather uniformly marbled with fusco-brownish; veins dark, pale at apex of larger areole: Legs very dark brown, entire coxae light colored except spot near base; trochanters pallid; femora with numerous, small, pallid spots, a slightly larger, nearly colorless spot on anterior aspect near apex, this mark not quite forming a subapical band; front and middle tibiae pale at middle and with another, rather distinct pale band at middle of apical half; tarsi fuscous. Venter black, with yellowish pubescence; genital segment and claspers distinctive, fig. 175 .

Female.-Length 7.60, width 2.60 ; larger and more robust than male; very similar to imale in coloration, but dorsum lighter colored; first antennal segment longer than in male, equal to distance between posterior margin of pronotum and a line drawn through front margins of eyes.

Known Distribution.-District of Columbia, Georgia, Illinois, Massachusetts, New.Jersey, New York, North Carolina.

Illinois Record.-Champaign: July 7, 1887, C. A. Hart, 1 ô.

\section{Phytocoris conspurcatus Knight}

Phytocoris conspurcatus Knight (1920, p. 61).

This species is distinquished by its dark, marbled membrane and by the pale band at the middle of the first and second antennal segments; the dorsum is thickly clothed with black, deciduous, scalelike hairs intermixed with small patches of dense, white, woolly hairs.

MALE.-Length 5.90, width 2.10. Head width 1.06 , vertex 0.34 ; infuscation similar 
to that of canadensis Van Duzee. Rostrum, length 2.60 , attaining base of genital segment. Antennae, first segment, length 1.20 , black, with irregular minute, white spots beset with from 14 to 16 almost colorless setae; second, 2.50 , black, with a lightcolored annulus at base and a second, similar band beginning at middle and extending dark fuscous to black, more or less pallid on under side at base; genital claspers and long tubercle above base of left clasper, fig. 175 , distinctive for species.

Female.-Very similar to male in size and coloration.

HABITS. - This is a predacious, bark-inhabiting species, which the author has taken
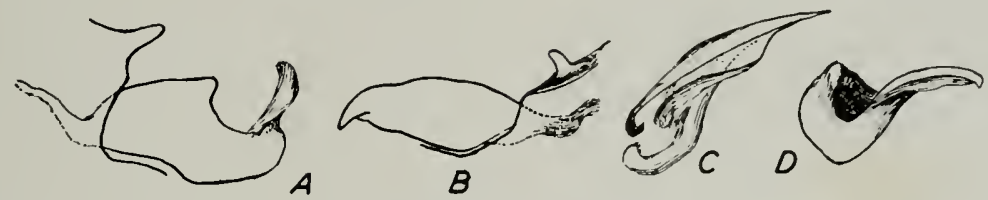

CORTICEVIVENS
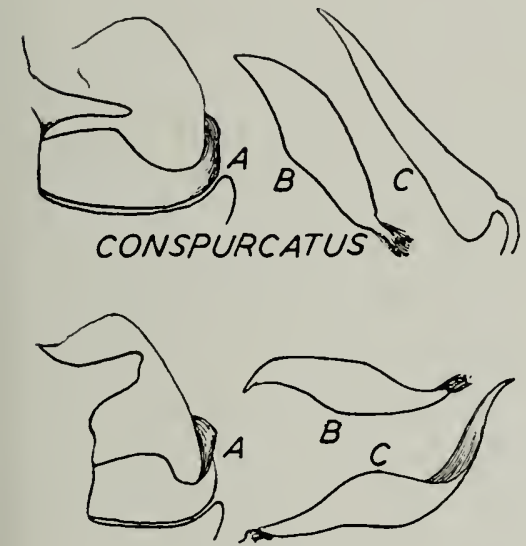

SULCATUS
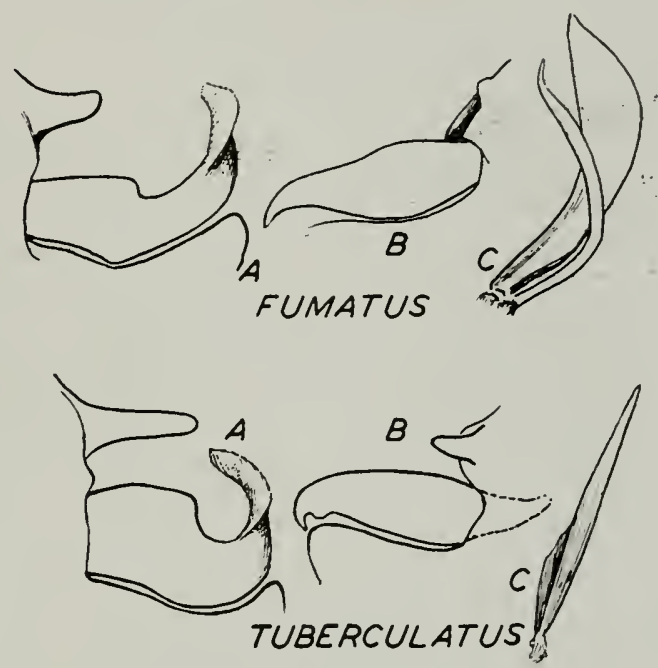

Fig. 175.-Male genital claspers of Phytocoris, Group I. $A$, left clasper, lateral aspect; $B$, right clasper, lateral aspect; $C$, flagellum; $D$, left clasper, caudal aspect.

for a space of 0.30 ; third, 1.48 , pallid at base and at middle; fourth, 1.11, black. Pronotum, length 1.54 , width at base 1.70 ; form and coloration very similar to those in eximius Reuter, but differing by having black, scalelike hairs; scutellum thickly covered with white, woolly pubescence. Hemelytra rather uniformly darkened, a triangular pallid spot at tip of corium bordering cuneus; thickly clothed with black, scalelike hairs intermixed with small patches of dense, white, woolly hairs. Membrane thickly marbled with dark fuscous; cubital vein pallid at apex of larger areole; dark spots scattered near apices of cells. Legs marked very much like those of canadensis, but pale band near apex of hind femora more or less interrupted on ventral side. Venter on the boles of linden (Tilia americana), elm (Ulmus sp.), walnut (Juglans nigra), pear (Pyrus communis), apple (Pyrus malus), willow (Salix sp.) and maple (Acer sp.) ; frequently attracted to light.

Known Distribution.-Connecticut, District of Columbia, Illinois, Iowa, Kansas, Maryland, Michigan, Minnesota, Mississippi, Missouri, New Hampshire, New Jersey, New York, Ontario, Pennsylvania, South Dakota, Wisconsin.

Illinois Records. - Twenty-three males and 23 females, taken May 17 to September, are from Alton, Antioch, Carbondale, Champaign, Darwin, Galesburg, Grafton, Havana, Mahomet, Odin, Palos Park, Quincy, Shawneetown, Starved Rock State Park. Urbana. 


\section{Phytocoris vittatus Reuter}

Phytocoris vittatus Reuter (1909, p. 28).

Not taken in Illinois; known only from New York; has been collected on prickly gooseberry (Ribes cynosbati).

\section{Phytocoris sulcatus Knight}

Phytocoris sulcatus Knight (1920, p. 64).

In form, this species is very similar to fumatus Reuter, but the latter is larger; the pronotum of sulcatus is more distinctly sulcate at the sides and immediately behind the calli; the pallid bands at the base and the middle of the second antennal segment are more distinct; the dorsum is distinctly paler; and the outer half of the clavus and the inner apical angles of the corium are very dark brown, almost black.

Male.-Length 6.00, width 1.80 . Head width 1.08 , vertex 0.30 . Rostrum, length 2.80 , extending to fifth abdominal sternite. Antennae, first segment, length 1.25, black, with one large and several small white, smooth spots; second, 2.64, mostly black, pallid at base and a yellowish band at middle; third, 1.47, fuscous, pallid at base; fourth, 1.21, dark fuscous. Pronotum, length 0.99 , width at base 1.60 ; lateral margins of disk and immediately behind calli distinctly sulcate. Dorsum clothed with silvery to yellowish, silky pubescence, intermixed with more nearly erect, short, black hairs. General color fuscous to black, with paler spots and areas; membrane pallid, rather thickly and evenly marbled with fuscous. Femora with a broad pallid area at base, apical half black with several pallid spots; hind pair with an irregular, oblique, subapical pallid band. Front and middle tibiae with black and white bands; hind pair without distinct white bands. Genital claspers, flagellum and a large, thick tubercle above base of left clasper, fig. 175, distinctive for species.

Female.-Length 6.00, width 2.03. More robust than the male but very similar in color and pubescence.

Habits.-Occurs on the bark of linden (Tilia americana), on bur oak (Quercus macrocarpa) and elm (Ulmus sp.); probably predacious.

Known Distribution.-Connecticut, District of Columbia, Illinois, Iowa, Kansas, Michigan, Minnesota, Pennsylvania, South Dakota, Virginia.
Illinois Records.-Five males and $7 \mathrm{fe}$ males, taken May 22 to Aug. 21, are from Argo, Beverly Hills, Champaign, Dubois, Galesburg, Quincy, St. Anne, Urbana.

\section{Phytocoris breviusculus Reuter}

Phytocoris breviusculus Reuter (1876, p. 68). M ALE.-Length 3.90, width 1.60. Head width 0.84 , vertex 0.30 ; lower face white, marked with reddish brown. Rostrum, length 1.94 , extending to sixth abdominal sternite. Antennae, first segment, length 0.63 , reddish brown, marked with four or five white, smooth spots, spines pallid; second, 1.51, dusky yellow, white annulus at base; third, 1.04 , fuscous, pallid at base; fourth, 0.78, fuscous. Pronotum, length 0.78 , width at base 1.38 , disk dusky yellow, central area more nearly pure yellow, basal edge white, this white area bordered by an undulating, fuscous line. Dorsum clothed with simple fuscous hairs thickly intermixed with white and yellowish, silky pubescence. Hemelytra pale yellowish; broad fuscous area along claval suture; inner apical angles and a broad, transverse band on basal half of corium fuscous. Cuneus yellowish to white; disk with several small brown dots; apex fuscous. Membrane thickly marbled with fuscous; two small, white spots on outer margin of apical half. Legs pale yellowish; hind femora very dark brown, this dark color broken by numerous pale dots; front and middle femora marked with reddish brown on apical half. Tibiae with three fuscous bands; hind pair dark fuscous with numerous white dots. Genital claspers distinctive, a prominent tubercle above base of left clasper.

Female.-Length 4.10, width 1.64. More robust than male, but very similar in color and pubescence.

HABITs.-A predacious species which may be collected about lights. Reared in Ohio on apple branches which were heavily infested with San José scale.

Known Distribution.-Alabama, District of Columbia, Illinois, Indiana, Mississippi, Ohio, Texas. Common in Texas, but rare east of the Mississippi River.

Illinois Records. - Albion: July 16, 1937, on blackberry, Mohr \& Burks, 3 ô. Alton: July 19-21, 1932, on Crataegus. Ross \& Dozier, $3 \hat{o}, 4$. F Firfield: June 12, 1934, DeLong \& Ross, 1 q . Jonesboro: Aug. 2, 1932, H. L. Dozier, 1 o. Urbana: 
July 31, 1932, H. L. Dozier, 1 ô ; Sept., 1932, T. H. Frison, 1 ô, 2 ㅇ.

\section{Group II}

\section{KEY TO SPECIES}

1. Apex of abdomen with claspers (males); couplets 2-17 illustrated in fig. $176 \ldots \ldots \ldots \ldots \ldots \ldots$

Apex of abdomen without claspers (females); fully mature, well preserved specimens necessary for this section of key................ 18

2. Basal shoulder of left clasper with thumblike projection, e.g., erectus.. 3

Basal shoulder of left clasper without thumblike projection, e.g., husseyi. 5

3. Basal projection of left clasper extending vertically as a tall, thick process bluntly rounded at apex. .

erectus, p. 199

Basal projection of left clasper rather slender and acute, e.g., canadensis. . 4

4. Right clasper with dorsal process extending half the length of ventral process......... canadensis, p. 193

Right clasper with dorsal process not over one-third the length of ventral process...... brevifurcatus, p. 194

5 . Basal shoulder of right clasper without angulate projection, e.g., schotti 6

Basal shoulder of right clasper with a thumblike or angulate projection, e.g., penipecten............. 9

6. Basal shoulder of right clasper with a rounded hump.......schotti, p. 197

Basal shoulder of right clasper without rounded hump, e.g., husseyi... 7

7. Genital segment with a distinct tubercle above base of left clasper......

husseyi, p. 199

Genital segment without tubercle above base of left clasper, e.g., obtectus................. 8

8. Base of left clasper with angulate shoulder......... obtectus, p. 199

Base of left clasper without angulate shoulder...........salicis, p. 196

9. Tip of right clasper hooked downward

penipecten, p. 199

Tip of right clasper projecting straight or curved upward, e.g., buenoi, spicatus................... 10

10. Tip of right clasper straight, e.g., buenoi....................11
Tip of right clasper curved upward, e.g., spicatus. . . . . . . . . . . 12

11. Base of left clasper convexly rounded

Base of left clasper sinuate. .... buenoi, p. 197

nigricollis, p. 197

12. Basal shoulder of right clasper with a slender fingerlike process projecting vertically, e.g., spicatus...... 13

Basal shoulder of right clasper with a more angulate process, e.g., lacunosus..................... 14

13. Basal fingerlike process of right clasper tapering very little on apical half. ...............spicatus, p. 196

Basal fingerlike process tapering gradually from base to apex.......... ............. cortitectus, p. 196

14. Thumblike process at middle of right clasper sloping away from tip of clasper.........lacunosus, p. 197

Thumblike process at middle of right clasper vertical in position, e.g., onustus...................15

15. Wall of genital segment with a prominent, blunt tubercle at a point well above base of left clasper.........

arundinicola, p. 198

Wall of genital segment without tubercle above base of left clasper...16

16. Apical half of right clasper with sides parallel to point near apex.

angustulus, p. 197

Apical half of right clasper tapering gradually from base, e.g., onustus.. 17

17. Length of right clasper beyond base of dorsal process equal to four times the width of base at this point onustus, p. 194

Length of right clasper beyond base of dorsal process not over two and one-half times the width of base at this point.......neglectus, p. 194

18. Corium with distinct black or dark fuscous mark across apical area, this mark extending obliquely from radius to inner apical angle of corium; dark area never broken with numerous, minute, light-colored spots.

Corium without distinct black mark across apical area; sometimes with a fuscous area, but this dark color broken by numerous, paler spots, or, if not, then dark-colored area on radius distinctly darker than oblique infuscation on corium ..........28 
19. Pronotal disk uniformly deep black, with a narrow, pale area at basal margin; scutellum yellowish, with an oblique, black mark on either side of median line beginning at middle of disk and extending to margin at a point slightly beyond middle.........nigricollis, p. 197

Pronotal disk pale grayish to very deep gray, always paler on middle and never deep black.........20

20. Scutellum with distinct black mark on either side of apical half extending from lateral margin obliquely cephalad to near middle of disk.......21

Scutellum with black spot at margin on either side of apical half, this mark scarcely longer than broad, at most not extending more than half way to middle of disk......24

21. Pale areas at lower margins of propleura extending upon sides of sternum; hind femora mostly black except at base; pale spots small, largest spot not wider than narrow pale band located slightly beyond middle of apical half..

husseyi, p. 199

Pale areas at lower margins of propleura not extending upon sides of sternum.................22

22. Hind femora of female with large irregular pale spots on anterior face, these spots connected by a longitudinal, almost colorless bar which does not attain subapical pale band; length $7.30-7.60$...onustus, p. 194

Hind femora of female with small spots; without distinct, longitudinal pale bar on anterior face.......23

23. Membrane with infuscation on central area tending to separate into small specks; front of head with black, transverse striations on either side of median line.

neglectus, p. 194

Membrane more uniformly infuscated, color not separating into small specks; front of head without distinct, black striations even when hemelytra are very dark; reddish lines usually evident on frons..... ............... spicatus, p. 196

24. Hind femora with distinct white band placed slightly beyond middle of apical half, and usually with large, light-colored spots near middle. ...25

Hind femora without distinct white band on apical half; light-colored spots usually rather small. .....27

25. Second antennal segment black except at base, dorsal aspect not distinctly paler; scutellum and clavus clothed with erect black hairs intermixed with prominent white, silky pubescence...........buenoi, p. 197 Second antennal segment distinctly almost white or yellowish on dorsal aspect, darker at apex and on area bordering light-colored basal annulus................... 26

26. Propleura mostly black, only lower margin white; tibiae with distinct light-colored and black bands..... ............ canadensis, p. 193 Propleura mostly pale, with a longitudinal, black ray crossing coxal cleft; tibiae light to dusky, not banded.......arundinicola, p. 198

27. Corium with very heavy, triangular black mark set obliquely across a pex; hind femora with two or three large white spots on dorsal surface; cuneus usually reddish. .erectus, p. 199 Corium with light, almost interrupted fuscous mark set obliquely across apex; hind femora with small white spots only; cuneus rarely if ever reddish.......brevifurcatus, p. 194

28. Apical half of corium distinctly greenish; second antennal segment black with pale annulus at base....... ........... penipecten, p. 199

No part of corium distinctly green. . .29

29. Hemelytra more brownish than black; dark color on apical area of corium and on middle of clavus broken into small spots............... 30

Hemelytra sometimes brownish, but usually black; dark area not distinctly broken into small spots....31

30. Second antennal segment uniformly black except for pallid annulus at base; vertex narrow, its width less than dorsal width of an eye....... schotti, p. 197

Second antennal segment chiefly yellowish brown, black at apex and on area bordering pallid basal annulus; vertex wider, equal to dorsal width of an eye.......... salicis, " p." 196 
31. Front and vertex almost colorless to yellowish, not distinctly marked with black, rarely with short, vague, red lines near each eye; scutellum almost colorless to yellowish; a small rounded, brown to fuscous spot located near either margin at middle of apical half... angustulus, p. 197

Front and vertex marked with transverse black lines............. 32

32. Scutellum chiefly very dark brown, with irregular paler spots; a median, slender, pale line present, this line irregularly invaded by the darker color...........obtectus, p. 199

Scutellum chiefly pale to grayish, but with black mark at either side on apical half.

33. Corium with a longitudinal pale area that extends upon base of cuneus without interruption; a black line paralleling radius but, at apex, curving outward to fracture.....

.lacunosus, p. 197

Apical half of corium rather distinctly darkened with fuscous, scarcely paler than dark marks along radius

cortitectus, p. 196

\section{Phytocoris canadensis Van Duzee}

Phytocoris eximius Knight (1920, p. 51) not Reuter.

Phytocoris canadensis Van Duzee (1920, p. 346).

MALE.-Length 5.70, width 2.00. Head width 0.94 , vertex 0.35 ; yellowish, frequently tinged with reddish and marked with black. Rostrum, length 2.40, attaining basal margin of genital segment. Antennae, first segment, length 1.28 , yellowish, with irregular fuscous mottling, bearing five or six long, almost colorless setae; second, 2.77. chiefly fuscous, paler at base for a space of 0.17 , infuscation distinctly paler on dorsal aspect of middle third, but becoming darker toward either end; third, 1.60 , chiefly dark fuscous, pale at base for a space of 0.14 , with another very narrow, lightcolored space at apex; fourth, 1.25, black. Pronotum, length 0.91 , width at base 1.60 , disk light yellow brown to fuscous, central area frequently grayish green, paler anteriorly, narrow light-colored area at basal margin, and six black points which frequently fuse located near basal margin; disk distinctly hairy, longest hairs at anter- ior angles, hairs taking color of surface from which they arise; propleura black, with lower margins and a mark extending across base of coxal cleft almost white. Scutellum dull yellow brown, with a black mark present on either side near apex. Hemelytra clothed with prominent yellowish pubescence intermixed with groups of white, deciduous woolly hairs, but dark hairs arising from dark areas; greenish gray to fuscous; base, middle and a triangular spot just before cuneus of corium, and several spots on embolium, paler and more or less translucent. Tip of embolium, an oblique, nearly triangular patch lying just inside of radius at apex of corium, and area bordering apical two-thirds of claval suture, fuscous to black. Cuneus translucent gray, with apex, a small point along inner margin, and a second near basal angle, black; paler parts usually showing some brownish or reddish coloration. Membrane fuscous, with a large, almost colorless area just beyond small areole and tip of cuneus, this area divided by a small fuscous spot which touches the margin; central area more or less invaded by a paler streak; cubitus distinctly pallid at apex of areoles. Legs, coxae and bases of femora pallid; front and intermediate femora with a series of irregular reddish brown to fuscous marks; posterior femora chiefly black with many large and small, light-colored spots; pale patches most numerous and tending to coalesce on inner side; an irregular, light-colored annulation located a short space before apex and a second one situated nearer middle, but latter annulus interrupted on outside. Tibiae with fuscous and pale annuli; hind pair infuscated and with irregular pallid spots; a broad, pale area on basal one-third; spines almost colorless to brownish. Genital claspers and flagellum, fig. 176, distinctive for species.

Female.-Length 5.70, width 2.05. Usually very similar to male in coloration; imperfect or poorly colored specimens can never with certainty be distinguished from females of closely related species.

Habits.-This species occurs on a number of plants in various situations; it is largely if not wholly, predacious. Collected in 1llinois on hornbeam (Carpinus caroliniana), gooseberry (Ribes sp.) and buttonbush (Cephalanthus occidentalis).

Known Distribution.-Connecticut, Georgia, Illinois, Indiana, Iowa, Kansas, 
Maine, Massachusetts, Michigan, Minnesota, Missouri, New Jersey, New York, North Carolina, Ohio, Ontario, Pennsylvania, South Dakota.

Illinois Records.-Eight males and 15 females, collected June 14 to Sept. 27, are from Antioch, Argo, Channel Lake, Danville, De Soto, Dolson, Galena, Harrisburg, Herod, Karnak, Lawrenceville, Marshall, Rock Island, Seymour, Shawneetown, Vienna. Blatchley $(1926 b$, p. 720$)$ records the species from Maywood under the name eximius Reuter.

\section{Phytocoris breviturcatus Knight} 53).

Phytocoris brevifurcatus Knight (1920, p.

This species is very similar to canadensis Van Duzee, but lacks the heavy, oblique, fuscous mark at the apex of the corium; the second antennal segment is darker fuscous on the middle third; the head and pronotum are distinctly grayish green on the paler parts; the posterior femora have smaller pale spots and are not distinctly banded with pale yellow brown.

MALE.-Length 5.80, width 2.14. Head width 0.95 , vertex 0.34 . Rostrum, length 2.51 , reaching to seventh abdominal sternite. Antennae, first segment, length 1.21 ; second, 2.55; third, 1.47; fourth, 1.34. Pronotum, length 0.91 , width at base 1.69 . Genital claspers distinctive for species, fig. 176 .

Female.-Length 5.80, width 2.20. Head width 0.96 , vertex 0.41 . Antennae, first segment, length 1.36 ; second, 2.77 ; third, 1.47 ; fourth, 1.21. Pronotum, length 0.91 , width at base 1.70 .

Known Distribution. - Illinois, New York, Ontario.

Illinois Record. - Horseshoe LAKE: July 11, 1935, DeLong \& Ross, 1 ô .

\section{Phytocoris neglectus Knight}

Phytocoris neglectus Knight (1920, p. 54).

This resembles canadensis Van Duzee, but the second antennal segment is uniformly black with a white annulation at the base, the middle tibiae have an apical white band and the infuscation at the middle of the membrane tends to form small specks.

Male.-Length 6.20, width 2.20. Head width 0.99 , vertex 0.32 . Rostrum, length 2.60, extending to fifth abdominal sternite. Antennae, first segment, length 1.17 , black, with several white, smooth spots; second, 2.68 , black, a narrow white annulus at base; third, 1.38, black, white at base; fourth, 1.05 , black. Pronotum, length 0.91 , width at base 1.75. Genital claspers and flagellum distinctive for species, fig. 176.

Female.-Length 6.00, width 2.30. More robust than male, but very similar in color and pubescence.

HaBits. - I have collected this species most frequently on the bark of apple trees where both nymphs and adults fed on psocids. It has, also, been collected on the bark of other trees and is probably predacious on soft-bodied insects living in such situations. In New York the species was collected from June to October, which indicates two generations for the season.

Known Distribution. - Illinois, Iowa, Maine, Massachusetts, Michigan, Minnesota, Mississippi, New Hampshire, New York, Ontario, South Carolina, South Dakota, Washington.

Illinois Records. - Elizabethtown: May 27-31, 1932, H. L. Dozier, 1 ô. FAIRFIELD: June 12, 1934, DeLong \& Ross, 1 ô. Galena: June 28, 1935, DeLong \& Ross, 1 o . Keithsburg: June 15, 1932, H. L. Dozier, $1 \hat{o}$. Shawneetown: June 23, 1936, DeLong \& Ross, 1 q. Urbana: June $13,1885,1$ '

\section{Phytocoris onustus Van Duzee} 344).

Phytocoris onustus Van Duzee (1920, p.

Male.-Length 6.80 , width 2.50. Head width 1.08 , vertex 0.35 ; head pale yellowish; oblique lines on frons, base and middle of tylus, lora, and base of jugum, fuscous to black. Rostrum, length 3.16, reaching fifth abdominal sternite. Antennae, first segment, length 1.41, black, with four or five white, smooth spots and a few yellowish bristles; second, 3.33, black, a narrow white annulus at base; third, 1.60 , black, narrow white a rea at base; fourth, 1.29, black. Pronotum, length 1.12 , width at base 2.00. Clothed with erect, short, black hairs intermixed with a moderate amount of recumbent, pale yellowish, silky pubescence. General color fuscous to black over a pale yellowish, ground color; propleura, except lower margin, black; lateral margins and basal band of pronotal disk, black; basal edge white; scutellum yellowish, a black marginal spot on either side on apical half; hemelytra 

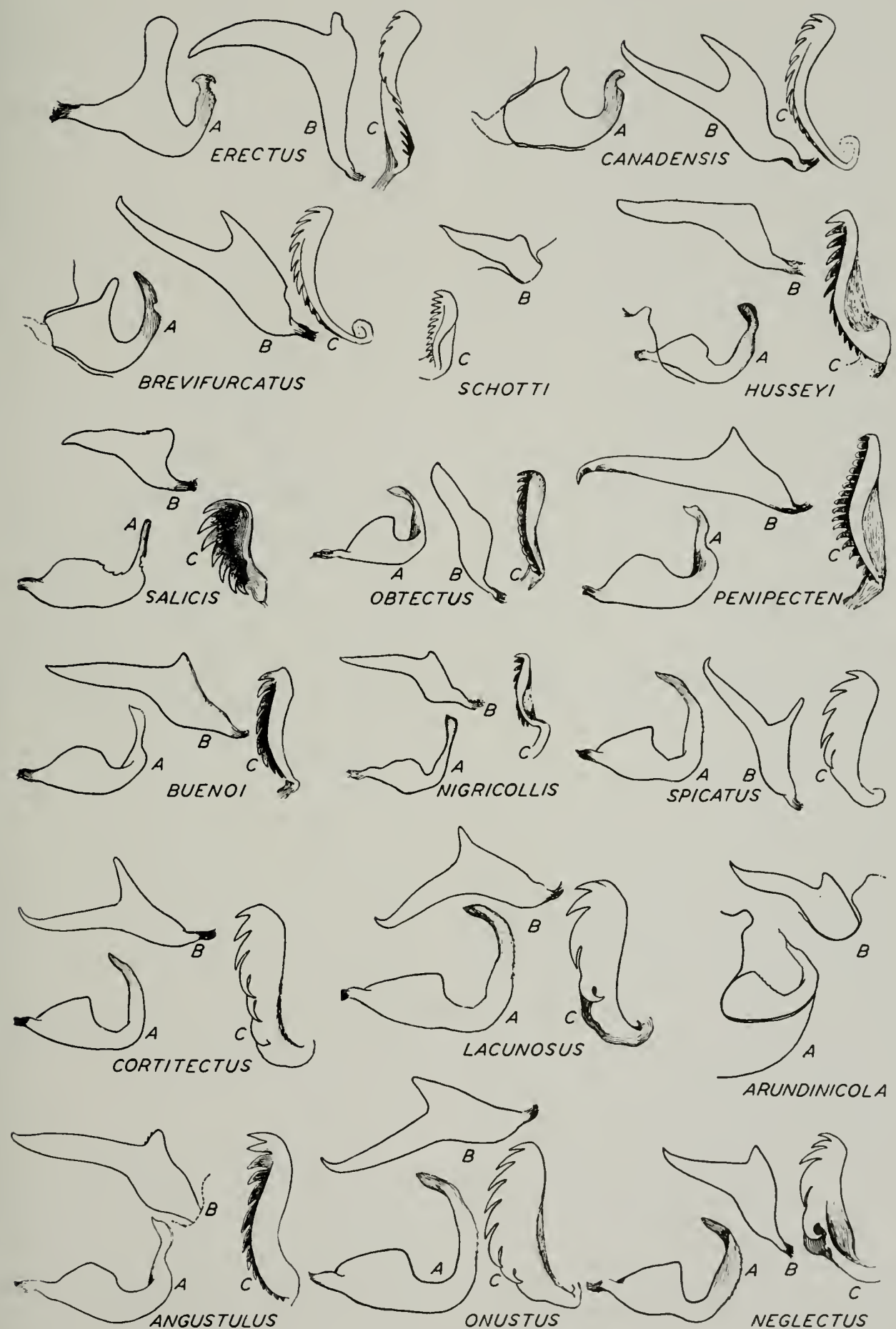

ARUNDINICOLA

Fig. 176.-Male gential claspers of Phytocoris, Group II. $A$, left clasper, lateral aspect; $B$, right clasper, lateral aspect; $C$, flagellum. 
shaded with very dark brown spots on embolium; an area at middle, and a triangular patch at outer apical angle of corium, pale yellowish and translucent; cuneus largely black with yellowish spots and a variable yellowish area at base. Membrane fuscous with a pale marginal spot on either side extending irregularly toward middle. Legs colored almost as in canadensis Van Duzee, but hind femora with large irregular pallid spots on anterior face, these spots connected by a longitudinal pale bar which does not attain subapical pale band. Genital claspers and flagellum distinctive for species, fig. 176.

Female. - Length 7.10, width 2.64. Larger and more robust than male, but very similar in coloration.

HaвIтs.-I have collected this species most frequently on the bark of hickory trees (Carya sp.) in shaded, humid surroundings. The color of this mirid matches the bark so closely that it is difficult to see when it is crouching in crevices on the trunk of the tree. Predacious habits are indicated.

Known Distribution. - Georgia, Illinois, Maine, Massachusetts, New Hampshire, New York, Ontario, Pennsylvania.

Illinois Record.-NortherN IllinoIs: July, 2 ㅇ․

\section{Phytocoris cortitectus Knight}

Phytocoris cortitectus Knight (1920, p. 55).

MalE.-Length 6.00 , width 2.00 . Head width 1.04 , vertex 0.32 . Rostrum, length 2.72, reaching to sixth abdominal sternite. Antennae, first segment, length 1.28 , black, with eight or nine smooth, white spots; second, 2.94, fuscous to black, with a yellowish dorsal spot and a narrow white annulus at base; third, 1.64, black, yellowish at base; fourth, 1.21, black. Pronotum, length 0.86 , width at base 1.60 ; calli whitish; disk dusky to fuscous; four black points located near posterior margin. Clothed with simple, black pubescence intermixed with tufts' of silvery, silky hairs. Hemelytra translucent and slightly darkened, irregularly shaded with fuscous; without a strong, oblique, fuscous mark across apical area of corium; cuneus pale, translucent, with apical half infuscated; membrane fuscous, central area varied with lighter color. Legs pallid and darkened with fuscous; femora with numerous, small, almost colorless spots, hind pair with a well-defined, oblique, pallid band at middle of apical half; middle tibiae with an almost colorless band at apex.

Female.-Length 6.20, width 2.16. Head width 1.01 , vertex 0.39 . Antennae, first segment, length 1.43; second, 3.11 ; third, 1.71 ; fourth, 1.43. Pronotum, length 0.95 , width at base 1.65. More robust than male, but very similar in color and pubescence.

HaBITs.-I collected specimens of this species only on the trunks of elm trees (Ulmus sp.) where the adults were well concealed as they crouched in crevices of the bark.

Known Distribution. - Illinois, New Hampshire, New York, Ontario.

Illinois Record.-Antroch: July 5-7, 1932, T. H. Frison, 1 o .

\section{Phytocoris spicatus Knight}

Phytocoris spicatus Knight (1920, p. 55).

The coloration of this species is very similar to that of neglectus Knight, but the membrane is more uniformly infuscated.

MaLE.-Length 6.00, width 2.00. Head width 1.04 , vertex 0.29 ; frons with reddish lines. Rostrum, length 2.81 , reaching sixth ahdominal sternite. Antennae,-first segment, length 1.38, black, with five or six white, smooth spots; second, 2.85 , black, a narrow white annulus at base; third, 1.56, black, narrow white area at base; fourth, 1.12 , black. Pronotum, length 0.91 ,-width at base 1.73. Clothed with fuscous to black, simple pubescence intermixed with patches and tufts of silvery and some golden, silky pubescence. Genital claspers and flagellum distinctive for species, fig. 176.

Female.-Length 6.30, width 2.20. More robust than male, but very similar in color and pubescence.

Known Distribution. - Illinois, Iowa, Maine, Maryland, Massachusetts, Minnesota, North Carolina, New York.

Illinois Record.-Galesburg: $1 \hat{\delta}$.

\section{Phytocoris salicis Knight}

Phytocoris salicis Knight (1920, p. 56).

MALE.-Fig. 177. Length 6.00 , width 2.12. Head width 0.97 , vertex 0.35 ; head yellowish; oblique lines on frons and mark on middle of tylus reddish. Rostrum, length 2.73, reaching seventh abdominal sternite. Antennae, first segment, length 1.27 , black, with three or four large, white, smooth spots; second,..2.85, idusky yellow to black, 
basal annulus white; third, 1.55, black, pallid at base; fourth, 1.16. Pronotum, length 0.99 , width at base 1.73 . General coloration dusky to brownish; spots on base of pronotal disk, tip of clavus, apex of embolium and of cuneus, black; fuscous color-

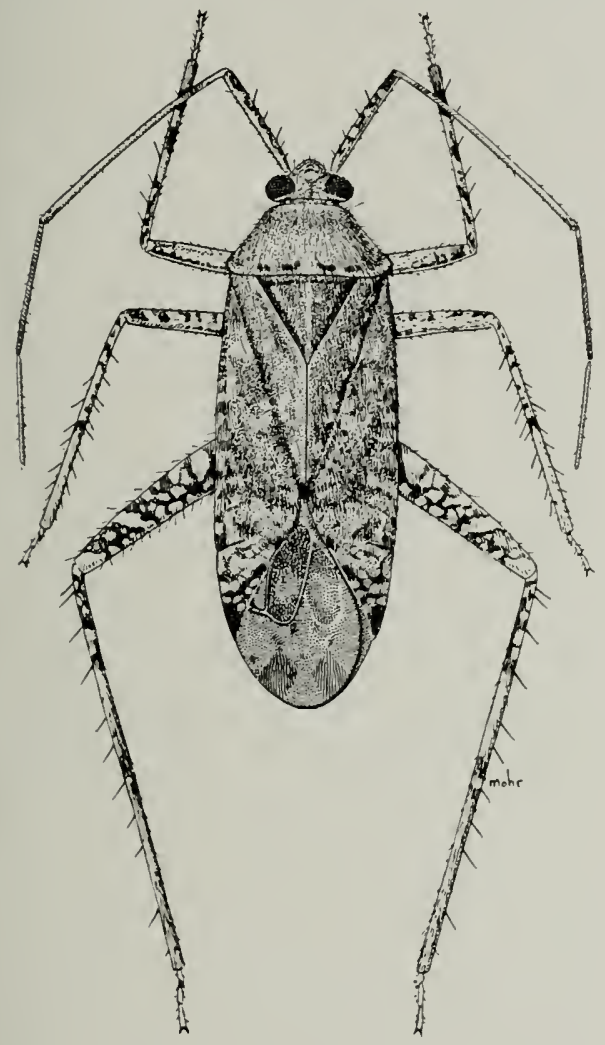

Fig. 177.-Phytocoris salicis, $0^{7}$.

ation of hemelytra interspersed with pallid and brownish marks and dots; membrane clear, marked with patches of fuscous; cubitus white around apex of larger areole. Legs pallid; apical half of femora marked with reddish brown; hind pair chiefly dark brown, with numerous white spots, a larger white spot forming an incomplete subapical band; tibiae banded with fuscous; apices of middle pair pallid; hind pair chiefly dark fuscous. Dorsum clothed with pale to brownish, simple pubescence thickly intermixed with silvery to golden yellow, silky hairs. Genital claspers and flagellum distinctive for species, fig. 176.

Fexiale.-Length 6.30, width 2.30. Antennae, first segment, length 1.34 , chiefly white, irregularly marked with reddish brown; second, 2.98, yellowish brown, more fuscous at apex and next to pallid base; third, 1.47, black, pallid at base; fourth, 1.12 , black. More robust than male and usually lighter in color.

Habits.-Breeds on willow (chiefly $S a$ lix nigra) where the species appears to be predacious on soft-bodied insects.

Known Distribution.-Connecticut, District of Columbia, Illinois, Iowa, Maine, $M$ aryland, Massachusetts, Michigan, Minnesota, Mississippi, New Hampshire, New Jersey, New York, North Dakota, Ohio, Ontario, Pennsylvania, South Dakota.

Illinois Records.-Seventeen males and 15 females, taken June 11 to July 9, are from Alton, Antioch, Elizabeth, Galena, Galesburg, Golconda, Monticello, Savanna, Seymour, Waukegan.

\section{Phytocoris lacunosus Knight}

Phytocoris lacunosus Knight (1920, p. 56).

Not taken in Illinois; known from Minnesota and New York. Collected on the bark of hornbeam (Carpinus caroliniana).

\section{Phytocoris angustulus Reuter}

Phytocoris angustulus Reuter (1909, p. 29).

Known from New York, North Carolina, Nova Scotia, Vermont; not yet collected in Illinois.

\section{Phytocoris buenoi Knight}

Phytocoris buenoi Knight (1920, p. 57).

Not taken in Illinois; known from Massachusetts, New York, Ontario. Adults and nymphs have been collected on Norway spruce (Picea excelsa).

\section{Phytocoris nigricollis Knight}

Phytocoris nigricollis Knight (1923d, p. 636).

Known only from New Hampshire and North Carolina.

\section{Phytocoris schotti Knight}

Phytocoris schotti Knight (1926g, p. 162).

The coloration of this species is suggestive of that of salicis Knight, but the dark areas are black rather than brown; the apical half of the corium is largely pallid, except 'near the inner margin, and "is without an oblique infuscation; the cuneus is almost 
entirely colorless, but the apex and two spots on the inner margin are black, while the outer margin is marked with red. The membrane is marbled with fuscous, and the areoles are chiefly dark fuscous, with white veins at apices. The legs are marked much as in salicis, but the black color on the femora is irregularly broken by two or three large, and many small, white spots.

MALE.-Length 5.20, width 1.90 . Head width 1.00 , vertex 0.26 ; frons with five or six oblique, reddish lines on either side of median line; base of tylus and spot on either side of basal half, dorsal margins of juga and lora, and slender median line on apical half of tylus, reddish. Rostrum, length 2.34, extending to fifth abdominal sternite. Antennae, first segment, length 0.97 , very dark brown, with several small, smooth white spots on dorsal aspect, spines pale; second, 2.30 , black, narrow pallid area at base; third, 1.23, black, pale at base and at extreme tip; fourth, 0.91, black. Pronotum, length 0.84 , width at base 1.50 ; propleura black; lower margin, and spot at top of coxal cleft, white; the white of lower margin continued as a ray upon black sternum. Clothed with fuscous to black, simple pubescence intermixed with white, silky pubescence; more yellowish hairs on head and embolium than black ones. Genital claspers distinctive for species, fig. 176.

Known Distributiox. - Illinois and New Jersey.

Illinois Record.-White Heath: Sept. 10, 1929, C. C. Goff, 1 ô, kc.

\section{Phytocoris arundinicola new species}

This species is distinguished from allied ones by its general pale gray color, with a conspicuous black spot on the inner apical angle of the corium; it also is distinguished by the pale and black, unspotted, first antennal segment. The structure of the male genital claspers is distinctive, fig. 176; the genitalia are apparently nearest in form to those of buenoi Knight and schotti Knight.

Male.-Length 5.60, width 2.16. Head width 0.95 , vertex 0.35 ; head white to yellowish, with incomplete lines on frons; marks on middle and on median line at apex, basal half of lora, and dorsal half of bucculae, reddish brown to fuscous; a pair of marks, beginning on collum and extending across collar and between calli, distinctly red orange. Rostrum, length 2.64 , extend- ing to sixth abdominal sternite. Antennae, first segment, length 1.16, tapering to become more slender on apical half, chiefly white, black on anterior aspect, with only one or two small, pallid spots cutting into edge of dark color, setae short, brownish; second, 2.51, chiefly yellowish brown, black at apex and next to pallid basal annulus; third, 1.34, yellowish, fuscous apically; fourth, 0.73 . Pronotum, length 0.88 , width at base 1.60 ; pale yellowish to dusky; calli pallid; lower margin of propleura and area on coxal cleft whitish, a black ray crossing lower margin of coxal cleft and flaring out at basal margin; basal edge of disk white, bordered by four black points which are often connected by dark color. Dorsum clothed with pale to brownish, simple pubescence sparsely intermixed with more recumbent, silvery, silky pubescence. Scutellum usually pale yellowish, sometimes dusky; a small fuscous spot indicated on either margin at middle of apical half. Hemelytra dusky gray, with an irregular black area on middle of claval vein and a subtriangular one on inner apical angle of corium; embolium uniformly yellowish gray, except for darkened extreme tip; cuneus with apex and spot on inner margin, and spot on inner margin of paracuneus, fuscous to black. Membrane uniformly pale fuscous, scarcely paler near apex of cuneus; cubitus white around apex of areoles, fuscous where it separates areoles. Legs pale yellowish. tibiae without dark bands; spines yellowish to dark brown; hind pair with black microsetae; femora dark brown to black, with numerous, minute, pallid spots; hind pair with two rather distinct pallid bands on apical half; tarsi fuscous to black. Venter almost white to yellowish; lateral line fuscous; sides of genital segment fuscous. Genital claspers distinctive for species, fig. 176.

Female.-Length 5.60, width 2.16. Head width 0.99 , vertex 0.41 . Antennae, first segment, length 1.21 ; second, 2.73 ; third, 1.55 ; fourth, 1.38. Pronotum, length 0.95 , width at base 1.6t. Very similar to male in color and pubescence, but light areas perhaps more extensive.

Habits.-Breeds on switch cane (Arundinaria tecta); doubtless predacious.

Holotype, male.-Vienna, Ill.: July 10, 1935, DeLong \& Ross.

Allotype, female. - Same data as for holotype.

Paratypes.-Illinois.-Vienca: Same 
data as for holotype, $1 \delta, 3 q$; June 14 , 1934, DeLong \& Ross, 3 o .

\section{Phytocoris husseyi Knight}

Phytocoris husseyi Kinight (1923d, p. 639).

Not taken in Illinois; known only from $M$ innesota and Ohio.

\section{Phytocoris erectus Van Duzee}

Phytocoris erectus Van Duzee (1920, p. 345). Male.-Length 5.40, width 2.00. Head width 0.94 , vertex 0.36 . Rostrum, length 2.51, extending to fifth abdominal sternite. Antennae, first segment, length 1.16, black, basal two-thirds with white, smooth spots so large that black ground color is reduced to a network; second, 2.50 , black, dorsal aspect partly yellowish brown, white annulus at base; third, 1.28, black, pallid at base and extreme tip; fourth, 1.20, black. Pronotum, length 0.87 , width at base 1.56 . Dorsum clothed with simple, fuscous pubescence intermixed with a moderate amount of silvery, silky pubescence. General color nearly white to yellowish, shaded with fuscous. Basal submargin of pronotal disk with the usual four black points; scutellum with oblique black marks on apical half; apical area of corium with heavy, very dark brown subtriangular mark, and a contrasting pallid spot just behind which joins with pallid basal half of cuneus; paracuneus reddish; membrane fuscous, with a paler spot near tip of cuneus and a smaller one just beyond on margin; cubitus white about tip of larger areole. Hind femora very dark brown, with numerous small and some large white spots and a rather distinct pallid annulus slightly beyond middle of apical half; tibiae banded with pallid and black, middle pair with pale band on apex. Genital claspers and Alagellum distinctive for species, fig. 176.

Female.-Length 5.30, width 2.10. More robust than male, but very similar in color and pubescence.

HABITs.-Predacious; Illinois specimens collected on willow (Salix sp.), cypress (Taxodium distichum) and hornbeam (Carpinus coroliniana).

KNown Distribution:-Alabama, District of Columbia, Illinois, Iowa, Louisiana, Maine, Maryland, Michigan, Minnesota, Mississippi, Missouri, New Hampshire, New York, Ohio, Ontario, Utah.

Illinois Records.-Twenty-seven males and 7 females, taken June 13 to Sept. 6, are from Algonquin, Antioch, Browns, Chicago, Duquoin, Eichorn, Galesburg, Harrisburg, Havana, Homer Park, Kankakee, Karnak, Mahomet, Maywood, Metropolis, Monticello, Pekin, Pulaski, Urbana, Vienna, White Heath.

\section{Phytocoris penipecten Knight}

Phytocoris penipecten Knight (1920, p. 58).

Not taken in Illinois; known only from Alabama, Connecticut, Louisiana, Massachusetts.

\section{Phytocoris obtectus Knight}

Phytocoris obtectus Knight (1920, p. 58).

Not taken in Illinois; known only from New York and Ohio.

\section{Group III}

The species of this group are apparently all phytophagous.

\section{KEY TO SPECIES}

1. Clavus and corium rather uniformly colored.................. 2

Clavus and corium not uniformly colored; marked with fuscous, or reddish brown to fuscous, with paler spots.................... 4

2. Hemelytra reddish; embolium and cuneus translucent and yellowish...

mundus, p. 201

Hemelytra yellowish to fulvous, or translucent and brownish........ 3

3. Hemelytra yellowish to fulvous; femora dusky yellow with numerous small, pale dots..........fulvus, p. 201

Hemelytra dusky brown, translucent; femora reddish brown, with conspicuous white spots...

uniformis, p. 201

4. Hemelytra pale to yellowish; corium with an oblique, fuscous mark on hasal half and a second one on inner apical angle; cuneus pale, apex and two spots on inner margin black....

junipericola, p. 201

Hemelytra marked otherwise....... . 5

5. Pronotal disk with black spots on basal margin; apical area of corium with strong fuscous marks............

exemplus, D. 201 
Pronotal disk without black spots... . 6

6. Light-colored dots and spots on hind femora uniting to form a subapical band or transverse pale mark..... 7

Dots on hind femora not forming a distinct light-colored band or large mark................... 8

7. Cuneus with a narrow white area along outer margin and two black dots on this white edge. . angustifrons, p. 201

Cuneus with outer margin reddish brown and marked with three or four white dots.........pinicola, p. 201

8. Length of second antennal segment twice as great as width of head.... ............. diversus, p. 200

Length of second antennal segment less than twice width of head......... ............. conspersipes, p. 201

\section{Phytocoris diversus Knight}

Phytocoris diversus $\cdot$ Knight $(1920 ;$ p. 60).

The general aspect of this species is suggestive of fulvus Knight, but the light, yellow brown coloration on the inner apical half of the corium and the cuneus is more distinct.
MaLE.-Length 5.00, width 1.70. Head width 0.97 , vertex 0.37 . Rostrum, length 2.03 , reaching fifth abdominal sternite. Antennae, first segment, length 0.71 , greenish yellow, darkened with deep brownish, with five or six smooth, white spots on dorsal side, and beset with 9 or 10 dark setae; second, 2.05 , dark fuscous, paler on basal half; third, 1.05 , black; fourth, 0.85 , black. Pronotum, length 0.78 , width at base 1.36 . Clothed with brownish, simple hairs intermixed with silvery, silky pubescence. Head, pronotum and ventral parts greenish to yellowish; base of pronotum, sides of tylus, dorsal margins of juga and lora, base of head, indistinct striae on front, sternum, and sides of venter, tinged with reddish brown; femora, except at bases, and tibiae, deep brownish, with many light to white spots; hind femora with rather large spots on dorsal aspect. Genital claspers and flagellum distinctive for species, fig. 178 .

Female.-Length 4.80 , width 1.73 . Very similar to male in' color and pubęscence.

Host Plant. - White pine (Pinus strobus).

Known Distribution.-Illinois, Maine, Minnesota, New Hampshire, New York.

Illinois Records.-Starved Rock State

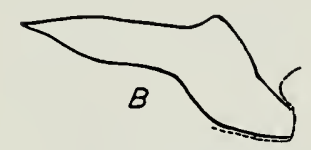

ANGUSTIFRONS
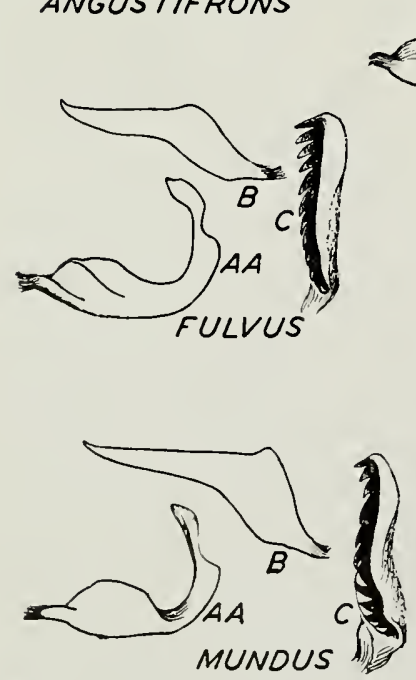
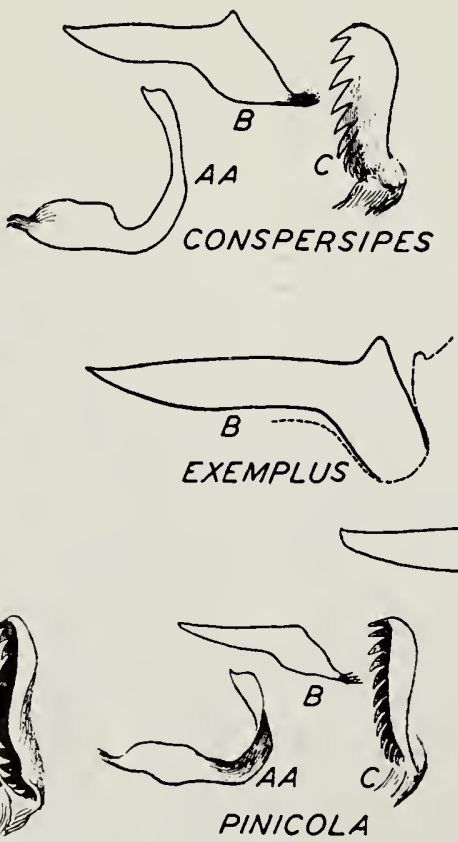

PINICOLA
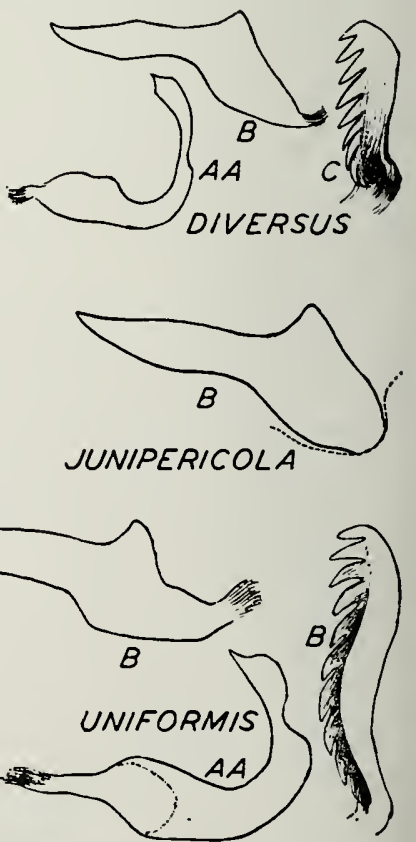

Fig. 178.-Male genital claspers of Phytocoris, Group III. $A A$, left clasper, dorsal aspect; $B$, right clasper, lateral aspect; $C$, fiagellum. 
PARK: July 14, 1932, on Pinus strobus, Dozier \& Park, 11 o, 19 \% ; Sept. 17, 1935, DeLong \& Ross, $1 \delta$. White Pines Forest State Park: July 12, 1934, DeLong \& Ross, $2 \hat{0}, 3$.

\section{Phytocoris mundus Reuter}

Phytocoris mundus Reuter (1909, p. 18).

Not taken in Illinois; known from District of Columbia, Maryland, New Jersey, Pennsylvania, Virginia. Feeds on Virginia pine (Pinus virginiana).

\section{Phytocoris fulvus Knight}

Phytocoris fulvus Knight (1920, p. 59).

Not yet taken in lllinois; known from Maine, New York, Ontario, Pennsylvania. Occurs on white pine (Pinus strobus).

\section{Phy tacoris uniformis .Knight ......}

Phybocoris.uniformis. Knight (1923d, p.. 643).

Originally described from Long Island, New York, and the coastal area of Massachusetts. This species has subsequently been recorded from Maryland, Mississippi, North Carolina, Virginia, but has not yet been taken in Illinois. It has been collected on pitch pine (Pinus rigida), which possibly is the normal host.

\section{Phytocoris pinicola Knight}

Phytocoris pinicola Knight (1920, p. 59).

Not taken in Illinois; specimens known from Connecticut, Massachusetts, Minnesota, Mississippi, New Jersey, New York. Feeds on pines (Pinus resinosa and P. sylvestris).

\section{Phytocoris angustifrons Knight} 164).

Phytocoris angustifrons Knight (1926g, p.

Not taken in Illinois; known only from Florida, Louisiana, Mississippi. Collected on pine (Pinus sp.).

\section{Phytocoris exemplus Knight}

Phytocoris exemplus Knight (1926g, p. 163). Known at present only from Louisiana, but should be found wherever the cypress (Taxodium distichum) grows; that is the tree on which it occurs.

\section{Phytocoris conspersipes Reuter}

Phytocoris conspersipes Reuter (1909, p. 22).

Not taken in Illinois; known from District of Columbia, Maryland, New Jersey, North Carolina, Pennsylvania, South Carolina, Virginia. Feeds on Virginia pine (Pinus virginiana).

\section{Phytocoris junipericola Knight}

Phytocoris junipericola knight (1927b, p. 16).

Known from District of Columbia, Indiana, Maryland; not yet taken in Illinois.

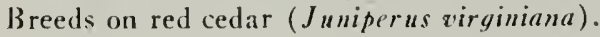

\section{Group IV}

The species of this group are phytophagous.

\section{KEI TO SPECIES}

1... Pronotal disk frequently.red hut without fouf distinct, reddish vittae on a palér background............ 2

Pronotal disk with four orange or red vittae on a paler background..... 8

2. Pronotal disk with four black spots on hasal submargin; scutellum usually uniformly pale, sometimes with indistinct fuscous dots forming a spot at cither side of apical half.

quercicola, p. 202

Pronotal disk without four distinct black spots on basal submargin; scutellum usually with orange or red at either side on apical half. . . 3

3. Scutellum unmarked, uniformly yellowish.................. 4

Scutellum marked with reddish or fuscous................. 5

4. Hemelytra rather uniformly fuscoreddish to roseate; embolium and outer margin of scutellum paler.... taxodii, p. 203

Hemelytra vellow; clavus and basal one-third of corium dark reddish; cuneus red with many minute, clear spots... . . . . . . luteolus, p. 209

5. Pronotum chiefly red, more area red than pale or fuscous.........6 6

Pronotum with more area pale or fuscous than red........... 7

6. Hemelytra with many small, distinct, white spots; calli darkened with fuscous.......... confluens, p. 205 
Hemelytra with only indistinct, white spots, nearly uniformly deep orange red; calli pale......puella, p. 207

7. Pronotal disk with base and lateral margins dark fusco-reddish; scutellum yellow, a red mark at either side on apical half but without vittae at middle of base.........

infuscatus, p. 204

Pronotal disk chiefly pale, not distinctly darkened laterally or at base; base of scutellum with an orangecolored vitta on either side of median line, these frequently extending to join with orange mark at either side on apical half.......olseni, p. 205

8. Second antennal segment almost colorless, with a slender, black line on anterior aspect; embolium and outer half of corium green; clavus greenish to fuscous, with a rather large, irregular, reddish blotch on middle and a smaller one on basal half...........tibialis, p. 205

Second antennal segment without a slender, black line on anterior aspect; embolium and outer half of corium marked with reddish.

9. Hemelytra with a yellow, triangular area just before cuneus; clavus, basal area of corium and embolium, and cuneus, bright red but with many small, paler markings...... ............ venustus, p. 206

Hemelytra and apical area of corium marked with reddish; or, if not, then basal half of corium not bright red. 10

10. First antennal segment reddish, with three or four large, smooth white spots and three or four small spots

rubellus, p. 202

First antennal segment not distinctly marked with red and white spots. .11

11. Apical area of corium, or area behind tip of clavus, without netlike marks; dorsum pale greenish yellow; markings of hemelytra dusky

caryae, p. 207

Apical area of corium with netlike markings of orange or red......12

12. Length of first antennal segment greater than width of head and vertex combined...... puella, p. 207

Length of first antennal segment less than width of head and vertex combined.........depictus, p. 208

\section{Phytocoris rubellus Knight}

Phytocoris rubellus Knight (1926g, p. 166).

MALE.-Length 4.80, width 1.54. Head width 0.86 , vertex 0.25 . Rostrum, length 1.94 , extending to base of fourth abdominal sternite. Antennae, first segment, length 0.81 , reddish, with three or four large, smooth white spots and about the same number of small ones, set with six or eight pallid bristles, some of which in length exceed thickness of segment; second, 2.10, yellowish, sometimes tinged with red, apex dusky; third, 1.06, yellowish, apex dusky; fourth, 1.00 , fuscous. Pronotum, length 0.71 , width at base 1.28 ; reddish to fuscous; median line and line extending upon vertex, and frequently a line on either side of pronotal disk, pallid. Scutellum reddish, basal angles and apex yellowish. Hemelytra reddish to fuscous; embolium with several obsolete pallid marks. Cuneus reddish, and scarcely darker at apex. Membrane pale fuscous, marbled with paler color; veins fuscous although pale to reddish at apices of areoles. Legs pale yellowish to reddish and marked with paler spots, exhibiting more red than in puella Reuter. Clothed with pallid to fuscous, simple pubescence intermixed with white, silky pubescence, the latter tending to form spots on hemelytra.

Female.-Length 4.80 , width 1.63 . Head width 0.86 , vertex 0.37 . Antennae, first segment, length 0.86 ; second, 2.06; third, 1.08 ; fourth, 0.95. Pronotum, length 0.77 , width at base 1.37. Coloration usually a deeper red than in male; hemelytra pallid to red.

Host Plant. - Sandbar willow (Salix longifolia).

Known Distribution. - Illinois, Indiana, Iowa, Kansas, Missouri, South Dakota.

Illinois Records.-Twenty-six males and 30 females, taken June 1 to Aug. 24, are from Alton, Grafton, Grand Tower, Havana, Kankakee, Meredosia, Putnam, Quincy, Savanna, Starved Rock State Park, Waukegan.

\section{Phytocoris quercicola Knight}

Phytocoris quercicola Knight (1920, p. 60).

MALE.-Length 4.70, width 1.70 . Head width 0.91 , vertex 0.30 . Basal half of lora, spot on either side of tylus, transverse mark across front, and four marks on vertex, 
red; front with prominent, nearly colorless hairs. Rostrum, length 2.20, extending to base of genital segment. Antennae, first segment, length 0.97 , pallid, three irregular marks on dorsal surface, broad, fuscobrownish or reddish band at apex, beset with six or eight prominent, pale spines; second, 2.25, pale brownish, pallid annulus at base, area next to this and at apex dark fuscous; third, 1.25, fusco-brownish, annulus at base and middle, and a narrow one at apex, pallid; fourth, 1.04, fuscous. Pronotum, length 0.75 , width at base 1.43 ; yellowish, outer halves of calli, and broad area extending rearward, fusco-brownish to dark fuscous; a basal, submarginal, fuscous line with two black points on either side of median line; narrow area at basal margin pallid; pubescence yellowish to dusky, longest hairs situated anteriorly and on collar. Scutellum pallid, median line frequently reddish, either side of this an indistinct vitta composed of small brownish dots. Hemelytra pale yellowish, more or less translucent; an irregular patch at middle of clavus, and a larger one just opposite on corium, fusco-brownish, dark color broken by small, irregular, light spots; frequently apex of corium with a smaller, dark patch and a series of fusco-brownish spots bordering claval suture; embolium and cuneus with small spots of reddish in hypodermis. Membrane pallid; infuscation usually composed of fine irregular spots; a large spot at apex and a smaller one at either side joining margin, central area and that within areoles more sparsely marked with fuscous dots; cubitus pallid, radius infuscated. Front and middle tibiae pallid, with three fuscous annuli; hind pair with two reddish brown bands on basal half; femora pallid, reticulated with reddish brown; hind pair with two irregular pallid bands on apical half, dark color broken by numerous light-colored spots. Venter pallid, sides flecked with reddish. Genital claspers and flagellum distinctive for species, fig. 179.

Fenale.-Length 4.80, width 1.80. Head width 0.95 , vertex 0.36 . Antennae, first segment, length 1.08 ; second, 2.25 ; third, 1.12 ; fourth, 1.0t. Pronotum, length 0.82 , width at base 1.56. Very similar to male in color and pubescence.

Host Plaxt.-Bur oak (Quercus macrocarpa).

Knowx Distribution. - Florida, Illinois, Iowa, Maryland, Massachusetts, Min- nesota, New York, North Carolina, Ontario, Virginia.

Illinois Records. - ChampaigN : June 27, 1932, on oak, Harper, 1 . Dubors: Aug. 8, 1917, 1 o. Galesburg: $1 \delta$; June 24, 1892, 1 ㅇ ; July 27, 1892, 2 \& . GlendoN PARK: Aug. 19, 1903, A. B. Wolcott, 1 o , FM. Urbana: June 27, 1932, Frison \& Ross, 2 ô, 1 q ; Aug. 11, 1932, on Quercus macrocarpa, H. H. Ross, 1 우 ; Sept. 12, 1891, C. A. Hart, 1 o .

\section{Phytocoris taxodii Knight}

Phytocoris taxodii Kright (1926g, p. 165).

This species is allied to rufus Van Duzee, a species known to occur only in Florida, but differs from it in the longer rostrum and longer first antennal segment; the basal half of the right genital clasper of the male is more slender in taxodii than in rufus.

MALE.-Length 5.10, width 1.70. Head width 0.94 , vertex 0.26 ; color of head yellowish, sometimes tinged with red. Rostrum, length 2.50, attaining base of genital segment. Antennae, first segment, length 1.03 , slightly thicker at base and apex, a few weak, yellowish setae on basal half, yellow to reddish; second, 2.34 , yellowish; third, 1.30 , yellowish to dusky; fourth, 1.05 , dusky. Pronotum, length 0.80 , width at base 1.40 ; reddish, becoming fusco-reddish near base of disk; narrow area at hasal margin, median line on collar, and area between calli, paler. Scutellum yellowish or tinged with reddish. Clothed with golden yellow to brown, simple pubescence sparsely intermixed with more recumbent, silvery, silky pubescence. Hemelytra yellowish to reddish; inner apical angles of corium dark red to fuscous, but this dark color not extending forward along radial vein; cuneus rose red, narrow area along outer margin yellow; membrane fusco-brownish, veins red. Ventral surface and legs yellowish; hind femora reddish, except basal one-third, and with many small, yellowish spots; base of hind tibiae reddish. Genital claspers distinctive, fig. 179.

Female.-Length 5.30, width 1.80. Head width 0.91 , vertex 0.34 . Antennae, first segment, length 1.10 ; second, 2.40 ; third, 1.31 ; fourth, 1.04. Pronotum, length 0.85 , width at base 1.49. Very similar to male in color and pubescence.

Host Plaxt.-Bald cypress (Taxodium distichum). 
Kxowy Distribution. - Georgia, Illinois, Louisiana, Mississippi.

Illinois Records.-ELIZABETHTOWN : July 25, 1930, on Taxodium distichum, segment. Antennae, first segment, length 1.08 , pale yellowish, fusco-brownish near apex, dusky at base, pubescence yellowish to dusky, basal half with five or six yellowish
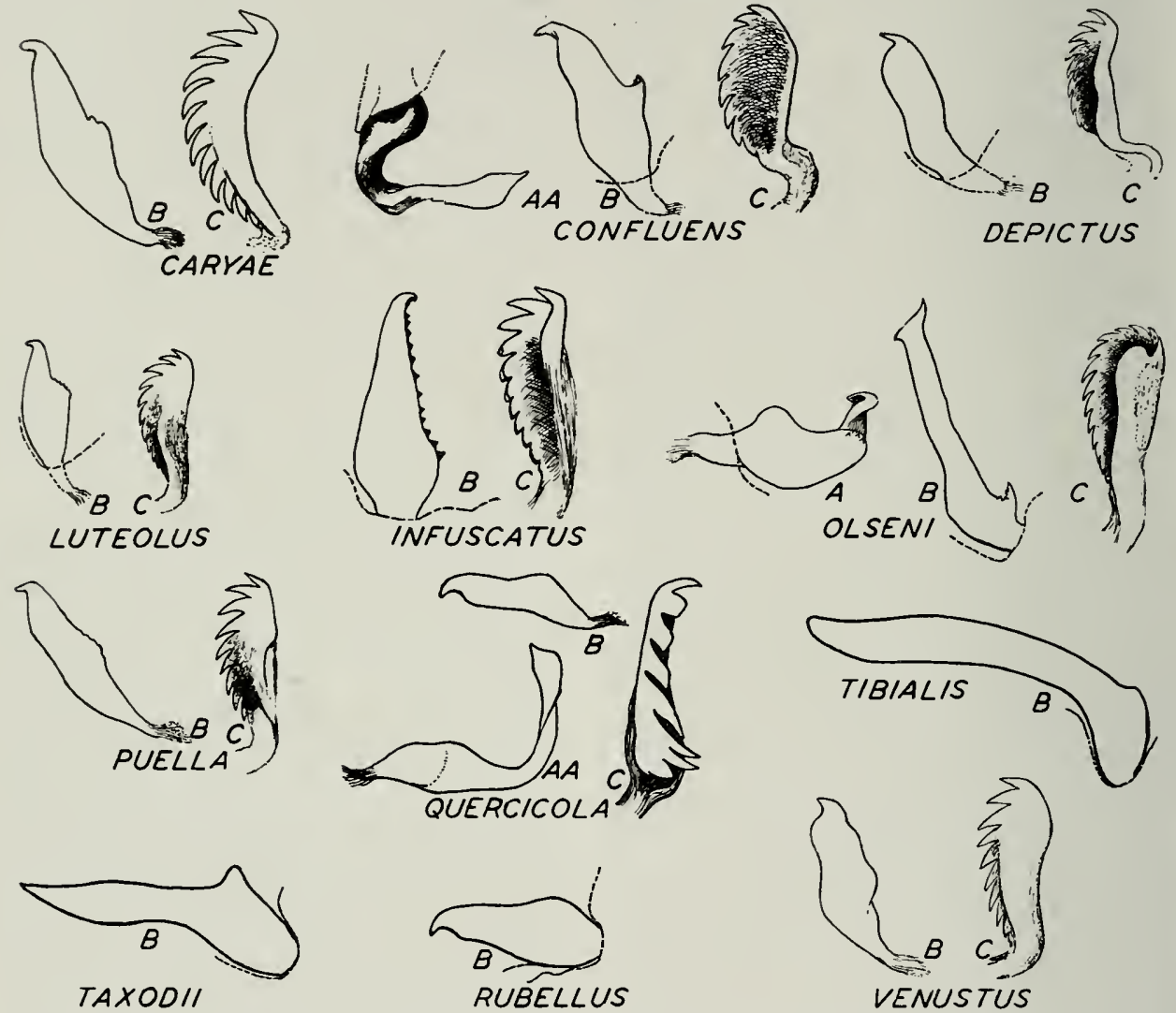

Fig. 179.--Male genital claspers of Phytocoris, Group IV. $A$, left clasper, lateral aspect; $A A$, left clasper, dorsal aspect; $B$, right clasper, lateral aspect; $C$, flagellum.

Knight \& Ross, 3 \&. Horseshoe Lake: July 11, 1935, DeLong \& Ross, 1 ㅇ. Pulaski: June 28, 1909, 2 ô.

\section{Phytocoris infuscatus Reuter}

Phytocoris infuscatus Reuter (1909, p. 20). Male.-Length 5.30, width 1.94. Head width 0.88 , vertex 0.28 ; color of head yellowish, dorsal half of juga, basal half of lora, bucculae in part, and mark between bases of antennae, dark red; tylus dark red, two irregular, yellowish marks on basal half separated by small red wedge at base; front and vertex clothed with prominent yellowish hairs; either side of front with indications of transverse reddish lines. Rostrum, length 2.70 , nearly attaining base of genital setae; second, 2.74, uniformly yellowish; third, 1.49, yellowish; fourth, 1.20 , yellowish to fuscous. Pronotum, length 0.84 , width at base 1.50; disk yellowish to fusco-reddish, basal submargin darker; calli and area between them pallid, collar yellowish, a reddish patch on either side of median line, also an orange spot just behind inner angle of each callus; clothed with rather prominent pallid to yellowish pubescence; propleura pallid, a fusco-brownish line crossing lower extremity of coxal cleft and extending to near posterior margin. Scutellum pale yellowish, a reddish spot on margin on either side of apical half, but broad, yellowish line at meson. Hemelytra with emboliar margins very slightly arcuate; reddish to fuscoreddish, with many more or less confluent, 
minute white spots, basal half more fuscous than reddish; cuneus red, broken by small, translucent spots at middle. Membrane smoky to fusco-brownish, infuscation of areoles somewhat broken into small spots, apical half with slightly darker fuscous area touching margin beyond cuneus. Legs pale yellowish; hind femora, except basal onethird, black with a red cast, with many, small yellowish spots and larger spots on dorsal aspect at middle, a yellowish band slightly beyond middle of apical half; front tibiae with indistinct brownish band on middle and near base; hind pair with broad, reddish band at base. Venter yellowish to fuscous, darker laterally and on genital segment. Genital claspers and flagellum distinctive for species, fig. 179.

Fenale.-Length 5.50, width 2.00. Head width 0.91 , vertex 0.39 . Antennae, first segment, length 1.23; second, 2.94; third, 1.55 ; fourth, 1.17. Pronotum, length 0.86 , width at base 1.51. More robust than male, very similar in coloration, but pale area on apical half of corium broader, and with pallid and orange rays behind calli.

Host Plant.-Hickory (Carya sp.)

KNown Distribution.-District of Columbia, Georgia, Illinois, Iowa, Massachusetts, Mississippi, New York, North Carolina, Ohio, Pennsylvania.

Illinois Records. - Illinors: June 26, 1892, 1 o . Bluff Springs: June 10, 1932, Ross \& Mohr, 1 \&. Dubors: July 3, 1909, 1 \&. Geff: June 12, 1934, DeLong \& Ross, 1 ․ Quincy: June 15, 1883, 1 ô.

\section{Phytocoris olseni Knight}

Phytocoris olseni Knight (1923d, p. 647).

Not taken in Illinois; known from Florida, Mississippi, New Jersey, New York, Virginia.

\section{Phytocoris tibialis Reuter}

Phytocoris tibialis Reuter (1876, p. 68).

MALE.-Length 5.10, width 1.90. Head width 0.88 , vertex 0.35 . Rostrum, length 2.60, extending to sixth abdominal sternite. Antennae, first segment, length 1.08 , yellowish, with four or five reddish brown marks; second, 2.38, yellowish, a distinct fuscous to black line on anterior aspect, with white annulus at base; third, 1.47, fuscous, pale yellowish at base; fourth, 1.30, fuscous. Pronotum, length 0.86 , width at base 1.47; greenish; disk with four longitudinal orange stripes. Hemelytra yellowish green to green; clavus with a rather large reddish blotch on middle and a smaller one on basal half; inner half of corium with reddish spots and blotches. Apex of cuneus and two spots on paracuneus reddish. Membrane fuscous, with irregular pale and translucent areas behind cuneus and extending across middle. Legs greenish yellow; front and middle tibiae with very dark red-brown line on dorsal aspect; hind femora with apical half dark red brown, this color area broken by numerous small and large, yellowish spots and a distinct subapical, pale yellowish annulus. Genital claspers distinctive, fig. 179; right clasper very long.

Female.-Length 5.50, width 2.00. Head width 0.88 , vertex 0.36 . Antennae, first segment, length 1.12; second, 2.34; third, 1.51; fourth, 1.35. Pronotum, length 0.86 , width at base 1.47. Clothed with yellowish to fuscous, simple pubescence sparsely intermixed with yellowish, silky pubescence. Coloration very similar to that of male.

HaBits.-Breeds among weedy, herbaceous plants in damp situations; Illinois specimens collected on mountain mint (Pycnanthemum sp.).

KNown Distribution.-Alabama, Connecticut, District of Columbia, Florida, Illinois, Iowa, Maryland, Massachusetts, Michigan, Minnesota, Mississippi, Missouri, New Jersey, New York, North Carolina, Ohio, Ontario, Texas, Virginia, Wisconsin.

Illinois Records.-Forty-four males and 23 females, taken June 22 to Oct. 2, are from Albion, Alto Pass, Anna, Browns, Carbondale, Cave-in-Rock, Dongola, Dubois, Fast St. Louis, Elizabethtown, Gibsonia, Golconda, Grand Tower, Havana, Herod, Lawrenceville, McClure, Metropolis, Monticello, Newton, Norris City, Olive Branch, Pulaski, Rosiclare, Shawneetown, Tenple Hill, York.

\section{Phytocoris confluens Reuter}

Phytocoris puella var. confuens Reuter (1909, p. 20).

Male.-Length 4.60 , width 1.43 . Head width 0.83 , vertex 0.26 ; head chiefly bright red; geminate mark at base of tylus, apices of juga and lora, and ventral margin of bucculae, pallid. Rostrum, length 2.20 . reaching sixth abdominal sternite, pale yel- 
lowish, black at apex. Antennae, first segment, length 1.00 , reddish yellow, pubescence and spines pale yellowish; second, 2.42, uniformly yellowish; third, 0.91, yellowish; fourth, 1.57, yellowish. Pronotum, length 0.70 , width at base 1.00 ; deep red, becoming almost black at anterior angles of disk; calli fuscous and red with almost colorless ray or spots behind each callus, basal margin with a slender, light colored area except at basal angles; propleura deep red, lower margins and xyphus pallid; clothed with yellowish to dusky pubescence; disk also with yellowish, silky pubescence. Scutellum red, basal angles and apex pallid: vague, light colored, median line present. Sternum and pleura dark red, ostiolar peritreme, and ventral margin of epimera, white. Hemelytra red, with many irregular, small to medium-sized spots; cuneus with pale spots on inner margin and across middle; hemelytra clothed with yellowish to dusky pubescence, intermixed with yellowish, silky pubescence which may be white over light spots. Membrane uniformly pale smoky, veins red. Legs pallid to yellowish; anterior femora reddish yellow at apices; tibiae with annulations; hind femora red, pallid at bases, with rather numerous, small, pallid spots although at times these spots nearly obsolete; hind tibiae with small red marks near bases; tips of tarsi fuscous. Venter white beneath, latero-dorsal margin deep red; each sternite with small spot of red laterally; eighth segment and base of genital segment dark fusco-reddish. Genital claspers and flagellum distinctive, fig. 179.

Female.-Length 5.50, width 2.03. Head width 0.90 , vertex 0.34 . Antennae, first segment, length 1.25 ; second, 3.16 ; third, 1.51 ; fourth, 1.30. Pronotum, length 0.86 , width at base 1.60. More robust than male, but very similar in color and pubescence.

Habits.-Collected on oak (Quercus sp.) and red birch (Betula nigra).

Known Distribution.-Connecticut, District of Columbia, Illinois, Kansas, Maryland, Massachusetts, Mississippi, New Jersey, New York, North Carolina, Ohio, Pennsylvania.

Illinois Records. - Ashley: Aug. 7, 1917, 2 9. Dolson: June 25, 1932, Rocky Branch, Frison \& Mohr, 1 o . Du BoIs: Aug. 8, 1917, 1 q. Fairfield: June 12, 1934, DeLong \& Ross, 1 o . Galena: June 30, 1932, on Quercus sp., Dozier \& Mohr, $1 \hat{o}$. Galesburg: June 27, 1893, $1 \hat{\jmath}$. Harris-
BURG: June 25, 1932, on Betula nigra, Ross, Dozier \& Park, 2 ô. OAKwood: June 14, 1930, T. H. Frison, 1 ㅇ.

\section{Phytocoris venustus Knight}

Phytocoris venustus Knight (1923d, p. 651).

MalE.-Length 4.50, width 1.60 . Head width 0.86 , vertex 0.28 ; head orange colored above; spot on either side of vertex and one at base, two spots on median line of front, and base of tylus, light colored; lower half of head pallid; base of juga, dorsal margin of lora, and irregular band across middle of tylus, bright red. Rostrum, length 2.00 , reaching sixth abdominal sternite, yellowish, black at apex. Antennae, first segment, length 0.97, pale yellowish, darker at apex, setae pale; second, 0.80 , uniformly yellowish ; third, 1.34, yellowish; fourth, 1.16, yellowish. Pronotum, length 0.68 , width at base, 1.37 ; pale, with two orange stripes behind either callus, outer stripe continued around callus and extending to anterior angle and collar; small orange spot before callus; collar orange red; propleura with red ray crossing lower half of coxal cleft, but not extending to posterior margin; clothed with moderately prominent, yellowish pubescence, this more prominent laterally and on scutellum and clavus. Scutellum orange red to deep red; basal angles and median line more or less pale. Sternum and pleura pallid, red areas on mesosternum and metepisternum; ostiolar peritreme white. Hemelytra yellow, with clavus and basal half of corium and embolium red, but with many, pale yellowish spots, these spots forming a large triangular area before cuneus; embolium sometimes with small red flecks on apical half; cuneus, and part of corium extending beyond cuneal fracture, red; outer margin of cuneus with four yellow spots, these sometimes almost confluent. Membrane smoky to pale fuscous, slightly paler on apical half, veins red, usually pale at apices of areoles. Legs pale to yellowish, fore femora with red flecks at apices; hind femora with netlike, bright red markings, these somewhat broken at middle of apical half by a yellowish area; hind tibiae with reddish spots near base. Venter yellowish, with red flecks along dorsal margin; genital claspers and flagellum distinctive for species, fig. 179.

Female.-Length 4.70, width 1.90 ; more robust than male, but very similar in color- 
ation. Head width 0.86 , vertex 0.36 . Antennae, first segment, length 1.04; second, 2.47; third, 1.38; fourth, 1.17. Pronotum, length 0.74 , width at base 1.38 . More robust than male, but very similar in color and pubescence.

Know Distribution.-Alabama, Connecticut, District of Columbia, lllinois, Maryland, New York.

Illinois Record.-Galesburg: July 24, 1892,1 하, 6 ㅇ․

\section{Phytocoris caryae Knight}

Phytocoris caryae Knight (1923d, p. 652).

Male.-Length 5.30, width 1.74. Head yellow, width 0.93 , vertex 0.28 ; small spot at dorsal margin of each eye, irregular large spot on either side of front, and spot on dorsal margin of lora, orange colored; front and vertex bearing prominent, pale hairs. Rostrum, length 2.20 , reaching fifth abdominal segment; pale yellowish, very dark brown at apex. Antennae, first segment, length 1.14 , yellow, anterior aspect with small orange spots, largest one located near apex, setae pale to dusky; second, 2.46, uniformly pale yellow; third, 1.50 , yellow; fourth, 1.16, yellow, dusky at apex. Pronotum, length 0.81 , width at base 1.44 ; greenish yellow, with four orange stripes on disk, these sometimes joining at base; calli pallid, collar with broad orange spot located on either side of median line, these spots extending posteriorly to calli; propleura with small orange ray behind lower half of coxal cleft; clothed with pale yellowish pubescence, a few dusky hairs at basal margin. Scutellum greenish yellow, an oblique orange mark on either side of median line. Sternum and pleura pale yellowish. Hemelytra pale to greenish yellow, mottled with brown orange; darker on clavus, with many large, irregular greenish yellow spots; apical one-fifth of corium nearly uniformly greenish yellow; embolium with a few scattering red orange spots; tip of clavus with a dusky spot and beset with prominent black hairs; cuneus yellowish and translucent, apex and margins flecked with reddish; a prominent, dull reddish spot at margin between corium and membrane; clothed with yellow pubescence, this darker near apex of corium; emboliar margins very slightly arcuate. Membrane nearly colorless, with pale fuscous marbling, coloring darkest within areoles and at middle; veins dusky yellow at apices of areoles. Legs almost white to yellowish; apical halves of femora flecked with bright red, larger spots on posterior pair; tibial spines fuscous, hind pair with a small, reddish spot at base of each spine, although these spots obscure apically; tips of tarsi dusky. Venter pale greenish yellow; genital claspers and flagellum distinctive for species, fig. 179.

Female.-Length 5.20, width 1.90. Head width 0.91 , vertex 0.36 . Antennae, first segment, length 1.21 ; second, 2.68 ; third, 1.51 ; fourth, 1.12. Pronotum, length 0.82 , width at base 1.47. More robust than male, but very similar in color and pubescence.

Host Plant.-Hickory (Carya sp.).

Known Distribution. - Illinois and New York.

Illinois Records. - Dubors: Aug. 8, 1917, 1 \&. Galesburg: June 2t, 1892, 1 q ; July 29, 1892, $1 \hat{\delta}, 4$. Monticello: June 28, 1914, Sangamon River, 1 o, 1 \&. SAVANNA: July 23, 1892, McElfresh, 1 \%

\section{Phytocoris puella Reuter}

Phytocoris puella Reuter (1876, p. 69).

Fenale.-Length 4.90 , width 1.90 . Head width 0.86 , vertex 0.36 ; head pale, with mark on either side of collum extending upon collar; irregular arc either side of front, base of lora and dorsal half of bucculae, orange colored. Rostrum, length 2.26, extending to fifth ventral segment, pale, black at apex. Antennae, first segment, length 1.26, pallid, indistinctly dotted with orange on anterior aspect; second, 2.80 , pale yellowish; third, 1.49, yellowish; fourth, 1.28, yellowish to dusky. Pronotum, length 0.78 , width at base 1.40 ; pale, disk with four orange stripes, paler forms with stripes broken at middle; anterior angles with orange stripe which extends upon collar; propleura with orange ray crossing lower half of coxal cleft and extending nearly to posterior margin. Scutellum pale, with an oblique orange vitta on either side of apical half. Hemelytra pale, with rather uniform orange, netlike markings; cuneus partly red; hemelytra clothed with pale yellowish pubescence intermixed with prominent. white, silky pubescence. Membrane pale, areoles infuscated and marbled within apical half, veins yellowish, pale at apex of areoles. Legs pallid, front tibiae with two nearly obsolete, orange yellow bands; hind femora with red, netlike marks on apical half, di- 
vided at middle of apical half by pallid annulus, fuscous hairs arising from red marks. Venter pallid, tinged with red near each spiracle.

MaLE.-Length 4.80, width 1.51. Head width 0.85 , vertex 0.21 . Antennae, first segment, length 1.21 ; second, 2.81 ; third, 1.56; fourth, 1.21. Pronotum, length 0.73 , width at base 1.25. Dorsum uniformly bright red, sometimes dotted with yellowish spots; calli pale; basal angles of pronotum and apex of scutellum yellowish to pale orange. Membrane pale smoky or nearly clear; areoles with rather fine, obscure, pale fuscous marks. Legs yellowish; apical half of hind femora with red, netlike markings and bearing fuscous to black hairs; a yellowish subapical band present; in this last respect very similar to female. Genital claspers, fig. 179. The sexes of puella exhibit a greater difference in color than do other, closely related species of this group.

HabiTs.-Collected on oak (Quercus sp.) and red birch (Betula nigra).

Known Distribution.-Connecticut, District of Columbia, Illinois, Maryland, Massachusetts, Michigan, Mississippi, New Jersey, New York, North Carolina, Ohio, Pennsylvania.

Illinois Records.-Eleven males and 20 females, taken June 12 to October, are from Anna, Ashley, De Soto, Dubois, Galena, Galesburg, Geff, Grand Detour, Harrisburg, Makanda, Marshall, Oregon, Palos Park, Starved Rock State Park, Urbana, White Pines Forest State Park. Blatchley (1926b, p. 729) records this species from Beverly Hills.

\section{Phytocoris depictus Knight}

Phytocoris depictus Knight (1923d, p. 654). MALE.-Length 4.10, width 1.50 . Head width 0.78 , vertex 0.27 ; head marked with orange and red as in puella Reuter. Rostrum, length 1.93 , reaching fifth abdominal sternite, yellowish, black at apex. Antennae, first segment, length 0.83 , thickest near base and tapering to become more slender just before apex, yellowish, with a few red dots on anterior aspect and with seven or eight fuscous setae on basal half of dorsal aspect; second, 1.97, uniformly pale yellowish; third, 0.96 , yellowish; fourth, 0.97 , yellowish. Pronotum, length 0.71 ; width at base 1.23 ; pale testaceous and dusky; calli lighter; disk with tour orange stripes; collar either side of median line and behind eye orange colored; clothed with pale yellowish pubescence, this fuscous near basal margin and sparsely intermixed with pale, silky pubescence; propleura with red mark crossing lower half of coxal cleft, this mark diffused behind cleft. Scutellum pallid, with orange mark either side of median line extending obliquely to lateral margin. Sternum pallid, episternum with red mark, epimeron chiefly red, ostiolar peritreme white, area just above reddish. Hemelytra with irregular, red, netlike markings, these produced by thickly placed and more or less confluent pale spots; basal half of corium nearly fusco-reddish; tip of clavus, and spot near inner basal angle of cuneus, black with prominent black hairs; clothed with golden yellow pubescence; central area with a few small spots of dense, silvery wool; cuneus bright red and with many rather small, pallid spots. Membrane pale fuscous; areoles and central area with clear spots; veins pale to fuscous. Legs pale to yellowish; apical two-thirds of hind femora dark red, with many large and small pallid spots, and an irregular, incomplete, pallid band at middle of apical half; a few black hairs arising from red area; spines on hind tibiae pallid, with reddish spot at base of each, except those spines at apex. Venter pale yellowish, with reddish dots on sides; base of genital segment fuscous; genital claspers and flagellum distinctive for species, fig. 179.

Female.-Length 5.10, width 1.77. Head width 0.86 , vertex 0.39 . Antennae, first segment, length 1.04; second, 2.55; third, 1.21; fourth, 1.04. Pronotum, length 0.85 , width at base 1.55. Larger and more robust than male, but very similar in coloration, although dorsum and membrane frequently with broader, light-colored areas.

Host Plant.-Bur oak (Quercus macrocarpa) and red oak (Q. rubra).

Known Distribution.-District of $\mathrm{Co}$ lumbia, Illinois, Minnesota, New York, Ohio.

Illinois Records.-Beverly Hills: Aug. 31, 1907, W. J. Gerhard, 2 q, FM. CARY: Aug. 27, 1905, W. J. Gerhard, 2 \%, FM. Fairfield: June 12, 1934, DeLong \& Ross, 1 o. Gibsonia: Oct. 2, 1934, Frison \& Ross, $1 \delta$. Golconda: June 22, 1932, on oak, Ross, Dozier \& Park, 1 ô. KeithsBURG: June 15, 1932, on red oak, H. L. Dozier, 1 ô. Shawnektown: June 23, 1936, DeLong \& Ross, $1 \hat{\delta}$. 


\section{Phytocoris 1uteolus Knight}

Phytocoris luteolus Knight (1923d, p. 649). Known only from Alabama and Connecticut; not taken in Illinois.

\section{MYRMECORINI}

\section{KEY TO GENERA}

Length of first antennal segment greater than width of head; scutellum not conically produced, fig. 180 ; dorsum with fine, short pubescence............

Paraxenetus, p. 209

Length of first antennal segment much less than width of head, only slightly greater than width of vertex; scutellum conically produced, fig. 181; dorsum, especially pronotum and scutellum, with long, erect hairs............. ............. Barberiella, p. 209

\section{Paraxenetus Reuter}

\section{Paraxenetus guttulatus (Uhler)}

Eucerocoris guttulatus Uhler (1887d, p. 150). MaLE.-Fig. 180. Length 6.40 , width at base of cuneus, 1.33 . Head width 1.00 , vertex 0.27 ; sulcus on median line of vertex. Rostrum, length 2.42 , extending slightly beyond posterior coxae or to second abdominal sternite. Antennae, first segment, length 1.46 ; second, 3.45 ; third, 2.85 ; fourth, 0.86 ; all segments slender, of nearly equal thickness, three basal ones yellowish to dusky brown, last segment reddish brown. Pronotum, length 0.95 , width at base 1.34. Emboliar margins strongly sulcate, or medially coarctate. General color fusco-grayish, tinged with fulvous, sometimes fulvous areas broad; cuneus, veins of membrane, and calli, fulvous to reddish; femora frequently fusco-reddish. Body clothed with recumbent, fine yellowish pubescence, femora rather sparsely set with long pilose hairs, these hairs longest on posterior pair.

Fenale.-Length 6.80 , width 1.51 . Head width 1.08 , vertex 0.39 . Antennae, first segment, length 1.51 ; second, 3.30 ; third, 2.94; fourth, 0.86 . Pronotum, length 1.08 , width at base 1.56. Very similar to male in form and coloration.

Host Plant.-Grape vines (Vitis sp.); one specimen collected in Illinois on walnut (Juglans nigra).
KNown Distribution.-District of Columbia, Illinois, Indiana, Iowa, Maryland, Mississippi, Missouri, New Jersey, New York, Pennsylvania, Texas, Virginia.

Illinois Records.-Collinsville: Aug. 14, 1899, McElfresh, 1 o. Danville: June 16, 1930, Frison \& Hottes, 1 . Dubols:

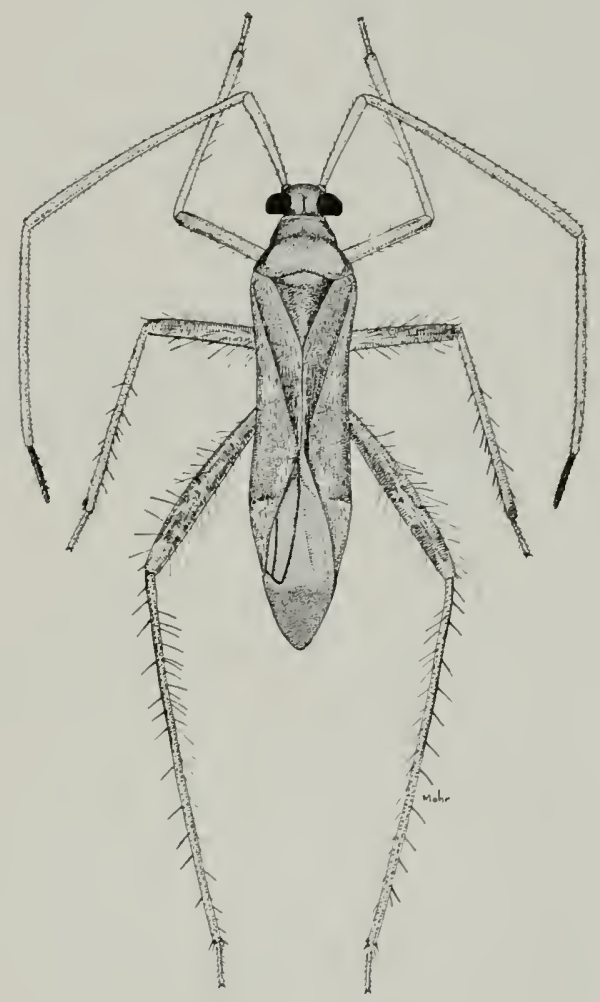

Fig. 180.- Paraxenetus guttulatus, $\sigma^{7}$.

July 3, 1909, 1 o . Graftox: July 20, 1932. on Juglans nigra, Ross \& Dozier, 1 ô. HAVANA: Aug. 15, 1907, Devil's Hole, 2 q. Herod: July 24, 1930, Knight \& Ross, 1 o . Quincy: Aug. 8, 1889, 3 \% ; Aug. 11, 1889, 1 . .

\section{Barberiella Poppius}

\section{Barberiella apicalis Knight}

Barberiella apicalis Knight (1923d, p. 657). This species, fig. 181, is more closely related to Fiebrigiella silzestri Poppius, described from Brazil, than to Barberiella formicoides Poppius, but differs from the former, at least, in the longer first antennal segment and in the shining, brownish and 
translucent apical area of the corium and embolium. The members of this genus are good ant mimics, and in their general aspect are very suggestive of the large species of Pilophorus.

MaLE.-Length 5.00, width 1.60. Head width 1.14 , vertex 0.43 ; head almost vertical; vertex and base of front distinctly impressed along median line but not grooved; head very dark brown, clothed with pale pubescence, this more prominent on front. Rostrum, length 1.99 , reaching bases of hind coxae, dark brown. Antennae, first segment, above ostiole. Hemelytra with emboliar margins strongly constricted at middle, disk nearly flat; cuneus strongly declivitous; clothed with moderately sparse, golden yellow pubescence interspersed with more nearly erect fine hairs, these more prominent on clavus; clavus dull fusco-brownish, a triangular pruinose field extending upon middle from corium; corium fuscous on basal half; a transverse pallid spot at middle; behind this a dark fusco-brownish area extending as far as a line drawn transversely through tip of clavus; apical area chiefly

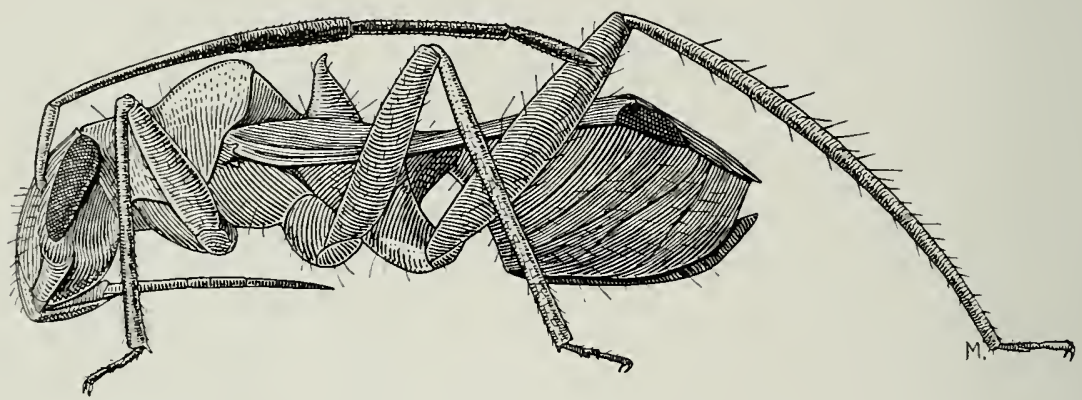

Fig. 181.-Barberiella apicalis, ㅇ․

length 0.52 , dark brown, with fine and dense pubescence and with two or three larger, erect hairs near apex, length of these less than thickness of segment; second, 2.03, cylindrical, slightly thicker than first segment, more slender near base, dark brown, with fine, dense pubescence; third, 1.11, slender, dark brown; fourth, 0.68, dark brown. Pronotum, length 1.24 , width at base 1.59 ; anterior angles 0.84 , anterior one-third nearly cylindrical to a point just behind calli, from thence flaring to posterior margin, but margin nearly a straight line; disk strongly convex; calli much reduced and with two impressed points between; very dark brown, darker anteriorly; surface leathery with pale pubescence and sparsely interspersed with erect, pilose hairs. Scutellum conically produced; point bent over and directed to the rear, fig. 181 ; sparsely set with long, pilose hairs; much of mesoscutum exposed, sloping downward to base of scutellum from which it is not distinctly separated; dark brown, moderately shining. Sternum and pleura dark brown; posterior half of epimeron white; ostiolar peritreme dark brown, with a protuberant point just pale brownish, somewhat translucent and shining, pruinose bordering the transverse dark band; cuneus uniformly brownish and translucent; membrane uniformly fuscobrownish, veins slightly darker. Legs uniformly dark brown, hind coxae with a pale or yellowish, opaque spot at antero-lateral angle; femora with coarse, leathery surface, sparsely clothed with erect, pale hairs; hind tibiae compressed, strongly curved, beset with yellow, spinelike hairs; tarsi fuscous, brownish at base. Venter black with a tinge of brown, moderately shining; strongly constricted at base, a pale mark on side just beneath that of corium; venter sparsely set with erect, pale hairs.

Female.-Length 5.50, width before base of cuneus 1.59. Very similar to male in form and coloration; abdomen broader at apex. Head width 1.32 , vertex 0.58 . Antennae, first segment, length 0.54 ; second, 2.10 , slender on basal half, clavate at apex $(0.11$ thick), exceeding thickness of first segment.

Known Distribution.-Illinois, Mississippi, New York, North Carolina.

Illinois Record.-ShawneEtows: June 27, 1936, DeLong \& Mohr, 1 ․ 


\section{HOST LIST}

Most species of Miridae are restricted to a single host plant or to a few closely related plants. Notable exceptions include the tarnished plant bug, Lygus oblineatus (Say), which may be found on almost any plant, and Plagiognathus politus Uhler, which occurs on a great many herbaceous plants. Both are so common and so diverse in their feeding habits that, to prevent repetition, neither is included under the various hosts in the following list. A number of mirids are predacious, but are associated with definite species of plants; in this list such mirids are indicated by an asterisk $\left(^{*}\right)$. Other species are possibly or probably pre-

\section{Acer negundo}

†Paracalocoris scrupeus (Say), 177

Plagiognathus negundinis Knight, 33 Acer rubrum

Coccobaphes sanguinareus Uhler, 138

Neolygus vitticollis (Reuter), 162 Acer saccharinum

Neolygus vilticollis (Reuter), 162 Acer saccharum

Coccobaphes sanguinareus Uhler, 139

Microphylellus elongatus Knight, 42

Neolygus hirticulus (Van Duzee), 163

Neolygus vitticollis (Reuter), 162

†Phytocoris corticevivens (Knight), 186 Acer spicatum

Neolygus belfragii (Reuter), 162 Acer sp.

*Deraeocoris nebulosus (Uhler), 67

+Diaphnidia pellucida Uhler, 92

*Phytocoris conspurcatus Knight, 188 Achillea millefolium

Lopidea heidemanni Knight, 88 Achillea sp.

$\ddagger$ Adelphocoris rapidus (Say), 174 Agropyron repens

Capsus ater (Linnaeus), 138

Alder; see Alnus

Alder, smooth; see Alnus rugosa

Alder, speckled; see Almus incana

Alfalfa; see Medicago sativa

Allium canadense

Labopidea allii Knight, 105

\section{Allium cepa}

Labopidea ainsliei Knight, 105

Labopidea allii Knight, 105

\section{Allium cernuwm}

Labopidea ainsliei Knight, 105

Labopidea allii Knight, 105

Alnus incana

†Deraeocoris alnicola Knight, 70

Neolygus alni Knight, 157

Alnus rugosa

*Ceratocapsus decurvatus Knight, 116

Ceratocapsus incisus Knight, 113

Ceratocapsus modestus (Uhhler), 111

*Deraeocoris poecilus (McAtee), 67

Neolygus clavigenitalis Knight, 163

* Mirid predacious, but associated with the plant under which it is listed.

$+\mathrm{Mirid}$ possibly or probably predacious, but associated with the plant under which it is listed.

\pm Mirid probably associated with the plant under which it is listed, but exact relationship of plant and mirid not demonstrated. dacious, at least in part, but are associated with definite plants; these are indicated by a dagger $(\dagger)$. Still other species have been collected on particular species of plants in sufficient numbers to make it probable that those plants are the food plants of the mirids, but the exact relationship existing between the mirids and the plants under which they are listed has not been demonstrated. Such species are indicated by a double dagger $(\ddagger)$. In species of Miridae not indicated by asterisk or dagger, the host relationship of the mirid and the plant species under which it is listed has been definitely established.

Psallus alnicola Douglas and Scott, 4

Psallus fuscotus Knight, 41

Alnus sp.

$\dagger$ Deraeocoris borealis (Van Duzee), 71

†Diaphnidia pellacida Uhler, 92

+ Plagiognathus similis Knight, 37 Alihaea rosea

Melanotrichus althaeae (Hussey), 96 Ambrosia trifida

Lygus plagiatus Uhler, 153

Ambrosia sp.

Chlamydatus associatus (Uhler), 25

Chlamydatus suavis (Reuter), 26

Ilnacora malina (Uhler), 83

†Plagiognathus blatchleyi Reuter, 35

Plagiognathus nigronitens $\mathrm{K}$ night, 30

Plagiognathus politus Uhler, 29

Reuteroscopus ornatus (Reuter), 48

Reuteroscopus sulphureus (Reuter), 49

Amorpha canescens

Lopidea instabilis (Reuter), 91

Psallus amorphae Knight, 44 Amorpha fruticosa

Lopidea amorphae Knight, 90

Psallus amorphae Knight, 44

Anthemis cotula

Polymerus basalis (Reuter), 167

Apium graveolens

Lygus campestris (Linnaeus), 154

Apple; see Pyrus malus

Arbor vitae; see Thuja occidentalis

Arrow-wood; see Viburnum

Artemisia canadensis

Lygus atritibialis Knight, 152

Psallus bakeri (Bergroth), 45

Artemisia sp.

Psallus bakeri (Bergroth), 45

Artichoke; see Helianthus tuberosus

Arundinaria tecta

*Phytocoris arundinicola Knight, 198 Asclepias sp.

¥Inacora divisa Reuter, 83

Macrolophus brevicornis Knight, 55

Ash; see Fraxinus

Ash, black; see Fraxinus nigra

Ash, red; see Fraxinus pennsyluanica

Ash, white; see Fraxinus americana

Aspen, American; see Populus tremuloia

Aspidium spinulosum

Monalocoris filicis (Linnacus), 58

Aster, golden; see Chrysopsis

Aster macrophyllus

Microphylellus nigricornis Knight, 41 
Aster, New England; see Aster novae-angliae Aster novae-angliae

Macrotylus amoenus Reuter, 51

Aster, prairie; see Aster sericeus

Aster sericeus

Psallus astericola Knight, 45

Aster umbellatus

Polymerus opacus Krnight, 170

Aster undulatus

Macrotylus sexguttatus (Provancher), 51 Aster sp.

Dicyphus discrepans Knight, 54

Plagiognathus cuneatus Knight, 34

Avena sativa

Trigonotylus ruficornis (Geoffroy), 130

Balm of Gilead; see Populus candicans

Basswood; see Tilia americana

Bean; see Phaseolus

Bedstraw; see Galium aparine

Bedstraw, northern; see Galium boreale

Beech; see Fagus

Beech, blue; see Carpinus caroliniana

Beech, water; see Carpinus caroliniana

Beet, cultivated; see Beta vulgaris

Beet, sugar; see Beta vulgaris

Beta vulgaris

$\ddagger$ Chlamydatus associatus (Uhler), 25

Betula lutea

†Deraeocoris betulae Knight, 70

Neolygus fagi Knight, 161

Orthotylus necopinus Van Duzee, 103

Betula nigra

$\ddagger$ Ceratocapsus pumilus (Uhler), 112

* Deraeocoris poecilus (McAtee), 67

$\ddagger$ Lopidea media (Say), 89

$\$$ Phytocoris confluens Reuter, 205

$\$$ Phytocoris puella Reuter, 207

$\$$ Plagiognathus atricornis Knight, 35

Plagiognathus similis Knight, 37

Betula pumila

Psallus parshleyi Knight, 44

Betula sp.

$\ddagger$ Plagiognathus politus Uhler, 29

Birch; see Betula

Birch, red; see Betula nigra

Birch, yellow; see Betula lutea

Blackberry; see Rubus

Bladder nut, American; see Staphylea trifolia

Bluegrass; see Poa pratensis

Bluegrass, Canada; see Poa compressa

Box elder; see Acer negundo

Brassica nigra

Campylomma verbasci (Meyer), 25

Bromus inermis

Capsus simulans (Stål), 138

Burning bush; see Evonymus atropurpureus

Butternut; see Fuglans cinerea

Buttonbush; sec Cephalanthus occidentalis

Calamagrostis canadensis

Collaria meilleurii Provancher, 126

Cane, switch; see Arundinaria tecta

Carex vesicaria

Teratocoris paludum J. Sahlberg, 128

Carex sp.

Teratocoris discolor Uhler, 128

Carpinus caroliniana

Ceratocapsus incisus Knight, 113

Neolygus carpini, Knight, 164

Neolygus johnsoni Knight, 162

* Phytocoris canadensis Van Duzee, 193

* Phytocoris erectus Van Duzee, 199

†Phytocoris lacunosus Knight, 197
Reuteria fuscicornis Knight, 94

Carya illinoensis

Neolygus caryae Knight, 161

Orthotylus ramus Knight, 100

$\dagger$ Phytocoris albifacies Knight, 186

Plagiognathus caryae Knight, 38

Carya ovata

Neolygus caryae Knight, 161

$\ddagger$ Neolygus quercalbae Knight, 160

Plagiognathus caryae Knight, 38

Carya sp.

Ceratocapsus fasciatus (Uhler), 109

†Ceratocapsus nigellus Knight, 111

+Deraeocoris grandis (Uhler), 71

$\dagger$ Eustictus venatorius Van Duzee, 66

\$Microphylellus modestus Reuter, 41

Orthotylus ramus Knight, 100

$\ddagger$ Paracalocoris scrupeus (Say), 177

Phytocoris caryae Knight, 207

Phytocoris infuscatus Reuter, 204

Phytocoris onustus Van Duzee, 194

Plagiognathus dispar Knight, 39

$\ddagger$ Plagiognathus politus Uhler, 29

Castanea sp.

Neolygus hirticulus (Van Duzee), 63

Neolygus omnivagus Knight, 163

Caulophyllum thalictroides

Horcias dislocatus (Say), 173

Cedar, red; see Funiperus virginiana

Celery; see Apium graveolens

Celtis occidentalis

Paracalocoris celtidis Knight, 179

Cephalanthus occidentalis

Neurocolpus nubilus (Say), 182

* Phytocoris canadensis Van Duzee, 193

Chenopodium album

Melanotrichus flavosparsus (Sahlberg), 96

$\ddagger$ Reuteroscopus ornatus (Reuter), 48

$\Varangle$ Reuteroscopus sulphureus (Reuter), 49

Chestnut; see Castanea

Chrysanthemum leucanthemum

Plagiognathus chrysanthemi (Wolff), 31

Chrysanthemum sp.

tLopidea confluenta (Say), 87

+ Polymerus basalis (Reuter), 167

+ Psallus seriatus (Reuter), 45

Chrysopsis villosa

Polymerus chrysopsis Knight, 171

Clematis virginiana

Halticus intermedius Uhler, 77

Clover; see Trifolium, Melilotus

Clover, prairie; see Petalostemum purpureum

Clover, red; see Trifolium pratense

Clover, sweet; see Melilotus

Clover, white; see Trifolium repens

Cocklebur; see Xanthium

Coltsfoot; see Tussilago farfara

Conium maculatum

Lygus campestris (Linnaeus), 154

Coralberry; see Symphoricarpos orbiculatus

Coreopsis sp.

$\ddagger$ Polymerus basalis (Reuter), 167

Cornus alternifolia

Neolygus communis Knight, 159

Cornus amomum

Plagiognathus cornicola Knight, 38

Cornus paniculata

Neolygus communis Knight, 159

Cornus stolonifera

Neolygus communis Knight, 159

Cornus stricta

Plagiognathus cornicola Knight, 38 
Cornus sp.

Neolygus omnivagus Knight, 163

¥Paracalocoris scrupeus (Say), 177

Corylus americana

Microphylellus longirostris Knight, 42

$\ddagger$ Microphylellus modestus Reuter, 41

Corylus sp.

†Ceratocapsus pilosulus Knight, 109

$\$$ Lopidea media (Say), 89

$\ddagger$ Plagiognathus politus Uhler, 29

Cotton; see Gossypium herbaceum

Cottonwood; see Populus

Crabapple; see Pyrus coronaria

Cranberry; see Vaccinium

Crataegus mollis

$\ddagger$ Microphylellus modestus Reuter, 41

Crataegus punctata

Orthotylus serus Van Duzee, 102

Crataegus tomentosa

Orthotylus serus Van Duzee, 102

Crataegus sp.

*Deraeocoris fasciolus K night, 70

†Deraeocoris quercicola Knight, 71

Diaphnidia pellucida Uhler, 92

Heterocordylus malinus Reuter, 107

Lygidea mendax Reuter, 146

Neolygus univittatus Knight, 160

Paracalocoris pallidulus McAtee, 178

Paracalocoris scrupeus (Say), 177

Plagiognathus dispar Knight, 39

Croton capitatus

Psallus seriatus (Reuter), 45

Croton texensis

Psallus seriatus (Reuter), 45

Croton sp.

Psallus seriatus (Reuter), 45

Cudweed; see Gnaphalium uliginosum

Cup plant; see Silphium perfoliatum

Currant; see Ribes

Cydonia oblonga

Lygidea mendax Reuter, 146

Cynodon dactylon

Trigonotylus brevipes Jakovlev, 129

Cypress, bald; see Taxodium distichum

Dactylis glomerata

Stenotus binotatus (Fabricius), 175

Daisy; see Chrysanthemum

Daisy, oxeye; see Chrysanthemum leucanthemum

Dock, see Rumex

Dog fennel; see Anthemis cotula

Dogwood; see Cornus

Elder; see Sambucus

Elm; see Ulmus

Elm, American; see Ulmus americana

Erigeron canadensis

Lygus apicalis Fieber, 154

Erigeron sp.

¥Lygus plagiatus Uhler, 153

Euphorbia adenoptera

Semium hirtum Reuter, 75

Euphorbia humistrata

Semium hirtum Reuter, 75

Evonymus atropurpureus

Paracalocoris evonymi Knight, 178

Fagus grandifolia

Neolygus fagi Knight, 161

Fagus sp.

Neolygus hirticulus (V'an Duzee), 163

Fern, cinnamon; see Osmunda cinnamonea

Fern, shield, see Aspidium spinulosum

Ferns (undifferentiated)

Ceratocapsus setosus Reuter, 115
Figwort, see Scrophularia leporella

Fleabane; see Erigeron

Foxglove, false; see Gerardia pedicularia

Fraxinus americana

Neoborus amoenus (Reuter), 140

Neoborus canadensis (Van Duzee), 141

Neoborus geminus (Say), 140

Neoborus glaber Knight, 140

Neoborus palmeri Reuter, 141

Neoborus pubescens Knight, 141

Neoborus rufusculus Knight, 143

Neoborus vittiscutis Knight, 143

Tropidosteptes cardinalis Uhler, 139

Xenoborus pettiti (Reuter), 145

Fraxinus nigra

Xenoborus conmissuralis Reuter, 144

Xenoborus neglectus Knight, 144

Xenoborus plagifer (Reuter), 144

Fraxinus pennsylvanica

Neoborus amoenus (Reuter), 140

Fraxinus sp.

†Lopidea media (Say), 89

Neoborus spp., 139

Neolygus hirticulus (Van Duzee), 163

$¥$ †lagiognathus dispar Knight, 39

Pseudoxenetus scutellatus (Uhler), 118

Xenoborus spp., 143

Gale, sweet; see Myrica gale

Galium aparine

Criocoris saliens (Reuter), 49

¥Lopidea heidemanni Knight, 88

Polymerus proximus Knight, 168

Galium boreale

Polynerus unifasciatus (Fabricius), 167

Garlic, wild; see Allium canadense

Geranium maculatum

Horcias dislocatus (Say), 173

Gerardia pedicularia

Macrolophus separatus (Uhler), 55

Gleditsia triacanthos

†Lopidea heidemanni Knight, 88

Lopidea incurva Knight, 88

Neolygus tinctus Knight, 157

Paracalocoris gleditsiae Knight, 180

Pilophorus walshii Uhler, 123

Plagiognathus delicatus (Uhler), 37

Plagiognathus gleditsiae Knight, 37

Gnaphalium uliginosum

Melanotrichus catulus (Van Duzee), 97

Goldenrod; see Solidago

Gooseberry; see Ribes

Gooseberry, prickly; see Ribes cynosbati

Goosegrass; see Galium aparine

Gossypium herbaceum

Lygus hesperus Knight, 151

Psallus seriatus (Reuter), 46

Grape; see Vitis

Grape, muscadine; see I'itis rotundifolia

Grass, Bermuda; see Cynodon dactylon

Grass, bluejoint; see Calamagrostis canadensis

Grass, brome; see Bromus inermis

Grass, couch; see Agropyron repens

Grass, orchard; see Dactylis glomeratn

Grass, panic; see Panicum huachucae

Grass, quack; see Agropyron repens

Grass, slough; see Spartina michauxiana

Grasses (undifferentiated)

Capsus ater (Linnaeus), 138

Collaria meilleurii Provancher, 126

Collaria oculata (Reuter), 127

Miris dolabratus (Linnaeus), 127

Stenodema trispinosum Reuter, 130 
Stenodema vicinum (Provancher), 130

Trigonotylus ruficornis (Geoffroy), 130 Gum, black; see Nyssa sylvatica

Gum, sour; see Nyssa

Gymnocladus dioica

+ Neurocolpus nubilus (Say), 182

Hackberry; see Celtis occidentalis

Hamamelis virginiana

Diaphnidia capitata Van Duzee, 92

Lopidea reuteri Knight, 91

Hamulus japonicus

Paracalocoris hawleyi Knight, 178

Hawthorn; see Crataegus

Hazelnut; see Corylus

Helianthus tuberosus

Ilnacora stalii Reuter, 84

+ Polymerus basalis (Reuter), 167

Helianthus sp.

Ilnacora stalii Reuter, 84

$\ddagger$ Melanotrichus-flavosparsus (Sahlberg), 96

Plagiognathus nigronitens Knight, 30

Hemlock; see Tsuga canadensis

Hemlock, poison; see Conium maculatum

Heracleuin lanatum

$\ddagger$ Lygus campestris (Linnaeus), 154

Hickory; see Carya

Hellyhock; see Althaea rosea

Hup tree; see Ptelea trifoliata

Hops; see Hamulus japonicus

Hornbeam, American; see Carpinus caroliniana

Hornbeam, hop; see Ostrya virginiana

Horseweed; see Ambrosia trifida

Ilex verticillata

Neolygus communis Knight, 159

Impatiens biflora

Lygus pabulinus (Linnaeus), 153

Indigo, false; see Amorpha fruticosa

Juglans cinerea

Plagiognathus albatus (Van Duzee), 36

Plagiognathus repletus Knight, 38

Fuglans nigra

†Cratocapsus uniformis Knight, 113

$\ddagger$ Diaphnidia pellucida Uhler, 92

*Phytocoris conspurcatus Knight, 188

Plagiognathus albatus (Van Duzee), 36

Plagiognathus punctatipes Knight, 39

Plagiognathus repletus Knight, 38

Funcus dudleyi

Lopus decolor (Fallen), 51

Funcus sp.

Lopus decolor (Fallen), 51

Mimoceps insignis Uhler, 125

Funiperus virginiana

Dichrooscytus tinctipennis Knight, 165

Dichrooscytus viridicans Knight, 165

Parthenicus juniperi (Heidemann), 76

Phytocoris junipericola Knight, 201

†Pilophorus juniperi Knight, 123

Kentucky coffee tree; see Gymnocladus dioica

Lamb's quarter; see Chenopodium album

Larch; see Larix laricina

Larix laricina

$\dagger$ Deraeocoris laricicola Knight, 73

†Pilophorus uhleri Knight, 122

Plagiognathus laricicola Knight, 39

Lathyrus venosus

Lopidea lathyri Knight, 91

Lead plant; see Amorpha canescens

Leafcup; see Polymnia canadensis

Linden; see Tilia americana

Locust; see Robinia pseudoacacia, Gleditsia triacanthos
Locust, black; see Robinia pseudoacacia

Locust, honey; see Gleditsia triacanthos

Loosestrife; see Lysimachia quadrifolia

Lycopersicon esculentum

Cyrtopeltis varians (Distant), 53

Lysimachia quadrifolia

Polymerus punctipes Knight, 169

Mallow; see Malva rotundifolia

Malva rotundifolia

Melanotrichus althaeae (Hussey), 96

Maple; see Acer

Maple, mountain; see Acer spicatum

Maple, red; see Acer rubrum

Maple, silver; see Acer saccharinum

Maple, sugar; see Acer saccharum

Meadow-sweet; see Spiraea salicifolia

Medicago sativa

Adelphocoris lineolatus (Goeze), 175

Lygus elisus Van Duzee, 152

Lygus hesperus Knight, 151

Melilotus sp.

Adelphocoris lineolatus (Goeze), 175

Adelphocoris rapidus (Say), 174

Milkweed; see Asclepias sp.

Mint, horse; see Monarda punctata

Mint, mountain; see Pycnanthemum sp.

Monarda punctata

$\ddagger$ Psallus seriatus (Reuter), 45

Mullein; see Verbascum

Mustard, black; see Brassica nigra

Myrica gale

Plagiognathus flavicornis Knight, 30

Nannyberry, see Viburnum lentago

Nyssa sylvatica

Lepidopsallus nyssae Johnston, 48

Nyssa sp.

Neolygus nyssae Knight, 164

Oak; see Quercus

Oak, blackjack; see 2uercus marilandica

Oak, bur; see 2uercus macrocarpa

Oak, live; see Quercus virginiana

Oak, post; see Quercus stellata

Oak, red; see Quercus rubra

Oak, scarlet; see Quercus coccinea

Oak, white; see 2uercus alba

Oak, yellow; see Quercus muhlenbergii

Oats; see Avena sativa

Onion, cultivated; see Allium cepa

Onion, wild; see Allium cernuum

Osmunda cinnamonea

Monalocoris flicis (Linnaeus), 58

Ostrya virginiana

$\ddagger$ Ceratocapsus pilosulus Knight, 109

Diaphnidia pellucida Uhler, 92

Neolygus ostryae Knight, 164

Reuteria fuscicornis Knight, 94

Panicum huachucae

Collaria oculata (Reuter), 127

Papoose root; see Caulophyllum thalictroides

Parsnip; see Pastinaca sativa

Parsnip, cow; see Heracleum lanatum

Pastinaca sativa

$\ddagger$ Lygus campestris (Linnaeus), 154

Pea, hoary; see Tephrosia sp.

Peach; see Prunus persica

Pear; see Pyrus communis

Pecan; see Carya illinoensis

Petalostemum purpureum

Lopidea minor Knight, 88

Phaseolus sp.

Halticus bracteatus (Say), 77

Lygus elisus Van Duzee, 152 
Lygus hesperus Knight, 151 †Opistheuria clandestina Van Duzee, 131 Phieum pratense Capsus ater (Linnaeus), 138

Miris dolabratus (I.innaeus), 127

$\ddagger$ Stenotus binotatus (Fabricius), 175

Phlox sp.

+Lopidea confluenta (Say), 87

Lopidea davisi Knight, 87

Picea excelsa

${ }_{\ddagger}$ Phytocoris buenoi Knight, 197

Picea mariana

Plagiognathus suffuscipennis Knight, 40

Picea sp.

Psallus piceicola Knight, 44

Pine; see Pinus

Pine, Austrian; see Pinus nigra var. austriaca

Pine, pitch; see Pinus rigida

Pine, red; see Pinus resinosa

Pine, Scotch; see Pinus sylestris

Pine, scrub; see Pinus virginiana

Pine, Virginia; see Pinus virginiana

Pine, white; see Pinus strobus

Pine, yellow, see Pinus echinata

Pinus echinata

$\dagger$ Eustictus flicornis (Walker), 66

Pinus nigra var. austriaca

Alepidia gracilis (Uhler), 119

Pinus resinosa

Alepidia gracilis (Uhler), 119

Dichrooscytus suspectus Reuter, 166

Phytocoris pinicola Knight, 201

*Pilophorus vanduzeei Knight, 120

Pinus rigida

Phytocoris uniformis Knight, 201

Pinus strobus

$\dagger$ Deraeocoris nubilus Knight, 69

*Deraeocoris pinicola Knight, 73

Phytocoris diversus Knight, 200

Phytocoris fulvus Knight, 201

$\dagger$ Pilophorus strobicola Knight, 122

Platylygus luridus (Reuter), 147

Psallus strobicola Knight, 45

Pinus sylvestris

Alepidia gracilis (Uhler), 119

Dichrooscytus rufipennis (Fallen), 166

Phytocoris pinicola Knight, 201

†Pilophorus strobicola Knight, 122

$\dagger$ Pilophorus whleri Knight, 122

*Pilophorus vanduzeei Knight, 120

Pinus virginiana

Alepidiella heidemanni Poppius, 119

†Deraeocoris nigritulus Knight, 73

Dichrooscytus suspectus Reuter, 166

Phytocoris conspersipes Reuter, 201

Phvtocoris mundus Reuter, 201

Pilophorus amoenus Uhler, 122

Pilophorus laetus Van Duzee, 121

Pinus sp.

Deraeocoris albigulus Knight, 73

¥Largidea grossa Van Duzee, 63

Phytocoris angustifrons Knight, 201

Plantago aristata

$\ddagger$ Lepidopsallus rubidus (Uhler), 47

$\ddagger$ Polymerus basalis (Reuter), 167

Plantago lanceolata

Halticus bracteatus (Say), 77

Plantain; see Plantago aristata

Platanus occidentalis

Plagiognathus albatus (Van Duzee), 36

Reuteria platani Knight, 95

Poa compressa
Capsus ater (Linnaeus), 138

Poa pratensis

Miris dolabratus (Linnaeus), 127

Polygonum muhlenbergii

$\dagger$ Deraeocoris histrio (Reuter), 69

Polygonum sp.

$\$$ Garganus fusiformis (Say), 181

$\$$ Lygus plagiatus Uhler, 153

Polymnia canadensis

Dicyphus gracilentus Parshley, 54

Lopidea confluenta (Say), 87

Macrolophus tenuicornis Blatchley, 56

Plagiognathus albifacies Knight, 35

Polvmnia uvedalia

Lopidea confluenta (Say), 87

Polymnia sp.

Macrolophus separatus (Uhler), 55

Poplar; see Populus

Poplar, balsam; see Populus balsamifera

Populus balsamifera

Lopidea cuneata Van Duzee, 89

Orthotylus knighti Van Duzee, 102

Populus candicans

Orthotylus knighti Van Duzee, 102

Populus deltoides

†Diaphnidia pellucida Uhler, 92

Lopidea cuneata Van Duzee, 89

Neolygus hirticulus (Van Duzee), 163

$\ddagger$ Neurocolpus nubilus (Say), 182

Populus tremuloides

+ Eustictus necopinus Knight, 66

Orthotylus candidatus Van Duzee, 102

Populus sp.

Neoborus populi Knight, 142

Potato; see Solanum tuberosum

Prunus persica

Neolygus caryae Knight, 162

$\ddagger$ Neolygus quercalbae Knight, 160

Psedera quinquefolia

Paracalocoris castus Mcttee, 178

Psedera sp.

Neolygus hirticulus (Van Duzee), 163

Ptelea trifoliata

$\Varangle$ Paracalocoris scrupeus (Say), 177

Pycnanthemum sp.

$\ddagger$ Phytocoris tibialis Reuter, 205

Pyrus communis

Neolygus communis Knight, 159

*Phytocoris conspurcatus Knight, 188

Pyrus coronaria

Lygidea mendax Reuter, 146

Pyrus malus

Campylomma verbasci (Meyer), 25

*Deraeocoris fasciolus Knight, 70

Diaphnidia pellucida Uhler, 92

* Eurychilopterella luridula Reuter, 73

Heterocordylus malinus Reuter, 107

Lygidea mendax Reuter, 146

Paracalocoris pallidulus McAtee, 178

* Phylocoris breviusculus Reuter, 190

* Phytocoris conspurcalus Knight, 188

*Phytocoris neglectus Knight, 191

Plagiognathus politus Uhler, 29

ouercus alba

$\uparrow$ Deraeocoris quercicola Knight, 7

Diaphnidia provancheri (Burque), 92

Microphylellus maculipennis Knight, 41

+ Microphylellus modestus Reuter, 41

Neolygus geneseensis Knight, 159

Neolygus omnivagus Knight, 163

Neolygus quercalbae Knight, 160

Neolygus semivittatus Knight, 163 
+ Peritropis husseyi Knight, 62 Pseudoxenetus regalis (Uhler), 119

Pseudoxenetus scutellatus (Uhlcr), 119

Quercus coccinea

Neolygus omnioagus Knight, 163

Quercus macrocarpa

†Ceratocapsus pilosulus Knight, 109

*Deraeocoris nebulosus (Uhler), 67

+Deraeocoris quercicola Knight, 72

$\dagger$ Hyaliodes brevis Knight, 58

Phytocoris depictus Knight, 208

Phytocoris quercicola Knight, 203

$\dagger$ Phytocoris sulcatus Knight, 190

Plagiognathus nigrolineatus Knight, 35 Reuteria querci Knight, 95

Quercus marilandica

†Pseudoxenetus regalis (Uhler), 119

Quercus muhlenbergii

Pseudoxenetus scutellatus (Uhler), 118

Quercus rubra

Neolygus omnivagus Knight, 163

Phytocoris depictus Knight, 208

$¥$ Pseudoxenetus regalis (Uhler), 119

Pseudoxenetus scutellatus (Uhler), 118

Quercus stellata

Lepidopsallus miniatus Knight, 48

Neocapsus cuneatus Distant, 147

Neolygus geneseensis Knight, 159

Quercus virginiana

Pseudoxenetus regalis (Uhler), 119

Quercus sp.

Ceratocapsus modestus (Uhler), 111

$\dagger$ Deraeocoris sayi (Reuter), 73

+Diaphnidia pellucida Uhler, 92

$\ddagger$ Phytocoris confluens Reuter, 205

$¥$ Phytocoris puella Reuter, 207

$\uparrow$ Pilophorus clavatus (Linnaeus), 124

Plagiognathus guttulosus (Reuter), 40

†Plagiognathus politus Uhler, 29

Quince; see Cydonia oblonga

Ragweed; see Ambrosia

Ragweed, giant; see Ambrosia trifida

Raspberry; see Rubus odoratus

Rhus aromatica

Platytylellus fraternus Knight, 134

Ribes cynosbati

$\ddagger$ Phytocoris tittatus Reuter, 190

Ribes oxyacanthoides

Horcias fallax Reuter, 173

Ribes sp.

Paracalocoris colon (Say), 180

* Phytocoris canadensis Van Duzee, 193

Poecilocapsus lineatus (Fabricius), 172

Robinia pseudoacacia

¥Diaphnidia pellucida Uhler, 92

+Lepidopsallus rubidus (Uhler), 47

Lopidea robiniae (Uhler), 89

Orthotylus robiniae Johnston, 100

Orthotylus submarginatus (Say), 103

Paracalocoris gleditsiae Knight, 180

$\ddagger$ Plagiognathus politus Uhler, 29

Rosa sp.

Plagiognathus rosicola Knight, 36

Rubus odoratus

Dicyphus agilis (Uhler), 53

Dicyphus famelicus (Uhler), 54

Rubus sp.

$\ddagger$ Phytocoris breviusculus Reuter, 190

Rumex sp.

Adelphocoris rapidus (Say), 174

Poecilocapsus lineatus (Fabricius), 172

Rushes; see Funcus
Sagebrush; see Artemisia

Salix amygdaloides

*Ceratocapsus fuscinus Knight, 116

Lygidea salicis Knight, 146

Lygus rubicundus (Fallen), 153

Salix fragilis

Orthotylus modestus Van Duzee, 104

Orthotylus ornatus Van Duzee, 103

Salix longifolia

Lygidea rosacea Reuter, 145

Orthotylus basicornis Knight, 102

Paracalocoris salicis Knight, 177

Phytocoris rubellus Knight, 202

Plagiognathus flavoscutellatus Knight, 32

Plagiognathus salicicola Knight, 36

Plagiognathus tinctus Knight, 31

Salix nigra

*Ceratocapsus fuscinus Knight, 115

Lopidea salicis Knight, 89

Lygidea obscura Reuter, 145

Orthotylus modestus Van Duzee, 104

Orthotylus neglectus Knight, 105

Orthotylus viridis Van Duzee, 101

* Phytocoris salicis Knight, 196

Salix syrticola

Plagiognathus syrticolae Knight, 31

Salix sp.

Ceratocapsus incisus Knight, 113

Ceratocapsus pumilus (Uhler), 112

†iaphnidia pellucida Uhler, 92

† Eustictus salicicola Knight, 66

Lepidopsallus rubidus (Uhler), 47

¥Lopidea heidemanni Knight, 88

$\$$ Lopidea media (Say), 89

Lygus atritylus Knight, 157

$\ddagger$ Lygus plagiatus Uhler, 153

Microsynamma bohemanni (Fallen), 42

$\ddagger$ Neurocolpus nubilis (Say), 182

$¥$ Opistheuria clandestina Van Duzee, 131

Orthotylus dorsalis (Provancher), 100

Orthotylus rossi Knight, 102

\pm Paracalocoris scrupeus (Say), 177

* Phytocoris conspurcatus Knight, 188

* Phytocoris erectus Van Duzee, 199

Pilophorus brunneus Poppius, 123

$\$$ Plagiognathus politus Uhler, 29

$\ddagger$ Platytylellus rubrovittatus (Stål), 133

$\ddagger$ Polymerus venustus Knight, 170

Sambucus sp.

$\ddagger$ Neurocolpus jessiae Knight, 183

Scirpus sp.

Teratocoris discolor Uhler, 128

Scrophularia leporella

Horcias dislocatus (Say), 173

$\ddagger$ Platytylellus rubellicollis Knight, 136

Sedges, see Carex, Funcus, Scirpus

Sheepberry; see Viburnum lentago

Sida spinosa

Reuteroscopus sulphureus (Reuter), 49

Silphium perfoliatum

Strongylocoris hirtus Knight, 80

Smartweed; see Polygonum

Smilacina racemosa

Horcias dislocatus (Say), 173

Snowberry; see Symphoricarpos orbiculatus

Solanum tuberosum

Poecilocapsus lineatus (Fabricius), 172

Solidago altissima

Polymerus venaticus (Uhler), 169

Strongylocoris breviatus Knight, 79

Solidago canadensis

Lygus vanduzeei Knight, 150 


\section{Solidago rugosa}

Lopidea media (Say), 89

Solidago sp.

Ilnacora malina (Uhler), 83

Plagiognathus politus Uhler, 29

Polymerus flavocostatus Knight, 168

Strongylocoris stygicus (Say), 79

Solomon's seal, false; see Smilacina racemosa

Spartina michauxiana

Trigonotylus tarsalis (Reuter), 129

Spiderwort; see Tradescantia

Spiraea salicifolia

Plagiognathus albonotatus Knight, 31

Spruce, black; see Picea mariana

Spruce, Norway; see Picea excelsa

Spurge; see Euphorbia

Staphylea trifolia

Lopidea siaphyleae Knight, 90

Sumach; see Rhus aromatica

Sunflower; see Helianthus

Sweet IVilliam; see Phlox

Sycamore; see Platanus occidentalis

Symphoricarpos orbiculatus

+Lopidea heidemanni Knight, 88

+ Plagiognathus politus Uhler, 29

$+P$ sallus seriatus (Reuter), 45

$\ddagger$ Reuteroscopus sulphureus (Reuter), 49

Tamarack; see Larix laricina

Taxodium distichum

Ceratocapsus taxodii Knight, 111

Orthotylus taxodii Knight, 101

Parthenicus taxodii Knight, 76

*Phytocoris erectus Van Duzee, 199

Phytocoris exemplus Knight, 201

Phytocoris taxodii Knight, 203

Pilophorus taxodii Knight, 121

†Plagiognathus politus Uhler, 29

Tephrosia sp.

Teleorhinus tephrosicola Knight, 52

Thuja occidentalis

Dichrooscylus tinctipennis Knight, 165

Dichrooscytus viridicans Knight, 165

Tickweed; see Coreopsis

Tilia americana

Ceratocapsus modestus (Uhler), 111

$¥$ Ceratocapsus rubricornis Knight, 109

*Deraeocoris nitenatus Knight, 72

Neolygus tiliae Knight, 161

Neurocolpus tiliae Knight, 182

* Phytocoris conspurcatus Kinght, 188

$\uparrow$ Phytocoris sulcatus Knight, 190

Plagiognathus sericeus (Heidemann), 34 Tilia sp.

$\dagger$ Deraeocoris quercicola Knight, 71

Timothy; see Phleum pratense

Tomato; see Lycopersicon esculentum

Touch-me-not; see Impatiens biflora

Tradescantia sp.

†Lopidea media (Say), 89

$\$$ Miris dolabratus (Linnaeus), 127

Trifolium pratense

$\ddagger$ Lopidea confluenta (Say), 87

Trifolium repens
Halticus bracteatus (Say), 77

Trifolium sp.

$¥$ Adelphocoris rapidus (Say), 1 it

Tsuga canadensis

Microphylellus isugae Knight, +2

Tupelo; see Nyssa

Tussilago farfara

Garganus fusiformis (Say), 181

Ulmus americano

Neolygus invitus (Say), 157

Reuteria irrorata (Say), 93

Clmus sp.

*Deraeocoris aphidiphagus Knight, 71

*Deraeocoris nitenatus Knight, 72

¥Diaphnidia pellucida Uhler, 92

+ Eurychilopierella luridula Reuter, 73

Lopidea heidemanni Knight, 88

+ Microphylellus modestus Reuter, 41

*Phytocoris conspurcatus Knight, 189

*Phytocoris cortitectus Knight, 196

$\dagger$ Phytocoris sulcatus K night, 190

I'accinium sp.

Plagiognathus repetitus Knight, 40

lerbascum sp.

Campylomma verbasci (Meyer), 25

lerbena stricta

Campvlomma verbasci (Meyer), 25

Vervain, hoary; see Verbena stricta

Vetchling; see Lathyrus zenosus

Viburnum acerifolium

Neolygus belfragii (Reuter), 162

I iburnum lentago

Lygidea viburni Knight, 145

Neolygus viburni Knight, 159

Viburnum sp.

Neolygus omnivagus Knight, 163

Virginia creeper; see Psedera quinquefolia

Virgin's bower; see Clematis virginiana

Vitis rotundifolia

Neolygus inconspicuus Knight, 161

Paracalocoris multisignatus Reuter, 180

Vitis sp.

Ceratocapsus modestus (Uhler), 111

Ceratocapsus pumilus (Uhler), 112

*Hyaliodes vitripennis (Say), 56

Paracalocoris scrupeus (Say), 177

Paraxenetus guttulatus (Uhler), 209

Waahoo; see Evonymus atropurpureus

Walnut; see Fuglans

Walnut, black; see Juglans nigra

Willow; see Salix

Willow, black; see Salix nigra

Willow, crack; see Salix fragilis

Willow, sand; see Salix syrticola

Willow, sandbar; see Salix longifolia

Willow, peach-leaved; see Salix amygdaloides

Winterberry; see Ilex verticillata

Witchhazel; see Hamamelis virginiana

Woodbine; see Psedera

Wormwood; see Artemisia canadensis

Xanthium sp.

Ilnacora stalii Reuter, 84

Yarrow; see Achillea 


\section{B IBLIOGRAPHY}

Ashmead, William $\mathrm{H}$.

1887. Hemipterological contributions. No. 1. Ent. Am, 3(8):155-6.

\section{Barber, Harry G.}

1914. New Hemiptera-Heteroptera, with comments upon the distribution of certain known forms. N. Y. Ent. Soc. Jour. 22(2):164-71.

\section{Bergroth, Ewald}

1898. Ueber einige amerikanische Capsiden. Wiener Entomologische Zeitung 17 (1) :33-5.

1920. List of the Cylapinae, with descriptions of Philippine forms. Annales de la Société Entomologique de Belgique $60: 67-83$.

Beyer, A. H.

1921. Garden flea-hopper in alfalfa and its control. U. S. Dept. Ag. Bul. 964. 27 pp., 14 figs.

Blatchley, W. S.

1926a. Some new Miridae from the eastern United States. Ent. News 37(6): 163-9.

1926b. Heteroptera or true bugs of eastern North America with especial reference to the faunas of Indiana and Florida. Nature Publishing Co., Indianapolis. $1116 \mathrm{pp}$.

\section{Brittain, W. $\mathbf{H}$.}

1917. The green apple bug in Nova Scotia. Nova Scotia Dept. Ag. Bul. 9. 70 pp., 6 pls.

\section{Burque, F. X.}

1887. Descriptions of certain species in Provancher 1886-90.

Cook, A. J.

1891. Kerosene emulsions. Mich. Ag. Exp. Sta. Bul. 76, p. 10.

\section{Distant, W. L.}

1880-93. Insecta. Rhynchota. HemipteraHeteroptera 1. Biologia CentraliAmericana. London. $\mathrm{xx}+462$ pp., 39 pls.

Douglas, John W., and John Scott

1865. The British Hemiptera 1. HemipteraHeteroptera. London. xii +627 pp., 21 pls.

1871. British Hemiptera: additions and corrections. Entomologist's Monthly Magazine 8(1):23-9; (3):60-3.

1875. British Hemiptera: additions and corrections. Entomologist's Monthly Magazine 12(5):100-2.

\section{Emmons, Ebenezer}

1854. Natural history of New York. Agriculture 5, Insects. Albany. viii +272 pp., $3+47$ pls.
Fabricius, Johann Christian

1794. Entomologia systematica 4. Hafniae. vi +472 pp.

1798. Supplementum entomologicae systematicae. Hafniae. $2+572$ pp.

\section{Fallen, Carl Friedrich}

1807. Monographia Cimicum Sueciae. Hafniae. $123 \mathrm{pp}$.

1828-29. Hemiptera Sueciae. Cimicides earumque familiae affines. London. iv +1-16 pp., 1828; 17-186 pp.. 1829.

\section{Fieber, Franz Xavier}

1859. Critirien zur generischen Theilung der Phytocoriden (Capsini aut.). Wiener Entomologische Monatschrift 2(10):289-327; (11):329-47. 6 pls.

1860-61. Fauna Austriaca, die europäischen Hemiptera. Halbflugler (RhynchotaHeteroptera). Nach der analytischen Methode bearbeitet. Wien. $16+108$ pp., 2 pls., 1860; 109-444, 1861.

\section{Fourcroy, Antoine Francois}

1785. Entomologia Parisiensis. Paris. 2 vols. 544 pp.

Fulton, B. B.

1918. Observations on the life-history and habits of Pilophorus walshii Uhler. Ent. Soc. Am. Ann. 11:93-6.

\section{Geoffroy, Etienne Louis}

1785. New species described in Fourcroy 1785.

\section{Gmelin, Johann Friedrich}

1790. Caroli a Linné systema naturae, thirteenth edition. Lipsiae. Tome 1, 4:2041-224.

Goeze, Johann A. E.

1778. Entomologische Beiträge zu des Ritter Linné Zwölften Ausgabe des Natursystems 2. Leipzig. $72+352$ pp.

Hahn, C. W., and G. A. W. Herrich-Schaeffer 1831-53. Die Wanzenartigen Insecten. Nürnberg. Vols. 1-3(p.32), 1831-35 by Hahn. Vols. 3(p. 33)-9, 1836-53 by Herrich-Schaeffer.

\section{Heidemann, Otto}

1892. Note on the food-plants of some Capsidae from the vicinity of Washington, D. C. Ent. Soc. W' ash. Proc. $2: 22+-6$.

1905. A list of Capsids from the state of New York, with the description of a new species. N. Y. Ent. Soc. Jour. $13(1): 48-50$.

Hottes, Frederick C., and Theodore H. Frison

1931. The plant lice, or Aphiidae, of 1llinois. Ill. Nat. Hist. Surv. Bul. $19(3): 121-447 . \quad 10$ pls. 
Hussey, R. F.

1924. A change of name (Hemiptera, Miridae). Brooklyn Ent. Soc. Bul. 19(5):165.

Jakovlev, B.

1880. Hemiptera-Heteroptera from Russia and adjacent countries (translated from Russian title). Russkoe entomologicheskoe obshchestvo '1rudy $11: 200-20$.

Johnston, Horace G.

1930. Four new species of Miridae from Texas. Brooklyn Ent. Soc. Bul. 25(5):295-300.

1935. Five new species of Miridae. Brooklyn Ent. Soc. Bul. 30(1):15-8.

\section{Kirschbaum, C. L.}

1855. Rhynchotographische Beiträge. Die Rhynchoten der Gegend von Wiesbaden. Erstes Hefe, die Capsinen. Jahrbücher des Vereins für Naturkunde in Herzogthum Nassau 10: 161-348. Also separate, W'ieshaden, $189 \mathrm{pp}$.

\section{Knight, Harry $\mathbf{H}$.}

1915. Observations on the oviposition of certain Capsids. Jour. Econ. Ent. $8(2): 293-8$.

1916a. Remarks on Lygus invitus Say, with descriptions of a new species and variety of Lygus. (Hemiptera, Miridae.) Can. Ent. 48(10):345-9.

1916b. Paracalocoris hawleyi n. sp., and var. ancora n. Ent. Soc. Am. Ann. 9(4): $377-8$.

1917a. New and noteworthy forms of North American Miridae (Hemiptera). Ent. News 28(1):3-8.

1917b. A revision of the genus $L y g u s$ as it occurs in America north of Mexico, with biological datil on the species from New York. N. Y. (Cornell) Ag. Exp. Sta. Bul. $391: 555-645.1$ pl.

$1917 c$. Notes on species of Miridac inhahiting ash trees (Fraxinus) with the descriptions of new species (Hemiptera). Brooklyn Ent. Soc. Bul. $12(4): 80-2$.

1917d. New species of Lopiden (Miridae, Hemiptera). Ent. News 28(10): 455-61.

1918a. Synoptic key to the subfamilies of Niridae (Hemiptera, Heteroptera). N. Y. Ent. Soc. Jour. 26(1):40-4. $1 \mathrm{pl}$.

1918b. Old and new species of Lopidea from the United States (Hemiptera, Miridae). Ent. News 29(6):210-6. 1 pl.

1918c. Additional data on the distribution and food plants of Lygus with descriptions of a new species and variety (Hemiptera, Miridae). Brooklyn Ent. Soc. Bul. 13(2):42-5.

1918d. Interesting new species of Miridae from the United States, with a note on Orthocephalus mutabilis (Fallen)
(Hemiptera, Miridate) Brooklyn Ent. Soc. Bul. 13(5):111-6.

1920. New and little-known species of Phylocoris from the eastern United States (Heteroptera, Miridiae). Brooklyn Fint. Soc. Bul. 15(2-3):49-66. 1 pl.

1921. Nonograph of the North Ameriean species of Deraencoris (Heteroptera, Miridae). Ninn. State F.nt. 18th Rep. 1920:76-210, pls. 8-9, figs. 2-44.

1922a. Nearctic records for species of Miridae known heretofore only from the Palaearctic region (Heteroptera). Can. Fint. 53(12):280-8.

1922b. The North American species of Labops (Heteroptera, Miridae). Can. Ent. 54(11):258-61.

1923a. A new Peritropis from the eastern United States (Heteroptera, Miridae). Ent. News 34(2):50-2.

1923b. A new species of Labopidea on garlic (Heteroptera, Miridae). Brooklyn Ent. Soc. Bul. 18(1):31.

1923c. A fourth paper on the sprecies of I.opidea (Heteroptera, Miridae). Ent. News 34(3):65-72. 2 pls.

1923d. The Miridae (or Capsidae) of Connecticut. In Bul. 34, Conn. Geol. and Nat. Hist. Surv., pr. 422-658, figs. $47-149$.

1925. Descriptions of twelve new species of Polymerus (Hemiptera, Miridae). Can. Ent. 57 (10):244-53.

1926a. Descriptions of four new species of Plagioguathus from the eastern United States (Hemiptera, Miridae). Ent. News 37(1):9-12.

1926b. A new Rhinacloa and three new species of Lepidopsallis (Hemiptera, Miridae). Brooklyn Fint. Soc. Bul. 20(5):225-8. (Dated 1925.)

1926c. Capsus simulans (Stål) and Labops burmeisteri Stanl recognized from the Nearctic region. Can. Fnt. 58(3): 59-60.

1926d. Descriptions of seven new species of Pilophorus (Hemiptera, Miridae). Brooklyn Fnt. Soc. Bul. 21(1):18-26.

1926e. Descriptions of nine new species of Bryocorinae (Hemiptera, Miridae). Brooklyn Ent. Soc. Bul. 21(3):101-8.

1926\%. Notes on species of Polymerus with descriptions of four new species and two new varieties. (Hemiptera, Miridae). Can. Ent. 58(7):164-8.

1926. Descriptions of eleven new species of Phytocoris from eastern North America (Hemiptera, Miridae). Brooklyn Ent. Soc. Bul. 21(4):158-68.

1926h. Descriptions of six new species of Miridae from eastern North America (Hemiptera, Miridae). Can. Fint. $58(10): 252-6$.

1926i. A key to the North American species of Macrolophus with descriptions of two new species (Hemiptera, Miri. dac). Ent. News 37(10):313-6. 
1926j. Descriptions of seven new Paracalocoris with keys to the Nearctic species and varieties (Hemiptera, Miridae). Ent. Soc. Am. Ann. 19(4):367-77.

1927a. Notes on the distribution and host plants of some North American Miridae (Hemiptera). Can. Ent. 59(2):34-44.

1927b. Descriptions of twelve new species of Miridae from the District of Columbia and vicinity (Hemiptera). Biol. Soc. Wash. Proc. 40(2):9-18.

1927c. Descriptions of fifteen new species of Ceratocapsus (Hemiptera, Miridae). Ohio Jour. Sci, 27(3):143-54.

1927d. New species and a new genus of Deraeocorinae from North America (Hemiptera, Miridae). Brooklyn Ent. Soc. Bul. 22(3):136-43.

1927. Descriptions of seven new species of the genus Orthotylus Fieber (Hemiptera, Miridae). Can. Ent. 59(8): 176-81.

1928a. New species of Labopidea and Macrotyloides (Hemiptera, Miridae). Can. Ent. 60(10):233-6.

1928b. List of Miridae and Isometopidae in Leonard 1928.

1929a. New species of Halticotoma and Sixeonotus (Hemiptera, Miridae). Brooklyn Ent. Soc. Bul. 23(5):241-9. (Dated 1928).

19296. Descriptions of five new species of Plagiognathus from North America (Hemiptera, Miridae). Ent. News 40(3):69-74.

1929c. New species of Neoborus and Xenoborus (Hemiptera, Miridae). Brooklyn Ent. Soc. Bul. 24(1):1-11.

1929 d. The fourth paper on new species of Plagiognathus (Hemiptera, Miridae). Ent. News 40(8):263-8.

$1930 a$. An European plant-bug (Adelphocoris lineolatus Goeze) found in Iowa (Hemiptera, Miridae). Ent. News 41(1):4-6.

1930b. New species of Psallus Fieber (He miptera, Miridae). Can. Ent. 62 (6) :125-31.

1930c. New species of Ceralocapsus (Hemiptera, Miridae). Brooklyn Ent. Soc. Bul. 25(4):187-98.

1930 d. A new key to Paracalocoris with descriptions of eight new species ( $\mathrm{He}$ miptera, Miridae). Ent. Soc. Am. Ann. 23(4):810-27.

1931. Dacota hesperia Uhler referred to Atractotomus, also descriptions of three new species (Hemiptera, Miridae). Brooklyn Ent. Soc. Bul. 26(1):36-8.

1934. Neurocolpus Reuter: key with five new species (Hemiptera, Miridae). Brooklyn Ent. Soc. Bul. 29(4):162-7.

1938. Strongylocoris Blanchard: six new species from North America (Hemiptera, Miridae). Iowa State Col. Jour. Sci. 13(1):1-7. 1 pl. 1939a. Three new species of Miridae from North America (Hemiptera). Bul. Brooklyn Ent. Soc. 34(1):21-3.

1939b. Reuteria Puton: four new species from the United States (Hemiptera, Miridae). Iowa State Col. Jour. Sci. 13(2):129-33. 1 pl.

Knight, H. H., and W. L. McAtee

1929. Bugs of the family Miridae of the District of Columbia and vicinity. U. S. Natl. Mus. Proc. 75:(13). 27 pp.

\section{Leonard, Mortimer D.}

1928. A list of the insects of New York. N. Y. (Cornell) Ag. Exp. Sta. Mem. 101. $1121 \mathrm{pp}$.

\section{Linnaeus, Carl}

1758. Systema naturae, tenth edition. Holmiae. 1. $2+824$ pp.

1761. Fauna Suecica, second edition. Stockholmiae. $46+578$ pp., 2 pls.

1767. Systema naturae, twelfth edition. Holmiae. $1(2): 533-1327$.

\section{McAtee, Waldo Lee}

1916. Key to the Nearctic species of Paracalocoris (Heteroptera, Miridae). Ent. Soc. Am. Ann. 9(4):366-90.

1919. Notes on two Miridae, Camptobrochis and Paracalocoris (Heteroptera). Ent. News $30(9): 246-7$.

Meyer-Dür, L. R.

1843. Verzeichniss der in der Schweiz einheimischen Rhynchoten (Hemiptera Linn.). Heft 1, familie Capsini. Solothurn. $x+115+\mathrm{iv}$ pp., 7 pls.

\section{Osborne, Herbert}

1898. Additions to the list of Hemiptera of Iowa. Iowa Acad. Sci. Pro. 5:232-47.

\section{Oshanin, B.}

1906-10. Verzeichnis der palaearctischen Hemipteren mit besonderer Berücksichtigung ihrer Verteilung im russischen Reiche. Annuaire du Musée Zoologique de l'Académie Imperiale des Sciences, St. Petersburg, xi-xv (Supplements). Vol. 1. Heteroptera. Lief. 1:lxxiv-393, 1906; Lief. 2:395586, 1908; Lief. 3: 587-1087, 1910 (1909). Vol. 2. Homoptera (190608). Vol. 3. Nachträge und Verbesserung zum 1 und 2 Bande. xvi +217 +1 pp., 1910.

\section{Parshley, Howard Madison}

1922. Report on a collection of HemipteraHeteroptera from South Dakota. S. D. State Ent. Tech. Bul. 2. 22 pp., 2 figs.

\section{Poppius, B. R.}

1914a. Übersicht der Pilophorus-arten nebst beschreibung verwandter Gattung (Hemiptera, Heteroptera). Annales de la Société Entomologique de Belgique 58:237-54. 
1914b. Einige neue Miriden-Gattungen und Arten aus Nord-Amerika und Cuba. Annales de la Société Entomologique de Belgique 58:255-61.

\section{Provancher, Abbé Léon}

1872. Descriptions de plusieurs Hémiptères nouveaux. Nat. Can, 4(3):73-9, (4):103-8, (10):319-20, (11):350-2, (12):376-9.

1886-90. Petite faune entomologique du Canada. Vol. 3, Les Hémiptères. Québec. 354 pp., 5 pls.

\section{Reuter, Odo Morannal}

Hemiptera gymnocerata Scandinaviae et Fenniae disposuit et descripsit. Pars 1. Cimicidae (Capsina). Acta Societatis pro Fauna et Flora Fennicae 1. 206 pp.

1876. Capsinae ex America boreali in Museo Holmiensi asservatae, descriptae. Ofversigt af Kongliga Svenska Vetenskaps-Akademiens Förhandlingar 32(9):59-92. (1875.)

1878. Hemiptera Gymnocerata Europae. Pt. 1. Helsingfors. 187 pp., 8 pls.

1904. Uebersicht der paläarktischen Stenodema-arten. Ofversigt af Finska Vetenskaps-Societetens Förhandlingar 46(15):1-21.

1907. Capsidae novae in insula Jamaica mense Aprilis 1906 a D. E. P. Van Duzee collectae. Ofversigt af Finska Vetenskaps-Societetens Förhandlingar $49(5): 1-27$.

1908. Neoborus (Xenoborus, n. subg.) commissuralis n. sp. Can. Ent. 40(4): 112.

1909. Bemerkungen über nearktische Capsiden nebst Beschreibung neuer Arten. Acta Societatis Scientarum Fennicae 36(2). i $+86+$ iii pp.

1912a. Hemipterologische miscellen. Ofversigt af Finska Vetenskaps-Societetens Förhandlingar 54, A(7):1-76.

19126. Zur Kenntnis der Termatophyliden. Ofversigt af Finska VetenskapsSocietetens Förhandlingar 56, A(1): 1-17.

\section{Sahlberg, John Reinhold}

1871. Hemiptera Heteroptera samlade under en resa i ryska Karelen sommaren 1869. Notiser ur Färhandlingar Sällskapets pro Fauna et Flora Fennicae 11:277-307.

\section{Sahlberg, Reinhold Ferdinand}

1842. Nova species generis Phylocoris (fiallen), ex ordine Hemipterorum descripta. Acta Societatis Scientiarum Fennicae 1: 411-2.

\section{Say, Thomas}

1832. Descriptions of new species of Heteropterous Hemiptera of North America. New Harmony. 39 pp.

1858. Same, reprinted. N. Y. State Ag. Soc. Trans. 17:755-812.
1859. Same, reprinted. 1.e Conte edition. $1: 310-71$.

Shull, W. E.

1933. An investigation of the Lygus species which are pests of beans (Hemiptera, Miridae). Idaho Ag. Exp. Sta. Res. Bul. 11. 42 pp.

Stål, Carl

1858. Beitrag zur Hemipteren-Fauna Sibirens und des russischen NordAmerika. Entomologische Zeitung herausgegeben von dem entomologischen Vereine zu Stettin 19(4-6): 175-98. 1 pl.

1862. Hemiptera Mexicana enumeravit speciesque novas descripsit. Entomologische Zeitung herausgegeben von dem entomologischen Vereine zu Stettin 23(1-3):81-118; (4-6):273$81 ;(7-9): 289-325 ;(10-12): 437-62$.

\section{Uhler, Philip Reese}

1861. Descriptions of a few new species of Hemiptera, and observations upon some already described. Ent. Soc. Philadelphia Proc. 1:21-4.

1872. Notices of the Hemiptera in the westtern territories of the United States, chiefly from the surveys of Dr. F. V. Hayden. In Hayden, U. S. Geol. Surv. Mont. Prelim. Rep., pp. 392 423.

1876. List of Hemiptera of the region west of the Mississippi River. U. S. Geol. Geog. Surv, Terr. Bul. 1:269-361.

1877. Report upon the insects collected by P. R. Uhler during the explorations of 1875 , including monographs of the families Cydnidae and Saldidae, and the Hemiptera collected by A. S. Packard, Jr. U. S. Geol. Geog. Surv. Terr. Md. Bul. 3:355-475, 765-801, pls. 27-8.

1878. Notices of the Hemiptera Heteroptera in the collection of the late T. W. Harris, M.D. Boston Soc, Nat. Hist. Proc, 19:365-446.

1887a. Observations on some North American Capsidae. Ent. Am. 2(12):229-31.

1887b. Observations on some Capsidae with descriptions of a few new species. No. 2. Ent. Am. 3(2):29-35.

1887c. Observations on North American Capsidae with descriptions of new species. No. 3. Ent. Am. 3(4):67-72.

1887d. Observations on Capsidae with descriptions of new species. No. 4. Ent. Am. 3(8):149-51.

1890. Observations on North American Capsidae, with descriptions of new species. No. 5. Md. Acad. Sci. Trans. 1:73-88.

1891. Observations on some remarkable 
forms of Capsidae. Fnt. Soc. Wash. Proc. 2:119-23.

1894. On the Hemiptera-Heteroptera of the island of Grenada, West Indies. Zoological Society of London Proceedings 1894(11):167-224.

1895. Descriptions of new Hemiptera in Gillette and Baker. A preliminary list of the Hemiptera of Colorado. Colo. Ag. Exp. Sta. Bul. 31, Tech. Ser. No. 1. 137 pp.

1899. A new destructive Capsid. Ent. News 10(3):59.

1904. List of Hemiptera-Heteroptera of $\checkmark$ Las Vegas Hot Springs, New Mexico. U. S. Natl. Mus. Proc. 27(1360): 349-64.

\section{Van Duzee, Edward Payson}

1910. Descriptions of some new or unfamiliar North American Hemiptera. Am. Ent. Soc. Trans. 36(1-2):73-9.

1912. Hemipterological Gleanings. Buffalo Soc. Nat. Sci. Bul. 10(2):477-512.

1914. A preliminary list of the Hemiptera of San Diego County, California. San Diego Soc. Nat. Hist. Trans. 2(1):1-57.

1915. New genera and species of North American Hemiptera. Pomona Jour. Ent. Zool. 7(2):109-21.

1916a. Check list of the Hemiptera (excepting the Aphididae, Aleurodidae and Coccidae) of America, north of Mexico. New York (N. Y. Ent. Soc.). $\mathrm{xi}+111 \mathrm{pp}$. 1916b. Monograph of the North American species of Orthotylus (Hemiptera). Calif. Acad. Sci. Proc., ser. 4, 6:87128. 1 fig.

1916c. Notes on some Hemiptera taken near Lake Tahoe, California. Calif. Univ. Ag. Exp. Sta. Tech. Bul. 1:229-49.

1917. Catalogue of the Hemiptera of America north of Mexico excepting the Aphididae, Coccidae and Aleurodidae. Calif. Univ. Pubs. Ent. 2. xiv $+902 \mathrm{pp}$.

1918. New species of Hemiptera, chiefly from California. Calif. Acad. Sci. Proc., ser. 4, 8:271-308.

1920. New Hemipterous insects of the genera Aradus, Phytocoris and Camptobrochys. Calif. Acad. Sci. Proc., ser. $4,9: 331-56$.

1921. Characters of some new species of North American Hemipterous insects, with one new genus. Calif. Acad. Sci. Proc., ser. 4, 11:111-34.

\section{Walker, Francis}

1873. Catalogue of the specimens of Hemiptera Heteroptera in the collection of the British Museum. London. Part 6. 210 pp.

\section{Wirtner, P. Modeste}

1917. A new genus of Bothynotinae, Miridae (Heteroptera). Ent. News 28(1):33-4.

\section{Wolff, Johann Friedrich}

1804. Icones Cimicum descriptionibus illustratae. Pt. 4, pp. 127-66, pls. 13-16. 


\section{INDEX}

Adelphocoris, 137, 174

lineolatus, 4, 15, 174, 175

rapidus, 15,174

superbus, 174

affinis, Horcias dislocatus, 173

Agalliastes associatus, 25

signatus, 45

suavis, 26

agilis, Dicyphus, 19, 53

agilis, Idolocoris, 53

ainsliei, Labopidea, 105

albatus, Plagiognathus, 36, 37

albatus, 28

similis, 37

vit tiscutis, 29, 37, 38

albatus, Psallus, 36

albifacies, Phytocoris, 185,186

albifacies, Plagiognathus, $23,27,35$

albigulus, Deraeocoris, $68,72,73$

albigulus, Paracalocoris pallidulus, 176, 178

albocuneatus, Plagiognathus obscurus, 28,33

albofasciata, Leucopoecila, 50

albonotatus, Plagiognathus, 31, 32

albonotatus, 28

compar, 29, 31

tinctus, 31

alboradialis, Plagiognathus, 28, 31

Alepidia, 118,119

gracilis, 119

squamosa, 119

Alepidiella, 118, 119

heidemanni, 119

allii, Labopidea, 4, 14, 105

alni, Lygus, 157

alni, Neolygus, 154, 157, 158

alnicenatus, Psallus, 43, 44

alnicola, Deraeocoris, 68, 70

alnicola, Psallus, 43, 44

althaeae, Melanotrichus, 14, 15, 95, 96

althaeae, Orthotylus, 96

Amblytylus, 24, 51

nasutus, 51

sexguttatus, 51

ambrosiae, Strongylocoris, 78, 80, 81

amoena, Coquillettia, 17, 52

amoenus, Macrotylus, 23, 51

amoenus, Neoborus, 4, 13, 140, 141

amoenus, 139

atriscutis, 140

palmeri, 141

scutellaris, 139,140

signatus, 140

amoenus, Orectoderus, 52

amoenus, Pilophorus, 120,122

amoenus, Tropidosteptes, 140

a morphae, Lopidea, 85, 86, 87, 90

amorphae, Psallus, 43,44

ancorifer, Apocremnus, 46

ancorifer, Psallus, 21, 44, 46

angusticollis, Platytylellus insitivus, 132, 134

angustifrons, Phytocoris, 200, 201

angustulus, Phytocoris, 191, 193, 195, 197

annulatus, Plagiognathus, 33, 34

annulatus, 27

cuneatus, 34

nigrofemoratus, 27,34 antennalis, Phytocoris, 184,185

aphidiphagus, Deraeocoris, 4, 68, 70, 71

apicalis, Barberiella, 21, 209

apicalis, Lygus, 148, 149, 154

apicatus, Plagiognathus repletus, 29, 38

Apocremnus ancorifer, 46

aptera, Cicada, 77

apterus, Halticus, 77

ardens, Paracalocoris scrupeus, 177

areolatus, Sixeonotus, 59, 60

arundinicola, Phytocoris, 191, 192, 195, 198

associatus, Agalliastes, 25

associatus, Chlamydatus, $21,25,26$

astericola, Psallus, 43, 45

ater, Capsus, 138

semiflavus, 138

tyrannus, 138

ater, Cimex, 138

Atomoscelis seriatus, 45

Atractotomus, 15, 17, 22, 51

crataegi, $\mathbf{5 1}$

magnicornis, 24

atricolor, Lepidopsallus rubidus, 47

atricornis, Plagiognathus, 28,35

atrinotatus, L.ygus, 162

atrinotatus, Neolygus, 156, 158, 162

atriscutis, Neoborus amoenus, 140

atritibialis, Lygus, 148, 149, 152

atritibialis, Strongylocoris, 78, 80

atritylus, Lygus, 157

atritylus, Neolygus, 155, 157, 158

aurantiacus, Miris dolabratus, 127

bakeri, Chlamydatus, 45

bakeri, Psallus, 43, 45

Barberiella, 19, 209

apicalis, 21, 209

formicoides, 209

basalis, Poeciloscytus, 167

basalis, Polymerus, 167

basalis, 166

fuscatus, 166,167

basicornis, Orthotylus, 97, 99, 102, 105

belfragii, Lygus, 162

belfragii, Neolygus, 155, 158, 161, 162

betulae, Deraeocoris, $68,69,70$

bidens, Paracalocoris scrupeus, 177

bifurcata, Reuteria, 93, 94

binotatus, Lygaeus, 175

binotatus, Neolygus canadensis, 156, 164

binotatus, Stenotus, 175

blatchleyi, Plagiognathus, 24, 35

blatchleyi, 27

nubilus, 27,36

bohemanni, Microsynamma, 21, 24, 42

bohemanni, Phytocoris, 42

borealis, Camptobrochys, 71

borealis, Deraeocoris, 68, 69, 70, 71

borealis, Platytylellus, 132, 136

Bothynotus, 64

modestus, 23, 64

hracteatus, Cylapus, 77

bracteatus, Halticus, 4, 13, 14, 15, 21, 77

breviatus, Strongylocoris, 78, 79, 80

brevicornis, Macrolophus, 55

brevifurcatus, Phytocoris, 191, 192, 194, 195 
brevipes, Trigonotylus, 129

brevirostris, Plagiognathus, 27, 28, 33

brevirostris, Polymerus, 167, 170

brevis, Hyaliodes, 56, 58

breviusculus, Phytocoris, 184, 190

brunneata, Eurychilopterella, 73, 74

brunneus, Fulvius, 21, 23, 61

brunneus, Lygus, 61

brunneus, Pilophorus, 120, 123

Bryocorinae, 17, 22, 58

buenoi, Phytocoris, 191, 192, 195, 197, 198

caesar, Lopidea, 91

Callicapsus histrio, 69

Callimiris tarsalis, 129

Calocoris, 137

norvegicus, 137

camelus, Ceratocapsus, 108, 110, 114

campestris, Cimex, 154

campestris, Lygus, 4, 148, 149, 154

Camptobrochis, 4, 66

grandis, 71

nebulosus, 67

nitens, 72

poecilus, 67

Camptobrochys borealis, 71

Campylomma, 24, 25

verbasci, 25

canadensis, Lygus, 164

canadensis, Neoborus, $140,141,143$

canadensis, Neolygus, 158, 163, 164

binotatus, 156,164

canadensis, 155,156

canadensis, Phytocoris, 189, 191, 192, 193, $194,195,196$

canadensis, Tropidosteptes, 141

candidatus, Orthotylus, 98, 99, 102

capitata, Diaphnidia, 91, 92

Capsinae, 17, 18, 19, 20, 131

Capsini, 131, 136

Capsus, 15, 17, 136, 138

ater, 138

semiflavus, 138

tyrannus, 138

chlorionis, 98

circumcinctus, 135

colon, 180

confluentus, 87

dislocatus, 173

filicornis, 66

fusiformis, 181

geminus, 140

imbecilis, 61

insignis, 135

insitivus, 133

invitus, 157

irroratus, 93

medius, 89

nubilus, 182

oblineatus, 148

rapidus, 174

robiniae, 89

scrupeus, 177

simulans, 138

stygicus, 79

submarginatus, 103

verbasci, 25

vitripennis, 56

cardinalis, Tropidosteptes, 4, 139

caricis, Cyrtorhinus, 95

Carolinae, Lygus, 154

carpini, Neolygus, 155, 158, 164 caryae, Lygus, 161

caryae, Neolygus, 15, 158, 161

caryae, 156

subfuscus, $156,162,163$

caryae, Phytocoris, 202, 204, 207

caryae, Plagiognathus, 29, 38

castus, Deraeocoris fasciolus, 70

castus, Paracalocoris, 176, 178

castus, Paracalocoris colon, 178

catulus, Melanotrichus, 96, 97

catulus, Orthotylus, 97

celtidis, Paracalocoris, 176, 179

Ceratocapsini, 75, 107

Ceratocapsus, 15, 17, 107, 108

camelus, 108, 110, 114

complicatus, $108,110,114$

decurvatus, $109,110,116$

digitulus, 109, 110, 115

fasciatus, $108,109,110$

fuscinus, 109, 110, 115

husseyi, 108, 110, 113

incisus, $109,110,113$

lutescens, 108, 109, 111

luteus, $108,110,111$

modestus, $21,108,110,111$

nigellus, $108,110,111$

nigrocephalus, 108,111

pilosulus, 108, 109, 110

pilosus, 109

pumilus, 109, 110, 112, 113, 114, 115, 116

quadrispiculus, $109,110,114$

rubricornis, $108,109,110$

sericus, $108,110,113$

setosus, $108,110,115$

taxodii, $7,10,108,110,111$

uniformis, $109,110,113,114$

vicinus, $108,110,112$

Chlamydatus, 24,25

associatus, $21,25,26$

bakeri, 45

pulicarius, 25,26

suavis, 25,26

chlorionis, Capsus, 98

chlorionis, Orthotylus, 97, 98, 99, 100

chrysanthemi, Miris, 31

chrysanthemi, Plagiognathus, 28, 31, 35

chrysopsis, Polymerus, 167, 171

Cicada aptera, 77

Cimex ater, 138

campestris, 154

clavatus, 124

dolabratus, 127

filicis, 58

lineolatus, 175

pabulinus, 153

ruficornis, 130

circumcinctus, Capsus, 135

circumcinctus, Platytylellus, 132, 135

citri, Rhinacloa, 77

clandestina, Opistheuria, 131

dorsalis, 131

ventralis, 131

claricornis, Lepidopsallus, 46, 47

clavatus, Cimex, 124

clavatus, Pilophorus, 120, 124

clavigenitalis, Lygus, 163

clavigenitalis, Neolygus, $155,156,158,161,163$

Clivinema, 64 villosa, 64

Clivineminae, 17,63

Clivinemini, 20,63, 64

coccineus, Horcias dislocatus, 173 
Coccobaphes, 137,138

sanguinareus, 138

Collaria, 20, 125, 126

meilleurii, 126

oculata, 126, 127

colon, Capsus, 180

colon, Paracalocoris, $3,177,180$

castus, 178

commissuralis, Nenoborus, 143, 144

communis, Lygus, 159

communis, Neolygus, $3,4,13,156,157,158$, 159

novascotiensis, 14,160

compar, Paracalocoris scrupeus, 177

compar, Plagiognathus albonotatus, 29, 31

complicatus, Ceratocapsus, $108,110,114$

confluens, Phytocoris, 201, 204, 205

confluens, Phytocoris puella, 205

confluenta, Lopidea, 82, 85, 86, 87, 90, 91

confluentus, Capsus, 87

confraternus, Platytylellus, 134

conspersipes, Phytocoris, 200, 201

conspurcatus, Phytocoris, 184, 185, 188, 189

convexicollis, Pycnoderes, 60

Coquillettia, 15, 17, 22, 52

a moena, 17, 52

mimetica, 21

cornicola, Plagiognathus, 27, 29, 38

corticevivens, Phy tocoris, 185, 186, 189

cortitectus, Phytocoris, 191, 193, 195, 196

costalis, Deraeocoris sayi, 73

crataegi, Atractotomus, 51

crataegi, Plagiognathus dispar, 28, 40

Criocoris, 22, 49

saliens, 21,49

cunealis, Paracalocoris scrupeus, 177

cuneata, Lopidea, $85,86,87,88,89$

cuneatus, Deraeocoris, 67

cuneatus, Neocapsus, 147

cuneatus, Plagiognathus, 26, 27, 34

cuneatus, Plagiognathus annulatus, 34

curtulus, Mesomiris, 131

Cylapinae, $4,17,61$

Cylapini, 19, 61

Cylapus, 61

bracteatus, 77

tenuicornis, 4, 19, 21, 61

Cyrtopeltis, 52,53

tenuis, 53

varians, 53

Cyrtopeltocoris, 19, 116, 117 illini, 117

Cyrtorhinus, 82, 95 caricis 95

davisi, Deraeocoris, $68,70,72$

davisi, Largidea, 19, 63

davisi, Lopidea, 4, 14, 85, 86, 87, 88

davisi, Pamillia, 108

davisi, Phytocoris, 185, 187

davisi, Plagiognathus, 28,38

davisi, Teleorhinus, 19

debilis, Plagiognathus tinctus, 28, 32

decolor, Lopus, 21, 51

decurvatus, Ceratocapsus, 109, 110, 116

delicatus, Orthotylus, 96

delicatus, Plagiognathus, 29, 36, 37

delicatus, Psallus, 37, 96

delta, Paracalocoris scrupeus, 177

depallens, Plagiognathus salicicola, 29, 36

depictus, Phytocoris, 202, 204, 208

Deraeocorinae, $17,20,64$
Deraeocoris, $4,17,65,66$

albigulus, $68,72,73$

alnicola, 68,70

aphidiphagus, $4,68,70,71$

betulae, $68,69,70$

borealis, $68,69,70,71$

cuneatus, 67

davisi, $68,70,72$

fasciolus, 68,70

castus, 70

fasciolus, 69

grandis, $68,69,71$

histrio, 4, 66, 68, 69

laricicola, $5,68,72,73$

nebulosus, $4,21,67,68$

nigritulus, $68,72,73$

nitenatus, $4,68,70,71,72$

nubilus, $4,7,23,67,68,69$

ornatus, 67,68

pinicola, 4, 6, 21, 68, 72,73

poecilus, $4,67,68$

quercicola, $68,71,72$

pallens, 70,71

quercicola, 70

ruber, 21

sayi, 68,73

costalis, 73

frontalis, 73

marginata, 73

sayi, 73

unicolor, 73

simulans, 138

Diaphnidia, 82, 91

capitata, 91, 92

pellucida, 19, 91, 92

provancheri, 91,92

Dichrooscytus, 137,165

elegans, 165

rufipennis, 165,166

suspectus, 165,166

tinctipennis, 165

viridicans, 165

Dicyphinae, $17,20,22,52$

Dicyphus, 53

agilis, 19,53

discrepans, 4, 21, 53, 54

famelicus, $21,53,54$

gracilentus, $10,53,54$

minimus, 53,54

notatus, 53

separatus, 55

vestitus, $4,23,53,54$

digitulus, Ceratocapsus, $109,110,115$

dilatatus, Pycnoderes, 21, 60, 61

discifer, Platytylellus fraternus, 132, 135

discoidalis, Hyaliodes vitripennis, 56

discolor, Teratocoris, 12,128

discrepans, Dicyphus, 4, 21, 53, 54

dislocatus, Capsus, 173

dislocatus, Horcias, 172, 173

affinis, 173

coccineus, 173

flavidus, 172,173

goniphorus, 173

gradus, 173

limbatellus, 173

marginalis, 173

nigriclavus, 173

nigritus, 173

pallipes, 173

residuus, 173

rubellus, 173 
scutatus, 173

dispar, Plagiognathus, 39

crataegi, 28, 40

dispar, 28

dispar, Plagiognathus punctatipes, 39

diversus, Phytocoris, 7,200

divisa, Ilnacora, 83

dolabratus, Cimex, 127

dolabratus, Miris, 12, 15, 23, 127

aurantiacus, 127

dorsalis, Lygus, 100

dorsalis, Opistheuria clandestina, 131

dorsalis, Orthotylus, 98, 99, 100, 105

drakei, Psallus, 44, 46

drakei, Pycnoderes, 60, 61

elegans, Dichrooscytus, 165

elisus, Lygus, 15, 148, 149, 152

hesperus, 151

elisus, Lygus pratensis, 152

elongatus, Microphylellus, 41, 42

Episcopus ornatus, 48

erectus, Phy tocoris, 9, 191, 192, 195, 199

Euarmosus, 66, 73

sayi, 73

Eucerocoris guttulatus, 209

Eurychilopterella, 65, 73

brunneata, 73,74

luridula, $21,73,74$

Eustictus, 64, 65

filicornis, 65,66

necopinus, 65,66

salicicola, 65

venatorius, $21,65,66$

evonymi, Paracalocoris, 176, 178

exemplus, Phytocoris, 199, 200, 201

eximius, Phy tocoris, 189, 193, 194

fagi, Lygus, 161

fagi, Neolygus, 155, 158, 161, 163

fallax, Horcias, 172,173

famelicus, Dicyphus, 21, 53, 54

famelicus, Idolocoris, 54

fasciatum, Megacoelum, 109

fasciatus, Ceratocapsus, 108, 109, 110

fasciolus, Deraeocoris, 68,70

castus, 70

fasciolus, 69

ferrugatus, Miris, 127

Fiebrigiella silvestri, 209

filicis, Cimex, 58

filicis, Monalocoris, 19, 23, 58

filicornis, Capsus, 66

filicornis, Eustictus, 65, 66

flaveolus, Plagiognathus politus, 26, 29

flavicornis, Plagiognathus, $28,30,31$

flavidus, Horcias dislocatus, 172,173

flavocostatus, Polymerus, 167,168

flavoscutellatus, Plagiognathus, 26, 32

flavosparsus, Melanotrichus, 96

flavosparsus, Orthotylus, 21

flavosparsus, Phytocoris, 96

formicoides, Barberiella, 209

forticornis, Rhinacloa, 24, 50

fraterculus, Platytylellus, 133, 136

fraterculus, Platytylellus insignis, 136

fraternus, Plagiognathus obscurus, 26, 33, 44

fraternus, Platytylellus, 131, 134

discifer, 132, 135

fraternus, 132

regalis, 132, 135

rubromarginatus, 132,135 frisoni, Lygus, 148, 151

frontalis, Deraeocoris sayi, 73

fulvidus, Plagiognathus, 27, 37

Fulviini, 20, 61

fulvipes, Polymerus, 167, 170

Fulvius, 4, 61

brunneus, 21, 23, 61

imbecilis, 61

fulvotinctus, Plagiognathus negundinis, 33

fulvus, Phy tocoris, 199, 200, 201

fumatus, Phytocoris, 185, 188, 189, 190

fumidus, Noctuocoris, 105

fuscatus, Polymerus basalis, 166, 167

fuscatus, Psallus, 43, 44

fuscatus, Psallus parshleyi, 44

fuscicornis, Microphylellus maculipennis, 40,41

fuscicornis, Orthotylus, 102

fuscicornis, Reuteria, 93, 94

fuscinus, Ceratocapsus, 109, 110, 115

fusiformis, Capsus, 181

fusiformis, Garganus, 181

Garganus, 137, 181

fusiformis, 181

geminus, Capsus, 140

geminus, Neoborus, 139, 140

geminus, Neolygus, $155,158,163$

geminus, Pilophorus, 120, 122

geneseensis, Lygus, 159

geneseensis, Neolygus, 156, 158, 159

gerhardi, Polymerus, 167, 171

gilvipes, Mecomma, 82, 95

glaber, Neoborus, 139, 140

gleditsiae, Paracalocoris, 176, 179, 180

gleditsiae, Plagiognathus, 11, 26, 27, 37

goniphorus, Horcias dislocatus, 173

gracilentus, Dicyphus, $10,53,54$

gracilis, Alepidia, 119

squamosa, 119

gracilis, Mimoceps insignis, 126

gracilis, Pilophorus, 119

gradus, Horcias dislocatus, 173

grandis, Camptobrochis, 71

grandis, Deraeocoris, 68, 69, 71

grossa, Largidea, 23, 63

grossum, Megacoelum, 66

guttulatus, Eucerocoris, 209

guttulatus, Paraxenetus, 209

guttulosus, Plagiognathus, 28, 40

guttulosus, Psallus, 40

Hadronema, 81, 84

militare, 82,84

Halticini, 75

Halticus, $17,75,77$

apterus, $\mathbf{7 7}$

bracteatus, $4,13,14,15,21,77$

intermedius, 21,77

harti, Hyaliodes, 56, 57

hawleyi, Paracalocoris, 4, 15, 176, 178

pallidulus, 178

heidemanni, Alepidiella, 119

heidemanni, Hesperophylum, 19, 74

heidemanni, Lopidea, 85, 86, 87, 88, 90

heidemanni, Sericophanes, 15, 116

Hesperophylum, 20, 64, 74

heidemanni, 19,74

hesperus, Lygus, 15, 148, 149, 151, 152

hesperus, Lygus elisus, 151

Heterocordylus, 82, 107

malinus, 2, 3, 4, 5, 21, 107

hirticulus, Lygus, 163 
hirticulus, Neolygus, 155, 156, 158, 163, 164 hirtum, Semium, 19, 75

hirtus, Labops, 19, 21, 81

hirtus, Strongylocoris, 78, 80, 81

histrio, Callicapsus, 69

histrio, Deraeocoris, 4, 66, 68, 69

Horcias, 137, 172

dislocatus, 172, 173

affinis, 173

coccineus, 173

Havidus, 172,173

goniphorus, 173

gradus, 173

limbatellus, 173

marginalis, 173

nigriclavus, 173

nigritus, 173

pallipes, 173

residuus, 173

rubellus, 173

scutatus, 173

fallax, 172,173

illini, vi, 172

husseyi, Ceratocapsus, 108, 110, 113

hussey, Peritropis, 62

husseyi, Phytocoris, 191, 192, 195, 199

Hyaliodes, 20, 52, 56

brevis, 56,58

harti, 56,57

vitripennis, $21,56,57,58$

discoidalis, 56

vitripennis, 56

Idolocoris agilis, 53

famelicus, 54

illini, Cyrtopeltocoris, 117

illini, Horcias, vi, 172

illini, Ilnacora, 83

illini, Polymerus, 166, 168

Ilnacora, 82

divisa, 83

illini, 83

malina, 21,83

stalii, $12,82,83,84$

imbecilis, Capsus, 61

imbecilis, Fulvius, 61

immaculatus, Orthotylus modestus, 97, 104

incisus, Ceratocapsus, 109, 110, 113

inconspicuus, Lygus, 161

inconspicuus, Neolygus, 155, 158, 161

incurva, Lopidea, 85, 86, 87, 88

incurvus, Pycnoderes, 60

infuscatus, Phytocoris, 202, 204

insignis, Capsus, 135

insignis, Mimoceps, 12, 125 gracilis, 126

insignis, Platytylellus, 133, 135

fraterculus, 136

insignis, Sixeonotus, 21, 59

insitivus, Capsus, 133

insitivus, Platytylellus, 21, 133

angusticollis, 132,134

insitivus, 132

instabilis, Lomatopleura, 91

instabilis, Lopidea, 84, 85, 86, 91

intermedius, Halticus, 21,77

invitus, Capsus, 157

invitus, Neolygus, $155,157,158,159,161$

irrorata, Reuteria, 93, 94, 95

irroratus, Capsus, 93

jessiae, Neurocolpus, 182, 183 johnsoni, Lygus, 162

johnsoni, Neolygus, 4, 156, 158, 162

juniperi, Parthenicus, 76

juniperi, Pilophorus, 120, 121, 123

juniperi, Psallus, 76

junipericola, Phytocoris, 199, 200, 201

knighti, Orthotylus, 98, 99, 102, 105

Labopidea, 82, 105

ainsliei, 105

allii, 4, 14, 105

planifrons, 105

Labopini, 19, 74, 81

Labops, 81

hirtus, $19,21,81$

lacunosus, Phytocoris, 191, 193, 195, 197

laetus, Pilophorus, $120,121,123$

Largidea, 63

davisi, 19,63

grossa, 23, 63

Largideini, 20, 63

laricicola, Deraeocoris, 5, 68, 72, 73

laricicola, Plagiognathus, 5, 27, 39

lasiomerus, Phytocoris, 21, 18t, 185

lateralis, Orthotylus, 98, 99, 104

lateralis, Polymerus unifasciatus, 166, 168

lathyrae, Lopidea, 91

lathyri, Lopidea, $85,86,87,91$

I.epidopsallus, 22,46

claricornis, 46,47

miniatus, 47,48

minusculus, 47

nyssae, $11,47,48$

rostratus, 46,47

rubidus, 47

atricolor, 47

rubidus, 47

L.eucopoecila, 24, 50

albofasciata, 50

limbatellus, Horcias dislocatus, 173

limbus, Paracalocoris, 176, 178

lineatus, Lygaeus, 172

lineatus, Poecilocapsus, 13,172

lineolatus, Adelphocoris, 4, 15, 174, 175

lineolatus, Cimex, 175

Lomatopleura instabilis, 91

longirostris, Microphylellus, 41, 42

Lopidea, 17, 81, 84

amorphae, $85,86,87,90$

caesar, 91

confluenta, $82,85,86,87,90,91$

cuneata, $85,86,87,88,89$

davisi, $4,14,85,86,87,88$

incurva, $85,86,87,88$

instabilis, $84,85,86,91$

heidemanni, $85,86,87,88,90$

lathyrae, 91

lathyri, $85,86,87,91$

media, $84,85,86,88,89$

minor, $85,86,87,88$

reuteri, $85,86,90,91$

robiniae, $84,85,86,89,90$

salicis, $85,86,88,89$

staphyleae, $4,84,85,86,90$

sanguinea, 90

L.opus, 24, 51

decolor, 21, 51

lucidus, Paracalocoris scrupeus, 177

lurida, Lvgidea rubecula, $1+7$

luridula, Eurychilopterella, 21, 73, 74

luridus, Platy/ygus, 147 
luteolus, Phytocoris, 201, 204, 209

lutescens, Ceratocapsus, 108, 109, 111

luteus, Ceratocapsus, $108,110,111$

Lygaeus binotatus, 175

lineatus, 172

pulicarius, 26

rufipennis, 166

unifasciatus, 167

L.ygidea, 137, 145

mendax, 3, 4, 5, 13, 145, 146

obscura, 145

rosacea, 145

rubecula, 145

lurida, 147

obscura, 145

rosacea, 145

salicis, 145,146

viburni, 145

Lygus, 17, 137, 148

alni, 157

apicalis, 148, 149, 154

atrinotatus, 162

atritibialis, 148, 149, 152

atritylus, 157

belfragii, 162

brunneus, 61

campestris, $4,148,149,154$

canadensis, 164

Carolinae, 154

caryae, 161

clavigenitalis, 163

communis, 159

dorsalis, 100

elisus, 15, 148, 149, 152

hesperus, 151

fagi, 161

frisoni, 148, 151

geneseensis, 159

hesperus, 15, 148,149,151, 152

hirticulus, 163

inconspicuus, 161

johnsoni, 162

neglectus, 162

nyssae, 164

oblineatus, $2,4,10,12,14,131,148,149$, 151,153

strigulatus, 149

omnivagus, 163

ostryae, 164

pabulinus, 4, 148, 149, 153

plagiatus, $4,148,149,153$

pratensis, 148, 149

elisus, 152

quercalbae, 160

rubicundus, $4,148,149,153$

semivittatus, 163

tenellus, 163

tiliae, 161

univittatus, 160

vanduzeei, $4,16,21,148,149,150,151$

viburni, 159

vitticollis, 162

\section{Macrolophus, 53, 55}

brevicornis, 55

separatus, $21,53,55,56$

tenuicornis, $23,55,56$

Macrotylus, 22, 51

a moenus, 23,51

sexguttatus, 21,51

maculipennis, Microphylellus, 41

fuscicornis, 40,41 maculipennis, 40

maerkelii, Pithanus, 19, 125

magnicornis, Atractotomus, 24

Malacocoris provancheri, 92

malina, Ilnacora, 21,83

malina, Sthenarops, 83

malinus, Heterocordylus, 2, 3, 4, 5, 21, 107

marginalis, Horcias dislocatus, 173

marginata, Deraeocoris sayi, 73

Mecomma, 82, 95

gilvipes, 82,95

media, Lopidea, $84,85,86,88,89$

medius, Capsus, 89

medius, Pycnoderes, 60

Megacoelum fasciatum, 109 grossum, 66

Megaloceroea, 125

recticornis, 125

meilleurii, Collaria, 126

Mela notrichus, 82,95

althaeae, 14, 15, 95, 96

catulus, 96, 97

flavosparsus, 96

Melinna modesta, 111 pumila, 112

mendax, Lygidea, 3, 4, 5, 13, 145, 146

Mesomiris, 125,131

curtulus, 131

Microphylellus, 25, 40

elongatus, 41,42

longirostris, 41,42

maculipennis, 41

fuscicornis, 40,41

maculipennis, 40

modestus, 21, 24, 41, 42

nigricornis, 40,41

tsugae, 41,42

tumidifrons, 41,42

Microsynamma, 24,42

bohemanni, 21, 24, 42

militare, Hadronema, 82, 84

mimetica, Coquillettia, 21

Mimoceps, 125

insignis, 12,125

gracilis, 126

miniatus, Lepidopsallus, 47, 48

minimus, Dicyphus, 53,54

minor, Lopidea, $85,86,87,88$

minusculus, Lepidopsallus, 47

minutulus, Phytocoris, 185, 187, 188

Mirinae, 12, 17, 18, 20, 23, 124

Miris, 125, 127

chrysanthemi, 31

dolabratus, $12,15,23,127$

aurantiacus, 127

ferrugatus, 127

vicinus, 130

modesta, Melinna, 111

modestus, Bothynotus, 23, 64

modestus, Ceratocapsus, 21, 108, 110, 111

modestus, Microphylellus, 21, 24, 41, 42

modestus, Neobothynotus, 64

modestus, Orthotylus, 99, 104

immaculatus, 97, 104

modestus, 98

mohri, Strongylocoris, 78, 81

Monalocoris, 22, 58

filicis, 19, 23, 58

morrisoni, Psallus, 43, 45

multisignatus, Paracalocoris, 176, 180

mundus, Phy tocoris, 199, 200, 201

mutabilis, Orthocephalus, 81 


\section{Myrmecorini, 131, 209}

nasutus, Amblytylus, $\mathbf{5 1}$

nebulosus, Camptobrochis, 67

nebulosus, Deraeocoris, 4, 21, 67, 68

necopinus, Eustictus, 65,66

necopinus, Orthotylus, 98, 99, 103

neglectus, Lygus, 162

neglectus, Neolygus, 154, 158, 162

neglectus, Orthotylus, 98, 99, 105

neglectus, Phy tocoris, 191, 192, 194, 195, 196

neglectus, Xenoborus, 144

negundinis, Plagiognathus, 27, 33

fulvotinctus, 33

Neoborus, 17, 136, 139

a moenus, $4,13,140,141$

amoenus, 139

atriscutis, 140

palmeri, 141

scutellaris, 139, 140

signatus, 140

canadensis, 140, 141, 143

geminus, 139,140

glaber, 139, 140

palmeri, 139, 141

populi, 140,142

pubescens, $140,141,142$

rufusculus, 140,143

tricolor, 140,143

vittiscutis, 140,142

Neobothynotus modestus, 64

Neocapsus, 137,147

cuneatus, 147

Neolygus, 17, 137, 154

alni, 154, 157, 158

atrinotatus, $156,158,162$

atritylus, 155, 157, 158

belfragii, $155,158,161,162$

canadensis, $158,163,164$

binotatus, 156, 164

canadensis, 155, 156

carpini, $155,158,164$

caryae, $15,158,161$

carvae, 156

subfuscus, $156,162,163$

clavigenitalis, $155,156,158,161,163$

communis, $3,4,13,156,157,158,159$

novascotiensis, 14,160

fagi, $155,158,161,163$

geminus, $155,158,163$

geneseensis, $156,158,159$

hirticulus, 155, 156, 158, 163, 164

inconspicuus, $155,158,161$

invitus, $155,157,158,159,161$

johnsoni, 4, 156, 158, 162

neglectus, 154, 158, 162

nyssae, $155,158,164$

omnivagus, $156,158,159,160,162,163,164$

ostryae, $156,158,164$

quercalbae, $156,158,160,163,164$

semivittatus, $156,158,160,163$

tiliae, $155,156,158,161$

tinctus, $155,157,158$

univittatus, $156,158,160$

viburni, $155,158,159$

vitticollis, $157,158,162$

Neurocolpus, $17,137,181$

jessiae, 182,183

nubilus, 181,182

rubidus, 182,183

tiliae, 181,182

nigellus, Ceratocapsus, 108, 110, 111 nigrellus, Parthenicus, 76, 77

nigriclavus, Horcias dislocatus, 173

nigricollis, Platytylellus, 132,133

nigricollis, Phy tocoris, 191, 192, 195, 197

nigricollis, Resthenia, 133

nigricornis, Microphylellus, 40, 41

nigritulus, Deraeocoris, $68,72,73$

nigritus, Horcias dislocatus, 173

nigritus, Plagiognathus, 27, 34

nigritus, Polymerus, 168

nigrocephalus, Ceratocapsus, 108, 111

nigrofemoratus, Plagiognathus annulatus, 27 , 34

nigrolineatus, Plagiognathus, 26, 34

nigronitens, Plagiognathus, 27, 30

nigropallidus, Polymerus, 166, 167

nigroscutellatus, Platytylellus, 132, 134

nitenatus, Deraeocoris, 4, 68, 70, 71, 72

nitens, Camptobrochis, 72

noctuans, Sericophanes, 116

Noctuocoris, 82, 105

fumidus, 105

norvegicus, Calocoris, 137

notabilis, Orthotylus, 97, 98, 100

notatus, Dicy phus, 53

novascotiensis, Neolygus communis, 14, 160

nubilipes, Polymerus, 166, 170

nubilus, Capsus, 182

nubilus, Deraeocoris, 4, 7, 23, 67, 68, 69

nubilus, Neurocolpus, 181,182

nubilus, Paracalocoris scrupeus, 177

nubilus, Plagiognathus blatchleyi, 27, 36

nyctalis, Orthotylus, 98, 99, 104

nyssae, Lepidopsallus, $11,47,48$

nyssae, Lygus, 164

nyssae, Neolygus, $155,158,164$

oblineatus, Capsus, 148

oblineatus, Lygus, 2, 4, 10, 12, 14, 131, 148 $149,151,153$

strigulatus, 149

obliquus, Orectoderus, 21, 23, 24, 52

obscura, Lygidea, 145

obscura, Lygidea rubecula, 145

obscurus, Plagiognathus, 32

albocuneatus, 28,33

fraternus, 26, 33, 44

obscurus, 26

obtectus, Phytocoris, 191, 193, 195, 199

ocellatus, Sericophanes, 116

oculata, Collaria, 126, 127

oculatus, Trachelomiris, 127

olseni, Phytocoris, 202, 204, 205

omnivagus, Lygus, 163

omnivagus, Neolygus, $156,158,159,160,162$, 163,164

onustus, Phytocoris, 191, 192, 194, 195

opacus, Polymerus, 167,170

Opistheuria, 131

clandestina, 131

dorsalis, 131

ventralis, 131

Orectoderus, 22,52

a moenus, 52

obliquus, $21,23,24,52$

ornatus, Deraeocoris, 67,68

ornatus, Episcopus, 48

ornatus, Orthotylus, 98, 99, 103

ornatus, Reuteroscopus, 21,48

Orthocephalus, 75,81

mutabilis, 81

Orthotylinae, 17, 18, 19, 20, 74 
Orthotylini, 75,81

Orthotylus, 17, 82, 97

althaeae, 96

basicornis, 97, 99, 102, 105

candidatus, 98, 99, 102

catulus, 97

chlorionis, 97, 98, 99, 100

delicatus, 96

dorsalis, 98, 99, 100, 105

flavosparsus, 21

fuscicornis, 102

knighti, 98, 99, 102, 105

lateralis, 98, 99, 104

modestus, 99, 104

immaculatus, 97, 104

modestus, 98

necopinus, 98, 99, 103

neglectus, 98, 99, 105

notabilis, $97,98,100$

nyctalis, 98, 99, 104

ornatus, 98, 99, 103

ramus, 97, 99, 100

robiniae, $97,99,100,101$

rossi, $97,99,102$

serus, $98,99,102$

submarginatus, 98, 99, 103

taxodii, 7, 97, 99, 101

ulmi, 97,100

viridis, 97, 99, 101, 102

ostryae, Lygus, 164

ostryae, Neolygus, 156, 158, 164

pabulinus, Cimex, 153

pabulinus, Lygus, 4, 148, 149, 153

pallens, Deraeocoris quercicola, 70, 71

pallidicornis, Phy tocoris, 184, 185

pallidicornis, Plagiognathus, 28, 30

pallidicornis, Plagiognathus politus, 30

pallidulus, Paracalocoris, 3, 178

albigulus, 176, 178

pallidulus, 176

pallidulus, Paracalocoris hawleyi, 178

pallipes, Horcias dislocatus, 173

pallipes, Strongylocoris, 78, 79, 80

palmeri, Neoborus, 139, 141

palmeri, Neoborus amoenus, 141

paludum, Teratocoris, 128

Pamillia, 107, 108

davisi, 108

par, Paracalocoris scrupeus, 177

Paracalocoris, $17,137,176$

castus, 176,178

celtidis, 176, 179

colon, $3,177,180$

castus, 178

evony $\mathrm{mi}, 176,178$

gleditsiae, 176, 179, 180

hawleyi, $4,15,176,178$

pallidulus, 178

limbus, 176, 178

multisignatus, 176,180

pallidulus, 3,178

albigulus, 176, 178

pallidulus, 176

salicis, 176,177

scrupeus, 176,177

ardens, 177

bidens, 177

compar, 177

cunealis, 177

delta, 177

lucidus, 177 nubilus, 177

par, 177

percursus, 177

rubidus, 177

sordidus, 177

triops, 177

varius, 177

trivittatus, 178

trivittis, 176,178

Paraxenetus, 209

guttulatus, 209

parshleyi, Psallus, 43, 44

fuscatus, 44

Parthenicus, 75, 76

juniperi, 76

nigrellus, 76, 77

taxodii, 7,76

vaccini, 21

pellucida, Diaphnidia, 19, 91, 92

penipecten, Phy tocoris, 191, 192, 195, 199

percursus, Paracalocoris scrupeus, 177

Peritropis, 4, 15, 61, 62

husseyi, 62

saldaeformis, 62,63

saldiformis, 62

perplexus, Pilophorus, 4, 120, 121

pettiti, Tropidosteptes, 145

pettiti, Xenoborus, 144, 145

Phylinae, 17, 18, 20, 22

Phy tocoris, 4, 17, 137, 184

albifacies, 185,186

angustifrons, 200, 201

angustulus, 191, 193, 195, 197

an tennalis, 184,185

arundinicola, 191, 192, 195, 198

bohemanni, 42

brevifurcatus, 191, 192, 194, 195

breviusculus, 184,190

buenoi, 191, 192,195, 197, 198

canadensis, $189,191,192,193,194,195,196$

caryae, 202, 204, 207

confluens, 201, 204, 205

conspersipes, 200, 201

conspurcatus, $184,185,188,189$

corticevivens, $185,186,189$

cortitectus, 191, 193, 195, 196

davisi, 185,187

depictus, 202, 204, 208

diversus, 7,200

erectus, 9, 191, 192, 195, 199

exemplus, 199, 200, 201

eximius, $189,193,194$

flavosparsus, 96

fulvus, 199, 200, 201

fumatus, $185,188,189,190$

husseyi, 191, 192, 195, 199

infuscatus, 202, 204

junipericola, 199, 200, 201

lacunosus, 191, 193, 195, 197

lasiomerus, $21,184,185$

luteolus, 201, 204, 209

minutulus, $185,187,188$

mundus, 199, 200, 201

neglectus, 191, 192, 194, 195, 196

nigricollis, $191,192,195,197$

obtectus, 191, 193, 195, 199

olseni, 202, 204, 205

onustus, 191, 192, 194, 195 .

pallidicornis, 184, 185

penipecten, 191, 192, 195, 199

pinicola, 200, 201

puella, 202, 204, 207, 208 
confluens, 205

purvus, 185,187

quercicola, 184, 188, 201, 202, 204

rubellus, 202, 204

rubicundus, 153

rufus, 203

salicis, 191, 192, 195, 196, 197, 198

schotti, 191, 192, 195, 197, 198

spicatus, $191,192,195,196$

sulcatus, $185,189,190$

taxodii, $7,201,203,204$

tibialis, 202, 204, 205

tuberculatus, $185,187,189$

uniformis, 199, 200, 201

venustus, 202, 204, 206

vittatus, 185,190

piceicola, Psallus, 43, 44

Pilophorini, 74, 118

Pilophorus, 15, 118, 119

amoenus, 120,122

brunneus, 120,123

clavatus, 120,124

geminus, 120,122

gracilis, 119

juniperi, 120, 121, 123

laetus, 120, 121, 123

perplexus, $4,120,121$

setiger, 120, 124

strobicola, 7, 120, 122

taxodii, 7, 120, 121

uhleri, 5, 7, 120,122

vanduzeei, 120, 122

walshii, 120,123

pilosulus, Ceratocapsus, 108, 109, 110

pilosus, Ceratocapsus, 109

pinicola, Deraeocoris, 4, 6, 21, 68, 72, 73

pinicola, Phy tocoris, 200, 201

Pithanus, 124,125

maerkelii, 19, 125

plagiatus, Lygus, 4, 148, 149, 153

plagifer, Tropidosteptes, 144

plagifer, Xenoborus, 144

Plagiognathus, 25, 26

albatus, 36, 37

albatus, 28

similis, 37

vittiscutis, $29,37,38$

albifacies, $23,27,35$

albonotatus, 31,32

albonotatus, 28

compar, 29, 31

tinctus, 31

alboradialis, 28, 31

annulatus, 33,34

annulatus, 27

cuneatus, 34

nigrofemoratus, 27,34

atricornis, 28, 35

blatchleyi, 24,35

blatchleyi, 27

nubilus, 27,36

brevirostris, $27,28,33$

caryae, 29,38

chrysanthemi, 28, 31, 35

cornicola, 27, 29, 38

cuneatus, 26, 27, 34

davisi, 28,38

delicatus, 29, 36, 37

dispar, 39

crataegi, 28, 40

dispar, 28

flavicornis, $28,30,31$
H avoscutellatus, 26, 32

fulvidus, 27, 37

gleditsiae, 11, 26, 27, 37

guttulosus, 28,40

laricicola, 5, 27, 39

negundinis, 27,33

fulvotinctus, 33

nigritus, 27,34

nigrolineatus, 26, 34

nigronitens, 27,30

obscurus, 32

albocuneatus, 28, 33

fraternus, 26, 33, 44

obscurus, 26

pallidicornis, 28, 30

politus, 29, 30, 31

flaveolus, 26, 29

pallidicornis, 30

politus, 27

punctatipes, 28, 39

dispar, 39

repetitus, 27,40

repletus, 38

apicatus, 29,38

repletus, 29

rosicola, 28,36

salicicola, 36

depallens, 29, 36

salicicola, 29

sericeus, 26, 34

similis, 29,37

suffuscipennis, 28, 40

syrticolae, $6,28,31$

tiliae, 34

tinctus, 31

debilis, 28, 32

tinctus, 28

viridulus, 31

planifrons, Labopidea, 105

platani, Reuteria, 92, 95

Platylygus, 137, 147

luridus, 147

Platytylellus, 131, 132

borealis, 132, 136

circumcinctus, 132, 135

confraternus, 134

fraterculus, 133,136

fraternus, 131, 134

discifer, 132, 135

fraternus, 132

regalis, 132, 135

rubromarginatus, 132,135

insignis, 133, 135

fraterculus, 136

insitivus, 21, 133

angusticollis, 132, 134

insitivus, 132

nigricollis, 132,133

nigroscutellatus, 132,134

rubellicollis, 132,136

rubrovittatus, 132, 133

zonatus, 132,133

Poecilocapsus, 137, 172

lineatus, 13, 172

Poeciloscytus basalis, 167 venaticus, 169

poecilus, Camptobrochis, 67

poecilus, Deraeocoris, $4,67,68$

politus, Plagiognathus, 29, 30, 31

flaveolus, 26, 29

pallidicornis, 30

politus, 27 
pollicaris, Reuteria, 93, 95

Polymerus, 17, 137, 166

basalis, 167

basalis, 166

fuscatus, 166,167

brevirostris, 167, 170

chrysopsis, 167, 171

flavocostatus, 167, 168

fulvipes, 167,170

gerhardi, 167, 171

illini, 166,168

nigritus, 168

nigropallidus, 166, 167

nubilipes, 166,170

opacus, 167,170

proximus, 166,168

punctipes, 166, 168, 169

severini, 167,170

unifasciatus, 167

lateralis, 166, 168

venaticus, 167,169

venustus, 166,170

populi, Neoborus, 140,142

pratensis, Lygus, 148, 149

elisus, 152

provancheri, Diaphnidia, 91, 92

provancheri, Malacocoris, 92

jroximus, Polymerus, 166, 168

Psallus, 24, 25, 43

albatus, 36

alnicenatus, 43,44

alnicola, 43, 44

a morphae, 43,44

ancorifer, $21,44,46$

astericola, 43,45

bakeri, 43,45

delicatus, 37,96

drakei, 44, 46

fuscatus, 43,44

guttulosus, 40

juniperi, 76

morrisoni, 43,45

parshleyi, 43, 44

fuscatus, 44

piceicola, 43,44

seriatus, $4,13,43,45$

sericeus, 34

strobicola, 43,45

sulphureus, 49

Pseudoxenetus, 118

regalis, 118,119

scutellatus, 118,119

pubescens, Neoborus, 140, 141, 142

puella, Phytocoris, 202, 204, 207, 208

confluens, 205

pulcher, Trigonotylus, 129

pulicarius, Chlamydatus, 25, 26

pulicarius, Lygaeus, 26

pumila, Melinna, 112

pumilus, Ceratocapsus, $109,110,112,113,114$, 115,116

punctatipes, Plagiognathus, 28, 39 dispar, 39

punctipes, Polymerus, 166, 168, 169

purvus, Phytocoris, 185,187

Pycnoderes, 22, 58, 60

convexicollis, 60

dilatatus, 21, 60, 61

drakei, 60,61

incurvus, 60

medius, 60

quadrimaculatus, 60 quadrimaculatus, Pycnoderes, 60

quadrispiculus, Ceratocapsus, 109, 110, 114

quercalbae, Lygus, 160

quercalbae, Neolygus, 156, 158, 160, 163, 164

querci, Reuteria, 93, 95

quercicola, Deraeocoris, 68, 71, 72

pallens, 70,71

quercicola, 70

quercicola, Phỵtocoris, 184, 188, 201, 202, 204

ramus, Orthotylus, 97, 99, 100

rapidus, Adelphocoris, 15, 174

rapidus, Capsus, 174

recticornis, Megaloceroea, 125

regalis, Platytylellus fraternus, 132, 135

regalis, Pseudoxenetus, 118, 119

regalis, Xenetus, 119

repetitus, Plagiognathus, 27,40

repletus, Plagiognathus, 38

apicatus, 29,38

repletus, 29

residuus, Horcias dislocatus, 173

Resthenia nigricollis, 133

rubrovittata, 133

Resthenini, 131

reuteri, Lopidea, $85,86,90,91$

Reuteria, 82, 92

bifurcata, 93,94

fuscicornis, 93, 94

irrorata, 93, 94, 95

platani, 92, 95

pollicaris, 93,95

querci, 93, 95

Reuteroscopus, 24, 48

ornatus, 21, 48

sulphureus, 12, 48, 49

Rhinacloa, 22, 50

citri, 77

forticornis, 24,50

Rhinocapsus, 25,40

vanduzeei, $21,24,40$

robiniae, Capsus, 89

robiniae, Lopidea, $84,85,86,89$, 90

robiniae, Orthotylus, 97, 99, 100, 101

rosacea, Lygidea, 145

rosacea, Lygidea rubecula, 145

rosicola, Plagiognathus, 28,36

rossi, Orthotylus, 97, 99, 102

rostratus, Lepidopsallus, 46, 47

rubecula, Lygidea, 145

lurida, 147

obscura, 145

rosacea, 145

rubellicollis, Platytylellus, 132, 136

rubellus, Horcias dislocatus, 173

rubellus, Phytocoris, 202, 204

ruber, Deraeocoris, 21

rubicundus, Lygus, 4, 148, 149, 153

rubicundus, Phytocoris, 153

rubidus, Lepidopsallus, 47

atricolor, 47

rubidus, 47

rubidus, Neurocolpus, 182,183

rubidus, Paracalocoris scrupeus, 177

rubidus, Sthenarus, 47

rubricornis, Ceratocapsus, 108, 109, 110

rubromarginatus, Platytylellus fraternus, 132. 135

rubrovittata, Resthenia, 133 .

rubrovittatus, Platytylellus, 132, 133

ruficornis, Cimex, 130

ruficornis, Trigonotylus, 129, 130 
rufipennis, Dichrooscytus, 165,166

rufipennis, Lygaeus, 166

rufus, Phytocoris, 203

rufusculus, Neoborus, 140,143

saldaeformis, Peritropis, 62, 63

saldiformis, Peritropis, 62

salicicola, Eustictus, 65

salicicola, Plagiognathus, 36

depallens, 29,36

salicicola, 29

salicis, Lopidea, $85,86,88,89$

salicis, Lygidea, 145, 146

salicis, Paracalocoris, 176, 177

salicis, Phytocoris, 191, 192, 195, 156, 197, 198

saliens, Criocoris, 21, 49

saliens, Strongylotes, 49

sanguinareus, Coccobaphes, 138

sanguinea, Lopidea staphyleae, 90

sayi, Deraeocoris, 68, 73

costalis, 73

frontalis, 73

marginata, 73

sayi, 73

unicolor, 73

sayi, Euarmosus, 73

schotti, Phy tocoris, 191, 192, 195, 197, 198

scrupeus, Capsus, 177

scrupeus, Paracalocoris, 176, 177

ardens, 177

bidens, 177

compar, 177

cunealis, 177

delta, 177

lucidus, 177

nubilus, 177

par, 177

percursus, 177

rubidus, 177

sordidus, 177

triops, 177

varius, 177

scutatus, Horcias dislocatus, 173

scutellaris, Neoborus amoenus, 139, 140

scutellatus, Pseudoxenetus, 118, 119

scutellatus, Xenetus, 118

semitlavus, Capsus ater, 138

Semiini, 74, 75

Semium, 19, 75

hirtum, 19, 75

semivittatus, Lygus, 163

semivittatus, Neolygus, 156, 158, 160, 163

separatus, Dicyphus, $\mathbf{5 5}$

separatus, Macrolophus, 21, 53, 55, 56

seriatus, Atomoscelis, 45

seriatus, Psallus, 4, 13, 43, 45

sericeus, Plagiognathus, 26, 34

sericeus, Psallus, 34

Sericophanes, 15, 17, 116

heidemanni, 15, 116

noctuans, 116

ocellatus, 116

sericus, Ceratocapsus, 108, 110, 113

serus, Orthotylus, 98, 99, 102

setiger, Pilophorus, 120, 124

setosus, Ceratocapsus, 108, 110, 115

severini, Polymerus, 167,170

sexguttatus, Amblytylus, 51

sexguttatus, Macrotylus, 21, 51

signatus, Agalliastes, 45

signatus, Neoborus amoenus, 140

silvestri, Fiebrigiella, 209 similis, Plagiognathus, 29, 37

similis, Plagiognathus albatus, 37

simulans, Capsus, 138

simulans, Deraeocoris, 138

Sixeonotus, 22, 58, 59

areolatus, 59, 60

insignis, 21, 59

unicolor, 59

sordidus, Paracalocoris scrupeus, 177

spicatus, Phytocoris, 191, 192, 195, 156

squamosa, Alepidia gracilis, 119

stalii, Ilnacora, $12,82,83,84$

staphyleae, Lopidea, $4,84,85,86$, so sanguinea, 50

Stenodema, 125, 130

trispinosum, $4,21,130$

vicinum, 4,130

Stenotus, 137, 175

binotatus, 175

Sthenarops malina, 83

Sthenarus rubidus, 47

strigulatus, Lygus oblineatus, 149

strobicola, Pilophorus, $7,120,122$

strohicola, Psallus, 43, 45

Strongylocoris, 75, 78

a mbrosiae, $78,80,81$

atritibialis, 78,80

breviatus, $78,79,80$

hirtus, $78,80,81$

mohri, 78, 81

pallipes, $78,79,80$

stygicus, $21,78,79,80$

Strongylotes saliens, 49

stygicus, Capsus, 79

stygicus, Strongylocoris, 21, 78, 79, 80

suavis, Agalliastes, 26

suavis, Chlamydatus, 25,26

subfuscus, Neolygus caryae, 156, 162, 163

submarginatus, Capsus, 103

submarginatus, Orthotylus, 98, 99, 103

suffuscipennis, Plagiognathus, 28,40

sulcatus, Phytocoris, 185, 189, 190

sulphureus, Psallus, 49

sulphureus, Reuteroscopus, 12, 48, 49

superbus, Adelphocoris, 174

suspectus, Dichrooscytus, 165, 166

syrticolae, Plagiognathus, 6, 28, 31

Systellonotini, 74, 116

tarsalis, Callimiris, 129

tarsalis, Trigonotylus, 129

taxodii, Ceratocapsus, $7,10,108,110,111$

taxodii, Orthotylus, 7, 97, 99, 101

taxodii, Parthenicus, 7, 76

taxodii, Phytocoris, 7, 201, 203, 204

taxodii, Pilophorus, $7,120,121$

Teleorhinus, 15, 17, 22, 52

davisi, 19

tephrosicola, 52

tenellus, Lygus, 163

tenuicornis, Cylapus, 4, 19, 21, 61

tenuicornis, Macrolophus, $23,55,56$

tenuis, Cyrtopeltis, 53

tephrosicola, Teleorhinus, $\mathbf{5 2}$

Teratocoris, 125,128

discolor, 12, 128

paludum, 128

Termatophylidae, 74

tibialis, Phytocoris, 202, 204, 205

tiliae, Lygus, 161

tiliae, Neolygus, $155,156,158,161$ 
tiliae, Neurocolpus, 181,182

tiliae, Plagiognathus, 34

tinctipennis, Dichrooscytus, 165

tinctus, Neolygus, $155,157,158$

tinctus, Plagiognathus, 31

debilis, 28, 32

tinctus, 28

tinctus, Plagiognathus albonotatus, 31

Trachelomiris oculatus, 127

tricolor, Neoborus, 140, 143

tricolor, Tropidosteptes, 143

Trigonotylus, 15, 125, 129

brevipes, 129

pulcher, 129

ruficornis, 129, 130

tarsalis, 129

triops, Paracalocoris scrupeus, 177

trispinosum, Stenodema, 4, 21, 130

trivittatus, Paracalocoris, 178

trivittis, Paracalocoris, 176, 178

Tropidosteptes, 136, 139

a moenus, 140

canadensis, 141

cardinalis, 4, 139

pettiti, 145

plagifer, 144

tricolor, 143

isugae, Microphylellus, 41, 42

tuberculatus, Phytocoris, 185, 187, 189

tumidifrons, Microphylellus, 41, 42

tyrannus, Capsus ater, 138

uhleri, Pilophorus, 5, 7, 120, 122

ulmi, Orthotylus, 97, 100

unicolor, Deraeocoris sayi, 73

unicolor, Sixeonotus, 59

unifasciatus, Lygaeus, 167

unifasciatus, Polymerus, 167

lateralis, 166, 168

uniformis, Ceratocapsus, 109, 110, 113, 114

uniformis, Phy tocoris, 199, 200, 201

univittatus, Lygus, 160

univittatus, Neolygus, 156, 158, 160

vaccini, Parthenicus, 21 vanduzeei, Lygus, 4, 16, 21, 148, 149, 150, 151

vanduzeei, Pilophorus, 120, 122

vanduzeei, Rhinocapsus, 21, 24, 40

varians, Cyrtopeltis, 53

varius, Paracalocoris scrupeus, 177

venaticus, Poeciloscytus, 169

venaticus, Polymerus, 167, 169

venatorius, Eustictus, 21, 65, 66

ventralis, Opistheuria clandestina, 131

venustus, Phytocoris, 202, 204, 206

venustus, Polymerus, 166,170

verbasci, Campylomma, 25

verbasci, Capsus, 25

vestitus, Dicyphus, 4, 23, 53, 54

viburni, Lygidea, 145

viburni, Lygus, 159

viburni, Neolygus, 155, 158, 159

vicinum, Stenodema, 4,130

vicinus, Ceratocapsus, 108, 110, 112

vicinus, Miris, 130

villosa, Clivinema, 64

viridicans, Dichrooscytus, 165

viridis, Orthotylus, 97, 99, 101, 102

viridulus, Plagiognathus, 31

vitripennis, Capsus, 56

vitripennis, Hyaliodes, 21, 56, 57, 58

discoidalis, 56

vitripennis, 56

vittatus, Phy tocoris, 185,190

vitticollis, Lygus, 162

vitticollis, Neolygus, 157, 158, 162

vittiscutis, Neoborus, 140,142

vittiscutis, Plagiognathus albatus, 29, 37, 38

walshii, Pilophorus, 120, 123

Xenetus regalis, 119

scutellatus, 118

Xenoborus, 136, 143

commissuralis, 143, 144

neglectus, 144

pettiti, 144,145

plagifer, 144

zonatus, Platytylellus, 132, 133 


\section{.}




\section{Recent_Publications of the Illinois Natural History Survey}

A.-ILLINOIS NATURAL HISTORY SURVEY BULLETIN.

Volume 21, Article 3.-Studies of Nearctic Aquatic Insects. By H. H. Ross and T. H. Frison. September, 1937. 52 pp., frontis. + 86 figs., bibliog. 50 cents.

Contents: I. Nearctic alder files of the genus Sialis (Megaloptera, Sialidae), by H. H. Rosa : and

II. Descriptlons of Plecoptera, with special reference to the Illinois specles, by T. H. Wrison

Volume 21, Article 4.-Descriptions of Nearctic Caddis Flies (Trichoptera), with special reference to the Illinois species. By Herbert H. Ross. March, 1938. 84 ppon frontis. + 123 figs., foreword, index. $\$ 1.00$.

Volume 21, Article 5.-Preliminary Studies on Parasites of Upland Game Birds acd Fur-Bearing Mammals in Illinois. By W. Henry Leigh. August, 1940. 10 Fo. frontis. +2 maps.

Volume 21, Article 6.-Preliminary investigation of oak diseases in Illinois. By J. Cedric Carter. June, 1941. 36 pp., frontis. +51 figs., bibliog. (Bound with Article 7.)

Contents: Review of literature; Methods of study; Incidence of oak diseasea; Canker and dieback diseases; Canker diseases; Dleback diseases, Root rot; Miacellaneous fungt

Volume 21, Article 7.-A needle blight of Austrian pine. By Robert L. Hulbary. Junt, 1941. 6 pp., frontis. +3 figs., bibliog. (Bound with Article 6.)

Volume 21, Article 8.-Duck Food Plants of the Illinois River Valley. By Frank C. Bellrose, Jr. August, 1941. 44 pp., frontis. +35 figs., bibliog., appendix.

Contents (partial) : Effect of water levels, floods, drought, fuctuation, turbidity ; Seed pr duction; Important duck food plants ; Plant competition and methods of control; Nater propagation; Management recommendations; Tolerant food plants; Methods of plantris List of waterfowl food plants.

B.-ILLINOIS NATURAL HISTORY SURVEY CIRCULAR.

32.-Pleasure With Plants. By L. R. Tehon. April, 1939. 32 pp., frontis. +9 figs. Contents: What 18 botanizing? Ways to botanize; Where to botanize; When to botanize; Ho to botanize; Studying plants; Equipment for atudying plants; The herbarium; books; Maps; Concluslon.

33.-Controlling Peach Insects in Illinois. By S. C. Chandler and W. P. Flint. Austat 1939. 40 pp., frontis. +32 figs.

Contents : Part I. Insects attacking bark and trunk of the peach tree; Part II. Insects attath ing twiga, foliage and fruit of the peach tree.

34.- Rout the Weeds! Why, When and How. By L. R. Tehon. January, 1940. (Secoad printing.) 47 pp., color frontis. +13 figs.

Contents: The importance of weeds; Weeds as economic factors; Weeds as harborers of insects Weeds as harborers of plant diseases ; Relation of weeds to public bealth; Control metl Thirteen noxious and pernicious weeds of lllinois.

35.-Diseases of Small Grain Crops in Illinois. By G. H. Boewe. September, 1939. 18 pp., frontis. +47 figs.

Contents: Nature of cereal diseases; Wheat diseases; Oats diseases; Barley diseasen; as diseases ; Cereal disease control.

37.-Outwitting Termites in Illinois. By W. E. McCauley and W. P. Flint. April, 1We: 23 pp. frontis. +19 figs.

Contenta: Termites and their habita; Structural control of termites; Control of termites chemicals ; Unified action againat termites.

38.-Windbreaks for Illinois Farmsteads. By J. E. Davis. December, 1940. 24 ms frontis. +19 figs.

Contents: Introduction; Planning the windbreak; Planting the windbreak; Care of the whes break; What the windbreak trees are like.

39.-How to Collect and Preserve Insects. By H. H. Ross. June, 1941. 48 pp., fronc +53 figs.

Contents: Where to collect; What to use; Special collecting equipment; Sending insects ldentification; How to bandle unmounted apecimens; How to mount and preaerve mena; How to label the apecimens; Housing the collection permanently; Identifying t: specimens; Useful books; How to ship a collection; Where to buy supplies.

\section{C.-ILLINOIS NATURAL HISTORY SURVEY MANUAL.}

1.-Fieldbook of Illinois Wild Flowers. By the staff. March, 1936. $406 \mathrm{pp}$, colo frontis. + 349 figs., index. $\$ 1.50$.

Contents: Introduction; Key to families: Description of species (650).

2.-Fieldbook of Illinois Land Snails. By Frank Collins Baker. August, 1939. 166 pp color frontis. +170 figs., 8 pls. $\$ 1.00$.

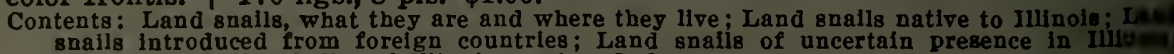
Bibliography; Check list of Illinois species; Index.

List of available publications, over 300 titles, mailed on request.

Address orders and correspondence to the Chief IlluNOIS NATURAL HISTORY SURVEY

Natural Resources Building, Urbana, Illinois

Payment In the form of $\delta$. S. Post Office money order made ont to State Treasurer of Illinols, Springficld, Illinols,

must accompany request for those publicationg on which a price ls sot. 